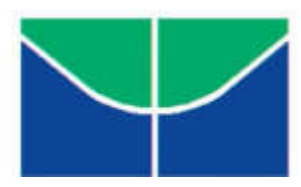

UNIVERSIDADE DE BRASÍLIA

FACULDADE DE EDUCAÇÃO

PROGRAMA DE PÓS-GRADUAÇÃO EM EDUCAÇÃO

DOUTORADO EM EDUCAÇÃO

O ENSINO DE CIÊNCIAS NO TIMOR-LESTE PÓS-COLONIAL E INDEPENDENTE, DESAFIOS E PERSPECTIVAS

Autor: Hélio José Santos Maia 


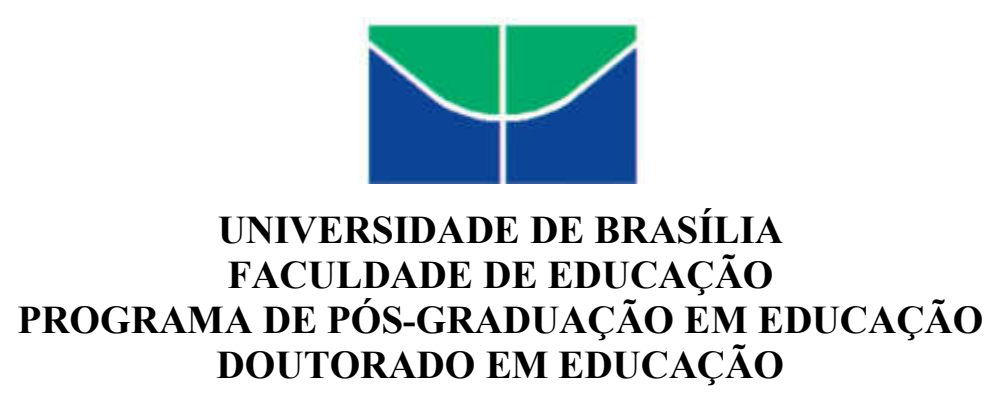

\title{
O ENSINO DE CIÊNCIAS NO TIMOR-LESTE PÓS-COLONIAL E INDEPENDENTE, DESAFIOS E PERSPECTIVAS
}

\author{
Autor: Hélio José Santos Maia
}

Tese de Doutorado apresentada à banca examinadora da Faculdade de Educação da Universidade de Brasília, como parte dos requisitos para a obtenção do título de Doutor em Educação, sob orientação da Professora Dra. Maria Helena da Silva Carneiro. 


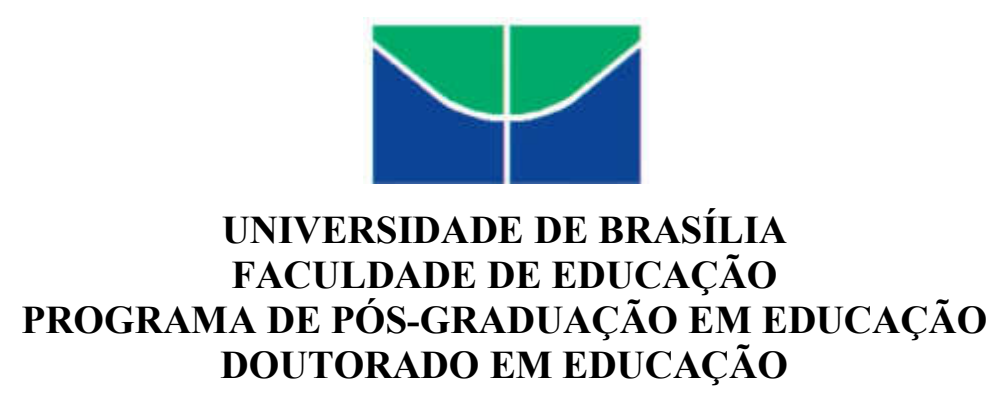

TESE DE DOUTORADO

Autor: Hélio José Santos Maia

Orientadora: Profa. Dra. Maria Helena da Silva Carneiro

Banca Examinadora

Prof $^{a}$. Dra ${ }^{\mathrm{a}}$. Maria Helena da Silva Carneiro - Orientadora (FE/UnB)

Prof ${ }^{a}$. Dr ${ }^{\mathrm{a}}$ Wivian Weller (FE/UnB)/Membro Titular

Prof. Dr. Cássio Costa Laranjeiras (IF/UnB)/Membro Titular

Prof $^{\mathrm{a}}$. Dr ${ }^{\mathrm{a}}$. Graciella Watanabe (FE/UnB)/Membro Titular

Prof. Dr. Fábio Pedro Souza de Ferreira Bandeira (UEFS)/Membro Titular

Prof ${ }^{\mathrm{a}}$. Dr ${ }^{\mathrm{a}}$. Raquel de Almeida Moraes (FE/UnB)/Membro Suplente 
Ficha catalográfica elaborada automaticamente, com os dados fornecidos pelo(a) autor(a)

Maia, Helio José Santos
O ensino de ciências no Timor-Leste pós-colonial e
independente, desafios e perspectivas / Helio José
Santos Maia; orientador Maria Helena da Silva
Carneiro. -- Brasilia, 2016.
333 p.
Tese (Doutorado - Doutorado em Educação) --
Universidade de Brasilia, 2016.
1. Escolarização universal. 2. Ensino de ciências.
3. Pós-colonialismo. 4. Timor-Leste. 5. Dominação
cultural. I. Carneiro, Maria Helena da Silva,
orient. II. Título.


Ao quebrar o silêncio a linguagem realiza o que o silêncio pretendia e não conseguiu obter.

Quando percebo, não penso o mundo, ele organiza-se diante de mim.

Maurice Merleau-Ponty 


\section{AGRADECIMENTOS}

Uma pesquisa não é produto do esforço do trabalho de uma única pessoa. Ela é o resultado de uma congregação de pessoas que auxiliam o pesquisador que funciona como o catalisador para que o produto da sua pesquisa se materialize. Neste sentido, agradeço imensamente à minha Orientadora Profa. Dra. Maria Helena da Silva Carneiro pelas constantes contribuições e auxílio, à professora Márcia Cavalcante, brasileira de nascimento, mas timorense de coração e companheira de jornada em 2007, que me auxiliou com os contatos no Ministério da Educação em Timor no retorno para a pesquisa, aos professores timorenses que contribuíram diretamente para realização da pesquisa em solo timorense, nomeadamente os professores Vicente Paulino, coordenador da Pós-Graduação da UNTL (Universidade Nacional de Timor Lorosa'e) no meu acolhimento na pós-graduação e por ter permitido o uso da biblioteca privativa da mesma, a José Mesquita que ajudou nas traduções do tétum para o português e pelas boas conversas produtivas sobre o Timor e a vida, João Freitas, formador de professores timorense que por meio de conversas ajudou a lançar luzes sobre problemas atuais do Timor, Sr. Cidálio que pacientemente me permitiu acesso ao currículo da educação básica e a autorização para a pesquisa nas escolas, Sra. Manuela Gusmão que com sua clareza teceu considerações fundamentais para a percepção dos agentes que atuam no currículo do ensino básico, a Sra. Filomena Lay, diretora do INFORDEPE (Instituto Nacional de Formação de Docentes e Profissionais da Educação), que por meio de entrevista apresentou considerações importantes sobre a formação de professores e a própria atuação destes professores nas escolas de educação básica.

Agradeço também especialmente aos professores Rogério Alegre, Helena da Costa Campos, Maria Joaquina Gutierres, Maria Lúcia que viabilizaram a execução do trabalho nas escolas.

Por fim, agradeço a paciência e compreensão da minha família, Lucia Ventura Maia, minha esposa, pelas intermináveis horas de atenção durante todo o trabalho e a minha filha Maria Tereza Ventura Maia, que tão novinha, compreendeu a importância do trabalho que realizei e "suportou" mais um momento de afastamento durante o tempo da pesquisa em Timor-Leste. Agradeço também a todos que direta ou indiretamente, contribuíram no clareamento de ideias ao opinarem sobre o desenvolvimento do trabalho, sobretudo, minhas irmãs, Profa. Dra. Urânia Maia e Ana Célia Maia. 


\section{RESUMO}

Esta tese observa o estado atual da educação em Timor-Leste com um recorte no seu ensino de ciências na educação básica, especificamente a educação primária. Neste sentido, procura respostas para indagações sobre como um país recente em sua autonomia, reconstruindo-se de longo processo colonial e posterior ocupação por outro país, constrói seu sistema educativo nas mais variadas frentes, sobretudo na escolha do seu currículo e na formação de professores. Aborda também os desafios do seu plurilinguismo diante da língua portuguesa como oficial para a instrução e sua baixa adesão pela população. Em busca de entendimento para a identidade timorense, empreende um estudo da sua história para estabelecer os fundamentos explicativos dos achados da pesquisa com estudantes da escola básica. Esta consiste em um estudo de concepções de conceitos de ciências entre duas amostras de estudantes, uma da escola pública e outra da escola privada, por meio de aplicação de situações-problema que versam sobre conteúdos presente no currículo de ciências. Como referencial teórico, em face aos desafios descolonizadores, utiliza a teoria pós-colonial em sua vertente educacional, ao tempo em que conecta em seu princípio filosófico a uma abordagem fenomenológica. Além da pesquisa bibliográfica empreendida e do levantamento de concepções de conceitos científicos entre os estudantes, o trabalho faz uso de algumas autonarrativas produzidas durante um ano de trabalho com formação de professores em língua portuguesa no âmbito de Cooperação Internacional Brasil-Timor em 2007, no Programa de Qualificação Docente e Ensino de Língua Portuguesa no Timor-Leste (PQLP). Entre os achados educacionais, podese apontar uma constante revisão do currículo da educação básica para adequações a políticas de governo; a dificuldade com a língua portuguesa como língua de instrução e a gradual diminuição de seu uso a partir das primeiras séries do ensino primário; a imprecisão conceitual dos estudantes para as situações-problema utilizadas em face a problemas que vão desde a utilização de livros didáticos em português, passando também pela própria dificuldade dos professores com a língua portuguesa, por sua formação básica e pelo esforço do Timor em sua formação continuada.

Palavras-chave: Ensino de ciências; Ensino primário em Timor-Leste; Estudo de concepções; teoria pós-colonial. 


\begin{abstract}
This thesis looks at the current state of education in Timor-Leste with the center of attention in their teaching of science in basic education, especially primary education. In this sense, looking for answers to questions about a recent country autonomy, rebuilding of long colonial process and subsequent occupation by another country, builds its education system in various fronts, especially in choosing your curriculum and teacher training. It also discusses the challenges of her multilingualism on the Portuguese language as official for education and low adherence of the population. Seeking understanding for the East Timorese identity, undertake a study of its history to establish the foundations of explanatory research findings with students of elementary school. This is a study of conceptions of science concepts between two samples of students, a public school and other private school, through application problem situations that deal with this content in the science curriculum. The theoretical approach in the face of the decolonizing challenges, using postcolonial theory in its educational aspect, the time you plug in your philosophical principle to a phenomenological approach. In addition to the undertaken literature search and survey of scientific concepts among students, the work makes use of some self narratives produced over a year of working with teacher training in Portuguese language within Brazil-Timor International Cooperation in 2007, the Program Teacher Qualification and Portuguese Language Teaching in Timor-Leste (PQLP). Among the educational findings, can be point a constant review of the basic education curriculum for adjustments to government policy, the difficulty with the English language as the language of instruction and the gradual reduction of its use from the first grades of primary education, the conceptual vagueness of students for problem situations used in the face of problems ranging from the use of textbooks in Portuguese, passing also by the difficulty of teachers with the Portuguese language, in basic training and the Timor effort in their training continued.
\end{abstract}

Key words: Science teaching; primary education in East Timor; Study concepts; postcolonial theory. 


\section{RESUMÈ}

Cette thèse se penche sur l'état actuel de l'éducation au Timor-Leste avec une coupe dans leur enseignement de la science dans l'éducation de base, en particulier l'enseignement primaire. En ce sens, la recherche de réponses aux questions sur une autonomie de campagne récente, la reconstruction de long processus coloniale et l'occupation ultérieure par un autre pays construit son système d'éducation dans divers domaines, en particulier dans le choix de votre formation du curriculum et enseignant. Il aborde également les défis de son multilinguisme sur la langue portugaise comme officiel pour l'éducation et la faible adhésion de la population. Cherchant la compréhension de l'identité du Timor oriental, entreprendre une étude de son histoire pour établir les bases des résultats de recherche explicatives avec les élèves de l'école élémentaire. Ceci est une étude des conceptions de concepts scientifiques entre deux échantillons d'élèves, une école publique et une école privée à travers l'application des situations problématiques qui traitent de ce contenu dans le programme de sciences. Pour faire face aux défis de la décolonisation, en utilisant la théorie postcoloniale dans son aspect éducatif, le temps que vous branchez votre principe philosophique à une approche phénoménologique. En plus de la recherche documentaire réalisée et l'étude des concepts scientifiques concepts chez les élèves, le travail fait usage de certaines autonarrativas produites au cours d'une année de travail avec la formation des enseignants en anglais au Brésil-Timor Coopération internationale en 2007, le programme Professeur Qualification et portugais Langue d'enseignement au Timor-Leste (PQLP). Parmi les résultats éducatifs, on peut pointer vers un examen permanent des programmes d'éducation de base pour les ajustements aux politiques gouvernementales; la difficulté avec la langue anglaise comme langue d'enseignement et la réduction progressive de son utilisation dès les premières années de l'enseignement primaire; l'imprécision conceptuelle des élèves pour les situations problématiques utilisés face à des problèmes allant de l'utilisation des manuels en portugais, en passant aussi par la difficulté des enseignants avec la langue portugaise, dans la formation de base et de l'effort Timor dans leur formation continué.

Most-clés: L'enseignement des sciences; l'enseignement primaire au Timor-Leste; Concepts d'étude; la théorie postcoloniale. 


\section{REZUMU}

Teze ida ne'e hare liu ba kondisaun ikus edukasaun iha Timor Loro Sa'e, konaba ensinu siensias bazikas ba edukasaun primaria. Buka hatene oinsa Timor Loro Sa'e hari nia sistema edukativu, kurikulu no formasaun ba profesor sira, Timor Loro Sa'e nudar nasaun foun, nebe liu hosi prosesu kolonial naruk, no mos foin hakses a'an hosi nasaun seluk nia ukun. Koalia kona mos ba dezafius plurilinguismu, lian portugues nudar lian ofisial nebe uza hodi hanorin iha eskola, ema barak maka la koalia lian ne'e. Peskiza ne'e halo ba estudantes eskola bazika, atu hetan referensia hodi hatene diak liu tan identidade timor nian. Teze ne'e mos buka hatene kosepsaun konseitu siensia konaba konteudu kurikulu siensia nian, liu hosi dalan aplikasaun situasaun-problema nebe uza tanesan rua: ida hosi eskola privada no seluk hosi eskola publika. Hanesan referensia teorika kona ba dezafiu deskolonizadores, uza teoria pos-kolonial iha nia variante edukasional nebe kesi ba prinsipiu filozofiku ba abordazem fenomenologiku. Alemde peskiza bibliografika no levantamentu konsepsaun konseitus sientifikus entre estudante sira, peskiza ne'e utiliza autonarativas balun nebe produz durante tinan ida ho formasaun lian portugues ba profesor sira, liu hosi ambitu koperasaun internasional BrasilTimor iha 2007; iha programa kualifikasaun dosente no hanorin lian portugues iha Timor Loro Sa'e (PQLP). Rezultadu peskiza hatudu katak, kurikulu edukasaun basika, iha Timor Loro Sa'e, muda beibeik tuir politika governu nian; difikuldade lian portugues hanesan lian instrusaun no diminuisaun gradual lian ne'e iha serie dahuluk iha ensinu primariu; konseitu estudante sira nian konaba situasaun-problema neb'e ladun lo'os tamba material didatiku ho lian portugues, nune'e mos profesor sira laiha formasaun basika nebe diak iha lian portugues, no mos laiha esforsu hosi governu Timor hodi fo formasaun beibeik ba professor sira.

Lian savi: Ensinu siensias, Ensinu primariu iha Timor Loro Sa'e, Estudu konsepsaun, teoria pos-kolonial 


\section{Dados Gerais - Timor-Leste}

Área: $15.007 \mathrm{~km} 2$

Moeda: Dólar Americano (USD)

População:1.261.072

habitantes (estimada em 2016)

PIB Per capita: US\$ 5.600,00

(2015)

Alfabetização:

População aos 15 anos que sabem ler e escrever: $67 \%$.

Fonte: Timor-Leste in CIA World

Factbook. Central Intelligence Agency. Consulta em 07/09/2016.

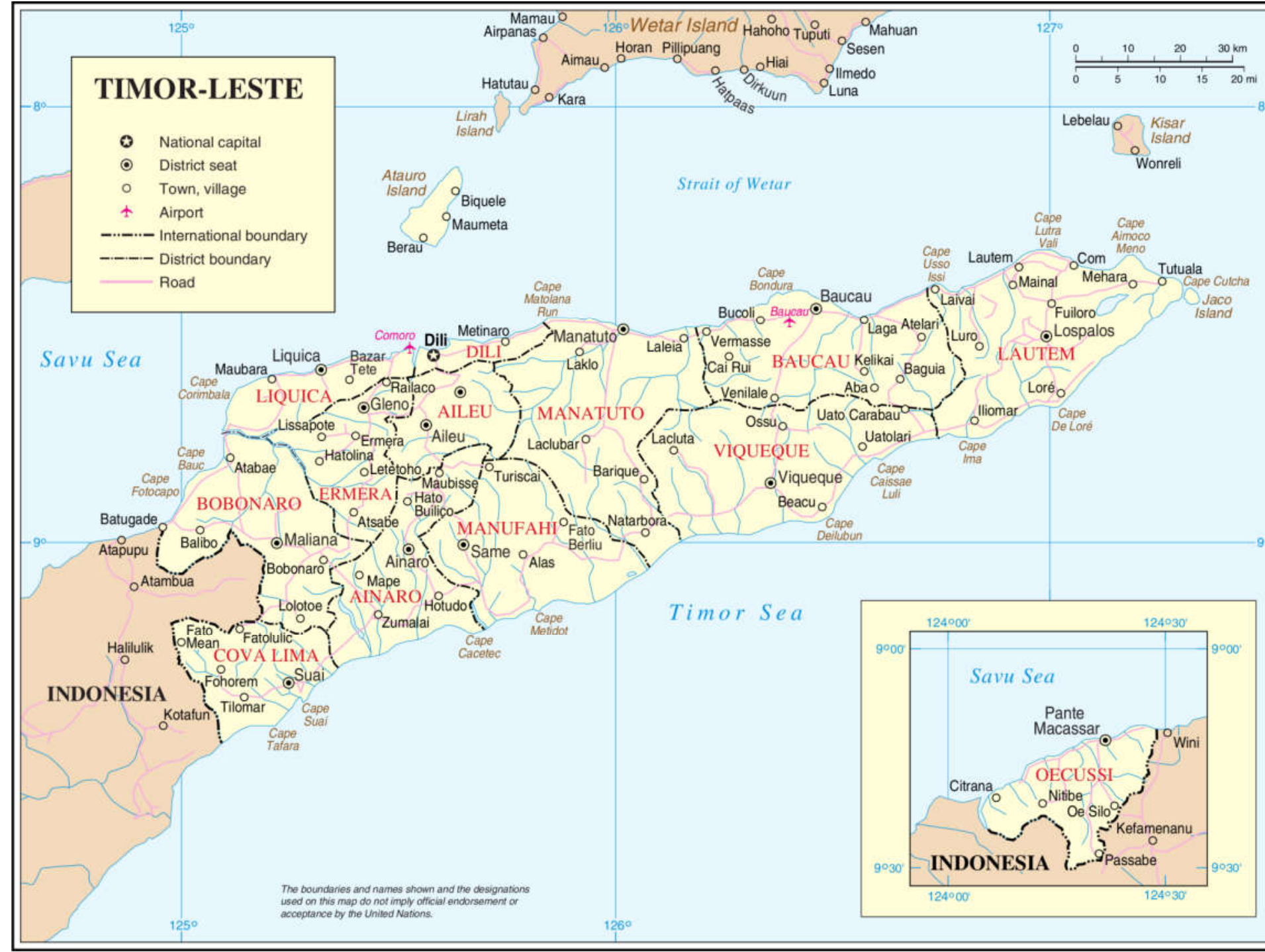




\section{LISTA DE TABELAS}

TABELA 1 Categorias de conceitos a serem contempladas nas

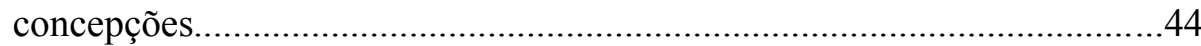

TABELA 2 Quadro da organização do ensino básico para o primeiro e segundo ciclo

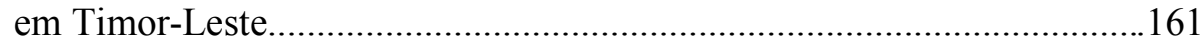

TABELA 3 Relação de respostas dos estudantes da Escola Básica Filial para a situação-problema 1.................................................................................206

TABELA 4 Relação de respostas dos estudantes da Escola Básica Filial para a situação-problema 2 ...........................................................................207

TABELA 5 Relação de respostas dos estudantes da Escola Básica Filial para a situação-problema 3...............................................................208

TABELA 6 Relação de respostas dos estudantes da Escola Básica Filial para a situação-problema 4................................................................209

TABELA 7 Relação de respostas dos estudantes da Escola João XXIII para a situação-problema 1 .....................................................................213

TABELA 8 Relação de respostas dos estudantes da Escola João XXIII para a situação-problema 2.................................................................215

TABELA 9 Relação de respostas dos estudantes da Escola João XXIII

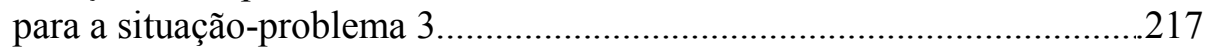

TABELA 10 Relação de respostas dos estudantes da Escola João XXIII

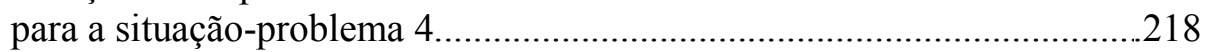

TABELA 11 Quadro de categorias de respostas obtidas - Escola Básica

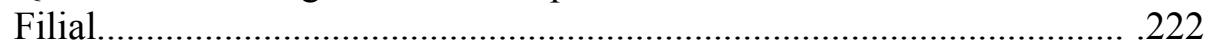

TABELA 12 Quadro quantitativo de respostas obtidas por categorias Escola João XXIII.........................................................................226 


\section{LISTA DE GRÁFICOS}

GRÁFICO 1 Frequência das respostas obtidas por categorias para a situação-problema 1 - Escola Básica Filial - Dili - Timor-Leste...............222

GRÁFICO 2 Frequência das respostas obtidas por categorias para a situação-problema 2 - Escola Básica Filial - Dili - Timor-Leste...............223

GRÁFICO 3 Frequência das respostas obtidas por categorias para a situação-problema 3 - Escola Básica Filial - Dili - Timor-Leste................224

GRÁFICO 4 Frequência das respostas obtidas por categorias para a situação-problema 4 - Escola Básica Filial - Dili - Timor-Leste...............225

GRÁFICO 5 Frequência das respostas obtidas por categorias para a situação-problema 1 - Escola João XXIII - Dili - Timor-Leste..................227

GRÁFICO 6 Frequência das respostas obtidas por categorias para a situação-problema 2 - Escola João XXIII - Dili - Timor-Leste..................228

GRÁFICO 7 Frequência das respostas obtidas por categorias para a situação-problema 3 - Escola João XXIII - Dili - Timor-Leste.

GRÁFICO 8 Frequência das respostas obtidas por categorias para a situação-problema 4 - Escola João XXIII - Dili - Timor-Leste. 


\section{LISTA DE ILUSTRAÇÕES}

FIGURA 1 Fotografia de encontro presencial do PROFEP-Timor em

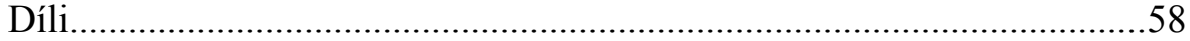

FIGURA 2 Foto da Cópia do Jornal Diário de Lisboa de 27 de agosto de 1975

informando sobre a saída do Governo Português de Timor-Leste para a

ilha de Ataúro - Museu da Resistência Timorense em

Díli.

FIGURA 3 Fotografia do texto da proclamação da independência de Timor-Leste, tirada da exposição permanente do Museu da Resistência Timorense em Díli.....

FIGURA 4 Foto de plantação de kanku em Díli - tabuleiro feito com esgoto represado.

FIGURA 5 Imagens mostrando algumas profissões no Timor-Leste retirada de livro didático oficial (Estudo do Meio - $1^{\circ}$ Ano do Ensino Básico. Porto: Ed. Porto, 2012. p. 36 e 58.).

FIGURA 6 Imagem que solicita da criança a identificação do padrão aceitável de asseio pessoal, retirado do Livro Didático oficial (Estudo do Meio - $2^{\circ}$ Ano do Ensino Básico. Porto: Ed. Porto, 2012. p. 62.).

FIGURA 7 Na bandeira de Timor-Leste, o amarelo representa os rastros do colonialismo,o preto o obscurantismo que é preciso vencer, o vermelho a luta pela libertação nacional e o branco a paz.

FIGURA 8 Belak (globo terrestre onde se inclui o território de Timor-Leste, símbolo da unidade nacional) Emblema Nacional de Timor-

Leste.

FIGURA 9 Fotografia da placa com o nome da Escola Básica Filial onde realizou entrevistas com alunos.................................................................182

FIGURA 10 Fotografia de uma sala de aula da Escola Básica Filial..............................182

FIGURA 11 Fotografia de crianças varrendo o pátio da Escola Básica Filial no início da manhã antes das aulas.

FIGURA 12 Fotografia dos alunos do matutino da Escola Básica Filial em "formação" antes das aulas.

FIGURA 13 Fotografia da turma de $6^{\circ}$ ano que participou do estudo de concepções.

FIGURA 14 Fotografia da fachada da Escola João XXIII em Audian - Díli.....................210

FIGURA 15 Turma de $7^{\circ}$ Ano do $3^{\circ}$ Ciclo da Escola João XXIII...................................211

FIGURA 16 Notícia do Jornal Timor Post atestando o radicalismo de uma direção de escola para o uso da língua portuguesa....................................236

FIGURA 17 Foto de alguns professores formadores, tutores e cursistas no Centro Nacional de Resistência Timorense (CNRT) em Díli.....................238

FIGURA 18 Foto de cena comum na cidade de Díli: animais e lixo...............................242

FIGURA 19 Foto de um valão de esgoto muito comum nas ruas de Dili......................243

FIGURA 20 Guerreiros com vestimentas típicas por ocasião da pose do Presidente da República Ramos-Horta em 2007.....................................250

FIGURA 21 Foto do embarque para o Timor, em Darwin, Austrália.............................274

FIGURA 22 Foto da casa da primeira morada em Bidau Lecidere.................................278 
FIGURA 23 Foto da rua no bairro Bidau Lecidere em Díli, onde se localizava a casa alugada inicialmente ..................................................279

FIGURA 24 Foto de crianças da periferia de Díli, Timor-Leste.....................................280

FIGURA 25 Foto da sala do Ministério da Educação e do estacionamento com alguns carros incendiados......................................281

FIGURA 26 Foto da reunião na Embaixada de Brasil em Díli com o

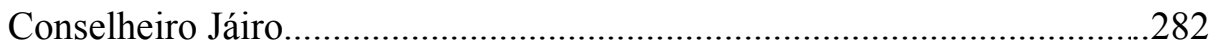

FIGURA 27 Foto dos professores brasileiros em frente a Embaixada de

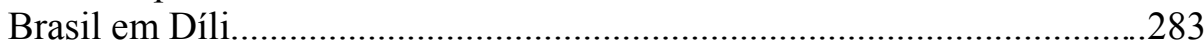

FIGURA 28 Foto de morador típico das montanhas com seus filhos.............................284

FIGURA 29 Foto da assinatura de acordos no campo da educação, BrasilTimor - Conselheiro Jário e Ministra da Educação D. Rosália...................287

FIGURA 30 Foto de encontro presencial com professores cursistas lorosae em Díli, Timor-Leste............................................................................298

FIGURA 31 Foto de alunos em escola primária do distrito de Vemasse - Timor-

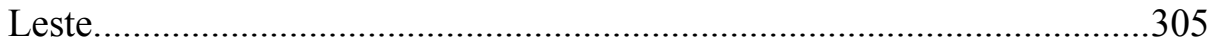

FIGURA 32 Foto de professores Cursistas em fase presencial em Baucau - Timor-Leste.

FIGURA 33 Foto de professores cursistas loromonu, ex-guerrilheiros de Baucau - Timor-Leste

FIGURA 34 Foto de professores cursistas loromonu de Baucau - TimorLeste. 


\section{LISTA DE SIGLAS E ABREVIATURAS}

AGF

AIDIT

APODETI

ASDT

CDT

CAPES

CPLP

CNRM

CNRT

CTS

CVA

FALINTIL

FE

F-FDT-L

FRETILIN

INFORDEPE

INL

ISC

INTERFET

LC

MEC-Timor

MFA

ML

PB

PC

PF

PQLP

OCDE

ONU

PISA

PROFEP-Timor

PROFORMAÇÃO

RDTL

TR

UDT

UNESCO

UNICEF

UNTAET

UNTIM

$\mathrm{VN}$

VOSTS
Agência Formadora

Associação para a Integração de Timor-Díli na Indonésia

Associação Popular Democrática Timorense

Associação Social Democrática de Timor-Leste

Comissão de Descolonização de Timor

Coordenação de Aperfeiçoamento de Pessoal de Nível Superior

Comunidade dos Países de Língua Portuguesa

Conselho Nacional da Resistência Maubere

Centro Nacional de Resistência Timorense

Ciência, Tecnologia e Sociedade

Caderno de Verificação de Aprendizagem

Forças Armadas de Libertação e Independência de Timor-Leste

Fundamentos da Educação

Forças de Defesa de Timor-Leste

Frente Revolucionária de Timor-Leste Independente

Instituto Nacional de Formação de Docentes e Profissionais da Educação

Instituto Nacional de Linguística

Identidade, Sociedade e Cultura

Força Internacional para o Timor-Leste

Linguagens e Códigos

Ministério da Educação de Timor-Leste

Movimento das Forças Armadas

Matemática e Lógica

Prova Bimestral

Professor Cursista

Professor Formador

Programa de Qualificação Docente e Ensino de Língua Portuguesa no

Timor-Leste

Organização para a Cooperação e Desenvolvimento Econômico

Organizações das Nações Unidas

Programme for International Student Assessment

Programa de Formação de Professores em Exercício na Escola

Primária do Timor-Leste

Programa de Formação de Professores em Exercício

República Democrática de Timor-Leste

Tutor

União Democrática Timorense

Organização das Nações Unidas para Educação, Ciência e Cultura

Fundo das Nações Unidas para a Infância

United Nations Transitional Administration for East Timor

Universitas Timor Timur

Vida e Natureza

Views on Science Technology-Society 


\section{SUMÁRIO}

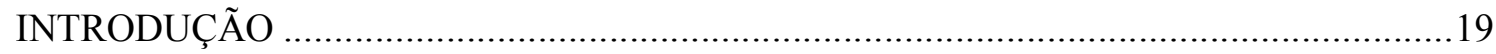

CAPÍTULO 1 - Exposição preambular.............................................................................22

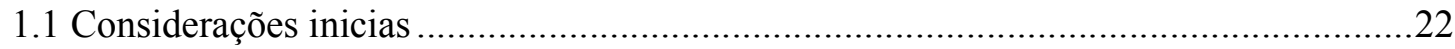

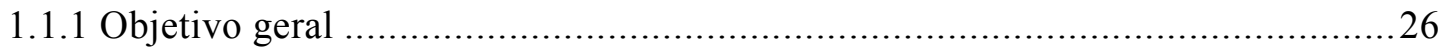

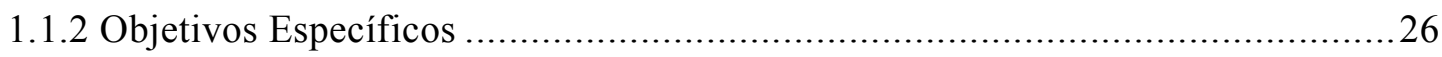

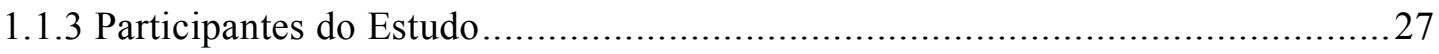

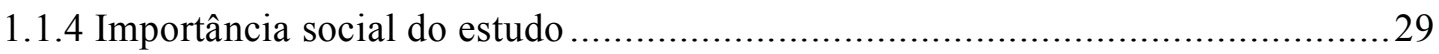

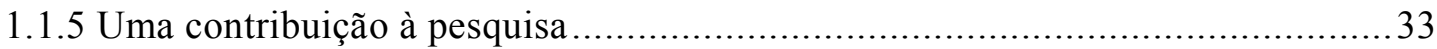

1.1.6 Problematização do objeto de estudo e hipótese principal ............................. 34

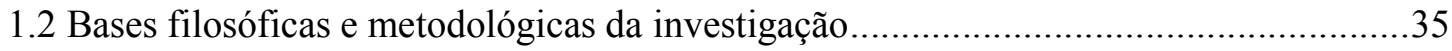

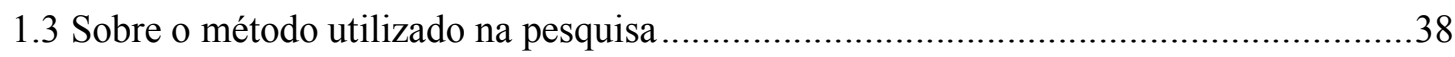

1.3.1 Procedimentos de pesquisa............................................................. 48

1.3.2 Critérios de escolha dos grupos participantes ....................................... 49

CAPÍTULO 2 - Colonização, invasão indonésia e autonomia............................................51

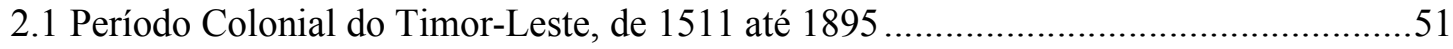

2.1.1 Breves considerações sobre a História Colonial do Timor-Leste até o século XIX

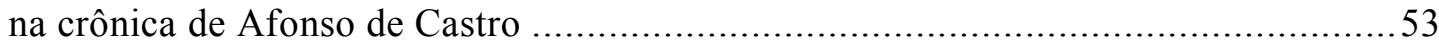

2.1.2 A ocupação branca de Timor compreendida por Teófilo Duarte até a primeira

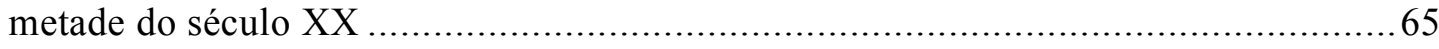

2.1.3 O sofrimento do Timor na ocupação japonesa na Segunda Guerra Mundial, movimentos libertários, independência unilateral e invasão Indonésia ..................... 75

2.1.4 Plebiscito pela independência, guerra das milícias destruição e reconstrução do

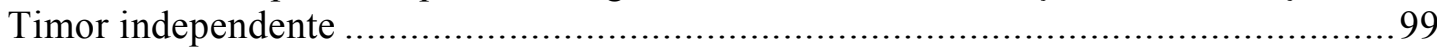

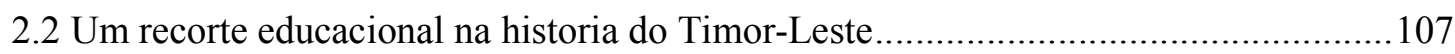

CAPÍTULO 3 - Fundamentação teórica do trabalho ....................................................... 114

3.1 Amparo Teórico - Fundamentando a Pesquisa ...................................................... 114

3.2 Bases da escolarização mundial e do ensino de ciências ......................................... 120

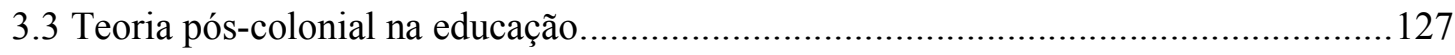

CAPÍTULO 4 - Achados educacionais: dados da pesquisa ............................................. 134

4.1 Narrativas e reflexões, a gênese da minha atuação na formação de professores, buscando o espírito do Timor-Leste em uma visão subjetiva ........................................... 134

4.1.1 Primeiro "encontro" com o Timor-Leste .................................................... 139

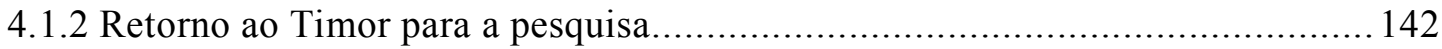

4.1.3 Desvelando o currículo de ciências da educação básica primária em Timor-Leste

4.2 Organização Curricular do Ensino Básico ............................................................... 160

4.2.1 Abordagem curricular no Estudo do Meio da escola primária - $1^{\circ}$ ano ............ 161 
4.2.2 Abordagem curricular no Estudo do Meio da escola primária $-2^{\circ}$ ano $\ldots \ldots \ldots \ldots . . .166$

4.2.3 Abordagem curricular no Estudo do Meio da escola primária - $3^{\circ}$ ano ............ 169

4.2.4 Abordagem curricular no Estudo do Meio da escola primária - $4^{\circ}$ ano ............ 173

4.2.5 Abordagem curricular no Estudo do Meio da escola primária - $5^{\circ}$ ano ............ 175

4.2.6 Abordagem curricular no Estudo do Meio da escola primária $-6^{\circ}$ ano ........... 177

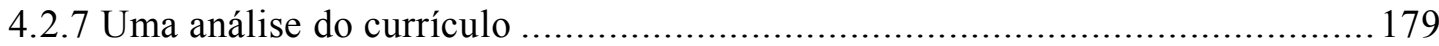

4.3 Concepções dos alunos para as situações-problema - Entendendo as respostas das

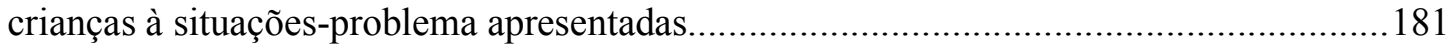

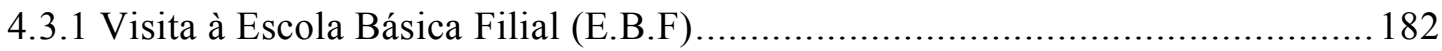

4.3.2 Visita à Escola João XXIII......................................................... 210

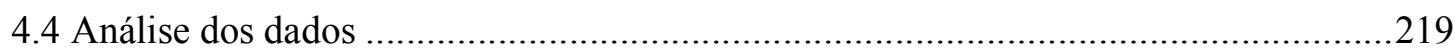

CAPÍTULO 5 - Resultados e conclusões - considerações finais......................................232

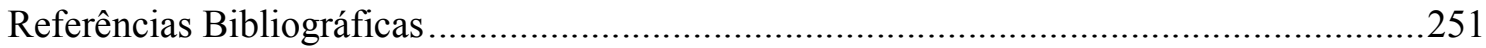

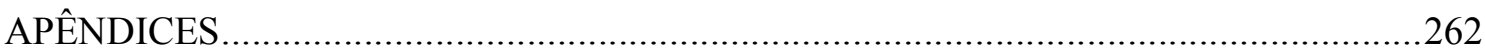

Anexo 1. Cópia da "Carta de Apresentação" do Programa de Pós-Graduação em Educação da Faculdade de Educação da Universidade de Brasília ..........................................................263

Anexo 2. Atestado de residência em Díli no Timor-Leste no ano de 2007..........................264

Anexo 3 - Entrevista com a Senhora Filomena Lay, Diretora do INFORDEPE, concedida no

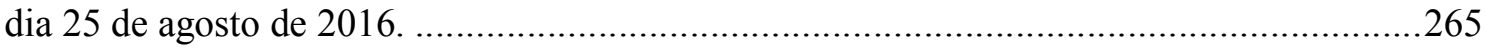

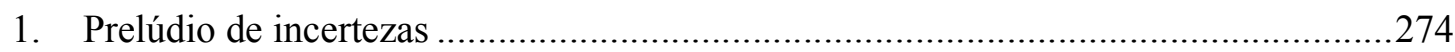

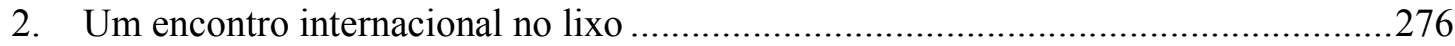

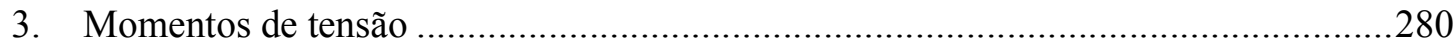

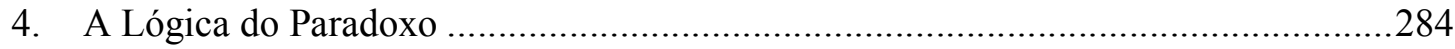

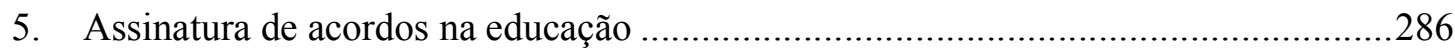

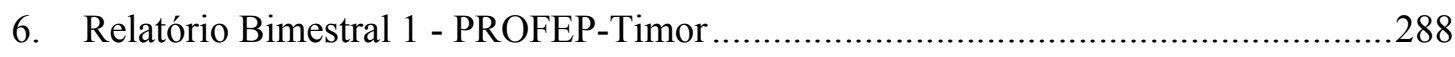

7. Anexos - Relatório Bimestral - PROFEP-Timor....................................................295

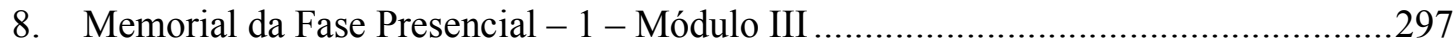

9. Memorial da Visita ao $1^{\circ}$ Encontro Quinzenal - PROFEP-Timor, à ilha de Ataúro -

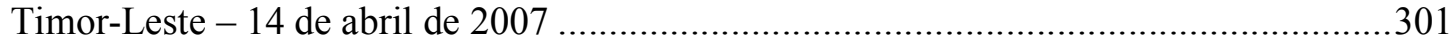

10. Memória do Encontro Quinzenal do dia 5 de maio de 2007 - PROFEP-Timor-Leste . 303

11. Memória do Encontro Quinzenal do dia 19 de maio de 2007 - PROFEP-Timor-Leste 309

12. Memória da Segunda Fase Presencial do Módulo III - Baucau ..............................313

13. Memória do acompanhamento do Encontro Quinzenal do dia 7 de julho de 2007.321

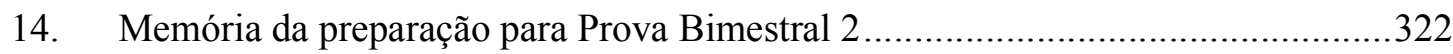

15. Memória da realização da PB2, 28 de julho de 2007 ............................................323

16. Breves observações em uma viagem a Kupang, Nusa Tengara .............................324 


\section{INTRODUÇÃO}

A presente tese é o resultado de uma vivência que tem sua gênese na experiência do autor na formação de professores nos últimos 16 anos, centrando-se, porém, na atuação neste campo no Timor-Leste no ano de 2007 que serviu de parâmetro para as inquietações que suscitaram os encaminhamentos do trabalho de pesquisa realizado, bem como pesquisa de campo realizada no país no ano de 2016. Neste sentido, procura entender como está ocorrendo o ensino de ciências na escola básica daquele país, buscando compreender os pressupostos que determinam o currículo de ciências, a formação de professores, a aquisição de conceitos na escola básica em contextos plurilinguístico, as dificuldades vividas enraizadas no seu passado histórico colonial e os impasses enfrentados nos contextos pós-coloniais de uma escolarização universal em um mundo globalizado.

Para obter-se uma visão geral do trabalho, se fará inicialmente no Capítulo 1, intitulado "Exposição preambular", uma explanação preliminar sobre aspectos gerais da pesquisa. Assim, no corpo desta seção são feitas considerações gerais que procuram mostrar o objeto de estudo e sua temática que será deslindada ao longo do trabalho.

$\mathrm{Na}$ sequência são apresentados os objetivos gerais e específicos a serem alcançados no estudo, considerações sobre os grupos participantes e suas particularidades em função das realidades da pesquisa de campo. Após esses apontamentos iniciais se procederá à argumentação sobre a importância social do estudo e os elementos motivadores que levaram à sua realização. Servindo de circunscrição inicial do objeto de estudo são feitas breves considerações sobre as fases da educação em Timor-Leste, para posteriormente abordar a problematização em conjunto com a hipótese principal a ser demonstrada. Em continuação preambular neste capítulo, são apontadas as bases filosóficas e metodológicas que permeiam e orientam o trabalho respectivamente, os procedimentos de pesquisa e a escolha dos integrantes.

No Capítulo 2, intitulado "Colonização, invasão indonésia e autonomia" é explanada a história do Timor-Leste, sob a ótica de dois antigos governadores portugueses, Afonso de Castro, que governou o Timor no século XIX e Teófilo Duarte cujo governo foi de 1927 a 1929 do século XX. O primeiro autor, provavelmente, apresenta uma das primeiras crônicas sobre o território timorense, em que lamenta o desprezo que Portugal deu ao Timor enquanto colônia quando comparado com o resto do império lusitano e o segundo autor apresenta os argumentos que justificam esse descaso português por essa colônia. Além dessas duas, foram 
utilizadas as obras de Barbedo de Magalhães (2007) em três volumes e algumas citações da obra de Ximenes Belo de 2013.

À luz dessas obras citadas, inicialmente são contempladas considerações sobre o domínio religioso católico e as bases para a percepção do atraso educacional pelo qual passou aquele território, procedendo-se apreciações sobre a história do Timor no século XX, com um maior detalhamento dos fatos marcantes da Segunda Guerra Mundial, bem como elementos que conduziram à declaração unilateral de independência do Timor-Leste de Portugal e os encaminhamentos que acarretaram a invasão da Indonésia, sua permanência e o papel da Resistência até a independência final.

Mesmo que pareça extenso, esse capítulo representa uma síntese dos fatos tratados nestes documentos históricos e a intenção aqui é servir de subsídio mínimo para se entender as "razões" do Timor, posteriores consequências sobre sua educação e o patamar que se apresenta atualmente. Neste caminho, dito de outra maneira, é impossível abordar e entender pontos que hoje são apenas efeitos de causas implantadas na história sem que se recorra à mesma de modo mais detalhado.

No Capítulo 3 intitulado "Fundamentação teórica do trabalho", são mostrados os conceitos envolvidos na pesquisa para a presente tese, bem como a tratativa dentro das concepções teóricas que a embasam, ainda que de modo analítico, optando-se em determinadas situações por um posicionamento crítico a respeito das mesmas. Nesse sentido, o capítulo procurará envolver conceitos no campo da teoria pós-colonial, abarcando assim as concepções conceituais associadas a multiculturalismo, transculturalismo ou interculturalismo, monoculturalismo, pluriculturalismo, currículo plural, relativização cultural, integração e inclusão social, todos atrelados ao ensino de ciências, de modo a vincular sua compreensão ao estudo das concepções de conceitos das ciências dos estudantes da escola primária em Timor Leste.

O Capítulo 4, cujo título é "Achados educacionais: dados da pesquisa", inicialmente aborda a gênese do trabalho do autor em formação de professores no Brasil no PROFORMAÇÃO (Programa de Formação de Professores em Exercício) com o intuito de estabelecer elos entre esta experiência e a vivida em Timor-Leste, seus atores e idiossincrasia, as similaridades e diferenças. Este capítulo também explicitará a partir das narrativas com o trabalho de formação de professores no PROFEP-Timor (Programa de Formação de Professores em Exercício na Escola Primária do Timor-Leste) em 2007, a essência do timorense, alicerçada na subjetividade da experiência vivida, no estranhamento imanente 
característico do olhar estrangeiro em choque cultural ${ }^{1}$. Em continuação estão delimitados os achados na pesquisa do levantamento de concepções dos estudantes de conceitos científicos básicos segundo o previsto apontado no capítulo 1 desta tese, resultados e análises interpretativas, da pesquisa realizada em Timor-Leste como trabalho de campo, embasado no referencial teórico.

No capítulo 5 são mostrados os resultados e as conclusões que se revelam diante do que se viveu e pesquisou, estabelecendo as conexões entre os dados coletados, os contextos culturais e a própria história do Timor-Leste. Neste capítulo estas tessituras se imbricam para que as conclusões sejam reveladas.

Por fim, nos apêndices podem ser encontrados alguns documentos, como o resumo do currículo na sua parte de ciência em tétum, as narrativas (dispensáveis para leitura) que podem auxiliar na construção de uma ideia sobre o trabalho de formação de professores, as tensões vividas, os conflitos que permitem a elaboração de uma nuvem de compreensões que emergem com uma percepção do todo.

\footnotetext{
${ }^{1}$ A expressão "choque cultural" foi cunhada pela primeira vez pelo antropólogo canadense Kalervo Oberg (1901-1973) em artigo de 1960 que a definiu como o resultado do contato com uma nova cultura, precipitada pela ansiedade que resulta de perda de todos os seus sinais e símbolos das relações sociais familiares (ORBERG, 1960). Bem apropriada para o sentimento que me acudiu diante do Timor.
} 


\title{
CAPÍTULO 1 \\ Exposição preambular
}

\subsection{Considerações inicias}

O mundo contemporâneo não é mais o mesmo quando comparado com o período em que foram lançadas as bases da escolarização tal qual se conhece, entre os séculos XV e XVII (ARIÈS, 1986). As tecnologias de informação e comunicação tornaram o planeta "uma aldeia global modelada por uma tecnologia que nos permite acompanhar o desenrolar dos eventos em tempo real, ainda que aconteçam a milhares de quilômetros de distância" (GRANT; KHURSHID, 2012). Um cenário confuso e de difícil previsibilidade com intenso fluxo de imigração, conflitos locais, guerras regionais, disputas ideológicas e religiosas, inseridas em cenários econômicos múltiplos, em panoramas desenhados por blocos econômicos diversos, são algumas modelagens que estão como pano de fundo para possibilitar uma visualização sobre a educação de modo geral e a educação em ciência especificamente nestes contextos.

Buscando-se as bases da escolarização contemporânea em meio a uma discussão sobre escolarização mundial e sua governança ${ }^{2}$ que a cada dia ganha corpo no campo da multiculturalidade, algumas reflexões são inquietantes. Os aspectos culturais particulares de cada povo surgem como elementos de estudos (FILHO, 2004). Diante dos desafios do tempo presente, a educação ganha outras emergências. Como afirma Cambi (1999, p.638),

\begin{abstract}
[...] novas exigências e novas fórmulas educativas, novos sujeitos dos processos formativos/educativos e novas orientações político-culturais. Três, em particular, foram relevantes e todas elas introduzidas pelas profundas transformações sociais e culturais ocorridas já nos decênio anteriores e que de modo particular fizeram sentir sua urgência (e a sua voz) na pedagogia mais recente [...]. O primeiro fenômeno foi o do feminismo, o segundo foi aquele ligado à emergência do problema ecológico, produzido pela industrialização descontrolada e pela ideologia do domínio/exploração da natureza, o terceiro liga-se ao crescimento de etnias presentes nos países desenvolvidos e aos problemas multiculturais que tal presença provoca.
\end{abstract}

Assim, entender estes e outros aspectos no âmbito do processo de escolarização nos modelos ocidentais disseminados pelo mundo é fundamental para a interpretação das consequências na formação dos cidadãos nos contextos pós-coloniais.

Ainda que um estudo profundo na literatura técnica disponível sobre o assunto seja substancial para a formação de um corpo de entendimento, observar estes e outros elementos

\footnotetext{
${ }^{2}$ Governança na educação é entendida aqui como conjunto de agentes atuantes no âmbito do público e do privado, bem como seus procedimentos, papéis e intervenientes no campo educacional.
} 
em operação é estimulante, pois permite contribuir nesta esfera com um olhar sobre as forças culturais em face a uma escolarização hegemônica e homogênea em contextos pós-coloniais. Neste sentido, o presente trabalho, ao investigar o currículo da educação básica, procura analisar, por meio de um estudo de concepções ou construtos dos estudantes, conceitos científicos adquiridos no componente curricular "Estudo do Meio" onde as ciências se inserem na escola primária em Timor-Leste.

A adoção dos termos "concepções" ou "constructos" para este estudo em lugar do termo "representação" mais comumente utilizado na literatura, se baseia do estudo realizado por Wortmann (2001) sobre as novas tendências neste campo, ao citar autores como André Giordan \& Gérard De Vechi (1996) que atuam na área de aprendizagem em Ciências que vêem o termo "representação" ser utilizado de muitas maneiras diferentes e variados significados a depender da escola de pensamento que os utilizam, como na Psicologia, filologia, Linguística, Etnologia, Filosofia, Sociologia, Pedagogia ou Didática. Segundo a autora, Giordan \& De Vechi,

referem que levantaram cerca de 28 qualificativos relativamente a esse termo, que incluem desde a ideia de pré-representações remanescentes até a de pré-requisitos, e 27 sinônimos, entre os quais estão as expressões já presentes e pupils paradigmes. Segundo eles, isso tende a tornar o conceito de representação "um conceito 'frouxo', de definição confusa, para não dizer uma simples palavra mascarante". Neste mesmo trabalho, publicado no início da década de noventa, os autores propuseram a substituição do termo representação - utilizado extensamente por investigadores e investigadoras francesas em didática das Ciências, como Guy Rumelhard, Brigite Peterfalvi, Jean-Pierre Astofi, Anne Vérin, Pierre Cláment, Samuel Joshua, e pelo próprio André Giordan em trabalhos anteriores - por concepção ou constructo, por lhes parecer ser necessário deixar mais claras as situações a que estariam se referindo. (WORTMANN, 2001, p. 153).

Os autores ainda apontam o termo "concepção" como um conjunto de ideias coordenadas e imagens coerentes, explicativas em um primeiro nível, para raciocinar diante de situações-problema por parte dos estudantes. "ressaltando a ideia de que esse conjunto traduz uma estrutura mental subjacente, que é responsável por essas manifestações contextuais" (WORTMANN, 2001, p. 153). Quanto ao termo "constructo", este evidencia a ideia da existência de um elemento motor que entra na construção de saberes. Para Wortmann (2001, p. 153), os autores,

entendem ser necessário lidar com os processos de evolução das representações dos sujeitos para relacioná-las com o que eles referem ser "as tramas conceituais". Tal procedimento lhes parece necessário para permitir o estabelecimento de estratégias pedagógicas fundadas na análise dos processos de aprendizagem. 
Nesta abordagem, o Timor-Leste, país recentemente saído do domínio colonial português e da violação da sua soberania pelo invasor ${ }^{3}$ indonésio, representa um "caldeirão cultural" com suas etnias em contextos plurilingüísticos, recente reconstrução e inserção no mundo como nação autônoma. Mundo este apoiado na ciência e no império das nações centrais, possivelmente sem muito espaço para reconhecimento de outros valores que não os científicos. Todavia, mesmo diante das circunstâncias atuais, esse aspecto multicultural do Timor sobrevive e aparece na sua escolarização em ciência?

A valorização do ensino científico parece ser unanimidade no discurso contemporâneo e este se associa às diversas concepções sobre a natureza da ciência. Desde as ingênuas que vêem a ciência como uma panaceia salvacionista, passando pelo utilitarismo tecnológico que facilita a vida, aos que a vêem como um potencial perigo para a sobrevivência da humanidade e para o planeta como um todo. Basta observar a literatura de ficção científica difundida nos roteiros de cinema e na cultura pop que transformam o mundo em um palco de disputa por poderes tecnológicos de aniquilação em massa, agentes portadores de descobertas diabólicas no campo da ciência que permitiriam o domínio e subjugação da espécie humana. Não é rara a analogia da aquisição do conhecimento científico com a perpetração do pecado original de Adão e Eva no paraíso na tradição judaico-cristã:

\begin{abstract}
A ideia de que o conhecimento científico é perigoso está profundamente enraizado na cultura ocidental. Adão e Eva foram proibidos de comer da Árvore do Conhecimento, e em "Paraíso Perdido" de Milton ${ }^{4}$ a serpente demarca a Árvore como a "mãe da ciência". Na verdade toda a literatura ocidental não tem sido gentil para os cientistas e está repleta com imagens de cientistas intrometendo-se na natureza, com resultados desastrosos. Basta considerar Frankenstein de Shelley, o Fausto de Goethe, e Admirável Mundo Novo de Huxley. Pode-se procurar com muito pouco sucesso um romance em que os cientistas se saiam bem - a imagem persistente é a de cientistas como um grupo sem alma, sem se preocupar com questões éticas. E onde há um filme simpático à ciência? Os cientistas são vistos como homens de meia-idade, emocionalmente debilitados, e perigosos. (WOLPERT, 1999, p.281).
\end{abstract}

Por outro lado, é marcante a presença atual de um discurso multicultural em que pela análise da existência de diferentes culturas, se busca um retorno às "origens", como sendo a saída para uma crise global de ordem política, econômica, moral, ambiental, etc. O retorno, pelo menos no campo do discurso, a um estado mais puro da ancestralidade de uma vida mais

\footnotetext{
${ }^{3}$ Nessa tese é feita diferenciação dos termos "colonização" e "invasão" em relação ao Timor, estando o primeiro associado ao domínio português e o segundo ao domínio indonésio. A literatura consultada sobre o assunto (CORRÊA \& MANCINI, 2004; PARREIRA, 2003; BRITO, 2006; SALOMÃO, 2012; BOVO, 2002) sempre referese a ação de Portugal sobre o Timor-Leste como processo colonizador enquanto a ação indonésia como invasão, haja visto que durante todo o domínio da Indonésia, a ONU nunca reconheceu a anexação do TimorLeste por aquele Estado, todavia reconhecia o território timorense como Território Não-Autônomo sob Administração Portuguesa, mesmo sob o domínio indonésio (CORRÊIA; MANCINI, 2004, p. 98).

${ }^{4}$ Paraíso Perdido de John Milton, obra poética publicada em 1667, trata-se de uma epopeia inspirada no livro do Gênesis bíblico, em que descreve a queda do homem por meio da tentação de Adão e Eva por Lúcifer e a expulsão do Jardim do Éden.
} 
integrada à natureza, com menos consumo, ou de outro modo, um consumo mais consciente com menos impacto sobre o ambiente, parece ser a tônica de um pensamento constante em vários campos da atuação humana. Como tal, nota-se reflexo disso também na educação em que modelos hegemônicos nos cânones ocidentais são postos em questionamentos e muitas vezes demonizados como uma ideologia culpada pelo estado de coisa em que se encontram nações pós-coloniais. Hilliard III (2009, p. 14) nos dá uma pequena amostra dessa tendência ao mencionar que,

o movimento multicultural está começando a entender a hegemonia europeia e os usos que ela faz da educação, bem como a magnitude dos efeitos de centenas de anos de deseducação consciente, estratégica, de comunidades inteiras. A ideologia da supremacia branca da ampla maioria dos beneficiários dessa hegemonia tem sido uma ferramenta de poder para a racionalização das estruturas de dominação e um instrumento para a sua manutenção.

Percebe-se nessa abordagem a resistência aos processos educativos ocidentais, em que o homem "branco" é representado como o elemento que exerce o poder, sendo a educação um instrumento de dominação e espoliação dos povos de cultura e etnia diversas. Na concepção de Gramsci é uma “dominação por consentimento", em que

todo poder de dominação se compõe indissoluvelmente de dois elementos que, mesclados, fazem sua força: a violência e o consentimento. [...] A força maior não é a violência dos dominantes, mas o consentimento dos dominados a sua dominação. (GODELIER, 1979, p.5).

Dominação por consentimento essa, que na educação é obtida por meio de um currículo, do que é ensinado ao colonizado, de que forma é ensinado e como posteriormente o sujeito assim "processado" (no sentido de processamento), pode ser usado na máquina imperialista de subjugação. A educação é assim, uma conquista de outro tipo de território, é a base do poder colonialista e consolida seu poder através de aparelhos judiciais e administrativos (ASHCROFT; GRIFFITHS; TIFFIN, 2003).

Levando-se em conta as considerações acima, pode-se supor que a ciência e seu ensino nos modelos ortodoxos como parte da educação estão sob uma espécie de censura, ainda que seu padrão clássico de ensino continue hegemônico. Se por um lado os aspectos de dominação e aculturação são usados como justificativa pelo multiculturalismo em busca do respeito das identidades multiculturais, por outro, a constante demonização da ciência pelo senso comum, coloca em xeque seu ensino centrado no utilitarismo e os malefícios daí advindos. Esta profusão de opiniões reforça a ideia, falaciosa ou não, de que a inserção do ensino de ciência em um universo multicultural deva refletir a necessidade das nações póscoloniais terem vez e voz na construção de um currículo para o ensino de ciências. 
Destarte, esta pesquisa intenciona uma análise da conjuntura em que o ensino de ciências atualmente se insere, levando-se em consideração correntes que se fazem representar nesse ensino, a saber, as abordagens do multiculturalismo, transculturalismo, dentro das concepções da Teoria Pós-Colonial, em um mundo globalizado, mas plural. Para isso, como referido acima, se fará um estudo de concepções de conceitos de ciências, por meio de situações-problema em um grupo de estudantes da escola primária de Timor-Leste, em função da sua recente inserção no mundo como nação autônoma e em reconstrução dos seus valores nos mais variados âmbitos, como na educação do seu povo e particularmente na educação em ciências.

As metas educativas do Timor-Leste a médio e a longo prazo, dão indicativos quanto ao caminho a seguir em sua educação. Ao observar o Plano Estratégico de Desenvolvimento (2011-2030) do Timor-Leste, o mesmo postula como perspectiva, a visão de que todas as crianças timorenses sejam atendidas pela escola e recebam uma educação de qualidade que as permitam alcançar o conhecimento e as habilidades para levar vida saudável e produtiva de modo a contribuir para o desenvolvimento da nação (UNESCO, 2015), porém, essa intenção é vaga e deve passar por uma ação educativa estruturada em que se visualize no presente as possibilidades de intervenção com vistas ao alcance dos objetivos futuros.

\subsubsection{Objetivo geral}

O objetivo geral da pesquisa aqui delimitada é o de realizar um estudo analítico dos saberes em ciências na escola primária do Timor-Leste, por meio de exame de concepções das crianças do ensino neste nível naquele país, pesquisando o currículo de ciências e quais os fatores intervenientes do ponto de vista histórico e cultural que determinam sua construção. Buscando compreender os desafios enfrentados pelo sistema educacional timorense para sua própria organização, sobretudo a organização curricular.

\subsubsection{Objetivos Específicos}

- Analisar o currículo de ciências no nível primário do Timor-Leste para buscar a compreensão dos determinantes históricos que o engendram;

- Identificar a influência cultural dos meios sociais nos repertórios das crianças nas ciências; 
- Investigar a presença ou não da valorização cultural do povo timorense no currículo de ciências;

- Caracterizar a história do Timor-Leste com vistas a estabelecer ligações com os elementos que influenciam o campo educacional atualmente.

\subsubsection{Participantes do Estudo}

Para este estudo foram delimitados dois grupos de participantes. O primeiro composto por alunos da escola primária pública de Timor-Leste do segundo ciclo 5 , nomeadamente do $6^{\circ}$ ano. Estudantes que estão em escola pública naquele país e que possuem no seu currículo conteúdos associados às ciências naturais no âmbito de "Estudos do Meio". O segundo grupo de estudantes integrantes do estudo procede da escola privada, também do ensino básico.

Dado os contextos culturais e plurilinguísticos da população timorense, e em função da dificuldade de deslocamento no território do Timor, os participantes estão limitados a estudantes da cidade de Díli (capital). Por suas características, Díli concentra etnias diferentes, sendo o ponto de congregação de estudantes, que em busca formação se deslocam para lá. De modo geral, os povos do Timor podem ser agregados em dois grandes grupos: os que vivem no leste, na cidade de Díli são os Lorosae e os do oeste, cidade de Baucau, são os Loromonu, embora, do ponto de vista étnico o Timor-Leste comporte outras etnias. Lorosae e Loromonu, em que pese serem timorenses, formam grupos culturais com costumes e línguas distintas e constantemente em conflitos. É possível perceber diferentes concepções acerca das ciências entre os integrantes apontados? Possivelmente, havendo intervenientes culturais que possam se expressar por meio de concepções prévias serão identificadas ideias singulares. Todavia, é de se esperar que o conhecimento proveniente da escolarização seja equivalente possivelmente diante de um currículo escolar unificado.

Em função da metodologia aplicada no levantamento de concepções utilizar situações-problema em busca de conceitos científico e estes, como será explicitado na metodologia, exigirem níveis de escolarização diferenciados, o agrupamento de indivíduos

\footnotetext{
${ }^{5}$ Ver na página 161 a tabela 2 que delimita a organização do ensino básico para o primeiro e segundo ciclos em Timor-Leste
} 
participantes ocorrerá a partir da série/ano onde os estudantes já passaram pelos conteúdos pertinentes na disciplina de "Estudos do Meio", a ser identificado a partir da análise curricular e das informações dos agentes da escola. Estima-se a participação total de quarenta estudantes ao todo em função do tamanho das turmas nos dois grupos integrantes, haja vista que é de, mais ou menos, 20 alunos que cada turma se constitui em boa parte das escolas do Timor ${ }^{6}$.

Inicialmente se previu neste projeto de pesquisa, a constituição de uma amostra de professores a serem investigados no tocante a suas concepções sobre o ensino de ciências no Timor-Leste, intenção essa que foi abandonada em função do tempo destinado à pesquisa. Não obstante ter buscado informações sobre o calendário do ano letivo em Timor, antes da viagem e ter sido informado que o recesso de meio de ano, semelhante ao Brasil, ocorria no mês de julho, para minha surpresa, ao chegar ao Timor para a participação em um evento internacional no final de julho de 2016, extraordinariamente, as escolas da educação básica estavam em recesso até o dia 14 de agosto. Como praticamente o estudo de concepções entre os estudantes se restringiu à última semana de permanência em Díli, e como não havia possibilidade de encontrar professores a não ser na escola, aproveitei o tempo para o trabalho de pesquisas nas bibliotecas da Universidade Nacional de Timor Lorosa'e (UNTL) e do Instituto de Formação de Professores. Associado a isso, realizou-se conversas e entrevistas com professores formadores deste instituto sobre o ensino em geral, currículo, ensino de ciências e formação continuada, informações estas que estão presentes no corpo desta tese.

As amostras dos estudantes se enquadraram como probabilísticas, pois, ao serem escolhidas em função da série de escolarização, todos os indivíduos daquela série tiveram a mesma oportunidade de participar. Segundo, Dionne \& Laville (1999, p.169), uma amostra probabilística é a "amostra da qual todos os elementos de uma população têm oportunidade conhecida e não-nula de fazer parte". Dentro dessa categoria, a amostra representou a totalidade da turma pesquisada, ou seja, todos tiveram a mesma chance de participar.

Dentro dos grupos participantes, praticamente havia uma homogeneização dos alunos quanto à faixa etária, ainda que alguns alunos não compartilhassem a mesma língua-materna, todos falavam o tétum, uma das línguas oficiais do país. Isso é essencial em função do

\footnotetext{
${ }^{6}$ Esse quantitativo reduzido de participantes se justifica em função da suspensão por parte do governo brasileiro do Programa de Qualificação Docente e Ensino de Língua (PQLP - Cooperação Brasil-Timor) no qual o autor fez parte no ano de 2007, que auxiliava com recursos financeiros o trabalho e a estadia em Timor-Leste. Sem esse auxílio, a ida àquele país ocorreu a expensas do autor. Ainda que as passagens tenham sido custeadas pela FAP-DF para participação de evento internacional $\left(2^{a}\right.$ Conferência Internacional do Conhecimento Científico em Timor-Leste) onde o autor apresentou trabalho, a estadia se restringiu a um mês com os custos de hospedagem, alimentação e transporte, representando parcela considerável de recursos, por conta do autor, que por ser um empreendimento custoso, abreviou ao máximo a estadia.
} 
tamanho da amostra. Como ensina Dionne \& Laville (1999, p.171), "quanto maior a homogeneidade, menor poderá ser a amostra, sem que sua representatividade — qualidade essencial de qualquer amostra - se encontre gravemente afetada por isso".

\subsubsection{Importância social do estudo}

O Timor-Leste é um pequeno país do sudoeste asiático, tido como a mais recente e pobre nação da Ásia. Como tal, contrasta em sua localização geográfica com grandes nações da sua vizinhança, tais como Austrália, Malásia, Singapura, Indonésia e um pouco mais ao norte com Tailândia, China e Japão. Sua história é um panorama de sofrimentos, lutas e conquistas em busca de uma autonomia do seu povo maubere ${ }^{7}$, só adquirida no início do presente século XXI.

Erguidos dos destroços da última guerra civil, a nação timorense agora autônoma, entende ser a educação do seu povo o caminho mais consistente para o estabelecimento da sua autonomia, para isso, conta com a colaboração internacional em diversos setores. $\mathrm{Na}$ educação básica, recebeu forte apoio do Brasil em acordos no setor, sobretudo na formação de professores timorenses, com o Programa de Qualificação Docente e Ensino de Língua Portuguesa no Timor-Leste (PQLP) financiado pela Coordenação de Aperfeiçoamento de Pessoal de Nível Superior (CAPES). Nesse programa de cooperação, docentes brasileiros foram enviados ao Timor-Leste e lá, envolvidos em diferentes projetos de formação de professores do ensino básico (primário, pré-secundário e secundário), ensino da língua portuguesa e curso superior na Universidade Nacional de Timor Lorosa'e (CASSIANI; LISINGEN \& LUNARDI, 2012).

Buscando um breve histórico sobre a educação no Timor-Leste, pode-se identificar quatro fases segundo Soares (2011). A primeira fase se insere no período de colonização portuguesa, em um grande intervalo de tempo que vai de 1511 até 1975, sendo caracterizada por ser direcionada às elites e com base nos currículos ocidentais, sem contemplar educação pública das massas. À época a Igreja Católica foi o principal agente do sistema educativo nacional e as Ciências Naturais não ocupavam muito espaço nos currículos, centrando-se esses na religião.

\footnotetext{
${ }^{7}$ O termo maubere refere-se a um nome comum do maior grupo étnico em Timor-Leste (TRAUBE, 1986). Durante o período colonial Português, maubere era geralmente usado para distinguir o timorense nativo do da classe alta, educada e portuguesa e, até certo ponto, os mestiços. "Maubere" foi muitas vezes empregado como sinônimo para os analfabetos, incultos e, até certo ponto, não civilizado.
} 
Durante o domínio colonial português, a Igreja Católica foi a instituição responsável pelo ensino fundamental em Timor-Leste, tendo estabelecido um número de escolas básicas e secundárias usando o currículo português. A este respeito, a educação de massa não foi um objetivo principal durante este tempo, resultando no fato de que a educação esteve voltada principalmente para a formação de uma elite social. Como resultado, com base nos dados estatísticos, em 1975, a taxa de analfabetismo em Timor-Leste foi estimadamente em torno de 90\%. (UNESCO, 2015, p. 4).

Em estudos estabelecidos por NICOLAI (2004), em 1937, mais de 400 anos depois que os Portugueses chegaram ao Timor-Leste, apenas 2.979 estudantes havia frequentado escolas missionárias. A primeira escola secundária pública foi aberta em 1952, e ao longo da década de 1960 houve uma expansão na educação. O número de estudantes matriculados na escola primária aumentou cinco vezes e o número no nível secundário duplicou. Essa relação da educação em Timor com a estruturação da sua sociedade no fim do período colonial e a constante e conturbada situação que provocava revoltas e constantes massacres no seio da sua população, pode ser entendida no estudo de Cunha (2001, p.117), ao apontar que sob o domínio português, até 1974,

embora o ensino secundário fosse quase inexistente e a taxa de analfabetismo permanecesse acima dos 90\%, uma incipiente elite timorense floresceu nos principais centros urbanos. Seu destino era geralmente o funcionalismo público cujos quadros eram integrados por $81 \%$ de timorenses -, as forças armadas ou, em casos mais raros, a continuação dos estudos na metrópole. Gerou-se, assim uma sociedade com dois setores bem caracterizados: o tradicional, constituído pela população rural, e o "evoluído", integrado pelos metropolitanos, mestiços, chineses e, sobretudo, pelos nativos letrados. Essa dicotomia foi acentuada com a distinção legalmente estabelecida pela metrópole entre os timorenses indígenas e os "assimilados". A sobrevivência de estruturas tradicionais ao lado da implantação de modelos europeus de economia e poder podem estar na base dos conflitos intratimorenses.

Logo após a invasão indonésia, em 1976, havia menos de 14 mil alunos em 47 escolas primárias e duas secundárias que serviam uma população de mais de 600 mil. Todavia, as estatísticas oficiais da Indonésia, apontam que não havia escolas secundárias. Em todo caso, no final do regime Português, não mais do que $10 \%$ da população poderia ser considerada instruída. Nesse período ainda não havia documentos orientadores ou algo que se assemelhe a currículo das disciplinas das ciências naturais.

A segunda fase da educação em Timor-Leste, ainda em Soares (2011), tem início por ocasião da invasão da Indonésia em 1975. Pode-se constatar que o Estado indonésio encontrou uma situação de altos índices de analfabetismo e poucas escolas para atender a uma grande população. Transformado em território indonésio, o Timor-Leste recebe a atenção do Estado invasor que estendeu a todos os cidadãos timorenses o direito de frequentar a escola, substituindo o sistema educativo português elitista e excludente para o sistema indonésio que possibilitava aos timorenses frequentar do estudo básico ao universitário. Essa mudança 
elevou, entre os anos de 1976 e 1999, o número de estudantes de 10 mil para 165 mil. Para atender a demanda, até o fim de 1998 a Indonésia havia construído 1028 estabelecimentos de ensino, incluindo aí uma Universidade, um Instituto Politécnico, um Instituto de Agricultura, uma Escola de Economia, uma Academia de Saúde e um Centro de Formação de Professores (ARNEBERG, 1999). Como imposição política, o dominador indonésio proibiu o uso da língua portuguesa, passando o bahasa indonésio a ser a língua oficial para a educação em todos os níveis.

O sistema educacional da Indonésia em Timor-Leste, compreendia dois anos de préescola, seis anos de educação primária, três anos de pré-secundária, três anos de educação geral ou técnica vocacional secundária, dois anos de educação politécnica e três ou quatro anos de educação universitária. Em 1994, as matrículas na escola primária tornaram-se obrigatórias, mas não houve instrumentos adequados para implementá-las. O senso de 1990 mostrou que no grupo de idade entre 35 a 39 anos, as taxas de analfabetismo eram muito elevadas, com $72 \%$ para homens adultos e $89 \%$ entre mulheres adultas, sendo ainda mais elevadas nas gerações mais velhas. (UNESCO, 2015).

Nos anos de dominação, o currículo introduzido trazia as disciplinas da área das Ciências Naturais (Física, Química e Biologia). A maior parte dos professores ensinando essas disciplinas era indonésia e não permaneceu quando da retirada do Estado indonésio do território do Timor-Leste, que em 1999 passou a ser administrado pela UNTAET (United Nations Transitional Administration for East Timor) órgão criado pela ONU, indo até 2002. Essa transição, marca a terceira fase da educação do Timor-Leste, sendo caracterizada, sobretudo, pela destruição quase total do sistema educativo herdado dos indonésios, pela guerra civil instalada entre milícias pró-indonésias e a resistência timorense. Somente a partir de 2001, as escolas que restaram voltaram à normalidade através de professores voluntários.

Nessa visão de fases da educação timorense, a quarta e última, se estende de 2002 até os dias atuais, caracterizando-se pela reconstrução, pelas cooperações internacionais que a exemplo do Brasil, teve participação nessa reconstrução em vários setores. Assim, inserido nessa fase, o projeto de pesquisa que norteia essa tese, foi motivado por indagações nascidas da experiência de formação de professores timorenses para atender a escola primária na área de ciências naturais, no âmbito da cooperação internacional Brasil-Timor-Leste no ano de 2007. Ao participar do projeto de formação chamado de PROFEP-Timor (Programa de Formação de Professores em Exercício na Escola Primária do Timor-Leste), baseado na metodologia aplicada no Brasil no PROFORMAÇÃO (Programa de Formação de Professores em Exercício), o proponente deste projeto que baseou esta tese, se deparou com a seguinte 
questão: como se faz uma escolha curricular em ciências para escola básica em um país póscolonial? Esse questionamento nasceu, quando convidado para revisar as provas nacionais de Biologia e Química que os estudantes em transição do equivalente ao ensino fundamental (ensino pré-secundário) para o ensino secundário fariam naquele ano (2007). Percebeu-se ao mesmo tempo a existência de questões muito complexas e outras nem tanto, quando comparadas com o que conhecia dos currículos de ciências no Brasil.

A curiosidade sobre quem determinava o currículo daquele país levou-me a solicitar dos responsáveis no Ministério da Educação timorense o currículo de ciências para poder balizar a análise das questões. Para surpresa, o MEC-Timor, informou naquela altura que ainda não haviam construído um currículo nacional. Quem então "julgava” o que seria importante em termos de aprendizagem em ciências para as crianças e jovens daquele país? Ao mesmo tempo, ao trabalhar na formação de professores da escola primária na área de Vida e Natureza (VN) do PROFEP-Timor, percebia lacunas importantes no conhecimento de ciências nestes professores em formação e que historicamente haviam sofrido a influência primeiramente dos portugueses e posteriormente dos indonésios na sua formação inicial.

Entender que o Brasil e o Timor-Leste são países distantes geograficamente e culturalmente é de grande importância. Porém, estão unidos pelo fato de terem sido colônias portuguesas e em comum a língua portuguesa, que para brasileiros é a língua materna, mas, que para timorenses é mais uma das tantas línguas faladas no país, algumas ágrafas ainda, outras mais faladas preferencialmente como o tétum, o bahasa indonésio e o inglês. Nesse contexto plurilinguístico, o português se tornou língua oficial de instrução e como tal, há a pretensão de se trabalhar nas salas de aula da educação primária em português para promover a implantação definitiva desta língua no país.

A principal justificativa para esse trabalho é buscar as bases do currículo de ensino de ciências e seu fazer docente em um país da Ásia (Timor-Leste), os elementos que o influenciam diante do papel das cooperações internacionais no campo da educação na construção desse currículo, para produzir subsídios que possam contribuir para possíveis e posteriores estudos comparativos com o Brasil. Salienta-se que estes estudos não serão o foco do presente trabalho. Todavia questões inquietantes são inevitáveis nesse sentido: como ocorrem as aulas de ciências na escola básica do Timor-Leste? Em que se assemelham e em que divergem do que é observado no Brasil? Quais são os fundamentos teóricos que suportam o currículo? Qual a influência do currículo português? Qual a influência do currículo brasileiro? Qual a influência do currículo indonésio? Quais as representações que os professores, os alunos e a sociedade tem do ensino de ciência naquele país? Embora 
responder esses questionamentos não seja o objetivo final do estudo neste trabalho, estima-se que sejam abordagens colaterais imperiosas, dadas as transversalidades possíveis ao se buscar os fundamentos de um currículo.

\subsubsection{Uma contribuição à pesquisa}

Estudar o currículo da educação básica no que tange ao ensino de ciência de um país, que tem uma história recente nesse aspecto, abre a possibilidade para a reflexão sobre a gênese de um currículo e seus objetivos, gerando com isso a oportunidade para compreender o que temos no Brasil e o que também queremos. Nesse sentido, a pesquisa na área de ensino de ciências e em seus contextos de aprendizagem ganha um contorno de importância por contribuir com dados e informações que se somam ao entendimento desses processos. $\mathrm{O}$ Timor-Leste que está nesse início do seu processo de reconstrução educacional, representa um "laboratório" para observações pragmáticas epistemológicas na base de como é construída a formação dos indivíduos nas ciências.

Para De Meis (2009, p.176-177),

Pesquisa-se muito pouco em educação em todo o planeta. Essa provavelmente é uma das principais causas da grande discrepância existente entre a produção do saber novo e a forma de como transmiti-lo. A comparação dos índices bibliométricos das diversas áreas do saber mostram o descompasso entre o descobrir e o ensinar. Nas últimas duas décadas menos do que $0,5 \%$ dos artigos científicos descrevendo novas descobertas estavam relacionados com algum aspecto da educação.

Embora a postura do autor citado acima, se centre em aspectos quantitativos da produção científica mundial e a pesquisa educacional ter muito mais abrangência em aspectos qualitativos, os números espantam e provavelmente colocam em questionamento o enfoque no caráter utilitarista da pesquisa educacional. Destarte, a pesquisa educacional nesse trabalho pode ser mais uma contribuição para a reflexão e o entendimento de como se educa em ciências as gerações jovens de países sem tradição de produção científica, em contextos póscoloniais, mais que anseiam por fazer parte de um mundo organizado cada vez mais inserido no conhecimento científico e tecnológico. Como atesta Salzano (2009, p.119),

Em um mundo que está cada vez mais cientificamente orientado e espera melhores habilidades de raciocínio de sua força de trabalho - particularmente habilidades de raciocínio cientificamente orientadas -, ensinar mais Ciências aos jovens e, ensinando melhor esta matéria, somente pode melhorar as possibilidades desses jovens terem condições de participar de uma economia e de uma sociedade que exigem essas habilidades para resolver problemas. 
Desse modo, é urgente uma investigação reflexiva sobre como a ciência está sendo ensinada em culturas distintas, considerando o mesmo princípio de valorização do conhecimento científico no mundo globalizado. Pensar em educação global em ciência é uma emergência do século XXI, onde os conceitos científicos em si, possuem a pretensão de universalidade, porém, as representações dos conceitos científicos, podem não ser universais, em função dos contextos culturais diferentes presentes na diversidade humana.

\subsubsection{Problematização do objeto de estudo e hipótese ${ }^{8}$ principal $^{-1}$}

O tema em que se inscreve a presente pesquisa centra-se na escolarização universal uniforme eurocêntrica ${ }^{9}$ versus o multiculturalismo na formação científica pós-colonial. Dentro dessa temática o principal problema de pesquisa centraliza-se na questão: o que influencia a formação científica básica formal em um povo que se reconstrói do domínio colonial e das destruições causadas por guerra civil, mas que busca uma identidade a partir de valores culturais que são diversos da cultura ocidental, porém, inseridos em um mundo escolarizado pelos valores culturais e curriculares ocidentais e a ação dos mesmos nas suas concepções das ciências? Como questões assessórias pretende-se explicar se há espaço para consideração cultural local no ensino de ciências em uma nação multicultural e plurilingüística? Conhecimentos prévios dos estudantes são levados em conta na tarefa docente de ensinar? Se forem, como são considerados? Obstáculos a serem superados? Contribuições a serem incorporadas como extensão para o conhecimento científico?

Buscando suporte nas ideias de Bernstein (2001), que aponta conexões diretas entre currículo e poder, pode-se entender que o papel do conhecimento nos currículos é servir de base para a difusão de ideias dominantes, favorecendo o estabelecimento de determinados grupos dentro das sociedades. Assim os currículos se fundam mais nas relações de poder do que no conhecimento em si. A partir desse entendimento, compreendendo o mundo como já imerso em um processo globalizante, é de supor que o Timor-Leste, ou qualquer outra nação em processo de formalização de sua educação, também opte por um ensino de ciências pautado pelo modelo ocidental já universalizado e dominante. Não obstante a ampliação dos temas associados ao multiculturalismo no ensino de ciências (CARTER; LARKE; TAYLOR;

\footnotetext{
${ }^{8}$ Ao observar o enfoque filosófico desta tese no item "1.2. Base filosófica e metodológica da investigação" se opta pela fenomenologia e como tal, a mesma não lida com o conceito de hipótese e sim, suposições, para as quais se busca respostas por meio da análise das narrativas dos sujeitos. Todavia, dado o perfil clássico de forma em uma tese, aqui o termo hipótese será utilizado.

${ }^{9}$ Embora o termo eurocentrismo caracterize-se como uma visão de mundo a partir do ponto de vista europeu, nesta tese o termo também é usado com significado de "Ocidental" que também representa um ponto de difusão de valores diferentes daqueles do oriente.
} 
SANTOS, 2007; ROWLAND; ADKINS, 2007; WANG, 2013), a principal hipótese converge no sentido de que a opção do sistema educacional timorense é pela escolarização formal nos parâmetros do ensino de ciências ocidental, por razões associadas à busca de inserção no mundo globalizado que não deixa espaço para modelos alternativos multiculturais; à conformação política da elite timorense alinhada ao mundo ocidental, sobretudo por seus fortes laços com Portugal; às cooperações internacionais no campo da educação, sobretudo com o Brasil e Portugal, ainda que estes sejam países sem grandes tradições na área das ciências (SCHWARTZMAN \& CHRISTOPHE, 2016; FIOLHAIS, 2016), concentram seu modelo formal no ensino de ciências tradicional, além de organizações internacionais, tais como UNESCO, UNICEF e outras tantas fundações que são também intervenientes neste processo.

\subsection{Bases filosóficas e metodológicas da investigação}

Procurando estabelecer coerência entre as ideias surgidas e os achados na pesquisa delimitada nesta tese, deve-se buscar um fio condutor que guie e permita ao leitor entender a visão de mundo do autor como pesquisador. Este, no entendimento de Triviños (2013, p. 13),

[...] por coerência, por disciplina, deve ligar a apropriação de qualquer ideia à sua concepção do mundo, em primeiro lugar, e, em seguida, inserir essa noção no quadro teórico específico que lhe serve de apoio para o estudo dos fenômenos sociais.

Neste sentido, o enfoque de pensamento filosófico que norteará a interpretação dos dados obtidos nas narrativas e na pesquisa de concepções nessa tese é o da fenomenologia. Esta se insere no idealismo filosófico e dentro deste, no idealismo subjetivo ${ }^{10}$ (TRIVIÑOS, 2013).

Merleau-Ponty (1999) em sua obra Fenomenologia da Percepção, publicada originalmente em 1945, externa o estranhamento que pode parecer existir diante da tentativa de definir ainda àquela altura a fenomenologia, mesmo meio século depois dos trabalhos seminais de Husserl. Porém, se justifica ao mencionar que a definição ainda estava longe de ser resolvida. Em todo caso, define a fenomenologia como sendo,

o estudo das essências, e todos os problemas, segundo ela, resumem-se em definir
essências: a essência da percepção, a essência da consciência, por exemplo. Mas a
fenomenologia é também uma filosofia que repõe as essências na existência, e não
pensa que se possa compreender o homem e o mundo de outra maneira senão a
partir de sua "facticidade". É uma filosofia transcendental que coloca em suspenso,
para compreendê-las, as afirmações da atitude natural, mas é também uma filosofia
para a qual o mundo já está sempre "ali", antes da reflexão, como uma presença
inalienável, e cujo esforço todo consiste em reencontrar este contato ingênuo com o

\footnotetext{
${ }^{10}$ No Idealismo subjetivo seu ponto fulcral está no entendimento de que somente pela soma das sensações sobre
} o mundo é que pode-se aperceber o objeto. (Nota do autor). 
mundo, para dar-lhe enfim um estatuto filosófico. É a ambição de uma filosofia que seja uma "ciência exata", mas é também um relato do espaço, do tempo, do mundo "vividos". (MERLEAU-PONTY, 1999, p.1).

Santos (1965, p. 712) em seu Dicionário de Filosofia e Ciências Culturais, de maneira mais descomplicada considera que,

A fenomenologia trata das significações. É a significação que faz que uma palavra seja palavra, do contrário é puramente um sinal. Mas a significação não está na palavra. Esta simplesmente chama a atenção para a significação. Nem tampouco a significação está no objeto da palavra, porque este pode não existir; por exemplo: círculo quadrado. As significações são, assim, objetos ideais. É ela que chama a atenção sobre o objeto. Em suma, a fenomenologia é a ciência descritiva das vivências da consciência pura. É assim uma doutrina e um método, além de uma tese idealista. É uma ciência que trata e descreve as essências das vivências da consciência pura. É portanto uma ciência a priori e universal. A priori porque descreve essências (isto é, objetos ideais e não empíricos). É universal porque se refere a todas as vivências. Como método leva-nos ao conhecimento das essências. Conhecimento evidente, fundado na intuição, não numa intuição sensível, mas eidética, de essências.

Por conseguinte, ao buscar concepções de conceitos científicos obtidos por meio da escolarização de saberes vividos e experienciados a partir da inserção em realidades culturais, tem-se a necessidade de um olhar que confronte o espaço e o vivido com o intuito de buscar o entendimento de um mundo tal qual ele é, sem a interferência ou deferência à sua gênese psicológica (MERLEAU-PONTY, 1999). Por esta razão, a inserção desta pesquisa no universo fenomenológico, parece ser mais adequada.

A valorização da percepção na fenomenologia por Merleau-Ponty, por exemplo, deixa evidente que há um mundo a ser conhecido. A compreensão desse mundo admite outros saberes que existem além do científico e antes mesmo deste, explicou e inteligiu o universo ao redor. A percepção sensível que permite o estabelecimento de um ponto de vista pela razão ou pela experiência também constrói o mundo da ciência. Como nos ensina Merleau-Ponty (1999, p.3),

Tudo aquilo que sei do mundo, mesmo por ciência, eu o sei a partir de uma visão minha ou de uma experiência do mundo sem a qual os símbolos da ciência não poderiam dizer nada. Todo o universo da ciência é construído sobre o mundo vivido, e se queremos pensar a própria ciência com rigor, apreciar exatamente seu sentido e seu alcance, precisamos primeiramente despertar essa experiência do mundo da qual ela é a expressão segunda. A ciência não tem e não terá jamais o mesmo sentido de ser que o mundo percebido, pela simples razão de que ela é uma determinação ou uma explicação dele.

A opção pela fenomenologia, especificamente a merleau-pontiana, também se assenta em sua atuação como docente na cátedra de Psicologia da Criança e Pedagogia na Sorbonne em fins dos anos 40 e no início dos anos 50 do século passado, onde manteve estudos sobre a 
fenomenologia da infância. Machado (2010, p.13) informa que a psicologia infantil, segundo Merleau-Ponty em seus cursos da Sorbonne,

afastou o adulto da criança mesma, ao criar teorias e propor procedimentos sobre como educá-la, em cada "etapa da vida", por meio do que se conceituou o "desenvolvimento humano". Esses procedimentos foram emoldurados pelas disciplinas especializadas tais como a Pedagogia, a Pediatria, a Psicologia, a Psiquiatria Infantil, bem como pelo mercado da produção cultural para a infância.

Desta forma, muitas contribuições podem ser extraídas nessa aproximação de Merleau-Ponty com o universo infantil das concepções de conceitos científicos pretendidas nesta pesquisa. Como menciona Machado (2010, p.12), "há que explorar um "saber efetivo", nas palavras do próprio autor. A diferença está em ouvir as crianças e acolhê-las em seus pontos de vista".

Em afinidade com os encaminhamentos metodológicos, descritos nos itens abaixo, essa investigação em educação nesse enfoque fenomenológico se integra ao intento de investigar a existência de realidades culturais imanentes aos seres humanos enquanto fenômenos que podem ser desvelados na pesquisa, em um universo escolarizado pela educação de base ocidental. Assim, para Pesce \& Abreu (2013, p.23),

A pesquisa com base fenomenológica busca empreender investigações acerca de fenômenos humanos. Nesse processo, o vivido e o experienciado assumem uma centralidade. As pesquisas desenvolvidas com base na Fenomenologia estão especialmente preocupadas com a análise dos relatos e as descrições dos sujeitos que vivenciaram o fenômeno em tela. A Fenomenologia questiona a premissa positivista de que o pesquisador deve buscar a neutralidade, salientando que tal premissa não considera as crenças e os valores presentes nos pensamentos e nas ações do investigador. [...] É comum que as investigações desenvolvidas com base na Fenomenologia voltem-se à análise dos relatos e das descrições dos sujeitos que vivenciaram o fenômeno.

Ao lidar com os diversos atores nesta pesquisa, estudantes, professores, fontes bibliográficas diversas, procurou-se reduzir todas as confluências de ideias, narrativas e autonarrativas a uma convergência que elucide os questionamentos feitos. Neste sentido, como aponta Creswell (2014, p.72),

um estudo fenomenológico descreve o significado comum para vários indivíduos das suas experiências vividas de um conceito ou um fenômeno. Os fenomenologistas focam na descrição do que todos os participantes têm em comum quando vivenciam um fenômeno. [...] O propósito básico da fenomenologia é reduzir as experiências individuais com um fenômeno a uma descrição da essência universal.

Com esse delineamento filosófico no universo fenomenológico, no próximo item se delimitará os métodos e passos dados na pesquisa. 


\subsection{Sobre o método utilizado na pesquisa}

Essa pesquisa é de natureza qualitativa e como tal, dada a pluralidade que esta modalidade de pesquisa envolve, defini-la também é complexo. Como menciona Angrosino $(2009$, p.8),

É cada vez mais difícil encontrar uma definição comum de pesquisa qualitativa que seja aceita pela maioria das abordagens e dos pesquisadores do campo. A pesquisa qualitativa não é mais apenas a "pesquisa não quantitativa", tendo desenvolvido uma identidade própria (ou, talvez, várias identidades).

Segundo Denzin \& Lincoln (2011, p. 3),

Pesquisa qualitativa é uma atividade situada que localiza o observador no mundo. A pesquisa qualitativa consiste em um conjunto de práticas materiais interpretativas que tomam o mundo visível. Essas práticas transformam o mundo. Elas transformam o mundo em uma série de representações, incluindo notas de campo, entrevistas, conversas, fotografias, registros e lembretes para a pessoa. Nesse nível, a pesquisa qualitativa envolve uma abordagem interpretativa e naturalística do mundo. Isso significa que os pesquisadores qualitativos estudam coisas dentro dos seus contextos naturais, tentando entender, ou interpretar, os fenômenos em termos dos significados que as pessoas lhes atribuem.

Ludke (1986) aponta que a pesquisa qualitativa ou também chamada de naturalística envolve a obtenção de dados descritivos, adquiridos no contato direto do pesquisador com a situação estudada, enfatiza mais o processo do que o produto e se preocupa em retratar a perspectiva dos participantes. Para Richardson (1999, p. 79), a "abordagem qualitativa de um problema justifica-se, sobretudo, por ser uma forma adequada para entender a natureza de um fenômeno social", bem ajustado ao que pretende esta pesquisa.

Neste sentido Creswell (2014, p. 51-52), assim se refere,

A pesquisa qualitativa começa com pressupostos e o uso de estruturas interpretativas/teóricas que informam o estudo dos problemas da pesquisa, abordando os significados que os indivíduos ou grupos atribuem a um problema social ou humano. Para estudar esse problema, os pesquisadores qualitativos usam uma abordagem qualitativa da investigação, a coleta de dados em um contexto natural sensível às pessoas e aos lugares em estudo e a análise dos dados que é tanto indutiva quanto dedutiva e estabelece padrões ou temas. O relatório final ou a apresentação incluem as vozes dos participantes, a reflexão do pesquisador, uma descrição complexa e interpretação do problema e a sua contribuição para a literatura ou um chamado à mudança.

Quando se fala em pesquisa qualitativa, Bogdan \& Biklen (1994) compreendem o termo como uma expressão genérica que para Triviños (2013, p. 120) significa,

por um lado, que ela compreende atividades de investigação que podem ser denominadas específicas. E por outro, que todas elas podem ser caracterizadas por traços comuns. Esta é uma ideia fundamental que pode ajudar a ter uma visão mais clara do que pode chegar a realizar um pesquisador que tem por objetivo atingir uma interpretação da realidade do ângulo qualitativo. (p.120). 
Dado o escopo desta investigação focar em concepções de conceitos científicos entre estudantes da escola básica de uma cultura oriental em contextos culturais diversos do pesquisador, que embora esteja inserida nos processos de escolarização universal, apresentam características próprias, pode-se mencionar aqui, encaminhamentos da pesquisa etnográfica como investigação qualitativa. Embora, como menciona Triviños (2013, p. 121),

\begin{abstract}
A tentativa de definir o que se entende por etnografia não é tarefa fácil. Em forma muito ampla podemos dizer que ela "é o estudo da cultura". Uma noção desta natureza, vaga, complexa, geral, serve, não obstante, para obter dela algumas premissas que se consideram básicas na pesquisa etnográfica. A primeira é que existe um mundo cultural que precisa ser conhecido, que se tem interesse em conhecer. Isto pode significar, e de fato na Antropologia foi assim, que, pelo menos, estamos em presença de duas realidades culturais: a que se deseja conhecer e a que é própria do investigador.
\end{abstract}

Neste sentido "etnografia significa a descrição de um povo. É importante entender que a etnografia lida com gente no sentido coletivo da palavra, e não com indivíduos" (ANGROSINO, 2009, p. 16). Estudar qualquer particularidade sociológica do Timor-Leste, envolve estudar seu povo, hábitos, a organização da sua sociedade, enfim, sua cultura, aqui entendida na concepção de Angrosino (2009, p. 16) como sendo o "modo de vida peculiar que caracteriza um grupo. (...) E estudar a cultura envolve um exame dos comportamentos, costumes e crenças aprendidos e compartilhados do grupo".

Tal entendimento aproxima-se do pretendido pelo pesquisador que também recorreu à pesquisa bibliográfica, que segundo Reis (2008) é a técnica mais simples da pesquisa, explica um problema a partir de referências teóricas, das contribuições e das informações retiradas de livros, revistas impressas e virtuais, material audiovisual, entrevistas, entre outros, de autores variados que versam sobre o tema em questão. Em seu livro Como elaborar Projetos de pesquisa, Gil (2002, p.45) coloca que na pesquisa bibliográfica: A principal vantagem reside no fato de permitir ao investigador a cobertura de uma gama de fenômenos muito mais ampla do que aquela que poderia pesquisar diretamente. Essa vantagem torna-se particularmente importante por requerer dados muito dispersos pelo espaço.

Tendo em vista as preocupações fundantes relatadas no item "1.1.4 Importância social do estudo", a presente pesquisa também se qualifica tecnicamente como pesquisa explicativa. Segundo Reis (2008, p.57), essa técnica de pesquisa,

tem como objetivo identificar os fatores que contribuem para que os fenômenos ocorram; se desenvolve e explica a razão destes e identifica os fatores determinantes. Esse tipo de pesquisa usa o método experimental quando é realizada nas ciências exatas e o método observacional quando realizada nas ciências sociais e humanas, o que acontece com o intuito de aprofundar o conhecimento da realidade, além das aparências dos fenômenos, possibilitando o controle e a manipulação de variáveis mais significativas. 
Por conseguinte, a metodologia utilizada neste trabalho, consiste no método observacional, clássico na pesquisa em ciências humanas e sociais, que segundo Gil, (2002, p.16),

\begin{abstract}
Por um lado, pode ser considerado como o mais primitivo e, consequentemente, o mais impreciso. Mas, por outro lado, pode ser tido como um dos mais modernos, vistos ser o que possibilita o mais elevado grau de precisão nas ciências sociais. [...] $\mathrm{O}$ método observacional difere do experimental em apenas um aspecto: nos experimentos o cientista toma providências para que alguma coisa ocorra, a fim de observar o que se segue, ao passo que no estudo por observação apenas observa algo que acontece ou já aconteceu.
\end{abstract}

Nesse sentido, identificado a técnica de pesquisa e a metodologia, os aspectos observacionais incidem também sobre fatos já ocorridos e registrados pelo autor em documentação produzida por ocasião da participação no PROFEP-Timor, como professor formador da área de ciências naturais. Essa documentação consiste em narrativas chamadas "memórias", estas eram denominações dadas aos relatórios individuais, que faziam parte da rotina do trabalho desenvolvido ${ }^{11}$. Como foram produzidas outras narrativas como hábito do autor em manter viva uma crônica diversa sobre o Timor, para não diferenciá-las, serão genericamente denominadas de "memórias". A cada encontro pedagógico presencial realizado, bem como acompanhamento de práticas pedagógicas dos professores timorenses, o professor formador, produzia uma memória reflexiva, onde relatava o desenvolvimento dos eventos observados. Esse material era então disponibilizado à coordenação do projeto para nortear relatórios regulares que eram enviados ao Brasil à Coordenação Nacional do PROFORMAÇÃO. Dessa forma os dados, relatos e resultados aqui apresentados, que serviram de base para as reflexões expostas, referem-se também a um recorte do vasto material produzido em um ano de trabalho, presentes nas memórias acima citadas.

Destarte, para um breve vislumbre de aspectos culturais que podem tipificar e descrever o timorense em seu cotidiano, a infância e alguns hábitos locais, bem como a formação de professores no ensino de ciências, nos apêndices dessa tese encontram-se algumas das memórias mais relevantes construídas em 2007, por ocasião da minha primeira estadia e refletem o meu estranhamento como "estranho sociológico em choque cultural". Sempre que necessário, estas memórias nos "apêndices" serão referendadas e por esta razão estão intituladas para facilitar o encontro de alusões necessárias. As narrativas exprimem uma espécie de "ansiedade" que possuía em registrar elementos de outro mundo totalmente alheio ao meu, ocidentalizado e normocentrado em valores culturais diferentes do timorense. $\mathrm{O}$

11 O hábito do autor na produção de "memórias" remonta ao ano 2000 por ocasião da participação do PROFORMAÇÃO que adotava o procedimento para acompanhamento das ações do Programa. 
registro representou uma forma de eternizar pela escrita fatos que de outra forma, distanciados no tempo do passado, poderiam levar-me à confusão entre ficção e realidade como é afeito aos recursos da memória.

Embora os registros disponibilizados nos apêndices representem uma pequena amostra das memórias produzidas, podem auxiliar no entendimento do espírito timorense e da minha inserção na conjuntura momentânea daquela nação, subsídio importante capturado pela ótica do estranhamento subjetivo, da experiência vivida e hoje, do distanciamento temporal.

Ainda assim, as memórias retratam a observação objetiva ou subjetiva do narrador. Quando o faz descrevendo a realidade concreta, se aproxima do que objetivamente é esta realidade, todavia, ao colocar elementos culturais da sua ótica imanente, influenciada pela cultura, a subjetividade retrata uma realidade imaginada ou interpretação. No campo da educação a subjetividade é possivelmente mais evidente ainda, pois, nossas observações são influenciadas pela nossa formação, pelas experiências que já tivemos e pelo meio a que pertencemos. Mas, de uma forma ou de outra, como salientam Cornnelly \& Clandinin (1995, p.11),

A razão principal para o uso da narrativa na investigação educativa é que os seres humanos somos organismos contadores de história, organismos que, individual e socialmente, vivemos vidas relatadas. O estudo das narrativas, portanto, é o estudo da forma em que os seres humanos experimentamos o mundo.

Por conseguinte, experimentar o mundo e perenizar lembranças por meio do registro narrativo, é trazer à tona a experiência passada à luz de um novo olhar em que a interpretação embasada em referenciais teóricos evidencia a importância dos percursos de vida, utilizando uma das ferramentas mais antigas que a humanidade dispôs para a construção da informação e do conhecimento, a narrativa. Sobre ela Benjamin (1985, p.205) nos ensina que,

\begin{abstract}
A narrativa, que durante tanto tempo floresceu num meio de artesão - no campo, no mar e na cidade -, é ela própria, num certo sentido, uma forma artesanal de comunicação. Ela não está interessada em transmitir o "puro em si" da coisa narrada como uma informação ou um relatório. Ela mergulha a coisa na vida do narrador para em seguida retirá-la dele. Assim se imprime na narrativa a marca do narrador, como a mão do oleiro na argila do vaso.
\end{abstract}

Embora o estudo de narrativas seja clássico nas pesquisas qualitativas, segundo Jovchelovitch \& Bauer (2002, p. 90), este estudo

conquistou uma nova importância nos últimos anos. Este renovado interesse em um tópico antigo - interesse com narrativas e narratividade tem suas origens na Poética de Aristóteles - está relacionado com a crescente consciência do papel que o de contar histórias desempenha na conformação de fenômenos sociais. No despertar desta nova consciência, as narrativas se tornaram um método de pesquisa muito difundido nas ciências sociais. A discussão sobre narrativas vai, contudo, muito além de seu emprego como método de investigação. A narrativa como uma forma 
discursiva, narrativas como história, e narrativas como história de vida e histórias societais, foram abordadas por teóricos culturais e literários, linguísta, filósofos da história, psicólogos e antropólogos.

Todavia, embora haja narrativas produzidas pelos participantes da pesquisa, boa parte das narrativas aqui tratadas, não são entrevistas narrativas em que o pesquisador, de modo imparcial, busca desvelar o entendimento de um fenômeno sociológico por meio das histórias dos agentes que vivenciam e ou fazem parte do fenômeno, são autonarrativas, ou, como menciona Angrosino (2009, p.104),

\begin{abstract}
Autoetnografia, ou a "narrativa do self", uma forma literária híbrida em que o pesquisador usa a sua própria experiência pessoal como base de análise. As autoetnografias são caracterizadas por evocação dramática, poderosas metáforas, personagens intensos, frases incomuns e a retenção da interpretação para convidar o leitor a reviver as emoções experimentadas pelo autor.
\end{abstract}

Portanto, ao serem produzidas pelo próprio pesquisador, estão sujeitas à crítica no que concerne à imparcialidade. Sobre isso, salienta-se que as narrativas produzidas pelo pesquisador, não tiveram a intencionalidade para elaboração de trabalho acadêmico e estão temporalmente deslocadas do presente, tratando-se apenas de um ímpeto, quase intuitivo, para não ser traído no futuro pela memória. Assim, acentua-se que não há necessidade da leitura dessas memórias para integrar o entendimento do que se aborda e discute na tese, funcionando apenas como um reforço para a percepção subjetiva do autor em sua pesquisa, funcionando como um auxiliar ao tempo presente.

Concomitante à utilização dos dados já relatados nas memórias dos encontros presenciais e da pesquisa bibliográfica, foi feito também o uso da técnica de entrevistas semiestruturadas, baseada em situações-problema aplicadas à alunos da escola primária em TimorLeste. Laville \& Dionne (1999, p.188), conceituam a entrevista semi-estruturada como "uma série de perguntas abertas feitas verbalmente em uma ordem prevista, mas na qual o entrevistador pode acrescentar perguntas de esclarecimento". Em Russel; Bell; Longden \& McGuigan (1993) se encontra a descrição da técnica in-depth interviews (entrevistas em profundidade - em uma tradução livre) para entrevista semi-estruturada. Por essa técnica se chega à elicitação dos conhecimentos da criança através de constantes reformulações de questionamentos, mediante a expressão das suas ideias, o que provoca reflexão e reconstrução das mesmas. Desse modo percebe-se que esse tipo de entrevista permite uma flexibilidade se traduzindo como uma ruptura com a uniformidade de uma entrevista estruturada, ocorrendo desse modo, um diálogo espontâneo entre entrevistado e entrevistador, mas seguindo um rigor acadêmico. 
Embora a técnica e suas formas de aplicação pareçam facilmente exeqüíveis, a dificuldade das crianças timorenses com a língua portuguesa representou um obstáculo. As crianças não dominam o português de modo que foi necessário adaptar o processo para uso de intérprete em um dos grupos de estudantes, a da escola pública, conforme se descreve na seção dos resultados desta tese. Os outros participantes, da escola particular, em função da delimitação do tempo que me foi oferecido pela diretoria da escola para o contato com os alunos, teve que mudar de enfoque. $\mathrm{O}$ que era para ser uma entrevista semi-estruturada com os alunos se transformou em um teste de caneta e papel. Ainda que as situações-problema tenham sido preservadas, os alunos responderam por escrito em português.

Como meios para a realização da pesquisa de levantamento de concepções em si, retornei ao Timor-Leste para a obtenção de dados. Aproveitando-se a ocorrência da $2^{\mathrm{a}}$ Conferência Internacional - Produção do Conhecimento Científico em Timor-Leste ${ }^{12}$, onde apresentei um trabalho intitulado "Crônicas sobre o Timor-Leste: um resgate da obra de Afonso de Castro" e por esta razão, conseguiu-se auxílio para compra de passagens e estadia durante os dias da Conferência (27 a 29 de julho de 2016) em agência de fomento do Distrito Federal.

O levantamento das concepções das crianças se deu em quatro grandes blocos de conhecimento das ciências do ensino primário. Os grupos integrantes de estudantes do TimorLeste, conforme apontado no item "1.1.3 Participantes do Estudo", foram constituídos na capital do país, Díli em duas escolas, uma pública e outra privada, perfazendo um total de quarenta e quatro alunos. A ideia inicial do projeto era fazer a pesquisa com um grupo de estudantes da segunda maior cidade do Timor-Leste, Baucau, porém, como citado, o recesso escolar em Timor, até o término da primeira quinzena de agosto, não me permitiu em função do visto de 30 dias no país.

As entrevistas foram construídas na base de situações-problema, em que o estudante é chamado a opinar sobre um fato ou fenômeno apresentado, e para explicá-lo é necessário recorrer ao seu entendimento, formal ou não sobre o fenômeno. Para Perrenoud (2007, p.114), "as situações-problema caracterizam-se por recortes de um domínio complexo, cuja realização implica mobilizar recursos, tomar decisões e ativar esquemas". Dessa maneira, as situaçõesproblema não foram usadas como um simples itens de avaliação de aprendizagem do seu processo de escolarização, mas, como questionamentos sobre o mundo real no qual o estudante vivencia sua existência, podendo ou não fazer uso dos conhecimentos adquiridos na

\footnotetext{
${ }^{12}$ A programação do evento pode ser obtida no endereço: <https://goo.gl/94zNqk>
} 
escola para respondê-las, abrindo espaço também para soluções culturais alternativas na resolução dos problemas.

Para mobilizar as concepções dos estudantes frente às situações-problema, foram apresentados desafios que supostamente eram familiares aos alunos, pois fazem parte do contexto cotidiano dos indivíduos. Tendo em vista o processo iniciado na escolarização básica com a língua portuguesa, conforme estava previsto na Constituição, inicialmente foram feitas propostas em português, porém, já antevendo complicação no entendimento do que pretendem, os problemas, foram também traduzidas para o tétum ${ }^{13}$. A coleta das informações dos estudantes da escola pública selecionada ocorreu por meio de gravação digital das falas, incluindo-se novos questionamentos a partir das respostas obtidas, como característicos de entrevistas semi-estruturadas. Para a escola privada, como citado, cada aluno recebeu cópia das situações-problema nas duas línguas e foram solicitados a escrever suas respostas em português.

As categorias em que se buscaram as concepções dos alunos foram pensadas para contemplar três das grandes áreas que integram o ensino de ciências, a física, a química e a biologia. Salienta-se que embora as situações-problema tenham sido projetadas antes do estudo do currículo em Timor-Leste, ficando sua permanência condicionada e esse conhecimento curricular, as mesmas foram preservadas, pois o novo currículo, abordado em seção posterior, contemplava estes conhecimentos. Abaixo, na tabela 1, estão delineadas as categorias onde as situações-problema se circunscreveram:

TABELA 1 - Categorias de conceitos a serem contempladas nas concepções

\begin{tabular}{|l|l|}
\hline Categoria & Discernimento \\
\hline - Universo e a Terra (Física) & $\begin{array}{l}\text { Nessa categoria deve-se procurar o entendimento das } \\
\text { crianças sobre os planetas do Sistema Solar, os } \\
\text { movimentos astronômicos da Terra (rotação e } \\
\text { translação), entre outros, como as estações do ano, } \\
\text { contagem do tempo, influência lunar nas marés, etc. }\end{array}$ \\
\hline $\begin{array}{l}\text { - Os componentes da Terra } \\
\text { (Química) }\end{array}$ & $\begin{array}{l}\text { Nessa categoria deve-se procurar o entendimento dos } \\
\text { componentes abióticos do Planeta Terra e noções sobre } \\
\text { os ciclos biogeoquímicos (água, oxigênio, carbono), } \\
\text { nutrientes do solo e como ocorre a obtenção de energia } \\
\text { pelos seres vivos. }\end{array}$ \\
\hline
\end{tabular}

\footnotetext{
${ }^{13}$ As traduções das situações-problema foram feitas pelo professor e engenheiro elétrico timorense José Manoel Mesquita.
} 


\begin{tabular}{|l|l|}
\hline $\begin{array}{l}\text { - Caracterização dos seres } \\
\text { vivos (biologia) }\end{array}$ & $\begin{array}{l}\text { Nessa categoria deve-se procurar o entendimento da } \\
\text { composição química orgânica, metabolismo, reação a } \\
\text { estímulos, reprodução e crescimento dos seres vivos. }\end{array}$ \\
\hline $\begin{array}{l}\text { - Meio ambiente (Física, } \\
\text { Química e Biologia) }\end{array}$ & $\begin{array}{l}\text { Nessa categoria deve-se buscar o entendimento sobre as } \\
\text { interações dos seres vivos em seus ambientes e as } \\
\text { variáveis que determinam a preservação e a conservação } \\
\text { do ambiente. }\end{array}$ \\
\hline
\end{tabular}

As situações-problema envolvem circunstâncias familiares do cotidiano das pessoas, porém, buscou-se avaliar o conhecimento escolarizado dos estudantes sobre o assunto. Partindo do entendimento da teoria da aprendizagem significativa de Ausubel, em que "o fator mais importante que influencia a aprendizagem é aquilo que o aluno já sabe" (AUSUBEL, 2000, p.10), se assume como principal pressuposto que os alunos têm conhecimentos sobre os assuntos para os quais se buscam explicações para as situaçõesproblema, ainda que no campo das concepções alternativas. Com vistas a uma melhor aplicação dos problemas, foi projetado um pré-teste com estudantes timorenses para a testagem e aferimento da compreensão das questões para no caso de identificar dificuldades nessa compreensão, se proceder aos ajustes necessários na proposição das situações-problema para a explicitação das mesmas. Porém, em virtude da exigüidade de tempo como informado, não foi possível a realização deste pré-teste. Em tempo, salienta-se que essas situaçõesproblema foram aplicadas a título de exame, a alunos de $3^{\circ}$ ao $5^{\circ} \mathrm{Ano} / 9$ da Escola Classe 10 de Sobradinho - DF e no geral, não representaram grandes problemas de compreensão, ressalvado a situação sobre marés, possivelmente por falta de familiaridade destes com o mar. Abaixo, as situações-problema e respectivas traduções em tétum.

Sendo o Timor-Leste uma ilha, a vivência da sua população com o mar é intensa, por essa razão, na categoria "Universo e a Terra" a busca de representação dos estudantes relacionou-se com o movimento das marés e foi proposta nessa base:

\section{Situação 1}

Com a intenção de obter bons resultados em uma pescaria, o pescador João saiu com seu barco em uma hora determinada do dia para aproveitar a elevação do nível do mar e

chegar até uma ilha onde há um banco de corais que atrai muitos peixes. Sem se 
preocupar com a hora de retorno, pois estava pescando bem, terminou com seu barco encalhado no banco de corais, pois o nível da água do mar baixou. O que aconteceu com o mar? E por que isso aconteceu?

\section{Situasaun 1:}

Atu hetan ikan barak, João nudar peskador, iha tempo nebe'e tasi nakonu, nia ho ro'osai ba peska iharai ketan ida, fatin ne'e ikan barak tebes. La hanoin atu fila lalais ba uma, tamba hakarak hetan ikan barak. Tasi maran halo ro'o metin iha karan leten no labele sai. Saida maka akontese? Tanba sa maka akontese?

Quanto à expectativa de resposta em um conhecimento escolarizado sobre o assunto, é de se esperar que estudantes respondam sobre as marés e a influência que a lua exerce sobre o fenômeno, podendo ter uma explicação mais ou menos elaborada sobre isso em uma abordagem científica. Todavia, explicações alternativas de ordem cultural podem ser obtidas, sobretudo de alunos que tradicionalmente têm familiaridade com pesca, mar e marés.

A situação-problema inserida na categoria "Os componentes da Terra", objetivou relacionar os componentes abióticos que são necessários ao desenvolvimento de seres vivos. Nesse sentido é apresentada a seguinte proposição:

\section{Situação 2:}

Em um experimento em sala de aula, estudantes resolveram cultivar milho em um copinho com água e algodão. Após alguns dias todos observaram que as sementes de milho germinaram, mas diferente do que acontecia no campo, o pezinho de milho durou apenas alguns dias e morreu. Por que o pezinho de milho plantado no copinho com algodão não se desenvolve como o milho plantado no campo?

\section{Situasaun 2:}

Hala'o pratika iha eskola laran, eskola oan sira tau batar musan iha kopu nebe'e iha be no algudaun. Liu tia loron balun, sira hare katak batar komesa moris, maibe batar ne'e

lahanesan ho batar nebe'e moris iha to'os. Batar oan ne'e moris lakeleur deit, mate fali.

Tamba sa maka batar iha kopu lahanesan ho batar iha to'os?

Em relação à expectativa de respostas de alunos escolarizados sobre o assunto, ainda que relacionem o pouco espaço no copinho para que o pé de milho se desenvolva, é de se 
esperar a indicação de ausência de componentes fundamentais do ambiente como nutrientes do solo, para que ocorra o desenvolvimento da planta. Em uma resposta mais elaborada podem apresentar além do solo, outras condições para que a planta se desenvolva, como luminosidade, gás carbônico, oxigênio e sais minerais.

Para a categoria "Caracterização dos seres vivos", o problema envolve reprodução de animais e para isso é criada uma situação que busca o entendimento da impossibilidade de reprodução de animais de espécies diferentes. Abaixo a situação-problema:

\section{Situação 3:}

No trato com a plantação de arroz, os búfalos brancos são robustos e fazem o trabalho adequadamente. Pensando na resistência e força do búfalo, um agricultor que também tinha uma égua muito ágil, pensou em unir as qualidades dos dois animais para a obtenção de um animal melhor. Após longos meses tentando juntar o búfalo com a égua para a obtenção de filhotes, desistiu, pois os animais não apresentavam interesse um pelo outro. Por que estes animais não tiveram filhotes?

\section{Situasaun 3:}

Kuda hare, karau mutin nudar balada neb'e forsa tebes hodi halai natar. Hare ba karau mutin nia forsa no servisu diak, tos nain nebe'e iha kuda inan ida servisu nain;entaun, nia hanoin atu hakabenkarau aman ho kuda inan atu nune'e,oan neb'e moris bele iha kualidade diak. Iha fulan barak nia laran, to'os nain ne'e buka meius oin-oin atu karau ho kuda bele kaben, maibe esforsu ne'e laiha rejultadu tamba, balada rua ne'e laiha atrasaun ba malu.

Tamba sa maka balada rua ne'e laiha oan?

Espera-se que estudantes escolarizados sobre reprodução animal e conceito de espécie expressem o entendimento de que animais só se reproduzem se forem da mesma espécie, ainda que haja alguns casos de híbridos na natureza em função da proximidade biológica de indivíduos do mesmo gênero, como ocorre com equinos (cavalos e jumentos). No caso apresentado no problema, embora os animais sejam mamíferos pertencem a famílias diferentes. O aluno deve tecer considerações que relacionem diferenças biológicas nos animais e, sobretudo a barreira da espécie.

Para a categoria "Meio ambiente", a situação-problema buscou a compreensão dos alunos sobre as interações que ocorrem entre seres vivos no ambiente ao tempo em que 
envolve entendimento sobre cadeias alimentares e desequilíbrio ecológico. Para isso será apresentada a seguinte situação:

\section{Situação 4:}

Um agricultor preocupado com ataque de ratos aos seus depósitos de milho resolveu criar alguns gatos com o intuito de espantar os ratos. Após alguns dias notou que o milho em seus depósitos parou de ser atacado por ratos, mais, passou a notar outra situação ocorrendo em seu milharal, ele estava sendo atacado por insetos. Como essa situação pode ser explicada?

\section{Situasaun 4:}

Tos nain preokupa ho laho nebe'e estraga batariha hokan, atu rejolve problema ne'e, to'os nain hakiak busa hodi hatauk laho sira atu nune'e labele estraga tan batar. Ikus mai, laho sira la estraga ona batarmai be, mosu fali problema foun, insektu (fuhuk) sira maka estraga fali batar. Oin sae atu esplika situasaun ida ne'e?

A expectativa de respostas para era situação em uma condição de escolarização centrase na percepção dos estudantes sobre cadeias alimentares, equilíbrio ecológico e de agentes intervenientes que podem influir nesse equilíbrio quando agentes estranhos são introduzidos. Outra expectativa mais elaborada envolve a ação humana provocando essas alterações.

O trabalho projetado para levantamento de concepções de professores sobre ensino de ciências em Timor, a partir de adaptação do VOSTS (Views on Science Technology-Society), questionário criado por Aikenheaed, Fleming \& Ryan (1989), não foi possível realizar, conforme foi explicado acima. Porém, procedeu-se o contato com professores formadores que atuam na formação continuada de professores em Timor, e a partir desses contatos, coletou-se informações importantes que estão presentes ao longo deste trabalho.

\subsubsection{Procedimentos de pesquisa}

Delimitando as ações necessárias para a consecução da pesquisa para a tese, pode-se identificar três procedimentos: pesquisa bibliográfica, análise de narrativas e produção de dados no estudo de concepções de conceitos em ciências com estudantes da escola básica em Timor-Leste. 
Quanto ao trabalho de pesquisa bibliográfica se contou com vasto material adquirido ao longo do tempo em várias fontes, entre elas os periódicos da CAPES que possibilitam a consulta a revistas especializadas, relatórios da UNESCO, material adquirido em Timor, Biblioteca Digital do Porto com seu acervo importante para consulta histórica sobre o TimorLeste e pesquisa intensa nas Bibliotecas da Pós-Graduação da UNTL (Universidade Nacional de Timor Lorosa'e) e do INFORDEPE (Instituto Nacional de Formação de Docentes e Profissionais da Educação) na primeira quinzena do mês de agosto de 2016.

As narrativas construídas no ano de 2007 representam outra fonte de material inédito, pois entre memórias das dinâmicas do projeto PROFEP-Timor, relatórios, narrativas pessoais e pequenos contos "antropológicos" sobre a gente do Timor, seus costumes e tradições, há mais de 700 páginas escritas que demandam leituras para seleção das narrativas representativas que sejam importantes para esta tese, haja vista que um grande número dessas narrativas envolvem outras percepções que extrapolam as ligações com o Timor-Leste e vão para o campo das vivências psicológicas pessoais. Além disso, o acervo particular sobre o Timor-Leste vivido, ainda conta com mais de duas mil fotografias, algumas, sempre que necessário foram inseridas ao longo deste texto.

Quanto à coleta de dados das concepções dos estudantes, considero a etapa mais sensível do trabalho. Sensível porque diante do que se espera em um projeto, nem tudo pode ser antecipadamente previsto. Assim, durante a coleta de dados naquele país os imprevistos tiveram que ser contornado por algumas mudanças metodológicas em função das circunstâncias que estão relatadas adiante no capítulo 4.

\subsubsection{Critérios de escolha dos grupos participantes}

Para a escolha dos grupos de estudantes integrantes do estudo levou-se em consideração o estudo do currículo da escola básica, já que não dispunha no Brasil deste documento que também não estava disponível na internet. Assim, em um trabalho preliminar se identificou no currículo os conteúdos envolvidos nas situações-problema elaboradas, e a partir disso optou-se pela aplicação na última série do segundo ciclo, ou seja, o $6^{\circ}$ ano, na escola pública e para o $7^{\circ}$ ano na escola privada. A opção pela escolha do $7^{\circ}$ ano na escola privada deveu-se a um imperativo da direção da escola que não me permitiu a aplicação das situações-problema em turmas de $6^{\circ}$ ano. Como já mencionado, a exiguidade de tempo não me permitiu a visita a outra escola. 
Ressalta-se que apesar da inexistência de um currículo de ciências por ocasião da participação na formação de professores do PROFEP-Timor em 2007, como já mencionado, o Timor-Leste construiu seu referencial curricular para a educação básica em 2010. Como o Ministério da Educação do Timor-Leste, possui uma Diretoria de Currículo, este passa por constantes revisões e alterações, de modo que as considerações aqui expostas representarão um instantâneo do currículo que vige em Timor, e, diga-se de passagem, já é do ano de 2015.

Maiores detalhes sobre currículo e a composição dos grupos de participantes, serão apresentados no capítulo 4. 


\section{CAPÍTULO 2 \\ Colonização, invasão indonésia e autonomia}

Este capítulo se constitui a partir do estudo de obras fundamentais para conhecer a História do Timor-Leste e se organiza em três fases, o Timor-Leste colonial, o período da invasão da Indonésia e o Timor-Leste atual. Para isso, foram utilizadas três obras fundamentais. A obra de Afonso de Castro, antigo governador do Timor do século XIX, a obra de Teófilo Duarte outro governador de meados do século XX e a obra de Barbedo de Magalhães, contemporâneo estudioso do Timor que produziu uma grande obra distribuídas em três volumes, onde estão detalhadas a história do Timor contemporâneo até o ano de 2007.

\subsection{Período Colonial do Timor-Leste, de 1511 até 1895}

A tarefa de entender a situação educacional no campo do Ensino de Ciências do Timor-Leste atual a partir da análise pontual dos elementos da contemporaneidade não bastam. Necessário se faz um exame detalhado que a amplitude dessa tese é limitada para sua explanação. Neste sentido, assumiremos aqui a compreensão advinda da prática pelo o que foi experimentado e vivido na formação de professores timorenses, bem como nas pesquisas de campo realizadas nas escolas com alunos e entrevistas realizadas no Instituto de Formação de Professores do Timor-Leste (INFORDEPE), para construirmos uma compreensão nessa base empírica. Todavia, não se pode omitir nesta tese as contribuições dos elementos teóricos que foram produzidos a partir das leituras e das análises especulativas de todos os contributos da bibliografia e da historiografia do Timor, da expectativa racional do que se observou, viveu-se e sentiu-se na construção desta pesquisa. Neste sentido, unindo-se o saber advindo dos elementos práticos com o adquirido a partir do saber teórico e da história, chamo em auxílio para esta compreensão entre o saber prático e o teórico o que nos ensina SANTOS (1962, p.15-16):

\footnotetext{
Consideravam os gregos, o saber de duas espécies: é o saber teórico e um saber prático. O saber prático é o saber que é dado pela experiência. O teórico vem de teoria, que, já vimos, para os gregos, é a contemplação, é um saber especulativo, discursivo, de discorrer, de correr daqui para ali, é o saber que o espírito constrói, comparando uns fatos com outros, e descobrindo seu nexo causal, suas origens, e incorporando-os, posteriormente, numa teoria, numa visão particular dos mesmos, que os inclua conexionadamente. Toda teoria se funda numa especulação, num espelhar os fatos do passado, comparando-os com os do presente, para descobrir, nestes como naqueles, o nexo que os liga. A teoria é, assim, uma construção do espírito feita sobre os fatos dados pela prática.
}

Neste sentido, pode-se dizer que para os gregos a História é um saber prático, não procuravam eles uma teoria sobre a História, nem descobrir o nexo dos fatos (SANTOS, 
1962). Muito embora nas concepções da História atual, com seus novos métodos e em consórcio com outras áreas das ciências como a Sociologia e a Antropologia, por exemplo, a História tenha se tornado também ela uma ciência com seus componentes teóricos, o que lhe confere uma nova fisionomia, diferente daquela dos gregos antigos.

Os fatos que ocorrem no tempo são objeto de análise da História, e a compreensão do que se passa hoje em Timor-Leste, se constrói e se compreende a partir desses elementos do seu passado. A documentação histórica do Timor-Leste e sua preservação, que atestam a veracidade das narrativas, sempre sofreram reveses, desde o período colonial, como deixa claro Afonso de Castro na sua crônica sobre a história colonial do Timor (As possessões portuguesas na Oceania), onde muitos dos documentos que podiam comprovar suas especulações foram perdidos ou não encontrados, até os tempos da invasão indonésia, onde muitos desses documentos, sobretudo aqueles até 1975, que tratavam das propriedades e guardavam o histórico fundiário, por exemplo, foram destruídos pela sanha das milícias próIndonésia em produzir "terra arrasada", quando da decisão por plebiscito da maioria da população timorense em se tornar independente daquele estado. O prejuízo dessa destruição documental, não ocorreu apenas no campo dos dados históricos, mas também, para as populações de refugiados que retornavam para suas casas e encontravam já outros lá habitando. Como comprovar então, que eram os antigos donos, já que toda a prova documental havida sido definitivamente perdida? A gravidade dessa situação, que no campo da justiça provisória instalada, impossível de resolver sem provas documentais, iria repercutir mais no futuro, nos conflitos internos. Em sua monumental obra Barbedo de Magalhães (2007) nos informa que,

os serviços de registro de propriedade tinham sido completamente queimados e os registros destruídos. Aparentemente, o livro com os títulos de propriedades de Díli foi levado para a Indonésia pelo chefe dos serviços correspondentes. Ao fazê-lo, salvou os títulos de propriedade registrados no período de ocupação indonésia, com o objectivo de apoiar reivindicações de propriedade de indonésios e as correspondentes compensações. Em todo o caso, os documentos que poderiam validar esses registros foram destruídos. E todos os registros anteriores, dos tempos dos portugueses, desapareceram. (Apud. FITZPATRICK, 2002, p.7). (Vol. III, p. $628)$.

Voltando ao fio condutor da pesquisa, nada se compreenderá de forma clara a justificar o atual estado de Educação em Timor-Leste, sem, no entanto, se fazer, ainda que superficial, um apanhado histórico do país, e para isso, como mencionado anteriormente, serão utilizadas três obras fundamentais, a de Afonso de Castro (As possessões Portuguesas na Oceania) de 1867 como fundamental para a compreensão do período colonial até o século XIX, a obra de Teófilo Duarte (Ocupação e Colonização Branca de Timor) de 1944, a 
grandiosa obra de Barbedo de Magalhães (Timor-Leste - Interesses Internacionais e actores locais) de 2007 que em três volumes e com vasta documentação recolhida, delineia detalhadamente os fatos históricos do Timor-Leste de 1944 até 2007 e por fim, como uma obra acessória, a de Dom Carlos Filipe Ximenes Belo, (Bispo de Díli e prêmio Nobel da Paz de 1996) “Os Antigos Reinos de Timor-Leste”.

\subsubsection{Breves considerações sobre a História Colonial do Timor-Leste até o século XIX na crônica de Afonso de Castro}

O século XIX marcou um período de forte produção no campo do conhecimento. Inúmeras ciências e novos ramos do saber têm sua gênese neste século e uma grande quantidade de contribuições foi dada por inúmeros registros feitos por desbravadores que entenderam a importância de perenizar narrativas para a posteridade, permitindo por meio de sua análise o entendimento de fatos e circunstâncias que de outro modo seriam superficiais e no campo das inferências vazias. Assim, aqui é resgatada uma dessas narrativas do século XIX que lança luzes para se entender a educação em Timor-Leste a partir de fatores históricos geradores. O presente texto, em seu estilo, apresenta algumas poucas inferências sobre a experiência vivida pelo autor no trabalho de formação de professores, centrando-se sua abordagem da obra de Afonso de Castro publicada em 1867 e disponível como arquivo digital no site da Biblioteca Digital Mundial ${ }^{14}$.

Não obstante o Timor-Leste ter sido encontrado por portugueses em 1511, a ilha não despertou interesse de Portugal. Até a segunda metade do século XIX, nada ou quase nada se escreveu sobre o Timor-Leste. Isso fica evidenciado na narrativa do governador português do Timor, Afonso de Castro (1824-1885), nomeado para o cargo em 1858, tendo permanecido até 1863. Em 1867 publica, provavelmente, uma das poucas obras do período colonial até o século XIX sobre o Timor-Leste, intitulada "As Possessões Portuguesas na Oceania". No prefácio o autor menciona que de todas as possessões portuguesas a menos conhecida era sem dúvida alguma a de Timor. Cita ainda que pouco ou nada se havia escrito sobre a colônia, não existindo arquivos inclusive no ministério da marinha. Os arquivos que pertenciam a Goa forneciam alguns esclarecimentos sobre o Timor, mas ainda assim, não eram de confiança, pois, segundo Castro, entre uma ou outra verdade se introduziu muita falsidade.

Em função da falta de documento sobre a colônia que servisse de referência para a consulta que embasasse a narrativa, Castro (1867) informa que apresentaria sobre o Timor

\footnotetext{
${ }^{14}$ A obra "As Possessões Portuguesas na Oceania" pode ser acessada na íntegra e baixada no site da Biblioteca Digital Mundial no endereço <http://www.wdl.org/pt/item/2398/>.
} 
simples conjecturas em vez de narrativas fieis, recorrendo à tradição para o conhecimento de fatos que os arquivos deveriam mostrar. Salienta ainda que omitirá tudo aquilo que sua razão rejeitar como fabuloso, procurando discriminar o verdadeiro do falso. Nota-se na descrição da sua metodologia na construção da narrativa, elementos do positivismo de Augusto Comte, pautado na coerência e na razão, muito em voga no final do século XIX. Isso nos remete à percepção da sua formação sólida na Escola Politécnica de Lisboa tendo em vista o curso iniciado em 1842 para a carreira de oficial de infantaria do Exército Português da Escola do Exército, concluído em 1845. Castro também dedicou-se ao jornalismo, colaborando com vários jornais e sendo redator do Esperança. Em 1854 foi eleito deputado por Timor e em 1858, foi nomeado governador do Timor, porém, Segundo Ximenes Belo (2013, p.293), “só tomou posse em 1859, pois teve de desempenhar o cargo de secretário nas negociações diplomáticas com os Países Baixos sobre as delimitações do território de S. Tomé”.

O livro de Castro acima referido é dividido em duas partes: a primeira centra-se na história do Timor-Leste até aquela data e a segunda tratará da economia e da política. Nos aspectos históricos, o autor evidencia na narrativa a luta dos missionários religiosos na árdua tarefa de conversão do homem "gentio" daquelas terras. A segunda parte relata os fatos dos governadores da ilha no aspecto administrativo, acentuando que seus papéis enquanto administradores se reduziram a quase somente sustentarem lutas contra indígenas e holandeses que disputavam o território. À data da publicação da sua obra, Castro (1867, p.IX) informa em tom de lamento, ao que se reduziu à empresa colonial portuguesa de outros tempos ao afirmar que:

Do nosso grande império do oriente, da famosa herança que nos legaram os Castros e Albuquerques ${ }^{15}$, das vastas conquistas que a terrível espada dos nossos guerreiros, ou a inspirada palavra dos nossos missionários nos traçaram no oriente, não nos resta hoje senão a pequena porção de território inserida no império anglo-indiano, chamada Goa, um canto de uma península no Império do Meio ${ }^{16}$, chamado Macau, e uma parte da ilha de Timor, como que encravada nos extensos domínios holandeses na Malásia.

Nota o autor que a empresa portuguesa, enquanto disputava suas possessões com os povos asiáticos sempre se saiu vitoriosa, todavia, não suportou a união dos índios e malaios aos esforços dos rivais europeus, sobretudo Holanda e Grã-Bretanha que futuramente retalhariam e dividiriam o vasto império fundado por Afonso de Albuquerque, levando-o a

\footnotetext{
${ }^{15}$ Citação em alusão a Afonso de Albuquerque (1453-1515) cujas ações militares e políticas foram fundamentais para o estabelecimento e consolidação do Império Português no Oceano Índico e a D. João de Castro (15001548), governador, capitão general e vice-rei do Estado Português da Índia, entoados por Camões em "Os Lusíadas" (canto I, est. 14) como "Albuquerque terríbil, Castro forte, e outros em quem poder não teve a morte". (nota do autor).

${ }^{16}$ Expressão antiga usada para designar a China, que se considerava "o país que está no centro do planeta Terra" e única superpotência econômica, política, tecnológica, social e cultural do mundo. (Nota do autor).
} 
sucumbir. Essa consideração permite-nos concluir que o empreendimento português não foi benevolente com os nativos das terras dominadas, já que isso possivelmente promoveu levantes e revoltas, diante da exploração e violência que exerciam sobre os domínios coloniais.

Era sentimento português autêntico a crença de que seu empreendimento imperialista no mundo vinculava-se à sua suposta superioridade civilizacional, na sua cultura, armamento e fé cristã, como europeus que eram. Assim, rivalizar com estes povos, por sua suposição, primitivos nestes aspectos, os tornavam invencíveis e legítimos na empreitada, já que acima dos bens econômicos angariados pelo processo colonizador, estava a difusão da civilização ocidental superior em suas diversas dimensões, da religião ao conhecimento de modo geral. Todavia, contender com semelhantes europeus que receberam o apoio dos nativos, revelou a assimetria de forças imputadas como agentes causadoras da sua derrocada. Enfatiza-se neste ponto, que a percepção desse aspecto do domínio colonial eurocêntrico é fundamental como linha mestra nas discussões apresentadas nesta tese. Observa-se em Castro (1867, p. X), referência à superioridade europeia diante dos nativos asiáticos ao aludir que:

Contra aqueles favorecia-nos a superioridade do armamento, a força da disciplina,
uma civilização mais adiantada, e não menos o ardor da fé, combatendo por Deus
para substituir a verdade da sua doutrina aos erros de Brahma, de Buda e de
Mahomet. Mas quando se nos opôs um inimigo que nos era igual em armamento, em
disciplina e em civilização, e a quem não pretendíamos converter à nossa religião,
desapareceram as vantagens da nossa parte, e tivemos de sucumbir à força do
número, não sem tingir de sangue inimigo todo o oriente.

É perceptível na citação acima, um caráter educacional como pretensão dos portugueses diante das culturas orientais, ainda que o enriquecimento econômico proporcionado pelo mercantilismo de matérias-primas adquiridas na ação exploratória extrativista fosse um dos maiores interesses, o domínio pela imposição de uma religião ocidental, era um contributo educacional civilizatório para estes povos com suas religiões “primitivas", eivadas de animismo.

O forte encaminhamento religioso do processo educativo pretendido por Portugal em terras orientais, certamente levou missionários à percepção da riqueza dos cultos praticados nas crenças das religiões autóctone, com uma variedade de adornos e símbolos, que chamavam a atenção pelo deslumbre exercido nas populações. Dessa maneira, intuiu-se que para os povos sensuais e dotados de ardente imaginação como os orientais, talvez não fosse adequado crenças protestantes, como o anglicanismo inglês, mais afeito a povos civilizados e meditativos (CASTRO, 1867). Dessa forma, Castro (1867, p. XII) ao analisar a religião mais adequada para os padrões do que pretendiam os nativos orientais, em tempos de disputa 
hegemônica entre Portugal e outras nações européias do período, como a inglesa, denota na sua abordagem, a percepção da superioridade do cristianismo católico para essa finalidade e assim se refere ao desejo do povo oriental:

"Querem estes uma religião que os deslumbre pelas pompas do culto e que os sujeite pelo princípio de autoridade, e a religião católica romana mais que nenhuma outra está neste caso. Uma festa religiosa em templo católico só por si fará mais prosélitos no oriente, do que todas as prédicas dos mais hábeis ministros protestantes".

Infere-se nesta afirmação, todo o empenho que foi devotado pelos missionários religiosos na imposição do catolicismo no período colonial timorense, como ferramenta de domínio travestida de educação.

Os impactos da religiosidade imposta pelos portugueses aos timorenses, certamente causou alterações nos seus referenciais culturais originais, permitindo uma inserção que possivelmente minou o universo de representações sobre a natureza que aqueles povos já possuíam. O colonialismo, portanto, vai além da irrupção e posse dos bens materiais dos povos colonizados, passando à subjugação de uma civilização antiga, como sendo primitiva, bárbara, por outra que entende ser necessária sua suplantação por algo etnicamente superior.

Ao observar a história da derrocada do império português no oriente, Castro (1867) percebe os erros da imposição cultural nos moldes do que foi feito, sem respeito aos elementos culturais da terra, e ventila a hipótese de que havia a necessidade do emprego de meios mais adequados para lidar com o oriental, que fosse diferente do empregado por Portugal. Ao legislar às cegas países tão diferentes culturalmente, deveriam ter focado em procedimentos mais apropriados ao ser social dos povos e aos seus usos e costumes. Percebese aqui, um reconhecimento das diferenças culturais orientais e a dificuldade de adequá-la a interesses e costumes ocidentais.

O declínio do império português no oriente diminuiu sobremaneira as possessões portuguesas, remanescendo apenas Goa na Índia, Macau na China e o Timor. Entre as que existiram e as que ainda eram colônia de Portugal,

nenhuma tão desamparada como Timor, e por isso nenhuma tão miserável, e que menos se ressinta da dominação de uma potência civilizada. Timor, que tem dois elementos essenciais para a sua prosperidade - fertilidade de solo e bastante população - acha-se na maior miséria. A indústria reduz-se ao fabrico de mal tecidos panos de algodão, com que os indígenas se cobrem, e ao fabrico de toscas panelas de barro. $\mathrm{O}$ comércio reduz-se à permutação dos poucos produtos do país, tais como cera, sândalo, café, milho, cavalos e búfalos por tecido de algodão, armas, pólvora, bebidas espirituosas, manilhas e facas. A agricultura reduz-se ao cultivo do milho, do arroz, do café, do trigo, e das batatas e poucos mais gêneros, seguindo-se os primitivos processos no granjeio destes produtos. (CASTRO, 1867, p.XIV). 
$\mathrm{Na}$ visão do autor e sob o parâmetro da prosperidade ocidental, a cultura de subsistência e a manufatura timorense do século XIX denotam pobreza e miséria daquelas terras abandonadas e isso permite uma inferência sobre a visão eurocêntrica de considerar pobre, selvagem, inculto, bárbaro, todos os povos que possuíam culturas e hábitos de vida diferentes dos europeus. Portanto, buscaram por meios exploratórios das riquezas dos povos dominados, ou por meio da subjugação cultural, imprimir valores que não faziam parte do repertório simbólico dos povos orientais em geral e dos timorenses em particular.

Isso fica patente no trecho em que Castro (1867) menciona que o povo vivia na miséria, tiranizado pelos reis e outros nobres da hierarquia timorense e mesmo esses, também não conheciam a abundância e o bem estar. Deixa evidente ainda que aquela ilha que poderia ser de grande vantagem para Portugal em função da sua posição geográfica, serve-lhe só de pesado encargo, absorvendo recursos e vidas de alguns portugueses que para lá se aventuraram.

A percepção de um homem como Afonso de Castro da terra timorense por ocasião do seu governo, tem como parâmetro o que testemunhou em outras possessões portuguesas de além mar, isso o leva a lamentar sobre o Timor, que em

\footnotetext{
três séculos de dominação não têm nem criado indústria, nem desenvolvido o comércio e a agricultura, nem civilizado o povo, nem firmado a nossa soberania. Parece que a civilização nunca ali penetrou, e se hoje abandonássemos a ilha poucos vestígios ficariam do nosso domínio. (CASTRO, 1867, p. XV).
}

Ocorre que o panorama acima traçado pela percepção de um atento observador pioneiro nos registros sobre o Timor, torna mais difícil tarefa de encontrar bases da educação timorense, pelo menos nos moldes da ocidental eurocêntrica, no seu período colonial pela ausência e negligência de Portugal. Porém, não se pode negar a existência de outro tipo de educação. Afinal, assume-se que somente pela sobrevivência de valores culturais e de mecanismos de manutenção e perpetuação desses valores para as gerações futuras, é que se torna possível a sobrevivência das sociedades, primitivas ou não.

Um exemplo ilustrativo que pode ser colocado para salientar a importância do conhecimento acumulado pela cultura e seus processos de transmissão, diz respeito a uma situação vivida: em certa ocasião no ano de 2007, em um encontro presencial (Figura 1) com professores timorenses à hora do almoço, fui apresentado a um guisado feito com flores de mamoeiro. Ao notar minha resistência ao consumir o prato, uma professora timorense se aproximou e me questionou sobre se estava gostando ou não da flor de mamoeiro daquela forma. Disse-lhe gentilmente que não estava acostumado com o amargor do sabor. A senhora 
professora prontamente disse-me que apesar do sabor desagradável, era aquilo que garantia a pequena mortalidade por malária do povo maubere há oito mil anos na ilha do Timor (memória em seu contexto: ver apêndice, narrativa 10, p.303). Aquela era uma tradição cultural passada de geração em geração. Ainda que careçam de informações sobre princípios ativos da bioquímica das folhas do mamoeiro, o que seria um conhecimento científico, o que vinculava esse conhecimento popular a sua efetividade, era a experiência acumulada mediante o êxito no tratamento da malária. Certamente um aprendizado efetivo nas gerações de timorenses construído historicamente. Conhecimento que poderia passar para a ciência a partir de alguns rigores investigativos. Como nos ensina Merleau Ponty (2011, p.3),

Todo a o universo da ciência é construído sobre o mundo vivido, e se queremos pensar a própria ciência com rigor, apreciar exatamente seu sentido e seu alcance, precisamos primeiramente despertar essa experiência do mundo da qual ela é a expressão segunda.

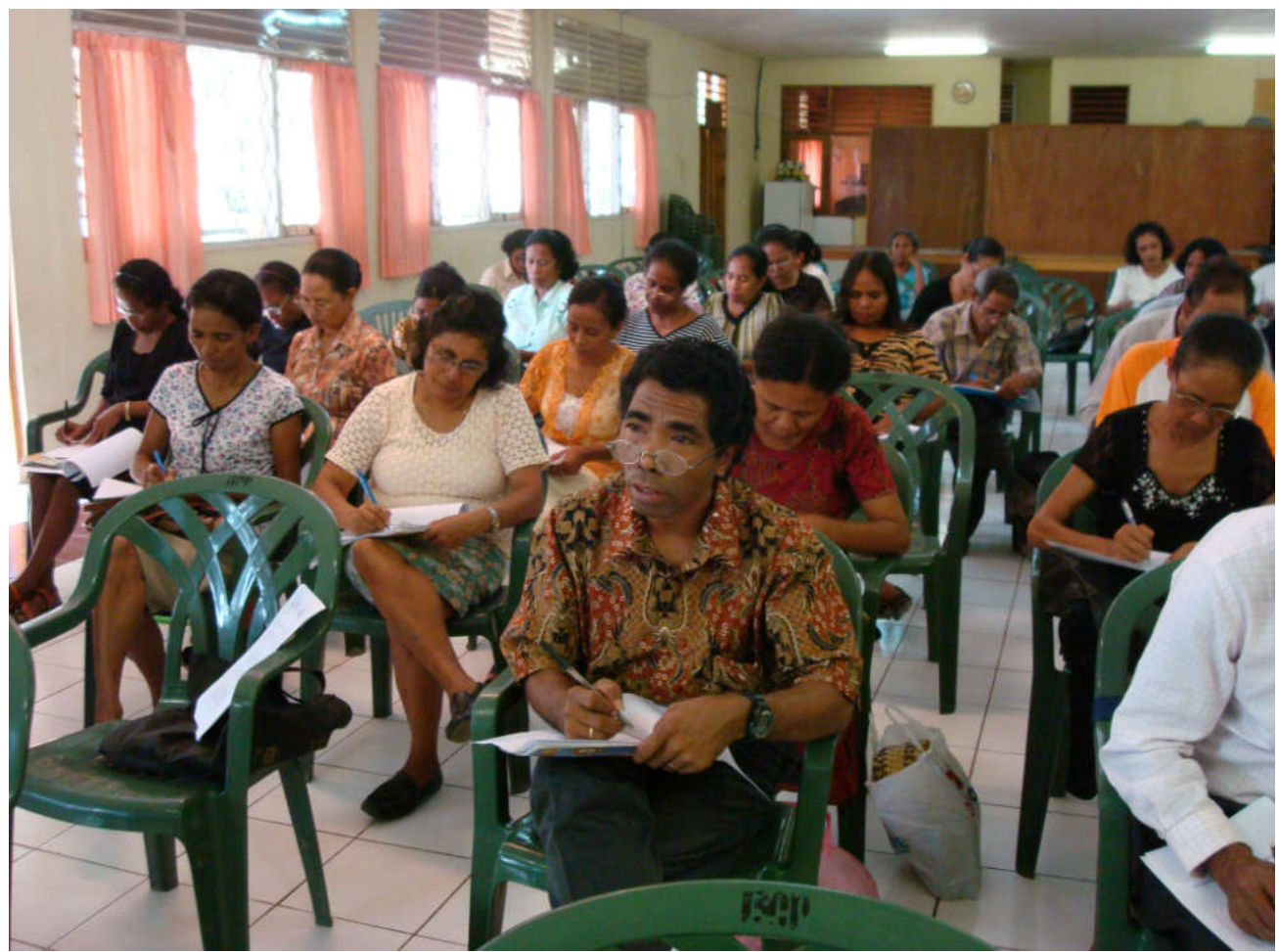

FIGURA 1 - Fotografia de encontro presencial do PROFEP-Timor em Díli

Assim, ainda que uma sociedade dita primitiva pelos parâmetros das civilizações ocidentais, com línguas ágrafas e sem outros recursos que a percepção de um "civilizado" europeu pudesse entender, não é difícil aceitar a presença de sistemas instrucionais usados na permanência do conhecimento de uma sociedade no campo da oralidade. Até porque há mais tempo da humanidade em um período pré-escrita do que posterior a esta e nem por isso o 
conhecimento e as experiências deixaram de ser transmitida. Como afirma Doren (2012, p.46-

47),

É verdade que a tradição oral levou a humanidade muito longe. Os primeiros impérios foram construídos sem escrita. Arte e até mesmo poesia grandiosa foram produzidas por homens que não conheceram a arte da escrita. O próprio Homero, o primeiro e, de certa forma, ainda o maior dos poetas, era iletrado. No seu tempo (por volta de 1000 a.C.), a maior parte do mundo era iletrada. Mesmo onde os homens aprenderam a escrever, como na Mesopotâmia, no Egito e na China, essa nova capacidade maravilhosa era utilizada apenas para criar registros. Não viam a escrita como uma forma incomparável de pensar melhor.

Ainda em se tratando da indiferença que um dito "superior" culturalmente observa a cultura de outro, o estranhamento da cultura timorense pelo governador europeu do século XIX é ainda maior, quando observa os hábitos sociais nas relações políticas, nas regras e na sociedade, o que o leva a entendê-los como "bárbaros" frente a sua "civilização". O TimorLeste em sua história colonial foi percebido como uma sociedade feudal composta por inúmeros reinos. Os reis eram chamados de liurais $^{17}$ e comandavam suas terras, os sucos $^{18}$, com rigor. O trecho abaixo trazido por Castro (1867, p.XV) é bem ilustrativo da sua impressão da "barbárie" timorense:

Os reinos regem-se pelo que se chama estylos, e a nossa suave legislação é ali desconhecida. Quem rouba uma cabeça de gado sofre ainda a pena capital; o prisioneiro de guerra é feito escravo; o assassino pode remir a pena dando aos parentes do morto uma pessoa que o substitua na família, juntando a isto certa soma; o suspeito de sanguice (feitiçaria) é irremissivelmente empalado, ou morto às pauladas, toda a sua família reduzida à escravidão, e os seus haveres confiscados em proveito do rei e do acusador. E a autoridade superior portuguesa, sem força para fazer respeitar as suas determinações, tem de ser indiferente a estes horrores, e de sancionar pelo silêncio tais estylos de sangue, para não ser desobedecida, quando tente reprimir tamanhas crueldades. Um ou outro governador, querendo adoçar os costumes daquele povo proibia a aplicação da pena capital; mas eram infrutíferas tais tentativas, principalmente nos reinos que estavam fora da ação do governo. E fora dela, existiam quase todos.

Percebe-se pelo o descrito acima, que os governantes portugueses não tiveram muita gerência sobre hábitos e costumes do povo timorense. Os liurais continuavam exercendo seu poder nos sucos, a sociedade se regia por leis próprias e costumes locais, as inúmeras línguas continuaram a existir e a língua portuguesa pouco difundida e falada esparsamente ${ }^{19}$. Na

\footnotetext{
${ }^{17}$ Afonso de Castro era da opinião que a palavra Tétum Leoreay ou Liurai provém da palavra portuguesa "Rei". Porém na opinião de Ximenes Belo (2013), a palavra Liurai provém do termo malaio "Lurah" significando autoridade. Os timorenses, ao nível do comércio, tinham contatos com mercadores de Java e de Ternate (Ilhas Molucas), bem antes da chegada dos portugueses.

${ }^{18}$ Suco é uma unidade político-administrativa tradicional e que, atualmente agrega um conjunto de aldeias. Um suco corresponderia tradicionalmente a um único clã (SILVA; SIMIÃO, 2007. p.86). Existem 498 sucos no território, numa média de 7 por subdistrito. <http://timor-leste.gov.tl/?p=91>

${ }^{19} \mathrm{Em} \mathrm{2007}$, por ocasião de uma vista a encontro presencial no distrito de Vemasse, um professor timorense falando sobre a dificuldade com a língua portuguesa disse que as crianças do Timor-Leste não nascem para a língua portuguesa, desde pequenas os pais só falam suas línguas maternas e elas, aprendem a pensar e a ver tudo com a língua dos pais. Então os professores, que também têm dificuldades com a língua portuguesa, devem trabalhar dobrado para fazer a tradução de tudo para as línguas das crianças e ainda arranjar um jeito de
} 
tentativa de regular essa situação, em 1860 o governador do Timor, Afonso de Castro, criou os distritos no território e à frente de cada um colocou um oficial militar que deveria dirigir aquele distrito pelo regulamento então publicado. No entanto, por falta de pessoal habilitado e de força para sustentar a autoridade do comandante, a medida administrativa não pôde ser executada. Muitos reinos continuaram na independência, em que se achavam, seguindo os seus estylos, e, pela análise de Castro (1867, p. XI), “o povo do Timor que poderíamos ter iniciado na civilização, continua seguindo os seus ferozes instintos, e no estado de barbárie em que se achava nos primeiros tempos da ocupação".

Fazendo uma análise mais atenta para essa situação, é de se notar que os governantes portugueses, tendo em vista a dificuldade para a implementação de mudanças dentro da sociedade timorense, preferiram acomodar-se de modo que fosse possível uma convivência mais amigável. É de se notar que enquanto boa parte das colônias portuguesas espalhadas pelo mundo teve o auxílio dos Jesuítas no processo de dominação cultural pela educação nos moldes ocidentais e pautada na religião cristã católica, no Timor, a ordem religiosa que operou foi a dos Dominicanos.

Nessa época vemos Timor inteiramente entregue à congregação de S. Domingos. São os frades que põem e dispõem, que fazem acordos com os regulos, que lhes movem guerra, ou com eles tratam da paz, que lhes impõem os encargos com que hão de contribuir para as despesas do estabelecimento, em uma palavra são os frades os senhores do grupo de ilhas do Timor e Solor ${ }^{20}$. O vigário visitador é o capitão, o juiz, o administrador, é tudo; e o que admira é que o governo dos frades não se enraizasse profundamente em Timor, e que a congregação não pusesse em prática todos os meios para conservar no seu domínio aquele país, como a Companhia de Jesus o havia feito no Paraguai. É que os fins da Ordem de S. Domingos eram diferentes dos da Companhia de Jesus. (CASTRO, 1867, p. XVI).

A ordem dos pregadores como passou a ser conhecida Ordem dos Dominicanos, tinha em seus princípios a pregação da palavra e mensagem de Jesus Cristo, combater os hereges e por em prática a Inquisição Católica, ou seja, a defesa da fé católica, desempenhando um papel bem mais centrado na proteção e difusão do catolicismo, do que na educação dos povos, como realizada pelos Jesuítas. Em que pese a Ordem religiosa ter sido fundada por Domingos de Guzmán (1170-1221) e em função do seu nome, ter ficado conhecida por Ordem Dominicana, era comum entre seus membros, assumir uma denominação etimológica da expressão em latim "domini canes", que pode ser traduzida como os "cães de Deus", os "cães a serviço do Senhor" ou os "cães de guarda do Senhor" (SILVA, 1982, p. 68). Se os Jesuítas

fazê-las pensar em português, pois fazer a tradução apenas da língua, não adiantava muito, pois as crianças quando voltam para suas casas iriam continuar ouvindo a família falar suas línguas, não treinando o português (Ver apêndice - narrativa 9, p. 301).

${ }^{20}$ Ilha indonésia pertencente ao arquipélago de Sunda, onde portugueses se estabeleceram em 1520. (Nota do autor). 
minavam as culturas pela doutrinação e pela educação, os Dominicanos tentavam fazê-lo pela pregação religiosa e pela coação da Santa Inquisição.

Andrade (2012, p.28-29) em seus estudos sobre a religião timorense atesta que um dos facilitadores da introdução do catolicismo em Timor deve-se à concepção primitiva das crenças timorenses. Desta forma,

pode-se a afirmar que, em linhas gerais, o mundo sobrenatural do timorense configura-se numa pirâmide, no vértice do qual está Maromak e na base os matebian (avós, espíritos dos antepassados), situando-se entre estes e Maromak os génios ou espíritos tutelares, que se consideram neste sistema divindades menores, os lulik. Um dos fatores muito importantes que facilitou a ação dos missionários em Timor foi o monoteísmo local, a crença num Deus único (Maromak, Fi-da'e-coro ou HiraHebana), embora vago e distante e a quem não se prestava, diretamente, culto. Os Missionários adotaram a palavra Maromak para designar o Deus Cristão e cuidaram de levar os timorenses ao culto direto a Maromak, sem passar pelo culto dos antepassados (matebian) e dos espíritos da natureza (lulik). Os timorenses, por sua vez, atribuíram aos sacerdotes católicos o título atribuído ao mais alto representante do seu culto animista, nai-lulik (senhor sagrado).

Mas, ainda que o processo de aculturação de um povo ocorra também pela religião, a imposição da língua do dominador é um dos meios de minar a cultura. Todavia, no caso do Timor-Leste, segundo Silva (2005, p.149),

a língua utilizada pelos timorenses, sem a exclusão das outras línguas da ilha, tem sido o Tétum. Na medida em que esta língua goza de prestígio entre a população. Durante muito tempo, os portugueses colonialistas - missionários e administradores - utilizaram o Tétum para iniciar seus trabalhos de evangelização e de imposição do catolicismo.

Diante disso, possivelmente, a presença dos Dominicanos em terras timorenses, tenha contribuído para a manutenção dos elementos culturais tradicionais do povo maubere em função da pouca atenção dada pelos Dominicanos à educação desse povo, menos ainda em língua portuguesa, em outros saberes que não fossem os religiosos. O oposto pode ser observado nas culturas onde os Jesuítas, com seu ímpeto educacional, exerceram domínio.

Os Dominicanos se estabeleceram inicialmente em Solor, uma pequena ilha vulcânica, hoje pertencente à Indonésia. Entre os seus feitos nessa ilha está a catequese do rei local que permitiu a construção de uma igreja. Posteriormente os dominicanos se estabeleceram em outras ilhas do arquipélago, sempre procedendo de forma semelhante, catequizando os mandatários locais, erguendo igrejas e fortalecendo os laços políticos que permitiam a difusão religiosa nas populações. Após esse domínio sorrateiro das ilhas que rodavam o Timor, aprontavam os dominicanos as condições para chegarem finalmente àquelas terras. Contudo a temiam diante das notícias que corriam sobre o grande contingente populacional e a iminência da morte. 
Era grande o desejo que tinham os nossos missionários de se introduzirem em Timor, que os naturais da ilha diziam ser extensíssima e muito povoada; era grande o desejo, porque se lhes afigurava que a semente do Evangelho deveria dar ali abundantíssima colheita. Mas o receio de abordar aquela terra, onde se supunha que a morte era certa, continha os missionários, que esperavam ensejo favorável para tentarem aquela empresa. (CASTRO, 1867, p.9-10).

A entrada dos dominicanos no Timor é atribuída ao Frei Antonio Taveiros, que "naquela ilha fizeram tantas conversões e que fundaram o nosso império em Timor, ponto que pela sua posição geográfica entre a China e a Austrália tem mui grande importância" (CASTRO, 1867, p. XVIII).

Percebe-se que a penetração definitiva de Portugal no Timor-Leste, se deveu, sobretudo, à obra dos Dominicanos. Nas palavras de Castro (1867, p. XVIII),

\begin{abstract}
Os dominicanos introduziram-se pois no arquipélago de Solor e Timor, e com tamanho ardor se entregaram à sua tarefa, que no ano de 1599 tinham já, segundo diz Fr. João dos Santos na Etiópia oriental, um colégio de meninos em Larantuka ${ }^{21}$, no qual se ensinava a ler, escrever, contar e latim, e haviam fundado dezoito igrejas, resultados estes que custaram a vida a alguns missionários, entre outros a Fr. Antonio Pestana, Fr. Simão das Montanhas, Fr. Francisco Calassa, Fr. João Tavares e Fr. Belchior, os quais pereceram às mãos dos gentios, colhendo assim a palma do martírio. Era a obra dos missionários religiosa e política. Ao passo que os animava o ardor da fé, entendia o patriotismo, e fundando a missão, fundavam um estabelecimento colonial. Rei catequizado, rei vassalo, ligado a Portugal por uma espécie de tratado pelo qual se obrigavam a pagar certa quantia em gêneros à autoridade superior portuguesa e a socorrê-la com certo número de homens em caso de guerra.
\end{abstract}

Afonso de Castro na sua crônica lamenta a inexistência de documentos escritos nos quais os padres firmaram contratos com os reis e estima que tenham existido em função das obrigações assumidas pelos reis de Timor. Entre elas, o pagamento do tributo chamado finta. Menciona ainda que este imposto foi até os primeiros governadores e representava vultosa soma em mantimentos e em sândalo com que os reinos contribuíam para as despesas do estabelecimento colonial. A finta foi abolida pelo governado António Moniz de Macedo, por ocasião do seu mandato entre 1725 a 1729, e substituída por um imposto de capitação por habitante, porém, nunca foi cobrado, levando à necessidade de instituir-se a finta novamente, perdendo ao longo do tempo seu valor a proporções irrisórias. Mesmo assim, essas insignificantes quantias dificilmente eram cobradas, levando a fazenda pública a dívidas substanciais e a graves dificuldades. Contudo, em tempos em que os valores do citado imposto eram substanciais,

Sustentavam os padres o estabelecimento por eles fundado, e com ela pagavam aos soldados indígenas, que angariavam, e aos capitães que comandavam as expedições empreendidas pelo vigário superior, o qual não obstante ser homem de paz e ministro de Deus não deixava de sustentar renhida luta com os chefes indígenas, que

\footnotetext{
${ }^{21}$ Laratuka trata-se de lugarejo localizado na Ilha das Flores na Indonésia. (Nota do autor).
} 
ou atacavam os nossos vassalos, ou pretendiam subtrair-se à nossa dominação. (CASTRO, 1867, p. XIX).

Porém, a convivência dos dominicanos no Timor não se deu em um clima amistoso. Durante o governo dos padres a guerra foi quase incessante, ora com os nativos, que se rebelavam frequentemente contra os portugueses, ora com os holandeses que tentavam repetidamente usurpar o que pudessem. "[...] A batalha seguia-se à catequese, e vemos naqueles tempos de paixões enérgicas um padre comandar as forças na peleja e mostrar na guerra tanto valor, quanta era na paz a sua humildade e fervor religioso". (CASTRO, 1867, p.XX).

\begin{abstract}
A tarefa dos religiosos foi pois introduzir o catolicismo entre aquele povo gentílico, e estabelecer a dominação portuguesa nas ilhas de Solor e Timor. E se não a estabeleceram solidamente, deixaram contudo as coisas em estado que os governadores não tiveram novas conquistas que fazer, mas só conservar o que os padres haviam conquistado. Porém sem força regular e composta de elementos estranhos ao país, a nossa dominação não pôde consolidar-se; e apesar da luta incessante, que tanto os religiosos como os governadores ali sustentaram, a nossa dominação em Timor tem sido mais nominal que real, e em vez de sermos soberanos não temos sido senão mal respeitados suseranos (CASTRO, 1867, p.XX).
\end{abstract}

Embora a luta dos religiosos e portugueses tenha sido intensa contra os Holandeses, estes conquistaram a porção ocidental da ilha do Timor. A luta de conquista que a Holanda empreendeu contra Portugal tem suas bases na luta da Holanda contra a Espanha, por ocasião da União Ibérica de 1580, em que Portugal passou a pertencer a Espanha em uma crise de sucessão do trono português. Todavia, após a independência de Portugal em 1640, "parecia que as hostilidades deviam cessar. Não aconteceu, porém assim, e a luta de Portugal com os Países Baixos nos mares das Índias prolongou-se a despeito da paz que reinava entre as duas nações na Europa”. (CASTRO, 1867, p. 38).

Assim, em 1651, após duras lutas, narradas a detalhe na crônica de Afonso de Castro, os holandeses terminaram por conquistar Kupang ${ }^{22}$, localizada no extremo oeste da ilha de Timor e procederam ao avanço até a metade de seu território, por expansão de conquistas territoriais e com a conivência dos chefes locais que,

\begin{abstract}
a troco de dádivas e presentes obteve a companhia contratos de paz e amizade com vários reis da ilha, e desses contratos com homens boçais, que não sabiam a que se obrigavam, fizeram mais tarde os holandeses derivar supostos direitos à soberania desses reinos. A guerra franca e leal que a Holanda nos fazia sucedeu pois uma guerra desleal, e o que pelas armas não tinha sabido conquistar, conquistou-o então pela astúcia de suas autoridades em Timor, as quais insinuando-se no ânimo de alguns dos reis, ganhando outros por presentes, e atemorizando a todos, conseguiram desligá-los de Portugal e avassalá-los à Holanda. E tão débil era o braço português em Timor, e tão desamparado se via o nosso governo ali, que, sem meios para obstar às tentativas daquela potência, assistia quase indiferente ao desmembramento da colônia. (CASTRO, 1867, p. 46-47).
\end{abstract}

\footnotetext{
${ }^{22}$ Cidade que viria a se tornar a capital da província indonésia de Sonda Oriental, localizada no extremo ocidental da ilha Timor (Timor Ocidental) ou Nusa Tengara. (Nota do Autor).
} 
Em 1859, um tratado firmado entre Portugal e Holanda fixa a fronteira entre o Timor Português (atual Timor-Leste) e o Timor Holandês (Timor Ocidental). Configuração que apresenta até os dias atuais. Embora uma sentença definitiva sobre os limites territoriais na ilha de Timor entre a Holanda e Portugal só tenha sido proferida e assinada em Haia e 3 de abril de 1913, conforme pode ser lido no documento da American Society of International Law (1915) sobre decisão judicial envolvendo questões de lei internacional. Sendo que o Timor Ocidental, a partir de 1945 passou a fazer parte da Indonésia por ocasião da sua independência.

Poderíamos supor que Portugal em função da diminuição territorial da colônia do Timor, devesse devotar mais atenção e cuidados em sua porção oriental, no entanto, não foi o que aconteceu, a colônia continuou tão abandonada quanto antes, enquanto a porção ocidental sob o domínio holandês experimentou maior prosperidade, que nas palavras plangentes de Castro (1867, p.47) sobre a colônia,

[...] que pela sua posição geográfica, pela riqueza do solo e pela densidade da sua população devia ter merecido todos os cuidados dos governos superiores, e achar-se hoje no mesmo grau de prosperidade que as colônias holandesas, não tem dado um passo nas vias do progresso, e os povos do interior da ilha têm presentemente a mesma rudeza, os mesmos hábitos ferozes que tinham, quando pela primeira vez foram visitados pelos nossos missionários.

Na observação do antigo governador do Timor, Afonso de Castro, que certamente foi um dos primeiros a escrever uma história do Timor colonial até o século XIX, antevendo mesmo uma importância geopolítica na sua localização, Portugal não havia se dedicado e empenhado esforços naquelas terras, quando comparado a todo empenho envidado pelos holandeses nas colônias circunvizinhas, não obstante o longo tempo de permanência na ilha parece que as características marcantes do domínio português foram a leniência e a omissão,

três séculos de dominação não têm pois produzido os resultados que era de esperar,
e a luz da civilização apenas bruxuleia, onde deveria espalhar vivos clarões. Nem a
indústria, nem o comércio, nem a agricultura têm tido desenvolvimento, e enquanto
muitas das ilhas da Malásia prosperaram admiravelmente nas hábeis mãos dos
holandeses, Timor nas mãos dos portugueses vegeta na mais horrível miséria, e nem
cremos que saia deste estado, enquanto não alterarmos o nosso regime colonial, e
enquanto não tentarmos introduzir em Timor sistema idêntico que fez de Java a
pérola da Oceania. (CASTRO, 1867, p.47).

Cabe aqui uma reflexão sobre o papel da educação no processo de dominação dos povos. Segundo Ashcroft; Griffiths; Tiffin (2013), a educação talvez seja o mais insidioso e, em alguns aspectos, o mais crítico dos vestígios colonialistas, às vezes imperceptíveis nas configurações neo-colonialistas. Tais padrões são reproduzidos não apenas através de currículos estabelecidos ou programas de textos definidos, porém, mais fundamentalmente, 
através de atitudes básicas na educação em si, tanto por sua natureza e seu papel particular dentro das nações, quanto na sua cultura. A educação, seja a ofertada pelo estado ou missionária religiosa, primária ou secundária e posteriormente terciária, sempre foi uma arma potente na artilharia do imperialismo.

Essa abordagem incita a ponderação de que possivelmente a "barbárie" apontada por Afonso Castro ao povo timorense, se deva, sobretudo, pela lacuna na educação nos moldes clássicos dos Jesuítas, cuja catequese provavelmente teve efeito de "amansamento" do espírito gentio nas terras por onde passaram. Assim, nessa compreensão, provavelmente não houve no processo colonial português, pelo menos até o século XIX, um processo de aculturação pela educação do povo timorense em função da presença dos Dominicanos e estes não tenham devotado atenção para a educação, só centrando dedicação a difusão da doutrina cristã sincretizada nos cultos locais. O domínio dos Dominicanos no campo da religião, presumivelmente, foi competente, pois nos dias atuais, boa parte da população do Timor ainda é cristã, com predomínio do catolicismo, não obstante terem vivido a partir de 1975 até 1999 sob o domínio de um país muçulmano.

Porém, cabe aqui mais uma consideração nessa análise, partindo do princípio que o ensinamento religioso, com propósito de catequese, é um tipo de educação, também passa a influir na cultura de povos que apresentam suas próprias crenças e que terminam por substituí-las ou mesclá-las. O que pode ter ocorrido no Timor no período colonial foi a difusão oral dos ensinamentos religiosos católicos, pelo menos para uma boa parte da população, sem que houvesse um processo de alfabetização ou transmissão de outro conhecimento escolarizado nos padrões ocidentais. Certamente à época se sabia perfeitamente a diferença entre dominar pela força e com violência subjugar os vencidos, e dominar pela retórica da conversão religiosa. Basta ver, para isso, o que dizia Castro (1867, p.6):

É diferente a posse que deriva da conquista da que deriva da conversão; e os laços que prendem um povo subjugado pela força ao povo vencedor, são diferentes daqueles que prendem um povo catequizado à nação dos seus catequistas. O modo de governar um não pode ser o mesmo que o de governar o outro; e ainda que os dois sistemas tendam ao mesmo fim, a civilização, os meios deverão ser diversos.

\subsubsection{A ocupação branca de Timor compreendida por Teófilo Duarte até a primeira metade do século $X X$}

Já no século XX, digna de nota também encontram-se as narrativas de Teófilo Duarte (1898-1958), outro português que governou o Timor-Leste nos anos de 1927 e 1929. 
Semelhante ao mencionado por Afonso de Castro, Duarte reflete que a ação de povoamento do branco português em Timor, foi a mais tardia dentre as colônias do império. Constata em seu livro Ocupação e Colonização Branca de Timor, que em 1929 era flagrante a ausência quase absoluta de brancos que não fossem funcionários, somando estes um total 340 apenas, contra 690 indivíduos mestiços (DUARTE, 1944, p.22).

Após considerações sobre a exígua presença do branco português e a exploração de culturas agrícolas como café, cacau, borracha a cargo dos herdeiros de um ex-governador, Celestino da Silva (1849-1911) que governou o Timor de 1894 a 1908, cuja produção destinava-se à exportação para as Índias Holandesas e o empreendimento agrícola contasse administrativamente com pouquíssimos brancos, o trabalho braçal era empenhado pelos "indígenas", Duarte (1944, p. 23-24) justifica os fatores que levaram a essa escassa ocupação portuguesa em Timor:

Como se vê, o esforço desenvolvido em Timor durante séculos, até o ano de 1929, não pode ombrear com o constatado em qualquer das nossas outras colônias. E porquê? Vejamos algumas das principais causas do fato, sem termos a pretensão de lhe encontrar uma explicação completa. Timor é a colônia portuguesa que se encontra mais afastada da metrópole - e com uma grande diferença - se não entramos em linha de conta com Macau. Natural era pois que, através dos séculos, a nossa atenção se concentrasse principalmente naquelas que nos ficavam mais próximas, sendo por isso mais frequentes os contatos com elas, mas conhecidos os seus recursos, e em que havia maiores possibilidades de fiscalização, quer através das entidades governamentais, quer das simples particulares que nelas empregavam as suas atividades. Ainda hoje, apesar da rapidez das comunicações, uma viagem normal para aquela nossa colônia da Insulíndia demora quarenta e cinco dias, enquanto que para a Guiné se faz em oito, e para Angola em vinte.

A distância como primeiro argumento de Duarte pesou para o pouco empenho português em investimento e colonização do Timor nos moldes das outras colônias. É espantoso que em 1944, época da publicação do seu livro, acima mencionado, ainda se levasse quarenta e cinco dias de navio para se chegar ao Timor-Leste. Para se perceber esse distanciamento no aspecto geográfico e inserido no tempo contemporâneo, recomendo aqui a leitura da memória "1. Prelúdio de incertezas" nos apêndices desta tese, p. 274. A viagem aérea atual para o Timor-Leste, partindo do Brasil, comparada com outros destinos mais afeitos aos brasileiros, como para os Estados Unidos ou Europa, é assustadora e dura em média 30 horas de vôo incluindo as intermináveis escalas, seja indo pelo Pacífico pela Austrália, ou pelo Atlântico, cruzando a África até o Qatar e a Bali na Indonésia. Não é de admirar que a distância Portugal-Timor no período colonial desanimasse aos mais destemidos empreendedores lusitanos.

Nas palavras de Duarte (1944, p.24), 
Este fator, o da distância, trazia pois como consequência, o pouco interesse pela colônia, que era conhecida pouco e mal das instâncias oficiais, e desconhecida quase em absoluto das entidades que se dedicavam a atividades coloniais. Uma pequena ilha perdida nos confins das Índias Orientais, apenas conhecida pelo precioso mas escasso comércio de sândalo, pouca atenção podia merecer ao país que possuía tantos e tão valiosos troféus, como a costa da Guiné, a Índia e o Brasil.

Outros fatores aventados por Duarte sobre o desinteresse português quando o assunto era o Timor, centra-se na tradição de aceitação corrente de que a "terra apresentava um clima horrível, que matava ou inutilizava fatalmente, o que provinha do desconhecimento quase absoluto do interior que era magnífico" (DUARTE, 1944, p.24). Associado a isso, a insubmissão dos nativos que acarretava frequentes chacinas dos raros europeus que por dever de ofício se faziam presentes no Timor e por fim, a falta de comodidades quase absoluta em uma colônia quase toda por ocupar. Segundo Duarte (1944, p.25),

\begin{abstract}
tudo isso criava uma lenda em volta de Timor, que fazia com que a colocação ali de qualquer funcionário fosse considerada como o pior castigo que se lhe podia aplicar. Como admirarmo-nos pois que os simples particulares nem sequer pensassem em tal colônia, quando tratavam de escolher uma para onde se expatriassem à procura de fortuna, ou pelo menos duma conveniente situação que lhes assegurasse um regular passadio? Timor, a odiada, a desprezada era a última colônia a atrair atenção dos portugueses. Ela era para nós, o que tantas outras representavam para países colonizadores de maiores recursos: uma ameaça para degradados e maus funcionários.
\end{abstract}

Posterior à visão de Afonso de Castro que publicara seu livro em 1867, Teófilo Duarte na sua publicação de 1944 estabelece que a situação de esquecimento a qual o Timor fícou relegado durou até o ano de 1894 quando assumiu o governo da colônia Celestino da Silva, apelidado de "Rei do Timor" (XIMENES BELO, 2013, p. 71), que era naquela altura major de cavalaria, mas que por ocasião da sua morte em 1911 tinha se tornado general, conselheiro de Estado, comendador da Torre e Espada, além de possuir a medalha de ouro do valor militar, a medalha de ouro da Rainha D. Amélia e a medalha de ouro de serviços relevantes no Ultramar. Essas honrarias se deveram aos altos serviços prestados à Pátria por ocasião da sua passagem pelo governo Timor.

Ao delinear a situação do Timor no período anterior imediato à sua posse, o cronista Duarte (1944) coloca os domínios portugueses no Timor como mais teórico do que reais, já que se mantinha às custas de combinações políticas com os régulos, nem sempre amigáveis, onde as ações rebeldes das populações locais não passavam por nenhuma reprimenda ou ato corretivo da parte de Portugal. Mais uma vez, percebe-se nas narrativas desses cronistas pioneiros da história do Timor, ainda que sob a ótica portuguesa, que os timorenses gozavam de liberdades nos seus domínios e que a ingerência de Portugal sobre o território não se fazia nos mesmos rigores observados em outras colônias. 
As forças de ocupação do território se reduziam a poucos oficiais que esparsamente eram distribuídos pelo litoral, responsáveis pela vigilância do território com o apoio de pouquíssimos soldados, que no dizer de Duarte (1944, p.27), "durante quase todo o ano permaneciam no hospital ou nos presídios para onde os arrastavam os seus vícios e o seu caráter de incorrigíveis vindos de Macau". Mesmo assim, durante as flutuações de "humor" das populações do interior do Timor, estes poucos soldados se refugiavam em Díli, permanecendo mais protegidos na cidade, esperando as vagas rebeldes se pacificarem para a retomada de seus postos, de onde se depreende que o interior encontrava-se sem um comando, ou alguma centralidade que conferisse soberania da Portugal naquelas terras.

Por estes achados, é perfeitamente compreensível entender o grau de autonomia que a população timorense guardou deste período colonial, na manutenção do seu plurilinguismo e dos seus valores culturais. Ainda que os régulos aceitassem a sanção pelo governo português das eleições que os sagravam mandatários, o faziam como prestação de vassalagem a Díli, uma formalidade que não implicava custo algum cumpri-la, mas que de certa forma, a cerimônia espetaculosa os atraiam mais do que o significado em si de obrigações devidas.

Embora seja natural pensar-se em uma unidade étnica de um só povo no território timorense neste período, o certo é que eram reinos independentes e quase sempre em contendas, disputando recursos, como terras e animais, e que por estas disputas se envolviam em batalhas cruentas, quase sempre produzindo dezenas de mortos, animais confiscados pelos vencedores, mais fora isso, as populações continuavam organizadas em seus territórios com certo grau de apaziguamento até que novos conflitos irrompessem pelas mesmas razões ou por outros motivos. Ou seja, não havia, de todo, a perspectiva de domínio e extermínio dos vencidos.

Nas palavras de Duarte (1944, p.29),

\begin{abstract}
As diversas tribos agremiadas em reinos mais ou menos importantes passavam os anos em guerras intestinais cujo fundamento era o desejo de roubarem aos vizinhos os seus gados, os produtos agrícolas, as mulheres e as terras. Não havia progresso compatível com tal desordem que era extensiva às centenas de milhares de timores, e ora se viam lutas formidáveis entre vinte e trinta mil homens de cada partido, ora elas se resumiam a pequenos mas numerosíssimos combates de centenas de guerreiros.
\end{abstract}

Estas contendas podem ser analisadas de pontos de vistas diferentes, a saber, para os comerciantes eram lucrativas já que auferiam largos proventos em decorrência da venda de pólvora e de armas, para os timorenses e sua índole guerreira, era preferível a posse do botim das terras que pilhavam do que o que poderiam arrancar da terra com o suor do seu trabalho, mas para Portugal, embora a situação fosse vergonhosa, era inevitável diante da escassa 
ocupação que exerciam em todos os sentidos. Superar essa situação só à custa de pesados sacrifícios com expedições e permanência de grandes contingentes. Outro aspecto a analisar deve-se ao fato de que as lutas ocorriam entre populações do próprio Timor, raramente entre os timorenses e os poucos portugueses. Essa paz era mantida pelos pactos de vassalagem que eram prestados entre os governantes timorenses e os representantes da autoridade portuguesa. Muitas vezes diante de contendores dos reinos locais, os governantes portugueses funcionaram como árbitros para avaliar sobre quem eram os vencidos e os vencedores. Nos casos da não aceitação das definições portuguesas, as lutas continuavam e o papel de Portugal era meramente teórico e impotente para a resolução dos conflitos.

Neste sentido, a importância de Celestino da Silva como governador do Timor por quatorze anos, a partir de 1894, tornou-se grande, pois foi o primeiro a perceber que a evolução econômica do Timor e da empresa colonial só começaria a ocorrer quando estas contendas frequentes cessassem. Neste sentido, começou uma obra de ocupação gradual e continua do território do Timor por ação de colonização propriamente dita. Entre suas ações mais emblemáticas estava a pacificação de povos em guerra por ação diplomática, ou seja, o encaminhamento aos régulos contendores de diplomatas portugueses que os presenteavam com armas e trabalhos na limpeza dos cafezais e outras lavouras daquelas terras, bem como benfeitorias de ordem geral, em troca do restabelecimento da paz entre os guerreiros. Desta forma, a pacificação ocorria aos poucos sem a necessidade de força ou interferência violenta por parte de Portugal. Duarte (1944, p.31) aponta que o oficial português diplomata,

deixava de ser o severo comandante de tropas e colunas, tudo raziando, devastando, e fazendo consistir a sua glória no número de vítimas caídas, para se transformar no colonizador, que após rudes combates a que o obrigava a índole insubmissa dos povos que lhe mandavam bater, procurava encaminhá-los no sentido da riqueza e civilização. Ampliação de plantações, abertura de estradas, limpeza de caminhos, etc., tudo isso eram trabalhos que faziam do Comandante militar ou de posto, o guia de todos aqueles que na véspera tratara com a severidade de um dominador.

As sábias instruções de Celestino da Silva revelaram-se como uma espécie de "manual de colonização", onde a ação diplomática, o absoluto conhecimento das línguas locais, bem como o levantamento das populações e seus hábitos culturais locais, os cuidados ambientais nas terras de cada reino bem como os cuidados com as lavouras de café e as de subsistência, representaram um modo de ação avançado e particular de ação colonial que Portugal experimentava na direção do Timor. Duarte (1944) nos informa sobre as instruções dadas por Celestino aos seus comandados portugueses que não deixam dúvidas sobre estes avanços na forma administrativa de conduzir o Timor: 
"É absolutamente indispensável que os comandantes militares subalternos se instruam sobre a língua dos indígenas, seus usos e costumes; que conheçam dentro da área da sua jurisdição, todos os caminhos ainda os mais recônditos, todas as povoações, todos os habitantes, os chefes indígenas e suas famílias; que lhes não passe despercebida a saída para fora, ou a entrada de qualquer; que tenham perfeito conhecimento de todos os casamentos, óbitos e nascimentos; que façam um arrolamento exato da população; que não deixem derrubar florestas cuja destruição possa exercer influência nas condições climáticas; que não deixem despir de arvoredo, as nascentes de água; que conservem sempre em bom estado os caminhos vicinais; que vigiem se os indígenas conservam em bom estado de limpeza as suas plantações de café, e se fazem cultivos suficientes para a sua alimentação; se há transgressão dos regulamentos de polícia rural de mercados; se o contrabando se exerce; se são respeitados os regulamentos que regem a venda do sal; e enfim se há quaisquer causas que possam vir a alterar o sossego público. É isto o que os Senhores comandantes militares têm o dever de exigir dos seus subalternos, além do mais que especialmente lhes determinem, por isso que das faltas, dos desleixos, da incúria deles, são os primeiros responsáveis". (DUARTE, 1944, p. 32).

Mas, no meio dessas ações diplomáticas que amansam os ímpetos guerreiros timorenses, o governador Celestino da Silva, fortalece os comandos militares estratégicos em torno de Díli e aos poucos avança sobre o território, aumentando o contingente militar e intervindo em contendas inter-reinos sempre que provocado, desse modo, pelo uso da força foi também expandindo seus domínios entre aquelas populações beligerantes. Estrategista militar que era, Celestino obteve sucesso enquanto estabeleceu um consórcio entre diplomacia e ação militar e foi avançando nas conquistas do território. Em uma situação ocorrida em 1895, oficiais subalternos não atenderam as recomendações estratégicas estabelecidas, como a violação dos espaços dos régulos locais e a violência exercida contra suas famílias, diante disso ocorreu verdadeira tragédia com muitas perdas humanas de ambos os lados, decapitações e incêndios de benfeitorias marcaram estas lutas cruentas e permite-nos entender o modo de ação que também permeariam as lutas pela independência do Timor no fim da década de 1990.

As ações desastrosas apontaram para o fato de que Díli e a sede do governo português deveriam ser protegidas nos seus diversos flancos e para isso o governador criou comandos militares especiais em torno de Díli que permitiam um maior perímetro de proteção, comandos estes, reforçados por guerreiros africanos trazidos pelos portugueses para o Timor, evitando-se assim as invasões das hordas timorenses tão comuns quando em revoltas. Este fortalecimento militar em torno de Díli foi permitindo aos poucos a expansão dos comandos militares portugueses por todo o território.

Em cinco anos instalaram-se várias linhas de postos de ocupação permanente, em direções perpendiculares às costas Norte e Sul, e dominando as regiões entre Batugadé e Bobonaro, Liquiça e Hatolia, Díli e Maubisse, Manatuto e contra-costa, Baucau e Ossu, o que juntamente com Viqueque e Alas significava o estabelecimento em toda a ilha, de postos militares agrupados em comandos. De quarenta em quarenta quilometros, estava-se seguro de encontrar um posto de 
oficial, sargento ou régulo fiel, com a sua guarnição, pequena é verdade, mas a que emprestava uma enorme força, moral e material, a proximidade de outros postos, e o apoio das repetidas colunas expedicionárias. (DUARTE, 1944, p. 40).

Pode-se dizer que neste período, o Timor já não gozava da liberdade outrora desfrutada ainda que sobre a colonização portuguesa, pois, a densa malha de comandos e postos oficiais, promovia uma espécie de aperto à estas liberdades guerreiras. A percepção da perda dessa liberdade gerava pequenas revoltas por todo o território que eram prontamente contidas pela eficiente malha militar espalhada pelo Timor, de modo que se reduziam a pequenos movimentos insurrecionais sem dificuldade de controle.

As palavras de Duarte (1944, p. 45), ao avaliar o período de 1894 a 1900, apontam que a ocupação portuguesa do período,

\begin{abstract}
se estendeu a todo o interior, e que as últimas revoltas anuais quase sempre insignificantes, e dominadas pelos recursos locais de cada comando, eram os estremeções epilépticos de um povo sufocando nas malhas apertadíssimas de uma organização administrativa que lhe paralisava os movimentos desordenados e atrabiliários. E tal resultado conseguiu-se sem auxílio de expedições do exterior, pois tirante a companhia desembarcada após o desastre 1895, sempre as campanhas se fizeram com moradores de Díli e Manatuto armados de espingardas Remington e principalmente com arraiais usando azagaia e catana, pois as quinhentas espingardas não chegavam para os milhares de timores que combatiam a nosso lado hoje, para serem batidos amanhã pelos seus adversários de véspera, agora nossos aliados.
\end{abstract}

Além de brilhante estrategista militar, o governador Celestino da Silva não subestimou a inteligência e sagacidade dos liurais. Sua vivência na administração colonial na África levou a considerar que: "Os régulos do Timor não têm ligeira semelhança com os dá África, são mais civilizados, mais inteligentes e muito menos dados aos vícios, têm muito orgulho e bem arreigado o sentimento dos seus direitos" (SILVA, 1897, p. 36). Diante desta percepção do astucioso espírito timorense, Celestino instituiu uma rede de espionagem que incluía amantes timorenses que ao mesmo tempo também gozavam da confiança de chefes locais funcionando como espiãs a serviço do governador. Outro ponto favorável ao domínio que se estendia aos poucos, diz respeito à utilização por parte do governador das rivalidades entre tribos diferentes, usando inclusive o expediente, quando lhe convinha, de enfraquecer uma tribo arredia aos interesses de Portugal, fornecendo à tribo rival, mas amiga, provimentos com pólvora e armas para enfraquecimento e domínio da tribo inimiga. Para isso contava com sua rede de espionagem, de informação e desinformação que urdia intrigas e fomentava os confrontos. A figura de Celestino para os poderosos locais passou a possuir a mística do senhor que tudo sabe e tudo ver. Uma figura imponente que assustava a todos pelo tamanho do poder que concentrou em suas mãos. Segundo Duarte (1944, p.65), 
Celestino da Silva ficou sendo sempre para o indígena, o homem cujos olhos perscrutavam tudo e a todos, aquele para quem não havia segredos por mais bem guardados que fossem; e significativo de tal estado de espírito, é o episódio de na revolta de 1912, isto é, quatro anos após a sua exoneração, os chefes principais terem voltado às avessas, o retrato que pendia das paredes da sala dum comando que acabavam de assaltar, a fim de que os seus olhos os não incomodassem nas resoluções que iam tomar.

Após o domínio territorial militar promovido ao longo do tempo pelo governador Celestino da Silva, a empresa colonial pode ser operada em seu viés econômico e a atividade agrícola da cafeicultura se mostrou rentável. Todavia, Celestino encontrava dificuldades para empreender o trabalho. Em situação semelhante ao que a narrativa da historiografia portuguesa utilizou amiúde no Brasil para falar da indolência dos indígenas brasileiros para o trabalho na colônia, Duarte (1944, p.67), também se utiliza desta narrativa ao mencionar as próprias palavras de Celestino da Silva neste sentido para o timorense:

“[...] sendo a cafeicultura uma importantíssima fonte de riqueza, e indiscutível a natural indolência dos indígenas, é indispensável que os comandos militares incitem o povo ao trabalho e forcem os régulos a cuidarem das plantações existentes improdutivas por falta de granjeio, e a fazerem outras. Se não obrigarmos estes povos ao trabalho, e os não ensinarmos, esta colônia permanecerá ainda por muito tempo no estado de atraso agrícola em que atualmente se encontra”.

No campo administrativo o governador Celestino da Silva instituiu um eficiente centro de comando, diminuindo ao seu modo o poder dos prelados da igreja que em tempos anteriores concentravam tanto poder que muitas vezes derrubavam até os governadores, mas, em função disso, granjeou fortes inimigos dentro do poder eclesiástico. Chama a atenção sua atuação no campo da educação e difusão da cultura europeia, cuja preocupação não era a popularização da educação formal no seio da sociedade timorense, mas, com a intenção de implantação definitiva da língua portuguesa e dos costumes europeus nas terras do Timor, segundo Duarte (1944, p.75),

obrigava os chefes indígenas a enviar às escolas e colégios os seus filhos maiores de nove e menores de quinze anos; não consentia que nos internatos se falasse senão o português e se não vestisse senão à europeia; e os jantares mais aparatosos que em Díli se davam, eram os oferecidos pelo Governador aos chefes e régulos. Fotografias há dalguns destes indígenas, mostrando-os vestidos de sobrecasaca; a outros fazia-os seus ajudantes de campo, comandantes de postos, pilotos, comandantes interinos do vapor, secretários gerais enfim, obrigando-os desta forma a entrarem no seio da civilização.

Não obstante todo o poder que concentrou, e as novas feições coloniais que havia consignado ao Timor, Celestino da Silva teve um final sem o devido reconhecimento no seu tempo. Quando em 1908 morreu o rei de Portugal vitimado por um tiro, cinco meses depois, 
um decreto o suspendia das funções de governador, sem um louvor, sem uma palavra de apreço. Nas palavras de Duarte (1944, p.84),

O gigante limitou-se a sorrir com amargura e desprezo, e embarcou para a Austrália, a fim de dissipar receios. Meses depois aportava a Portugal, seguia para o desterro de Almeida a comandar Cavalaria 7, e morreria em 1911, minado pelas febres, e mais ainda pelos desgostos que a ingratidão dos seus contemporâneos lhe tinha causado.

O afastamento de Celestino de Silva representou para o Timor uma espécie de refresco aos poderosos locais. Celestino havia estabelecido as novas bases administrativas e militares do Timor-Leste. Embora tenha havido a nomeação de outros governadores sem muito destaque posterior à saída de Celestino, alguns anos depois, em 1911 especificamente, tem destaque no governo em Timor de Filomeno da Câmara, que também terá atuação brilhante como governador. Considerado desde a exoneração de Celestino da Silva, como o único governador de Timor que teve posição de grande relevo. Segundo Duarte (1944, p.85),

Logo no início do seu governo, teve de dominar a mais temerosa revolta indígena de que ali havia memória. Os chefes timorenses libertos da golilha ${ }^{23}$ que a saída de Celestino quebrara, aproveitaram-se do pretexto da elevação do imposto de capitação, para tentarem sacudir o jugo a que mal se podiam acomodar. Um oficial e vários sargentos que permaneciam no interior foram trucidados; a primeira coluna comandada pelo Governador teve um desastre sério em Aituto, vendo-se obrigada a abandonar uma peça de artilharia, vário material, e a retirar precipitadamente para Aileu. O pavor em Díli, perto do local do combate, foi enorme, pois os fatos avolumaram-se de tal modo, que davam o Governador como chacinado, e os rebeldes avançando sobre a capital.

As notícias intempestivas levaram a população branca de Timor a embarcar no vapor "Díli" em debandada. Desfeita a boataria, a chegada de algumas companhias de soldados africanos e da Índia, conduziu a situação para um caminho mais favorável. Mesmo assim, foram seis meses de luta intensa.

Manufai, o eterno fulcro de rebeliões, o histórico ninho de rebeldias foi batido e obrigado a submeter-se, sendo a mortandade tão grande, e a lição de tal maneira dura, que ela lhe serviu até agora. Apenas Okussi se manteve rebelde e foi dominado no ano seguinte, após uma campanha rápida e sem grandes lances. (DUARTE, 1944, p. 86).

A fama de bárbaro de Filomeno da Câmara se estabeleceu nessas guerras e passou a incomodar intelectuais na metrópole influenciados com as ideias humanitárias em voga em Portugal a partir de 1910. O barbarismo se deveu ao fato de, intencionando cooptar a confiança de guerreiros timorenses para combaterem ao seu lado contra os rebeldes, Filomeno passou a permitir os hábitos tribais milenares dos guerreiros em se apropriar do botim dos

\footnotetext{
${ }^{23}$ Argola de ferro fixada num poste ou pelourinho, à qual se prendiam criminosos ou escravos pelo pescoço; argola.
} 
vencidos, em degolar seus inimigos e empilharem cabeças em uma demonstração de superioridade e força, que ao final dos combates, a lúgubre pilha de crânios era ainda chutada, entoando-se cânticos, o hino guerreiro do "Lorçá" que provocava pavor nos soldados portugueses.

Mas, apesar das circunstâncias que levaram Filomeno ao controle da situação das rebeldias locais, o novo governador se notabilizou pelo fomento que deu à lavoura cafeeira com o plantio de milhões de mudas de café que se expandiu para locais onde antes não se cultivava, além de outras tantas experimentações de variedades em outras áreas para aclimatação. Além de café, houve uma expansão de outras culturas como o coqueiro. $\mathrm{O}$ esforço de Filomeno da Câmara fez a empresa colonial expandir-se sobremaneira, ainda que as custas do trabalho quase forçado das populações do Timor, que sobre o jugo da dominação sofriam com a empresa colonial portuguesa tardia. O certo é que o esforço do governador após sua exoneração do cargo não se seguiu por seus sucessores, tendo estas atividades econômicas, que foram implantadas por Filomeno, não rendido adequadamente como se esperava em um futuro próximo, mas já sem o governador. Em outros campos Filomento da Câmara também teve atuação destacada, como a criação da Caixa Econômica, a reforma do ensino, entre outros, que constituem o corpo de suas realizações. Deixou o governo em 1917.

Posterior a sua saída, se sucederam no governo do Timor, administradores de curta duração que apenas se mantinham sem grandes realizações, e deixavam fenecer as poucas iniciativas que uns legavam para os outros. Neste período, há destaques para alguns que contribuíram para a literatura como foi o caso de Teófilo Duarte que governou o Timor entre 1926 a 1928 e Álvaro da Fontoura e seu governo de 1937 a 1939. Entre os feitos deste último, está o estabelecimento em Díli em 1938 da "Casa Portuguesa”, onde era possível comprar livros, papel, tinta, etc., além de ter criado um jornal denominado "Timor". Porém sua maior contribuição ficou conhecida como "Álbum Fontoura"24,

\footnotetext{
Um valioso documentário fotográfico que mandara organizar naquela ilha e do qual constam, além de elementos importantes sobre a vida, administração, fomento, etc., da colônia, centenas de fotografias de indígenas timorenses, muitas das quais utilizáveis não só no ponto de vista estritamente etnográfico, mas sob aspecto de somatologia antropológica. (CORREIA, 1954, p. 69).
}

Outro governador português que merece ser citado foi Manoel de Abreu Ferreira Carvalho que governou o Timor entre 1940 e 1945. Conhecido como o governador da ocupação japonesa da Segunda Guerra Mundial. Um capítulo de sofrimento e dor para a

\footnotetext{
${ }^{24} \mathrm{O}$ monumental Álbum Fontoura está disponível online no endereço <https://goo.gl/avdEpB>
} 
história do Timor-Leste. Essa ocupação se deu de 1942 a 1945 até a rendição dos japoneses após o lançamento das bombas atômicas realizadas pelos americanos no território japonês.

\title{
2.1.3 O sofrimento do Timor na ocupação japonesa na Segunda Guerra Mundial, movimentos libertários, independência unilateral e invasão Indonésia
}

Sobre a ocupação japonesa de Timor, a historiografia se apresenta ambígua, pois, há documentos que atestam que o Timor na Segunda Guerra Mundial foi primeiro invadido pelos australianos e holandeses (FREI, 1996), que em face à expansão japonesa pelo Pacífico viram o Timor, em função do seu posicionamento geográfico, como uma área estratégica a ser defendida para se evitar uma possível invasão do Japão em território australiano.

Segundo Barbedo de Magalhães (2007, vol. 1, p.5),

\begin{abstract}
A maior parte dos livros publicados em Portugal sobre as ocupações de Timor Português durante a Segunda Grande Guerra descreve, por vezes com detalhe, as invasões australianas e holandesas, por um lado, e a japonesa, por outro. Descrevem, igualmente, as humilhações a que a administração portuguesa foi sujeita pelos sucessivos ocupantes $\mathrm{e}$ as horríveis torturas e os numerosos assassinatos de timorenses e portugueses, às mãos dos ocupantes japoneses e das colunas negras, predominantemente constituídas por habitantes de Timor Holandês e criadas, armadas e dirigidas por militares japoneses.
\end{abstract}

Mas, o certo é que no cenário da guerra, a cidade de Díli na época é descrita como totalmente arrasada por bombardeios, quem mais sofreu perdas e danos foi o povo timorense. As baixas são calculadas com base em quantitativos da população timorense antes da guerra e posteriormente e na taxa de crescimento populacional asiático da época. Como a diferenças destes valores representam um decréscimo populacional, ainda que se estime um valor de cerca de 20 mil pessoas que migraram para o lado ocidental da ilha (o Timor Holandês), houve acentuadas perdas por mortes. Estimam-se entre 60 mil e 80 mil timorenses mortos no período para uma população estimada de 527.000 habitantes. Para Barbedo de Magalhães (2007, Vol. 1, p.9),

Se tomarmos como válido o número de 60.000 , em cerca de 527.000 habitantes, isso corresponderá a cerca de $11,4 \%$ da população. Se usarmos o número de 80.000 vidas perdidas, isso corresponderá a $15 \%$ da população de Timor Português. Trata-se, em qualquer dos casos, de percentagens enormes, só compatíveis às da União Soviética e da Polónia. Em termos relativos poderemos dizer, com segurança, que a população de Timor Português foi, em percentagem da população global, uma das três mais sacrificadas, em todo o mundo, na Segunda Grande Guerra, apesar de Portugal ter permanecido neutro.

Após a guerra e a rendição dos japoneses o território timorense retornou para o domínio colonial português. O mesmo não ocorreu com o território do Timor Ocidental que 
não retornou ao domínio colonial holandês. A Indonésia que havia sido ocupada também pelos japoneses, aproveitando-se do enfraquecimento holandês durante a Segunda Guerra em função da invasão da Alemanha Nazista à Holanda, proclamou sua independência em 1945. Com o término da guerra, a Holanda apoiada pelas potências aliadas, empreendeu a tentativa de recuperação colonial, produzindo um conflito armado interno, conhecido como Revolução Nacional da Indonésia que durou mais de quatro anos. Neste conflito, embora a Holanda dominasse as principais cidades, não prevaleceu no campo. Após acertos diplomáticos e por forte resistência e determinação da Indonésia, a revolução finalizou-se em dezembro de 1949 com o país livre (DRAKELEY, 2005). Dado a pluralidade cultural e linguística da Indonésia, que se integra, enquanto nação, por cerca de 17 mil ilhas, das quais aproximadamente 6 mil são habitadas por populações que falam em torno de 700 línguas, o lema do país é "Unidade na Diversidade" (Bhinneka Tunggal Ika).

Estas considerações sobre a independência da Indonésia nos remete a algo muito importante para situar o valor que a língua portuguesa goza no território timorense e constitucionalmente ter se tornado língua oficial do Timor nos tempos atuais, sobretudo como língua de instrução. A existência atual do Timor-Leste como nação autônoma deve-se à colonização portuguesa, pois, caso o Timor-Leste, tivesse sido anexado pela Holanda em sua expansão territorial ainda no século XIX, certamente o Timor-Leste teria se tornado uma província da Indonésia por ocasião da independência da mesma do domínio holandês, como ocorreu durante o período de invasão da Indonésia entre os anos de 1975 a 1999. A língua portuguesa, apesar de ter sido proibida de se falar em Timor durante esse período da invasão indonésia, funcionou como língua de resistência com a qual a guerrilha revolucionária timorense se comunicava nestes duros anos. Possivelmente, neste ponto se encontre uma explicação plausível para a adoção da língua portuguesa, ainda que atualmente ela represente um dos grandes desafios à educação timorense.

Os sucessivos governadores que se seguiram ao pós-guerra, empenharam-se na reconstrução do Timor, sempre ocupando o posto por curtos períodos, alguns se dedicaram ao fomento de pequenos negócios e indústrias, sem maiores destaques na administração colonial, até o ano de 1974 quando toma posse o último governador português no Timor, o coronel Mario Lemos Pires. O ano de 1974 foi marcado por algumas particularidades, como a criação 
da primeira associação política em Timor Português, a UDT (União Democrática Timorense), nome sugerido por Ramos-Horta ${ }^{25}$, embora o mesmo não tenha integrado o partido criado.

Segundo Barbedo de Magalhães (2007, Vol. II, p. 232),

De acordo com o primeiro comunicado da UDT, os princípios básicos deste partido eram os seguintes: (...) "Autonomia progressiva", (...) "mas sempre à sombra da bandeira de Portugal", "Defesa do direito à autodeterminação.", (...) "Da integração de Timor numa comunidade de língua portuguesa" (...) "de Portugal multirracial e pluricontinental" (...) "dos princípios democráticos" (...).

Porém, em 27 de julho de 1974, dois meses depois da eclosão da Revolução dos Cravos $^{26}$ em Portugal (25 abril de 1974), após discurso do presidente de Portugal à época, o General António Sebastião Ribeiro de Spínola, ao considerar que as colônias portuguesas tinham direito à independência completa, a UDT mudou seu objetivo e passou a defender uma independência a médio prazo. (BARBEDO DE MAGALHÃES, 2007, p. 232).

Estes ímpetos revolucionários passaram a influenciar o Timor e no mesmo ano de 1974, Ramos-Horta liderou uma greve de trabalhadores que reivindicava melhores salários, sendo criada uma comissão para a defesa dos trabalhadores que culminaria na criação de outro partido político denominado ASDT (Associação Social Democrática de Timor-Leste).

O primeiro manifesto do partido foi redigido por Ramos-Horta e seus princípios eram o socialismo e a democracia, além do direito à independência (autonomia progressiva com vista a uma independência), da rejeição do colonialismo e prevenção ativa contra o neocolonialismo, da participação imediata dos elementos válidos timorenses na administração e governo local, da política de boa vizinhança e de cooperação com países da região, entre outros. (PIRES, 1981). Para Ramos-Horta, a "autonomia progressiva" consistia em uma descolonização gradual e no seu entendimento, por um período de até dez anos para a completa independência.

Em maio do mesmo ano, outro partido surge com o nome inicial de AIDIT (Associação para a Integração de Timor-Díli na Indonésia) e posteriormente designado por APODETI (Associação Popular Democrática Timorense), em cujo manifesto apresentava como princípio a integração, com autonomia, na comunidade indonésia, introdução da língua indonésia como disciplina obrigatória nas escolas secundárias e abertura das escolas primárias da língua indonésia, não eliminando as portuguesas já existentes.

\footnotetext{
25 José Manual Ramos-Horta, porta-voz da resistência timorense no exílio na época da invasão indonésia, por sua luta na diplomacia internacional pela independência do Timor, recebeu o Prêmio Nobel da Paz em 1996. Tornou-se presidente do país, governando entre 2007 a 2012.

${ }^{26}$ Revolução de orientação socialista que depôs o regime ditatorial do Estado Novo vigente em Portugal desde 1933, liderada por um movimento militar, inaugurando um regime democrático e uma nova Constituição de 25 de abril de 1976. (Nota do autor).
} 
Em busca de fortalecimento as duas organizações políticas pioneiras, a UDT e a ASDT, pensaram na possibilidade de juntar-se em uma frente unificada, mas, os entendimentos não ocorreram de modo que a última, inspirada nos movimentos revolucionários de Portugal, nos processos de independência das colônias africanas e sob a influência dos estudantes timorenses que regressavam da metrópole, passou por transformação ideológica tornando-se FRETILIN (Frente Revolucionária de Timor-Leste Independente).

Segundo Barbedo de Magalhães (2007, vol. II, p. 235), o primeiro manifesto da FRETILIN afirmava que:

\footnotetext{
"A Associação Social-Democrata Timorense considera-se intérprete dos mais profundos anseios dos Povos do Timor-Leste, e em razão disso proclama-se o único representante legítimo do Povo e passa a designar-se Frente Revolucionária de Timor-Leste Independente (FRETILIN). FRETILIN é um Movimento Vanguardista que encarna as aspirações mais profundas dos povos, ou seja, o pensar, o sentir e a vontade de Libertação dos Povos do Timor-Leste".
}

Ainda de acordo com o manifesto da FRETILIN, os líderes do movimento negociarão com o governo português, com vista ao reconhecimento da FRETILIN como o único representante do povo de Timor-Leste, que quer obter a imediata independência. Estes líderes do movimento eram todos jovens, alguns filhos de liurais que haviam estudado em Portugal, outros com formação em seminários no Timor-Leste, haviam obtido estudos formais, mas, apenas um, com formação em Psicologia em Lisboa, conhecia o marxismo-leninismo e sob sua influência, decidiu-se que a base ideológica e filosófica da FRETILIN seria o marxismoleninismo. Estavam lançadas as bases que gerariam as motivações que levou a Indonésia a invasão do Timor em 1975.

Embora o novo partido fosse de orientação comunista, não havia consenso ideológico em torno desse encaminhamento e não tardaram a surgir divergências entre seus membros, pois, não obstante a maioria ter perspectiva política de esquerda, havia aqueles, que a exemplo de Ramos-Horta se denominava social-democrata, havia outros católicos fortemente anticomunistas e ainda nacionalistas anticolonialistas. Mas, mesmo dentro dessa miscelânea ideológica, todos apontavam para o caminho da liberdade e da democracia, ainda que em termos gerais, não entendessem muito bem o que viria a ser "democracia", como aponta Barbedo de Magalhães (2007, vol.II, p. 239),

É óbvio que o programa da FRETILIN não era muito democrático, no sentido que esta palavra tinha no Ocidente. Mas os timorenses nunca tinham feito a experiência da democracia, até 1974. Portugal, a potência colonial, viveu em ditadura durante cerca de 50 anos, e não permitiu, durante todo esse tempo, que a democracia fosse praticada ou sequer discutida em qualquer parte do seu império. 
Sob os novos ares revolucionários de Portugal, o que inicialmente no discurso do General Spínola, era um direito dos povos a sua "independência", foi se conduzindo para direito à "liberdade", o que de certa forma mudava o caráter de independência e conduzia para um neocolonialismo, em que Portugal funcionaria como uma espécie de "tutor" dos territórios portugueses ultramarinhos, sem os rigores da dominação colonial.

\begin{abstract}
Por seu lado, os dirigentes dos movimentos de libertação das colônias, receosos de que Portugal pudesse favorecer ou facilitar soluções pseudo-democráticas e, de facto, neocolonialistas, contrárias aos objectivos pelos quais tantos africanos tinham lutado, ao longo de tantos anos de guerra, com tantos sacrifícios e com tanto sangue vertido pelos seus povos, concentraram posições e declaram a sua disposição de recusar quaisquer soluções parcelares enquanto Portugal não reconhecesse o direito à independência de todas as suas colônias. (MATTOSO, Vol. 8, 1994, p. 57).
\end{abstract}

Estas ameaças passaram a preocupar os timorenses o que levou a um convencimento de que para a obtenção da independência havia a necessidade de movimento revolucionário semelhante àqueles que haviam ocorridos nas colônias africanas, com luta e derramamento de sangue. Embora houvesse entendimentos da ONU para que Portugal garantisse a descolonização em uma transição pacífica, os timorenses se colocaram em prontidão para uma vanguarda revolucionária.

De fato, considerava-se geralmente que uma guerra de libertação era tão difícil e implicava tanto sofrimento e tantos sacrifícios que só um povo muito empenhado a podia fazer ano após ano. A força de uma guerrilha era considerada a medida da adesão do povo. Ao lutarem e darem as suas vidas pela terra mãe, no quadro de uma organização político-militar, os guerrilheiros e o povo que os apoiava mostravam, como num referendo democrático feito todos os dias, qual era a sua vontade. Não era necessária mais prova nenhuma para se saber qual era o verdadeiro querer do povo. (BARBEDO DE MAGALHÃES, 2007).

As tendências revolucionárias para a independência estavam sendo gestadas e no panorama regional, em palcos de conflitos entre capitalistas e comunistas como o ocorrido na Guerra do Vietnã e a iminente derrocada dos Estados Unidos naquele território, passou a incomodar os vizinhos do Timor, como os australianos que já percebiam as tendências revolucionárias esquerdistas que estavam em formação naquele território de modo que o Primeiro-Ministro trabalhista da Austrália, Edward Gough Whitlam (1916-2014), foi á Indonésia persuadir o então presidente Hadji Mohamed Suharto (1921-2008) sobre as vantagens de absorver o Timor Português.

Para piorar a situação de equilíbrio tênue, em setembro de 1974, o principal líder da APODETI em viagem à Indonésia afirmou que havia um imenso apoio popular da ordem de 75 a $90 \%$ dos timorenses que desejavam a integração à Indonésia. Essa afirmação foi 
largamente difundida pela imprensa indonésia sem nenhuma crítica o que impactou os ânimos da FRETILIN e a levou a organização de manifestações em Díli para demonstrar que as afirmações do líder da APODETI não correspondiam à realidade. Por sua vez, os indonésios ficaram surpresos ao observar que as grandes manifestações em Díli não receberam nenhuma retaliação de Portugal, o que de certa forma, demonstrava que Portugal aceitaria qualquer encaminhamento que o Timor tomasse. Em outra frente, a UDT havia enviado à Indonésia líderes para refutar as afirmações da APODETI, embora as autoridades indonésias não lhes tenham dado atenção.

O clima de tensão passou a reinar e o Timor a sofrer a interferência da propaganda da Indonésia pelos meios de comunicação, sobretudo o rádio. Segundo Barbedo de Magalhães (2007, vol. II, p. 245),

As mensagens emitidas pelas rádios de Kupang e de Atambua ${ }^{27}$, a partir de Timor Indonésio, eram deste gênero: Portugal abandonará Timor, Timor não tem possibilidades de se tornar independente; a Indonésia não aceitará a independência de Timor; a Indonésia é um país rico e, por isso, Timor só colherá benefícios da integração; a Indonésia apóia a APODETI e a Indonésia invadirá o Timor se este quiser caminhar para a independência; A guerra traria muitos prejuízos a Timor e foi por isso que a APODETI foi criada.

Assim, três correntes de entendimento sobre os destinos do Timor passaram a fazer parte do cotidiano do timorense, a que pretendia a continuação do domínio de Portugal com perspectiva de independência a médio ou longo prazo, outra que queria a anexação do Timor a Indonésia e aquela que pretendia a independência total e imediata do país. Diante das ameaças reais dos entendimentos da Austrália com a Indonésia em favor da anexação do Timor, embora houvesse desentendimentos e contradições, a UDT termina por se unir à FRETILIN em uma frente que previa a futura independência do Timor em um prazo de 5 a 10 anos. Isso agradou a Portugal, pois havia um meio termo, uma moderação que não era mais o radicalismo esquerdista da FRETILIN e nem o radicalismo direitista da UDT. Esse meio termo lançou um programa importante de descolonização. Segundo Hill (2002, p. 120),

O programa da coligação era: total independência para o povo de Timor-Leste, repúdio da APODETI e da integração num país estrangeiro, a adoção do português como língua oficial de Timor-Leste e o recurso ás Nações Unidas para que apoiassem Portugal no processo de descolonização.

O certo é que os ingredientes para um conflito estavam lançados. A Austrália temia a autonomia do Timor, pois para ela era uma incógnita como ocorreriam as negociações sobre a

\footnotetext{
${ }^{27}$ Cidade indonésia do Timor Ocidendal, fronteiriça ao Timor-Leste. (Nota do autor).
} 
fronteira marítima do Timor $\mathrm{Gap}^{28}$, sendo muito mais confortável sua negociação com a Indonésia do que com Portugal ou com um Timor-Leste independente. Seus interesses na exploração do petróleo timorense frente a uma situação de autonomia do Timor traziam temores acerca do encaminhamento ideológico que os grupos internos timorenses estavam tomando, sobretudo o alinhamento comunista com outras nações que conduzisse à existência de uma nação na sua vizinhança que fosse uma "nova Cuba". Aliado a isso, a forte presença no Timor de uma máquina de espionagem indonésia eficiente, deixavam às claras todas as intenções autonomistas dos timorenses e seus meandros, tornando inevitável o desfecho de uma anexação daquele território.

Em todo caso, em 1975, diante dos esforços de Portugal para a construção de um processo de descolonização e da união entre UDT e FRETILIN, houve ganhos de autonomia para o Timor, sobretudo por uma primeira experiência democrática que os timorenses tiveram ao eleger as administrações locais e regionais, além do início da descolonização do sistema educativo. Para piorar a situação, diante da coligação entre as principais forças políticas do Timor, dois eventos jogaram mais "lenha na fogueira", a saber:

\begin{abstract}
a rádio Kupang, em Timor Indonésio, começou a acusar os líderes da UDT e o governador Lemos Pires de serem pró-comunistas, por darem o seu apoio a uma coligação com a FRETILIN. E em fevereiro de 1975, a imprensa australiana publicava relatórios que diziam que a Indonésia estava a preparar uma invasão de Timor Português. (BARBEDO DE MAGALHÃES, 2007, vol. II, p. 249).
\end{abstract}

Porém, em abril de 1975, as rádios indonésias de Kupang e de Atambua arrefeceram o tom e pararam de acusar os lideres timorenses de comunistas e até convidaram lideranças da UDT e da FRETILIN a visitar a Indonésia separadamente. Possivelmente essa mudança tática tenha sido o resultado de uma reunião ocorrida em Londres entre o General Indonésio Ali Murtopo e alguns dos seus diplomatas com o Dr. Almeida Santos, que era Ministro da Coordenação Interterritorial do governo português e alguns membros do Movimento das Forças Armadas $(\mathrm{MFA})^{29}$ de Portugal. Nesta reunião Portugal concordou em não por dificuldades a quaisquer esforços que a Indonésia fizesse para promover a integração. (DUNN, 2001).

A conjuntura mundial da época estimularia o ímpeto revolucionário da FRETILIN. De um lado a derrota dos norte-americanos na guerra do Vietnã e o fracasso em Laos e no Camboja, por outro lado o movimento de independência das nações africanas e da ex-colônia

\footnotetext{
${ }^{28}$ Zona de fronteira marítima e do subsolo acordada entre Austrália e Indonésia em 1972 em discordância com Portugal sobre os princípios a seguir na delimitação dessa fronteira. Embora a exploração petrolífera na região tenha sido regulamentada pelo Tratado do Mar de Timor assinado em 2002 pela Austrália e pelo Timor-Leste independente, os impasses sobre as delimitações dessa fronteira perduram até os dias de hoje. (Nota do autor).

${ }^{29}$ Movimento militar português responsável pela Revolução dos Cravos de 1974. (Nota do autor).
} 
australiana de Papua Nova Guiné, foi suficiente para motivar o movimento de independência do Timor. A coligação entre UDT e FRETILIN se tornava frágil, já que apenas a FRETILIN era convidada para os eventos de sagração de independências das ex-colônias portuguesas na África. Para acentuar ainda mais as cisões da frágil coligação, por ocasião do primeiro aniversário da FRETILIN em 1975, a população timorense fez uma grande festa sagrando a popularidade do partido e seus encaminhamentos ideológicos, o que para a UDT colocava em risco o processo de independência do Timor.

A militância política da FRETILIN passou a atuar fortemente em todo o território timorense. Os militantes foram exortados a largarem seus empregos, os estudantes a contribuírem para a causa da libertação, foram enviados para todos os distritos, com a condição de falarem as línguas locais, e atuarem junto aos camponeses ajudando-os nas atividades diárias no campo e à noite, no processo de conscientização política sobre a causa timorense, além de terem iniciado um projeto e alfabetização dos camponeses e suas famílias para que as massas de analfabetos aprendessem a ler. $\mathrm{O}$ trabalho de base na conscientização política da FRETILIN, seu monumental esforço para conhecer detalhes das culturas locais dos povos do Timor, além do esforço para ensinar a ler e a escrever, não deixou dúvidas sobre os encaminhamentos ideológicos que o Timor estava construindo. Para se ter uma ideia da repercussão dessas ações do partido, por ocasião do retorno do Major português Francisco Mota da MFA a Portugal em território australiano, em Darwin, a jornalista australiana Jill Jollife o entrevistou e quando perguntado a respeito da sua impressão sobre a atuação da FRETILIN no Timor, respondeu:

\begin{abstract}
Eu penso que estavam a fazer um trabalho muito bom porque estavam a trabalhar no meio dos camponeses e à noite tinham discussões políticas... Penso que era o começo de uma melhoria de literácia. Eles estavam a usar um método do brasileiro Paulo Freire. Não é preciso ser-se comunista para se dizer que para educar essas pessoas e aumentar a sua literácia, os mais capazes devem trabalhar junto do povo. A UDT não faz isso. Eu falei com muitas pessoas da UDT e disse-lhes isso. Eles concordaram, mas, são funcionalismo, são funcionários públicos, e se vão para as montanhas viver e trabalhar, eles perdem os seus empregos. (HILL, 2002, p. 133).
\end{abstract}

Sem dúvida, o efeito do trabalho destas brigadas promovidas pela FRETILIN era mesmo aumentar a adesão popular a sua causa, angariando a simpatia e conferindo-lhe substância para sua principal argumentação de ser o único representante do povo de TimorLeste. "Estava a seguir o exemplo dos movimentos de libertação das colônias portuguesas em África. Ao fazê-lo, a crítica australiana de que a FRETILIN só representava a elite timorense de Díli cairia por terra". (BARBEDO DE MAGALHÃES, 2007, vol. II, p. 252).

De facto, este programa de aprendizagem da leitura e da escrita, usando o método de Paulo Freire, e incluindo noções de higiene e de cuidados primários de saúde, foi 
uma boa pedagogia para dar força ao povo. Os conceitos revolucionários transmitidos ajudavam a crescer a esperança num futuro melhor sem dominação colonial. (BARBEDO DE MAGALHÃES, 2007, vol. II, p. 252).

Em maio de 1975 a frágil coligação entre UDT e FRETILIN se desfez. Os argumentos da UDT estavam na acusação do espancamento de um líder da UDT por membros da FRETILIN, além das divergências ideológicas ligadas ao fato da FRETILIN ser comunista. No entendimento de líderes da UDT era mais coerente para o futuro do Timor uma coligação com a APODETI. Embora as acusações e os argumentos da UDT fossem reais, segundo BARBEDO DE MAGALHÃES (2007, vol. II, p.253), "a verdadeira razão era a influência dos serviços secretos indonésios sobre o Presidente da UDT".

As ações radicais por parte dos partidos, sobretudo pela FRETILIN no controle dos partidários de oposição, levou a violência, como espancamentos, o que fortaleceu o discurso de oposição que passou a acusar a FRETILIN de radicalismo na tentativa de desacreditá-la nas suas campanhas internacionais. Outra intenção era fazer crescer o medo entre os timorenses de que um Timor-Leste independente governado por comunistas radicais poderia ser um perigo para as liberdades e futuro da nação.

Já em maio de 1975, foi criado a Comissão de Descolonização de Timor (CDT) que conduziu a conversações entre o governo Português e os partidos do Timor-Leste, de modo a tentarem um acordo para estabelecer as linhas de um processo de descolonização. Porém, já nas primeiras negociações a FRETILIN considerou que a APODETI deveria desaparecer como partido, no máximo, permanecer apenas como uma corrente de opinião ou uma associação de amizade, Timor-Indonésia. A existência da APODETI como partido só se justificaria se o mesmo aceitasse a independência. Por sua vez, a CDT em reunião com a APODETI conseguiu da mesma a aceitação da independência, porém, a APODETI declarou que em vez do direito à independência, seria mais coerente reconhecer o direito à autodeterminação. Porém, após a independência caso a maioria do povo timorense votasse no partido, negociaria a integração com a Indonésia.

As negociações da CDT com os partidos levaram a organização de conversações que ocorreriam em Macau com a finalidade de estabelecer um acordo sobre o processo de descolonização. Porém, a FRETILIN, se recusando a aceitar a APODETI como um partido legítimo nessas negociações, resolveu não participar do encontro em Macau. Em todo caso estas conversações alcançaram um acordo sobre a descolonização por meio da promulgação da Lei 7/75 de 17 de julho. De acordo com esta lei,

no terceiro domingo de outubro de 1976, seria eleita pelos timorenses, por voto directo, secreto e universal, uma Assembleia Popular. Seria essa assembleia que decidiria, por maioria simples, através de voto directo e secreto, o futuro de Timor. 
A assembleia poderia, eventualmente, mudar o calendário, mas caso tal não acontecesse, as prerrogativas portuguesas, como potência administrante, terminariam dois anos depois, no terceiro domingo de outubro de 1978. Entretanto, haveria um alto comissário e um governo transitório formado pelo alto comissário e por cinco secretários de Estado, e um conselho consultivo do governo, formado por dois membros de cada conselho regional e por quatro membros de cada uma das associações políticas timorenses como tal reconhecidas e que desejassem nele participar. (BARBEDO DE MAGALHÃES, 2007, vol. II, p. 257).

Mas, as aproximações da UDT com a Indonésia e suas convergências anticomunistas levaram a execução de um golpe promovida pela UDT em 11 de agosto de 1975. Uma tentativa de antecipação da independência do Timor-Leste de Portugal, sem a participação da FRETILIN, mas com a anuência e o apoio dos serviços secretos da Indonésia. Este evento, em que a UDT cooptou apoio da polícia militar de Díli, conferiu-lhe um braço armado intimidador que chegou a se apossar de espaços como a Rádio Timor e outros prédios públicos. Os ânimos exaltados que se seguiram nos dias subsequente, exigia posturas diplomáticas de ambos os lados para o retorno ao ponto de equilíbrio anterior, mas, membros da UDT, prosseguiam com suas ações anti-FRETILIN pelo território timorense. Entre confusões e barbáries, com prisões e espancamentos entre membros dos partidos, acentuadas pelas confusões que estavam ocorrendo em Portugal ainda no âmbito da Revolução dos Cravos, em que ocorriam lutas entre as forças mais radicais de esquerda e forças mais moderadas e democráticas que estava a por em risco a transição democrática em Portugal, o descontrole geral em Timor, exigia medidas urgentes, que não mais era possível à Administração Portuguesa, gerando a contra-ofensiva da FRETILIN.

Segundo Barbedo de Magalhães (2007, vol. II, p. 264),

A partir daí, a FRETILIN assumiu a responsabilidade de controlar a situação, já que as autoridades portuguesas não estavam a garantir a paz e a segurança. Quase todas as unidades militares, quer em Díli quer no interior do país, colaboraram com esta decisão, uma vez que a maior parte dos membros timorenses das forças armadas portuguesas, embora não estivessem filiados na FRETILIN ou em qualquer outro partido político, eram a favor da independência.

O inevitável começou a ocorrer. Em 20 de agosto de 1975, deflagrou-se a guerra entre as forças da FRETILIN e da UDT. A FRETILIN considera esta data como a aquela da criação das suas próprias forças, as "FALINTIL (Forças Armadas de Libertação e Independência de Timor-Leste $)^{30}$. Esta é também a data do começo de uma curta guerra civil entre a FRETILIN e a UDT" (BARBEDO DE MAGAHLÃES, 2007, vol. II, p.265).

Os apoiadores e militantes de ambos os lados, quando capturados passaram a sofrer maus-tratos, como espancamentos bárbaros e até mortes. Diante do caos instalado, Portugal tentou até obter apoio dos australianos na evacuação de mulheres, crianças, funcionários

\footnotetext{
${ }^{30}$ Estas forças, nascidas no movimento de resistência revolucionária, também designam as Forças Armadas atuais da República Democrática de Timor-Leste (RDTL).
} 
públicos e outras pessoas que demonstrassem a vontade de sair de Timor. Porém, a Austrália manifestou-se em apenas oferecer alojamento em Darwin, sem, no entanto participar na evacuação em si a partir de Díli. Por outro lado, diante da solicitação de ajuda à Cruz Vermelha Internacional, esta alegou a existência de outras prioridades e não teriam como responder a tempo a solicitação, o governo da Indonésia, silenciou-se. Por um acaso, no dia 24 de agosto, um cargueiro norueguês "Loyd Bake" que passava entre as ilhas de Timor e Ataúro foi em direção a Díli após receber por rádio pedido de ajuda e resgatou refugiados portugueses e timorenses os deslocando até Darwin, no norte da Austrália. Os combates se sucediam e a ameaça de invasão da Indonésia era agora real. A marinha portuguesa via rádio chegou a receber um telegrama assinado por Ramos-Horta enviado da Austrália, para que FRETILIN e UDT entrassem em negociação de paz, pois uma invasão da Indonésia era iminente.

Entre os momentos dramáticos de evacuação pode-se citar o ocorrido com o pequeno cargueiro português "Mac Díli", que havia retornado ao porto de Díli para uma segunda operação de resgate, pois a primeira havia ocorrido no dia 27 de agosto na retirada da Administração Portuguesa, governador e funcionários (Figura 2), após quinze dias de

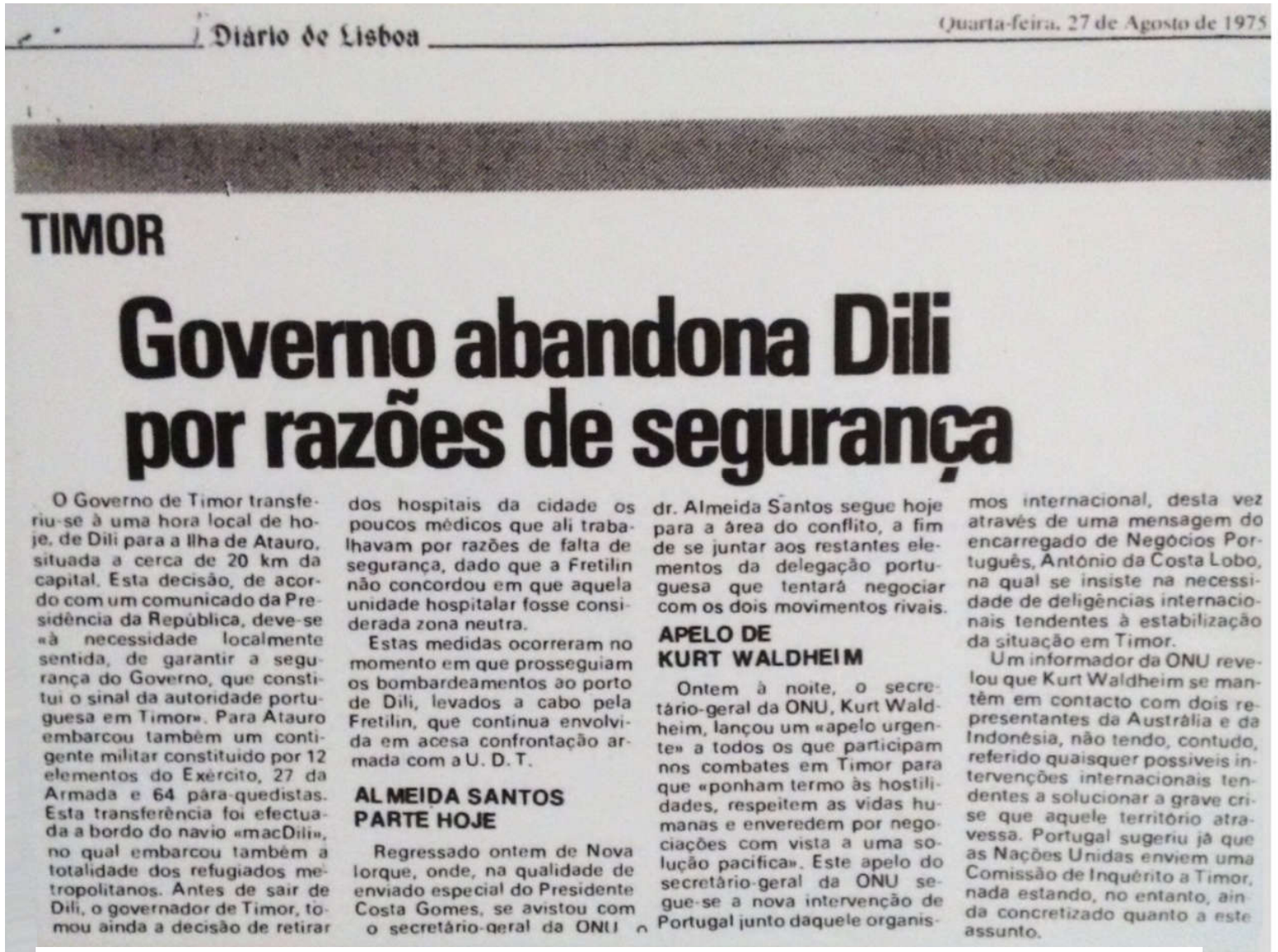

Figura 2 - Foto da Cópia do Jornal Diário de Lisboa de 27 de agosto de 1975 informando sobre a saída do Governo Português de Timor-Leste para a ilha de Ataúro - Museu da Resistência Timorense em Díli 
conflagrações, para a ilha de Ataúro. Neste dia mais de 726 pessoas embarcaram no cargueiro, entre eles, portugueses, chineses e cidadãos de outros países, o Cônsul da República da China (Taiwan). Durante o dramático embarque o porto foi bombardeado e várias pessoas se feriram com gravidade, incluindo-se paraquedistas portugueses. Em incursões feitas pelos páraquedistas descobriu-se um acampamento da UDT, onde capturaram um morteiro e munições, o mesmo ocorrendo no quartel-general da FRETILIN. No dia seguinte a esse evento uma fragata indonésia aportou em Díli e resgatou o Cônsul da Indonésia juntamente com sua equipe. (PIRES, 1981).

Algumas tratativas para um cessar fogo foram feitas, porém sem resultados, pois nunca havia consenso que permitisse o estabelecimento de uma mesa de negociação entre os dois partidos e seus apoiadores.

No início de setembro, as forças da UDT encurraladas sob ataque da FRETILIN na fronteira com a Indonésia, fizeram um apelo aos indonésios para obterem comida e munição e que permitissem a entrada em seu território para se salvarem do fogo da FRENTILIN. Nas conversações entre militares indonésios, membros do serviço secreto e os representantes da UDT ocorridas na fronteira, os indonésios informaram que a ajuda estava condicionada ao envio de uma petição ao Presidente Suharto com um apelo à integração na Indonésia. Embora essa não fosse uma vontade da maior parte da população timorense, não havia outra saída diante das circunstâncias. Assim, os líderes políticos das forças anticomunistas subscreveram a petição em 7 de setembro e, em torno de 900 timorenses, puderam atravessar a fronteira para Indonésia.

Diante dessa rápida vitória da FRETILIN, que na altura de 24 de setembro havia conquistado as últimas resistências da UDT, esta solicitou uma delegação da Cruz Vermelha Internacional com autorização para ir e vir onde quisessem no território do Timor, para que fosse feita uma estimativa sobre as baixas produzidas na guerra civil. Neste sentido, indicaram um total de mortos em torno de dois a três mil pessoas. A FRETILIN, na aparente calmaria instalada, estabeleceu uma administração transitória na expectativa de retorno da Administração Portuguesa para conduzir o processo de descolonização e a definitiva transferência do poder. Nesse intervalo, contando com o auxílio da Cruz Vermelha, procedeuse o tratamento dos feridos, organizou a distribuição de alimentos para a população, reorganização das finanças, colocaram para funcionar a Rádio Maubere para fazer frente à desinformação que era divulgada pelas rádios indonésias e criaram também um jornal para a divulgação de informações no território do Timor. 
Já durante a administração FRETILIN, no início de outubro ocorreu o primeiro grande ataque feito pelas forças indonésias ao território timorense na fronteira. A superioridade indonésia era tão grande que restou como única alternativa as FALINTIL, após brava resistência, a retirada da área. Neste incidente cinco jornalistas internacionais foram assassinados pelas forças indonésia, mas, o material jornalístico recolhido, não deixava dúvida sobre o papel da Indonésia nesse evento, já que esta imputava a invasão à resistência timorense anticomunista organizada a partir de seu território.

Alguns fatores podem ser imputados como determinantes para a declaração unilateral de Independência do Timor-Leste feita pela FRETILIN no dia 28 novembro de 1975 (figura $3)$. Entre eles, as dificuldades nos contatos com as autoridades portuguesas e o desinteresse do Governo Australiano sobre a invasão militar da Indonésia iniciada desde outubro. Neste sentido, e diante do avanço das forças indonésias pelo território,

Às $18 \mathrm{~h} 00$ do dia 28 de novembro de 1975, Xavier do Amaral, Presidente da FRETILIN, chegou ao Palácio do Governo. A bandeira portuguesa que tinha flutuado em Díli durante séculos foi arreada, pela última vez, e a nova bandeira da República Democrática de Timor-Leste, RDTL, foi içada. Nessa altura, Francisco Xavier do Amaral proclamou a independência da República Democrática de TimorLeste com as seguintes palavras: "Encarnando a aspiração suprema do Povo de Timor-Leste e para salvaguarda dos seus mais legitimos direitos e interesses como Nação soberana, o Comité Central da Frente Revolucionária de Timor-Leste Independente - FRETILIN - decreta e eu proclamo, unilateralmente, a independência de Timor-Leste que passa a ser, a partir das 00.00h de hoje, a República Democrática de Timor-Leste, anticolonialista e anti-imperialista.

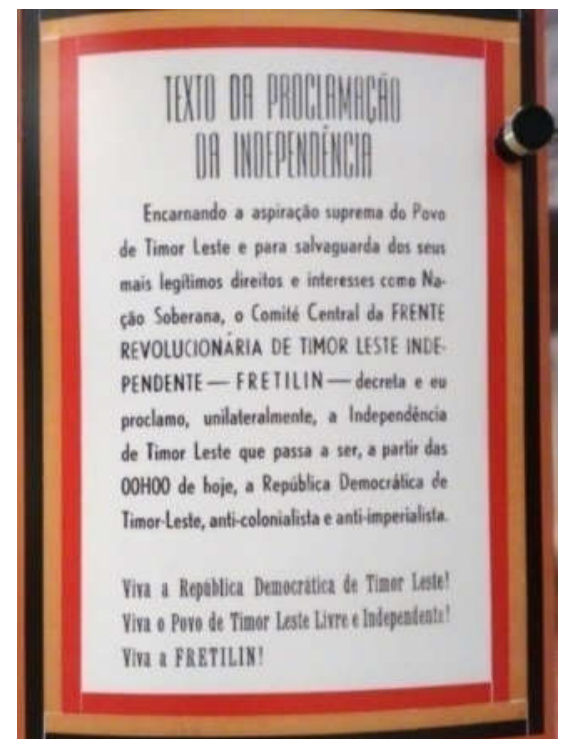

VIVA A REPÚBLICA DEMOCRÁTICA DE TIMOR-LESTE! VIVA O POVO DE TIMOR-LESTE LIVRE E INDEPENDENTE! VIVA A FRETILIN!"

\section{Francisco Xavier do Amaral - Presidente da FRETILIN e da República} Democrática de Timor-Leste.

Cerca de 2000 pessoas, que estavam presentes nos jardins em frente do Palácio do Governo, Saudaram a declaração. (BARBEDO DE MAGALHÃES, 2007, vol.II, p. 272).

Como sequência à Proclamação de Independência no dia seguinte Xavier do Amaral prestou juramento como Presidente, promulgando a Constituição da República Democrática do Timor-Leste. Dado a emergência do ato, esta

Figura 3 - Fotografia do texto da proclamação da independência de Timor-Leste, tirada da exposição permanente do Museu da Resistência Timorense em Díli.
Constituição se assemelhava a de GuinéBissau. Estabelecido os nomes para a composição do primeiro governo de

Timor-Leste, o presidente Francisco Xavier do Amaral exortou a todos os países 
anticolonialistas e anti-imperialistas do mundo e em nome da militância internacionalista, cooperação em todos os campos, todavia, nenhuma arma, caso tenha sido enviada por qualquer país amigo, chegou até a resistência armada de Timor, não obstante o severo e constante avanço das tropas indonésias no seu território. Agravando ainda mais a situação no dia 2 de dezembro, o Ministério dos Negócios Estrangeiros australiano avisou a todos os australianos em Timor-Leste que deixassem o país imediatamente.

Em um último ato de desespero e após conclamar ajuda do mundo para a situação de Timor-Leste sem respostas positivas, o Comitê Central de FRETILIN decidiu enviar os Ministros Mari Alkatiri, José Ramos-Horta e Rogério Lobato para fora do Timor,

\begin{abstract}
a fim de realizarem trabalho diplomático em diversos países e nas Nações Unidas. Eles tinham três missões fundamentais: obter o reconhecimento da RDTL por um grande número de Estados, levantar a questão nas Nações Unidas e conseguir o seu envolvimento na procura de uma solução que respeitasse o direito internacional e obter apoio militar. (BARBEDO DE MAGALHÃES, 2007, vol. II, p. 276).
\end{abstract}

Os esforços dos emissários da RDTL para obtenção de ajuda não surtiram efeitos. A China havia disponibilizado armas para até oito mil soldados, mas, não se comprometia a levá-las ao Timor, logo as relações desta com a Indonésia melhorariam e esse auxílio prometido nunca se efetivaria. A Austrália, definitivamente não se intrometeria nos assuntos da Indonésia, por mais que os timorenses lembrassem aos australianos sobre o sofrimento e a mortandade em massa que haviam sofrido na Segunda Guerra para se evitar uma invasão japonesa ao território australiano. A União Soviética se esquivou diante do contato de Rogério Lobato, o mesmo ocorrendo com outros países comunistas da época. Apenas os países africanos recém-idependentes foram mais receptivos, tendo Moçambique inclusive prometido, por meio do seu presidente Samora Machel, enviar homens altamente treinados para auxílio ao Timor, ajuda que nunca chegou, pois a invasão Indonésia se efetivaria antes.

Diante disso, a causa timorense estava condenada ao esquecimento e o pior, ao descaso. Isso possivelmente contribuiu para explicar o desconhecimento da opinião pública mundial por longo tempo, sobre o que se passava em Timor-Leste. A Indonésia começou a invasão sorrateiramente por meio do seu serviço secreto, porém, posteriormente à declaração unilateral de independência do Timor-Leste, no dia 7 de dezembro já havia tomado Díli. Nos últimos dias de 1975, já era uma invasão densa, inabalável, embora desorganizada, pois os requintes de brutalidade terminaram por horrorizar os timorenses, que sempre generosos e gentis, passaram a recusar essa integração. Portugal por seu lado fez apelos ao Conselho de Segurança da ONU e terminou por cortar relações diplomáticas com a Indonésia. Seguiram-se 
intensas negociações na ONU onde se repudiou a invasão da Indonésia, bem como se aprovou resoluções pela retirada imediata, mas, nada surtiu efeito.

Barbedo de Magalhães (2007) menciona a influência e as tratativas do presidente indonésio Suharto, com os Estados Unidos por meio do seu próprio presidente que à época era Gerald Ford, bem como com a Austrália, por meio do Primeiro-Ministro Gough Whitlam. Na agenda, a questão do Timor, recebeu o apoio necessário, colocando a anexação como a melhor saída para o impasse. O fato é que a cada dia aumentava o contingente dos soldados indonésios no território do Timor-Leste. Em 18 de dezembro, foi anunciado um governo provisório indonésio em Díli. O progressivo avanço da invasão e a tomada de espaços elevaram em abril de 1976, a ocupação para cerca de trinta e cinco mil soldados da Indonésia em todo o Timor.

O que para parte da população parecia uma via para escapar do comunismo, a anexação do território pela Indonésia havia se transformado em um pesadelo devido à brutalidade com que o processo se dava. Até aqueles timorenses que inicialmente apoiaram a invasão da Indonésia, foram aos poucos se posicionando contrários até a quase generalização de repúdio ao ato.

Barbedo de Magalhães (2007, Vol. II, p.289) menciona que a ação da propaganda indonésia sobre os benefícios que fariam ao Timor convenceram até autoridades eclesiásticas, acrescentando que,

o Bispo D. José Joaquim Ribeiro sentiu alívio quando viu "anjos a cair do céu" como ele comentou com um dos seus colabores, quando, em 7 de dezembro de 1975, viu pára-quedistas indonésios a ser lançados sobre Díli. Um missionário português que na altura vivia em Timor havia já longos anos disse ao autor Barbedo de Magalhães que esta tinha sido a expressão que o bispo tinha usado, por acreditar que os militares indonésios libertariam Timor-Leste do comunismo.

Todavia, segundo o autor citado acima, dias após essa chegada dos pára-quedistas, que eram "anjos" a princípio, o próprio bispo passou a encará-los como verdadeiros "demônios", frente à tamanhas atrocidades que praticavam como roubos, saques, massacres e violações por onde passavam.

Uma lembrança curiosa sobre este evento dos pára-quedistas indonésios saltando sobre Díli em 1975 foi-me narrada em 2007 por um senhor timorense que era segurança do hotel em que residi e que na época era soldado das FALINTIL. Contou-me ele que enquanto os indonésios desciam de pára-quedas sobre Díli, ele operava uma metralhadora em uma espécie de casamata e que matou tantos indonésios quantas balas tinha a disposição. Mas, a quantidade de pára-quedistas era tanta que faltou munição de modo que teve que abandonar o posto e evadir-se dali. 
Assim as FALINTIL, o braço armado da FRETILIN, bravamente reagiam e ainda conseguiram manter-se no domínio de boa parte do território timorense nos primeiros anos de dominação, porém, como aponta BARBEDO DE MAGALHÃES (2007), "o apoio ocidental à Indonésia permitiu-lhe destruir todas as bases da Resistência e, ao fim de três anos de guerra, eliminar o seu líder máximo, Nicolau Lobato" (p.292). A profusão e superioridade de armamento da Indonésia arrasaram o território. Intensos bombardeios indonésios eram feitos com os aviões fornecidos pelos americanos. Nos campos culturas agrícolas foram destruídas, aldeias inteiras foram varridas do mapa e em torno de $90 \%$ do gado existente morreu em função das bombas e balas. Uma parcela do que sobreviveu a isso, morreu de fome por falta de pastagem. Uma calamidade para o timorense do campo que apenas levava sua vida integrada à natureza e aos fazeres para a subsistência.

Diante de toda atrocidade, o argumento indonésio sempre presente de combate ao comunismo, levou à FRETILIN a radicalizar ainda mais, opondo-se a qualquer diálogo e reafirmando o marxismo-leninismo como a sua base ideológica, reforçando o que foi visto no processo de descolonização da África portuguesa. A FRETILIN entendia que negociações para a paz seria o primeiro passo para a rendição definitiva do Timor, sendo psicologicamente necessária uma ideologia revolucionária mais radical.

Essa linha radical era um imperativo defendido por Nicolau Lobado em oposição à linha mais moderada defendida pelo ainda presidente da RDTL, Xavier do Amaral, que menos politizado, via o radicalismo como uma ameaça ao próprio povo timorense que já começava a morrer de fome nas montanhas. Portanto, as diferenças internas na FRETILIN, ameaçavam a própria unidade da resistência.

\begin{abstract}
Muitos consideraram que a divisão entre marxistas e não marxistas era a principal divisão no interior da resistência. Mas, embora os conceitos marxistas fossem estranhos a quase todos os timorenses, nomeadamente aos militares, que misturavam a cultura e os valores tradicionais com influências católicas e ideias conservadoras aprendidas na escola, no seminário e no exército português, a principal divisão, nestes tempos, era entre os que queriam continuar a lutar, mesmo em circunstancias tão difíceis, e os que estavam demasiado cansados e sem esperança e preferiam reder-se e esperar que, eventualmente, um dia acontecesse um milagre libertador. (BARBEDO DE MAGALHÃES, 2007, vol. II, p. 299).
\end{abstract}

Nesta confusa e complexa divergência ideológica, outro fenômeno ocorria e representava mais uma dificuldade. Como não bastasse conflitos existentes entre os quadros civis da FRETILIN, ainda havia conflitos com os quadros militares das FALINTIL que não aceitavam facilmente a submissão aos civis. Para piorar, passaram a ocorrer conflitos culturais, "entre liurais e nobres (datos), da estrutura tradicional timorense, e os 
revolucionários que defendiam uma sociedade sem classes, sem ricos nem pobres, sem liurais e sem súbditos". (BARBEDO DE MAGALHÃES, 2007, vol. II, p.300).

Essas contradições e divergências, sobretudo as que ocorriam no seio da FRETILIN, também mostraram sua face cruel. Qualquer sinal de fraqueza ou postura mais maleável como proposta de diálogo com os indonésios, podia ser vista como traição com medidas punitivas severas. Havia um patrulhamento que gerava medo entre os seus próprios membros, pois todos estavam sujeitos à chamada "violência revolucionária". Como informa Barbedo de Magalhães (2007, vol. II, p.301),

de facto, a chamada "violência revolucionária", responsável por torturas e até o assassinato de cerca de 200 membros da FRETILIN às mãos de outros camaradas, muito difícil de evitar em condições tão extremas como as da guerra que era imposta à resistência, foi um dos aspectos mais controversos da ideologia "marxista" de alguns quadros.

Estas pressões internas no movimento revolucionário funcionaram como um expurgo onde os mais fracos sucumbiram, fugiram ou se rederam aos ocupantes. Nesse contexto de contradições, o ainda presidente Xavier do Amaral, que não era marxista, foi acusado de traição e se retirou de uma reunião importante sobre os destinos do movimento de resistência, indo se refugiar no seu reino tradicional.

em 7 de setembro de 1977, o Conselho Permanente do Comité Central da FRETILIN acusou Xavier do Amaral de alta traição. Foi então submetido a um julgamento presidido por Alarico Fernandes e foi torturado. Diversos membros da FRETILIN e das FALINTIL também foram acusados. Alguns deles foram espancados ou mesmo mortos. Alarico Fernandes e os outros líderes sabiam que qualquer traição de um membro da resistência podia dar origem a muitas mortes e, eventualmente, ao fim da racionalidade e do humanitarismo. Isto deixou feridas. Mais de 25 anos mais tarde, as viúvas de alguns destes cerca de 200 membros da FRETILIN eliminados, acusados de traição, ainda clamam por justiça para as memórias dos seus ex-maridos. (BARBEDO DE MAGALHÃES, 2007, vol. II, p. 300).

Diante da destituição de Xavier do Amaral, em 16 de outubro de 1977, o líder da resistência, Nicolau Lobado foi eleito Presidente da FRETILIN e da RDTL por unanimidade. Mesmo aprisionado pelos membros das FALINTIL, Xavier do Amaral teve destino humilhante, foi capturado pelas forças indonésias que o levaram para Bali, onde foi obrigado a trabalhar para um general indonésio de maneira submissa.

$\mathrm{Na}$ quase total ausência de auxílio do exterior, e dia após dia as sucessivas derrotas, um dos últimos bastiões de resistência, o Monte Metebian, onde se concentravam 140.000 timorenses que eram protegidos por um exíguo contingente das FALINTIL com apenas 527 armas, estavam cercados por 45.000 soldados indonésios. A única alternativa para a FRETLIN e as FALINTIL diante das circunstâncias foi pedir para a população se render o 
que abriu uma brecha para evitar a completa destruição da resistência. Mas, em 22 de novembro de 1978, a última base da resistência timorense caia nas mãos das forças indonésias. No mês seguinte, no dia 31 de dezembro, Nicolau Lobato foi morto em combate.

Nos estertores das ações finais sobre os guerrilheiros, uma estratégia usada pelo exército indonésio no processo de "limpeza final" dos grupos de resistência timorense nos últimos redutos em que as FALINTIL ainda atuavam, consistiu na atitude covarde de mobilizar cerca de quarenta mil timorenses, entre 15 e 55 anos de idade, para seguirem à frente das tropas indonésias como escudos humanos, desarmados e a formar cordões contínuo de cerco em torno dos lugares onde se suspeitava da presença dos guerrilheiros da FRETILIN. Na visão de Barbedo de Magalhães (2007, vol. II, p. 341),

Foi assim que dezenas de milhares de homens e jovens timorenses foram obrigados a presenciar cenas de uma selvageria inimaginável, praticadas pelos ocupantes sobre os guerrilheiros e suas mulheres, mesmo grávidas, e sobre seus filhos e filhas, incluindo bebês.

Essa ferocidade na ação indonésia, provocou a reação da Igreja e da própria população timorense que diante do barbarismo, passou a recusar a presença indonésia em seu território. Esse fato de certa forma garantiu o combustível necessário para a reorganização da resistência. Assim, no despontar de 1979, ainda que nomes importantes da resistência também tenham sido exterminados, a partir dessa vacância de liderança, Xanana Gusmão assumiu a resistência. Todavia, "em finais de 1979, 90\% dos combatentes e 80\% das armas estavam perdidas". (ACÁCIO, 2006, p. 89). Segundo Barbedo de Magalhães (2007, vol. II, p.311),

nos finais de 1979, não havia mais de 1500 homens das FALINTIL, que dispunham apenas de 500 armas. Estavam divididos em pequenos grupos, isolados uns dos outros, e sem quaisquer comunicações com o mundo exterior. Em julho de 1979, um censo indonésio mostrava que mais de um quarto da população tinha morrido, vítima da guerra e da fome. As estimativas que a igreja fez nessa altura levavam a pensar que a percentagem de mortos seria mesmo superior a um terço da população. O número de cabeças de gado estava então reduzido a um décimo do valor anterior à invasão. Isso significava que, ao fim de quatro anos de resistência, com o objetivo de vencer os ocupantes, o povo timorense tinha pago um preço tremendamente elevado e sua resistência estava quase completamente destruída.

Destroçados em todos os sentidos, no ano de 1981, a Resistência renasceu sob a liderança de Xanana Gusmão, um dos dois líderes do Comitê Central da FRETILIN que havia sobrevivido. Neste tempo, desempenhou importante papel na reorganização das forças dispersas. Porém, a estratégia agora era outra. Diante das circunstâncias que a situação impunha a abertura ao diálogo e aos patriotas, mesmo àqueles que colaboravam com os indonésios, era a via como estratégia de luta. 
Em meio à desolação provocada pela desarticulação e dispersão da Resistência, após dois anos de tentativas, aos poucos foi possível restabelecer contatos entre os vários grupos. A articulação desses grupos era fundamental e para isso, se organizou a Primeira Conferência Nacional para a Reorganização do País. Nessa conferência clandestina, realizada em março de 1981, foi eleito como líder da FRETILIN, Kay Rala Xanana Gusmão. As fitas gravadas dessa conferência foram transcritas em 1983 por Abílio Araujo, que à altura era o Chefe da Delegação Externa da FRETILIN em Lisboa. Essa transcrição permitiu uma amplitude maior de informações, sobre o movimento, para o mundo e ofereceu importante material de análise para os novos rumos e estratégias da resistência. Além da eleição dos novos líderes do Comitê Central da FRETILIN, a Conferência reafirmou a linha ideológica do partido como sendo Marxista-Leninista. Porém, como menciona Barbedo de Magalhães (2007, vol. II, p.326),

a aprovação formal do Partido Marxista-Leninista não se refletiu na estratégia, nem na estruturação, nem, muito menos, correspondeu a uma maior radicalização da Resistência. Pelo contrário, foi acompanhada de uma análise crítica mais livre e franca dos cinco primeiros anos da luta e da definição de uma estratégia para o futuro, muito mais realista, aberta, compreensiva, humana e eficaz.

A ênfase mostrada aqui sobre a fundamentação ideológica da FRETILIN é importante para clarear muitos aspectos da política atual em Timor-Leste, embora os encaminhamentos ideológicos do partido no futuro tenham tomado outros rumos. Mas, à época da resistência, na visão dos seus líderes e pela observação das lutas de libertação dos povos do colonialismo e do imperialismo, bem como dos movimentos organizados que conduziram a independências dos seus países, não resta dúvida de que a ideologia mais apropriada aos movimentos revolucionários centrava-se no marxismo. Como pode ser notado na referência de Barbedo de Magalhães (2007, Vol. II, p. 326-327) sobre o assunto:

\begin{abstract}
Acontece que a maior parte das guerras de libertação com sucesso tinha sido conduzidas ou inspiradas na análise e na disciplina marxista-leninista. Marx produziu as melhores ferramentas analíticas do seu tempo, para repensar a história política e os fenômenos sócio-econômicos. Mao usou e adaptou o esquema analítico de Marx à guerra popular prolongada que conduziu, nas condições reais da China, e também teve sucesso. A teologia da libertação não era conhecida em Timor, e foi necessário percorrer um longo e árduo caminho para a Igreja Timorense, ela própria, desempenhar um papel crescente na libertação do seu povo. O pequeno livro vermelho de Mao era quase o único livro em que os líderes timorenses podiam encontrar conceitos e um pensamento organizado para utilizar na sua prática política e na análise da guerra. Por todos esses motivos o marxismo-leninismo tinha sido proclamado, em 1977, como a ideologia de base da FRETILIN.
\end{abstract}

Outra referência importante a se fazer sobre a liderança de Xanana Gusmão é sua ênfase no uso da língua portuguesa, como língua da resistência, tanto na comunicação diária como na divulgação de documentos, pois, os indonésios haviam proibido o uso do português 
em todo território. Não admitiam seu uso, por associá-lo aos rebeldes comunistas da FRETILIN. O seu uso era um atestado de que quem o utilizasse era militante da resistência ou um subversivo de outra ordem, merecendo punição por isso. Possivelmente, a inserção do português como língua oficial do Timor-Leste na Constituição do Timor independente, além de ser a língua do colonizador secular, tenha suas raízes nessa atitude de rebeldia frente ao agente invasor. Barbedo de Magalhães (2007, vol. II, p. 330) apresenta um exemplo, com relação ao uso da língua portuguesa, da atitude de Xanana Gusmão na Conferência organizada para a reestruturação da resistência, transcrito abaixo:

\begin{abstract}
Vale a pena notar que todos os documentos preparados para esta reunião por Xanana Gusmão, tal como o seu discurso e também o relatório da conferência, foram ditos ou escritos em português. Embora já nenhum dos membros do Comitê Central que tinha estudado em universidades portuguesas estivesse ainda vivo nas montanhas de Timor, e a maior parte dos quadros também já tivesse sido morta, a língua portuguesa manteve-se, até ao fim da luta, como a língua da Resistência. Era uma necessidade para os contactos internacionais, nomeadamente com Portugal e com os países de língua portuguesa recentemente independentes que tanto apoio deram à FRETILIN, e também uma reação contra a língua indonésia.
\end{abstract}

No bojo da nova estratégia moderada e tendente ao diálogo adotada pela FRETILIN, em 1982 Xanana Gusmão escreveu ao Governador Mário Carrascalão, convidando-o ao diálogo e este aceitou. A própria Indonésia começava a arrefecer as ações e até promoveu diversas tentativas de aproximação à Resistência. Segundo Carrascalão (2006, p. 155),

Em dezembro de 1982, após muitas tentativas falhadas do Exército Indonésio para uma aproximação de paz com a Resistência Armada, as suas partes iniciaram os contactos e isso fez com que, pela primeira vez desde 1975, fosse possível aos timorenses passarem um Natal com menos tiros, menos prisões, menos torturas, menos lágrimas e com as igrejas ainda mais abarrotada de fies. Havia menos desconfiança nas ruas. As pessoas falavam mais ente si quando se viam nas ruas ou nos seus locais de trabalho. Era um tempo de alguma esperança. Todos pareciam estar à espera que alguma coisa acontecesse.

Com o avanço das tratativas de paz, em 1983, Xanana consegue um encontro com o Comandante das forças indonésias em Timor, Coronel Purwanto. Xanana Gusmão apresentou uma proposta de Plano de Paz e uma solução dialogada com a participação da ONU. Em todo caso, deste encontro resultou um cessar-fogo. "Infelizmente, a contra-informação indonésia conseguiu apresentar ao mundo e até convencer o Governo Português de que estas conversações de paz não passavam de uma rendição da FRETILIN" (BARBEDO DE MAGALHÃES, 2007, vol. II, p. 348). Todavia, elas permitiram a reorganização clandestina da Resistência.

Ainda no ano de 1983, em outros campos da vida do timorense, outro fato importante que mostra a interferência da Indonésia no cenário internacional quando o assunto era $\mathrm{o}$ 
Timor, diz respeito à ação da Indonésia diante do desagrado com a posição da Igreja em Timor-Leste pela atuação de Dom Martinho Lopes, Bispo de Díli, contrário à desumanidade que os invasores promoviam em Timor. Neste sentido, a Indonésia havia conseguido por pressão no Vaticano a nomeação do novo Bispo, Monsenhor Ximenes Belo à frente da Diocese de Díli. Todavia, em sinal de desaprovação, os padres timorenses se recusaram a assistir à cerimônia de posse em sinal de protesto diante do fato. Para os padres timorenses, era uma afronta a nomeação do padre mais jovem entre os padres timorenses e que passara os longos anos da ocupação indonésia de dor e sofrimento para o povo, no estrangeiro, sem testemunhar a dureza da vida timorense daqueles tempos difíceis.

No mês de agosto do mesmo ano, o frágil cessar-fogo que havia permitido a reorganização da Resistência, foi quebrado. Militares indonésios haviam molestado sexualmente a esposa de um timorense em uma das aldeias e isso motivou as FALINTIL a abaterem 16 militares indonésios. Em retaliação, as forças indonésias mataram centenas de homens da aldeia que foi totalmente arrasada, pondo um recomeço à guerra com os mesmo expedientes já utilizados, inclusive a estratégia, calamitosa para o timorense, do uso dos escudos humanos.

Nesta nova fase da guerra, foi notável a colaboração dos padres timorenses em auxílio à Resistência. Além de prestarem apoio moral à população, colaboraram de maneira insuspeita, muitas vezes com transporte e abrigo a Xanana Gusmão e a outros membros da Resistência. Houve até ocasiões que padres chegaram a transportar um rádio emissor e outros equipamentos de comunicações e até uma metralhadora pesada para os guerrilheiros nas montanhas. (BARBEDO DE MAGALHÃES, 2007).

Com o tempo e diante do sofrimento dos novos enfrentamentos no recomeço da guerra, Xanana Gusmão foi percebendo que uma vitória naquela situação, em que a superioridade da Indonésia se mostrava incontestável, era praticamente impossível com os mesmo métodos. Assim, entendendo que a vitória só poderia ocorrer no campo político e no plano internacional, Xanana colocou a democracia multipartidária, "e não a independência, sob a égide de um partido líder, como objectivo, e o realismo do contexto local, regional e mundial, e não a ideologia, como quadro de referência da luta." (BARBEDO DE MAGALHÃES, 2007, vol. II, p. 375). Em 1987, como via inicial para atingir este objetivo, desvinculou as FALINTIL da FRETILIN, com a intenção de transformá-la definitivamente em Forças Armadas Nacional e não mais um braço armado de um partido. Neste sentido, a Resistência para ter visibilidade e se tornar realmente nacional, levou Xanana Gusmão a se retirar da FRETILIN e para isso, Xanana anuncia o seu completo afastamento do marxismo- 
leninismo e reformula os novos objetivos da Resistência. Esta atitude gerou incompreensões e descontentamento de muitos timorenses, sobretudo os membros da FRETILIN.

No ano seguinte, em 1988, Xanana Gusmão criou o CNRM (Conselho Nacional da Resistência Maubere) e procurou se justificar aos seus apoiadores, sobretudo, os timorenses que estavam no exterior, as intenções da sua atitude. Neste sentido, escreveu uma mensagem dirigida aos estudantes timorenses na Indonésia onde se explicava. Segundo BARBEDO DE MAGALHÃES (2007), "as reações negativas que essas mudanças suscitaram no exterior levaram à nomeação de Ramos-Horta como representante especial do CNRM e do próprio Xanana" (vol. II, p. 380). Com isso, a batalha diplomática adquiriu nova dinâmica de maior eficiência.

Com o entendimento de que um grande líder desponta na adversidade por sua capacidade de antecipar o futuro e pela percepção dos movimentos da contemporaneidade, Xanana capitalizou sua ação de ruptura ideológica e alçou a problemática do Timor a outro patamar. Segundo BARBEDO DE MAGALHÃES (2007, Vol. II, p. 386),

\footnotetext{
O facto de Xanana Gusmão ter feito toda a viragem ideológica e estratégica antes da queda do Muro de Berlim e do esboroar do poder da superpotência comunista deulhe uma credibilidade que uma evolução feita mais tarde, eventualmente fruto das circunstâncias exteriores, não lhe daria. Dai a importância de a ter feito atempadamente, apesar da oposição da ala externa da FRETILIN. O apoio internacional que, depois do fim da Guerra Fria, a Causa de Timor foi progressivamente granjeando deve muito a essa visão do carismático líder da Resistência.
}

A nova conjuntura produzida pela derrocada comunista internacional após a queda do Muro de Berlim, a derrota da União Soviética no Afeganistão, a abertura política promovida pela Perestroika e pela Glasnost de Mikhail Gorbachev, bem como a própria queda do regime comunista com o colapso econômico da União Soviética, colocou o presidente da Indonésia, Suharto em um papel secundário na sua cruzada anti-comunista em Timor, o que o levou a promover certa abertura, permitindo, inclusive, a entrada de turistas e jornalistas no território timorense. Porém, o fato mais marcante que haveria de colocar o Timor-Leste definitivamente no mapa internacional com uma visibilidade nunca vista, foi a visita do Papa João Paulo II à Díli em 12 de outubro de 1989. Os holofotes da imprensa mundial para este evento levou a juventude timorense a organizar a primeira manifestação pública que denunciava o desagrado dos timorenses com a integração à Indonésia. Isso inaugurou uma nova fase da Resistência.

Porém, essa manifestação não foi um incidente em que a poderosa força de controle indonésio ficou a observar. Houve violência na tentativa de controlar a visibilidade que jornalistas davam ao incidente, ocorrendo inclusive a retenção de máquinas fotográficas e 
filmadoras de jornalistas e cinegrafistas. Era frustrante para os indonésios perceberem que toda uma preparação meticulosa para um evento internacional como esse, fosse malogrado pela resistente e persistente ação dos timorenses descontentes com seu domínio. Pior ainda era perceber que todo o processo de "indonesianização" perpetrado contra a cultura e na vida timorense não havia resultado em grande coisa. Barbedo de Magalhães (2007, Vol. II, p. 395) menciona que,

Durante mais de dez anos a Indonésia tinha apostado na indonesianização das crianças e dos jovens timorenses. Daí o esforço posto na educação, sob o estrito controlo das autoridades indonésias. Ao fim de catorze anos de ocupação o resultado era absolutamente frustrante e traduzia-se numa manifestação anti-indonésia, numa cerimónia que tinha sido preparada até o mais ínfimo pormenor durante meses.

Fazendo um adendo, o termo "indonesianização" foi criado por Donald Weatherbee, professor norte-americano da Universidade da Carolina do Sul que após viagem ao território timorense em 1980, escreveu um artigo publicado em 1981, intitulado "The Indonesianization of East Timor". Segundo Mendes (2005, p.160-161),

a "indonesianização" de Timor é o neologismo criado para o processo de integração de Timor-Leste na República da Indonésia, ou seja, um processo político gradual por forma a tentar criar a identificação cultural e psicológica com a Indonésia, que incluía igualmente a integração econômica, tanto no plano interno da província como da ligação desta com a economia nacional (o que se lhe afigurava como prioritário, dado o extremo grau de pobreza da ilha agravado por quatro anos de intervenção militar que destruiu as frustes estruturas existentes). Foi neste contexto que surgiu o argumento de que a anexação pusera termo a uma separação forçada dos timorenses com os seus irmãos indonésios. Era claro que se estava perante uma falácia argumentativa, de finalidade legitimadora, que pretendia unir o que supostamente estaria separado mesmo antes do advento do colonialismo europeu, e que este acentuou. ${ }^{31}$

A exposição da mídia internacional às questões do Timor reacendeu os ânimos dos movimentos libertários por parte dos estudantes timorenses que passaram a colaborar com o movimento pró-democracia dentro da Indonésia e no Timor a partir da criação da Universidade de Timor-Leste (Universitas Timor Timur, UNTIM) pelo governo indonésio. Foram criadas também redes clandestinas da Resistência, como uma forma de compensar a destruição dos sistemas de comunicação da FRETILIN. Essas redes foram instituídas mais ou menos espontaneamente, compostas por pequenos grupos de estafetas que passaram a servir como elo de comunicação entre guerrilheiros e suas famílias residentes em Díli. Estes transportavam de comunicação, medicamentos, roupas a alimentos. As redes clandestinas se

\footnotetext{
${ }^{31}$ Embora o autor citado acima se refira a "falácia argumentativa" sobre o fato do Timor Português não guardar relações de proximidades com Nusa Tengara (Timor Holandês), por uma vivência pessoal em uma viagem que realizei a Kupang em 2007, atravessando toda a porção ocidental da ilha, pude observar as semelhanças entre o povo de lá com o povo timorense (memória "16. Breves observações em uma viagem a Kupang, Nusa Tengara" (p. 324). Sem uma investigação mais profunda do ponto de vista antropológico, apostaria que as populações são as mesmas.
} 
expandiram e passaram a fazer parte dos alvos da espionagem indonésia que sempre desarticulavam uma ou outra célula o que gerava a fuga dos seus colaboradores para as montanhas onde eram integrados à guerrilha. Outros tantos fugiam do país e ainda outros eram capturados e presos. Neste período, em novembro de 1992, Xanana Gusmão foi também preso e levado para uma prisão em Jakarta. Ao colaborar com os carcereiros de modo a ser julgado e não morto, tornou-se inspiração e símbolo para a juventude indonésia, também desejosa de liberdade e democracia. Se por um lado a prisão de Xanana levou a uma desarticulação das redes clandestinas, por outro, os movimentos libertários que antes se restringiam ao território do Timor, estavam agora presente também no coração da Indonésia (BARBEDO DE MAGALHÃES, 2007, vol. II, p. 416).

No cenário internacional as disputas pelo petróleo e gás natural no Mar do Timor por parte da Austrália e seus acordos com a Indonésia, levou Portugal a apresentar queixa ao Tribunal Internacional de Justiça contra esses acordos que previam a exploração dos recursos do Mar de Timor. Essa postura de Portugal marcou sua posição internacional de potência administrante para assegurar os direitos timorenses, embora em 1995, o Tribunal de Haia tenha se considerado sem condições de deliberar sobre a demanda. Porém, essas manifestações internacionais só acentuavam a visibilidade do Timor no cenário internacional.

Em reconhecimento pela luta travada no campo diplomático por Ramos-Horta e Ximenes Belo, houve a atribuição do Prêmio Nobel da Paz a estes, elevando a causa do Timor a uma exposição internacional nunca antes vista. Para completar essa exposição ainda mais aos holofotes internacionais, em 1997, ocorreu um encontro inusitado em um jantar em Jakarta entre o Presidente Nelson Mandela e o líder timorense Xanana Gusmão, ampliando ainda mais o prestígio desses líderes do Timor a nível mundial. Com esse gesto, Nelson Mandela havia colocado o prisioneiro Xanana Gusmão ao nível de um Chefe de Estado (BARBEDO DE MAGALHÃES, 2007, Vol. II, p.440).

As confluências entre o entendimento da causa timorense em nível internacional e a exposição do corrupto governo indonésio da família Suharto no mesmo nível, levaram, em 1996, a pressões internacionais de entidades financeiras para que houvesse abertura do regime indonésio e a preparação para uma sucessão. Ainda que Suharto tenha resistido por mais dois anos no poder, a crise financeira no país, associadas às manifestações pró-democracia obrigaram-no a abrir caminho para um sucessor, o presidente Habibie. Este sinalizou a possibilidade de autodeterminação do Timor. 


\subsubsection{Plebiscito pela independência, guerra das milícias, destruição e reconstrução do Timor independente}

Um consenso da Resistência timorense era o entendimento de que a independência do Timor dependeria da democratização da Indonésia. Desta forma, o caminho aberto pela troca de governo naquele país, levou a ONU a propor e organizar um referendo em solo timorense, ainda que as questões de segurança fossem um tema delicado, tanto a ONU quanto as lideranças timorenses resolveram aproveitar a janela de oportunidades que se abria sob o novo governo de Habibie. Assim, em 30 de agosto de 1999, 78,5\% dos timorenses votaram pela independência.

Porém, nem tudo deu certo como se pretendia. Logo que foram conhecidos estes resultados do referendo, segundo Barbedo de Magalhães (2007), forças indonésias e milícias por estas criadas e dirigidas destruíram Timor-Leste e deportaram para Indonésia cerca de um quarto da população. As atrocidades que se seguiram ao dia 30 de agosto de 1999, rivalizam com as piores cenas de barbárie que o Timor pôde testemunhar ao longo de sua história. A maior parte das casas e dos prédios públicos foi incendiada e massacres de pessoas que votaram a favor da independência ocorreram por todo o país. Barbedo de Magalhães (2007) informa que depois de muitos episódios de massacres que se verificavam em Timor, "cerca de 300.000 ou mais timorenses fugiram para as montanhas para escaparem à morte ou à deportação. Aí permaneceram escondidos, enquanto as suas casas eram saqueadas e incendiadas". (Vol. III, p. 601).

Foi ainda necessária uma enorme disciplina das FALINTIL para evitar se envolver em confrontos com as milícias para impedir os argumentos das forças indonésias pela permanência no território com o pretexto de obstar que os timorenses se matassem uns aos outros. Segundo Barbedo de Magalhães (2007, Vol. III, p. 604),

o Vice-Comandante das FALINTIL, Taur Matan Ruak ${ }^{32}$, desesperado com a situação, ameaçou retaliar. Mas Xanana Gusmão falou com ele ao telefone, via satélite, em 7 de Setembro, e proibiu-o, terminantemente, de o fazer, fosse qual fosse o custo de vidas humanas. Qualquer retaliação daria origem a uma nova "guerra civil" entre timorenses que era exactamente o que a Indonésia desejava para poder dizer ao mundo, mais uma vez, como em 1975, que suas forças eram imprescindíveis para evitar que os timorenses se matassem. O fundamental era conseguir que houvesse uma intervenção internacional patrocinada pelas Nações Unidas. Só isso é que poderia pôr fim à violência.

\footnotetext{
${ }^{32}$ General das FALINTIL e atualmente (2016) Presidente da República Democrática de Timor-Leste. (Nota do autor).
} 
Neste contexto caótico de morte e violência generalizada, apesar da enorme urgência em por fim ao quadro desolador, demorou duas semanas até que a Organização das Nações Unidas conseguisse aprovar a criação de uma força internacional de paz. O ajustamento dirigido pela ONU conduziu à aprovação definitiva pelo Conselho de Segurança, no dia 15 de setembro de 1999, do envio de uma força para restaurar a paz liderada pela Austrália, chamada INTERFET (Força Internacional para o Timor-Leste), composta, além da Austrália, inicialmente por Portugal, Nova Zelândia, depois as Filipinas e a Malásia e por fim os Estados Unidos. A sua intervenção foi prudente, lenta e eficaz de modo que em 31 de outubro daquele ano, saíram de Timor-Leste os últimos soldados indonésios. Em 19 de outubro, o parlamento indonésio reconheceu o resultado do referendo e revogou a sua lei de integração. Estavam lançadas as condições para a estruturação do novo Estado. (Barbedo de Magalhães, 2007, Vol. III).

Embora a atuação da INTERFET tenha sido elogiada em todos os sentidos, um episódio quase provocou um novo confronto, agora entre a INTERFET e as FALINTIL. A presença de uma força armada no interior do país que a INTERFET entendia ser de guerrilheiros levou o seu comando a tentar desarmá-los. Sobre isso, Barbedo de Magalhães (2007, vol. III, p. 621) assim se referiu:

\begin{abstract}
A mais controversa atitude da chefia da INTERFET foi a de pretender desarmar as FALINTIL. É um facto que a INTERFET era objecto de críticas por parte das milícias e de militares indonésios por pretender desarmar as milícias e não desarmar as FALINTIL que, nalgumas zonas e depois do referendo, decidiram proteger as populações e combater as milícias que as ameaçavam. Mas também era óbvia a radical diferença entre um exército de libertação e uma força de ocupação, por um lado, e por grupos de assassinos civis formados, comandados e pagos pelas forças de ocupação. Quer Xanana Gusmão, quer Taur Matan Ruak discordaram completamente e não aceitaram que as FALINTIL fossem desarmadas.
\end{abstract}

Neste episódio, ainda segundo Barbedo de Magalhães (2007), quando o General Peter Cosgrove, Comandante da INTERFET tentou convencer o General Taur Matan Ruak, Comandante das FALINTIL a desarmar as suas forças, Matan Ruak com coragem e determinação, replicou: "Se quer desarmar as FALINTIL, prepare-se para o combate". Em um entendimento coerente o General Australiano desistiu desta tentativa. Arrefecidos os ânimos, as FALINTIL aceitaram ser acantonadas pela INTERFET.

Conduzidos para uma nova fase da vida timorense, em 25 de outubro de 1999 foi criada a UNTAET (United Nations Transitional Administration for East Timor), liderada pelo brasileiro Vieira de Mello, que desempenhou um papel importante na pacificação, no apoio humanitário e na construção do Estado. Todavia, os desafios para a reconstrução e instalação de um país foram inúmeros, a começar pela indecisão sobre seu sistema jurídico, sobre 
problemas ligados a habitação e a propriedade. Os registros de propriedades foram destruídos pelos militares indonésios e suas milícias. Muitos timorenses que habitavam em outras regiões do país, migraram para Díli em função das bases da INTERFET estarem alojadas lá e por esta razão, oferecerem mais segurança, mas isto acarretou situações de disputas por terrenos e casas. As pessoas que haviam fugido ou que tinham sido deportadas para a Indonésia, ao retornarem para seus antigos lugares de origens, já acharam outras pessoas. Mais ingredientes para crises futuras. Em meio a estas demandas, em julho de 2000, foi criado o primeiro Gabinete do Governo de Transição em Timor-Leste. Porém, estranhamentos entre os principais líderes timorenses, Mari Alkatiri e Xanana Gusmão expôs suas diferenças e fragilizou a evolução do processo de transição na consolidação da Nação Timorense.

Enquanto Xanana Gusmão queria uma ampla discussão sobre a redação da Constituição, os líderes da FRETILIN preferiam seguir uma via mais rápida. Desta forma, segundo Barbedo de Magalhães (2007, vol. III. p.647),

sem ter havido um amplo debate pré-constitucional, uma Assembléia Constituinte eleita democraticamente em 30 de Agosto de 2001, na qual a FRETILIN tinha a maioria, redigiu em sete meses uma Constituição que atribuía ao Presidente um papel meramente simbólico. Era-lhe quase completamente vedado demitir o Governo e faltavam-lhe instrumentos para exercer, com eficácia o papel de Comandante Supremo das Forças Armadas.

Nesta Constituição a escolha do português e do tétum como línguas oficiais de TimorLeste, embora aprovada sem oposição pela Assembléia Constituinte, revelou-se uma escolha muito trabalhosa. As dificuldades na generalização de seu ensino fizeram com que muitos jovens educados em língua indonésia se sentissem marginalizados, apesar da língua indonésia e o inglês serem consideradas, na Constituição, como línguas de trabalho (BARBEDO DE MAGALHÃES, 2007).

Sobre as dificuldades das línguas em Timor, uma constatação de Barbedo de Magalhães (2007, vol III, p. 658), no ano da publicação da sua obra, aponta para algo que pode ser considerado válido até hoje, 15 anos após a definitiva independência do país:

\footnotetext{
Seis anos depois desta decisão da Assembleia Constituinte timorense, ainda persistem dificuldades de comunicação entres os timorenses. De algum modo poderse-á dizer que o tétum é a língua da Nação Timorense (embora pouco ou nada falada na ponta leste), o português é, em grande parte, a língua do Estado, a língua indonésia é uma língua veicular, e o inglês é uma língua de trabalho, nomeadamente nos contactos internacionais. Numerosas outras línguas e dialectos são utilizados localmente, nomeadamente nas relações familiares.
}

A reintrodução da língua portuguesa não está sendo bem sucedida. Embora o governo português tenha enviado um grande número de professores para Timor-Leste, nos primeiros anos desta medida, os cursos e as ações de formação foram feitos com pouco critério e com 
resultados modestos. Em uma segunda fase é que o esforço se concentrou na preparação de professores timorenses, ajustando para um efeito multiplicador mais amplo (Barbedo de Magalhães, 2007). O Brasil também atuou na área educacional a partir de acordos de Cooperação Técnica celebrado em Díli em 20 de maio de 2002 e promulgado como Decreto $\mathrm{n}^{\mathrm{o}} 5.104$ de 11 de junho de 2004 e pelo Decreto $\mathrm{n}^{\mathrm{o}} 5.274$ de 18 de novembro do mesmo ano. Este último decreto instituiu o Programa de Qualificação Docente e Ensino de Língua Portuguesa no Timor-Leste.

O Decreto $n^{\circ} 5.274 / 2004$, no parágrafo único do artigo 1, previa a efetuação do custeio de até cinquenta bolsas anuais para o desenvolvimento de pesquisa e qualificação de docentes no território timorense, a partir da publicação do decreto até o exercício financeiro de 2014, quando foi suspenso. Ainda este decreto, em seu artigo $3^{\circ}$, menciona que "Caberá à CAPES executar e gerenciar o Programa de Qualificação de Docente e Ensino de Língua Portuguesa no Timor Leste, bem assim disciplinar, na forma legal, o detalhamento relativo à sua implementação" e no artigo $4^{\circ}$ menciona que "aos bolsistas selecionados caberá a execução do ensino da língua portuguesa e outras atividades relacionadas à formação de docentes de diversos níveis das instituições de ensino timorenses".

Nesta etapa da independência do Timor-Leste e da sua inserção no mundo como país independente, buscando sua integração na Comunidade dos Países de Língua Portuguesa (CPLP), é que o autor desta pesquisa se inscreve e passa a testemunhar o percurso da história timorense a partir de 2007. O primeiro envio dos cinquenta professores brasileiros, como previsto no Decreto 5.274/2004, ocorreu no ano de 2005 no preâmbulo de novas turbulências. Neste ano, no primeiro Governo constitucional do Timor-Leste em que Xanana Gusmão era o Presidente, devido às pressões da Austrália e dos EUA, as forças da ONU se retiraram do país. Segundo analistas, essa retirada foi precoce, pois o Timor ficou em uma situação de grande vulnerabilidade agravada pela crise social ligada a falta de habitação e seus tantos problemas fundiários, desemprego, crise entre os membros das FALINTIL e da polícia militar. Para Barbedo de Magalhães (2007, vol. III, p. 716),

O atraso do desenvolvimento, em parte resultante do comportamento hostil da Austrália, que retardou o acesso aos rendimentos provenientes dos recursos do Mar de Timor, originou uma situação de desemprego generalizado potencialmente explosiva e facilmente aproveitável por quaisquer entidades, internas ou externas.

O "barril de pólvora" estava posto novamente, sobretudo por conta da Crise das Forças Armadas, da Polícia e do próprio Estado que se manifestou no ano de 2006. Neste ano mais cinqüenta professores brasileiros foram mandados ao Timor-Leste como previa o acordo de 
cooperação bilateral e assistiram ao desenrolar dos fatos. Esta nova crise remonta a conflitos antigos, além da falta de diálogo entre os principais líderes timorense, de sucessivos erros cometidos ao longo de todo o período de transição, da arrogância e pretensões hegemônicas da FRETILIN e da sua liderança e da interferência de interesses estrangeiros (BARBEDO DE MAGALHÃES, 2007).

Quando a UNTAET, no período de sua administração, selecionou os indivíduos que constituiriam a Polícia de Timor-Leste, a maior parte dos escolhidos tinha sido policiais do tempo da ocupação Indonésia. Segundo Barbedo de Magalhães (2007, vol. III, p.721), citando Loro Horta (2006), essa situação,

resultou de pressões de Xanana Gusmão que pretenderia ter na Polícia inimigos da FRETLIN. Admitamos que a razão não tenha sido essa, mas antes o desejo de Xanana Gusmão de integrar ex-colaboracionaistas, num intuito de reconciliação que evitasse a sua perigosa marginalização. Mas, fossem quais fossem as intenções de Xanana, o simples facto de um timorense bem informado expressar esta opinião é, já de si, significativo.

Para agravar ainda mais essa situação, o Ministro da Administração Interna, Rogério Lobato, criou corpos de Polícia adicionais, como a Unidade de Intervenção Rápida, a Unidade de Patrulha de Fronteira e a Unidade de Reserva da Polícia. Essas Unidades foram dotadas de novos fardamentos, melhores e modernos equipamentos, aí incluídos meios de transportes, armas, sistema de comunicação, superiores aos da F-FDT-L (Forças Defesa TimorLorosae) $)^{33}$.

Segundo Barbedo de Magalhães (2007, Vol. III, p. 722),

Enquanto os militares continuaram a vestir fardas de variadas proveniências, diferentes umas das outras, a comer mal e a dispor de armamento desactualizado, a Polícia, sobretudo as suas novas unidades entretanto criadas, além de melhor armadas, também comiam melhor e eram mais bem pagas. Todos estes factores criaram mal-estar no Exército, sendo o melhor armamento da Polícia motivo de grande preocupação entre os militares.

Neste imbróglio urdido, outra situação crítica vem a tona, a maior parte dos policiais era das regiões ocidentais, ou seja, de etnia "Loromonu" e a maior parte dos militares, compostos por membros da primeira incorporação das FALINTIL e oficiais superiores, antigos guerrilheiros, eram na sua grande maioria de etnia "Lorosae", da ponta leste. Assim, as rivalidades históricas entre dois grupos étnicos hostis voltaram a se acirrar. Em muitos episódios que remontam ao ano 2000, enfrentamentos desses grupos, como insultos e outros conflitos de toda ordem já haviam acontecidos, gerando expulsões e desligamentos de

\footnotetext{
${ }^{33}$ Forças de Defesa de Timor-Leste foi a nova designação criada em 2001 para as FALINTIL.
} 
indivíduos das forças militares. A crise que irrompeu em 2006, representou apenas o ápice de uma situação que se desenrolava há tempos sem que as autoridades prestassem maiores atenções.

Em 9 de janeiro de 2006, 159 oficiais e militares de outras patentes, do $1^{\circ}$ Batalhão (Lospalos) e de outras unidades assinaram uma petição dirigida ao Presidente Xanana Gusmão em que se queixavam da má gestão e da discriminação nas promoções entre "Lorosaes" e "Loromonus" (os timorenses da região leste e os da região ocidental de Timor-Leste, respectivamente). Essa carta chegou dois dias depois (11 de Janeiro de 2006) às mãos do Presidente Xanana Gusmão que imediatamente a reenviou ao Ministro da Defesa, Dr. Roque Rodrigues, e ao Comandante das "FALINTIL - Forças de Defesa de Timor-Leste" (F-FDT-L ou FDTL), Brigadeiro-General Taur Matan Ruak, sem, no entanto, ter reunido com qualquer um deles para tratar do assunto. (BARBEDO DE MAGALHÃES, 2007, Vol. III, p. 224).

Manifestações das autoridades sobre a petição dos militares foram postergadas sem ter merecida a devida atenção. Em março de 2006, 594 militares que já haviam abandonado os quartéis foram exonerados do Exército por Matan Ruak que recebeu apoio do PrimeiroMinistro Mari Alkatiri da FRETILIN em sua decisão. Este contingente representava um terço dos membros das forças armadas e o Governo não avaliou os riscos que isso implicava. Constitucionalmente as competências de Xanana Gusmão como presidente eram insuficientes para resolver a situação, isso revelou a todos a limitação imposta pela Constituição praticamente elaborada pelos constituintes da FRETILIN.

Em 23 de março de 2006 o Presidente Xanana Gusmão profere forte discurso à nação onde ficam expostos os desajustes políticos promovidos por seu limitado poder de ação pela Constituição e o posicionamento da FRETILIN em manobras para diminuir o prestígio das Forças Armadas. O desagrado dos militantes da FRETILIN diante do duro discurso de Xanana, poucas horas após o término já produziu seus efeitos, jovens militantes começaram a atear fogo a várias casas em Dili. Tumultos se seguiram isolados na capital até que no dia 24 de abril começou uma manifestação dos peticionários que usavam uniformes da F-FDT-L, mas desarmados, aos quais se juntaram cerca de cinco mil pessoas solidárias à causa e marcharam até o Palácio do Governo lá permanecendo até o dia 28. Nestes cinco dias foram ocorrendo incidentes isolados de violência crescente por toda Dili, onde "Lorosaes" e "Loromonus" se atacavam mutuamente nos mercados e nas praças de Dili. Diante do crescente acirramento da violência em 27 de abril o Primeiro-Ministro e o Presidente se reuniram a fim de criar uma Comissão de Notáveis para analisar o problema em busca de solução. Como as decisões não estavam tendo a agilidade necessária, a confusão se irrompeu na Praça do Palácio do Governo. Os peticionários já não tinham controle sobre a turba e a manifestação estava a ser liderada por estudantes que começaram a incendiar carros e 
apedrejar o Palácio. O Presidente e o Primeiro-Ministro foram retirados as pressas para um local seguro.

A turba enfurecida deixou o Palácio do Governo e se dirigiu a Taci Tolu, sede do Quartel-General das FALINTIL (F-FDT-L). As ordens das autoridades constituídas eram para as F-FDT-L intervir e cercarem o perímetro do Quartel-General. Segundo Barbedo de Magalães (2007), "dos confrontos havidos, que se prolongaram até o dia seguinte, resultaram em cinco mortos confirmados". A tensão aumentou e começaram a ocorrer conflitos entre as polícias, que supostamente estavam do lado dos peticionários das regiões ocidentais, e os militares que se mantiveram nas fileiras do Exército.

Nos dias seguintes, sob ordens superiores, membros da polícia passaram a realizar patrulhas e Díli, com o intuito de conter a violência. Diante do caos instalado, moradores de Díli começaram a fugir para as montanhas. Os professores brasileiros, monitorados pela Embaixada foram aconselhados a não saírem de seus alojamentos até segunda orientação.

No dia 3 de maio mais "combustível" foi adicionado ao conflito: o Comandante da Polícia Militar, Major Alfredo Reinado, e os Majores Marcos Tilman e Alves Tara, todos eles "Loromonus", abandonaram os seus postos, armados, e com alguns dos seus homens. Foi essa situação que levou à divisão mais acentuada do Exército entre Lorosaes e Loromonus. O Major Reinado era um homem prestigiado por sua preparação e experiência. Havia sido formado pela Academia de Defesa da Austrália, em Camberra em 2005, onde viveu por nove anos. Agora amotinado representava uma das maiores ameaças a serem enfrentadas.

Os ânimos acirrados, a confusão instalada e o clima de insegurança, levaram a uma atitude extrema por parte do Ministro da Administração Interna, Rogério Lobato: a distribuição de armas a civis, nomeadamente, membros de gangues de luta marcial, visando garantir a segurança da FRETILIN que realizaria um Congresso nos próximos dias. Relatórios posteriores a essa fase, porém, dão conta de que estes elementos civis armados nestas condições tinham a intenção expressa de eliminar opositores ao Governo e peticionários, embora isto tenha sido negado veementemente por Alkatiri. Todavia, estes homens armados e municiados passaram a atacar unidades da F-FDT-L.

A escalada de violência, associada ao descontrole desses grupos civis armados, levou o Primeiro-Ministro da Austrália John Howard, em 12 de maio a anunciar que, embora não tivesse havido qualquer pedido, a Austrália tinha já forças preparadas para intervir em TimorLeste, caso viesse a ser solicitada nesse sentido. Segundo Barbedo de Magalhães (2007, Vol. III, p 742), "apesar de Ramos-Horta continuar a dizer que não eram necessárias forças 
estrangeiras, a Austrália enviou dois navios de guerra para junto das águas territoriais de Timor-Leste, com pessoal pronto a desembarcar".

Exortado ao diálogo por Ramos-Horta, Major Reinado recusou e apelou para que a população "Loromonu" de Dili abandonassem a cidade, pois não havia condições e segurança de lá permanecerem, o que foi interpretado como uma ameaça de ataque a Díli. Em fins de maio, os combates entre policiais, militares e os grupos de civis armados produziram algumas dezenas de mortes, grande insegurança e instabilidade. A preocupação com os brasileiros no Timor, levou a Embaixada Brasileira a remover 38 pessoas para hotéis mais protegidos no centro de Díli e outros 33 deixaram o país pela Austrália. Alguns professores que quiseram permanecer foram abrigados no conjunto de prédios da ONU, também em Díli. O acirramento dos confrontos levou as autoridades timorenses a solicitar novamente a presença das forças da ONU, australianas, portuguesas e de outros países para reporem a segurança (BARBEDO DE MAGALHÃES, 2007, vol. III).

Segundo Barbedo de Magalães (2007, Vol. III, p.754),

A chegada a Timor-Leste de militares australianos, a pedido dos órgãos de soberania timorenses, representou uma entrega de parte da soberania em mãos estrangeiras, mas evitou a guerra civil e a sua transformação num Estado falhado, como John Howard chegou a considerá-lo. A demissão dos Ministros da Defesa e do Interior, primeiro, e do Primeiro-Ministro, depois, conduziram a alguns desanuviamento.

As forças de paz retornaram ao Timor e em julho o Major Alfredo Reinado foi preso. Porém, conseguiu fugir da prisão em 30 de agosto de 2006 juntamente com seus homens, graças a uma suspeita distração das forças australianas e neozelandesas. O resto do ano de 2006, mesmo com a presença das forças de segurança, continuou tenso, com conflitos localizados pelo país. Possivelmente o mais grave acontecimento ocorrido a brasileiros neste período, diz respeito ao assassinato do missionário brasileiro Edgar Gonçalves no dia 11 de novembro deste ano, quando retornava de um culto religioso com sua irmã em um carro e terminou entrando em uma rua onde estavam em confrontos jovens de gangues de lutas marciais. Segundo testemunhas, não obstante as súplicas dos brasileiros e a insistência em identificarem-se como estrangeiros, o missionário foi alvejado com um tiro no pescoço.

O problema dos peticionários não foi resolvido e o Major Alfredo Reinado continuou amotinado nas montanhas com cerca de seiscentos homens. Nesse clima de tensão, praticamente já não havia professores cooperantes do Brasil no país e foi nessa tensão que ocorreu o processo de seleção da CAPES em final de 2006 e início de 2007 para a formação de uma equipe de treze professores com o objetivo de integrar o PROFEP-Timor (Programa de Formação de Professores em Exercício na Escola Primária do Timor-Leste) e dar 
continuidade ao acordo de cooperação Brasil-Timor no campo educacional. Neste ponto, minha história se entrecruza com a do Timor-Leste, entre tensões, temores e incertezas (memória "1. Prelúdio de incertezas", apêndices, p. 274). O ano de 2007 além de ter sido de trabalho intenso na formação de professores, foi um ano de tensões. Sob a recomendação da Embaixada do Brasil (memória 3. Momentos de Tensão, apêndices, p. 280), mantive a mala pronta durante todo o ano para uma eventual saída de emergência.

\title{
2.2 Um recorte educacional na historia do Timor-Leste
}

No campo educacional, um território tão conflituoso como o do Timor, também passou por altos e baixos, refletindo a condução colonial por tão longo tempo. Como mencionado, ainda no período colonial, com uma postura de maior domínio, Portugal foi efetivando uma rede administrativa composta por postos nas aldeias além de representações militares que foi diminuindo o poder dos régulos nos seus domínios, passando a ter um papel de intermediadores entre o povo e as autoridades coloniais. Desempenhavam funções na organização da cobrança de impostos, do repasse de homens para o serviço público, sobretudo nas guarnições militares. Os datos em nível dos sucos possuíam influência sobre os usos e costumes indígenas além de participarem ativamente nos processos eleitorais dos régulos e outros chefes.

A gradual expansão dos portugueses nos mais variados setores da vida timorense foi ocorrendo de modo paulatino. Sem sobressaltos, muitas coisas foram sendo assimiladas pelos timorenses sem muita dificuldade. No contato entre os missionários católicos com os régulos de vários distritos, passou a ocorrer o convencimento de que estes enviassem seus filhos para a escola. Segundo Ximenes Belo (2013, p.56),

\begin{abstract}
A partir do segundo quartel do século XIX, a pedido dos missionários e das autoridades civis, alguns régulos começaram a mandar os seus filhos para serem educados nas escolas das missões católicas. Alguns iam para Lahane e outros para Soibaba. Outros mandavam os filhos para a Escola Régia (primária) de Díli.
\end{abstract}

Dessa maneira o domínio português sobre as classes dos nobres e gradualmente dos populares em geral, não se fazia apenas pelos pactos de vassalagem que eram celebrados, Portugal sabia que a formação educacional era uma arma importante no domínio dos ânimos timorenses, desse modo, como nos informa Ximense Belo (2013, p.45),

A nível de instrução e do ensino, começaram a afluir às escolas, quer do Governo quer das Missões, jovens de todas as camadas sociais, mesmo os filhos do povo. Pouco a pouco criou-se uma nova "burguesia", ou melhor, a classe dos funcionários timorenses: os professores e catequistas, os intérpretes e escrivães, os enfermeiros, 
os guarda-fios, os "olheiros", isto é, os encarregados das construções (edifícios e estradas) e das plantações de café ou de palmares de coqueiros.

A instrução entre os filhos dos liurais que frequentaram as escolas missionárias e a escola masculina de Díli, passou a ser um instrumento de domínio, já que muitos desses filhos substituíram os pais quando estes foram morrendo, de modo que em alguns casos, o fato de saberem ler e escrever passou a ser usado como critério para se exercer o poder de chefe nos sucos e aldeamentos. Segundo Ximenes Belo (2013, p. 46),

\begin{abstract}
Nalguns sucos, acontecia que muitos dos novos chefes de suco não pertenciam à família dos verdadeiros liurais. Só porque "andavam na escola" e conseguiram tirar a $2^{\mathrm{a}}, 3^{\mathrm{a}}$ ou $4^{\mathrm{a}}$ classes, eram nomeados pelo Governo para chefes do suco. Enquanto os descendentes das casas reais que não frequentavam a escola ficaram relegados para o segundo plano. Mas, entre o povo, e, segundo os costumes ancestrais, o verdadeiro "liurai" ou "dato" é aquele que descendia dos antigos régulos, mesmo que não soubesse ler nem escrever.
\end{abstract}

Com o passar do tempo e diante da renitência de muitos liurais não enviarem seus filhos para a escola, foram perdendo o prestígio e caindo em descrédito, já que para compreender os informes, as determinações do governo português, havia a necessidade de compreender a língua escrita. Nota-se nessa situação a valorização da educação para os portugueses como um sinal de superioridade civilizacional, onde as tradições e conhecimentos mantidos na oralidade já não eram importantes. O registro escrito e a compreensão destes representavam a forma governamental de administração e domínio, já que quem estava fora dessa uniformização colonial não podia compartilhar do exercício do poder.

Por isso, ao longo de várias décadas, alguns liurais, que por direito eram herdeiros do "trono" da sua casa real, tiveram de renunciar em favor dos parentes que sabiam ler e escrever. Nota-se, portanto, que, nalgumas zonas de Timor, descendentes dos verdadeiros e antigos liurais reclamam que os primos ou familiares dos seus avós foram nomeados liurais só porque "andavam na escola" e que os seus avós tiveram de renunciar porque não sabiam ler nem escrever, e não podiam, por causa disso, estabelecer contactos com as autoridades portuguesas. (XIMENES BELO, 2013, p.57).

Estas considerações sobre a educação no universo colonial mostram a poderosa arma de mudança cultural entre os povos antigos de cultura ágrafa. A rejeição de culturas ancestrais por parte dos indivíduos bafejados pela cultura letrada é sedutora no campo da superioridade do domínio civilizacional, mas também no domínio político.

É indiscutível a participação dos missionários religiosos católicos na construção da educação em Timor, porém, sem grande participação governamental nesta empreitada, fundaram colégios e procederam a instrução básica, ainda que excludente. Já no final do século XIX, como aponta Figueiredo (2011, p. 435-436),

a obra destes missionários deve ser feita em várias vertentes pelas quais se desenvolveu a sua ação. Assim, a par da instrução literária ministrada diligenciou o 
padre Medeiros a abertura, em Dili, de dois colégios, um masculino e outro feminino, com vista a educar rapazes e raparigas, estas últimas com o apoio do Instituto Canossiano de Macau. Com efeito, as Irmãs Canossianas estabeleceram-se em Timor com a finalidade de educar e cristianizar as mulheres indígenas, em regime de internato e externato, a quem se ensinava português, costura, lavores, música e piano. As educadas iam de todos os reinos e eram, principalmente, filhas das autoridades gentílicas. Com a fundação dos dois colégios, frequentados por filhos dos régulos e principais de toda a metade oriental da ilha, pretendia-se lançar as bases de uma sociedade "civilizada", da qual estes haviam de estar entre os principais factores de dinamização. Além de Díli, também Manatuto passou a ter uma escola feminina, muito frequentada, dirigida pelas madres canossiana, sendo algumas das suas alunas, internas.

Desde a expulsão, no século XVIII, das ordens religiosas, sobretudo dos Jesuítas dos domínios portugueses promovida por Marquês de Pombal, padres seculares assumiram a missão educadora em Timor, contando com o auxílio de religiosos de ordem. Embora esta educação estivesse voltada para a nobreza timorense, não era uma educação nos modelos clássicos do humanismo, pautado no conhecimento greco-romano, antes disso, estava voltada para o ensino de ofícios, técnicas agrícolas, administrativas, para os homens e prendas domésticas para as mulheres, ainda que nestas intenções houvesse a aprendizagem da leitura, da escrita e da língua portuguesa. Figueiredo (2011, p.439) evidencia isso ao apontar que,

\begin{abstract}
em 1899, para trabalhar ao lado dos padres seculares, tinham ido para a colônia alguns jesuítas. Dois deles, os reverendos Sebastião Maria Aparício da Silva e Manuel Fernandes Ferreira, fixaram-se em Soibada, onde havia uma simples missão que, em 1897 ou um pouco antes, terá sido fundada pelo padre Antonio Antunes. Os jesuítas ali edificaram, além de uma igreja, um colégio para rapazes, oficinas de pedreiro e carpinteiro, e um observatório. Os alunos, ao mesmo tempo que frequentavam a escola, onde se lhes ensinava a ler, a escrever, a contar, a falar o português, contabilidade, doutrina cristã e os princípios da moral e da educação cívica, aprendiam também os ofícios de carpinteiro, pedreiro e oleiro, e trabalhavam nas tarefas de manutenção da missão e na fábrica de sabão ali existente durante algum tempo. Em 1903, a pouca distância, foi erigido o colégio da Imaculada Conceição, feminino, entregue às Irmãs Canossianas. Cinco religiosas dirigiam um internato de mais de 60 raparigas, que ali aprendiam a instrução primária: ler, escrever, contar e música; e tarefas ligadas ao serviço doméstico: coser à mão e à máquina, fazer meia, rendas, bordar, talhar roupa, lavar e engomar, etc. Mais tarde, a montagem de uma secção de tecelagem permitia-lhes confeccionar panos e fabricar as suas roupas e as que os rapazes do colégio vizinho vestiam.
\end{abstract}

Essas iniciativas missionárias contavam com o trabalho educacional de padres estrangeiros professores vivendo em Timor, com a incumbência de ministrar este padrão educacional à elite timorense. Porém, no ano de 1924, como informa Mendes (2005, p. 317),

D. José da Costa Nunes, bispo de Macau, cria uma escola de formação de professores primários que fossem simultaneamente catequistas. Pouco depois, surge o Colégio de Sto. António para filhos de europeus e foi reaberta a Escola de Artes e Ofícios. [...] O ensino do sexo feminino continuou nas mãos das Canossianas. 
Anos depois, em 1936, o próprio Bispo de Macau criou o Seminário de Nossa Senhora de Fátima, em Soibaba, com a intenção de formar o clero timorense. A direção inicial deste seminário ficou a cargo do clero secular, sendo passado logo depois para a Companhia de Jesus. O papel deste seminário foi de grande importância na formação de uma elite intelectual que, mas tarde, vira ocupar postos-chave na administração portuguesa, ou nos cargos eclesiásticos, como foi o caso de D. Martinho da Costa Lopes e o próprio D. Carlos Ximenes Belo, prêmio Nobel da Paz e bispos de Díli. Além destes, formou também nomes importantes que se destacaram na luta pela independência de Timor, como Francisco Xavier do Amaral, primeiro presidente da FRETILIN e do Timor-Leste, os irmãos Lobato, Nicolau e Rogério, Presidente da RDTL durante a ocupação indonésia e Ministro de Estado respectivamente, entre outros.

Porém, a obra missionária educacional dos padres em Timor, sofreria um revés durante a invasão japonesa na Segunda Guerra Mundial. No rastro da crueldade que a dominação nipônica exerceu sobre o Timor,

\begin{abstract}
os anos de invasão japonesa interromperam a actividade dos missionários, que foram ora assassinados, ora encerrados no campo de concentração de Liquiçá, tendo alguns conseguido escapar refugiando-se na Austrália. Em 4 de Setembro de 1940 havia sido criada a diocese de Díli, pela Bula Sollenibus Conventionibus. Depois da guerra foi nomeado bispo de Díli D. Jaime Garcia Goulart (1945-1966), que havia exercido as funções de Administrador Apostólico (1941-45). A acção missionária retorna então seu ritmo. O bispo reconstrói igrejas destruídas e reabre as escolas. [...] Foram então formados quatro novos colégios, um deles atribuído aos Salesianos, que se haviam fixado em Timor em 1946. (MENDES, 2005, p. 318).
\end{abstract}

Diante da dificuldade na democratização da língua portuguesa em Timor e sua baixa penetração na sociedade timorense, uma preocupação já na década de 60 , levou as missões a sugerir uma escolarização doméstica, na tentativa de multiplicar os efeitos de uma ação educacional voltada a poucos. Segundo Mendes (2005, p. 319), esse modelo proposto,

consistia na atribuição de material didático rudimentar às famílias em que houvesse algum membro capaz de ensinar as primeiras letras às crianças, e a elaboração de um vocabulário básico Tétum-Português. Com estas duas medidas, pretendia-se expandir o conhecimento da língua portuguesa.

Em 1974, pouco antes do processo revolucionário pela independência do Timor se efetivar, mas, já bafejando os ventos dos desejos autonomista em função da mobilização de estudantes e intelectuais, sobretudo os militantes da FRETILIN que empregaram o método Paulo Freire para alfabetizar as massas camponesas, o Bispo de Dili, D. José Joaquim Ribeiro, apresentava posicionamento de hostilidade para com e viragem à esquerda que se fazia sentir e era duramente criticado por estas posturas. Na visão de Mendes (2005, p. 319), mesmo diante disso, importa sublinhar, 
o papel de grande relevo educativo que a Igreja e designadamente as missões tiveram na formação de um sistema educativo e de uma elite que veio a abraçar a doutrina nacionalista e sonhou um Timor independente, bem como na inculturação que fez perdurar, através da religião, a cultura e a língua portuguesas.

Nos anos que se seguiram à invasão da Indonésia, o sistema educacional timorense passou a ser o mesmo do Estado indonésio e obrigatoriamente em idioma bahasa, sendo a língua portuguesa proibida. Embora o domínio indonésio em Timor-Leste tenha sido uma barbárie, como exposto acima, o Estado invasor, agora tratando o Timor como sua $27^{\mathrm{a}}$ província, também estendeu a este território as ações de Estado. Neste sentido, no campo educacional a Indonésia proporcionou uma expansão ao Timor-Leste, que em todos os séculos de colonização portuguesa, ainda não havia experimentado. Segundo Jones (2003, p. 41), "os portugueses deixaram o país com um sistema educacional embrionário e uma população predominantemente iletrada". Embora seja um assunto delicado a ser discutido, pois no rastro do nacionalismo que se seguiu a invasão indonésia, quase tudo que se referia ao invasor, ainda que positivo, tendia a ser desmerecido ou minimizado, é indiscutível o benefício experimentado pelo povo timorense no campo da educação sob o domínio indonésio.

Neste sentido, o número de escolas em Timor-Leste aumentou de maneira exponencial de modo que em 1985, havia uma escola primária em cada aldeia. Em Censo Demográfico realizado em 1995, dados apontam uma rápida melhora na alfabetização da população, sendo que 33\% das pessoas acima de 15 anos haviam completado o ensino primário. Todavia, mesmo com os esforços empreendidos, essas taxas estavam abaixo do resto do Estado Indonésio que à altura contava com $65 \%$ da população nestas condições (Jones, 2003). Isso reforça a tese de que o atraso educacional sob a colonização portuguesa está refletido nestes números.

Os valores incontestáveis são indicados por Jones (2003, p.42),

A maior fonte de orgulho para a Indonésia desde a anexação de Timor Leste em 1975 tem sido a sua oferta de educação básica. O número de escolas foi multiplicado, e cada aldeia passou a ter uma escola primária por volta de 1985. A Tabela 1 mostra a evolução do número de escolas, professores e alunos ao nível do ensino primário, e a Tabela 2 mostra a evolução para o ensino médio e ensino superior. O número de alunos do ensino primário nos primeiros dois ou três anos de domínio indonésio parece ter sido menor do que nos últimos anos de domínio Português, refletindo presumivelmente as dificuldades que os indonésios experimentaram em impor ordem e iniciar um novo sistema de educação. Mas os números cresceram rapidamente até o início da década de 1980. (Tradução do autor).

$[\ldots]$ 
TABLE 1: East Timor - Trends in primary school education, 1976-93

\begin{tabular}{lcccrc}
\hline School year & No. of schools & $\begin{array}{c}\text { No. of } \\
\text { teachers }\end{array}$ & $\begin{array}{c}\text { No. of new } \\
\text { pupils (000) }\end{array}$ & $\begin{array}{c}\text { Total no. of } \\
\text { pupils }\end{array}$ & $\begin{array}{c}\text { Pupils per } \\
\text { scbool }\end{array}$ \\
\hline $1976-77$ & 47 & 499 & 10.5 & 13.5 & 287 \\
$1977-78$ & 107 & 614 & 18.8 & 23.0 & 215 \\
$1978-79$ & 202 & 959 & 22.4 & 41.5 & 205 \\
$1979-80$ & 208 & 1610 & 13.3 & 59.1 & 284 \\
$1980-81$ & 293 & 1515 & 21.7 & 68.7 & 234 \\
$1981-82$ & 339 & 1821 & 52.1 & 77.6 & 229 \\
$1982-83$ & 376 & 2226 & 38.0 & 90.4 & 241 \\
$1983-84$ & 400 & 2446 & 38.6 & 99.4 & 249 \\
$1984-85$ & 410 & 2614 & 31.7 & 100.6 & 245 \\
$1985-86$ & 497 & 2910 & 31.3 & 111.2 & 224 \\
$1986-87$ & 540 & 3359 & 31.4 & 126.7 & 235 \\
$1987-88$ & 559 & 3723 & 27.2 & 129.6 & 232 \\
$1988-89$ & 565 & 4894 & 27.9 & 105.1 & 186 \\
$1989-90$ & 574 & 4739 & 20.9 & 100.4 & 175 \\
$1990-91$ & 559 & 4574 & 28.9 & 95.9 & 171 \\
$1991-92$ & 590 & 4653 & 21.1 & 104.4 & 177 \\
$1992-93$ & 654 & 5260 & 24.1 & 110.6 & 169 \\
$1993-94$ & 652 & 6656 & 27.4 & 128.0 & 196 \\
\hline
\end{tabular}

Source: Timor Timur Dalam Angka (1993:Table 4.1.3).

(Jones, 2003, p.43).

TABLE 2: East Timor - Trends in secondary and tertiary education, 1976-93

\begin{tabular}{lccccc}
\hline School year & $\begin{array}{c}\text { No. of lower } \\
\text { secondary } \\
\text { schools }\end{array}$ & $\begin{array}{c}\text { No. of lower } \\
\text { secondary } \\
\text { students }\end{array}$ & $\begin{array}{c}\text { No. of upper } \\
\text { secondary } \\
\text { schools }\end{array}$ & $\begin{array}{c}\text { No. of upper } \\
\text { secondary } \\
\text { students }\end{array}$ & $\begin{array}{c}\text { No. enrolled } \\
\text { in tertiary } \\
\text { education }\end{array}$ \\
\hline $1976-77$ & 2 & 315 & - & - & - \\
$1977-78$ & 9 & 926 & - & - & - \\
$1978-79$ & 14 & 1041 & - & - & - \\
$1979-80$ & 15 & 1248 & - & 64 & - \\
$1980-81$ & 19 & 2474 & 1 & 225 & - \\
$1981-82$ & 23 & 4272 & 1 & 454 & - \\
$1982-83$ & 28 & 5453 & 2 & 977 & - \\
$1983-84$ & 35 & 8247 & 2 & 1541 & - \\
$1984-85$ & 43 & 9836 & 2 & 2770 & - \\
$1985-86$ & 57 & 11735 & 7 & 5310 & 443 \\
$1986-87$ & 71 & 22905 & 17 & 7599 & 675 \\
$1987-88$ & 81 & 26787 & 19 & 10889 & 799 \\
$1988-89$ & 90 & 28342 & 22 & 10088 & 969 \\
$1989-90$ & 90 & 28964 & 31 & 14574 & 1210 \\
$1990-91$ & 94 & 31482 & 35 & 19634 & 1383 \\
$1991-92$ & 97 & 24261 & 38 & 17177 & 2037 \\
$1992-93$ & 101 & 21972 & 42 & 17947 & 2199 \\
$1993-94$ & 103 & 21779 & 43 & 18303 & 2658 \\
\hline
\end{tabular}

Source: Timor Timur Dalam Anglea (1993:Tables 4.1.4, 4.1.6, 4.1.7, 4.1.23, 4.1.55).

(Jones, 2003, p.43).

Os números acima por si só bastam para servirem de contraste com o que Portugal deixou de herança no sistema educacional. Todavia, esses ganhos educacionais não perduraram no tempo. A crise instalada com o processo de independência levou a quase total destruição física das escolas e dos documentos das mesmas. As milícias pró-indonésia não pouparam essa estrutura educacional montada pelo Estado Indonésio durante a ocupação. 
Aliado a isso, com o início do Timor-Leste independente, a opção pela língua portuguesa e o tétum para a instrução, possivelmente reduziu esses ganhos a quase zero, pois, como a quase totalidade dos professores eram indonésios ou timorenses formados na Indonésia, a maior parte se retirou para a Indonésia com a autonomia, produzindo um "vazio" educacional. 


\section{CAPÍTULO 3 \\ Fundamentação teórica do trabalho}

Falar em escolarização em Timor-Leste representa um grande desafio. Embora o processo de uniformização educacional mundializado, associado às mídias que facilitam o trânsito intercultural, o panorama cultural local se mostra em sua inteireza como resultado da mistura e inserção com o global. É de se supor que não há mais no mundo atual lugar isento da cultura científica, por seus usos ou por seus saberes. O trânsito de ideias diferentes daquelas nascidas no universo escolarizado é vista como algo pertencente ao senso comum, ao folclore e que, portanto, algo coadjuvante nos saberes da educação escolarizada.

\subsection{Amparo Teórico - Fundamentando a Pesquisa}

O mundo conturbado que vivemos atualmente, representa um desafio ao entendimento ortodoxo que dele se tinha há algumas décadas. Muitos campos da atuação humana estão sendo revistos em busca de novos enfoques e referenciais. A educação de modo geral e a educação em ciências especificamente não têm sido deixadas de lado nessa busca. Há algum tempo trabalhos acadêmicos surgem com enfoques diferenciados para o ensino de ciências dentro de concepções que exploram uma diversidade de aspectos que vão desde o feminismo (HOWES, 2002), passando por teoria crítica e pós-estruturalistas voltadas para o conhecimento científico, educação e exercício de poder (BARTON; OSBORNE, 1998) e encaminhamentos que associam o uso da diversão como motivadores ao ensino de ciência (APPELBAUM; CLARK, 2001).

Porém, crescem em quantidade pesquisas e trabalhos acadêmicos voltados para o ensino de ciências dentro de perspectivas sócio-culturais (CARTER, 2004; LEMKE, 2001), ensino de ciências em interações bilíngüe (MORTON, 2012) e em construtos da teoria pós-colonial, além da interculturalidade e educação científica (ABDULLAHI, 2007; VALLADARES, 2011), multiculturalismo na educação (BARAKOSKA, 2013), transculturalismo (AIKENHEAD, 2001;2002; AIKENHEAD; JEGEDE, 1999). Ao que tudo indica, a preocupação nos trabalhos acadêmicos sobre ensino de ciências nesses vários aspectos, procura situar a existência de um conhecimento tido como científico em frente a uma profusão de outras abordagens sobre o mundo. Há outras formas de conhecer que pertencem a círculos culturais etnicamente construídos, e servem como abordagem utilitarista para cada 
povo e que encerram suas verdades, ainda que conheçam versões de outras culturas que não lhes parecem verdadeiras.

Cobern e Loving (2001), contam uma história narrada pessoalmente por uma pesquisadora chamada Gibson em 1996 que estava trabalhando em uma estação científica em floresta de uma ilha do Pacífico Sul. Ela conta que em uma conversa travada com um habitante autóctone da ilha, este mencionou o fato dos ocidentais pensarem que somente eles sabiam por que o oceano aumenta e diminui de volume regularmente, atribuindo este efeito à influencia da lua. Porém, estavam errados, pois o oceano aumenta e diminui seu volume em função das saídas e do retorno das grandes tartarugas marinhas dos seus ninhos na areia. Assim, o oceano diminui quando sua água corre para os ninhos vazios e aumenta seu volume quando a água é forçada a sair dos ninhos por ocasião do retorno das tartarugas. Dessa história podem-se extrair algumas questões que colocam em confronto dois modos de explicar o fenômeno natural das marés: um, seria o aceito pela ciência oficial ocidental como sendo o fenômeno regulado pela lua e outro, o alternativo contado pelo nativo como estando o fenômeno sobre a regulação do deslocamento das grandes tartarugas.

Ainda Cobern e Loving (2001), nos trazem questionamentos importantes sobre essa situação da história narrada acima: a explicação do nativo é científica porque ele tem conhecimento exato das marés do oceano que afetam a ilha? Ou não é científica porque sua explicação é cientificamente inapropriada? A ciência é universal porque sua avaliação científica padrão para explicar a ação das marés aplica-se a todas as ocorrências locais dos fenômenos de maré?

O conhecimento científico e seu ensino, dada a profusão de olhares das ciências humanas e sociais para o seu objeto, torna-o questionável nos aspectos que se ligam à uniformização das ciências ocidentais como o sistema mais correto e verdadeiro de conhecer a natureza e de certa forma de reconstruí-la por sua interferência. Com o avanço das investigações que se seguiram no campo da etnografia, da antropologia, as ciências naturais passam a ser tidas, nesse universo de saberes, como mais um componente em uma ecologia de saberes (SANTOS, 2010). Porém, saberes tradicionais com base em mitos e no sobrenatural, que sejam explicações alternativas à fenômenos perfeitamente explicados pela ciência, talvez não consigam resolver problemas de ordem mais complexas, que só a ciência consegue fazêlo.

Ao considerar a escolarização nos padrões ocidentais para o ensino de ciências, o entendimento dos vários aspectos da cultura ocidental e suas multiplicidades sociais nas concepções das crianças em relação aos conceitos científicos, é encontrado em muitos 
trabalhos, e aqui, para compreensão mais ampla sobre os construtos das crianças de conceitos das ciências no que tange à concepções prévias, o principal suporte teórico que será usado é o oferecido pela teoria da aprendizagem significativa de Ausubel (2000). Por essa teoria, entende-se que uma nova informação é incorporada ao conhecimento já presente na estrutura cognitiva do aluno. Sendo esse conhecimento prévio, ao qual o autor referiu-se como subsunçor, uma espécie de ancoradouro onde os novos conhecimentos se ligarão, de modo não arbitrário e que o conhecimento a ser aprendido tenha relevância social e seja potencialmente significativo.

Fazendo um adendo aqui, pode-se argumentar sobre a incoerência na utilização da teoria cognitivista de Ausubel e seu construto da valorização do conhecimento prévio dos indivíduos e o enfoque fenomenológico, já que a princípio, em uma observação superficial, essas ideias não dialogam. A fenomenologia na sua busca da essência das coisas evidencia-se pela suspensão do juízo, de onde é perceptível a impossibilidade de se utilizar conhecimentos prévios. Todavia, sobre isso, em comunicação pessoal, Dante Galeffi ${ }^{34}$ ensina que,

\begin{abstract}
O uso da fenomenologia é uma atitude de radicalidade, de corte, com todos os construtos previamente estabelecidos, pela história, pela ciência, no sentido de uma distância das coisas construídas para que se estabeleça um retorno às coisas mesmas. Isso significa uma abertura para um instante, ao mesmo tempo, uma atenção aos dados e processos da cognição, da afetação a consciência, etc. Assim, não há incompatibilidade, à medida em que Ausubel vai recorrer as estruturas prévias, isso é uma atitude fenomenológica na medida em que está reduzindo a sua compreensão de campo a certos eixos que estão sendo compreendidos como estruturadores, como nucleadores da afetação da consciência, etc. Em uma observação rápida, pode-se pensar que não haja compatibilidade, porque a fenomenologia não é uma técnica, é um método, e como tal, é uma atitude investigativa, não é um sistema de conhecimento já dado, pelo contrário, é uma revisão, a pôr em suspenso todo um sistema de conhecimento já dado, para que se perceba aí os desvios e os ocultamentos que ocorrem no campo da linguagem, das relações de interesse de poder. Assim, sendo a fenomenologia essa atitude, temos que investigar sim, as estruturas prévias, porque isso é o a priori do ponto de vista transcendental.
\end{abstract}

Distingue-se, portanto nessa tese, a necessidade de um instrumental pedagógico que suporte os possíveis achados culturais nos estudos de concepções, por isso se recorre a Ausubel, mesmo em um enfoque fenomenológico atrelado ao viés das percepções vividas e testemunhadas que formam um arcabouço metodológico para compreensão do espírito do timorense, sua inserção no mundo, autopercepção na escolarização globalizada, por meio das narrativas e da hermeneutica fenomenológica necessária a sua análise.

O processo de escolarização em ciência nos cânones ocidentais, que de certa forma dita as regras e os preceitos do fazer ciências, é capaz mesmo de promover mudanças conceituais

\footnotetext{
${ }^{34}$ Dante Galeffi é professor titular do Programa de Pós-Graduação em Educação da Faculdade de Educação da Universidade Federal da Bahia (UFBA). Atua em enfoque fenomenológico, com intensa produção acadêmica com inúmeros livros e artigos publicados sobre o assunto. (Nota do autor).
} 
que releguem saberes culturais a segundo plano ou os substitua? Ou conceitos científicos adquiridos vão integrar-se a uma estrutura mais semelhantes aos perfis epistemológicos de Barcelard? Nesse sentido, Bachelard (1979, p.24) vai falar que "a hierarquia dos conhecimentos se distribui de forma diversa segundo as utilizações e essas diversas conceitualizações vão esboçar o perfil epistemológico de cada um”. Evidencia ainda que um perfil epistemológico se dirige a conceitos particulares:

\begin{abstract}
Insistimos no fato de um perfil epistemológico dever sempre referir-se a um conceito designado, de ele apenas ser válido para um espírito particular que se examina num estádio particular da sua cultura. É esta dupla particularização que torna um perfil epistemológico interessante para uma psicologia do espírito científico. (p.25).
\end{abstract}

Mortimer (2000, p.27), usando a noção bachelardiana de perfil epistemológico em estudo sobre mudança conceitual, percebeu em estudantes a persistência de concepções prévias mesmo após o trabalho com os conceitos científicos, estes, ao invés de substituírem os entendimentos prévios, passavam a conviver com os mesmo. Nesse sentido, o autor postulou a hipótese de que "a aprendizagem de Ciências em sala de aula pode ser descrita como uma mudança do perfil conceitual do estudante, cujo novo perfil inclui também, mas não exclusivamente, as novas ideias científicas."

O que possivelmente pode ocorrer na aquisição do conceito científico pela escolarização, é seu aporte em um subçunsor pré-existente na mente do indivíduo, como postula Ausubel, mas que, longe de tornar o subçunsor mais elaborado, promovendo até a obliteração do conceito primário, conforme a teoria, conviva com a ideia anterior e ganhe importância diferenciada de acordo com os contextos culturais. É certo que defender a ciência como sendo portadora de explicações racionais, coerência e mais capacidade de resolver problemas, não é suficiente para generalizações em todos os campos da atuação humana. Há uma série de situações para as quais a ciência ainda não tem respostas definitivas, isso não significa que haja lacunas de conhecimento, outros saberes podem preenchê-las adequadamente, ainda que ditos não científicos. Nesse sentido, evoco Merleau-Ponty (2004, p.5-6):

Trata-se de saber se a ciência oferece ou oferecerá uma representação do mundo que seja completa, que se baste, que se feche de alguma maneira sobre si mesma, de tal forma que não tenhamos mais nenhuma questão válida a colocar além dela. Não se trata de negar ou de limitar a ciência; trata-se de saber se ela tem o direito de negar ou de excluir como ilusórias todas as pesquisas que não procedem como ela por medições, comparações e que não sejam concluídas por leis, como as da física clássica, vinculando determinadas consequências a determinadas condições. Não só essa questão não indica nenhuma hostilidade com relação à ciência, como é ainda a própria ciência, nos seus desenvolvimentos mais recentes, que nos obriga a formulála e nos convida a responder negativamente. 
O estudo das concepções das crianças sobre conhecimentos científicos encontra-se bem estabelecido e importa, sobretudo, por lastrear o fazer pedagógico dos professores no ensino de ciência, que ao levar em consideração o que o aluno já sabe, pode melhor elaborar a instrução. Outra utilidade de estudos semelhantes é servir de base para um diagnóstico sobre os saberes aprendidos na escola como ponto de partida para observar se objetivos educacionais estão sendo atingidos. Compreender o nível e o tipo de concepção que os estudantes da escola básica possuem sobre conceitos das ciências, é também entender o meio sociocultural que o cerca e sua influência no estabelecimento dos conhecimentos prévios. Como salienta Carneiro (2007, p.71),

As pesquisas nessa área evidenciaram outra concepção de aluno. Não se trata mais de considerar o aluno como alguém que não sabe nada. Ele passa ser considerado um sujeito que chega à escola com um conhecimento já adquirido, construído a partir das relações que ele estabelece com seu meio sociocultural.

Assim, para entender o que caracteriza os conhecimentos prévios dos alunos, serão utilizados os discernimentos oferecidos por Driver (1986), que aponta, por exemplo, que os esquemas conceituais alternativos nos estudantes são persistentes e não se modificam facilmente mediante o ensino tradicional. Outro contributo de Driver (1986) atesta que os estudantes utilizam linguagem do senso comum e termos indiferenciados para expressar suas ideias. Portanto, a influência do seu meio social será patente nessa expressão. Nesse sentido, buscar a influência do meio sociocultural no tipo de concepção das crianças parece ser um dos elementos mais instigante nessa pesquisa, haja vista, a possível existência de intervenientes culturais peculiares da multicultural visão de mundo do oriental.

Em sociedades plurais, como a do Timor-Leste, em que os diversos povos com suas 16 línguas maternas [Tétum, Galoli, Idá, Macassai, Uaimá, Cairuhi, Dagadá, Meidique, Vauneque, Dagadá enaneti, Caruhy, Bunac, Vaqueno, Toco-dede, Fataluku, Quemac e Mambae (XIMENES BELO, 2013, p. 39)] e seus sistemas de crenças que lhe conferem identidades particulares, as concepções de mundo e suas explicações podem refletir-se como múltiplas concepções sobre hábitos e costumes e até sobre conceitos científicos quando seus componentes passam por processo de escolarização.

Neste caminho, é premente a conceituação de "multiculturalismo" como um viés elucidativo nas discussões educacionais tão prestigiadas atualmente. Segundo Race (2011) "multiculturalismo" como um conceito tem diferentes histórias e origens em diferentes países. O Canadá, por exemplo, foi o primeiro país do mundo a adotar o "multiculturalismo" como uma política oficial em 1971 em uma tentativa de alcançar unidade através da diversidade. O governo canadense atual assim se refere a esta política: 
O multiculturalismo canadense é fundamental para nossa crença de que todos os cidadãos são iguais. Multiculturalismo é a garantia de que todos os cidadãos possam manter suas identidades e orgulhar-se de sua ascendência mantendo um sentimento de pertencimento. A aceitação confere aos canadenses um sentimento de segurança e auto-confiança, fazendo-os mais abertos para o acolhimento de diversas culturas. A experiência canadense tem mostrado que o multiculturalismo incentiva a harmonia racial e étnica, bem como o entendimento inter-cultural e desencoraja a guetificação, o ódio, discriminação e a violência. (CIC, 2016). (Tradução do autor).

Nos Estados Unidos, multiculturalismo é definido, segundo Banks \& Banks (2007) como um posicionamento filosófico e um movimento que pressupõe que o gênero, diversidades étnica, racial e cultural de uma sociedade pluralista deve refletir-se em todas as estruturas institucionalizadas das instituições de ensino, incluindo seu pessoal, normas e valores, o currículo e até mesmo nos corpos dos estudantes. No âmbito da educação, os autores citados apontam ainda que, outra ideia importante é que alguns estudantes, por causa destas características, tem melhores chances de aprender em escolas estruturadas desta forma do que o contrário, em escolas que não observam a inclusão respeitando as características culturais.

Dada a pluralidade das definições para multiculturalismo e em função do escopo desta tese tratar do ensino de ciências em uma sociedade com diversidade cultural do ponto de vista sociológico e antropológico, a conceituação a ser levada em conta centra-se na visão canadense como mencionada acima, ligado aos aspectos raciais, étnicos e culturais, sem, no entanto negligenciar discussões do ponto de vista de gênero, caso haja necessidade.

A convivência com a sociedade multicultural de Timor-Leste em 2007 e o contato com seu embrionário sistema educacional, nos impele ao entendimento de que sua educação possivelmente deva-se pautar por uma construção transcultural. Neste sentido, o conceito de transculturação, na concepção do antropólogo cubano Fernando Ortiz que cunhou o termo em 1947, é um fenômeno de fusão, troca e convergência de culturas.

É um processo no qual sempre se dá algo em troca ao que se recebe; é um "toma lá e dá cá", como dizem os castelhanos. É um processo no qual ambas as partes da equação resultam modificadas. Um processo no qual emerge uma nova realidade composta e complexa; uma realidade que não é uma aglomeração mecânica de caracteres, nem sequer um mosaico, mais um fenômeno novo, original e independente. (ORTIZ, 1978. p.5)

Uma sociedade transcultural, nesta concepção, aceita a outra cultura que ao fundir-se com a sua, emerge uma nova com feições próprias. Onde o ancestral e o moderno se fundem em algo diferente, sem que para isso a cultura antiga se perca e a nova se imponha. Trata-se de uma propriedade emergente, ou um consenso entre culturas. O Timor-Leste e sua abertura para cooperações internacionais parece que caminha neste sentido, pois sua sociedade é 
naturalmente plural, não há o entendimento do que vem a ser o monoculturalismo inerente a culturas colonizadoras, como a portuguesa, em que valores, língua, tradições, etc., são os mesmos partilhados por todos.

A abordagem de culturas dentro dessas multiplicidades exige ter em mente outro conceito importante emprestado da antropologia cultural, que é o de relativismo cultural. Este conceito nasce com as ideias de Franz Boas (1858-1942), considerado o fundador da antropologia cultural norte-americana, mas, ficou nomeadamente conhecido por seu discípulo Melville Herskovits (1895-1963). Segundo Miller (2011, p.14), relativismo cultural é

\footnotetext{
perspectiva segundo a qual cada cultura deve ser compreendida em termos das ideias e dos valores dessa cultura, e não deve ser julgada mediante os padrões de outra. Segundo Boas, nenhuma cultura está mais avançada que outra. Esta posição contrasta notavelmente com a dos evolucionistas culturais do século XIX.
}

Destarte, dentro destes conceitos apontados acima, aliado à teoria pós-colonial, foram feitas as análises dos achados da pesquisa presentes no capítulo 4.

No tópico a seguir serão situadas as bases globalizantes da educação a partir do empreendimento das grandes navegações como o momento inicial do processo de expansão comercial, cultural e educacional. O papel da dominação pela língua que ocorreu em dois caminhos: o domínio das línguas autóctones pelos colonizadores, muitas gramaticalizadas pelos mesmos, facilitando o domínio pela comunicação e o outro caminho, a imposição das línguas européias para educação e difusão do conhecimento produzido pela difusão do livro, produzindo uma aculturação pela superioridade da disseminação dos saberes da ciência.

\subsection{Bases da escolarização mundial e do ensino de ciências}

No atual discurso sobre a educação nos mais variados contextos, sejam naqueles associados ao senso comum ou nos inseridos no âmbito acadêmico, um consenso parece vir à tona, este traz a globalização como uma palavra-chave usada amiúde para descrevê-la. A globalização envolve uma multiplicidade de diversos significados e dimensões do fenômeno. Seu discurso se imiscui no campo da economia, dos mercados, da concorrência por postos de trabalho, da produção, de mercados e serviços, das finanças, da informação, do estilo de vida e em todos os casos, as consequências políticas postas em andamento pela globalização econômica (BECK, 1999), modificam as conjunturas locais das suas sociedades. A presença de empresas transnacionais extrapola em suas dimensões e ações a existência do Estado. Opera-se a nível econômico no mundo inteiro e os negócios migram para onde as condições que os favoreçam sejam melhores, diminuindo a interveniência dos Estados Nacionais sobre os negócios. Em vista disso, as sociedades locais devem estar adequadas à ação global em 
todos esses campos, cujo mais evidente é o econômico. Presumivelmente, produzir uma sociedade global homogênea que se insira e compreenda essas dinâmicas, é adequá-la a aceitação sem estranhamento desse novo mundo.

Nesse entendimento, a educação parece ser uma das melhores vias para transformação com vistas à uniformidade da humanidade diversificada culturalmente, não estando esse fenômeno associado apenas ao final do século XX e início do século XXI. Assim como o processo de globalização comercial começou com as Grandes Navegações do século XV empreendidas pelos europeus, outros caudatários vieram a reboque neste processo a exemplo da catequese jesuítica e seu contorno educacional. Possivelmente, além da difusão da fé cristã, a educação disseminada por meio das ordens religiosas no cerne da colonização objetivou modelar os povos para uma concepção de mundo e de sociedade nos modelos europeus. Porém, como afirma Harari (2015, p.289-290),

\begin{abstract}
O centro de poder global só passou para a Europa entre 1750 e 1850, quando os europeus humilharam as potências asiáticas em uma série de guerras e conquistaram grandes partes da Ásia. Em 1900, os europeus controlavam firmemente a economia mundial e a maior parte de seu território. Em 1950, a Europa Ocidental e os Estados Unidos, juntos, eram responsáveis por mais da metade da produção global, ao passo que a porção da China havia sido reduzida a 5\%. Sob a égide europeia, surgiram uma nova ordem global e uma nova cultura global. Hoje todos os humanos são, muito mais do que em geral estão dispostos a admitir, europeus em suas vestimentas, ideias e gostos. Podem ser ferrenhos opositores dos europeus em sua retórica, mas quase todos no planeta vêem a política, a medicina, a guerra e a economia da perspectiva dos europeus e escutam músicas compostas em estilos europeus com palavras em idiomas europeus. Até mesmo a próspera economia chinesa de hoje, que possivelmente logo reconquistará a primazia global, é edificada sobre um modelo europeu de produção e financiamento.
\end{abstract}

Possivelmente, a globalização comercial iniciada nas grandes navegações, também tenha inaugurado a escolarização mundial em bases semelhantes, na medida em que seus agentes de educação, a exemplo dos Jesuítas que em seu Ratio Studiorum delimitaram "as linhas mestras da organização didática e sobretudo sublinharam o espírito que deveria animar toda a atividade pedagógica da Ordem" (FRANÇA, 1952, p.16), homogeneizando e difundindo uma cultura e um modo de entendimento do mundo que se prestou perfeitamente na conformação cultural dos povos para a aceitação e assimilação de padrões comportamentais necessários ao estabelecimento do empreendimento colonial no germe da globalização. Assim,

a globalização econômica e financeira não ocorreu de um momento para outro, nem constitui a totalidade do fenômeno em questão. Trata-se apenas de um aspecto, o mais saliente hoje, do processo de planetarização da cultura ocidental, que se inicia com a era moderna. [...] Com efeito, o dinamismo peculiar da civilização européia levou-a, a partir de fins do século XV, a expandir-se progressivamente por todo o globo, sob a forma de dominação política, exploração econômica e imposição de padrões culturais. Este expansionismo, impulsionado inicialmente pelas grandes navegações e pelo projeto mercantilista e colonizador que as gerou, teve como mola 
propulsora e condição de eficácia a racionalidade tecnocientífica, com sua visão de um mundo a ser recriado à imagem e semelhança do homem, segundo suas ideias e seus interesses. (DOWEL, 2007. p.13).

No modelo colonial português, em que pese os valores eurocêntricos que se imprimiu aos colonizados, houve também uma assimilação e difusão por parte dos portugueses de valores culturais coloniais, sobretudo bens materiais. Até porque o processo mercantil leva à Europa produtos manufaturados e matéria-prima africana e asiática para seu deleite. Muitos desses elementos foram incorporados aos hábitos e costumes portugueses para uso nos trópicos coloniais onde exerciam o poder e alguns outros para a utilização na Europa. Os negócios portugueses além de atenderem a metrópole e o mundo europeu, atendiam também as colônias, multiculturando-as ou gestando culturas coloniais miscigenadas, pois,

\begin{abstract}
os portugueses, senhores de numerosas terras na Ásia e na África, se haviam apoderado de uma rica variedade de valores tropicais. Alguns inadaptáveis à Europa. Mas todos produtos de finas, opulentas e velhas civilizações asiáticas e africanas. Desses produtos, o Brasil foi talvez a parte do império lusitano que, graças às suas condições sociais e de clima, mais largamente se aproveitou: o chapéu-de-sol, o palanquim, o leque, a bengala, a colcha de seda, a telha à moda sino-japonesa, o telhado das casas caído para os lados e recurvado nas pontas em cornos de lua, a porcelana da China e a louça da Índia. Plantas, especiarias, animais, quitutes. O coqueiro, a jaqueira, a mangueira, a canela, a fruta-pão, o cuscuz. Móveis da Índia de da China. (FREYRE, 2003. p. 11-12).
\end{abstract}

Como pode ser visto possivelmente os bens materiais das colônias africanas e asiáticas tenham sido mais facilmente assimilados pelos europeus nessas transações interculturais do que os bens imateriais, aí compreendidas representações do mundo, técnicas de trabalho, crenças religiosas, expressões artísticas, culinária, línguas, etc. É perfeitamente compreensível que as narrativas dos povos colonizados com suas línguas ágrafas tenham sido registradas pelos próprios colonizadores em suas línguas européias e certamente a essência cultural de um povo, que só uma língua autóctone pode conferir a sua narrativa, tenham sido corrompidas pelo interveniente linguístico do colonizador. A língua tétum autóctone do Timor-Leste, por exemplo, tem um papel quase coadjuvante neste país. Isso é evidenciado por Hull e Eccles (2005, p.XV), ao afirmar que,

\begin{abstract}
o tétum e o português, as duas línguas principais do Timor-Leste, emergiram quase milagrosamente ilesas dos vinte e quatro anos de uma ocupação brutal estrangeira que visava a destruição da identidade desta pequena nação na orla do Pacífico. No seu Congresso de Agosto do ano 2000, o Conselho Nacional da Resistência Timorense votou pela restauração do estatuto do português como língua oficial em Timor-Leste e declarou o tétum (denominado lia-tetum pelos seus falantes) a sua língua nacional. A Constituição Nacional, promulgada no dia 20 de maio de 2002, elevou o tétum à posição de língua co-oficial.
\end{abstract}

Assim mesmo, o tétum contemporâneo é produto da interferência linguística dos portugueses. É considerado “como a língua veicular de uma nação cujos cidadãos falam 
dezesseis línguas diferentes (HULL; ECCLES, 2005, p. XV)”. A elite dirigente do TimorLeste, remanescentes e mestiços de tradição lusitana, tem se esforçado, como prioridade, pela padronização da língua e, "para este fim, foi inaugurado o Instituto Nacional de Linguística (INL) na Universidade Nacional de Timor Lorosa'e em 2001 (HULL; ECCLES, 2005, p. XV)”. Um esforço da intelectualidade local educada.

Dentro dessa perspectiva, a partir da interferência das ordens religiosas na educação colonial, a assimilação da língua do colonizador em sua expressão oral e escrita, passou a fazer parte do processo de dominação dos povos. Ensina-se a ler e a escrever na língua do colonizador, para também forjar um modo de pensar, de se comportar, de atuar no universo colonial, procurando estabelecer os paradigmas culturais hegemônicos do dominador. A análise pós-colonial procura expor os diversos mecanismos sociais e ideológicos que potências coloniais usaram para manter a hegemonia sobre as mentes e corpos dos povos colonizados e explicar como ambos, os colonizadores e colonizados são moldados por sua participação em tal sistema (STANLEY, 2011).

Muito ocorreu também, a exemplo do que fizeram os jesuítas no Brasil, a gramaticalização e dicionarização de línguas autóctones de povos antigos. Se por um lado o registro estabeleceu a preservação de línguas que de outro modo pelo processo colonial de imposição linguística as levaria ao desaparecimento, por outro lado, favoreceu o processo de dominação ao instrumentalizar o colonizador com uma ferramenta conhecida pelo colonizado, a sua própria língua. Nessa empresa, o colonizador passou a modelar seu pensamento e suas intenções em um universo linguístico familiar ao dominado, facilitando a conquista e a adaptação cultural.

A educação escolarizada pelos moldes eurocêntrico gestada no período colonial difundiu saberes e formou elites nas colônias, estabelecendo uma casta governante composta pelos filhos dos colonos e por mestiços remediados que compunham a máquina administrativa colonial e as altas patentes das forças de seguranças locais. Estas eram responsáveis pela contenção, através da coação armada, das revoltas potenciais dos contingentes de nativos que ficaram à margem do processo educacional e consequentemente, afastados do usufruto dos bens que produziam. Transformados em serviçais da empresa colonial, produziram e geraram riquezas que fortaleceram e fizeram prosperar ainda mais as metrópoles.

O modelo de organização dos saberes pelo registro, embora não seja na história algo recente, desde as civilizações hidráulicas que já conheciam a escrita, se registra o conhecimento, permitindo que as gerações futuras o acesse e aperfeiçoe, possibilitou certo nível de difusão de saberes. Todavia, na Idade Média, com o florescimento das cidades, após 
o período das hordas bárbaras na Europa, em um recomeço de pacificação, por volta de 1100, se testemunha um surgimento de uma fase cultural riquíssima. Ainda que não tenha a prensa de Gutenberg tido seu protagonismo, a Europa vê surgir artefatos culturais importantes, como o papel da China, tinta árabe, a caneta com ponta de feltro que de certa forma facilitou o trabalho dos copistas. É também no século XII que surge Hugo de São Vítor em uma das mais importantes escolas da época, a Abadia de São Vítor na França. Ao testemunhar a ânsia dos jovens em busca do saber, elabora um livro com o intuito de auxiliar na construção dos itinerários intelectuais dos estudantes, o "Didascálicon da arte de ler" de 1127. Como menciona Marchtonni (2001, p.9), tradutor da obra de Hugo de São Vítor para o português, no prefácio da edição de 2001, sobre o estímulo que representou aquele livro para os jovens da época,

Com efeito, incitando seus jovens a "ler tudo", Hugo estava inaugurando aquela era do livro, que daria vida à Universidade e duraria até o começo do terceiro milênio, quando o livro está sendo substituído pela página eletrônica, prancheta onde leremos on Une via rádio jornais, revistas e livros.

Foi, porém, um invento europeu do século XV, a prensa de tipos móveis de Gutenberg, a responsável pelo lançamento das bases materiais que permitiram o desenvolvimento do que viria a ser conhecido nos dias de hoje como economia do conhecimento. Pela prensa, eventos marcantes como o Renascimento Cultural e a Revolução Científica dos séculos XVI e XVII ampliaram a difusão e a inclusão de novos indivíduos na roda da história do conhecimento. Pela invenção de Gutenberg em torno de 1430,

\begin{abstract}
no espaço de cinqüenta anos, a maior parte dos livros importantes que tinham sido escritos foram reeditados à maneira nova. Em 1490, os editores lamentavam o sucesso do novo empreendimento, que parecia ter esgotado rapidamente o seu produto, ao mesmo tempo que abriria um novo mercado, enorme e faminto. [...] Assim que os livros antigos foram impressos, começaram a ser escritos outros novos. Tratavam de coisas novas e eram escritos de formas diferentes. Os livros abordavam temas que pareciam inteiramente originais: novos conceitos, novas disposições políticas. Novos sonhos daquilo em que o mundo se poderia transformar. (DOREN, 2012, p. 425).
\end{abstract}

Para Doren (2012), estes livros mudaram a educação por todo lado, pois agora os estudantes tinham, antes de qualquer coisa, de aprender a ler, sendo a educação de então baseada, sobretudo na oralidade. Mesmo com o estímulo à leitura dado por Hugo de São Vítor, é possível que, em função dos custos, uma cópia manuscrita de livros não fosse tão popularizada. A leitura também trouxe novas formas de pensar nos problemas antigos. A difusão dessas ideias pela palavra escrita, possivelmente permitiu a mais pessoas empreenderem seus talentos para o advento de novos conhecimentos e com eles a colocação 
em xeque de estruturas arcaicas baseadas na guarda e proteção do conhecimento na mão de poucos que podiam pagar por uma cópia manuscrita de um livro.

Um século após Gutenberg, a maior parte das estruturas morais e religiosas da época pré-letrada desmoronaram. Mais um século e as estruturas artísticas e intelectuais ruíram. Durante os trezentos anos que se seguiram a 1490, todas as nações da Europa se encontravam ou num estado de revolta ativa, ou travando uma batalha desesperada contra as novas ideias de governo. Gutenberg tem o mérito de ter sido um dos inventores mais revolucionários da história. (DOREN, 2012, p. 426.)

Centrando a compreensão no advento do livro impresso como ponto de partida para a formação de todo um sistema educacional inovador que começou a se estruturar no século XVI, baseado no letramento e no cultivo da compreensão dos clássicos da literatura grecoromana, tanto no campo das artes quanto no campo da filosofia e das ciências antigas, se erigiu as bases da civilização ocidental moderna e sua poderosa "máquina" eurocêntrica de dominação cultural pela escolarização da educação uniforme e universal. Não se pode dizer que o saber acumulado, registrado, e, sobretudo, aquele que se desenvolveu no campo das ciências, é apenas mais uma forma cultural de saber diante das outras formas culturais que a humanidade desenvolveu. É possivelmente, o mais poderoso em função da profusão de problemas que conseguiu resolver, embora tenha criado outros tantos para os quais busca solução em um interminável ciclo de criação e resolução.

Pode-se achar as bases históricas da alfabetização científica da ciência moderna na civilização ocidental no século XVII com Fanscis Bacon ao observar que todo conhecimento científico tem por finalidade servir o homem e dar-lhe poder sobre a natureza. Esse caráter pragmático pode ser notado em Thomas Jefferson em 1798, por ocasião do seu exercício da vice-presidência dos Estados Unidos, ao observar que a ciência que estava sendo ensinada nas escolas da época em qualquer nível de ensino era pouco prática e via a ciência como a chave para os tesouros da natureza (HURD, 1998).

Herbert Spencer em 1859 via os cursos de ensino de ciências da época como uma coleção de fatos mortos e que não conseguiam elucidar os esforços consideráveis que podem produzir o bem-estar humano. Observou ainda que o desenvolvimento da indústria e seus progressos, bem como o desenvolvimento social dependiam da ciência e que esse conhecimento estava sendo ignorado na educação (SPENCER, 1859).

Percebe-se ao citar esses nomes e a literatura dessas datas, que uma preocupação inicial com a educação científica remonta à própria evolução da ciência e continua sendo uma inquietação que ocupa as discussões até os nossos dias. Pois,

A produção maciça de novos conhecimentos, verificada a partir do século XIX, não ocorreu de maneira uniforme no mundo. O rápido crescimento do conhecimento foi, 
e continua a ser centralizado em alguns países do hemisfério Norte que produzem $75 \%$ do novo saber gerado a cada ano: os EUA, Inglaterra, Rússia, Alemanha, França, Japão, Canadá e Itália. Esses países representam somente 15\% da população e neles ocorreu a maior parte das descobertas que promoveram as grandes mudanças dos últimos três séculos. O resto do planeta, $85 \%$ da população mundial, produz em conjunto somente $25 \%$ do novo saber gerado a cada ano. Há, portanto, uma dicotomia entre as populações do mundo, um pequeno grupo que produz conhecimento de um lado e uma grande maioria que consome conhecimento do outro. A capacidade de produzir novos conhecimentos é um dos fatores determinantes na distribuição atual do poder econômico mundial. (DE MEIS, 2009. p. 174).

Outro agravante relaciona-se ao crescimento populacional que concentra a maior parte dos jovens nos países pobres do planeta e que não está inserida na pequena parcela daqueles que produzem conhecimento científico no mundo. Assim, destaca De Meis (2009, p.175) "o grande desafio para a educação moderna é que os países de menor desenvolvimento científico são os responsáveis pela educação da maior parcela de jovens do planeta”.

Essa assimetria na produtividade do conhecimento e na formação específica nas disciplinas científicas nos remete a uma preocupação com os currículos de ciência, tanto aqueles que têm na incumbência a formação do professor (currículo de ensino de ciências) quanto os que estão voltados para o ensino básico. No Brasil, por exemplo, o currículo de ciência se funda, sobretudo pela influência dos Estados Unidos que o determinaram por meio dos financiamentos educacionais, que no dizer de Siqueira $(2011$, p.53) era,

\footnotetext{
um currículo para "formar cientistas", num período posterior a Segunda Guerra Mundial. Essas tentativas curriculares descoladas de nossa realidade sócio-políticoeducacional, contudo, se fizeram presentes nas escolas, deixaram marcas que até hoje se percebe, como, por exemplo, as Feiras de Ciências.
}

Ao mencionar o Brasil e a influência norte-americana na construção do currículo de ciências, se está apenas apontando a influência cultural que um país exerce em outro pela exportação de modelos que servem aos mais variados interesses. Todos os territórios que estiveram sob domínio colonial do imperialismo das potências centrais, hoje estando como nações autônomas do ponto de vista dos seus mapas políticos, têm como remanescentes dessa dominação elementos culturais tais com sua educação e sua ciência. Essa persistência cultural pós-colonial se funda na associação da ciência moderna com os impérios europeus. Na visão de Harari (2015, p.292-293), embora a ciência moderna tenha,

uma grande dívida para com tradições científicas antigas, como as da Grécia clássica, da China, da Índia e do Islã, [...] sua característica singular só começou a tomar forma no início da era moderna, de mãos dadas com a expansão imperial da Espanha, Portugal, Grã-Bretanha. França, Rússia e Holanda. Durante o início do período moderno, chineses, indianos, muçulmanos, polinésios e indígenas americanos continuaram a fazer importantes contribuições à Revolução Científica. As ideias de economistas muçulmanos foram estudadas por Adam Smith e Karl Marx, tratamentos usados pela primeira vez por indígenas americanos foram parar 
em textos médicos britânicos e dados extraídos de informantes polinésios revolucionaram a antropologia ocidental. Mas até meados do século XX as pessoas que reuniram essas várias descobertas científicas, criando disciplinas científicas, eram as elites governantes e intelectuais dos impérios globais europeus. O Extremo Oriente e o mundo islâmico produziram mentes tão inteligentes e curiosas quanto as da Europa. No entanto, entre 1500 e 1950 eles não produziram nada que chegasse perto da física newtoniana ou da biologia darwiniana.

Portanto, em conformidade com Harari (2015), a força da dominação colonial imperialista não se restringiu à superioridade do seu domínio militar frente a territórios menos favorecidos nesse aspecto, mas a uma superioridade de um modo de pensar e agir conferida pela ciência. Um domínio cultural que permaneceu hegemônico mesmo após a libertação dos territórios das mãos das nações imperialistas. Essa permanência pode ser traduzida pela adoção de uma escolarização, hoje praticamente homogênea em todo planeta, nos cânones expansionistas da difusão científica.

No tópico a seguir, serão tratados elementos da teoria pós-colonial, que servirá de aporte para discutir a possibilidade de inserção de aspectos culturais no ensino de ciências, autores que pesquisam na área e discussão dos conceitos envolvidos na teoria. Isso se faz necessário diante dos movimentos de descolonização cultural que ganha corpo mundialmente, principalmente entre as nações que passaram pela colonização e que procuram um status próprio do ponto de vista cultural na sua literatura, na sua arte e em outros aspectos dos saberes, aí incluída também a ciência.

\subsection{Teoria pós-colonial na educação}

Muita controvérsia paira sobre o termo "pós-colonial". Admite-se uma variedade de interpretações e caminhos a seguir na busca da melhor abordagem para exprimir o encaminhamento que sirva de base para um dado estudo específico. Certamente o termo procura estabelecer uma espécie de abrangência que encerre uma gama de termos desgastados pelo uso e restritos pela empregabilidade, tais como "imperialismo", "crítica terceiromundista", "neocolonialismo e práticas culturais de resistência" e "geopolítica do intercâmbio cultural" (SHOHAT, 2000). O desgaste dos encaminhamentos associados ao termo "terceiromundista",

ajuda a explicar o atual entusiasmo pelo termo "pós-colonial", uma nova designação para os discursos críticos que tematizam as questões derivadas das relações coloniais e suas sequelas, cobrindo um período histórico amplo (incluindo o presente)." (SHOHAT, 2000, p.105).

É certo que encarar toda a discussão sobre a literatura, educação, política, economia e outros setores na abrangência da teoria pós-colonial, como pertencendo a um lugar que 
contém todos os que saíram da dominação colonial, é colocar em um mesmo pacote, países como a Austrália, os Estados Unidos, junto com Índia, Brasil, Timor-Leste e tantos outros. Apesar de o pós-colonial englobar todos os elementos culturais surgidos posteriormente à colonização europeia, entende-se aqui, que os europeus remanescentes e seus descendentes diretos nas ex-colônias, continuaram na hegemonia do comando em grande parte das excolônias que se tornaram países independentes e terminaram também por influenciar os campos da educação e da literatura, para mencionar apenas esses dois. Desse modo, ao buscar o conhecimento cultural dos povos que foram dominados no sistema colonial, nos referiremos à cultura das populações autóctones que tiveram a sobrevivência dos conhecimentos culturais conquistados ao longo da sua história, ameaçados pela dominação estrangeira, e até, suplantados por esta. Assim, no rastro do pós-colonialismo, surgem à luz a importância da sua consideração, discussão e como podem fazer parte de um universo, que embora esteja globalizado, é multicultural.

O processo de dominação estabelecido no período de colonização encontrou na educação uma via de destruição dos valores e dos conhecimentos tradicionais de muitos povos, e o ensino de ciência, ainda que em épocas em que a própria ciência se estabelecia, parece ter sido muito satisfatória para essa dominação em um colonialismo mais tardio. Os professores pautados pela valorização do conhecimento científico talvez promovam nos estudantes um sentimento de inferioridade acerca dos seus próprios conhecimentos tradicionais. Possivelmente, estes conhecimentos terminem sendo relegados ao campo do pitoresco, do senso comum, sem valor prático na resolução de problemas, sobretudo, quando se trata de populações autóctones dominadas em seu território por nações imperialistas ocidentais e que, portanto, com valores culturais implantadas na ciência.

Aikenhead (2001) menciona intensa lealdade dos professores de ciências aos valores associados ao cientificismo, ao estabelecer os conhecimentos científicos como nãohumanistas, puramente racionais e empíricos, universal, impessoal, socialmente estéril e livre de vulgarização, dogma, julgamentos, ou valores culturais humanos. $\mathrm{O}$ trabalho do professor de ciência parece centrar-se no esforço de fazer os estudantes valorizarem o conhecimento científico de tal modo a promover uma espécie de aculturação em que o currículo das ciências estabeleça definitivamente nos estudantes os valores da ciência ocidental.

Por outro lado, a aculturação dos estudantes que promove a sua inserção nos valores das ciências ocidentais, também os insere no universo do uso das tecnologias digitais sobretudo, e estas passam a exercer grande influência em suas vidas, instrumentalizando-os para a discussão sobre temas relacionados às próprias ciências e tecnologia. A alienação dos 
estudantes em relação à aceitação dos valores ocidentais, sobretudo nas ciências, diminui o capital cultural para sua participação eficaz nas sociedades ocidentais ou por estas influenciadas. Para Aikenhead (2001), o problema da alienação é mais agudo para estudantes aborígenes cujas visões de mundo, identidades e línguas maternas criam um fosso cultural ainda maior entre si e as ciências da escola.

Os estudos sobre o ensino de ciência na perspectiva sócio-cultural, que levantam pontos de vista críticos, sociológicos, históricos, políticos e socioambientais sobre a construção do conhecimento científico e sua coexistência com outros sistemas de conhecimento tão variados e múltiplos quanto as culturas humanas, tem desafiado a concepção da ciência ocidental tradicional, para a qual a ciência está livre de valores, o conhecimento é objetivo, erigidos em verdades universais (CARTER, 2008).

Embora vivamos em um mundo em que se diz procurar estreitar as relações humanas a nível global, o contraste com as reivindicações das identidades dos diversos povos, clama pela sobrevivência das individualidades culturais, o que é paradoxal no aspecto da globalização. Dessa forma, possivelmente existam forças contraditórias atuando em diferentes campos, incluindo a educação e a oposição entre uma escolarização mundial uniforme e uma escolarização plural e cultural é uma expressão da dicotomia do local versus global. Ao discutirmos escolarização sob a ótica da globalização, em que os saberes hegemônicos se sobrepõem aos saberes culturais dos povos que sofreram processo de colonização, é inevitável a utilização da Teoria Pós-Colonial como referencial teórico.

Sem sombra de dúvida, qualquer construção que considere a Teoria Pós-Colonial, verá como momento fundador o trabalho do palestino, radicado nos Estados Unidos, Edward Said, chamado "Orientalismo", cuja primeira edição é de 1976 (SAID, 2008). Neste trabalho, que amplia concepções anti-coloniais de Frantz Fanon em sua obra Black skins, whitemasks de 1968 (FANON, 2008), Said, ao analisar a literatura produzida até então sobre o Oriente, percebe intenções preconceituosas acerca da cultura Oriental, ao tempo que se enaltecia, por contraste, a superioridade da cultura Ocidental. Outros autores desenvolveram e ampliaram esta temática na década de 1990, sobretudo por meio dos estudos pós-coloniais de Homi K. Bhabha, Stuart Hall (BHABHA, 2001; HALL, 2003) e do antropólogo Arjun Appadurai (APPADURAI, 1996).

Com relação ao ensino de ciências com uma abordagem que utiliza elementos da Teoria Pós-Colonial, a exemplo do multiculturalismo, se destacam os trabalhos realizados por pesquisadores em comunidades tradicionais (AIKENHEAD, 2001; ALFRED, 2009; BATTISTE, 1998; HAMMERSMITH, 2009; WATERFALL, 2002). Diante da ênfase que 
estes estudos têm demonstrado no campo do multiculturalismo e do transculturalismo, destacam-se nesse domínio os trabalhos de Lyn Carter (CARTER, 2004; 2005; 2006; 2011), em que procura discutir a valorização dos saberes das culturas de povos tradicionais no ensino de ciência em abordagens universais pautadas na uniformidade eurocêntrica.

Estudos têm sido realizados por pesquisadores em comunidades tradicionais (ALFRED, 2009; BATTISTE, 1998; HAMMERSMITH, 2009; WATERFALL, 2002), percebendo a influência e os efeitos da colonização, bem como das políticas educacionais que interferem no conhecimento tradicional desses povos, por meio de uma educação em língua do colonizador e com base eurocêntrica. Battiste (1998) por exemplo, pesquisando comunidades aborígenes do Canadá, discute a necessidade do conhecimento aborígene ser contemplado em um currículo transformado, ou até mesmo em um currículo plural que por meio das suas línguas, abrace a rica diversidade de conhecimento desses povos, proporcionando a consciência necessária para o respeito e proteção dos aborígines.

O que se percebe nestes estudos, relaciona-se à busca de alternativas de uma educação multicultural, em que as visões das populações tradicionais entrem nos currículos escolares a serem trabalhados nestas comunidades. Sobre isso, questões importantes surgem, tais como: (1) o conhecimento científico sobre os fenômenos da natureza são isentos de aspectos culturais? (2) Haveria uma tendência na pesquisa atual no campo do ensino de ciências, a uma sociologia da ciência que busca artificialmente valorizar aspectos culturais sobre o conhecimento científico? (3) Ou há de fato a necessidade de incorporar valores culturais às bases do conhecimento científico ocidental produzido? E se assim o for, para onde isso levará?

Com relação à primeira questão (1) feita no parágrafo anterior, contribuição importante para uma reflexão sobre a mesma é oferecida por Bishop (2003), que ao analisar o papel da educação matemática ocidental, salienta que de todos os temas que foram impostos a alunos na escolas coloniais, sem dúvida, pode-se considerar que o menos carregado culturalmente foi a matemática. A matemática de alguma forma sempre foi percebida como universal e, portanto, livre de cultura. Assim, concebeu-se a matemática, em tempos coloniais e até nossos dias, como um fenômeno culturalmente neutro diante de outras formas do imperialismo. $\mathrm{O}$ que não ocorria com o ensino de História ou de Religião, por exemplo, pois ao serem ensinadas essas disciplinas abordavam a história e a religião do colonizador e não a dos colonizados. Todavia, o autor salienta que ideias matemáticas, como quaisquer outras ideias, são construções humanas, tendo, portanto, uma história cultural. Assim, a matemática que a maioria das pessoas aprende na escola contemporânea não é a única matemática de existe. 
Para reforçar essa afirmação, exemplifica citando que existem muitos sistemas de contagens diferentes no mundo, como em Papua Nova Guiné que foram documentados cerca de 600 destes sistemas, contendo vários ciclos de números, nem todos de base decimal. Então, como ocorre com a matemática, que a primeira vista é tida como isenta de cultura, mas, representa apenas mais uma forma conhecimento construída culturalmente, o conhecimento produzido pela ciência ocidental também representa a produção de uma cultura.

Para a segunda questão (2), busca-se reflexão nas abordagens sobre a natureza da ciência. Estas colocam em discussão tipos diferentes de tratamentos, as de viés internalistas e aquelas de caráter externalistas. A sociologia da ciência, a analisa do pondo de vista externalista, ou seja, são considerados no entendimento da natureza das ciências, valores sociais, culturais, políticos e até mesmo questões econômica para entender-se o fazer científico. Essa visão se consubstancia no pós-guerra, com o advento da guerra fria e dos problemas daí advindos, levando sociólogos, historiadores e filósofos a se debruçarem sobre as questões científicas, minimizando o entendimento da ciência em seu caminho positivista no estabelecimento do saber conceitual sobre os fenômenos da natureza, o que se enquadra no percurso internalista. Não obstante isso, o processo de ensinar ciência, sobretudo no ensino básico, ainda centra-se nos aspectos internalistas. Procura-se ensinar o conceito do produto da ciência, atemporal, descontextualizado, imparcial, isento de subjetividade, o que diminui os aspectos externalista no ensino nesse nível. Possivelmente isso se deve ao fato dos docentes entenderam a abordagem externalista da ciência, como inferências das ciências humanas e, portanto, passíveis da subjetividade e da criatividade não admitida para as ciências naturais nesse tipo de concepção.

Já a terceira questão (3), de caráter externalista, busca resposta no campo das ciências humanas, especialmente da sociologia, da história e filosofia das ciências, admitindo considerações de natureza cultural como intervenientes na construção do entendimento científico do mundo. Estando nesse campo, uma fronteira tênue a separar senso comum de conhecimento científico. As perspectivas de análise dos currículos de ciências têm incorporado novos caminhos que podem em si, conter falácias e modismos, possivelmente pervertendo o processo de ensinar ciências. Resta analisar ao que serve essas abordagens. Quando se fala nesses novos caminhos, a tendência atual é evidenciar o multiculturalismo e o transculturalismo, abordagens contidas também no "guarda-chuva" que representa a teoria pós-colonial. O primeiro traz em sua máxima concepção a valorização da multiplicidade cultural e vias para o respeito e a preservação de todas nos currículos. O segundo aponta a necessidade de entender as transformações presentes na junção de culturas diferentes, como 
uma nova propriedade emergente nessas interações. Todavia, antes de empreender uma jornada nesse caminho, é necessário o entendimento mais aprofundado sobre o assunto. $\mathrm{O}$ ensino de ciência estabelecido é visto nessa perspectiva como um saber tradicional, dominante, que traz o traço do imperialismo das nações hegemônicas ocidentais capitalistas, e a ciência que é ensinada apresenta o caráter cultural do dominador e seu modo de se difundir e de pensar o mundo, o concebe mais como um mercado consumidor, que para esse propósito, deve ser modelado pelos valores do conhecimento ocidental, ai incluso a ciência, do que como um conhecimento libertador. A educação nessa análise é vista como uma forma de dominar pela homogeneização povos diferentes, suplantando suas culturas, fragilizando suas resistências em benefício do estabelecimento dos seus propósitos (NORBERG-HODGE, 2013).

Mas, não seria essa concepção de minimizar a importância do fazer ciência naturais, sobretudo, ai compreendendo também a sua divulgação, nos modelos vigentes, uma tentativa de transformar as ciências naturais como algo menor em face a outros saberes? O saber científico acumulado, que trouxe respostas tecnológicas para a resolução de inúmeros problemas e também para a criação de outros tantos, deve ter outra forma de ser ensinada? Ou se busca um ensino que incorpore com o mesmo peso da importância do ensino de ciências, outros saberes que podem ser compreendidos como formas alternativas de verdades perfeitamente assimiláveis? Ai incluso saberes metafísicos do sobrenatural, do míticoesotérico, do religioso, do folclórico, enfim, do senso comum multicultural.

Nesse sentido, abro espaço para uma crítica: as abordagens multiculturais parecem ser uma falácia que acentuam ainda mais a separação entre uma educação cognitiva que forma indivíduos para compreender a ciência e sua natureza, e outra educação que trabalha indivíduos para compreender o mundo em caminhos alternativos de concepções vinculadas às suas "verdades culturais". Nesse entendimento, percebe-se a nítida dicotomia entre o sucesso e o fracasso que podem advir do tipo de educação que se pratica. É perceptível em muitos discursos a existência de entendimentos do "politicamente correto" que em última análise, recriminam as conquistas da ciência (HUNTER, 2005; COFNAS, 2015) como sendo perigosas, maléficas, potencialmente destruidoras, agressivas ao meio ambiente, para citar apenas algumas. Desse modo, um ensino de ciências que incorpore essa compreensão negativa, longe de buscar estabelecer a compreensão de processos e conceitos dos avanços da ciência, apenas ensinam as pessoas a reagir e recusar esses avanços.

Trazendo essa compreensão para um tema atual como exemplificação na sala de aula, muitas vezes quando o assunto é "alimentos transgênicos", o professor dispensa mais seu tempo de sala de aula abordando os potenciais malefícios dessa conquista das ciências 
biológicas, do que na compreensão de todos os processos envolvidos e conceitos necessários para o estabelecimento da conquista científica em si, tais como o entendimento dos avanços advindo da engenharia genética que permite a utilização de plasmídeo $^{35}$ na multiplicação e inserção de genes especiais em outros seres. Isso é a evidência da luta travada entre concepções externalistas versus internalistas da ciência no estabelecimento de conceitos.

A primeira premissa a ser tratada quando o assunto é multiculturalismo refere-se ao entendimento das diversas culturas que devem ser olhadas e respeitadas dentro do processo educativo. Nesse sentido, o multiculturalismo, pode ser entendido também como um "caldeirão" de considerações diversas e muitas vezes divergente de posicionamentos e opiniões com base nas particularidades culturais. Todavia, quando se procura aplicar essa aceitação multicultural com base nas múltiplas opiniões afeitas à abordagem multiculturalista para o ensino de ciências, pode-se recorrer ao entendimento de Bachelard $(2011$, p.18) que de certa forma, traduz o purismo internalista que deve prevalecer no que se refere às ciências. Para ele,

A ciência, tanto por sua necessidade de coroamento como por princípio, opõe-se absolutamente à opinião. Se, em determinada questão, ela legitimar a opinião, é por motivos diversos daqueles que dão origem à opinião; de modo que a opinião está, de direito, sempre errada. A opinião pensa mal; não pensa: traduz necessidades em conhecimentos. Ao designar os objetos pela utilidade, ela se impede de conhecê-los. Não se pode basear nada na opinião: antes de tudo, é preciso destruí-la. Ela é o primeiro obstáculo a ser superado. Não basta, por exemplo, corrigi-la em determinados pontos, mantendo, como uma espécie de moral provisória, um conhecimento vulgar provisório. O espírito científico proíbe que tenhamos uma opinião sobre questões que não compreendemos, sobre questões que não sabemos formular com clareza.

Ainda que na abordagem pós-colonial se estabeleça múltiplas vozes para postular a valorização cultural dos povos, não se pode negar a importância das ciências modernas como vias de acesso a conquistas que nenhum outro sistema de conhecimento pode estabelecer. Ninguém de modo consciencte se sentiria confortável e seguro ao saber que em um avião a pleno vôo, onde fosse passageiro, estivesse como piloto um xamã de uma nobre tribo tradicional sem experiência alguma em aviação, mas com larga experiência no mundo espiritual. De modo semelhante, há de se convir que ninguém se sentiria tranqüilo perdido em uma floresta tropical densa sendo guiado por um piloto de avião que entende tudo de GPS e localização geográfica mediada por máquinas, mas nada sobre como se localizar em um floresta densa. Conhecimentos diversos têm funções diversas e podem conviver um com o outro.

\footnotetext{
${ }^{35}$ Moléculas de DNA bacteriano independente do DNA dos cromossomos, que tem replicação autônoma. É implicado como um dos mecanismos que justifica a resistência bacteriana a antibióticos. Tem sido largamente usada na engenharia genética na tecnologia de transgênicos. (Nota do autor).
} 


\section{CAP§íTULO 4 \\ Achados educacionais: dados da pesquisa}

Este capítulo delimitará os achados na pesquisa de concepções de conceitos científicos segundo o previsto no item "1.3 Sobre o método utilizado na pesquisa" no capítulo 1 desta tese, resultados e análises interpretativas. Neste capítulo também se explicitará a partir das narrativas com o trabalho de formação de professores no PROFEP-Timor, a essência do timorense, alicerçada na subjetividade da experiência vivida. Inicialmente será abordada a gênese do meu trabalho em formação de professores no Brasil no PROFORMAÇÃO na tentativa de estabelecer elos entre esta e a vivida em Timor-Leste, seus atores e idiossincrasia, as similaridades e diferenças. Acentua-se que a experiência no PROFORMAÇÃO no Brasil, foi determinante para a participação no PROFEP-Timor e dado a sua relevância, torna-se necessário certo detalhamento da mesma.

\subsection{Narrativas e reflexões, a gênese da minha atuação na formação de professores, buscando o espírito do Timor-Leste em uma visão subjetiva}

A experiência com formação de professores no Brasil no Programa de Formação de Professores em Exercício (PROFORMAÇÃO) levou-me ao Timor-Leste. Antes de apontar na direção deste país, é necessário situar a gênese da minha experiência em formação de professores no Brasil.

$\mathrm{Na}$ eminência de ir ao Timor-Leste, as expectativas iniciais se espelhavam no trabalho realizado no Programa no Brasil entre os anos 2000 a 2002, a princípio como professor formador da área de conhecimento Vida e Natureza (VN) no Estado da Bahia para posteriormente atuar como professor multiplicador ${ }^{36}$. Testemunhar àquela altura uma realidade no país que embora conhecesse não era sensível, a existência de professores leigos, teve certo impacto na minha atuação profissional até então. Isso me impôs o desafio de buscar realizar o melhor possível no meu campo de atuação para contribuir na mudança, ou ao menos início dela. No princípio da primeira década do presente século, foi feito um grande esforço no Brasil para a superação dessa realidade e o PROFORMAÇÃO, procurou formar em magistério a nível médio, milhares de professores sem a mínima habilitação necessária para o exercício da docência na escola primária.

\footnotetext{
${ }^{36} \mathrm{O}$ papel do professor multiplicador era receber as formações em encontros nacionais do Programa e repassálas em seu Estado para os professores formadores em suas respectivas áreas, para que pudessem propagá-las para tutores e cursistas.
} 
O trabalho experienciado e vivido no período, formando e acompanhando práticas pedagógicas me levou a salas de aulas improvisadas em casebres espalhados pelo interior da Bahia em uma região pobre que englobava municípios do Polígono da Seca no sertão baiano, a saber, municípios de Tucano, Quijingue, Euclides da Cunha e Itapicuru. Embora participassem do Programa professores cursistas das zonas urbanas desses municípios, boa parte do contingente era da zona rural, denotando o descaso com que o homem do campo sempre fora tratado no país. Nestes três anos pude testemunhar o esforço que professores em busca de formação adequada, faziam para ampliar os horizontes de crianças desvalidas da sorte em áreas de dificuldade alimentar e hídrica. Naquela altura despertei para o entendimento de que da mesma forma como existia desigualdade entre trabalhadores urbanos e rurais, em sua cultura, trabalhos, ganhos salariais, também existiam as mesmas desigualdades entre os professores da cidade e do campo, embora se espere dessa categoria de trabalhadores certa homogeneidade, pelo menos na formação.

A impressão que tinha dos professores do campo é que estes eram "menores" em todos os sentidos, nos ganhos porque a maior parte estava na condição de professores leigos e recebiam menos, nas instalações escolares, pois muitos na zona rural faziam das suas próprias casas e casebres salas de aulas e nas dificuldades que iam do transporte à logística para o estudo do material do curso. Muitos dispunham somente da noite à luz de velas e candeeiros para realizá-lo, pois nos finais de semana a cada 15 dias eram realizados os encontros presenciais em que se reuniam com tutores e professores formadores em seus municípios e uma vez a cada dois meses, eram deslocados para a sede onde existia a Agência Formadora (AGF) do Programa, que no caso dos municípios que atendia, era a cidade de Tucano-BA, para aulas presenciais com os professores formadores das suas respectivas áreas. Essa fase representava um momento desgastante para todos, mas, ruim mesmo era para o professor cursista que na maior parte das vezes ficava em alojamentos improvisados em salas de aula da própria escola onde se reuniam, quando as prefeituras não alugavam casas para melhor acomodá-los. Revisitando memórias da época, reproduzo abaixo um trecho de uma delas de junho de 2001:

Salvo o desgaste natural que os cursistas sempre sentem devido ao afastamento de casa e de seus afazeres rotineiros, por tantos dias, em alojamentos desconfortáveis e sem privacidade, o que leva há alguns momentos de desatenção ou dispersão, com alguns ruídos de conversas na sala, o projeto de Vida e Natureza transcorreu muito bem. Penso que a aceitação e compreensão dos temas tratados, se farão presentes nos resultados dos instrumentos de avaliação para Vida e Natureza. (Memória da Fase Presencial da Oficina de Vida e Natureza do Módulo III - Grupo II - AGFTucano-BA - 17 de junho de 2001). 
As dificuldades no Programa não estavam apenas na logística necessária para o estudo e acompanhamento de momentos presenciais. Muitas vezes manifestei desencantamento com resultados, tanto a partir de elementos obtidos pelas avaliações e nos instrumentos de acompanhamento como as memórias dos cursistas, quanto por meio das impressões das práticas pedagógicas assistidas. Como pode ser lido abaixo, um desses momentos de reflexão sobre resultados em uma memória de setembro de 2001:

\begin{abstract}
Algum tempo atrás, pensava o PROFORMAÇÃO como uma pedra preciosa não lapidada e, como tal, poderíamos extrair a mais bela e preciosa das pepitas lapidada ou um mero pedaço de pedra sem valor. Ao pensar hoje o PROFORMAÇÃO, vejo farsa, engodo, mentiras e oportunismo. A deslealdade entre os cursistas é algo agressivo e notável. Os CVAs (Cadernos de Verificação de Aprendizagem) viraram um festival de cópia sem interesse na aprendizagem, e ele seria um instrumento importante para colhermos os pontos fracos dos PCs (Professores Cursistas). As práticas pedagógicas estão, em alguns casos, que não são poucos, regredindo à qualidade que se tinha antes do PROFORMAÇÃO, a impressão que tenho é que quem já era bom professor continua bom, quem não tinha compromisso, piorou sua prática. Os memoriais, pelo que leio freqüentemente nas fichas de acompanhamento, ou se mantêm estáveis sem muita evolução, ou pioraram. Um simples memorial, que procura ser um instrumento de reflexão da prática diária do PC. Ele sabe o que está fazendo, e mesmo assim, não há concordância, não há preocupação com a ortografia, e por aí vai. Imaginem então, cobrarmos perfeição ou aprimoramento em Projeto de Trabalho ou relatório parcial se ele nem mesmo sabe ler e escrever textos corriqueiros corretamente. (Memória da Segunda Reunião Mensal - Módulo III AGF-Tucano - 16 de setembro de 2001).
\end{abstract}

Revisitando estas memórias distanciadas no tempo, vejo a perturbação que sentia em ter que compactuar com uma estrutura montada para promoção de professores que deveria ser pela formação adequada, mas que na minha visão, se transformava em uma corrida pela quantidade. Era necessário extirpar do Brasil essa chaga de professores sem a formação adequada, ao menos do ponto de vista legal, nem que para isso, a qualidade ficasse comprometida. Até que nos esforçamos nos primeiros tempos para atuar de modo adequado nos ditames da filosofia de formação de professores do ponto de vista qualitativo. Mas, com o passar do tempo e após verificações dos resultados avaliativos, passou-se a trabalhar pelo processo de obter resultados que manifestassem melhores notas, sem, no entanto, a evidenciação de melhorias na prática pedagógica do professor. Isso pode ser revelado pelo meu sentimento diante do que vivia no acompanhamento das rotinas e das práticas pedagógicas de professores cursistas. Os trechos analisados das memórias a seguir, refletem os sentimentos de expectativas frustradas e referem-se a uma das últimas memórias já do final do Programa na AGF que atuava.

Mais uma vez nos encontramos para finalizar um módulo, pelo menos no que se refere a Reuniões Mensais. Estamos todos cansados, alguns chateados, outros desesperados, porém, todos vivos. O PROFORMAÇÃO tem nos dado muitas lições, como: precisamos de profissionalismo, organização, objetividade, só podemos confiar no que é formalizado, entre tantas outras. Tenho a impressão que educação é 
coisa de amador. Depois do ensaio de erros e acertos do módulo I e a depuração no módulo II não é admissível que continuemos cometendo os mesmos erros no módulo III. [...] Falemos dos encontros quinzenais: Havia nos módulos anteriores, o I e o II, uma preocupação com o memorial, com o plano de aula e com a prática pedagógica que no módulo III perdeu espaço para os exercícios de reforço. Já protestei na AGF sobre isso, tem-se, genericamente, dado muito mais atenção aos estudos dos guias pautados nos exercício de reforço que o professor formador elabora, e não se tem discutido a própria formação do professor cursista, no que se refere a sua prática pedagógica. Confesso que não me sinto estimulado em visitar prática pedagógica de cursistas. O que os olhos não vêm o coração não sente. Se pensarmos que estamos no fim do $3^{\circ}$ módulo e encontramos práticas pedagógicas dignas de um completo amador, digo, completo leigo, sobretudo em docência, fico imaginando o que não acontecia antes do PROFORMAÇÃO. (Memória - $4^{\mathrm{a}}$ Reunião Mensal - AGF-Tucano - 28 de novembro de 2001).

A revolta é mais patente com este estado de coisa na continuidade da narrativa acima em que me espanto com o empenho de professores em formação, mas que já atuavam há anos na docência nas séries iniciais. O tom ácido reflete o espírito indignado frente a realidades testemunhadas que só o distanciamento pode perceber. Reproduzo aqui, sem desfaçatez ou cinismo, o que para mim era evidente nas intenções do Programa:

E isso em pessoas que já estão "ensinando" há 20, 25 anos. No mínimo esse professor padece de um monstruoso mal chamado preguiça, ou se viciou no "trabalho" fácil que se tornou o ato de "ensinar" da maneira como o fazem, ou vivese a desesperança de ser professor e está-se com a doença chamada síndrome da desistência, motivada, sobretudo, pelos baixos salários e pelo desrespeito com que são tratados e para descontar dão o mesmo tratamento a quem não tem nenhuma responsabilidade ou culpa sobre sua situação, o aluno. (Memória - $4^{\mathrm{a}}$ Reunião Mensal - AGF-Tucano - 28 de novembro de 2001).

Por perceber o Programa como algo importante que poderia fazer a diferença no futuro, mas ao testemunhar e sentir a pressão por bons resultados a todo custo, ao menos, os dados numéricos que apareciam nos gráficos de rendimentos e nos achados quantitativos, sentia também uma espécie de vergonha em fazer parte da engrenagem que reproduzia e sustentava a estrutura. Hoje posso ver muitos trabalhos produzidos na época do PROFORMAÇÃO, e em boa parte, os "louvores e glórias" parecem referir-se a outro programa. Infiro que muitos se basearam em dados numéricos ou foram deduzidos nas instâncias administrativas a partir de relatórios superestimados e filtrados em suas imperfeições. Para mim, ao menos no trecho da memória abaixo, ainda que reflita uma subjetividade de exageros, o sentimento era outro.

Já posso imaginar, daqui a alguns anos, olhando as legiões de analfabetos funcionais, nordestinos, sobretudo, amealhados por políticos para empregos eleitoreiros, analfabetos funcionais, aqueles que foram à escola e se comportam como se nunca tivessem passado por ela, sem qualificação, porém com título de escolaridade, e nas enquetes da vida, pessoas indagarem pela escolaridade do indivíduo e este, com comprovante na mão, mas sem prova prática das suas habilidades apreendidas na sistemática da escola, e após o desdém do entrevistador ao dizer que ele falsificou aquele certificado, argumentará que: tive um professor ou professora que era leiga, que fez um tal PROFORMAÇÃO. Não sou culpado, sou vítima. Ao presenciar tal situação, farei como Pedro fez ao negar Cristo por três 
vezes. Não, PROFORMAÇÃO!? Não, nunca ouvi falar. (Memória - $4^{\mathrm{a}}$ Reunião Mensal - AGF-Tucano - 28 de novembro de 2001).

Como se estivesse escrevendo uma carta para mim mesmo no futuro, e as memórias aqui delimitadas se prestaram muito bem para isso, dando-me a chance de revisitar o passado e perceber os percursos formativos que passei, seja nas leituras, seja nas vivências trilhadas, revejo o que era e o que sou. Até mesmo nas ironias expressas para, de certa forma, amenizar qualquer sensação de culpa, a percepção sobre o vivido é revelador. O trecho abaixo é bastante elucidativo sobre o sentimento diante dos discursos constantes explícitos ou velados:

Espero que no futuro não tenhamos vergonha do que estamos corroborando hoje. Sei que muitos de nós argumentamos que não se pode permitir que um pai de família ou mãe de família perca seu emprego de anos como professor, só porque não tem nenhuma habilidade para sê-lo! Que mal há? É só educação gente! Não faz mal a ninguém! Analfabetos a mais ou a menos nesse país que cresce e se agiganta não faz diferença nenhuma, vamos lá! Passemos todo mundo, vamos à farra do PROFORMAÇÃO, olha que se não o fizermos estaremos destoantes dos resultados das outras AGF do Brasil. Seremos os ruins, os incompetentes que não conseguiram atingir os objetivos de qualificar profissionalmente os professores leigos, pobres vítimas nossas, eles não têm culpa alguma, são trabalhadores que, se não desenvolveram a boa prática pedagógica, é por culpa do Professor Formador das áreas de Fundamentos da Educação e de Organização do Trabalho Pedagógico! Ora, se ele não sabe falar e escrever com um mínimo de correção é por culpa do professor formador de Linguagens e Códigos! Coitadinhos, não aprenderam a fazer conta nenhuma por culpa da professora formadora de Matemática e Lógica! Não consegue explicar para os alunos o funcionamento do mundo por culpa única e exclusiva do incompetente professor de Vida e Natureza! Sem contarmos o bando de tutores que só pensavam em se livrar do Programa. (Memória - $4^{\mathrm{a}}$ Reunião Mensal - AGFTucano - 28 novembro de 2001).

Em face ao meu compromisso na época como professor formador do Programa e pelo empenho nas formações de repasse das orientações nacionais, terminei sendo convidado pela coordenação do Programa para exercer o papel de professor multiplicador e passei a frequentar os encontros nacionais para discutir e preparar as formações nos módulos de estudo que viriam. Pude então nessa época testemunhar como o Programa estava ocorrendo pelo Brasil a fora $^{37}$ pelo contato com outros multiplicadores. Diante de depoimentos e louvores de coordenadores, professores, gerentes do Programa, a nível estadual ou mesmo federal, inúmeras vezes tive a sensação que estava em outro programa e não no que testemunhava. Ainda que pela ironia, refletir isso no trecho da memória a seguir:

Não aguento mais tanta hipocrisia de pessoas que se desmancham em elogios ao desenvolvimento homogêneo do cursista. Em viagem recente a Brasília para capacitação do Módulo IV, tive a oportunidade de discutir com professores do Estado do Amazonas sobre como viam e desenvolviam o PROFORMAÇÃO. Todos são unânimes ao afirmar que lá é maravilhoso, que o caboclo cursista é o melhor professor do mundo, (adendo: só para vocês terem uma idéia, boa parte dos professores cursistas do Amazonas não tinham completado a $3^{\mathrm{a}}$ série do ensino

\footnotetext{
${ }^{37}$ Lembrando que o PROFORMAÇÃO concentrou-se, sobretudo, nas regiões Norte, Nordeste e CentroOeste do Brasil, onde a existência do professor leigo era maior.
} 
fundamental, eles, a AGF, fizeram uma prova e habilitaram todo mundo). E o que dizer do Maranhão, do Tocantins, de Alagoas, e da própria Bahia? Está tudo ótimo com a prática pedagógica do cursista, os resultados são ótimos, mesmo tendo boa parte de $\mathrm{AGFs}$ que nunca visitou prática pedagógica de $\mathrm{PC}$, nunca compareceu a encontros quinzenais nos municípios do $\mathrm{PC}$, nunca acompanharam provas bimestrais, está tudo ótimo. Vai até ter PROFORMAÇÃO 2! (a revanche!). Então, só me resta imaginar, que na nossa $\mathrm{AGF}$, somos todos limitados, PF, TR e PC, temos alguma deficiência que nos desqualifica! Parece-me que somente nós temos PCs com práticas pedagógicas horrorosas. (Memória - 4a Reunião Mensal - AGFTucano - 28 de novembro de 2001).

Ante as considerações acima, arremato a memória da época com o espírito da descrença em frente ao que percebia nas posturas elogiosas que se teciam ao Programa, e ainda usando de ironia, escrevi esse trecho crítico e bem elucidativo:

\footnotetext{
Não sei não... Quando a esmola é demais o santo desconfia. Leiamos nas entrelinhas dos fatos: quem financia o Projeto? (Banco Mundial)! Quem é o consultou que ajudou a organizar o projeto? (um especialista inglês, Michael Moore)! Quando foi lançado o projeto? (Em ano eleitoral)! Vai haver continuidade? (Em ano não eleitoral?)! Qual o maior interesse do professor do Estado? (Estar longe de sala de aula)! Como se paga o salário dos Tutores? (10 contos por cabeça de PC, até 12 , no máximo)! E se o PC for reprovado? (O tutor perde dinheiro)! Onde é a parte do corpo humano que mais dói? (o bolso)! O que é mais importante qualidade ou quantidade? (Claro que é quantidade)! (Memória - $4^{\text {a }}$ Reunião Mensal - AGFTucano - 28 de novembro de 2001).
}

Ainda que as memórias apresentem uma crônica da desesperança e fiz questão aqui de não ocultá-las ou negá-las, a contribuição do PROFORMAÇÃO para muitos professores foi incontestável. Conheci alguns que logo após a conclusão do curso, entraram em faculdades para pedagogia e prosseguiram na seara de estudo e aperfeiçoamento. Mesmo ciente de todas as deficiências do Programa diante das duras realidades dos professores cursistas que convivi, nunca facilitei ou diminui o rigor no processo formativo, não com o intuito sádico de fazê-los sofrer, mas sim, com o esmero de quem cuida e se preocupa com o indivíduo em uma perspectiva de futuro.

\subsubsection{Primeiro "encontro" com o Timor-Leste}

Com essa visada do PROFORMAÇÃO, fui ao Timor-Leste. A preparação do espírito para o enfrentamento da formação de professores em outro país com as características de "terra arrasada" que visualizei nas crônicas sobre o Timor, nas notícias de jornais que corriam o mundo diante do histórico de guerra civil e pela crise de 2006, encontrava parâmetro no que vivi no PROFORMAÇÃO apenas pela expectativa da pobreza e das condições semelhantes de escolas e práticas pedagógicas testemunhadas no Brasil. Mas, estava ciente da dificuldade 
que a língua portuguesa representaria, até porque, antes de partir para aquele país, já sabia que apenas uma pequena parcela da população falava a língua. Mas, acima de qualquer percalço, presente ou futuro, o desconhecido era convidativo, talvez porque nele é que está sempre a esperança.

O Timor se mostrou em seu cartão de visita, inesperado, e para mim, assustador. A tensão da chegada se justificava em função do ocorrido no dia 23 de fevereiro (ver narrativa “1. Prelúdio de incertezas" nos apêndices, p. 274 e notícia da época: Timor-Leste: Soldados australianos matam dois civis). Meu sentimento foi de hostilidade, como se não fôssemos bem-vindos. Diferente dos territórios geográficos em que vaguei em terras inóspitas do nordeste baiano, encarando os rincões de secura e sol do sertão, visitando professores desvalidos no PROFORMAÇÃO, não rivalizaram com aquilo que sentia na primeira visão do Timor, úmido e sombrio. Isso alertou em mim que as diferenças entre o que vi e vivi no Brasil, não se comparariam ao que poderia encontrar no Timor.

Mas quantas daquelas sensações eram reais? Perceber o real com afastamento das próprias sínteses do vivido antes e dos discursos testemunhados por outros já seriam suficiente em si para compreender os sentimentos? Para Merleau-Ponty (1999),

\footnotetext{
O real deve ser descrito, não construído ou constituído. Isso quer dizer que não posso assimilar a percepção às sínteses que são da ordem do juízo, dos atos ou da predicação. A cada momento, meu campo perceptivo é preenchido de reflexos, de estalidos, de impressões táteis fugazes que não posso ligar de maneira precisa ao contexto percebido e que, todavia, eu situo imediatamente no mundo, sem confundilos nunca com minhas divagações. [...] $\mathrm{O}$ real é um tecido sólido, ele não espera nossos juízos para anexar a si os fenômenos mais aberrantes, nem para rejeitar nossas imaginações mais verossímeis. A percepção não é uma ciência do mundo, não é nem mesmo um ato, uma tomada de posição deliberada; ela é o fundo sobre o qual todos os atos se destacam e ela é pressuposta por eles. (p.6).
}

O que aquele mundo possuía acima de tudo, acima do medo e do estranhamento, era a possibilidade de desvelá-lo e aceitá-lo para além dos meus preconceitos, para além das minhas experiências. Era um novo universo que se abria. O que precisava fazer era tomar contato com aquela gente, como se fosse da própria gente, por mais que as diferenças gritassem na aparência, no espírito, na língua, nos costumes. Afinal, estava ali para "formar" em língua portuguesa professores em exercício na minha área de ciências, que cuidariam do futuro do Timor-Leste, as suas crianças. Estas são, como todos nós, cidadãs do mundo e por sua presença recente no mundo estão livres para existir sem as amarras que vão se construindo e tolhendo os adultos. Foi com esse sentimento, em busca de entendimento do espírito timorense, que travei meu primeiro contato com crianças timorenses. Um contado dialogal, quase um solilóquio pela barreira da língua. Não ocorreu na escola, nem em espaços 
ortodoxos, ocorreu em um depósito de lixo (ver narrativa "2. Um encontro internacional no lixo" - apêndice, p. 276). O encontro me permitiu uma reflexão do meu papel como "aculturador" naquela sociedade a partir do olhar para sua infância, exposta aos riscos dos ambientes insalubres, já nos modelos dos descartes ocidentais e talvez imunizados de toda sorte. Naquele momento a perspectiva de aculturação e visão de mundo assustou-me. Teria que passar minha visão de mundo e do mundo da ciência para professores passarem para estas crianças. Uma administração de representações em cadeia e vinda do meu olhar.

Mas, se aquelas crianças estavam no lixo, qual seria a representação, escolarizada ou não, que tinham sobre isso? Afinal, é de se esperar que pelos modelos curriculares ocidentais, hábitos de higiene para prevenir o contato com microrganismos morbígenos devem ser tratados desde a mais tenra infância. Havia na escola timorense essa preocupação? Aquelas crianças estavam na escola? Se estavam, o que havia de desconecto entre o que possivelmente aprenderam no mundo imaginado e o mundo real? Mas, estarei fazendo os questionamentos corretos sobre isso? As crianças de fato, constroem concepções do mundo a partir da escola?

Recorrendo aos pressupostos merleau-pontyano, é possível perceber seu entendimento sobre esse universo infantil segundo Machado (2010, p.18):

\footnotetext{
No final dos anos 1940, Merleau-Ponty propõe algo hoje consolidado no campo da Antropologia e da Sociologia da infância: que o adulto enxergue a criança do seu próprio ponto de vista, "do ponto de vista do pesquisado" (e não do ponto de vista do pesquisador). Essa propositiva resume a crítica do filósofo às pesquisas de Jean Piaget; a proximidade com a Antropologia, somada à sua forte crítica à noção de "representação de mundo" para pensar a criança pequena, traduzem, em grande parte, a originalidade da obra sobre a infância de Merleau-Ponty. O filósofo afirma que não se encontra, na criança, uma tese sobre o mundo, daí a impossibilidade de discorrermos sobre sua "representação" dele.
}

Para Machado (2010) ainda, Merleau-Ponty define a vida infantil em uma perspectiva da gestalt, assim, a percepção da criança é como a experiência de uma primeira organização de dados; desenvolver-se, amadurecer, crescer é revelar capacidade de reorganização desses dados iniciais.

Ao observar as crianças timorenses naquele primeiro contato, havia mesmo a necessidade do relativismo cultural no sentido de Franz Boas, para não utilizar os parâmetros ocidentais de análise. Provavelmente, precisaria mergulhar na cultura timorense e suas escolhas para lidar melhor com os contrastes, as contradições e os paradoxos daquela sociedade pós-colonial, adotando costumes e instrumentos dos "imperialistas", como pode ser exemplificado pelo uso da moeda norte-americana para suas transações comerciais (memória 4. A Lógica do Paradoxo, apêndices, p. 284). 


\subsubsection{Retorno ao Timor para a pesquisa}

A previsão inicial do projeto de pesquisa para retorno ao Timor-Leste em busca da coleta de dados, a princípio estava "nebulosa", pois com a interrupção do PQLP, não poderia contar com o auxílio financeiro que a CAPES, por intermédio do Programa proporcionaria, ainda que tivesse que participar de uma seleção para tal. Diante disso, a possibilidade de um difícil autofinanciamento da viagem não estava descartada. Mas, após nove anos consegui retornar ao Timor-Leste ${ }^{38}$ para coleta de dados por uma via imprevista inicialmente. No início de 2016 recebi uma informação de que a $2^{\mathrm{a}}$ Conferência Internacional da Produção do Conhecimento Científico em Timor-Leste que ocorreria em Díli entre os dias 27 a 29 de julho de 2016, estava com as inscrições abertas para trabalhos de pesquisa. Inscrevi um trabalho na expectativa de ser aceito. A carta de aceite da organização da Conferência veio em março e esta foi a possibilidade de estar em Timor e fazer a coleta de dados da pesquisa. O trabalho inscrito foi um fragmento desta tese e trata de um pequeno histórico da educação em Timor do período colonial português até o século XIX. Seu título "Crônicas sobre o Timor-Leste: um resgate da obra de Afonso de Castro". Com trabalho aceito, consegui recurso para minha ida ao Timor em função disso. Auxílio para passagens e estadia durante a apresentação do trabalho, pela agência de fomento do Distrito Federal. Ao menos os custos mais elevados da viagem, as passagens, estavam resolvidos, embora tenha custeado o restante: hospedagem por um mês em hotel, alimentação, transporte e compra de livros que foram fundamentais neste trabalho.

No primeiro dia da Conferência encontrei com o organizador da mesma, Professor Dr. Vicente Paulino, Coordenador da Pós-Graduação da Universidade Nacional de Timor Lorosa'e. Apresentei-me ao mesmo, contei do projeto de pesquisa e das minhas intenções. $\mathrm{O}$ professor me acolheu e disse-me que após a Conferência poderia pesquisar na Biblioteca da Pós-Graduação e poderia me ajudar no que precisasse. A abertura da Conferência foi proferida pelo ex-presidente da República, o Prêmio Nobel da Paz Ramos-Horta. Gravei todo o interessante pronunciamento intitulado "A Produção do Conhecimento Científico em TimorLeste: Timor e Timorense: Antes do Futuro".

Nos dias que se seguiram ainda durante $2^{\mathrm{a}}$ Conferência Internacional, uma das sessões de comunicação oral chamou-me a atenção. Denominada Cultura e Arte, foram apresentados quatro trabalhos que versavam sobre tradições culturais do país, recolhidas por pesquisadores

\footnotetext{
${ }^{38}$ Em 2010, a convite da Agência Brasileira de Cooperação (ABC) e do MEC, retornei ao Timor-Leste para avaliação do PROFEP-Timor. A visita técnica visava identificar a necessidade da presença de professores formadores brasileiros na condução do mesmo.
} 
da Universidade Nacional de Timor Lorosa'e (UNTL). Tratavam de rituais cerimoniais do povo Mambae do distrito de Ainaro, outra tratava da cerimônia "atali'a gi-falunu", termo na língua macassai que significa "lareira sagrada" e que mostra a construção de lareira de pedra em casa sagrada do Timor, cujo objetivo é proteger e defender a própria casa incluindo os seus donos e uma outra sobre a significação de pana gobol (ventre da mulher) na cultura dos bunakenses. Diante do nível de detalhamento das narrativas, pode-se perceber a riqueza da cultura ancestral, dos anciões, como normalmente eles mencionam. Todavia, após a explanação dos trabalhos sobre esses elementos culturais, aberto o espaço para as perguntas, fiz uma única pergunta que se presta perfeitamente como ponto de partida para conhecer a cultura do Timor e sua valorização pela educação. A questão foi: "Diante da riqueza cultural do Timor-Leste, suas tradições dentro do plurilinguismo, como essas tradições estavam sendo valorizadas no currículo da educação básica do Timor?” Embora tenha dirigido a questão à todos os apresentadores de trabalho, apenas o professor mediador Dr. Vicente Paulino respondeu nestes termos:

Na verdade o currículo do ensino básico já está desenvolvido, não buscando a tradição timorense, especificamente a questão dos valores tradicionais não estão presentes neste currículo. Isso significa que há uma decadência, decadência no sentido de deixar para trás os valores tradicionais timorenses especificamente, nesse sentido. Quando falamos de nós, quais são os verdadeiros valores timorenses em si? Estamos falando sobre valores timorenses antes e depois de agora. Neste caso a educação deve se interessar por todos os valores timorenses dentro do currículo, começando pelo ensino básico, pré-secundário e do ensino secundário, assim poderíamos dar uma visibilidade das características timorenses no mundo globalizado. Se isso não for colocado no currículo, significa que nós estamos a deixar a nossa cultura para trás. Ou seja, em alguns casos, as expressões dos homens dizem que (usa uma expressão em tétum e traduz): "a cultura dos antepassados já não tem benefício para nós no tempo presente", coisas passadas já não servem para era contemporânea. Assim, se nós deixarmos que isso aconteça, afastando as tradições culturais do currículo, estamos deixando morrer as nossas características timorenses. Um outro aspecto interessante, tomo como exemplo dos portugueses que não ligam muito para sua cultura quando estão em seu país, mas, quando em diáspora, afastados da sua terra, se congregam em torno dessa cultura. Assim, também ocorre em Timor. O timorense em diáspora promove muito mais a cultura da sua terra do que os que estão aqui dentro do Timor-Leste, isto é amor. Então, em relação à questão do currículo, compete às autoridades do Ministério da Educação ter atenção a isso. (Dr. Vicente Paulino, comunicação oral $-2^{\mathrm{a}}$ Conferência Internacional do Conhecimento Científico em Timor-Leste).

De certa forma estas ponderações do professor Vicente Paulino já respondem uma das questões deste trabalho sobre considerações culturais timorenses no ensino em geral e no ensino de ciência em particular. Ao tempo em que identifica o problema da ausência desses valores culturais no currículo, coloca as autoridades do Ministério da Educação como as responsáveis por estas alegações da ausência da cultura timorense no currículo e sua possível inserção. A Conferência transcorreu bem, com timorenses, australianos, portugueses e 
brasileiros (eu e mais outra brasileira que reside em Timor e participa de missão evangélica e que apresentou trabalho no campo da linguística), sendo a "porta de entrada" para a etapa de pesquisa de campo desta tese. Na segunda-feira seguinte ao término da Conferência, me reuni com o professor Dr. Vivente Paulino para que me indicasse nomes e pessoas com quem pudesse falar sobre várias questões como currículo, ensino básico, formação de professores e outros assuntos. O professor reiterou a disposição em me auxiliar, apresentou-me às responsáveis pela biblioteca para que me atendessem nas necessidades da minha pesquisa.

\subsubsection{Desvelando o currículo de ciências da educação básica primária em Timor-Leste}

A ideia de que a educação é sempre algo para o bem é unânime nos meios acadêmicos, sobretudo em Timor-Leste. Certamente a oferta de uma educação de qualidade corrobora com este pressuposto, quando os responsáveis pelas políticas públicas na área educacional possuem a intenção de realmente beneficiar a população com uma educação que coloque os indivíduos livres e com a capacidade de pensar e exercer sua cidadania em plenitude. Os sistemas de ensino, no entanto, podem ser estruturados por meio dos currículos e das práticas pedagógicas para produzir cisões no seio das sociedades, gerando um efeito contrário do que seria uma sociedade construída nos ideais de unidade e identidade nacional.

Diante dos acirramentos étnicos e o papel que a educação desempenha, é possível entender que a educação pode ter duas faces: uma negativa e outra positiva, como demonstram Bush \& Saltarelli (2000), quando apresentam a face negativa como associada à distribuição desigual da educação criada para preservar privilégios e usada como arma de repressão cultural e de produção ou mesmo doutrinação via livros-didáticos para a promoção de intolerância. Sendo positiva quando provê uma educação para a paz, refletindo os benefícios de uma educação de qualidade. Isso inclui a minimização do impacto em conflitos que uma educação promotora de oportunidade oferece: a promoção de tolerância linguística e étnica e o 'desarmamento' da história.

Inicialmente no período colonial português na sociedade timorense a educação foi um direito apenas dos filhos dos liurais, ficando a população alijada do processo educacional, talvez a preservação do pluriliguismo seja um traço da exclusão de boa parte da população da educação formal.

A dura reconstrução do país autônomo de Timor-Leste a partir de 2002 representou grandes desafios em vários setores, sendo o educacional um dos mais sensíveis, haja vista que os modelos educacionais que se sucederam ao longo da sua história, representaram elementos 
exóticos à sua identidade enquanto nação. Sendo assim, uma das primeiras preocupações do novo estado, foi reformular o sistema educacional de modo a impregnar uma feição nacional, com foco na construção de uma identidade, que pela educação, passasse a se afirmar em busca do fortalecimento da nação timorense. Como menciona Shah (2009, p.1),

Em 2002, Timor-Leste emergiu dos séculos da colonização portuguesa e de duas décadas de ocupação brutal da Indonésia e de aproximadamente três anos de governo das Nações Unidas, para se tornar um dos mais novos estados-nação do mundo. Tão logo alcançou a independência, o ainda nascente estado, juntamente com os parceiros para o desenvolvimento, priorizou uma reforma radical no setor da educação. Um componente crítico nesse campo era a transformação do currículo primário para garantir que o conteúdo e a pedagogia do que seria ensinado nas salas de aula timorenses funcionassem para apoiar, em vez de impedir, os esforços de reconstrução social e cívica. (tradução do autor).

Assim, em busca do status de democracia o Timor-Leste pretendeu, no âmbito educacional, fortalecer-se estabelecendo condições para uma democracia eficaz. Na visão de Bernstein (1998, p.24), duas são as condições para tal:

A primeira condição é que os sujeitos devem sentir que têm alguns interesses na sociedade. Os "interesses" constituem uma má metáfora, porque com ela não me refiro somente a que os indivíduos se preocupem por receber algo, mas também por dar algo. Esta ideia de "interesse" tem dois aspectos: receber e dar. As pessoas devem sentir que têm interesses em ambos os sentidos. Em segundo lugar, os sujeitos devem confiar que as instâncias políticas que eles crêem, satisfarão esses interesses ou cederão espaços para outros se eles falharem. Em certo sentido, não importa muito se não forem alcançados esses interesses ou só se consigam parcialmente, sempre que haja boas razões para não satisfazê-los no todo ou em parte.

Mas, em qualquer dos casos a sociedade é fundamental nessa estruturação da educação. Neste viés, ao se analisar o currículo da escola primária, o primeiro nível a ser priorizado com uma reforma curricular, foi o fortalecimento de uma identidade nacional. Ainda que em seu início contasse com a cooperação internacional, a exemplo da que o Brasil lhe prestou, a busca por uma feição própria para seu sistema educacional sempre foi a principal intenção do Estado. Em que pese os elementos externos intervenientes neste currículo, os caminhos para sua construção estão sendo buscados de modo a contemplar uma feição própria.

Porém, nas conversas com professores da UNTL sobre o atual currículo da educação básica em Timor, a expressão de desconhecimento do assunto, ou até mesmo de ignorância sobre o mesmo, deixaram transparecer que pela dinâmica de sua construção, nunca poderia representar algo acabado e de domínio dos agentes da educação. Neste sentido, entendi o desafio que teria para desvendá-lo. Era uma temática de sentido "lulik".

Aqui faço uma digressão para explicar esse elemento tão perceptível nas tradições e costumes timorense. Em Timor-Leste, as tradições "lulik" são muito intensas e múltiplas 
coisas possuem aura "lulik". Em língua tétum "lulik" como substantivo significa cerimônia, um rito animista. Em sentido lato é o que é sagrado, venerando, intocável e em sentido restrito, pode ser feitiço, ídolo. Como adjetivo, e com uso mais frequente "lulik" é o que é proibido, vedado, temido, misterioso, sagrado, santo (COSTA, 2001, p.235). Então uma expressão do tipo: “Uma Lulik” em tétum significa "Casa Sagrada”. Uma construção comum nas aldeias, onde se guardam os objetos sagrados dos antepassados e das tradições daquele povo.

Os sacerdotes antigos das "Casas Sagradas" em um tempo em que não havia o registro escrito eram os encarregados por guardar os ritos e a genealogia dos antepassados da aldeia. Memorizava, sobretudo, a linhagem genealógica nobre dos liurais e quando estava velho e próximo da morte, passavam esses segredos (Lulik) para seu substituto que tinha a responsabilidade de também memorizar tudo que um dia pertenceu à memória de outros tantos sacerdotes que o antecederam.

Assim, em claro e bom tétum, estava diante de um "kurrikulu lulik". Após alguns contatos com professores timorenses nos primeiros dias e, sobretudo a recomendação para uma visita ao Ministério da Educação, agendei uma visita ao Diretor Geral do Ensino Básico. Em um primeiro contato, pude perceber um desconforto em torno do currículo e das línguas de instrução previstas na Constituição Nacional. O Diretor Geral, após certa relutância em apresentar-me o currículo do ensino básico que havia solicitado, diante de algumas desconfianças pertinentes, depois de detalhada apresentação sobre quem era e minhas intenções, lhe mostrei carta de apresentação do Programa de Pós-Graduação em Educação da Faculdade de Educação da Universidade de Brasília (anexo 1 - apêndices, p. 263), comprovante de residência emitido pela Embaixada Brasileira no ano de 2007 (anexo 2 apêndices, p. 264), para confirmar minha ligação antiga com o Timor e para atestar a fidelidade do que estava falando, resolveu apresentar-me o currículo do ensino básico, que aquela altura parecia para mim um mistério, o "lulik" envolto em véus de proteção e incógnita.

O senhor Diretor resgatou de um armário quatro volumes onde dois eram imensos, com mais de 600 páginas cada um e outros dois com uma média de 200 páginas. Para minha infelicidade todos os materiais, apesar de estarem atualizados, pois datavam de 2015, apresentavam-se em língua tétum, sem as habituais versões em português. Continuaram para mim um "lulik". Perguntei-lhe sobre as versões em português, como normalmente fazem, já que a língua portuguesa, constitucionalmente é língua oficial de instrução, o senhor Diretor em claro português falou-me que o currículo atual estava sofrendo ingerências políticas e que 
percebia certa diminuição da importância da língua portuguesa na educação, já que de longas datas, haviam forças políticas no Timor, trabalhando para a superação da língua portuguesa e que aquele currículo apenas em versão tétum já era um reflexo dessa ação. Perguntado sobre quais forças políticas estavam atuando com essa finalidade, não quis entrar em detalhes para não se comprometer certamente. Ocupava um cargo importante no Ministério da Educação e não queria parecer que estava contra o governo. Embora defendesse veementemente a permanência da língua portuguesa para a nação.

Falou-me ainda, que apesar de ter estudado sua pós-graduação em nível de mestrado na Nova Zelândia e em língua inglesa, pensava que, pelos laços históricos coloniais com Portugal e pela importância da língua portuguesa na Resistência Timorense na luta pela independência, deveria ser popularizada, pois, assim como no inglês, a língua portuguesa possuía vasta publicação científica também e perfeitamente cabida nesse sentido para o desenvolvimento do Timor. Todavia, reforçava essa questão sobre a diminuição das atenções ao português como língua oficial a ser usada na educação. Indagado sobre se haviam mudado a Constituição para esse intento, me informou que estas novas tendências não eram constitucionais, pois não haviam feito nenhuma mudança na lei, mas eram informais, como se fosse um ensaio.

Em todo caso, pedi permissão ao diretor geral para a cópia daqueles materiais mesmo em tétum, da parte do currículo de ciências. Não houve relutância para fazê-lo, só me advertiu sobre o horário de trabalho do pessoal de apoio que era até o meio-dia na parte da manhã, mas, retornavam após o almoço às 14 horas. Comecei a copiar com o escâner do aparelho celular, já que tinha muito trabalho pela frente. Mesmo em tétum, notei que os tomos mais volumosos eram na realidade planos de aulas detalhadas, em cima do currículo, para aulas a serem dadas na primeira e segunda classe do primeiro ciclo do ensino básico. Com todo respeito indaguei ao diretor sobre o que era aquilo. O senhor, um tanto sem jeito me informou que aquilo era uma espécie de controle, e que eu podia perceber com isso o nível de ingerência que a educação estava sofrendo. Continuei os questionamentos sobre quem determinava essas ações, e informou-me que eram provenientes das orientações do UNICEF (Fundo das Nações Unidas para a Infância) e recebia a anuência de profissionais timorenses que aceitavam aquilo. Mesmo sendo planos de aula, resolvi proceder ao escaneamento do material na parte do currículo de ciências e de saúde, já que o modelo curricular do ensino básico coloca as ciências e saúde em um componente curricular que chamam "Estudo do Meio", onde além das ciências, estão geografia, história, sociologia e civismo. 
O volume com o currículo propriamente dito era um dos menores e em função do tamanho deixei para copiá-lo já ao final do expediente. Logrei êxito na enfadonha e cansativa tarefa. Havia finalmente adquirido o currículo (ver o currículo original em tétum nos apêndices dessa tese, p. 329), ainda que em língua tétum, o que pode parecer a primeira vista uma espécie de criptografia. Mas, com o auxílio de intérprete timorense e em alguns casos de um bom dicionário, foi possível traduzir os elementos necessários. Ressalta-se que não foi feita uma tradução do currículo ao pé da letra por considerar essa possibilidade uma espécie de desautorização das próprias autoridades timorenses no campo da educação, haja vista que as versões autorizadas, em português, dos documentos educacionais são realizadas seguindo critérios e procedimentos de profissionais homologados pela autoridade timorense. Assim, as considerações sobre o currículo mais adiante, representou uma transposição de tradução oral feita por um intérprete, gravadas e transformadas em texto, que embora guardem o sentido do currículo, não representa sua literalidade conforme o original em tétum, disponível nos anexos.

Diante das informações que o diretor do ensino básico havia passado sobre a problemática que viviam em relação ao currículo, algumas ainda no campo das entrelinhas, fui investigar mais detalhadamente o que estava ocorrendo com as reformas curriculares. $\mathrm{Na}$ biblioteca da pós-graduação da UNTL não encontrei informações necessárias, em conversas com os professores da própria Universidade, tive a impressão que desconheciam o assunto ou que não queriam se manifestar, alguns informaram inclusive que não tinham a responsabilidade sobre esse nível educacional.

Partir então para o INFORDEPE (Instituto Nacional de Formação de Docentes e Profissionais de Educação), antigo Ex-CNRT (Centro Nacional da Resistência Timorense), onde no ano de 2007 trabalhei no PROFEP-Timor. Lá entrei em contato com a antiga administradora, que hoje está em outra função, a senhora Manuela Gusmão, irmã do expresidente da República Xanana Gusmão. Conversamos muito tempo sobre algumas amenidades, notícias do Brasil e dos conhecidos, mas, toquei no assunto do currículo. Com olhar pesado e triste, me confessou que era um assunto que a incomodava bastante, até porque os companheiros de jornada na educação em Timor, não a escutavam. Neste sentido mencionou que havia ingerência de órgãos como a UNICEF e grupos de profissionais americanos e australianos que estavam "tomando conta" do currículo e que de fato a língua portuguesa estava perdendo espaço. Via a educação de qualidade como algo que deveria permanecer em foco, e que as línguas tétum e portuguesa, deveriam ser o centro da atenção na 
educação, que a instabilidade causada por tanta flutuação de intenções não permitiria o Timor se desenvolver a partir da educação.

Um aspecto interessante a se avaliar no que se refere à educação em Timor-Leste foi levantado pela senhora Manuela Gusmão ${ }^{39}$ quando esta fez uma conjectura sobre diferenças existentes entre a educação no Brasil e em Timor. No seu entendimento, o Timor-Leste não possui um corpo de intelectuais que tenha em seu passado se debruçado sobre os problemas educacionais timorenses e que desses pensamentos tenha resultado algo substancial para se pensar e balizar a condução da educação. O que não acontecia no Brasil em que a presença de pensadores como Anísio Teixeira, Paulo Freire, Fernando de Azevedo, Darcy Ribeiro, para citar apenas alguns, contribuiu para sempre com seus pensamentos de modo a consubstanciar uma base referencial sobre a educação na realidade brasileira. Coisa que não ocorrida no Timor, em que todo o referencial que tinham neste campo era meros empréstimos do pensamento realizado por educadores que assim o fizeram para suas realidades nacionais e que não necessariamente serviam ao Timor-Leste.

Neste sentido, ainda questionei dona Manuela sobre o fato de pensamentos em educação serem universais e que não importando onde foram pensados, podiam ter uma serventia para os seres humanos em suas construções educacionais. Mas, ela mencionou as realidades linguísticas e culturais, além das peculiaridades das culturas, afetadas por suas histórias, como sendo particulares e que merecem também pensamentos particulares que integrem esses fatores de modo a produzir soluções locais para problemas locais.

Continuamos a falar sobre o que ocorria no ensino básico no Timor e mencionou as mudanças que estavam em curso. Ainda que em uma fase de teste, já eram vistos em aplicação em algumas escolas. Para ela, o professor da escola básica, por experiência própria, já que por muitos anos ela mesma atuou como professora primária, é o "autor" da sua aula e para isso, em seu programa visualiza as maneiras de repassar conteúdos com vistas a atingir os objetivos. Portanto, planos de aulas, por exemplo, deveriam ser construídos pelos professores que conheciam seus alunos, sua escola, seus materiais de trabalho e não vir elaborados, prontos, fechados a partir da autoridade da educação como estava acontecendo, conforme pude atestar com as cópias dos materiais que fiz no Ministério. Aquelas mudanças pareciam ser formas de controle que tinham influência de vários "atores" no campo

\footnotetext{
${ }^{39}$ A senhora Manuela Gusmão fez mestrado no Centro de Pesquisa e Pós-Graduação sobre as Américas (CEPPAC), do Instituto de Ciências Sociais da Universidade de Brasília (UnB), com dissertação defendida em 2010 com o título "Cooperação Bilateral Brasil - Timor-Leste na profissionalização docente em serviço: "Perspectivas e desafios do século XXI". Disponível no endereço eletrônico do repositório da UnB: <http://repositorio.unb.br/bitstream/10482/8454/1/2010_MariaManuelaGusmao.pdf>.
} 
educacional com interesse na diminuição da importância da língua portuguesa. Solicitada a mencionar quem eram esses "atores", não quis se manifestar.

Porém, em pesquisa bibliográfica na Biblioteca do INFORDEPE, tive contado com uma obra portuguesa de Ana Margarida Ramos e Filipe Teles chamada "Memória das Políticas Educativas em Timor-Leste: A consolidação de um Sistema (2007-2012)", publicada em 2012, produto de consultoria desses profissionais da Universidade de Aveiro, Portugal, onde é perfeitamente possível entender a gênese desses impasses sobre o currículo e as línguas oficiais de educação.

Uma abordagem desses autores sobre o currículo do ensino pré-escolar já dá indícios sobre o que ocorre no currículo em geral, no da escola básica em particular e a dificuldade do próprio Ministério da Educação de verificar o cumprimento do mesmo, bem como o trabalho desenvolvido e outras tantas dificuldades,

\begin{abstract}
Apesar das tentativas de coordenação por parte do Ministério, a verdade é que não existem mecanismos formais capazes de permitir acompanhar e avaliar com detalhe o trabalho desenvolvido, as condições em que é feito, bem como os programas seguidos e a qualificação dos profissionais (e voluntários) que o exercem. Há, contudo, algumas tentativas de coordenação, nomeadamente através de reuniões regulares periódicas com várias organizações a desenvolverem trabalho no terreno, como a UNICEF, World Vision, Plan International, Child Fund, Save the Children, Fundação Alola, Talha foundation ou o Instituito Mary Mackillop. (RAMOS \& TELES, 2012. p.55).
\end{abstract}

Pode-se observar pela citação acima, que muitos interesses rondam o currículo da educação em Timor. Em consonância com que informou a senhora Manuela Gusmão, ao mencionar que em sua opinião quem tem que decidir o que é melhor para o Timor são os timorenses conscientes. A interferência de diversos "atores" nessa questão parece mesmo ser um campo de disputas. Mas adiante Ramos \& Teles (2012, p.55-56), informam que:

\begin{abstract}
A falta de enquadramento legal talvez explique também alguma controvérsia suscitada a propósito da língua veicular de ensino no pré-escolar [...]. A ausência de legislação é, também por isto, um fator que conduz à indefinição quanto a políticas e metodologias de atuação claras. [...] Depois da escolha do Tétum e do Português como línguas oficias de Timor-Leste, opção inscrita na Constituição da República, o Ministério deu seguimento a este dispositivo constitucional, através da Lei de Bases da Educação, definindo-se como línguas veiculares de ensino. Sublinhe-se, a este propósito, e anterior a este mandato governamental, a adoção de uma política de transição entre a língua indonésia e a língua portuguesa no sistema de ensino, [...] que, paulatinamente, facilitou a mudança gradual, dando, ainda um período considerável para a formação de docentes e necessária adaptação à mudança. Este processo, apesar de ter sido totalmente completado, suscitou algumas dúvidas em determinados setores da sociedade, despertando diferentes sensibilidades.
\end{abstract}

Embora esse território curricular no que tange as línguas de instrução possua regulamentação legal como o previsto na Constituição e na Lei de Bases da Educação que não foram alteradas até o momento em outro sentido, pelo que pode ser percebido nas conversas 
relatadas acima, há um avanço em sentido contrário que vem tomando espaço intencionalmente ao longo desse tempo. No livro de Ramos \& Teles (2012, p.56), já há um prenúncio da situação que ora observo em Timor. Segundo esses autores,

Kirsty Gusmão ${ }^{40}$, na qualidade de Embaixadora da Boa Vontade da UNESCO, Presidente da Comissão Nacional da UNESCO e Presidente da Comissão Nacional da Educação de Timor-Leste, tem apoiado várias iniciativas ligadas às questões da língua de educação, aspecto que considera central para o desenvolvimento da qualidade educativa. Consciente da sensibilidade que envolve o tema, mas também da sua importância, impulsionou a elaboração de um documento cujas conclusões e implementação pretendia propor ao Ministério da Educação para adoção nacional. Este processo, contudo, pelos riscos que comporta, está ainda a ser alvo de ponderação e reflexão no seio do Ministério, não se prevendo, a breve trecho, desenvolvimentos consideráveis que contrariem os instrumentos legais já definidos.

A partir de 2009, Kirsty Gusmão formou um grupo de trabalho composto por especialistas portugueses e australianos além de proceder consulta popular sobre o assunto, o que gerou a formação de um grupo menor formado por membros da igreja, das ONGs, Ministério da Educação, além de contar com apoio de técnicos especialistas da Universidade de Melbourne e da Universidade de Estocolmo, gerando o estudo Educação Multilíngue Baseada na Língua Materna - Política Nacional, que defende que os níveis iniciais de formação, incluindo o pré-escolar, sejam realizados nas línguas maternas dos alunos (RAMOS \& TELES, 2012). Prevendo-se que de forma gradual, e ao longo do tempo escolar subsequente, sejam introduzidas, sucessivamente, as línguas oficiais, primeiro o tétum e depois o português. Inclusive, pelo o que apontou a senhora Manuela Gusmão. Nos tempos atuais observa-se nitidamente uma redução do tempo de aula para língua portuguesa. Possivelmente já está em curso o plano traçado nos anos anteriores para a definição dos papéis das línguas na educação timorense.

Em conversa com o professor formador do INFORDEPE, senhor João Freitas, este evidencia a confusão que se está a criar na educação do Timor com a intenção de substituir a língua portuguesa por línguas maternas nas séries do primeiro ciclo. Segundo o mesmo, atualmente estão a implementar um novo currículo, a princípio como um projeto piloto para algumas escolas, que está funcionando desde o primeiro ciclo $\left(1^{\mathrm{a}}, 2^{\mathrm{a}}\right.$ e $3^{\mathrm{a}}$ classes $)$, que só introduz a língua materna e o tétum. Depois do $1^{\mathrm{o}}$ ciclo, a partir da $4^{\mathrm{a}}$ classe se introduz a língua portuguesa, só oral, não há trabalho com o português escrito. Somente na $5^{\mathrm{a}}$ classe é que se introduz a escrita em português, isso reforça a ideia de diminuição da importância da

\footnotetext{
${ }^{40}$ Kirsty Sword Gusmão, ex-primeira dama do Governo Xanana Gusmão, fundadora da ONG Fundação Alola que busca auxílio às mulheres timorense, ativista de longas datas na resistência timorense, tendo inclusive servido como espiã no período da invasão Indonésia onde conheceu Xanana Gusmão na prisão e o ensinou inglês durante um tempo que residiu em Jakarta como e ativista pelos Direitos Humanos. Posteriormente à libertação de Xanana, casaram-se e tiveram três filhos. Divorciaram em 2015, mas, continua atuante no Timor como membro da Comissão Nacional da Educação. (Nota do autor).
} 
língua portuguesa na educação básica. Essas questões têm levantado grandes discussões no Parlamento timorense, mas, não têm efeito. Há na administração da educação a presença de funcionários graduados que parecem ser anti-língua portuguesa. Mais uma vez, cita também a interferência de organizações internacionais que estão intrometendo-se. Acha-se que não vai durar muito tempo essa interferência, pois há muitos protestos por parte dos professores nas escolas que não têm aceitado isso no currículo. Muitos professores lamentaram essas mudanças e até resistem, pois, a identidade autônoma do Timor-Leste enquanto país é atribuída à língua portuguesa em grande parte, como já referido anteriormente.

Segundo ainda o professor Freitas, há intenções que vem de fora. Forças internacionais queriam impor seus propósitos políticos para que, interesses fossem defendidos, sobretudo no que se relaciona à língua Portuguesa. Por exemplos, houve questionamentos dos americanos que indagaram muito sobre o fato do Timor-Leste usar como moeda o dólar americano e optar pela língua portuguesa como língua oficial.

O professor João Freitas ilustra uma história pitoresca da qual foi testemunha. Contou que em Baucau, há alguns anos atrás, quando soldados autralianos e americanos perambulavam pelo Timor, observou uma cena muito pueril sobre o assunto, mas, que mostra como estão esses interesses nessas disputas. $\mathrm{Na}$ frente da sua casa, pode observar quando um automóvel das forças australianas parou em frente a uma casa onde crianças estavam brincando à porta, e soldados ofereceram balinhas às mesmas, fazendo a alegria da garotada, ao tempo que falavam da Austrália com os polegares para cima, apontando o país como "Ok" e "Yes" como sendo positiva para o Timor-Leste, ao tempo que apontavam o polegares para baixo para se referir a Portugal como negativo "no". Caso patente, segundo o professor, de "doutrinação ideológica" das crianças para atrair a simpatia das mesmas.

Outro grande problema apontado por Freitas, é que se constrói um currículo e algum tempo depois se muda. Parece que há um confronto muito voltado para o currículo. Não é a toa a existência no Ministério da Educação do Timor-Leste de uma Diretoria Nacional de Currículo, que por sua dinâmica e pela ingerência de novos governos que se sucedem, levam a ideias divergentes que lutam para se impor. Ou dizendo de outro modo, as políticas de governos não são políticas de Estado e quando pelos meios eleitorais se mudam os governos, novas propostas de políticas públicas tendem a mudar, não havendo continuidade neste sentido para uma política permanente de Estado.

O professor João Freitas ainda expressou sobre o crescimento do Estado ao longo desses anos em Timor-Leste. A presença do Estado se faz sentir em todos os setores no Timor-Leste, o que representa muitas vezes custos desnecessários que oneram os cofres 
públicos e que bem poderiam se concentrar em áreas mais sensíveis. É verdade que historicamente a população carente precisou do suporte do Estado para se reequilibrar, mas, este tem se mantido paternalista. Por exemplo, segundo Ramos-Horta em conferência proferida durante a abertura da $2^{\mathrm{a}}$ Conferência Internacional Produção do Conhecimento Científico em Timor-Leste, o país tem a energia elétrica mais cara do mundo, e não obstante isso, boa parte da população não paga energia elétrica, tendo o Estado que subsidiar e arcar com as despesas para sua produção. Isso é um assunto associado ao tamanho do Estado.

É perceptível nos últimos 10 anos, o surgimento de muitos prédios novos, suntuosos até, todos pertencentes à máquina burocrática do Estado Timorense, isto é um elemento marcante que denota um Estado que a cada dia fica mais poderoso e constrói uma máquina burocrática e administrativa que se evidencia nas próprias construções estatais. As obras mais antigas que já existiam continuam com sua estrutura, muitas vezes necessitando de reformas, como é o caso do MEC e de escolas mais antigas que sobreviveram à destruição, estão estragadas pelo tempo, as habitações das pessoas timorenses são muito simples e muitas ainda de palha, mesmo na capital Dili, mas, não obstante essas situações, o prédios públicos recentes, exibem uma espécie de ostentação. É evidente que a organização do Estado não se mede apenas pela sua estrutura predial das construções que o suportam, mas sua atuação em áreas estratégicas como a educação e a saúde, são evidentemente muito mais perceptíveis do ponto de vista dos serviços que presta e isso, ainda está deixando muito a desejar.

Resta saber se essa suntuosidade dos prédios públicos se reflete na prestação de serviços ao público. Segundo o João Freitas, há políticas públicas que são muito abstratas e muitas não tem benefício algum. Um exemplo, nos últimos anos, o presidente da república e comitiva saíram a visitar todos os distritos do Timor-Leste, eles conseguem até visualizar os problemas e as necessidades das populações, mas retornam aos seus gabinetes e nada é feito, não são implementadas ações que atendam às necessidades locais e que foram testemunhadas nessas visitas. Sem contar o custo imenso que isso representa, pois as comitivas nesses deslocamentos custam muito caro para o orçamento do Estado. Funcionários comuns nestes deslocamentos ganham quarentas dólares de diárias e os diretores ganham sessenta, são equipes de 10 a 20 pessoas nestes deslocamentos constantes, sem contar o custo do combustível dos carros oficiais do Estado e estes deslocamentos, contando todos os Ministérios, ocorrem entre 20 a 30 vezes por mês. O povo permanece na carência, pois por mais que os políticos e as autoridades visitem e testemunhem a carência e a necessidade das populações locais, não realizam estudos técnicos de viabilidade para implementar projetos que mudem a situação e promovam o bem-estar social. Embora hoje o Timor-Leste tenha 
reservas financeiras importantes e o orçamento esteja na casa dos bilhões de dólares, nem sempre foi assim, mas, ao que parece, esses recursos de fundo de petróleo e outras receitas, não estão sendo gastos como deveriam. O professor João Freitas menciona ainda a riqueza mineral do Timor-Leste em todo o território, mas, não obstante isso, o timorense está a viver sobre essa riqueza na carência.

Por exemplo, cita a mina de Buolaca $^{41}$ por sua riqueza, com petróleo brotando à "flor da terra" além de outros lugares semelhantes em Timor em que o petróleo está lá, sem a necessidade de prospecção, mas sem exploração. Outros exemplos são jazidas de mármore sem nenhuma exploração. Os poços marítimos encontram-se em exploração por parte da Austrália, mas isso é um assunto que volta sempre a discussão a exemplo do que atualmente se faz, a delimitação das fronteiras marítimas entre Austrália e Timor. Enquanto o Timor quer uma divisão mediana nas águas territoriais fronteiriças com a Austrália, esta não aceita esse posicionamento. Certamente que a relutância não se dá no campo geográfico, mas sim no econômico, como a área marítima de Timor-Leste é bem mais rica em petróleo, se cria os litígios na tentativa de se apropriar dos recursos petrolíferos.

Estas discussões entre outras, também perpassam a esfera educacional, pois é comum a representação no imaginário timorense de que pela educação, superarão qualquer entrave que representa obstáculos ao desenvolvimento econômico. Então, a valorização e persistência constantes de mudanças no currículo talvez reflitam essa inquietação sobre o próprio desenvolvimento. Embora se encontre opiniões em Timor sobre a necessidade de incutir no currículo as particularidades da identidade timorense em busca de um purismo cultural, traço marcante em toda trajetória da sua história, as ingerências internacionais no currículo também parece ser o novo palco de batalha no Timor atual. Catanas, metralhadoras, guerrilha da resistência, parece que cederam espaços para a luta no campo da burocracia estatal dos gabinetes e das decisões movidas por interesse os mais diversos.

Entre esses novos atores neste "palco" do campo da educação em Timor, é perceptível a interveniência de organismos internacionais e universidades estrangeiras na construção de um modelo de currículo para o país. Professores que atuam na área de formação de professores em Timor, quando consultados sobre os agentes que estão por trás das reformas e de novos encaminhamentos para a educação a partir do seu currículo, são unânimes em afirmar a interveniência de órgãos internacionais, já apontados, como a UNICEF, mas também são conhecidas a atuação da Universidade de Aveiro de Portugal e fundações como

\footnotetext{
${ }^{41}$ Fiz um registro de documentário sobre esta mina de petróleo a céu aberto a partir da Rádio e Televisão de Timor-Leste, emissora estatal onde é possível visualizar o petróleo jorrando à flor da terra.
} 
World Vision, Plan International, Child Fund, Save the Children, Fundação Alola, Taliha Foudation ou o Instituto Mary MacKillop (RAMOS \& TELES, 2012).

Mas, qual o interesse desses organismos na educação de Timor-Leste? Beech (2012) pode oferecer indícios do que ocorre quando nos fala da influência estrangeira na educação em diversos países, onde ONGs e universidades encontram o espaço necessário para a comercialização de conhecimentos nesse setor. As universidades vêem nesse espaço a possibilidade de incrementar seus ganhos. Salienta ainda o autor, citando Lyotard (1984) que há alguns anos, o conhecimento em nosso tempo é produzido para ser vendido e,

\begin{abstract}
Assim, se o departamento de educação de determinada universidade desenvolve certo conhecimento sobre como tornar uma escola (ou um sistema educacional distrital ou nacional) mais eficiente e eficaz, deve vender esse conhecimento no mercado de forma a contribuir com o desempenho da organização. Já faz algum tempo que as universidade estão envolvidas no negócio de consultoria. No entanto, tal como aconteceu com o mercantilismo, que alimentou o imperialismo europeu na busca de novos mercados desde o século XVI, a atual situação financeira das Universidades em lugares como o Reino Unido cria fortes incentivos para a colonização de novos mercados para a venda de consultoria, especialmente nos países menos desenvolvidos. Assim, muitas universidades criam (ou reforçam) unidades especiais para desenvolvimento internacional, tornando-se atores poderosos no jogo de promoção de ideias educacionais orientadas para políticas. (BEECH, 2012, p. 415).
\end{abstract}

Pode-se pensar que embora o forte nestas “colaborações" seja o discurso da busca de modelos eficientes para implementação de educação de qualidade, o apelo econômico na caça de mercados internacionais para a difusão de soluções no campo educacional tem conduzido o mundo para uma homogeneização de padrões "educacionais de qualidade". As nações não possuem mais gerências sobre seus currículos e seu modo de operar educação. Sob os auspícios de trabalhos acadêmicos que atestam por meio das suas pesquisas modelos eficientes de educar a população, se veicula um discurso global de qualidade educacional ao alcance de todos e determinístico para as nações encontrarem o caminho para um futuro de desenvolvimento e prosperidade econômica. A educação como a vanguarda do sucesso nacional, ideia quase unânime, sobretudo entre os países em desenvolvimento que "compram" esse discurso como uma via de solução dos seus problemas atuais.

\footnotetext{
Esse discurso é global por seu escopo espacial (a educação em todo o mundo é seu objeto). É também um discurso global no sentido de tratar-se de uma teoria que, em nome de um verdadeiro conhecimento, e de algumas ideias sobre o que constitui uma boa educação, oferece um modelo universal de educação como estratégia global capaz de resolver a maioria dos problemas educacionais nos mais diferentes contextos locais. (BEECH, 2012, p. 422).
}

Estas visões uniformizantes de pensar a educação no âmbito local em detrimento de um pensamento global impedem o surgimento de novas ideias nos contextos das realidades 
locais e até o surgimento de pensadores originais que pensem a educação em seus países bem como maneiras de ação em busca de seus próprios caminhos. Tudo é importado como solução e o império dos argumentos exóticos como a panaceia para a resolução de todos os problemas nacionais, é reforçado pela exemplificação do sucesso das nações exportadoras desses modelos. Não é a toa a ênfase que se coloca nos rankings dos países que se destacam no campo da educação como a oferecida pelo PISA (Programme for International Student Assessment) da OCDE (Organização para a Cooperação e Desenvolvimento Econômico). Sem mencionar os diversos programas de cooperação no campo dos intercâmbios de estudo sobre educação que universidades estrangeiras promovem, por exemplo, na formação dos timorenses na pós-graduação stricto senso no âmbito da educação. Cada timorense que retorna ao país como mestres e doutores depois dessas formações funcionam como agentes de multiplicação das ideias "exóticas" às realidades locais.

O discurso formal globalizante busca uma uniformização de padrões educacionais onde seja possível comparar sistemas educacionais e sua eficiência com parâmetros semelhantes. Neste sentido, há a necessidade de igualar os desiguais, ainda que as realidades culturais, sociais e ambientais, sejam diversas. É pela atuação de organismos internacionais que aferem a qualidade da educação entre os países com seus instrumentos homogêneos, como o faz a já mencionada OCDE pelo exame do PISA, que se reafirma a ideia de atraso e avanço nos sistemas educacionais. Quem estiver muito aquém dos parâmetros construídos como padrões de qualidade e não consegue pontuar dentro dos parâmetros exigidos, são relegados ao final do ranking como possuidor de educação sofrível e que precisa de incrementos para a mudança, no entanto, não se busca avaliar a eficiência dos modelos em função das realidades locais. É o local servindo de contraponto ao global e neste sentido, o uniformitarismo do politicamente desejado como o melhor padrão mundial de educação, serve de base para uma espécie de propaganda de modelos educacionais de qualidade, em que os conceitos a serem tratados na educação local, muitas vezes estão em choque com elementos destas culturas.

Assim, buscar o entendimento do que ocorre na educação local de um país é perceber as peculiaridades culturais, os elementos exóticos que intervém nessa construção educacional, os interesses que determinam a ênfase nas reformas educacionais, a possibilidade de até visualizar o futuro que virá em função do empreendimento do presente.

Compreender a educação em ciências do Timor-Leste, embasado nos parâmetros bibliográficos da qualidade ocidental é limitar a análise ao próprio olhar, ao próprio repertório 
de indivíduo iniciado em suas próprias concepções de qualidade determinado por um mecanismo maior de replicação de ideias.

Quando se observa o ponto de partida da educação timorense a partir do seu passado de um modelo excludente, voltado para a formação de uma elite local composta pelos filhos dos nobres liurais e seus coligados, percebe-se que os padrões atuais inclusivos representam mudanças e avanços nestes padrões e que o modelo implantado pelas colaborações estrangeiras é eficiente neste sentido. Mas, é cabível aqui salientar que o encaminhamento para modelos globalizantes atende à regra da educação como mercado. Propostas prontas, aferidas e respaldadas pela pesquisa científica, propagadas e difundidas a exaustão nas revistas de divulgação científicas da área, que, diga-se de passagem, possivelmente, não aceitam visões divergentes daquela que é o padrão uniforme dos seus parâmetros, funcionam como o filtro necessário para a aceitação do que deve ser visto como correto.

Trazendo a temática para próximo da realidade brasileira, um exemplo disso é o que nos apresenta Beech (2012) quando cita a absorção do discurso educacional global pelos sistemas educacionais brasileiro e argentino na década de 1990 que conduziu a profundas reformas nestes sistemas educacionais e ao estabelecimento de novas ideias e práticas em educação, contribuindo para a limitação do surgimento de outras maneiras de pensar a educação, bem como suas práticas e outros modos de ação. No entendimento de Beech (2012, p. 422-423),

\begin{abstract}
As ideias e práticas que podem ser incluídas no discurso educacional global implicaram uma ruptura significativa com o tipo de educação até então oferecida na Argentina e no Brasil. Por exemplo, durante as décadas de 1980 e 1990, as agências internacionais promoveram uma educação baseada no desenvolvimento de competências. Esse tipo de educação é muito diferente da definição enciclopédica tradicional de conhecimento nos sistemas educacionais do Brasil e da Argentina, países nos quais a educação baseava-se na transmissão de fatos e informações que o estudante deveria memorizar. Sendo assim, considerando essas diferenças, não se tratava apenas de ver alguns aspectos desses sistemas de ensino como ineficientes. A ideia era que esses sistemas deveriam ser inteiramente modificados, e o modelo a ser seguido era o modelo universal de educação para a era da informação, promovido pelas agências, baseado nos princípios de descentralização, de autonomia escolar, de profissionalização dos professores, de currículo baseado em competências e de estabelecimento de sistemas centrais de avaliação.
\end{abstract}

Todavia é de se pensar, que por mais que essas mudanças implementadas sejam pensadas racionalmente como as melhores diante dos parâmetros tidos como tradicionais de educar, resta saber se a implementação de mudanças pelos novos parâmetros das agências internacionais foi operada dentro dos padrões exigidos, ou não passaram de arremedos para o atendimento de determinações legais nacionais em função de reformas. No corpo desse pensamento, ainda é possível conjecturar sobre se de fato houve mesmo as mudanças 
pretendidas nos modelos tradicionais de educação baseado no memorístico e na repetição para um modelo mais centrado nos pretendidos por padrões globalizantes, ou se houve apenas adaptações que na aparência atendem a adesão a estes parâmetros, mas, permaneceram no tradicionalismo do passado.

Atentando para os dados obtidos em teste internacionais como o PISA em que o Brasil se destaca negativamente nestas aferições rotineiras no campo das ciências, matemática e linguagem, é de se encaminhar para duas vias de compreensão: ou o padrão globalizante pretendido internacionalmente como modelo educacional no Brasil não foi realizado adequadamente permanecendo o país no seu antigo modelo tradicional, atestando uma falha sistêmica que passa pela formação básica de professores nas instituições de nível superior, bem como na formação continuada, à ineficiência dos regulamentos legais, ou de fato, se pensarmos na realização adequada desses projetos por seus diversos atores, o modelo é ineficiente também.

Para nos aproximarmos de uma explicação para o exposto acima, também recorremos a Beech (2012, p. 423) para apontar que,

\begin{abstract}
as mudanças significativas da década e 1990 na Argentina e no Brasil, no nível da retórica oficial, não se traduziram necessariamente em práticas. Pelo contrário, como apontaram alguns educadores entrevistados, na Argentina e no Brasil, a implementação do modelo universal de educação promovido pelas agências internacionais encontrou resistência, reinterpretações e uma série de problemas práticos inesperados.
\end{abstract}

Porém, essas resistências se devem ao quê? Ao papel do professor na sua baixa adesão em função de fatores que vão da sua formação à carência dos instrumentos necessários para a viabilização das mesmas? Ao descrédito dos modelos explicativos trazidos por um discurso exterior em confronto e em desacordo com as realidades locais? Ou à natural resistência das pessoas a aceitarem mansamente modelos que tentam se impor pela força? Claro que esta não é uma análise fácil de se fazer e respostas para estas indagações não passarão de uma tênue tentativa de reduzir por meios de explicações superficiais, um problema tão complexo.

Para contribuir no campo das resistências ao "novo", o que de certa forma pode auxiliar na compreensão do que também se passa no Timor-Leste, tomo aqui a liberdade em contribuir com mais uma digressão. Por experiência própria entre os anos de 2008 e 2011 quando participei da implementação de um programa de ensino de ciência no Brasil na rede pública de educação do Distrito Federal, projeto chamado de "Ciência em Foco", como supervisor de formação do Programa, pude atestar a existência de vários discursos para a não aceitação e efetivação do Programa e que podem oferecer uma superficial explicação para a 
resistência dos seus atores em colocar em prática o Programa. O "Ciência em Foco" procurou atender aos dois níveis do ensino fundamental, as séries iniciais e finais, baseava-se na "aprendizagem por investigação" (HARLEN, 2012), onde as crianças auxiliadas pelos roteiros de pesquisas, pelos conteúdos dos manuais didáticos e pelo material de apoio laboratorial, que iam de equipamentos experimentais para o suporte didático a materiais de fácil aquisição no mercado usados como material didático nas atividades do dia-a-dia em sala de aula no ensino de ciências, buscavam, em um modelo construtivista, a aquisição de conceitos fundamentais das Ciências.

A princípio o discurso dos professores para a justificativa de operacionalizar o ensino de ciências em modelos tradicionais de aula, em que os alunos passivamente são apresentados a conteúdos complexos em aulas expositivas com a utilização dos recursos tradicionais como a lousa e o giz, além do livro didático, centrava-se no argumento da falta de material de laboratório e até mesmo do próprio laboratório para um ensino mais voltado para a experimentação e investigação. Com a chegada do Programa Ciência em Foco e sua fartura de materiais e técnicas, os professores passaram a argumentar que era muito o material disponibilizado e que a organização e preparação das aulas demandavam um tempo que não dispunham para sua preparação, além de demandarem muita dedicação a estudos que antecediam as aulas e isso era inviável sem uma assistência. No entanto o Programa também dispunha de uma assistência, uma acessória a este professor pela participação de tutores que estavam sempre à disposição para auxiliá-lo no que fosse possível. No entanto, era baixa à adesão a solicitação desses auxílios e o que se via, em função da imposição do Programa pela Secretaria de Educação, eram adaptações grosseiras promovidas pelos professores para "gastar" o material disponível. Muitas vezes as aulas que eram previstas para que alunos participassem e usassem ativamente os equipamentos e os materiais investigativos, eram reduzidas a aulas demonstrativas, em que o professor sozinho operava o experimento para a assistência dos alunos.

Outro argumento para a gradual desistência na adesão ao Programa se fazia sentir no campo ideológico em que professores passaram a repetir um discurso sobre os gastos governamentais feitos na realização do Programa, como dispêndio de dinheiro que atendiam a interesses escusos dos políticos com a empresa proprietária do modelo e isso foi uma das mais poderosas argumentações para não realizar as atividades didáticas, em que os benefícios que os alunos poderiam tirar da metodologia, foram minimizados como irrisórios frente às intenções econômicas por trás do Programa como provenientes de um modelo imperialista que apenas queria "vender" para ter ganhos pecuniários uma ideia burguesa pensada para 
atrapalhar mais do que para ajudar os indivíduos nas suas aprendizagens. Algo estranho como um argumento para uma proposta que buscava apenas um incremento ao ensino de ciências para o ensino fundamental, ainda que tivesse seus custos financeiros justificados (se estima que o Programa custava R \$ 15,00 por aluno/mês) para a manutenção de toda sua estrutura.

Então, é fácil perceber também em Timor-Leste situações em que os modelos educativos são os tradicionais e os múltiplos argumentos por sua opção repetem em muitas situações o discurso situado no Brasil, como falta de recursos didáticos, dificuldade na formação continuada, e algo que não ocorre no Brasil, mas, é frequente no Timor, a dificuldade com a língua portuguesa como língua de instrução e a instabilidade das propostas curriculares em constante mudança na mesma cadência das mudanças dos políticos que se sucedem no poder pela via democrática e constitucional das eleições.

Diante disso, a apresentação dos elementos que se seguem sobre o currículo da educação básica em Timor-Leste representa apenas um instantâneo do momento em que se realizou a investigação, pois, dado a instabilidade que o currículo, em constante reforma, apresenta, não há garantia de duração para o mesmo dentro em breve.

Abaixo são expostos os elementos curriculares de todo o componente curricular denominado Estudo do Meio, embora nos anexos só conste a parte do mesmo, ainda que em tétum, em relação às ciências.

\subsection{Organização Curricular do Ensino Básico}

A escola primária do Timor-Leste, se estende do $1^{\circ}$ ao $6^{\circ}$ ano, comumente chamados pelos timorenses de "classe" e se divide em dois ciclos. A tabela 2 mostra a organização dos componentes curriculares e sua carga horária, observe-se que há um gradual aumento de carga horária para a língua portuguesa com o passar dos anos. Isso, na configuração oficial, ainda vigente, mas, como já informado, essa carga horária para a língua portuguesa vem sendo reduzida. Não existe uma disciplina denominada "ciências" propriamente dita. No currículo, como mencionado, há uma disciplina abrangente designada "Estudo do Meio" e compreende o estudo de componentes da identidade do país, os indivíduos e a família, o espaço geográfico em um conjunto de áreas que abrange a História, Geografia, Sociologia, Civismo, saúde e os conteúdos associados às ciências naturais. 
TABELA 2 - Quadro da organização do ensino básico para o primeiro e segundo ciclos em Timor-Leste

\begin{tabular}{|c|c|c|c|c|}
\hline & \multicolumn{2}{|c|}{ Primeiro Ciclo do Ensino Básico } & \multicolumn{2}{|c|}{ Segundo Ciclo do Ensino Básico } \\
\hline $\begin{array}{c}\text { Componente } \\
\text { Curricular }\end{array}$ & $\begin{array}{c}\text { Tempo de } \\
\text { aplicação } 1^{\circ} \text { e } 2^{\circ} \\
\text { Ano }\end{array}$ & $\begin{array}{c}\text { Tempo de } \\
\text { aplicação } 3^{\circ} \text { Ano }\end{array}$ & $\begin{array}{c}\text { Tempo de } \\
\text { aplicação } 4^{\circ} \text { Ano }\end{array}$ & $\begin{array}{c}\text { Tempo de } \\
\text { aplicação } 5^{\circ} \text { e } 6^{\circ} \\
\text { Anos }\end{array}$ \\
\hline $\begin{array}{l}\text { Linguagem } \\
\text { Português } \\
\text { Tétum }\end{array}$ & $\begin{array}{ll}8 \\
3\end{array}$ & $\begin{array}{l}4 \\
4\end{array}$ & $\begin{array}{l}5 \\
3\end{array}$ & $\begin{array}{l}8 \\
6\end{array}$ \\
\hline Matemática & 5 & 5 & 5 & 5 \\
\hline $\begin{array}{l}\text { Religião } \\
\text { (opcional) }\end{array}$ & 1 & 1 & 1 & 1 \\
\hline Estudos do Meio & 7 & 7 & 7 & 7 \\
\hline Educação Física & 2 & 2 & 2 & 2 \\
\hline Artes e Cultura & 2 & 2 & 2 & 2 \\
\hline $\begin{array}{l}\text { Número total de } \\
\text { períodos }\end{array}$ & $\begin{array}{l}24 \text { períodos de } 50 \\
\text { minutos cada }=20 \\
\text { horas por semana }\end{array}$ & $\begin{array}{l}24 \text { períodos de } 50 \\
\text { minutos cada }=20 \\
\text { horas por semana }\end{array}$ & $\begin{array}{l}24 \text { períodos de } 50 \\
\text { minutos cada }=20 \\
\text { horas por semana }\end{array}$ & $\begin{array}{l}24 \text { períodos de } 50 \\
\text { minutos cada }=20 \\
\text { horas por semana }\end{array}$ \\
\hline
\end{tabular}

Fonte: MEYCS. (2004), p. 17.

\subsubsection{Abordagem curricular no Estudo do Meio da escola primária - $1^{\circ}$ ano}

No $1^{\circ}$ ano, a criança é introduzida a identificar-se como indivíduo, portador de diferenças que lhe permite compreender-se menino ou menina, com nome e ligado a uma família. Percebe que os indivíduos à sua volta também são possuidores de identidades nomes e sobrenomes que os ligam a outras famílias. Há uma valorização acentuada na percepção da construção da identidade, com elementos que o identificam, tais como nomes e sobrenomes, datas de nascimento de todos os membros da família, dos colegas, para que a criança entenda que há uma série de particularidades de cada um que pode ser acessada em seu conjunto, atribuindo-lhe uma personalidade, uma identidade.

Essa preocupação com a identidade individual e coletiva está fortemente presente no currículo e possivelmente se associa ao forte espírito de resistência tão necessário à construção da democracia do Timor-Leste. As lutas para superar as dominações que sofreu ao longo de sua história e preservar cultura e pluriliguismo do país se devem, sobretudo, a este espírito de reconhecimento das individualidades inseridas em estruturas mais amplas de fortalecimento como a família, as comunidades e o país como um conjunto concêntrico de forças que se suportam e que garantem o existir autônomo como um país democrático, possivelmente uma especificidade deste currículo.

No que tange às identidades, as crianças do $1^{\circ}$ ano também são exortadas a divisar as diferenças nas características físicas, diversidade das formas, altura, peso, cor de pele, cabelos, ao tempo que são levados a respeitar as diferenças como mais um elemento que 
fortalece a identidade individual. A valorização do indivíduo e suas particularidades buscam reforçar a ideia de que é a diversidade que permite uma maior amplidão nas aptidões de todos e isso é uma das garantias do fortalecimento do país.

Ainda em busca do fortalecimento da identidade, a criança é levada a perceber-se como sendo portadora de gostos, preferências e afinidades. Assim, pelo currículo, o professor deve estimulá-las a entender que podem gostar ou ter preferências por coisas diferentes, como comidas, animais, brincadeiras e desse modo, são introduzidas nos elementos locais, como alimentos típicos, frutos entre outros. Observa-se aqui, que neste aspecto o currículo começa a se aproximar dos elementos das ciências no seu componente biológico.

No rastro das percepções das identidades, o currículo traz o componente biológico e coloca a preocupação com o corpo ao estudar suas partes constitutivas com o intuito de formalizar a terminologia a ser aprendida em língua portuguesa, ainda que bem superficial. Nota-se também neste conteúdo, o direcionamento para os papeis e funções que cada parte do corpo representa para criança, sua importância como parte no todo. Ao se reconhecer como entidade biológica, nota-se também pelo currículo do $1^{\circ}$ ano, que a criança é estimulada a identificar de que parte do seu corpo mais gosta. Este encaminhamento se afirma na mesma linha das preferências e afinidades de cada um e procura uma ligação para o conteúdo "órgão dos sentidos", pois ao identificar-se com esta ou aquela parte do corpo, o professor deverá encaminhar essa identificação para os meios de percepção, e estes por sua vez, estabelecem uma espécie de qualificação dos sentidos e sua importância na interação com o mundo.

Ao aplicar noções de percepção pelos órgãos dos sentidos, o conteúdo se dirige para os cuidados que todos devem ter com os mesmos e se busca a aprendizagem sobre os hábitos de higiene e as observações sobre a boa saúde. Há forte ênfase nesses cuidados, possivelmente, dado o grau de precariedade no sistema de saúde, saneamento básico e hábitos alimentares. Basta ver as condições de saneamento na cidade de Díli, por exemplo, com seus esgotos a céu aberto correndo para o Pacífico, lixo espalhado por todo canto e as plantações de kanku nos tabuleiros construídos com água represadas dos esgotos (Figura 4). Um aspecto pontual que se pode aqui mencionar ainda, é a recomendação de ferver a água antes de bebêla como um atributo fundamental dos cuidados com a saúde, isso reflete a falta de estruturação adequada e universal com o saneamento básico, sendo mais fácil, ao menos na situação atual, ensinar técnicas de purificação e cuidados com a água do que o investimento do Estado em uma estrutura de tratamento de água que atenda ao país. Entre os conteúdos ainda pode-se citar preocupação com os dentes e com orientações a idas periódicas ao 
dentista, a aplicação de vacinas e consulta a médicos. Dado a precariedade nestes aspectos, esses conteúdos aparecem de modo formal apenas.

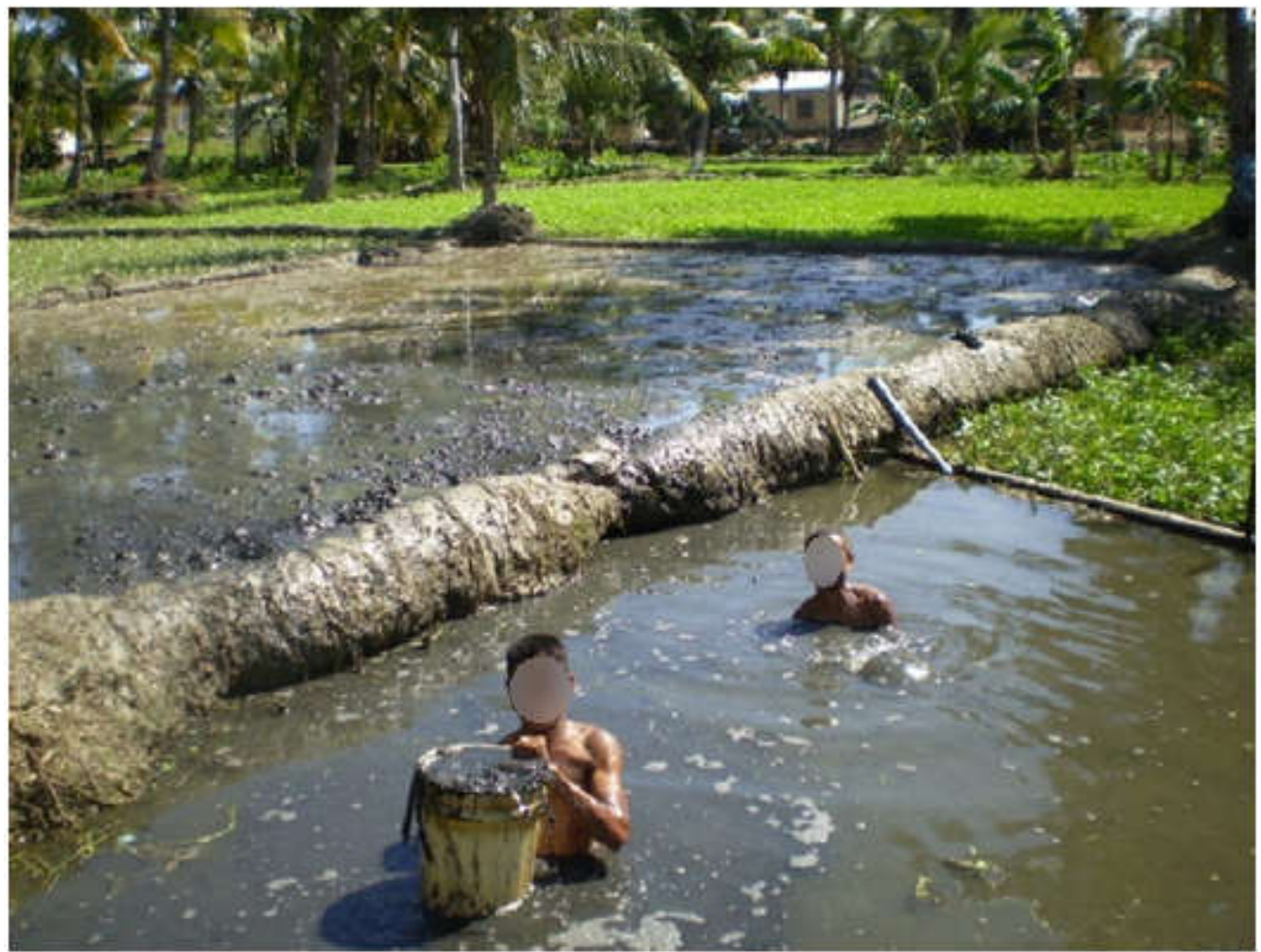

FIGURA 4 - Foto de plantação de kanku em Díli - tabuleiro feito com esgoto represado

Outro elemento presente no currículo sobre o Estudo do Meio é o reconhecimento da estrutura familiar. Seus componentes, a valorização dos seus nomes, os locais de origem no país, os papéis bem delimitados sobre cada membro da família quanto à profissão que exercem, procurando valorizar as profissões mais comuns na cultura timorense, tais como os vendedores ambulantes de peixe, os agricultores, os fabricantes e comerciantes de tais ${ }^{42}$, sem deixar de reconhecer, no entanto, outras profissões como professores, médicos e enfermeiras, entre outras. Ao inserir a família como um ponto básico de suporte da cultura timorense, se estabelece também contato com o lugar em que a família habita, sendo a casa e sua estrutura, conteúdo previsto. Nesse sentido, buscando respeitar os recursos diferenciados de cada família, que permitem a esta ou a aquela ter casas diferenciadas, as crianças são estimuladas a reconhecer a diversidade de habitações em função de vários aspectos. Outro aspecto associada à habitação, está ligado à valorização das chamadas "Uma Lulik"43, muito valorizada na cultura timorense por sua tradição ancestral e por suas cerimônias. Todavia, mesmo na

\footnotetext{
${ }^{42}$ Espécie de estola ritual que é usada em diversas cerimônias ou para saudar pessoa que se lhe tem apreço.

${ }^{43}$ Casas sagradas são casas características timorenses, construídas segundo regras bem específicas, sendo lugares onde se guardam os objetos sagrados das aldeias.
} 
diversidade que se pode verificar nas habitações, as crianças são chamadas a perceber as funções de cada parte das casas e neste aspectos há semelhanças ao se identificar os espaços comuns das habitações das famílias, conferindo um senso de igualdade funcional a todas.

Sobre o domínio da família, neste componente curricular são estudados os animais domésticos. As famílias timorenses, por uma questão de hábito, ancestralidade, necessidades alimentares, sempre possuem animais domésticos, sendo muito comum na cidade de Díli a presença de porcos, cães, gatos e galinhas, ainda que no campo as famílias também convivam com outros animais domésticos como búfalos, outros animais não domesticados fazem parte do ambiente timorense como crocodilos por exemplos.

Outro conteúdo presente neste currículo do $1^{\circ}$ ano diz respeito ao espaço escolar. Os alunos aprendem a reconhecer os domínios da escola e suas funções, tais como a sala de aula, sala de professores, a área para o recreio, as casas de banho (sanitário), etc. Neste sentido, os materiais escolares são percebidos como instrumentos que facilitam a aprendizagem e devem ser acondicionados nos espaços adequados de modo a acessá-los facilmente sempre que necessário. As crianças também são apresentadas ao papel dos componentes da escola, o professor, os alunos, os trabalhadores da limpeza, etc. Percebe-se ao longo de todo o currículo, uma preocupação centrada nas funções de cada um e a importância dos papéis que desempenham.

Em um crescente de ampliação sobre o estudo do meio, partindo-se inicialmente do indivíduo, depois para a família, chega-se à comunidade e suas instituições. Aqui mais uma vez, o currículo enfatiza a realidade das profissões mais comuns no Timor, os mercadores de peixe, os artesãos construtores de tais, policiais, professores, padeiros, médicos, etc. (figura 5), para que as crianças se sintam representadas pelas profissões dos seus pais. Enfatiza-se o papel de cada profissão, quais instrumentos de trabalho utilizados e o que produzem quando for o caso, o local onde exercem suas atividades, quem exerce cada profissão, se a profissão garante o futuro ou não, nota-se aqui certa distinção nas profissões por grau de importância, embora haja a preocupação em mostrar que todas são relevantes ao prestar-se a papéis específicos, sempre se evidencia que pelo estudo e qualificação, o indivíduo pode alcançar profissões mais importantes, evidenciando um caráter utilitarista do currículo. 

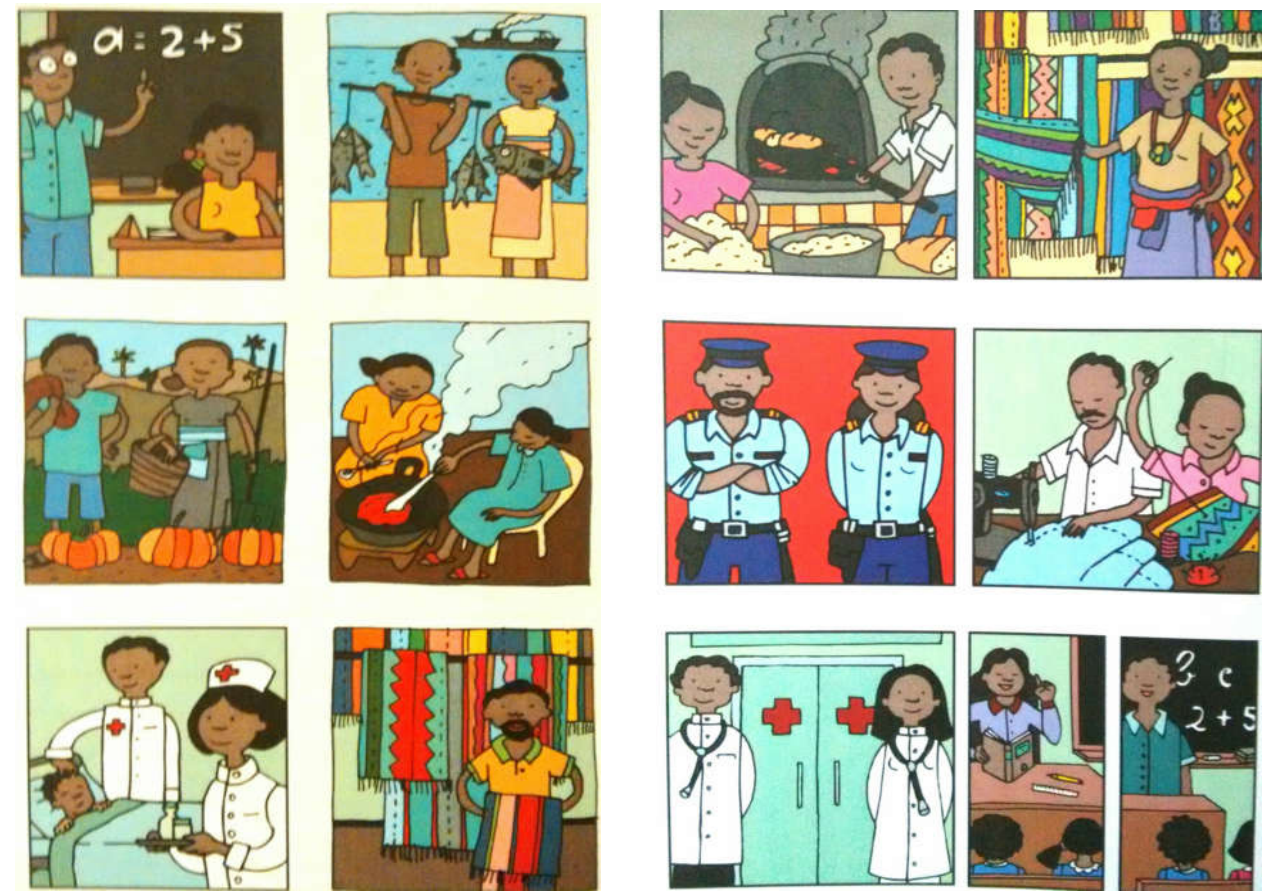

Figura 5. Imagens mostrando algumas profissões no Timor-Leste retirada de livro didático oficial (Estudo do Meio - $1^{\circ}$ Ano do Ensino Básico. Porto: Ed. Porto, 2012. p. 36 e 58.)

Identificadas as profissões como funções que são desempenhadas na sociedade, são estudadas as instituições e os serviços locais, desse modo, procura-se a organicidade das comunidades como lugares que se prestam serviços em espaços específicos, hospitais, centros de saúde, escolas, departamentos de polícia, corpo de bombeiros, mercado, hotéis, Correios, sede do suco, etc. Na organização das instituições, a criança é levada a compreender a organização do espaço urbano, aprendendo noções espaciais do que está à direita, à esquerda, à frente, atrás, assim como, identifica aquelas instituições públicas ou privadas existentes no entorno dos lugares onde residem. Neste estudo espacial a criança é levada a compreender que estes espaços podem ser representados em diagramas, sendo introduzidas na produção e reconhecimento de mapas. São ainda estimuladas a observarem o trajeto que fazem para chegar à escola, buscando reconhecer instituições existentes naquela comunidade.

Após essa ampliação a criança é apresentada aos conteúdos sobre sua inserção no ambiente natural. Este por sua vez, está sujeito ao estado do tempo e para entender isso, são levadas a perceber que há dias diferentes, alguns com chuva, outros muito secos e ensolarados, alguns muito quente, outro menos quentes e essas variações permitem a realização de atividades diferenciadas. A criança toma contato com o entendimento de que as variações das condições climáticas se devem a fatores como as estações do ano e no conteúdo, centrado na realidade timorense, se evidencia a existência de duas estações apenas para o Timor, a estação das chuvas e a estação seca, sem evidenciar a terminologia normalmente 
adotada quando o assunto é estação do ano: primavera, verão, outono e inverno. Todavia, para se identificar estas duas estações, é estudado o calendário, os meses do ano, evidenciando no mesmo as datas marcantes para cada um, como aniversário, Natal, Ano Novo. O calendário é estudado como um conjunto de dias que compõem um conjunto de meses e por sua vez constitui o ano. A unidade dia é dividida nos três períodos, manhã, tarde e noite, sendo percebidas pelas atividades que a criança realiza em cada uma delas. Neste aspecto começam a estudar os fatores que determinam estas mudanças, como os movimentos da Terra.

O estudo do meio para o $1^{\circ}$ ano finaliza com a percepção da criança sobre o local onde vive. As particularidades da paisagem, o tipo de atividade que a comunidade desempenha, se a pesca, o plantio de arroz, criação de búfalos, ou mesmo a paisagem urbana das cidades, enfim, o currículo procura integrar traços da realidade timorense, na perspectiva de inserção no mundo.

\subsubsection{Abordagem curricular no Estudo do Meio da escola primária $-2^{\circ}$ ano}

Seguindo a mesma abordagem já observada para o $1^{\circ}$ ano, o currículo do $2^{\circ}$ ano contempla os elementos que identificam o indivíduo em um reforço para o estabelecimento de uma identidade pessoal inserida em uma comunidade. A criança é levada a perceber sua importância no mundo como um ser possuidor de preferências em todos os sentidos, que deve ser respeitada nestes elementos afetivos, mas que está em constante mudança, no aspecto físico em função do seu crescimento e nos aspectos mental e intelectual, haja vista que as preferências podem mudar também, sendo a escola o lugar de convivência social e de diversidade em que as individualidades garantem a riqueza da sociedade. Nota-se no currículo neste aspecto, a necessidade de integração e fortalecimento de laços.

As preferências individuais continuam perpassando o currículo, e mais uma vez, busca reforçar nas crianças o reconhecimento das diferenças a partir desses elementos que fortalecem a individualidade, ao mesmo tempo, tenta encaminhar para um conjunto de características da cultura timorense. Na parte introdutória do currículo do $2^{\circ}$ Ano, pode-se notar a ênfase nas etapas do crescimento. A criança deve perceber-se como um ser em transformação, reconhecendo em si e nos colegas alterações biológicas que se refletem nestas mudanças externas, como aumento da estatura e do peso.

Neste ritmo, o currículo traz mais uma vez a inserção do indivíduo na sua família, agora mediada pelas observações da criança sobre mudanças também no seio familiar, apresentando noções, ainda que superficiais, da árvore genealógica. Identificando os componentes familiares a partir dos avós maternos e paternos até sua localização dentro da 
unidade familiar. Este aspecto procura o fortalecimento dos laços familiares e o estabelecimento da sensação de "pertencimento" a núcleos sociais que irão, em um crescente, formar a identidade timorense.

Em relação ao estudo do espaço escolar, as crianças reforçam o que já haviam estudado no $1^{\circ}$ Ano e avançam em outros aspectos, como a compreensão da estruturação de horários para atividades e para as aulas ao longo da semana, reafirmando a noção de tempo e rotinas, assim como, são introduzidos elementos como o trabalho com projetos dentro do espaço escolar, com o intuído de fortalecer a necessidade de organização como essencial para a aprendizagem e ampliação das capacidades. No mesmo ritmo, marcado pelas mudanças pessoais e pela ampliação da compreensão do espaço escolar, a criança é levada a perceber também as variações do tempo ao longo do período semanal de aula, as variações do clima, da temperatura, dos ventos e chuvas. Embora o timorense tenha o firme entendimento das duas estações marcantes do Timor, compreende a existência de variações dentro destes períodos, entendendo o tempo como fundamental no estabelecimento de atividades voltadas para a pesca, como as condições de maré e lunação, para agricultura, entre outros. Nesta etapa da escolarização, procura-se também a assimilação de variações de número de dias nos meses do ano, retomando as noções de calendário já vistas no $1^{\circ}$ ano. São ampliadas as noções de movimentos da Terra em torno do Sol para marcar essas diferenciações, estabelecendo as primeiras noções de hora e suas frações.

Ao explorar o espaço do entorno do indivíduo, o currículo volta-se também para o próprio corpo e re-explora os órgãos dos sentidos mais uma vez, ampliando o conhecimento das crianças sobre as especificidades de cada órgão, seus cuidados, suas características, suas particularidades na percepção do ambiente por variadas vias. Do ponto de vista biológico, o estudo dos órgãos dos sentidos se restringe a esta caracterização, sem um aprofundamento nos constituintes anatômicos. O encaminhamento que o estudo segue guia os estudantes para os cuidados com a saúde e mais uma vez foca na higiene do asseio pessoal e na importância de banhos diários (ver representação da figura 6 de um livro didático), dos procedimentos do antes e do depois das refeições e hábitos higiênicos ao utilizar-se dos sanitários. Reforça aqui a ideia do auto-cuidado no aspecto da saúde como primordial em função da precariedade da assistência à saúde como um todo. No entanto, como mencionado, percebe-se ainda hoje em uma cidade como Díli, a falta de cuidados com o esgotamento sanitário e no destino do lixo. 
A alimentação é levada em consideração no aspecto saúde, e a ênfase na diversidade reflete uma preocupação do currículo com o bom estado físico das crianças. Os aspectos preventivos são evidenciados sobre os curativos, e os cuidados já tratados no $1^{\circ}$ Ano são ampliados no $2^{\circ}$ Ano, tais como cuidados com os dentes que pelo currículo já deve ser mostradas noções da dentição de leite e permanente, bem como o período em que a primeira
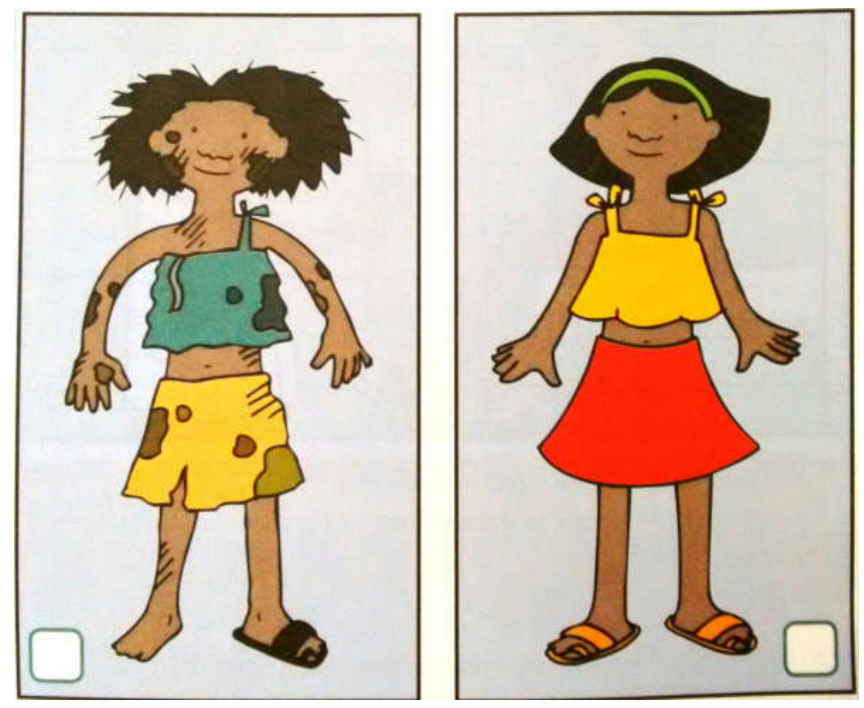

Figura 6. Imagem que solicita da criança a identificação do padrão aceitável de asseio pessoal, retirado do Livro Didático oficial (Estudo do Meio - $2^{\circ}$ Ano do Ensino Básico. Porto: Ed. Porto, 2012. p. 62.)

dentição começa a cair. Sobre a importância da vacinação o currículo enfatiza que as mesmas ajudam a prevenir as doenças, mas não são curativas, aspecto fundamental na manutenção da saúde.

$\mathrm{Na}$ abordagem do currículo no aspecto do conhecimento da comunidade, a criança é levada, mais uma vez, a ampliar seus conhecimentos sobre as instituições e os serviços locais, devendo identificar o itinerário que percorre da sua casa à escola, percebendo as instituições que estão no trajeto e a relação de proximidade entre elas, bem como, noções de coordenadas muito simplórias, como o que está à direita, ou à esquerda, à frente ou atrás e um determinado referencial, o reconhecimento do nome de logradouros da sua própria casa, do trajeto que faz e da sua própria escola. Ao reconhecer o percurso realizado, o currículo evoca o reconhecimento de algumas instituições presentes na comunidade, seu papel, quem exerce os serviços que são prestados à sociedade como um todo, evidenciando a importância dos serviços públicos como um direito de todas as pessoas da comunidade. 
O currículo de $2^{\circ}$ Ano também evidencia aspectos associados ao clima de TimorLeste, reforçando a ideia das duas estações marcadamente presentes no ano. Mas, avançando na compreensão de que o clima é determinante para a presença de fauna e flora adaptada ao Timor. O currículo assim prevê o tratamento dos aspectos físicos do meio local que caracterizam a fauna, procurando esclarecimento sobre as diferenças entre animais selvagens e domésticos, bem como a gênese dos animais domésticos a partir dos selvagens em função das necessidades agrícolas e pastoris dos homens do passado.

A abordagem dos aspectos biológicos da fauna é bem mais abrangente no currículo do $2^{\circ}$ Ano, compreendendo noções de habitat, alguns aspectos de nicho ecológico, bem como comportamento dos animais no que concerne a alimentação com noções introdutórias de cadeia alimentar, movimentação dos organismos, etc., fazendo-se também alusão aos tipos de revestimentos corporais dos animais.

São previstos no currículo para o conhecimento da flora, a aprendizagem sobre os elementos ambientais essenciais para o surgimento dos vegetais, como o estudo dos solos, água, da luz solar. O currículo também evidencia a importância no estudo da anatomia

vegetal, pelos componentes externos das plantas, folha, flor, caule, raiz, frutos e sementes. No que concerne à diversidade dos vegetais, mais uma vez se procura associar às condições climáticas e aos diversos meios onde as plantas se encontram, fazendo-se uma abordagem superficial na classificação como sendo aquática e terrestre. Nota-se também uma preocupação sobre o papel das plantas para vida do homem por fornecer a alimentação necessária por meio do seu cultivo, bem como a utilização das mesmas para habitação, vestuário etc., permitindo outra classificação como sendo as plantas cultivadas e as plantas espontâneas.

\subsubsection{Abordagem curricular no Estudo do Meio da escola primária - $3^{\circ}$ ano}

No $3^{\circ}$ ano, de modo semelhante aos anteriores, há o reforço da identidade, agora no campo da naturalidade timorense, juntamente com o reconhecimento das divisões do território em sucos, subdistritos e distritos, reafirmando que a naturalidade é conferida pela identificação do suco, do subdistrito e do distrito de origem de cada um. Pelo currículo a criança deve ser apresentada ao mapa político do Timor-Leste para a identificação espacial do seu lugar de origem. Neste sentido, este reconhecimento reafirma o senso de pertencimento à nação, já que as crianças também tomam contato com o conceito de nacionalidade se 
identificando como timorense, bem como reconhece a existência de outras nacionalidades no mundo.

No âmbito das ciências, a criança toma contato mais detalhadamente com as funções vitais do corpo, reconhecendo quatro dessas funções, a digestiva, a respiratória, a circulatória e a excretora. Ainda que superficialmente, deve o professor ampliar o conhecimento das mesmas sobre o funcionamento de cada um desses sistemas e suas partes constitutivas. Para o sistema digestório, a criança além de reconhecer sua anatomia, deve aprender hábitos alimentares higiênicos antes e após as refeições, entender a importância de dietas balanceadas com variedade de alimentos, substâncias nutritivas, importância da hidratação, entre outros.

Quanto ao sistema respiratório as crianças devem aprender os movimentos que permitem a renovação do ar ou ventilação pulmonar, as estruturas anatômicas componentes do sistema, e a função de cada uma. No estudo destes sistemas, são apresentadas as primeiras noções sobre os gases envolvidos no processo, como o oxigênio, o dióxido de carbono e o vapor d'água. Como no estudo do sistema digestório, os estudantes tomam contato com os cuidados que devem observar em relação ao sistema respiratório para a preservação da saúde, como evitar-se, por exemplo, o hábito de fumar, livrando-se de ambientes fechados onde pessoas estejam fumando. Este é um aspecto interessante do currículo, já que reflete uma preocupação com a saúde futura das crianças, pois na sociedade timorense o tabagismo é um hábito corriqueiro nas mais variadas faixas etárias.

O sistema circulatório também deve ser estudado na perspectiva dos seus componentes anatômicos e suas funções, como o coração, as artérias as veias e os capilares sanguíneos e seus respectivos papéis na circulação do sangue. Procura-se associar a função da circulação dos outros sistemas anteriores, o digestório e o respiratório, já que pela circulação se transporta elementos que penetraram no corpo por aqueles sistemas. Como anteriormente, alem do estudo morfofisiológico as crianças devem compreender os cuidados com a saúde do sistema circulatório, como a prática de esportes, evitar alimentação gordurosa e com abuso de sal, a ingestão de bebidas alcoólicas, etc.

Estuda-se o sistema excretor na mesma perspectiva dos anteriores, os componentes e suas respectivas funções. Os órgãos ganham muita relevância no reconhecimento que as crianças devem fazer. Para seu estudo o professor deverá conectar as funções do sistema circulatório com o excretor para proporcionar o entendimento do papel filtrador deste sistema. É observada também a importância que se deve dar à hidratação corporal para o adequado funcionamento do sistema e os cuidados que se deve dispensar ao mesmo. Ampliando ainda mais o tema, estão pontos associados à excreção de impurezas do corpo, não só pela via renal, 
mas por outras vias como a sudorese pela pele, evidenciando o papel das glândulas sudoríparas.

No que tange ao conhecimento da família no $3^{\circ}$ Ano, a criança é levada a entender as semelhanças que membros de uma mesma família apresentam e por meio da ampliação da árvore genealógica pode perceber quais os membros da família se parecem mais entre si. Mesmo associando as semelhanças, as crianças reforçam sua compreensão sobre sua identidade como sendo particular, mas, que pela interação com seu núcleo familiar adquirem conformações de conjunto, sendo a história dos antepassados e dos pais, elementos fundamentais para a preservação da identidade familiar.

Nos estudos da comunidade, a criança é levada a compreender que faz parte de estruturas sociais como a escola primeiramente, e nela pode desempenhar papéis como na organização de materiais para auxiliar o professor, registro do tempo, entre outras atribuições. Ao ter estudado a naturalidade, passa a perceber os colegas nesta ótica. Cada pessoa pode ter origens que os identifica a lugares, línguas e hábitos culturais diferentes. Compreende também que os membros das comunidades exercem profissões diferentes e as ocupações representam atividades econômicas que garantem o sustento financeiro. Também nesta etapa, são reforçados os conhecimentos já adquiridos nos anos anteriores sobre as instituições presentes na comunidade.

No terceiro ano, as crianças tomam contato com os elementos associados à identidade timorense no aspecto territorial, cultural, simbólico. As crianças devem conhecer dados oficiais sobre o Timor-Leste como nome oficial, nome local, clima, capital, número de distritos, subdistritos e sucos, línguas oficiais e línguas de trabalho, religiões, etc. No aspecto cultural, algumas lendas devem ser conhecidas como, por exemplo, a lenda do crocodilo que da origem à ilha ${ }^{44}$, além de costumes e tradições como o barlaque ${ }^{45}$, a briga de galos, produção de tais e o desluto são alguns elementos culturais que devem ser estudados.

\footnotetext{
${ }^{44}$ Lenda de Timor-Leste: Conta a lenda que, há muito tempo, um crocodilo muito velhinho vivia numa ilha da Indonésia chamada Celebes. Como era muito velho, o crocodilo não tinha forças para apanhar peixes. Estava quase a morrer de fome. Então, resolveu ir procurar, em terra, um animal para comer. Andou, andou, e, como não encontrou nada para comer, ficou sem forças para regressar á água. Um menino, que por ali passava, encontrou o crocodilo cansado e, com pena dele, resolveu ajudá-lo. Pegou-lhe pela cauda e arrastou-o até à água. Agradecido, o crocodilo disse ao menino que o levava a passear pelas águas do mar sempre que ele quisesse. O menino aceitou e, a partir daquele dia, fizeram muitas viagens juntos. Tornaram-se grandes amigos! Mas... Certo dia, o crocodilo, com muita fome, pensou em comê-lo. Resolveu perguntar aos outros animais o que achavam da ideia. Todos lhe disseram que ele estava a ser muito mau, porque queria comer o menino que lhe tinha salvado a vida. O crocodilo percebeu que estava a ser injusto e ficou com vergonha. Decidiu ir para longe e pediu ao menino que fosse com ele. O menino aceitou. Saltou para cima do crocodilo e seguiram viagem pele mar. Depois de muito andar, o crocodilo começou a sentir-se cansado. Resolveu parar para descansar, mas o seu corpo transformou-se em pedra e em terra. Cresceu tanto que ficou do tamanho de uma ilha em forma de crocodilo. O menino passou a ser o primeiro habitante da ilha. Apareceu, assim, a ilha de Timor-Leste! Terra do Sol Nascente.

${ }^{45}$ Casamento ou contrato de matrimônio, segundo os usos e costumes tradicionais, em que se assiste a uma troca de bens de valor equivalente entre as famílias dos noivos. A família do noivo deverá dar búfalos, cavalos e belak (medalhão timorense de grandes dimensões), enquanto que a família da noiva oferece porcos, tais e mortén (colar de coral raro de grande valor).
} 
Quanto aos símbolos nacionais, as crianças timorenses devem conhecer os significados da bandeira nacional (ver figura 7). Aprender o hino nacional e reconhecer o emblema nacional designado Belak (ver figura 8).

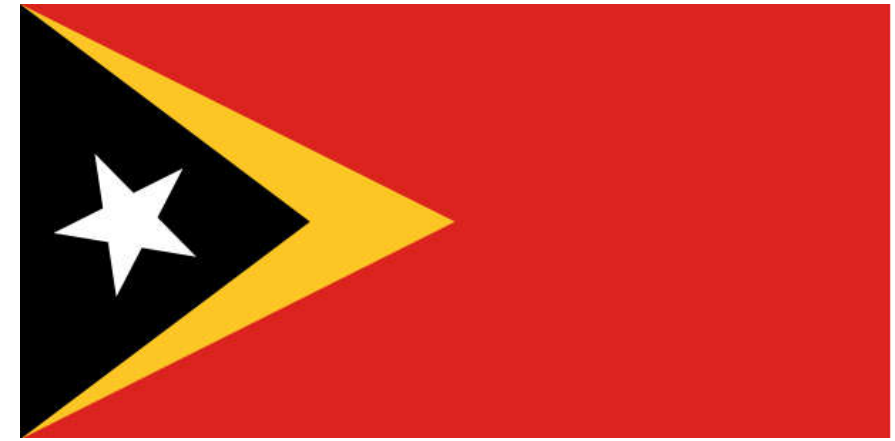

Figura 7. Na bandeira de Timor-Leste, o amarelo representa os rastros do colonialismo, o preto o obscurantismo que é preciso vencer, o vermelho a luta pela libertação nacional e o branco a paz.

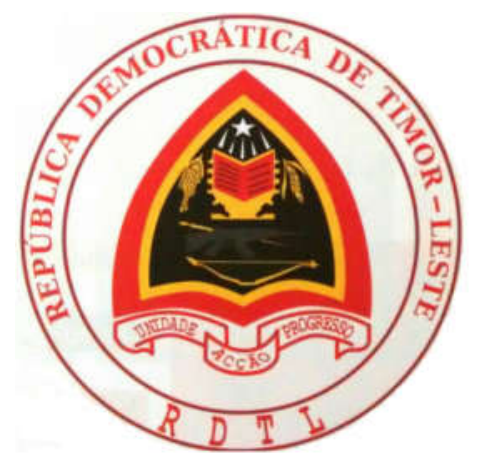

Figura 8. Belak (globo terrestre onde se inclui o território de Timor-Leste, símbolo da unidade nacional) Emblema Nacional de Timor-Leste

Outros aspectos que são tratados no $3^{\circ}$ Ano diz respeito às fronteiras nacionais. As crianças devem observar em mapas a localização do Timor-Leste e compreender que o país possui fronteira terrestre com a Indonésia e fronteiras marítimas com Indonésia e Austrália.

Pelo estudo do ambiente natural a criança deve reforçar o que já estudou nos anos anteriores relativo aos aspectos climáticos de Timor e suas variações, além de ser introduzida em conceitos associados a desastres naturais, tais como vendavais, ciclones, tufões, terremotos, tsunamis, entre outros. Neste sentido, também deve conhecer alguns instrumentos utilizados na meteorologia, como termômetros e pluviômetros.

Nesta série, também estudam o relevo de Timor-Leste e suas diversas formas e aprendem e identificar o que seja ilha, planície, serra, vale, planalto e montanha, reconhecendo os pontos culminantes de Timor, como o monte Ramelau e o monte Matebian. São previstos também o estudo dos meios aquáticos importantes existentes no país, como as ribeiras e as águas termais. 
Em relação à fauna, os conteúdos já vistos nos anos anteriores são ampliados e as crianças têm noções iniciais sobre ciclos de vida e classificação biológica, cadeias alimentares, onde aprendem classificar os animais em herbívoros, carnívoros, granívoros, omnívoros e insetívoros, além de aprofundamento no que tange a habitat e nicho ecológico.

São apresentadas também noções, ainda que superficiais, sobre reprodução, estabelecendo a classificação dos animais como ovíparos e vivíparos. Sobre outros hábitos de seres vivos, evidenciam-se os meios de deslocamento dos animais e revestimento corporal. Por último, no que se refere aos animais, são apresentadas noções amplas sobre a classificação biológica dos animais vertebrados e invertebrados.

No campo da botânica o currículo amplia os conteúdos já tratados nos anos anteriores e os órgãos vegetais são estudados quanto ao tipo de raiz, caule, folhas, flores e frutos, bem como os fatores importantes que contribuem para o crescimento dos vegetais.

\subsubsection{Abordagem curricular no Estudo do Meio da escola primária - $4^{\circ}$ ano}

Também aqui, o currículo do $4^{\circ}$ Ano no que se refere ao "Estudo do Meio" evidencia a importância da identidade dos indivíduos e reforça o valor da família, ampliando noções da história familiar, das árvores genealógicas, das naturalidades dentro da ilha de Timor.

Outros conteúdos já tratados são ampliados no $4^{\circ}$ ano como os relacionados ao tempo, dia e calendário, buscando entender a organização dos meses ao longo dos 365 dias do ano determinado pelo movimento de translação e rotação da Terra e para isso também são estendidos conhecimentos sobre as horas e suas frações.

No que se refere ao corpo humano, todos os conteúdos dos sistemas fisiológicos estudados no $3^{\circ}$ Ano são revistos de maneira amplificada, com maior detalhamento, além dos cuidados que se deve ter para com o organismo de modo geral.

No que tange às inserções dos indivíduos na sociedade, os conteúdos relacionados, apresentam os direitos e os deveres de todos, começando pelo espaço escolar onde aprendem as regras de convivência e comportamento em coletividade, se estendendo para a comunidade. Aqui também a criança é levada a compreender a importância do planejamento para execução de projetos, bem como avaliar-se de modo a verificar se os objetivos dos projetos foram atingidos. No campo das profissões, as crianças são levadas a projetar o que deseja ser quando adultos, diante das profissões no Timor que lhes foram apresentadas ao longo dos anos anteriores. 
No rastro das profissões e no campo do trabalho, se associam as diversas atividades desempenhadas pelos membros da sociedade com os aspectos econômicos do Timor-Leste, encaminhado conteúdos ligados a agricultura, indústria, comércio, artesanato, entre outros.

Compreendendo-se como um membro da sociedade, com deveres e direitos, as crianças mais uma vez são levadas a associar as instituições com o tipo de serviços que as mesmas prestam diante das mais variadas demandas. Nesta parte do currículo, as instituições são ampliadas para esferas mais abrangentes do governo e os estudantes passam a tomar contato com a história oficial do país, dos primeiros habitantes a milhares de anos, passando pela colonização portuguesa e o domínio indonésio à independência.

Os conteúdos associados aos costumes e tradições são ampliados e os diversos distritos são estudados a partir das suas variações culturais e tradições. Posteriormente, os conteúdos inserem o Timor-Leste no mundo a partir da sua própria organização política e depois do ponto de vista geográfico no sudoeste asiático. Do ponto de vista da organização da estrutura administrativa, os conteúdos abordam a estruturação da administração, fazendo diferenciação do ponto de vista da administração formal e da estrutura administrativa tradicional. Assim, as crianças devem estudar a composição das comunidades em pequenos grupos que integram as cnuas, que em conjunto por proximidades geográficas, vão integrar os sucos que são administrados por um chefe. Ainda que existam alguns sucos independentes, a sua maioria agrupa-se em reinos ou regulados, que são regidos por liurais, os reis ou régulos.

Quanto à administração formal, os conteúdos procuram situar o Timor-Leste como uma República Parlamentarista, onde o chefe de Estado é o Presidente da República eleito por sufrágio direto e universal, com mandato de cinco anos, tendo entre suas atribuições a nomeação do Primeiro-Ministro entre os membros do parlamento eleito após as eleições legislativas.

Os conteúdos previstos no currículo sobre o ambiente natural de Timor-Leste, também amplia o que já foi visto anteriormente, e trata do relevo e dos aspectos físicos do país, situando as regiões de montanhas, planícies, vales e planaltos, além de tratar também da hidrografia onde são estudadas as ribeiras, já que inexistem em Timor rios perenes. Ainda nesse domínio, são estudados aspectos do clima e desastres naturais associados às variações climáticas da região como a monção asiática e a monção australiana, além de outros desastres associados a sismos e tsunamis.

Os aspectos biológicos, mais uma vez se ligam ao estudo da fauna e da flora, repetindo e ampliando o já visto nos anos anteriores, inserindo agora, animais e vegetais em regiões específicas na ilha, como nos manguezais, no litoral e nas formações florestais. 


\subsubsection{Abordagem curricular no Estudo do Meio da escola primária - $5^{\circ}$ ano}

No $5^{\circ}$ Ano reforçam-se o entendimento da identidade timorense e mais uma vez a genealogia de cada um é ampliada, procurando estabelecer o contato da criança com seu local de origem e dos familiares e o tempo em que cada um nasceu em seu passado, fazendo uma ligação com o tempo cronológico marcado pelos dias e pelas horas. Procura-se ampliar ainda mais as noções dos movimentos da Terra nestas definições de dia, noite, estações do ano, o ano em si, a década, o século, etc.

No aspecto biológico a criança começa a estudar o sistema esquelético, como estrutura de sustentação dos músculos que comporá o sistema locomotor e posteriormente, a pele é estudada com seu papel de revestimento. Os conteúdos da fisiologia já estudados nos anos anteriores são retomados com maior aprofundamento para o sistema urinário que já é tratado nos seus componentes com forma e funções. O currículo prevê uma atenção maior para doenças endêmicas que afligem o timorense como a malária, a dengue, a encefalite japonesa, com suas respectivas sintomatologias, profilaxia, tratamentos, etc.

No que tange aos conteúdos associados à sociologia, como anteriormente a escola é um dos pontos de partidas e nesta série são abordadas noções de participação e convivência social, como o diálogo, consenso, votação e aceitação dos resultados segundo a vontade da maioria para levá-las a compreender que uma comunidade se estabelece segundo acordos democráticos, a partir dos quais o passado da comunidade é estudado situando-as no tempo histórico e distribuindo-as geograficamente pelo Timor.

Neste particular o principal aspecto das comunidades que se deve evidenciar nesta série são as atividades econômicas locais e aí, o professor deve identificar em sua sala as procedências de cada aluno para melhor situar o aspecto econômico que mais caracteriza da comunidade. Tais como o comércio local, os sistemas de transporte principais, as culturas agrícolas, a criação de gado, o extrativismo florestal, as atividades pesqueiras, a exploração mineral, a indústria e o artesanato, atividades ligadas ao turismo e a cultura.

Os estudos sobre o país a partir das instituições e serviços nacionais são estudadas na ótica das suas constituições e o papel que exercem na sociedade a partir da oferta dos mesmos pelo Estado timorense, assim, a criança deve compreender os serviços de saúde, educação, justiça, segurança, comunicações, entre outros como um direito de todos e um dever do Estado. Ainda que pareça algo utópico atualmente, são garantias previstas na Constituição e objetivos a serem alcançados pelo Estado. Neste aspecto o currículo também prevê o estudo da organização política e administrativa da República Democrática de Timor-Leste a partir da 
sua Constituição. Assim, são estabelecidas noções sobre os princípios fundamentais, direitos e deveres, organização de poderes políticos, defesa e segurança nacional, etc.

A História do país se aprofunda e começam a estudar as navegações portuguesas e a chegada destes à ilha, o passado colonial, as particularidades da sua colonização e as eternas lutas da resistência ao colonialismo até o período mais recente, com o surgimento da FRETILIN e dos outros partidos, a independência unilateral e a invasão da Indonésia, o plebiscito de independência e a administração da ONU.

Nos elementos associados às ciências o estudo da fauna é retomado com uma especificidade maior, onde são estudados aspectos ligados a simetria corporal dos animais, revestimentos corporais ligado aos ambientes e às necessidades dos organismos, deslocamento, hábitos alimentares, onde se ampliam o papel que desempenham nas cadeias alimentares e o equilíbrio que mantém em função destes papéis de herbívoros, carnívoros, onívoros. São estudados também noções de espécie associados ao conceito de reprodução e seus tipos, se assexuada, sexuada, a participação dos gametas no processo sexuado, a impossibilidade de existir reprodução entre espécies diferentes, os tipos de reprodução (vivíparos, ovíparos ou ovovivíparos).

No que se refere ao estudo da flora, os conceitos da botânica são aprofundados e os alunos ampliam o entendimento do papel de cada órgão vegetal a partir do estudo das raízes, formas, desenvolvimento em função dos ambientes e dos nutrientes do solo e funções que desempenham. Da mesma forma o caule deve ser estudado com seu detalhamento nas funções de suporte, transportes de seiva bruta e elaborada, tipos, etc., bem como as folhas em suas diversas funções, constituição, formas e adaptações ao ambiente e o papel na fotossíntese. Também as flores devem ser estudadas na sua estrutura e seu papel reprodutivo. Aqui também o aluno deve ter noções das plantas sem flores como briófitas e pteridófitas.

No $5^{\circ}$ ano o currículo prevê também, noções de geografia a partir do estudo da superfície terrestre, seus continentes, oceanos e representações da própria Terra no globo terrestre e no planisfério, para em seguida conhecer cada continente a partir do asiático. Ainda nestes estudos do planisfério, os alunos devem associar o local da Terra e suas variações climáticas, tendo noções das zonas climáticas e os fatores que as determinam, situando por fim o Timor-Leste neste enquadramento climático.

$\mathrm{Na}$ abordagem do clima o currículo também prevê o estudo das alterações climáticas e suas consequências, associadas ao efeito estufa e seu aumento como consequência da intensa produção do gás carbônico pela atividade humana, danos à camada de ozônio, chuvas ácidas e os desastres naturais como inundações, queimadas, erosão do solo, sismos, tsunamis. 
Outro conteúdo que introduzido nesta série é o Sistema Solar que é estudado por seus constituintes, os planetas, os satélites naturais, o Sol como uma estrela, os movimentos dos planetas e especificamente dos da Terra e o que influenciam, a Lua e suas fases, bem como um maior aprofundamento que a mesma desempenha nas marés. Nesta abordagem, a Terra é também estudada no aspecto da localização geográfica e os pontos cardeais, relacionando-os à posição do Sol no nascente e no poente.

\subsubsection{Abordagem curricular no Estudo do Meio da escola primária - $6^{\circ}$ ano}

No currículo do $6^{\circ}$ ano são previstos os conteúdos associados à identidade à partir das etnias, os traços físicos, culturais, psicológicos dos indivíduos, alargando o entendimento identitário para os elementos étnicos que lhes são comuns no seio da sua comunidade. Onde a família passa a ser estudada neste componente étnico a partir dos ancestrais, introduzindo o componente tempo que deve ser ampliado para faixas cronológicas maiores como a década e o século já visualizados na série anterior.

O corpo é estudado a partir da alimentação, dos nutrientes e suas funções no organismo, culminando no estudo da pirâmide alimentar, para amplificar o papel da digestão e a função de cada órgão neste processo, ao mesmo tempo em que o integra aos sistemas respiratório e circulatório com seus componentes e funções, complementando com o estudo da excreção pelo sistema excretor e por outras vias, como a sudorese. São acrescidos a esta série, cuidados com o corpo em relação a ferimentos, hemorragias, cortes, arranhões, fraturas, queimaduras, distensões, mordeduras, picadas de animais, todos associados a prevenção e tratamento.

No $6^{\circ}$ ano a instituição escola é estudada do ponto de vista da Constituição do país e de sua importância como uma instituição social, seus compondes e o papel que cada um exerce, etc. Neste sentido deve ser estudado outras instituições a partir da análise do seu passado na comunidade local e para isso, são estudados as fontes documentais que podem esclarecer e informar a todos suas origens.

Mais uma vez se enfatiza o conhecimento das atividades econômicas locais e seus mais variados aspectos e com o detalhamento maior do que o visto no $5^{\circ}$ ano, no que se refere ao setor primário, secundário e terciário.

Com relação à História, o aluno deve ter noções da trajetória recente de Portugal para situá-lo nas motivações que levaram a Metrópole a se afastar do Timor por ocasião da Revolução dos Cravos. Neste contexto é estudado o processo de descolonização e seus componentes políticos em Timor, com uma abordagem mais ampla sobre a invasão indonésia 
a resistência timorense, os diversos massacres, até a consulta popular que originou as milícias pró-indonésia e a necessidade de intervenção da ONU e as forças de paz, culminando no processo de paz e nos governos constitucionais. $\mathrm{O}$ currículo, ainda atrelado à sua história, traz no componente de civismo um detalhamento sobre a importância dos símbolos nacionais, do Hino Nacional e o valor que o timorense deve dar a estes em função das duras lutas para alcançar sua independência.

As atividades econômicas devem ser estudadas a partir da geografia, ou seja, a predominância de cada uma nas diversas regiões do Timor e sua inserção no mundo asiático. Os países vizinhos e a influência regional de cada um. Nesta inserção de Timor no mundo, os países da CPLP (Comunidade dos Países de Língua Portuguesa) são também estudados em seus vários aspectos. Outras comunidades de países são visualizadas até a abordagem das Organizações das Nações Unidas, seu papel integrador e pacificador no mundo, bem como sua atuação histórica em Timor.

No componente biológico a fauna é estudada já dentro da classificação biológica, fazendo-se distinção entre vertebrados e invertebrados e dentro de cada filo, devem ser considerados os principais grupos. Nos vertebrados, os peixes, anfíbios, répteis, aves e mamíferos, com suas caracterizações e nos invertebrados, apenas o estudo dos artópodos (insetos, aracnídeos, crustáceos) e dos moluscos.

A botânica, como nos anos anteriores é também contemplada a partir das características das plantas e suas estruturas funcionais como já abordado para as outras séries, atendo-se para o papel da fotossíntese e fazendo-se uma introdução à flora de Timor-Leste e sua distribuição em cada zona.

Componentes da química e da física começam a ser introduzidos nesta série a partir do estudo da água e suas propriedades, distribuição no planeta Terra, seus estados físicos e processos de mudança, o ciclo da água no planeta. A partir do entendimento do estado gasoso, são estudados os outros componentes do ar na atmosfera terrestre.

A Terra também é estudada nesta série no que se refere ao relevo, rochas e minerais, componentes do solo, variações dos mesmos. Os conhecimentos sobre o Sistema Solar são revisados e ampliados no seu entendimento, retomando os movimentos astronômicos da Terra de rotação e translação e em que interferem na vida dos seres vivos, marcando os mais variados ritmos. 


\title{
4.2.7 Uma análise do currículo
}

Em sua obra, Bernstein (1996) tipifica os currículos quando à sua estruturação em currículo coleção e currículo integrado. Para esta classificação o autor embasa-se nos padrões de compartimentação dos saberes, prática pedagógica, conteúdos, por exemplo, que são estabelecidas pelos códigos e pelas relações de poder e de controle, neste sentido conceituou as relações de poder como sendo de classificação e as de controle como sendo de enquadramento. Como menciona Lopes (2013, p.138) ao referir-se ás concepções de Bernstein,

\begin{abstract}
Classificações fracas estão relacionadas a relações de poder menos assimétricas. Quanto mais fraca a classificação, maior a inter-relação dos conteúdos. O enquadramento refere-se à forma do contexto no qual é feita a transmissão do conhecimento, à força da fronteira entre o que pode e o que não pode ser transmitido numa relação pedagógica. Em outras palavras, deve ser entendido como se referindo ao grau de controle de professores e alunos sobre a seleção, organização e ritmo do conhecimento transmitido e recebido nas relações pedagógicas.
\end{abstract}

Dito de outra forma, a "classificação" na acepção de Bernstein pode-se referir "ao maior ou menor grau de isolamento e separação entre as diversas áreas de conhecimento que constituem o currículo (...). Quanto maior o isolamento, maior a classificação" (SILVA, 2005, p.72). Assim, um currículo do tipo tradicional é fortemente classificado em função da nítida separação dos conteúdos, já um currículo que exiba uma maior interdisciplinaridade, apresenta fraca classificação. Já o "enquadramento" se atém às formas pelas quais os objetivos educacionais devem ser alcançados, assim, "quanto maior o controle do processo de transmissão por parte do professor, maior é o enquadramento, enquanto o ensino-centrado no aluno é fracamente enquadrado" (SILVA, 2005, p.73).

Desta forma, nos currículos coleção "as áreas e campos de conhecimento são mantidos fortemente isolados, separados. Não há permeabilidade entre as diferentes áreas de conhecimento" (SILVA, 2005, p.72). Já os currículos integrados, "as distinções entre as diferentes áreas de conhecimento são muito menos nítidas, muito menos marcadas. A organização do currículo obedece a um princípio abrangente ao qual se subordinam todas as áreas que o compõem" (SILVA, 2005, p.72).

Neste sentido, dentro de uma compreensão das concepções de Bernstein, o componente curricular "Estudo do Meio" da escola básica em Timor-Leste, pode ser apontado como fracamente classificado, já que integra de modo interdisciplinar história, geografia, sociologia, ciências, saúde e higiene e civismo. Porém, é fortemente enquadrado, já que o 
professor exerce grande controle no processo de transmissão, pois, possivelmente em função das dificuldades da língua portuguesa, ele é o "intérprete" dos alunos em duas vias, a do entendimento do conteúdo em si e da tradução para a língua tétum.

Para Lopes (2013, p. 139),

É possível termos currículos altamente classificados, porém pouco enquadrados, nos quais alunos e professores têm maior controle sobre o ritmos da transmissão de conteúdos, por exemplo. Igualmente é possível existir um currículo fracamente classificado, com maior inter-relação de conteúdos, mas com processos altamente estratificados e centralizados de definição de como essa inter-relação se desenvolve. Bernstein adverte, portanto, que o código integrado não é garantido apenas pelo fato de uma disciplina utilizar conhecimentos de outra. Essas são apenas inter-relações intelectuais. A integração pressupõe minimamente um grau de subordinação das disciplinas a determinados temas gerais e maior controle por parte de professores e alunos no processo de planejamento curricular.

Embora na explicitação acima sobre o currículo do Estudo do Meio, onde as ciências estão inseridas, tenha envolvido todas as áreas que o compõe, centro a atenção nesta análise às ciências em si. Assim, percebe-se que este currículo apresenta conteúdos comuns sobre as ciências, com a particularidade de focar quase nos mesmos conteúdos para todas as classes. Introduzindo, um ou outro conteúdo novo conforme se avança para séries mais adiantadas.

Infere-se que este currículo pode ser classificado também como em espiral, dentro da concepção de Jerome Bruner (1915-2016). Este acreditava que o currículo deve revisitar ideias anteriormente aprendidas, expandindo-as até que a criança atinja um entendimento mais completo das ideias individuais e como elas se relacionam entre si. Neste entendimento, o currículo em espiral se organiza apoiado em ideias apresentadas de modo repetido, oportunizando ao longo do tempo a organização das mesmas a partir do simples para o complexo, do geral para o específico, examinando-as uma em relação à outra (HARDEN \& STAMPER, 1999).

Analisando os pontos fundamentais do currículo em relação à adequação do mesmo às situações-problema a serem aplicadas para os estudantes, verifica-se que os conteúdos contemplados no $4^{\mathrm{o}}$ e no $5^{\mathrm{a}}$ ano estão apropriados para a aplicação dos problemas para os estudantes de $6^{\circ}$ ano e acima, pelo menos em suposição.

Um problema que se verifica com relação aos conteúdos de ciências e das demais áreas neste currículo, diz respeito ao livro didático oficial na escola de Timor. Este material está em língua portuguesa e conforme se verá adiante, boa parte das crianças do Timor tem problemas com a língua portuguesa. Assim, embora o currículo seja relativamente simples, sem excessos conteudistas, e ainda adotando essa constante revisita aos conteúdos já 
trabalhados, há um abismo entre o que se aprende efetivamente e o que se memoriza. Abaixo, no levantamento das concepções isso fica patente.

\subsection{Concepções dos alunos para as situações-problema - Entendendo as respostas das crianças à situações-problema apresentadas.}

Salienta-se que para a pesquisa pediu-se autorização da Diretoria de Educação Básica do Ministério da Educação do Timor-Leste. Em tempo questionou-se à autoridade do Ministério da Educação sobre a existência de um comitê de ética para avaliar a adequação da pesquisa já que haviam crianças envolvidas. A resposta dava conta que não tinha nenhum comitê nesse sentido e por se tratar de pesquisa que visava levantamento de conhecimentos sobre conceitos estudados na escola primária, visualizava-se o trabalho como adequado, inclusive para contribuir como auxílio ao Ministério na tomada de medidas após análise e conclusões da mesma.

Apesar da autoridade da Educação Básica ter retido a carta de apresentação do Programa de Pós-Graduação em Educação da UnB que levava e cópia do comprovante da Embaixada Brasileira em Timor (vide anexos 1 e 2 - p. 263-264) que atestava a minha residência no país no ano de 2007, o responsável se limitou a me indagar sobre as escolas onde faria a aplicação da pesquisa. Já escolhidas antecipadamente por uma questão de logística em relação à facilidade de deslocamento e por estarem dentro do parâmetro pretendido (escolas de educação básica), apenas mencionei o nome delas, mas, não recebi nenhum documento com a autorização por escrito para o procedimento. Indagada sobre esta necessidade, a autoridade se limitou a dizer que não havia essa imposição e que eu estava autorizado a proceder ao trabalho de pesquisa.

O narrado acima transcorreu na primeira semana de estadia para o trabalho de campo em Timor-Leste, no dia 01 de agosto de 2016, mas, para o meu desconforto, fui informado que as escolas da educação básica estavam em recesso até o dia 15 daquele mês. Como seria natural, vivi um período de ansiedade até a data da primeira visita às escolas, mas aproveitei o tempo para o trabalho de pesquisa do currículo e de outros materiais na biblioteca da Pós-

Graduação da UNTL, na biblioteca do INFORDEPE, conversas e entrevistas com os professores formadores do último órgão. 


\subsubsection{Visita à Escola Básica Filial (E.B.F)}

Os nomes e fotografias dispostas abaixo foram modificadas para resguardar a privacidades dos envolvidos na pesquisa. Assim,os estudantes escolhidos para o levantamento de concepções pretendido foram crianças da faixa etária de 11 a 12 anos, do sexto ano do segundo ciclo. A escola chamada Escola Básica Filial (Figura 9) situa-se à Rua de Nularan em Bidau, Díli. Possui 720 alunos dos dois ciclos iniciais da educação básica, ou seja, comporta alunos do $1^{\mathrm{o}}$ ao $6^{\mathrm{o}}$ ano do ensino básico.

Ao conversar inicialmente com o senhor diretor professor Natalino Aleixo, dois dias

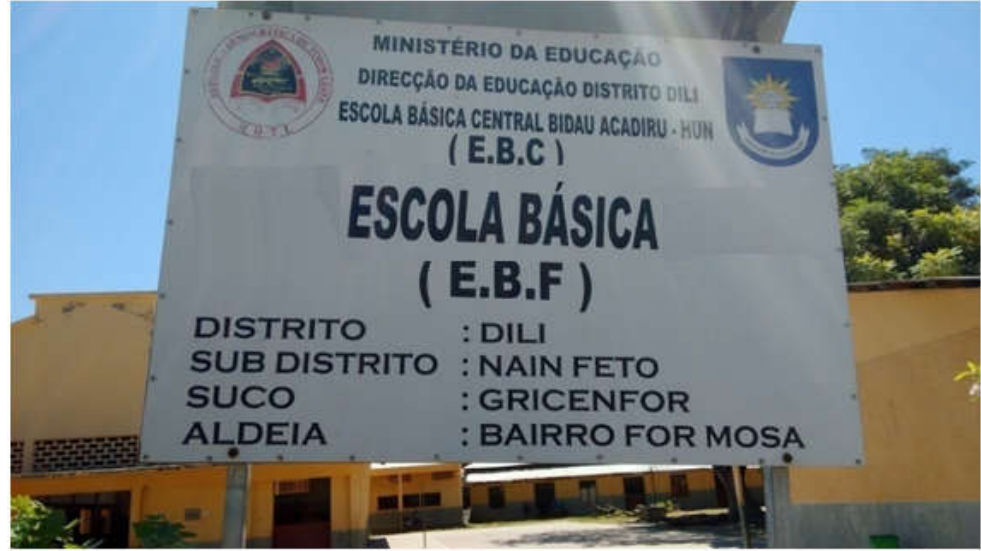

Figura 9. Fotografia da placa com o nome da Escola Básica Filial onde realizou entrevistas com alunos antes da visita para as entrevistas com os alunos, apresentei as motivações do projeto de pesquisa, e a experiência vivida anteriormente em Timor para fortalecer os laços, bem como as tratativas com o $\mathrm{Sr}$. Cidálio, diretor do Ensino Básico no Ministério da

Educação. O diretor não colocou nenhuma objeção sobre realizar a aplicação das situaçõesproblema para os alunos. Mostrei as questões para que me situasse em que classe os alunos podiam respondê-las e este me disse que estariam melhores para o $6^{\circ}$ ano.

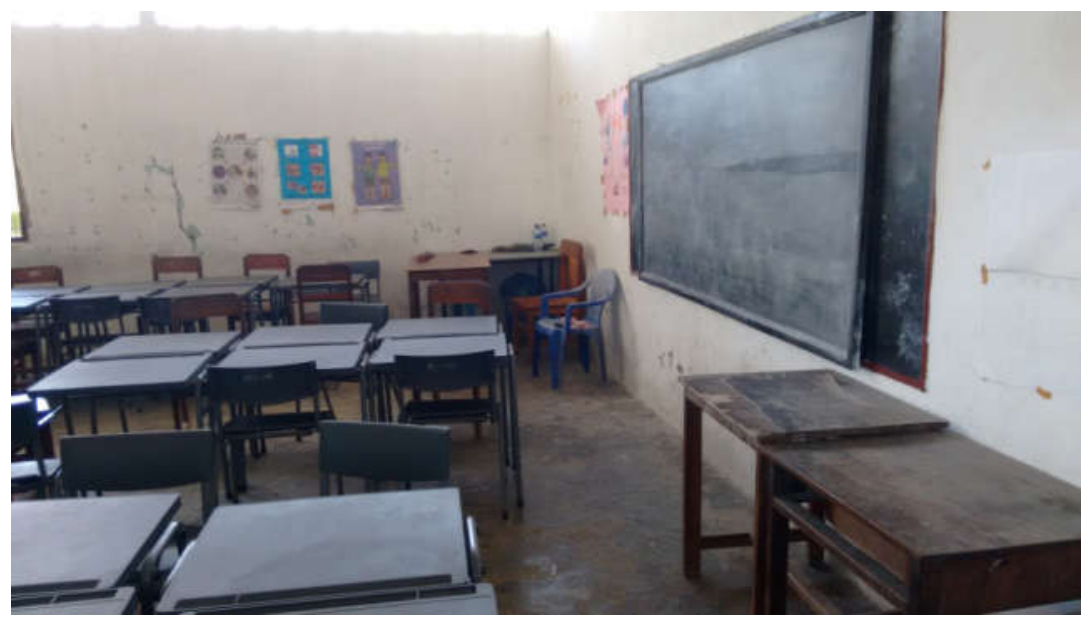

Figura 10. Fotografia de uma sala de aula da Escola Básica Filial
Alguns aspectos a serem observados da escola. A mesma é ampla, embora descuidada. As pinturas das paredes são desgastadas pelo tempo, há mato crescendo em várias áreas, e o mobiliário das salas de aula (Figura 10) é velho e empoeirado. Lembra-me 
os próprios espaços escolares que testemunhei no ano 2007. Ao chegar à escola no início da manhã, alguns alunos varriam o pátio (Figura 11), retirando a poeira e as folhas mortas. Cumprimentei o professor Natalino Aleixo e este mencionou que antes do trabalho iria à “formação". Perfilou todos os alunos no pátio da escola por turma e série (Figura 12), realizou duas orações, cantaram o Hino Nacional do Timor e orientou turma por turma para que tomassem suas salas.

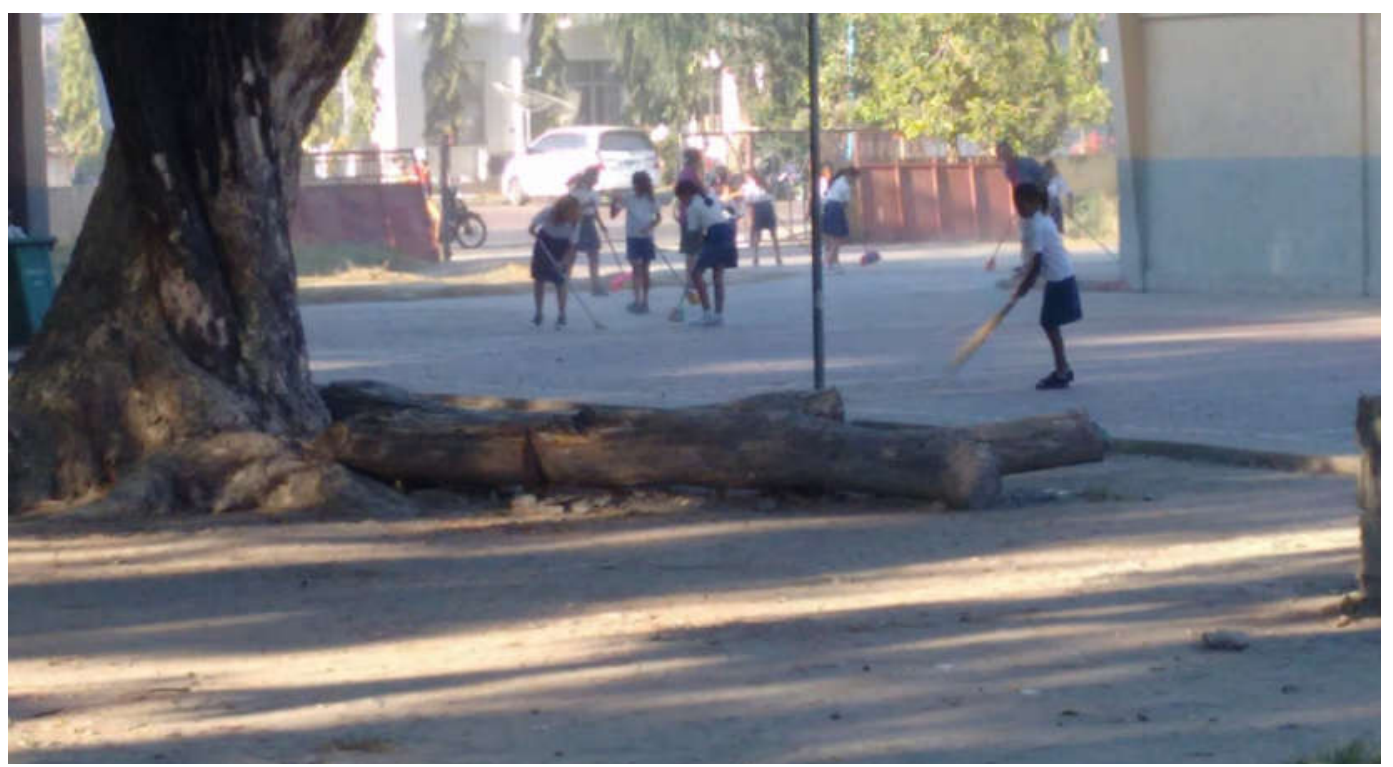

Figura 11. Fotografia de crianças varrendo o pátio da Escola Básica Filial no início da manhã antes das aulas

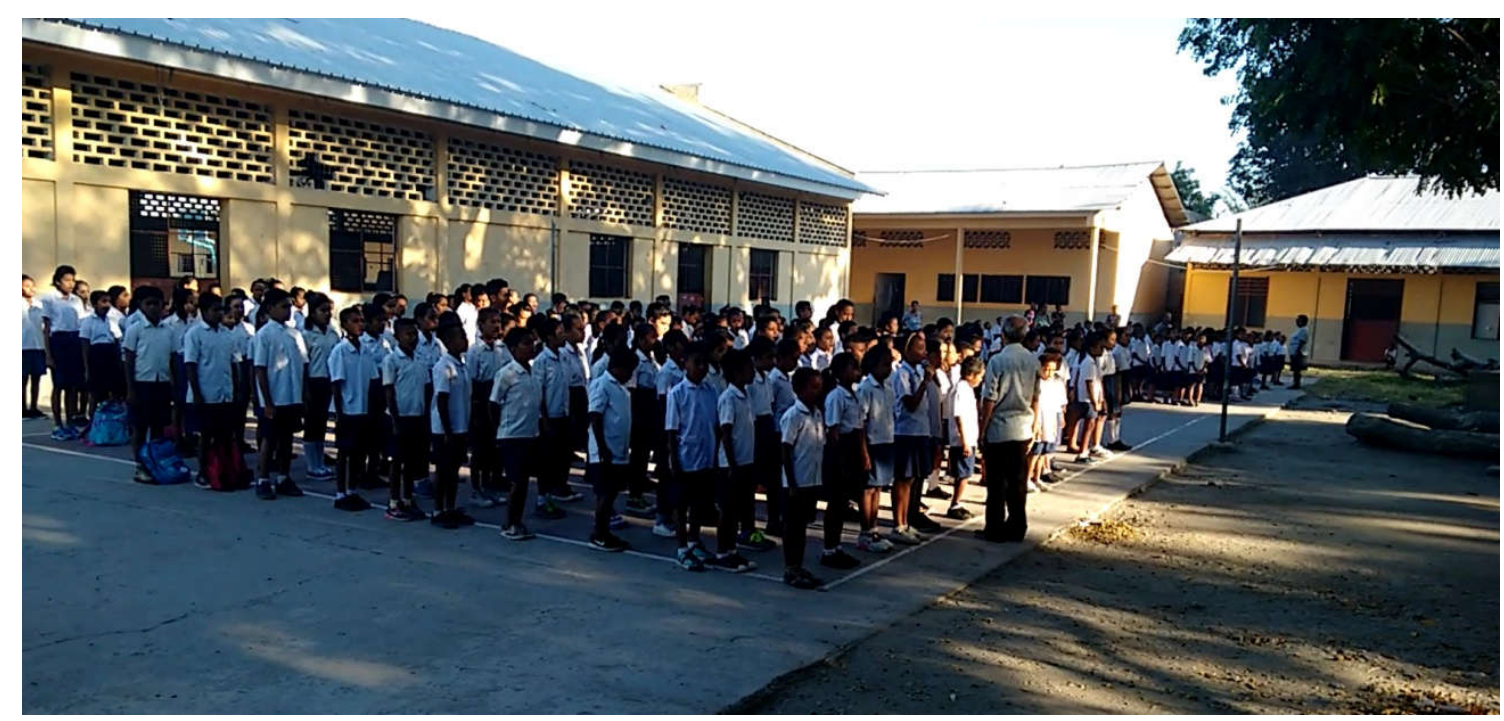

Figura 12. Fotografia dos alunos do matutino da Escola Básica Filial em "formação" antes das 
Após esses momentos inicias o diretor me colocou em contato com a senhora professora Cândida Belo de uma das turmas do $6^{\circ}$ ano (Figura 13) do segundo ciclo para que explicasse o que pretendia. Mostrei-lhe as situações-problema e lhe perguntei se suas crianças poderiam responde-las, a mesma anuiu e me perguntou de quantos alunos precisaria, disse-lhe que seriam necessários 20 alunos. Sem maiores problemas, a professora Cândida concordou e

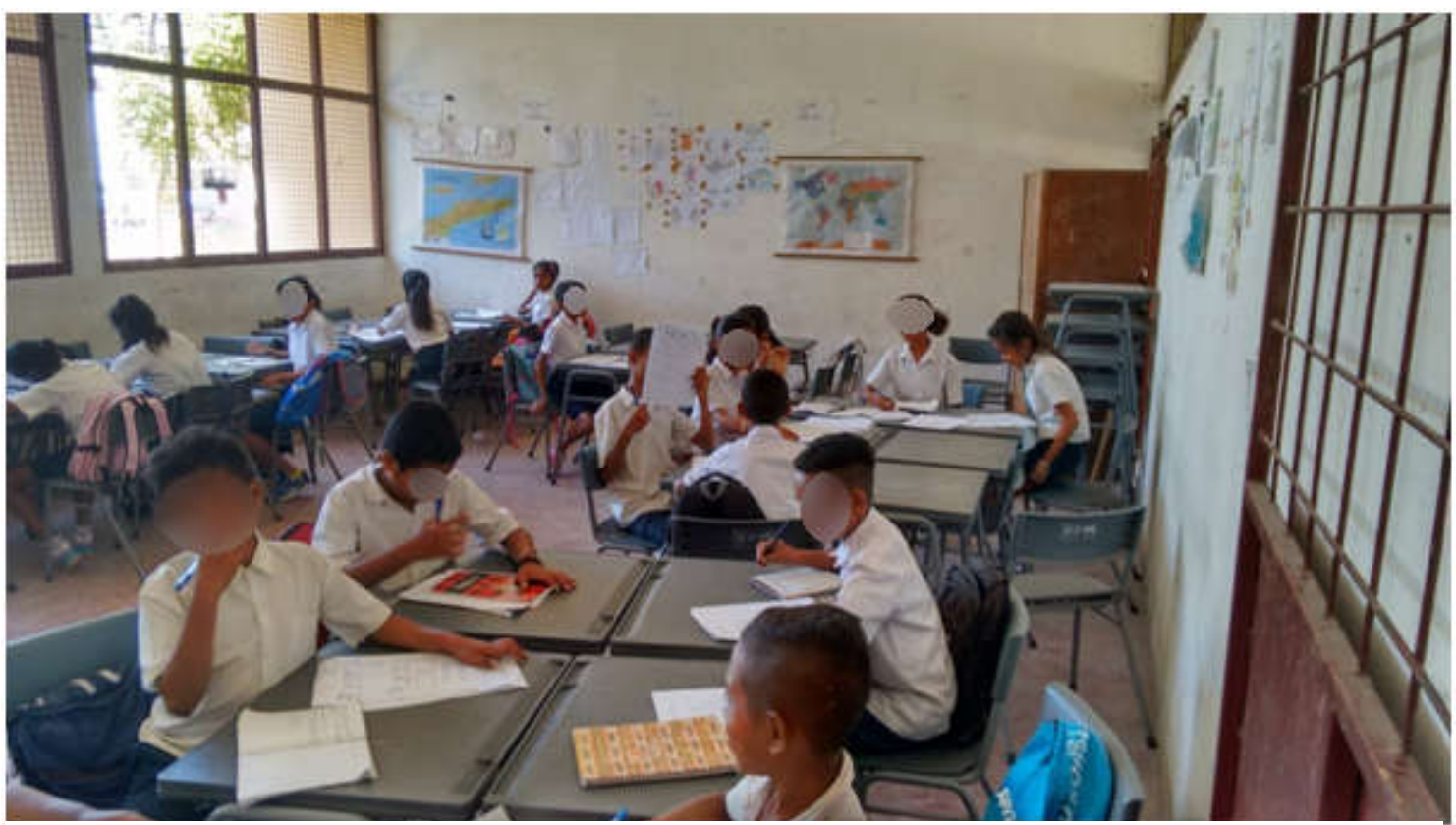

Figura 13. Fotografia da turma de $6^{\circ}$ ano que participou do estudo de concepções

me questionou se havia a necessidade da presença dela nos contatos com os alunos. Antes de responder perguntei-lhe se eles saberiam responder em língua portuguesa, mas, esta atestou que bem poucos conseguiriam fazê-lo. Então lhe disse que precisaria dela presente para, se possível, esclarecer alguns pontos obscuros que poderiam aparecer para os alunos. Imediatamente o senhor diretor arranjou um substituto para sua turma e fomos para uma sala reservada onde me sentei em uma cadeira, tendo uma mesa a me separar dos estudantes. Mas uma vez esclareci à professora que as crianças não seriam identificadas por seus nomes ou por qualquer via que permitisse saber de quem se tratava posteriormente, que o anonimato estava garantido.

Abaixo está descrito de modo detalhado todo o processo de entrevista e dos acontecimentos nesta etapa da pesquisa na Escola Básica Filial. Ainda que pareça enfadonho seu detalhamento, julgo ser necessário esse encaminhamento para a formação de uma percepção mais pormenorizada sobre as dificuldades enfrentadas, o nível de compreensão dos questionamentos, as interferências dos participantes no procedimento de pesquisa, se coadunando com uma abordagem fenomenológica. Como aponta Creswell (2014, p. 72), esta, 
foca na "descrição do que todos os participantes têm em comum quando vivenciam um fenômeno [...]. O propósito básico da fenomenologia é reduzir as experiências individuais com um fenômeno a uma descrição da essência universal". Assim, é fundamental a descrição e o detalhamento a seguir como vivência da pesquisa.

O primeiro estudante da turma selecionada entrou na sala onde aguardava. Um garoto muito tímido de 12 anos. Com o auxílio da professora Cândida esclareci os motivos da minha presença entre eles naquele dia e salientei que as situações-problema que apresentaria não visavam atribuir notas ou de alguma forma avaliar. Que ele se sentisse a vontade para responder da melhor maneira possível. A professora permitiu que o mesmo sentasse. $\mathrm{O}$ cumprimentei, disse-lhe meu nome e o que estava fazendo. O garoto se apresentou também dizendo como se chamava. Aparentemente havia entendido o que lhe disse. Mas, em todo caso, a primeira pergunta que fiz ao aluno foi sobre a possibilidade de responder em português, e o aluno disse que não era muito bom em língua portuguesa, a professora concordou. Em seguida, li em português a primeira situação-problema (repetirei adiante as situações-problema já relacionadas para facilitar o acompanhamento desta seção).

\section{Situação 1:}

Com a intenção de obter bons resultados em uma pescaria, o pescador João saiu com seu barco em uma hora determinada do dia para aproveitar a elevação do nível do mar e chegar até uma ilha onde há um banco de corais que atrai muitos peixes. Sem se preocupar com a hora de retorno, pois estava pescando bem, terminou com seu barco encalhado no banco de corais, pois o nível da água do mar baixou. O que aconteceu com o mar? E por que isso aconteceu?

Em um breve momento não me respondeu, como se não tivesse entendido. Tentei simplificar explicando mais uma vez em português. Perguntei em tétum:

- "Bele hatene?" (pode entender?).

O aluno balançou a cabeça em negativa. Diante disso, a professora que acompanhava tudo, solicitou dele, em tétum, que lesse a primeira situação-problema em voz alta. O aluno leu em português sem problemas de leitura, como se estivesse entendo tudo, pois a leitura era pausada, clara e sem engasgos. O que chama a atenção é o fato de a língua tétum usar os 
mesmos fonemas da língua portuguesa de modo que é facilmente possível para um aluno timorense, ainda que não conheça nada em português, ser capaz de ler nesta língua.

Logo após, a professora pediu-lhe que também lesse em tétum a mesma situação. Ao encerrar a leitura, perguntei-lhe:

-Você pode me explicar o que aconteceu? - e ainda reforcei em tétum:

- "Bele explika?"

A criança ficou em silêncio por aproximadamente três minutos e a professora interveio, solicitando dele em tétum:

- "Ato reponde pergunta ne'e san hatene" (Pode responder o que você entendeu).

A criança continuou em silêncio sem nada responder por longos minutos, embora a professora continuasse a falar em tétum com ele.

Expliquei mais uma vez para a professora que ele poderia responder em tétum, e que aquilo não representava uma ameaça, ou que era para nota. Que explicasse a ele não temer dar uma resposta que não tivesse muita certeza, que ficasse a vontade para responder. A professora conversou mais uma vez em tétum, o que suponho tenha sido essas minhas considerações, mas, mesmo assim o aluno se manteve calado. Até que a professora me perguntou se podia ajudar em tétum e explicar para ele do que se tratava a situação-problema 1. Respondi sim, que podia.

É óbvio que não poderei afirmar em que nível foi a explicação da professora em tétum, pois só conheço rudimentos da língua. Mas, a explicação da professora foi longa e aparentemente detalhada. Como as conversas foram gravadas, possuo o áudio de todas elas ${ }^{46}$. Após o silêncio do aluno mesmo diante das considerações da professora, sugeri que lesse a situação-problema 2. A professora falou-lhe para que lesse a outra situação e o aluno prontamente leu em voz alta em português e em tétum como já havia feito para a situação 1 . Mais uma vez o aluno recebeu orientações da professora em tétum e ainda assim permaneceu em silêncio por longo tempo. A professora até parecia um pouco irritada com a criança frente ao seu silêncio. Após algum tempo a professora me perguntou se podia chamar mais um

\footnotetext{
${ }^{46}$ A opção por não transcrevê-las, além do que já se mencionou no item sobre a metodologia, justifica-se pelo fato de que todas as interlocuções da professora (intérprete) com seus alunos passaram a ocorrer em tétum e dificilmente poderia fazer a transcrição "ao pé da letra", ou seja, em tétum, sem a ajuda de um timorense e dado a minha curta estadia em Díli, afinal a ida às escolas ocorreu apenas uma semana do meu retorno ao Brasil em função do recesso das escolas em Timor, conforme já apontado. Assim, não tive condições de fazer uma transcrição em língua tétum. Dessa forma, as considerações das respostas dos estudantes aqui elencadas, são traduções que a professora deu diante das respostas dos alunos em tétum.
} 
colega para auxiliá-lo. Não relutei em permitir, até porque não me sentia na condição de negar, pois, já tinha percebido que diante do silêncio da primeira criança, talvez não fosse possível esperar expressões da mesma diante das outras situações-problema. A professora retornou com outra criança, desta vez uma garota.

A segunda criança também leu a primeira situação-problema em português, em tétum e a professora a esclareceu sobre o que deveria fazer, ou seja, explicar o porquê do barco ter encalhado no banco de corais. Incentivei a troca de ideias entre as duas crianças. Elas trocaram algumas informações em tétum e a primeira criança por fim, explicou, segundo a tradução da professora, que:

- O barco havia encalhado porque o mar secou!

A segunda criança concordou e acrescentou:

- O pescador teria que esperar o mar voltar a encher para poder sair dali.

Ou seja, havia uma interpretação do texto, mera e simplesmente, do que tinha acontecido e as respostas apenas afirmavam o óbvio, sendo tautologias, mas, nenhuma consideração sobre a maré e o que a influenciava. Pedi à professora que perguntasse aos estudantes se sabiam explicar o fato do mar ter "secado" e porque "encheria" novamente, pelo o que havia mencionado a segunda criança. A garota apenas falou que:

- Foi por falta de água ou do enchimento do mar.

Pedi para professora perguntar à aluna, por que isso acontece? O que explica a maré? A professora fez a pergunta em tétum e algumas considerações sobre o assunto. A aluna ficou em dúvida e não soube explicar e a professora insistiu na pergunta sem resultados. Após o silêncio da aluna, a professora volta a perguntar para o primeiro aluno, que também se mantém calado. A professora mencionou que as crianças estavam com medo. Tranquilizei-os dizendo que não havia problema. Porém, meu mal-estar aumentava diante daquela situação, como se estivesse "forçando" uma resposta "correta" que não aparecia. Mas, intervim e pedi para analisarem a situação-problema 2 . 


\section{Situação 2}

Em um experimento em sala de aula, estudantes resolveram cultivar milho em um copinho com água e algodão. Após alguns dias todos observaram que as sementes de milho germinaram, mas diferente do que acontecia no campo, o pezinho de milho durou apenas alguns dias e morreu. Por que o pezinho de milho plantado no copinho com algodão não se desenvolveu como o milho plantado no campo?

As crianças partiram para a leitura da segunda situação, como anteriormente. Leram em português e em tétum. Fizeram silêncio por um tempo, até que pedi para professora perguntá-los de outro modo:

- É possivel ter uma plantação de milho em algodão!?

A aluna manifestou-se inicialmente tentando responder em português, mas a professora reagiu dizendo para ela explicar em tétum, pois teria dificuldade em português. A aluna expressou uma resposta em tétum e a professora ajustou a explicação com algumas considerações, o que denota, possivelmente, que a explicação da aluna não tenha agradado à professora, que retornou com pergunta:

- Qual é o alimento da planta?

Diante dessa pergunta as crianças começaram a mencionar:

- Água, solo, ar, sol... Alimentos...

A professora interrompeu dizendo que ainda faltava coisa. Não fizeram qualquer consideração à fotossíntese. É possível perceber que as crianças já “estudaram” o conteúdo, mas, não conseguem relacionar a importância do solo e seus nutrientes minerais para o desenvolvimento da planta, o que inabilita o algodão da possibilidade de sustentar o vegetal.

A professora, já demonstrando impaciência, pede para dupla fazer a leitura da situação-problema 3 . 


\section{Situação 3}

No trato com a plantação de arroz, os búfalos brancos são robustos e fazem o trabalho adequadamente. Pensando na resistência e força do búfalo, um agricultor que também tinha uma égua muito ágil, pensou em unir as qualidades dos dois animais para a obtenção de um animal melhor. Após longos meses tentando juntar o búfalo com a égua para a obtenção de filhotes, desistiu, pois os animais não apresentavam interesse um pelo outro. Por que estes animais não tiveram filhotes?

O mesmo já descrito anteriormente se processa. Fizeram a leitura nas duas línguas e permaneceram em silêncio. Perguntei:

- É possivel nascer filho de um casal de animais onde um é um búfalo e o outro uma égua?

A professora traduziu em tétum. Os estudantes trocam ideias entre si e a aluna apenas diz em tétum, traduzido para o português pela professora:

- Não é possível! São animais diferentes!

O garoto completa:

- Não podem se casar!

Porém, os estudantes não apresentaram maiores explicações sobre conceito de "espécie". Com estes dois alunos fomos para a última situação-problema, a número 4. Após a leitura e breve troca de ideias, a garota respondeu em tétum, segundo a tradução da professora, que:

- Os insetos comiam o milharal!

Mais uma resposta tautológica. 


\section{Situação 4}

Um agricultor preocupado com o ataque de ratos aos seus depósitos de milho resolveu criar alguns gatos com o intuito de espantar os ratos. Após alguns dias notou que o milho em seus depósitos parou de ser atacado por ratos, mas, passou a notar outra situação ocorrendo em seu milharal: ele estava sendo atacado por insetos. Como essa situação pode ser explicada?

Pedi à professora para perguntar se ela saberia explicar o porquê dos insetos comerem o milharal depois que o agricultor havia espantado os ratos com os gatos. A aluna apenas afirmou que:

- Os gatos haviam matado os ratos!

O garoto concordou e acrescentou que:

- Os gatos não podiam comer os insetos!

Nesta situação, apesar de não conseguirem relacionar um problema associado à cadeia alimentar expressamente, em que os ratos, apesar de comerem o milho no silo, também controlavam a população de insetos no campo, há indícios nestas respostas de uma possível compreensão de uma relação de causa e efeito.

Como não estava sendo produtivo, após mais de uma hora com as duas primeiras crianças, a professora, diante do avançar da hora e de minha manifestação inicial sobre a quantidade de alunos que necessitaria, dispensou os dois primeiros e trouxe quatro crianças de vez. Três garotas e um garoto. Da porta da sala me perguntou se podia ser os quatro de vez. Não me senti a vontade para negar ou fazer considerações metodológicas sobre a situação e mencionei que não havia problema algum, certo de que o auxílio da "equipe" fosse mais producente.

Fizemos as considerações iniciais novamente, distribuir as situações-problema para cada aluno e informei que podiam ler em tétum as mesmas situações que também estavam em português. Pedimos que lessem em silêncio para não atrapalharem uns aos outros, a situação 1. Ao serem solicitados para explicarem a situação. Um dos estudantes apenas disse:

- Sistema solar! 
Solicitei à professora que fizesse uma pergunta sobre o que era necessário para que o mar enchesse ou, maré alta e seu oposto. A professora questionou em tétum e deu algumas dicas. Uma das crianças mencionou:

- Movimento de rotação da Terra em 24 horas!

No entanto, não se referiu à Lua e sua influência no fenômeno das marés. Outra aluna, influenciada pelas respostas anteriores acrescentou:

- Movimento de translação!

A professora reagiu e fez uma longa conversa no grupo. A última aluna do quarteto mencionou então que:

- O barco encalhou porque o pescador estava pescando bem!

Uma conclusão que apenas reforça a literalidade do texto. Após as considerações sobre a rotação da Terra sobre as marés, sem o entendimento do papel da Lua, a professora se deu por satisfeita com as respostas das crianças, e terminou concordando com a explicação. Dizendo de outra maneira, as marés ocorriam em função da rotação da Terra. Ainda que tenha solicitado maiores explicações sobre o fato de que em alguns momentos do dia a maré está baixa e em outros, alta, o que determinava, neste movimento de rotação da Terra, essas diferenças? Nem as crianças e nem a professora fizeram maiores considerações.

Nota-se que as crianças fazem interpretação do texto e possuem rudimentos de informações sobre o assunto, embora tenham estudado no ano anterior, conforme informação da própria professora, estão de acordo com o currículo do $5^{\circ}$ ano: movimento de rotação e translação da Terra, fases da Lua, seu movimento de translação em torno da Terra, influências da Lua na formação das marés. Possivelmente, o fato de estudarem esses conteúdos em um livro-didático em português, limite a assimilação de conteúdos de forma integral. No entendimento da teoria da aprendizagem significativa de Ausubel, por falta de subsunçores adequados (e infiro, em função da dificuldade com a língua), esses conhecimentos fícam "à deriva na estrutura cognitiva das crianças" e nem funcionam como organizadores prévios para servirem de "ancoragem" de novos conhecimentos. Já que as informações são memorizadas, em um passado recente, é possível serem "resgatadas" sem formarem um corpo conceitual substancial.

Neste ritmo o grupo de crianças partiu para a segunda situação-problema. Todos do mesmo modo, em quase uníssono, conseguiram ler em português de modo que entende-se 
perfeitamente o que estão lendo, como já salientado acima, mas, ao lerem o tétum é que entendem de fato do que a questão trata. Fazendo-se uma breve analogia, é como se uma pessoa que conhecesse a pronúncia do inglês soubesse perfeitamente ler nesta língua, sem, no entanto entender do que se trata. A segunda situação já produziu respostas mais satisfatórias do conhecimento científico. Sob o estimulo da professora e após longo "discurso", ao perguntar novamente ao grupo,

- Qual é o alimento dos vegetais!?

A esta pergunta os estudantes foram compondo um "quebra-cabeça". Um disse "água", outro disse "ar... gás carbônico", um outro acrescentou "luz solar" e uma garotinha disse “sais minerais!”. A professora festejou o trabalho de equipe, embora não tenham explicado mais explicitamente o cerne da questão, já que ninguém relacionou diretamente a ausência de nutrientes minerais e orgânicos no algodão para explicar a diferença deste com o solo.

A professora por conta própria avançou à terceira situação-problema para o quarteto. Todos leram do mesmo modo já descrito anteriormente. Pedi para que a professora perguntasse se era possível realizar aquela ideia do agricultor de misturar os animais. Uma aluna apenas respondeu:

- Não pode reproduzir!

Outra complementou:

- Os animais não se interessaram um pelo outro!

Um estudante respondeu que:

- Não se reproduzem porque são animais diferentes!

Por fim uma aluna respondeu que:

- Não podem ter filhos!

A professora dando-se por satisfeita perguntou a todos em português:

- O que é reprodução?

O quarteto de alunos em quase uníssono, responde em português um conceito memorizado: 
- A reprodução é multiplicação através da doação de seres semelhantes assegurando a descendência ou a próxima geração!

O interessante neste particular é a dificuldade que as crianças exibem com a língua portuguesa e não obstante, conseguem "recitar" um conceito nesta língua. Isso reforça a contradição neste modelo de instrução bilíngue em que as crianças memorizam em uma língua que não dominam o que não aprendem na língua que dominam.

As crianças do quarteto partiram para a quarta situação. Procederam a leitura e começaram a confabular entre si após a professora perguntar se podiam explicar, mas não conseguiram se expressar. Reforcei a situação pedindo para a professora perguntar sobre o motivo pelo qual houve aumento de insetos comendo o milho no campo. Os alunos não responderam mais uma vez. A professora então conduziu maiores explicações em tétum e pediu para os alunos

- Levantem a voz e falar como fazem quando estão em sala de aula! Expressar tudo que vocês sabem!

Por fim, depois de um longo discurso da professora sem obter resultado, uma das aulas resolveu se expressar e disse:

- Coloca em um balde!

A professora explicou que ela estava querendo dizer, para evitar que os insetos comecem o milho no campo tinha que colocar esse milho em baldes fechados com uma tampa sobre um plástico, para tapar bem e não estragar o milho. Como a professora havia esboçado concordância, outra criança disse:

- Proteger o milho dos insetos.

Outra criança apenas disse que era para:

- Matar os insetos!

Uma das crianças não quis responder. A professora dispensou o grupo e mais uma vez me disse que eles estavam com medo. Em todo caso, o quarteto não conseguiu fazer relação com a ruptura de um elo da cadeia alimentar para explicar a situação.

Novo grupo de crianças foi trazido. Outro quarteto com dois garotos e duas garotas. Ao entrarem na sala, os cumprimentei com um "bom dia" e todos retornaram com um "bom dia senhor!". 
Mais uma vez pedi para a professora explicar para todos os alunos os motivos da minha presença e esclarecer que não era uma avaliação para nota ou coisa parecida. Todos também foram orientados para a leitura da primeira situação-problema. Depois da leitura, a professora frisou em português e em tétum:

- O que aconteceu com o mar? E por que isso aconteceu?

Reafirmando apenas as questões ao final da situação-problema 1. Em uma breve confabulação entre alunos e professora, um dos alunos respondeu:

- Falta de água!

O aluno parecia querer explicar o que aconteceu com o mar. A própria professora, diante do que já havia indagado aos outros grupos, perguntou:

- Por que "faltou” água no mar?

Uma aluna respondeu apenas:

- Falta de chuva!?

Resposta, possivelmente, associada à "seca" ou "período seco" com falta de chuva. Outra criança respondeu apenas:

- País!

A professora reage e diz que ele:

- Está confundindo ciências sociais com ciências naturais!"

O mesmo garoto que havia respondido laconicamente "país", falou novamente:

- Lua!

A professora ignorou, e continuou a falar em tétum, como se desconhecesse o papel da Lua nas marés. Os alunos continuaram a usar palavras-chaves na expectativa de formarem um corpo de "ideias" que pudesse chegar a uma resposta conclusiva, tais como: "Sol!"; "Chuva!"; "Nuvens!"; “Terra!". A professora continuou a reagir diante dessas respostas.

Era perceptível, diante o diálogo em tétum, que a professora tentava construir um caminho para levar as crianças a uma conclusão, pois as palavras soltas (todas ditas em português) continuaram: "dia e Noite!"; "vinte e quatro horas!"; "tempo!". Até que três alunos responderam ao mesmo tempo: 
- Movimento de rotação!

Outro completou dizendo:

- Movimento de translação!

Um dos alunos mencionou:

- Maré!

Essas últimas respostas receberam a anuência da professora, como se a expressão dos alunos fosse a explicação definitiva para a situação-problema. Esse "exercício" da professora proporciona o entendimento de que aqueles alunos já haviam sido apresentados ao conteúdo em questão. Porém, as expressões vagas, lacônicas e descontínuas, revelam, mais uma vez, que a aquisição conceitual era apenas memorística e estava à deriva na estrutura cognitiva dos mesmos.

Diante da aparente conclusão da situação-problema 1, a professora solicitou que todos lessem a situação-problema 2. Diante das circunstâncias, havia me tornado apenas um observador. Ao fim da leitura, o diálogo em tétum entre a professora e os alunos se seguiu como se estivessem buscando um consenso. Em determinado momento a professora perguntou:

- O que as plantas precisam para viver!?

Em resposta os alunos começaram a perfilar respostas:

- Água!

$-\mathrm{A} r$ !

- solo!

- Dióxido de carbono!

- Oxigênio!

Durante essa recitação, a professora incentivava:

- Mais...? Mais...? Ainda falta!

Enquanto os alunos iam se expressando. Como os estudantes fizeram silêncio, a professora continuou em português: 
- Mas... Falta ainda coisas! Como se fosse os nutrientes das pessoas!... Duas palavras... ainda faltam!".

Um aluno timidamente menciona:

- Alimentos!"

A professora então promove a recitação com todos:

- Então... água, ar, sol, solo, dióxido de carbono... E...? Vocês em casa quando plantam flores necessitam de...? Falta uma coisa que está no solo!

Um aluno responde:

- Chuva!

A professora reage:

- Não! Chuva é água!... É igual ao alimento da própria pessoa!... Que tem aqueles tipos de nutrientes! Vocês sabem quais são os tipos de nutrientes!?

Um aluno responde:

- São sete!

A professora pergunta:

- Quais são?

Novamente os alunos começam a recitar palavras soltas pertinentes ao assunto. Um diz:

- Hidratos de carbono!

Outro menciona:

- Fibras!

A professora insiste em que recitem os nutrientes e os alunos continuaram:

- vitaminas!

- Hidratos de carbono!

- Água!

Até que uma aluna disse:

- Sais minerais!

A professora anuiu contente. Os alunos haviam chegado à palavra-chave que era determinante para explicar a situação no entendimento da professora. Esta, diante da construção coletiva, os incentiva:

- Vamos embora... Outra vez!? 
E os estudantes, em português, recitaram todos juntos o que as plantas necessitam para viver:

- Água, sol, ar, solo, dióxido de carbono e sais minerais!

Sem retornar à explicação sobre a questão inicial a professora, já demonstrando impaciência diante do avançar da hora, pediu a todos para que lessem a situação-problema 3.

Após a leitura a professora pergunta em tétum se:

- Podem esses animais ter filhotes!?

As crianças responderam:

- La hanesan!" (Não são iguais!).

E novamente a professora pergunta em português:

- Então... O que é a reprodução?"

As crianças, como as anteriores, recitaram em português, ao mesmo tempo, a definição:

- A reprodução é o processo através qual os seres vivos dão origem a seres vivos semelhantes garantindo a mesma geração!

A professora confirma com todos, "

- Não podem reproduzir! Não são semelhantes!

Como no outro grupo, não houve maiores considerações sobre definição de espécies e as conclusões ficaram mais ou menos no campo do tautológico.

Dando por encerrado as respostas para a situação-problema 3, pedimos para os alunos lerem a situação 4. Após a leitura, apesar de reforçar a pergunta final da situação-problema pedindo para que os alunos a explicassem, a professora conduziu uma discussão com os mesmos como se estivesse solicitando deles uma solução para a situação. Entendi que aquilo era um reflexo do que já havia acontecido com o grupo anterior. Possivelmente diante das explicações em tétum da professora, os alunos começaram a dizer:

- Espantar insetos!

- Guardar armazém!

- Guardar armário!

Após cada conclusão a professora dizia:

- Não pode! - Por fim ela perguntou: - O que é que pode conservar?

Um garoto respondeu:

- Geleira! 
A professora sorriu e disse que não podia deixar o milho na "geleira" (geladeira em tétum). Que na "geleira" só milho fresco verde, peixe, carne, etc. E continuou a perguntar:

- Milho seco? Onde pode guardar!?

Uma garota por fim respondeu:

- Balde?

A professora anuiu e completou com a pergunta:

- Balde...! E deixa o balde assim aberto? - Um aluno respondeu:

- Fecha o tampão!

Como pareciam ter resolvido um problema para evitar o inseto no milho, a professora fez a seguinte pergunta:

- Mais grande que um balde, o que poderia ser para guardar o milho?

Outra criança responde apenas:

- Balde grande!

A professora concorda, mas, perguntou às crianças:

- Vocês não assistem programas de TV para apanhar o que o nosso governo realiza nestas situações? Não sabem? Não dá para imaginar? O que é que é grande!?

Após breve silêncio, pergunta novamente:

- Quando a gente quer comprar petróleo guarda onde?

Um aluno respondeu:

- Bidon!

A professora traduziu como se fosse um vaso plástico grande, um tonel. Como se houvessem resolvido a situação dá por encerrado a situação-problema 4, sem, no entanto, relacionar o aumento dos insetos com o desaparecimento dos ratos.

Próximo ao meio-dia, a professora demonstrando pressa, me perguntou se já bastava. Percebendo seu desconforto, perguntei se poderia completar a pesquisa no dia seguinte e a mesma concordou. Minha preocupação agora era só uma: como construir dados a partir daqueles achados?

No dia seguinte, após a "formação" do professor Natalino Aleixo, retomei os trabalhos com a professora Cândida Belo e pedi a princípio que comparecessem mais dois alunos apenas naquele momento. Esperei na sala do dia anterior e a professora conduziu dois garotos para a leitura das situações-problema. Após as apresentações, mencionei o propósito do trabalho, e me coloquei como se estivesse solicitando a ajuda deles para a resolução daqueles problemas. Semelhantes aos outros alunos podiam ler em português, mas não conseguiam 
falar. Aparentemente, o padrão anterior se manteve. A professora os fez ler em voz alta em português, como se estivesse mostrando que pelo menos um dos domínios da língua, o de ler, os alunos tinham. E de fato, a impressão que se tem é que estão lendo compreendendo. Porém, não conseguem articular com a mesma desenvoltura uma resposta em português. Assim, leram também a situação 1 em tétum.

Semelhantes aos outros grupos, também se mantiveram em silêncio como se buscassem maiores informações sobre o que fazer. Mas uma vez pedi para que explicassem:

- Bele explika situasaun?

Um dos alunos apenas se expressou em tétum o que a professora traduziu por:

- O pescador perdeu a hora e encalhou o barco!

O outro reafirmou que:

- O pescador encalhou porque a água baixou!

Mais uma vez os alunos repetiam um padrão já observado com outros alunos no dia anterior. Ou seja, se atém à interpretação do texto com respostas tautológicas. Perguntei sobre os motivos de a água ter baixado. O primeiro aluno respondeu que:

- Foi por causa da maré!

Insistir sobre o que provocava a maré. $\mathrm{O}$ aluno não respondeu e a professora voltou a conversar com eles sobre os movimentos da Terra, sem no obstante mencionar o papel da Lua no fenômeno. Após certo tempo um dos alunos arriscou:

- Rotação da Terra por dia!

A professora voltou a se expressar em tétum como se estivesse zangada. Vendo que possivelmente representasse uma bronca, pedi para que lessem a segunda situação-problema.

As duas crianças leram os textos e, após alguns esclarecimentos feitos pela professora, embora esta tenha me afirmado que não estava dando respostas, os alunos responderam sobre a necessidade de alguns fatores para que o pé de milho se desenvolvesse, como a "água, a luz solar, o gás carbônico”, resposta semelhante ao já observado com as crianças do dia anterior. Tiveram muita dificuldade de informar sobre a necessidade dos sais minerais e foram induzidos pela professora a expressarem. Entre a tradução da professora das falas do mesmo, percebeu-se que possuem a ideia de que as plantas também "comem o solo", ao mencionarem que no algodão "Não havia comida para a planta", ao contrário dos sais minerais para o desenvolvimento das plantas encontrados no solo. Não foi mencionado aqui também o termo 
"fotossíntese" ou algo sobre o processo, mas, o tipo de respostas apresentada, ainda que com o auxílio da professora, permite o entendimento de que já haviam tido contato com as informações dos conceitos que se pretendeu levantar com a situação-problema 2.

Para a situação-problema 3, as duas crianças afirmaram que os:

- Animais não podiam ter filhos!

Um dos alunos completou dizendo que:

- Não eram animais iguais!

Novamente a professora solicitou o conceito de reprodução e também aqui, os dois alunos recitaram a definição. Dado a constância das respostas memorizadas, perguntei à professora se eles estavam vendo o assunto "Reprodução" neste ano. Esta respondeu que apesar de já terem visto o ano passado, ela sempre fazia revisão dos conteúdos anteriores. Certamente na mesma base do memorístico.

Sem muito entusiasmo, como se estivesse cansada a professora solicitou às crianças a leitura da última situação-problema. Antes da interferência da professora, ao final perguntei às crianças:

- Bele explika situasaun!?

As crianças após longo silêncio, balbuciando as palavras escritas no texto, foram despertadas pela professora que perguntou:

- Como fazendeiro pode proteger milho dos insetos!?

Aproveitei e pedi para ela perguntar outra coisa:

- Por que os insetos haviam aumentado no campo após o desaparecimento dos ratos?

Mesmo após estas perguntas permaneceram em silêncio, até que um respondeu:

- Aumento dos gatos!

Pedi à professora para perguntar se ele achava que os gatos haviam aumentado e contraditoriamente, respondeu que "não". Um dos alunos nada respondeu e a professora, como se quisesse se livrar daquela situação, perguntou-me se e podia chamar mais alunos. Concordei e agradeci à dupla que se retirou. Em breve tempo a professora retornou com um quarteto.

Dessa vez, mais quatro estudantes, se sentaram e receberam as questões para a leitura. Ao finalizarem a professora apenas pediu: 
- Explica situação para o senhor!

Como se mantiveram em silêncio, pergunto:

- Bele explika situasau 1?

Uma das alunas, falou algo bem baixinho em tétum. Pedi a professora para traduzir. A professora informou que ela apenas disse que:

- Pescador perdeu a hora de voltar!

Uma conclusão meramente interpretativa do texto. A outra estudante deu também uma explicação:

- Porque acontece maré e o barco não pode sair!

Diante das respostas a professora pergunta:

- Por que acontece maré?

Novamente aqui um dos alunos responde:

- Movimento de rotação!

Após a aprovação da resposta, a professora perguntou:

- Movimento de rotação tem quantas horas?

Os alunos respondem:

- Vinte e quatro horas!

A professora completa:

- A Terra gira em volta de si...? - e os alunos completam - mesma!

Aproveitando a conclusão perguntei o que influenciava, nestas vinte e quatro horas de rotação, o movimento das marés? Mas, a professora como se não quisesse prolongar mais a conversa, apenas ordena:

- A outra situação!

Fica evidente que não havia por parte da professora o entendimento da influência da Lua no fenômeno.

As crianças procedem a leitura da situação 2 e após o silêncio habitual, a professora os incentiva a explicar a situação e disse: 
- Fala... Diz assim: "senhor Helio, na minha compreensão..."

Uma das crianças repete:

- Senhor Helio, na minha compreensão... - E completou a frase em tétum. A professora promoveu um diálogo entre eles que por fim, recitam:

- Sais minerais, água, luz, ar, dióxido de carbono, oxigênio, solo.

A professora completou:

- Estes são elementos necessários servir alimento de uma planta!

Sem maiores considerações, adiantou: “outra situação!”. Sua impaciência era patente, sinto que não estava sendo produtiva a indução e condução da professora aos alunos. Todavia, não vejo muito espaço de interferência, pois, além de ser a professora das crianças, a mesma está fazendo a tradução para mim.

$\mathrm{Na}$ sequência as crianças lêem a Situação 3. Uma das alunas toma a iniciativa e respondeu:

- Na minha compreensão os dois animais não são iguais!

Outro aluno completou:

- Não pode se reproduzir!

A professora acrescenta:

- Não podem se acasalar... Então, vocês sabem o que é reprodução?

Todos em coro recitam mais uma vez:

- A reprodução é o processo através do qual os seres vivos dão origem a seres semelhantes, assegurando a descendência ou mesmo a geração!

Chama a atenção pequenas variações na recitação dos conceitos de reprodução proferidos por grupos diferentes. Sem mais delongas a professora solicita: "Situação 4!". Após a leitura da última situação-problema, a aluna que já havia tomado a iniciativa na resposta anterior, também dá uma respostas em tétum. Peço para a professora traduzir e esta começa a dialogar com as crianças. A criança apenas disse:

- Insetos estraga o milho!

Outro aluno sugeriu: 
- Guardar o milho em sacola plástica!

A professora reagiu mencionando que:

- É muito milho para guardar em sacola plástica!

A professora continuou a falar em tétum com as crianças, perguntando:

- Qual era a cultura tradicional do Timor!?

Sem obter respostas, explicou para mim novamente um assunto do qual já havia falado. Muitas crianças ali eram filhos de agricultores e vinham de distritos com suas línguas maternas e tinham que aprender tétum por causa da escola e com o tempo perdiam o contato com as tradições.

Após uma série de expressões em tétum para as crianças, tentando explicar como fariam para armazenar o milho e tendo fugido totalmente à questão da situação-problema, a professora, por fim, se dirige especificamente a uma aluna e pergunta:

- Onde seus avós conservam o milho para plantar!?

A criança não soube responder. A professora se espantou e dirigiu a pergunta a outro aluno, dizendo que apenas um lugar bastava. A criança então responde:

- Bidon.

A professora completa:

- Bidon é igual como balde! O importante é ser grande!

Diante deste diálogo, percebi que provavelmente as concepções que estavam aparecendo alí eram as da professora. $\mathrm{Na}$ ausência de explicações por parte das crianças, a professora podia está conduzindo em tétum, explicações para que as crianças expressassem.

Tentando buscar das crianças um jeito tradicional de guardar o milho, por fim explicou que era comum no Timor, os agricultores guardarem o milho em uma espécie de estrado de bambu. Mencionei que no Brasil era comum chamarem isso de "jirau". Ela então completou que os agricultores ainda podiam isolar o estrado com fogo ou outra coisa para se evitar o contato com as pragas. Agradeci e me despedi das crianças e solicitei à professora, meio sem jeito, mais um grupo de crianças que seria o último. Em alguns minutos, a professora trouxe mais um quarteto de alunos. 
Pedi mais uma vez para a professora informar aos alunos que não tivessem medo ou algum tipo de receio, que podiam ler as situações e responder da maneira como achassem melhor. Como das vezes anteriores, leram a situação 1. Depois de certa relutância em expressarem-se, com o auxílio direto da professora, um dos alunos timidamente disse algo em tétum. Como a primeira situação-problema versa sobre as marés, a professora disse-me que ele havia mencionado que:

- O mar não pode secar!

Perguntei a ele se sabia dos movimentos da maré, pergunta que foi traduzida pela professora. $\mathrm{O}$ aluno se limitou a anuir. Outro aluno, semelhante ao padrão já obtido disse:

- O pescador encalhou o barco!

Outro disse que o:

- Pescador não podia pescar com o mar seco!

Aqui nota-se mais uma vez, respostas tautológicas. Ao serem questionados sobre o que aconteceu com o mar na situação e o porquê do fato, os alunos manifestam apenas o entendimento do descrito na questão. Com o auxílio da professora, mais uma vez apontam para explicar a situação em termos do movimento de rotação da Terra em torno do Sol. Semelhante às outras crianças, é possível perceber a indução da professora nesse caminho de entendimento. Assim, percebe-se que entendem perfeitamente o que está escrito e o que a ideia expressa, mas não elaboram explicações sobre o fenômeno que explica a situação.

Quanto á situação 2, as crianças também se expressaram na mesma base que as anteriores. Mencionam, com a ajuda da professora, os elementos essenciais para que os vegetais se desenvolvam, e procedem ao recital "água, luz, ar, dióxido de carbono, sais minerais". Porém, quando são perguntados sobre o porquê do milho não se desenvolver no algodão, como se desenvolve no campo, não conseguem fazer a associação entre estes elementos e a ausência de alguns deles no algodão.

Ainda esse grupo de alunos foi chamado a ler a situação-problema 3. Com o mesmo procedimento para leitura e discussão, após certo tempo em silêncio, uma das crianças informou que:

- Os animais não teriam filhotes porque eram diferentes e isso não era possível!

Após essa expressão, as outras crianças se manifestaram. Um disse que:

- Búfalo e égua nunca teriam filhotes! 
Outro disse apenas:

- Desiguais!

Um último mencionou que:

- O agricultor desistiu!

A professora em auxílio, mais uma vez, indagou-os sobre o que afinal era reprodução e surpreendentemente, da mesma maneira que as anteriores o quarteto se expressou como se estivessem recitando, o conceito que tinha aprendido sobre reprodução e em língua portuguesa. Esse é um aspecto interessante a se analisar, já que os livros didáticos são em língua portuguesa e é muito comum se observar na sala de aula, a repetição coletiva de conceitos que estão escritos nos livros para a memorização, até porque, como já mostrado, a leitura da língua portuguesa não representa um problema, os alunos constroem as definições memorizadas sem entender aparentemente, pelos motivos já apresentados em relação à compreensão da língua portuguesa.

Já para a quarta e última situação-problema, após a leitura da situação os estudantes em silêncio nada responderam ao que pedi à professora para reafirmar o que o problema solicitava. Os alunos começaram a expressar-se de modo tautológico. Um aluno afirmou apenas que:

- Os insetos estavam atacando o milharal!

Depois de um determinado tempo e diante do diálogo da professora, começaram a pensar em uma solução que evitasse esse ataque dos insetos, como já feito nas vezes anteriores e iniciaram conjecturas para soluções que protegesse o milho, como guardá-lo em locais protegidos como "baldes!", "bidon!" para se evitar o contato com os insetos. Um dos alunos respondeu:

\section{- Colher o milho!}

Dessa forma, mais uma vez, perderam de vista o questionamento inicial e sua relação com cadeia alimentar, com as consequências do desequilíbrio da cadeia em função do desaparecimento dos ratos.

Ao finalizar, agradeci todos. A professora perguntou minha opinião sobre os alunos e mencionei que tinham noções sobre as necessidades vegetais, compreendiam que animais diferentes não podiam ter filhos, portanto, já havia entendimento sobre reprodução. Porém, no entendimento das marés e suas causas, tinham noções imprecisas. A professora argumentou que desde o primeiro ano que têm noções sobre tempo, calendário, movimentos da Terra, 
mas, o assunto parecia ainda complexo para eles. Sobre a compreensão da situação-problema 4, havia uma tentativa de resolver o problema da perda do milho na lavoura sendo devorado pelos insetos, mas, não foi feita nenhuma relação entre a situação e o desequilíbrio promovido com desaparecimento dos ratos. Não obtive respostas da professora sobre isso.

Para auxiliar nas análises, as tabelas 4 a 7 abaixo apresentam as respostas dos alunos da Escola Escola Básica Filial obtidas nas situações-problema relacionadas.

TABELA 3. Relação de respostas obtidas dos alunos da Escola Básica Filial à situaçãoproblema 1

\begin{tabular}{|c|c|}
\hline \multicolumn{2}{|r|}{ Situação-problema 1} \\
\hline Aluno & Resposta \\
\hline 01 & O barco havia encalhado porque o mar secou! \\
\hline $\mathbf{0 2}$ & $\begin{array}{l}\text { O pescador teria que esperar o mar voltar a encher para poder sair dali! - foi por } \\
\text { falta de água ou do enchimento do mar. }\end{array}$ \\
\hline $\mathbf{0 3}$ & Sistema solar! \\
\hline 04 & movimento de rotação da Terra em 24 horas! \\
\hline 05 & movimento de translação! \\
\hline 06 & O barco encalhou porque o pescador estava pescando bem! \\
\hline 07 & "Falta de água!" \\
\hline $\mathbf{0 8}$ & Falta de Chuva" \\
\hline 09 & Lua!" \\
\hline 10 & "movimento de rotação", "movimento de translação", "maré" \\
\hline 11 & "o pescador perdeu a hora e encalhou o barco!" "rotação da Terra por dia! \\
\hline 12 & "o pescador encalhou porque a água baixou!" "foi por causa da maré!". \\
\hline 13 & "pescador perdeu a hora de voltar!". \\
\hline 14 & "porque acontece maré e o barco não pode sair!". \\
\hline 15 & movimento de rotação! \\
\hline 16 & Não respondeu. \\
\hline 17 & "o mar não pode secar!" \\
\hline 18 & "o pescador encalhou o barco!" \\
\hline
\end{tabular}




\begin{tabular}{|c|l|}
\hline $\mathbf{1 9}$ & pescador não podia pescar com o mar seco! \\
\hline $\mathbf{2 0}$ & Não respondeu \\
\hline
\end{tabular}

TABELA 4. Relação de respostas dos estudantes da Escola Básica Filial para a situaçãoproblema 2

\begin{tabular}{|c|c|}
\hline \multicolumn{2}{|r|}{ Situação-problema 2} \\
\hline Aluno & Resposta \\
\hline 01 & água, solo, ar, sol... Alimentos... \\
\hline $\mathbf{0 2}$ & água, solo, ar, sol... Alimentos... \\
\hline 03 & água, luz solar, ar... gás carbônico e sais minerais! \\
\hline 04 & água, luz solar, ar... gás carbônico e sais minerais! \\
\hline 05 & água, luz solar, ar... gás carbônico e sais minerais! \\
\hline 06 & água, luz solar, ar... gás carbônico e sais minerais! \\
\hline 07 & "água!"; "ar!"; "solo!"; "dióxido de carbono!"; "oxigênio!". \\
\hline 08 & "alimentos!". \\
\hline 09 & "chuva!" \\
\hline 10 & hidratos de carbono! "fibras!", "sais minerais!". \\
\hline 11 & “água, a luz solar, o gás carbônico. \\
\hline 12 & "água, a luz solar, o gás carbônico. "Não havia comida para a planta" \\
\hline 13 & sais minerais, água, luz, ar, dióxido de carbono, oxigênio, solo. \\
\hline 14 & sais minerais, água, luz, ar, dióxido de carbono, oxigênio, solo. \\
\hline 15 & sais minerais, água, luz, ar, dióxido de carbono, oxigênio, solo. \\
\hline 16 & sais minerais, água, luz, ar, dióxido de carbono, oxigênio, solo. \\
\hline 17 & "água, luz, ar, dióxido de carbono, sais minerais \\
\hline 18 & "água, luz, ar, dióxido de carbono, sais minerais \\
\hline 19 & "água, luz, ar, dióxido de carbono, sais minerais \\
\hline 20 & "água, luz, ar, dióxido de carbono, sais minerais \\
\hline
\end{tabular}


TABELA 5. Relação de respostas dos estudantes da Escola Básica Filial para a situaçãoproblema 3

\begin{tabular}{|c|l|}
\hline \multicolumn{2}{|c|}{ Situação-problema 3 } \\
\hline Aluno & \multicolumn{1}{|c|}{ Resposta } \\
\hline $\mathbf{0 1}$ & Não é possível! São animais diferentes! \\
\hline $\mathbf{0 2}$ & Não podem se casar! \\
\hline $\mathbf{0 3}$ & Não pode reproduzir \\
\hline $\mathbf{0 4}$ & Os animais não se interessaram um pelo outro. \\
\hline $\mathbf{0 5}$ & Não se reproduzem porque são animais diferentes! \\
\hline $\mathbf{0 6}$ & Não podem ter filhos! \\
\hline $\mathbf{0 7}$ & Não são iguais! \\
\hline $\mathbf{0 8}$ & Não pode reproduzir! \\
\hline $\mathbf{0 9}$ & Não se interessam! \\
\hline $\mathbf{1 0}$ & Não são semelhantes! \\
\hline $\mathbf{1 1}$ & Animais não podiam ter filhos! \\
\hline $\mathbf{1 2}$ & Não eram animais iguais! \\
\hline $\mathbf{1 3}$ & Na minha compreensão os dois animais não são iguais! \\
\hline $\mathbf{1 4}$ & Não pode se reproduzir! \\
\hline $\mathbf{1 5}$ & Não respondeu. \\
\hline $\mathbf{1 6}$ & Não respondeu. \\
\hline $\mathbf{1 7}$ & Os animais não teriam filhotes porque eram diferentes e isso não era possível \\
\hline $\mathbf{1 0}$ & Búfalo e égua nunca teriam filhotes! \\
\hline
\end{tabular}


TABELA 6. Relação de respostas dos estudantes da Escola Básica Filial para a situaçãoproblema 4

\begin{tabular}{|c|l|}
\hline \multicolumn{2}{|c|}{ Situação-problema 4 } \\
\hline Aluno & \multicolumn{1}{|c|}{ Resposta } \\
\hline $\mathbf{0 1}$ & "Os insetos comiam o milharal!"; \\
\hline $\mathbf{0 2}$ & Gatos não podiam comer os insetos! \\
\hline $\mathbf{0 3}$ & Coloca em um balde! \\
\hline $\mathbf{0 4}$ & Proteger o milho dos insetos! \\
\hline $\mathbf{0 5}$ & Para matar os insetos! \\
\hline $\mathbf{0 6}$ & Não respondeu \\
\hline $\mathbf{0 7}$ & Espantar insetos! \\
\hline $\mathbf{0 8}$ & Guardar armazém! \\
\hline $\mathbf{0 9}$ & Guardar em baldes! Fechar com tampão! \\
\hline $\mathbf{1 0}$ & Guardar em tonel. \\
\hline $\mathbf{1 1}$ & Aumento dos gatos! \\
\hline $\mathbf{1 2}$ & Não respondeu \\
\hline $\mathbf{1 3}$ & Insetos a estraga o milho! \\
\hline $\mathbf{1 4}$ & Guardar o milho em sacola plástica! \\
\hline $\mathbf{1 5}$ & Baldes! \\
\hline $\mathbf{1 6}$ & Que os insetos estavam atacando o milharal \\
\hline $\mathbf{1 7}$ & Os gatos haviam matado os ratos! \\
\hline $\mathbf{1 8}$ & Baldes, bidons! \\
\hline $\mathbf{2 0}$ & Colher o milho! \\
\hline
\end{tabular}




\subsubsection{Visita à Escola João XXIII}

Após o trabalho na Escola Básica Filial, resolvi realizar a aplicação das situaçõesproblema em outra escola que fosse diferente da anterior. Para isso foi escolhida uma escola particular, a Escola João XXIII (Figura 14), de orientação católica e situada á Rua da Felicidade em Audian, Díli.

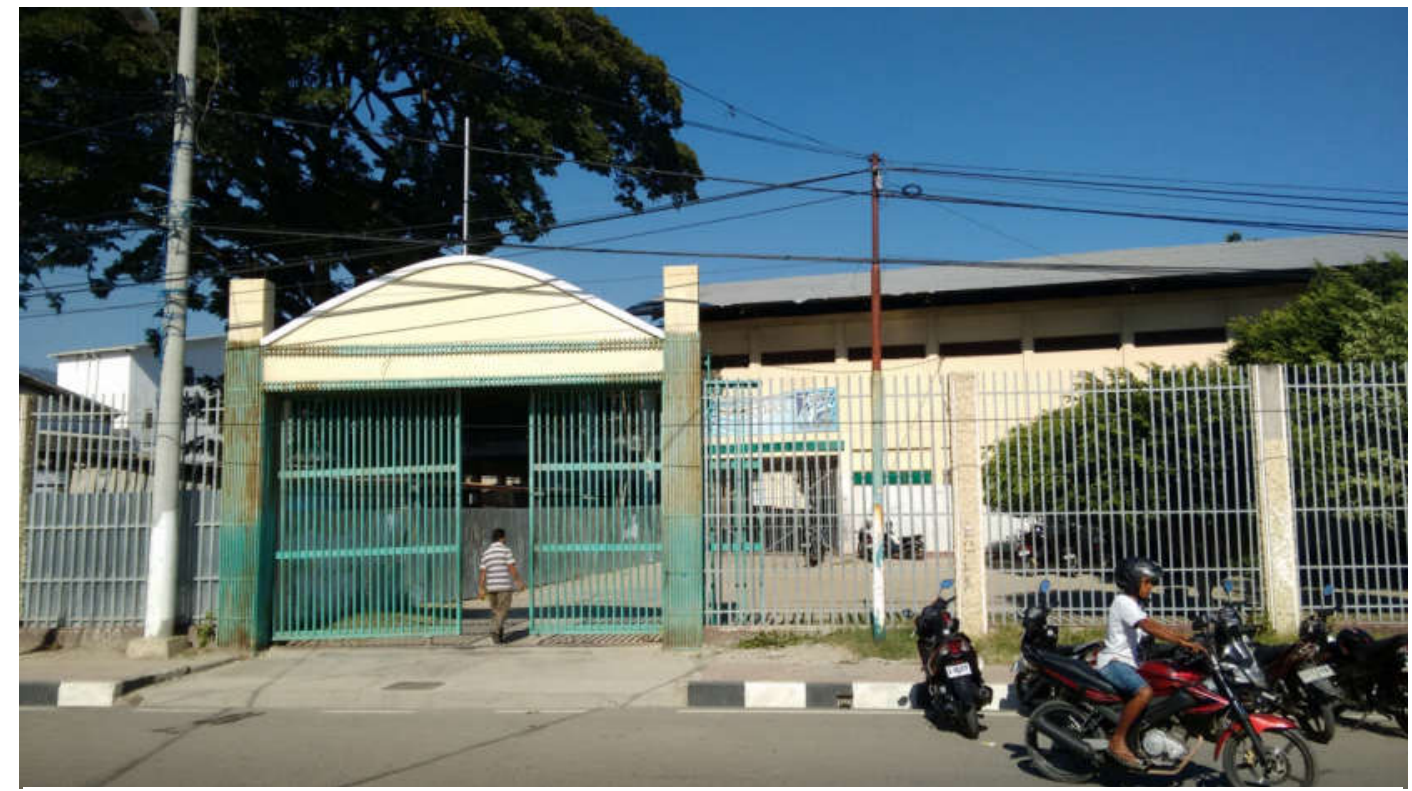

Figura 14. Fotografia da fachada da Escola João XXIII em Audian - Díli

O primeiro contato foi feito com senhora Diretora Maria Rosália Amâncio. Contei-lhe do projeto, sobre o meu trabalho em Timor no ano de 2007 e as permissões do Diretor do Ensino Básico do Ministério da Educação. Fiz algumas questões sobre a escola e entre elas, se adotava o currículo da educação básica do Timor, a diretora confirmou que sim. É importante salientar que em Díli há escolas internacionais, como a Escola Portuguesa, que não adotam o currículo do Timor e sim, de seus países. Por fim, mostrei-lhe as situações-problema e pedi para situar uma classe que poderia responder as situações em função do currículo. A senhora Rosália Amâncio, que não fez objeções, ficou com uma cópia das questões e pediu que retornasse na manhã do dia seguinte.

No retorno me informou que as questões seriam mais bem aplicadas ao $7^{\circ}$ ano, portando aos estudantes do início do $3^{\circ}$ ciclo. Resolvi aceitar, até porque se tratava de uma série acima da turma que apliquei na escola pública. Porém, fez outras ressalvas, só disporia de uma hora para ficar com a turma e diante do retrospecto com as entrevistas gravadas na Escola Básica Filial, resolvi mudar a metodologia e transformar as situações-problema em um teste de caneta e papel. Mas, uma preocupação me ocorreu, se aplicasse por escrito, 
certamente teria muito trabalho depois em traduzir do tétum para o português, e dado o exíguo tempo que possuía, talvez não fosse possível. Informei minha preocupação à senhora Rosália Amâncio que me tranquilizou dizendo que os alunos podiam responder em português.

Para me auxiliar, destacou a professora Eugênia Soares de Língua Portuguesa. Na sala escolhida,estava havendo aula de inglês, o professor interrompeu e me cedeu o lugar.

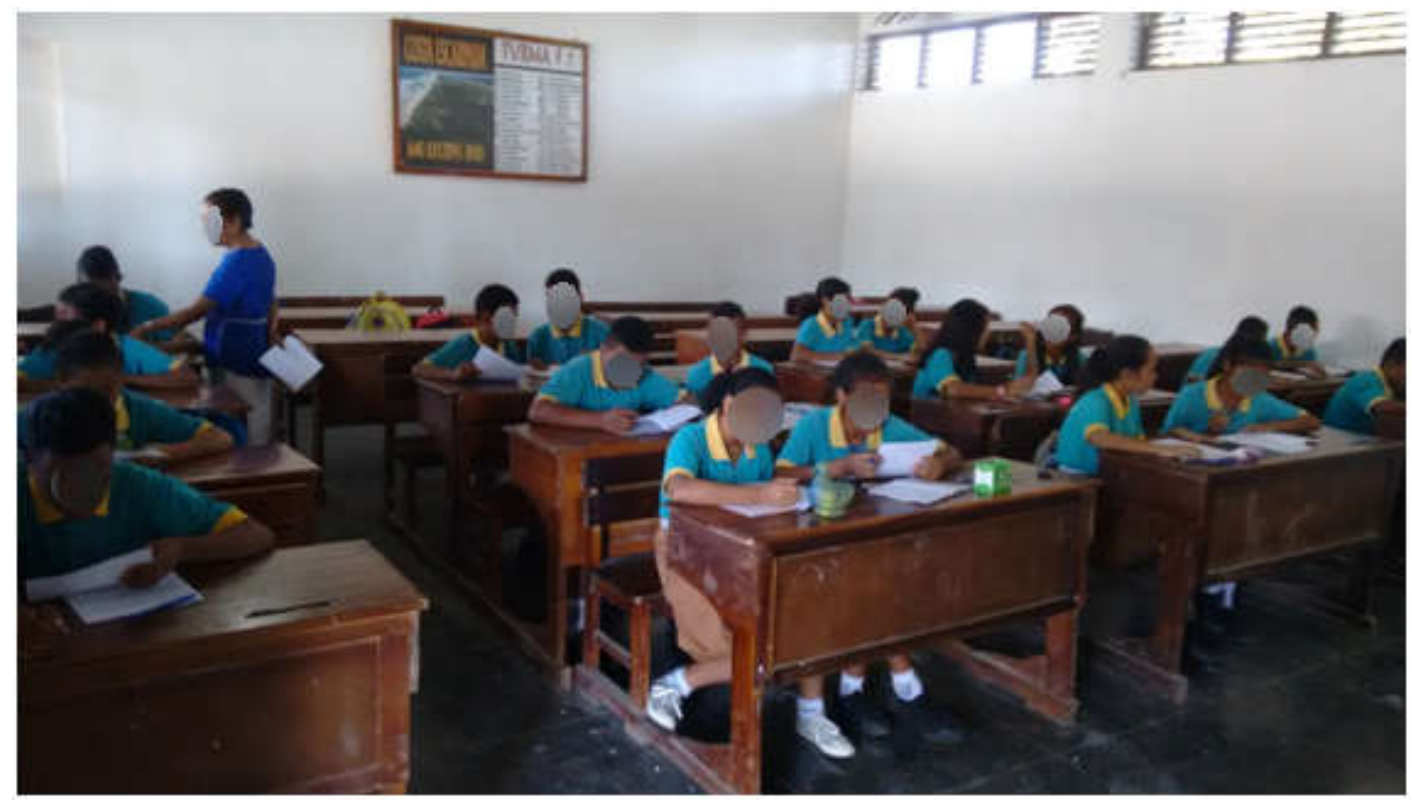

Figura 15. Turma de $7^{\circ}$ Ano do $3^{\circ}$ Ciclo da Escola João XXIII

Apresentei-me aos estudantes, e tive o cuidado de perguntar se todos conseguiam me entender em português e se todos poderiam responder por escrito e em português. Para minha surpresa, informaram que sim. Contei dos propósitos da minha pesquisa, os tranquilizei sobre a finalidade. Não era avaliação para nota ou coisa parecida e que não precisavam se identificar. Alertei que teríamos apenas uma hora para ler e responder. Eram ao todo 24 alunos e a professora que me acompanhava informou que a faixa etária dos estudantes era de 12 e 13 anos de idade (Figura 15). Repassei a todos as situações-problema e informei que se houvesse alguma dúvida podiam perguntar, além do que, as situações estavam também em tétum.

Próximo ao prazo de uma hora os estudantes começaram a devolver as questões e ao término do prazo, já haviam finalizado. Agradeci a todos, a professora que havia me acompanhado e à Diretora Senhora Rosália Amâncio.

Embora as questões tenham sido aplicadas para uma série do $3^{\circ}$ ciclo e em uma escola privada católica, respondidas em português, para minha surpresa as respostas não estão tão divergentes do que foi observado para a Escola Básica Filial. As respostas destes estudantes para as situações-problema podem ser observadas na sua totalidade nas Tabelas 8 a 11 abaixo. Salienta-se que manteve-se a mesma escrita dos estudantes nestas transcrições e isso permite 
perceber que o domínio da língua portuguesa é limitado. Mesmo tendo aplicado outra metodologia, as respostas obtidas também podem ser configuradas nas mesmas categorias que aquelas da escola pública. Houve também a repetição de respostas entre alunos diferentes, o que significa que alguns copiaram de outros.

Para situação-problema 1, por exemplo, há respostas do tipo:

- Certamente quando a água do mar baixou que aconteceu os peixes morram. Estas aconteceu porque a temperatura entre o sol.

(...)

- O que aconteceu com o mar é que João não pode sair do mar porque o nível da água do mar é baixou, e joão é um pescador maravilhosa, ele não ver a situação do mar mais ele preocupado em pescar o peixe.

(...)

- Porque o nível da água do mar baixou e barco precisa de mar grande para apanhar o peixe.

Entre as respostas para essa situação-problema, não há vestígios de respostas conceituais.

Já na situação-problema 2, os alunos apresentam respostas mais satisfatórias que aproximam do nível conceitual, embora haja predomínio de respostas tautológicas, ainda que de um modo sofrível na língua portuguesa. Há respostas tais como:

- O milho plantado no algodão não se desenvolve como o milho plantado no campo porque o milho no copinho, plantado com o algodão não se desenvolve tanto como o milho plantado na terra, na natureza.

(...)

- Porque o milho que está dentro do copo é diferente com o milho que está na tera. Porque o milho que está dentro do copo tem uma material químico. E o milho que está na terra e vem da natureza.

(...)

- Porque o aluno aluno para cultivar o milho não pode cultivar na água e pode cultivar na terra quando cultivar o milho na água porque o energia para viver.

As respostas para a situação-problema 3 apresentam uma aproximação maior ao nível conceitual, embora haja respostas que podem ser enquadradas como tautológicas. Isso pode ser verificado em respostas como: 
- Porque são dois animais de diferentes espécies. Se fossem o búfalo juntar com a búfula pode ser um filho.

(...)

- Estes animais não tiveram filhotes porque certamente quando dois animais não são iguais não pode ter filhotes.

(...)

- Búfalo não pode casar com a égua, porque os animais não apresentavam interesse para tem o filhotes.

Semelhante ao tipo de resposta obtida na escola pública, aqui também, as respostas dos alunos para a situação-problema 4, não permite o entendimento de que compreendam a relação entre o desaparecimento de ratos e o aumento de insetos. Algumas respostas podem ser observadas abaixo:

- Os milhos que foi estragado e atacado de um inseto por que vem dos lixos que tem nesta situações.

(...)

- Está situção é o agricultor tem ser aplica uma boneca de pessoa.

(...)

- Esta situação acontece porque se quando o rato está no vazio os insetos não pode atacar o milho porque o rato está em baixo da terra e eles comem tudo o inseto que está debaixo da terra mas o gato não pode porque ele só esta em de cima da terra e eles não ver o que e que acontece dbaixo da terra.

TABELA 7. Relação de respostas dos estudantes da Escola João XXIII para a situaçãoproblema 1

\begin{tabular}{|c|l|}
\hline \multicolumn{2}{|c|}{ Situação-problema 1 } \\
\hline Aluno & \multicolumn{1}{|c|}{ Resposta } \\
\hline $\mathbf{0 1}$ & $\begin{array}{l}\text { Certamente quando a água do mar baixou que aconteceu os peixes morram. Estas } \\
\text { aconteceu porque a temperatura entre o sol. }\end{array}$ \\
\hline $\mathbf{0 2}$ & $\begin{array}{l}\text { Aconteceu com o mar porque o João é um pescador e saiu não ver e por isso o peixe } \\
\text { aconteceu com o seu barco em uma hora determinada do dia para aproveitar a } \\
\text { elevação do nível. }\end{array}$ \\
\hline
\end{tabular}




\begin{tabular}{|c|c|}
\hline 03 & $\begin{array}{l}\text { O que aconteceu com o mar é que João não pode sair do mar porque o nível da água } \\
\text { do mar é baixou, e joão é um pescador maravilhosa, ele não ver a situação do mar } \\
\text { mais ele preocupado em pescar o peixe. }\end{array}$ \\
\hline 04 & $\begin{array}{l}\text { Aconteceu com o mar e o nível da água do mar baixou porque quando a noite o nível } \\
\text { da água do mar sem baixou. }\end{array}$ \\
\hline 05 & $\begin{array}{l}\text { Porque o nivel da água do mar baixou e barco precisa de mar grande para apanhar } \\
\text { o peixe. }\end{array}$ \\
\hline 06 & $\begin{array}{l}\text { Acontece que barco não pode sair porque mar muito baixo e mar também precisa de } \\
\text { muitas águas, que o barco pode sair. Acontece porque no momento o mar é muito } \\
\text { baixo. }\end{array}$ \\
\hline $\mathbf{0 7}$ & $\begin{array}{l}\text { Barco não pode sair porque o mar mais baixo isso porque barco precisa muito do } \\
\text { mar para o barco pode sair do mar. Porque naqueçe momento o mar mais baixo. }\end{array}$ \\
\hline 08 & $\begin{array}{l}\text { Certamente quando a água do mar baixou que aconteceu maioria dos peixes } \\
\text { morram. Estas aconteceu porque a temperatura entre o sol. }\end{array}$ \\
\hline 09 & $\begin{array}{l}\text { Porque nivel da água do mar baixou. Barco precisa mar pequeno para apanhar o } \\
\text { peixe. }\end{array}$ \\
\hline 10 & Porque. \\
\hline 11 & $\begin{array}{l}\text { O barco que está no mar porque está encalhado entre o corais e o barco de joão não } \\
\text { pode sair do mar então quando o João quer sair do mar ele tende esperar. }\end{array}$ \\
\hline 12 & $\begin{array}{l}\text { Aconteceu com o mar é o nível da água do mar baixou porque quando a noite o nível } \\
\text { da agua da mar sem baixou. }\end{array}$ \\
\hline 13 & $\begin{array}{l}\text { O barco que está no mar porque mar de baixo e o barco do João não pode sair do } \\
\text { mar então quando o João sair o mar que esperar. }\end{array}$ \\
\hline 14 & Porque o sol dar água para o mar. \\
\hline 15 & $\begin{array}{l}\text { Porque neste momento tem mar baixo. Acontece barco também não pode sai porque } \\
\text { este mar baixo e barco precisa água e terra. }\end{array}$ \\
\hline 16 & $\begin{array}{l}\text { Neste momento o mar baixou. O barco não pode entrar no mar porque o mar baixou } \\
\text { e o barco precisa de água para entrar no mar. }\end{array}$ \\
\hline 17 & Banco de corais, pois o nível da água do mar baixou. \\
\hline 18 & $\begin{array}{l}\text { Com intensão de obter bons resultados em uma pescaria o pescador João elevação } \\
\text { do nivel do mar e chegar. }\end{array}$ \\
\hline 19 & $\begin{array}{l}\text { O pescador João tem que andar porqur o mar baixou por isso não pode sair e } \\
\text { porque ele quer muitos peixes e não voltou para casa. }\end{array}$ \\
\hline 20 & $\begin{array}{l}\text { O pescador João tem que andar porque o mar baixou, por isso não pode sair, e } \\
\text { porque ele quer muitos peixes e não voltou para casa. }\end{array}$ \\
\hline 21 & $\begin{array}{l}\text { Sim João é pesacador, mas João usar opinião para pescaria mas João ver de muito } \\
\text { peixe e João não analiza porque pois o nivel de água do mar baixou e João não ver }\end{array}$ \\
\hline
\end{tabular}




\begin{tabular}{|c|c|}
\hline & $\begin{array}{l}\text { de situação são mal, e pacencia o João não pode de saiu, volta para casa, pois o } \\
\text { João estava pescador não bem, porque com seu barco encalhado no barco de corais } \\
\text { e pois o nivel de água do mar baixou. }\end{array}$ \\
\hline 22 & $\begin{array}{l}\text { Aconteceu é, sim, o João é pescador, mas o João não usar de opinião para pescaria, } \\
\text { mas o João ver de muito peixe e o João não alilizar de situação, porque pais o nível } \\
\text { da água de mar baixou e o João não ver de situação está mal e pacercia o joão não } \\
\text { pode de saiu vota para casa, pois o João estava pescando não bem, porque terminou } \\
\text { com seu barco encalhado no banco de corais e posi o níve de água do mar baixou. }\end{array}$ \\
\hline 23 & $\begin{array}{l}\text { Porque o João vai para a pesca o peixes não pensar para voltar para a casa porque } \\
\text { o João quero encontrar o peixe, João é pescador, mas João não usar o opinião para } \\
\text { pescaria, mas João ver de muito peixe e João não alalisa porque pois o nivel da } \\
\text { água do mar baixou e João não ver de situação do mar. }\end{array}$ \\
\hline 24 & $\begin{array}{l}\text { Porque João vai para pescar o peixe não pensar para voltar a casa porque João } \\
\text { quero encontrar o peixe, João é pescador, mas João não usar o opinião para } \\
\text { percuária, mas João ver de muito peie a João não alalisa, porque pois o nivel de } \\
\text { água dp mar baixpu e João não ver de situção são mal. }\end{array}$ \\
\hline
\end{tabular}

TABELA 8. Relação de respostas dos estudantes da Escola João XXIII para a situaçãoproblema 2

\begin{tabular}{|c|c|}
\hline \multicolumn{2}{|r|}{ Situação-problema 2} \\
\hline Aluno & Resposta \\
\hline 01 & $\begin{array}{l}\text { O milho plantado no algodão não se desenvolve como o milho plantado no campo } \\
\text { porque o milho no copinho, plantado com o algodão não se desenvolve tanto como o } \\
\text { milho plantado na terra, na natureza. }\end{array}$ \\
\hline 02 & Porque o milho germinaram no copo são iguais do copo. \\
\hline 03 & Porque o milho que germinaram no chão copo não são iguais no campo. \\
\hline 04 & $\begin{array}{l}\text { Porque o pezinho de milho plantado no copinho de algodão não se dezenvolve como } \\
\text { o milho plantado no campo porque o algodão não aferece o seu próprio semente } \\
\text { como o semente de campo. }\end{array}$ \\
\hline 05 & $\begin{array}{l}\text { Pezinho de milho plantado no copinho com algodão não se desenvolve como o milho } \\
\text { plantado no campo porque o milho precisa viver na terra que não há no copinho. }\end{array}$ \\
\hline 06 & $\begin{array}{l}\text { Porque o milho que está dentro do copo é diferente com o milho que está na tera. } \\
\text { Porque o milho que está dentro do copo tem uma material químico. E o milho que } \\
\text { está na terra e vem da natureza. }\end{array}$ \\
\hline 07 & $\begin{array}{l}\text { Porque o milho qu eestá dentro do copo é diferente com o milho que está na terra. } \\
\text { Porque o milho que está na terra porque as pessoas que cuidar e não tem materia } \\
\text { que pode estragar o milho. }\end{array}$ \\
\hline 08 & $\begin{array}{l}\text { O milho plantado no algodão não se desenvolve como o milho plantado no campo } \\
\text { porque o milho no copinho, plantado com o algodão não se desenvolve tanto como o } \\
\text { milho plantado na terra, na natureza. }\end{array}$ \\
\hline
\end{tabular}




\begin{tabular}{|c|c|}
\hline 09 & $\begin{array}{l}\text { Pezinho de milho plantado no copinho com algodão não se desenvolve como o milho } \\
\text { plantado no campo porque o milho precisa viver na terra que não há no copinho. }\end{array}$ \\
\hline 10 & $\begin{array}{l}\text { Porque o pezinho de milho não é vive no um copo e só vive no chão. Não é de um } \\
\text { copo. }\end{array}$ \\
\hline 11 & $\begin{array}{l}\text { Porque o milho que está no copo estão diferentes com o milho que está plantado no } \\
\text { campo porque a raíz que está no copo não tem muitas oxigênio com o milho que está } \\
\text { plantado no campo e eles não pode crescer porque o copo está pequeni e a raíz do } \\
\text { milho não encontra o oxigênio porque o milho só pode plantado de uma grande } \\
\text { varzio. }\end{array}$ \\
\hline 12 & $\begin{array}{l}\text { Porque o pezinho de milho plantado no copinho com algodão não oferece seu } \\
\text { próprio água e durou apenas alguns dias e morreu. }\end{array}$ \\
\hline 13 & $\begin{array}{l}\text { Porque o milho não controlio porque o milho quando cultivo do copo não são iguais } \\
\text { no plantado no campo o milho cultivo do terra porque. }\end{array}$ \\
\hline 14 & Porque o milho no copinho não nasce. \\
\hline 15 & $\begin{array}{l}\text { O milho é uma planta no copinho com algodão não se desenvolve como vive na } \\
\text { terra. }\end{array}$ \\
\hline 16 & $\begin{array}{l}\text { O milho plantado no copinho com algodão não se desenvolve como o milho plantado } \\
\text { no campo porque o mulho que plantado no copinho com algodão não terra. }\end{array}$ \\
\hline 17 & Porque o pezinho de milho plantado no copinho com algodão. \\
\hline 18 & Porque o milho no copinho não tem minerais. \\
\hline 19 & $\begin{array}{l}\text { Porque os ambientes diferentes quer dizer o ambiente de dentro não iguais com o } \\
\text { ambiente de fora. }\end{array}$ \\
\hline 20 & $\begin{array}{l}\text { Porque os ambientes diferentes, diferentes quer dizer o ambiente de dentro não } \\
\text { iguais com o ambiente de fora. }\end{array}$ \\
\hline 21 & $\begin{array}{l}\text { Porque o milho este durou alguns dias e morreu mas diferente que aconteceu no } \\
\text { campo. }\end{array}$ \\
\hline 22 & $\begin{array}{l}\text { Porque o milho esta durou alguns dias e morreu mas diferentes que aconteceu no } \\
\text { campo. }\end{array}$ \\
\hline 23 & $\begin{array}{l}\text { Porque o aluno aluno para cultivar o milho não pode cultivar na água e pode } \\
\text { cultivar na terra quando cultivar o milho na água porque o energia para viver. }\end{array}$ \\
\hline 24 & $\begin{array}{l}\text { Porque o aluno aluno para cultivar o milho não pode cultivar na água e pode } \\
\text { cultivar na terra quando cultivar o milho na água porque o energia para viver. }\end{array}$ \\
\hline
\end{tabular}

TABELA 9. Relação de respostas dos estudantes da Escola João XXIII para a situaçãoproblema 3

\section{Situação-problema 3}




\begin{tabular}{|c|c|}
\hline Aluno & Resposta \\
\hline 01 & $\begin{array}{l}\text { Estes animais não tiveram filhores porque estes animais certamente dois animais } \\
\text { não iguais não podem ter filhotes. }\end{array}$ \\
\hline 02 & Porque os dois animais difeentes os pais. \\
\hline 03 & $\begin{array}{l}\text { Porque são dois animais de diferentes espécies. Se fossem o búfalo juntar com a } \\
\text { búfula pode ser um filho. }\end{array}$ \\
\hline 04 & $\begin{array}{l}\text { Após longos messes tentando juntar búfalo com a égua para a obtenção de filhotes, } \\
\text { desistiu pois o animais apresentava interesse um pelo outro porque o sexu de estes } \\
\text { animais não são iguais. }\end{array}$ \\
\hline 05 & $\begin{array}{l}\text { Búfalo não pode casar com a égua, porque os animais não apresentavam interesse } \\
\text { para tem o filhotes. }\end{array}$ \\
\hline 06 & Porque os búfalos com a égua é não é casamento por isso não tinha filhotes. \\
\hline 07 & Porque os búfalos com a égua é não é casamento por isso não tinha filhotes. \\
\hline 08 & $\begin{array}{l}\text { Estes animais não tiveram filhotes porque certamente quando dois animais não são } \\
\text { iguais não pode ter filhotes. }\end{array}$ \\
\hline 09 & $\begin{array}{l}\text { Búfalo não pode casar com a égua, porque os animais não apresentavam interesse } \\
\text { para tem o filhotes. }\end{array}$ \\
\hline 10 & Porque eles são diferentes sexos. \\
\hline 11 & $\begin{array}{l}\text { Porque os animais são de dois gêneros diferentes o cavalo não pode casar com o } \\
\text { búfalo. Se o cavalo e o búfalo estão a casar então estas duas animais não pode ter } \\
\text { filhos porque o cavalo só pode se casar com o cavalo e o búfalo também. }\end{array}$ \\
\hline 12 & $\begin{array}{l}\text { Os animais não tiveram filhotes porque os animais não são iguais e o búfalo e a } \\
\text { égua não tem interesse com o outro. }\end{array}$ \\
\hline 13 & $\begin{array}{l}\text { Porque os animais são iguais. Porque os búfalos brancos são robustos e fazer o } \\
\text { trabalho adequadamente. O cavalo são iguais adequadamente. }\end{array}$ \\
\hline 14 & Porque o sexo não igual \\
\hline 15 & Este animais não tiveram filhotes porque as espécies não são iguais. \\
\hline 16 & Desistiu, pois o sanimais não apresentavam. \\
\hline 17 & No trato na plantação de arroz os búfalos brancos são robustos e fazem o trabalho. \\
\hline 18 & Estes animais não tiveram filhotes porque o búfalo não pode casar com égua. \\
\hline 19 & Estes animais não tiveram filhotes porque o búfalo não pode casar com égua. \\
\hline 20 & $\begin{array}{l}\text { Porque por longos meses tendando juntar o búfalo com a água para obtenção de } \\
\text { filhotes desistiu, pois eles os animais. }\end{array}$ \\
\hline
\end{tabular}




\begin{tabular}{|c|l|}
\hline $\mathbf{2 1}$ & $\begin{array}{l}\text { Porque, após longos meses tentando juntar o búfalo com a égua para a obtenção de } \\
\text { filhotes, desistiu pois o animal não apresentavam interesse um pelo outro. }\end{array}$ \\
\hline $\mathbf{2 2}$ & Estes animais não tiveram filhotes porque o búfalo não pode casar com égua. \\
\hline $\mathbf{2 3}$ & $\begin{array}{l}\text { Porque após longos meses tentando juntar o búfalo com a égua para a obtenção de } \\
\text { filhotes, desistiu, pois os animais não apresntavam interesse um pelo outro porque } \\
\text { estes animais não tiveram. }\end{array}$ \\
\hline $\mathbf{2 4}$ & $\begin{array}{l}\text { Porque no trato com a plantação de arroz, os búfalos brancos são robustos e fazem } \\
\text { o trabalho adequadamente. Pensando na resistência e força do búfalo, um agricultor } \\
\text { que também tinha uma égua muito agil, pensou em unir as qualidades dos dois } \\
\text { animais. }\end{array}$ \\
\hline
\end{tabular}

TABELA 10. Relação de respostas dos estudantes da Escola João XXIII para a situaçãoproblema 4

\begin{tabular}{|c|c|}
\hline \multicolumn{2}{|r|}{ Situação-problema 4} \\
\hline Aluno & Resposta \\
\hline 01 & $\begin{array}{l}\text { Os milhos que foi estragado e atacado de um inseto por que vem dos lixos que tem } \\
\text { nesta situações. }\end{array}$ \\
\hline $\mathbf{0 2}$ & não respodeu \\
\hline $\mathbf{0 3}$ & Está situção é o agricultor tem ser aplica uma boneca de pessoa. \\
\hline 04 & $\begin{array}{l}\text { Quando assim o agricultura tem que mudar os seus depósitos de milho para outro } \\
\text { lugar. }\end{array}$ \\
\hline 05 & $\begin{array}{l}\text { Como essa situação pode ser explicar porque gatos e ratos estragam o milho no } \\
\text { quintal. }\end{array}$ \\
\hline 06 & $\begin{array}{l}\text { Aqui situação } n^{\circ} 4 \text { Eu não pode de explicar porque eu não sabe de este pergunta. E } \\
\text { assim eu pede desculpa. }\end{array}$ \\
\hline 07 & Porque passou a notar outra situação ocorrendo no seu milharal. \\
\hline 08 & $\begin{array}{l}\text { Este situação se explica como os milhos que estava atacado ou estragados de insetos } \\
\text { porque vem dos situaçóes. Exemplo: este situação está em problema e o ar fabricas. } \\
\text { Este ar pode ser transformar os insetos que pode estragar os milhos, não só os } \\
\text { milhos mas todos as plantações que foi estragados. }\end{array}$ \\
\hline 09 & $\begin{array}{l}\text { Como essa situação pode ser explicar porque gatos e ratos e o animal que muito } \\
\text { gostam para estragam o milho no quintal. }\end{array}$ \\
\hline 10 & não respodeu \\
\hline 11 & $\begin{array}{l}\text { Esta situação acontece porque se quando o rato está no vazio os insetos não pode } \\
\text { atacar o milho porque o rato está em baixo da terra e eles comem tudo o inseto que } \\
\text { está debaixo da terra mas o gato não pode porque ele só esta em de cima da terra e }\end{array}$ \\
\hline
\end{tabular}




\begin{tabular}{|c|c|}
\hline & eles não ver o que e que acontece dbaixo da terra. \\
\hline 12 & Quando o rato não depositos o milho o milho tence ser insetos. \\
\hline 13 & $\begin{array}{l}\text { Esta situação acontece porque se quando o rato está no vazio os insetos não pode } \\
\text { atacar o milho porque o rato está em baixo da terra. }\end{array}$ \\
\hline 14 & Essa situação o milho já está a morrer. \\
\hline 15 & Essa situação podemos dizer que o agricultor tem de conservar bem. \\
\hline 16 & Essa situação podemos dizer que o agricultor tem de conservar bem o milho. \\
\hline 17 & $\begin{array}{l}\text { Mais passou a notar outra situação ocorrendo em seu milharal, ele estava sendo } \\
\text { atacado por insetos. }\end{array}$ \\
\hline 18 & Um agricultor com ataque de ratos. \\
\hline 19 & $\begin{array}{l}\text { Esta situação pode ser explicar com o agricultor, e o agricutor vão criar o cão para } \\
\text { atacar os ratos e os milharal. }\end{array}$ \\
\hline 20 & $\begin{array}{l}\text { Essa situação pode ser explicada com o agricultor, e o agricultor vão criar o cão } \\
\text { para atacar os ratos e as milharal. }\end{array}$ \\
\hline 21 & Após alguns dias notou que o milho em seus depósitos. \\
\hline 22 & $\begin{array}{l}\text { Porque após alguns dias notou que o milho em seus depósitos parou de ser atacado } \\
\text { por ratos. }\end{array}$ \\
\hline 23 & Porque um agricultor preocupado com ataque de ratos ao sseys depósitos de milho. \\
\hline 24 & não respondeu \\
\hline
\end{tabular}

\subsection{Análise dos dados}

Para permitir uma análise mais adequada das respostas às situações-problema, foram criadas quatro categorias que permitem circunscrever as respostas obtidas. Assim, concebeuse as seguintes categorias para as respostas: conceituais, tautológicas, culturais e incongruentes. Para melhor entendimento abaixo estão descritas o que significam cada categoria e que tipos de respostas permitem abrigar.

Ainda que pareça arbitrária, na categoria de "Respostas Conceituais", procurou-se circunscrever todas as respostas que apresentaram elementos que denotam escolarização ou indícios de conceitos aprendidos na escola, ou até mesmo uma formulação do conceito científico propriamente dito. Portanto, ainda que alguns não tenham expressado respostas completas no âmbito do conceito científico, é possível perceber nas respostas estes indícios. 
Pode parecer limitado e errôneo esse entendimento de "conceito" que se está fazendo aqui, até porque, Asubel (2000, p.2), define conceito como sendo,

objetos, eventos, situações ou propriedades que possuem atributos, discernimentos comuns e são designados pelo mesmo sinal ou símbolo. Existem métodos gerais de aprendizagem de conceitos: (1) formação de conceitos, que ocorre principalmente em crianças pequenas; e (2) assimilação de conceitos, que é a forma dominante de aprendizagem de conceitos em crianças em idade escolar e adultos. Na formação de conceitos os critérios de atributos dos mesmos são adquiridos através da experiência direta, ou seja, através de estágios sucessivos de geração de hipóteses, testes e generalização. Á medida que aumenta o vocabulário de uma criança, no entanto, novos conceitos são adquiridos principalmente através do processo de assimilação de conceito visto que os critérios de atributos de novos conceitos podem ser definidos pelo uso em novas combinações de referências existentes disponíveis na estrutura cognitiva da criança.

Porém uma análise de respostas em que se buscam conceitos científicos em crianças timorenses que não falam português, mas que supostamente, estudam conceitos nessa língua, inviabilizaria qualquer tentativa das mesmas em responder com palavras e sentidos que indicam uma escolarização em ciências.

Neste sentido, uma resposta para a situação-problema 1, onde se exige certo grau de entendimento sobre o movimento de rotação da Terra e a influência da Lua para determinação das marés, que foi dada nesta base: - "movimento de rotação da Terra em 24 horas!”, foi categorizada como resposta conceitual, pois aponta indícios de um conhecimento escolarizado.

$\mathrm{Na}$ acepção da terminologia filosófica tradicional, tautologia, segundo o Dicionário de Filosofia de Abbagnano (2007), significa genericamente um discurso (em especial, uma definição) vicioso porquanto inútil, visto repetir na consequência, no predicado ou no definiens o conceito já contido no primeiro membro. No Dicionário de Filosofia e Ciências Culturais de Santos (1965, p.1319), o termo tautologia aparece com três sentidos:

a) Proposição idêntica, cujo sujeito e predicado constituem um mesmo conceito, ou sejam, são unívocos, embora expressos por termos verbais diferentes.

b) Empregado pejorativamente quando o predicado nada mais diz que o sujeito.

c) Sofisma que consiste em parecer ter demonstrado uma tese ao repetir-se com outras palavras o que se desejava provar.

Desta forma, repostas categorizadas como "Tautológicas" foram aquelas que apenas reafirmam o óbvio da situação-problema sem não obstante demonstrar um pensamento mais elaborado ou que aprofundem o entendimento. $\mathrm{O}$ estudante apenas conclui o que a própria pergunta solicita ou afirma uma justificativa do tipo "porque sim". Na situação-problema 3, por exemplo, quando a criança responde: - "Os animais não se interessaram um pelo outro.", 
está apenas repetindo o que o problema da situação expressa, sendo este tipo de afirmação categorizado como uma resposta tautológica.

Já na categoria "Respostas Culturais", embora o termo cultura seja polissêmico, a circunscrição das respostas nesta categoria, "Cultura" tem o sentido naturalista de conhecimentos específicos que fazem parte das crenças e ideias de um povo. Neste entendimento, Abbagnano (2007, p. 226), apresenta o sentido de cultura como tendo se fundado no Renascimento:

\begin{abstract}
O Renascimento, na tentativa de redescobrir o significado genuíno do ideal clássico de Cultura, quis restabelecer seu caráter naturalista: concebeu a Cultura como formação do homem em seu mundo, como a formação que permite ao homem viver da forma melhor e mais perfeita no mundo que é seu. A própria religião, segundo esse ponto de vista, é elemento integrante da Cultura não porque prepare para uma outra vida, mas porque ensina a viver bem nesta. O Renascimento, além disso, modificou o caráter contemplativo do ideal clássico, insistindo no caráter ativo da "sabedoria" humana.
\end{abstract}

Dado a existência de valores diferenciados por parte das crianças nas salas de aula em Timor-Leste, pois os alunos, sobretudo nas escolas de Díli, podem proceder de diferentes distritos com identidades linguísticas e culturais diferentes, o significado "cultura" usado aqui, origina-se também da antropologia social e neste sentido concerne a significados compartilhados em seus aspectos simbólicos. Assim, diante da possibilidade de encontrar respostas alternativas no campo de explicações míticas, ou que de alguma maneira demonstrem conhecimentos tradicionais simbólicos sobre o assunto, esta categoria foi criada. Uma resposta que aponte hábitos ou práticas culturais como no caso da situação-problema 4, quando uma criança responde: - “Guardar em baldes! Fechar com tampão!”, por mais que não tenha apontado um caminho esperado, esta resposta foi categorizada como cultural.

$\mathrm{Na}$ categoria "Respostas Incongruente" inscreveu-se aquelas respostas inadequadas quanto ao sentido esperado do ponto de vista conceitual. Nesta acepção, o incongruente, segundo Santos (1965, p. 837), corresponde ao, “que não condiz, não concorda, não convém; o incompatível, o incoerente. Assim, se diz que há incongruência quando algo não convém ao de que se fala, como argumentos incongruentes, conclusões incongruentes”. Todavia, na categoria foram inscritas também respostas, que embora não estejam dentro do conceito esperado, os estudantes respondem para solucionar outro problema que não é central na situação. Um exemplo de resposta categorizada como incongruente pode ser dada à situaçãoproblema 2, quando a criança responde: - "alimentos!” ou - "Chuva!”

A Tabela 11 mostra um quantitativo de respostas dos alunos da Escola Básica Filial, às situações-problema, distribuídas nas categorias elencadas. Para uma melhor visualização desses resultados foram construídos, a partir dos dados da tabela, os gráficos de 1 a 4 . 
Enfatiza-se, mais uma vez, que o estabelecimento de respostas na categoria "respostas conceituais" representa um aproveitamento de ideias e expressões dos alunos que dão indícios de exposição aos conteúdos pertinentes, sem, no entanto expressarem, necessariamente os conceitos propriamente ditos.

TABELA 11. Quadro quantitativo de respostas obtidas por categorias - Escola Básica Filial

\begin{tabular}{|l|c|c|c|c|c|}
\hline & $\begin{array}{c}\text { Respostas } \\
\text { Conceituais }\end{array}$ & $\begin{array}{c}\text { Respostas } \\
\text { Tautológicas }\end{array}$ & $\begin{array}{c}\text { Respostas } \\
\text { Culturais }\end{array}$ & $\begin{array}{c}\text { Respostas } \\
\text { Incongruentes }\end{array}$ & Não respondeu \\
\hline Situação-problema 1 & 4 & 10 & 0 & 4 & 2 \\
\hline Situação-problema 2 & 9 & 0 & 0 & 11 & 0 \\
\hline Situação-problema 3 & 13 & 4 & 0 & 1 & 2 \\
\hline Situação-problema 4 & 2 & 3 & 6 & 6 & 3 \\
\hline
\end{tabular}

\section{Gráfico 1. Frequência das respostas obtidas por categorias para a situação-problema 1 - Escola Básica Filial - Dili - Timor-Leste}

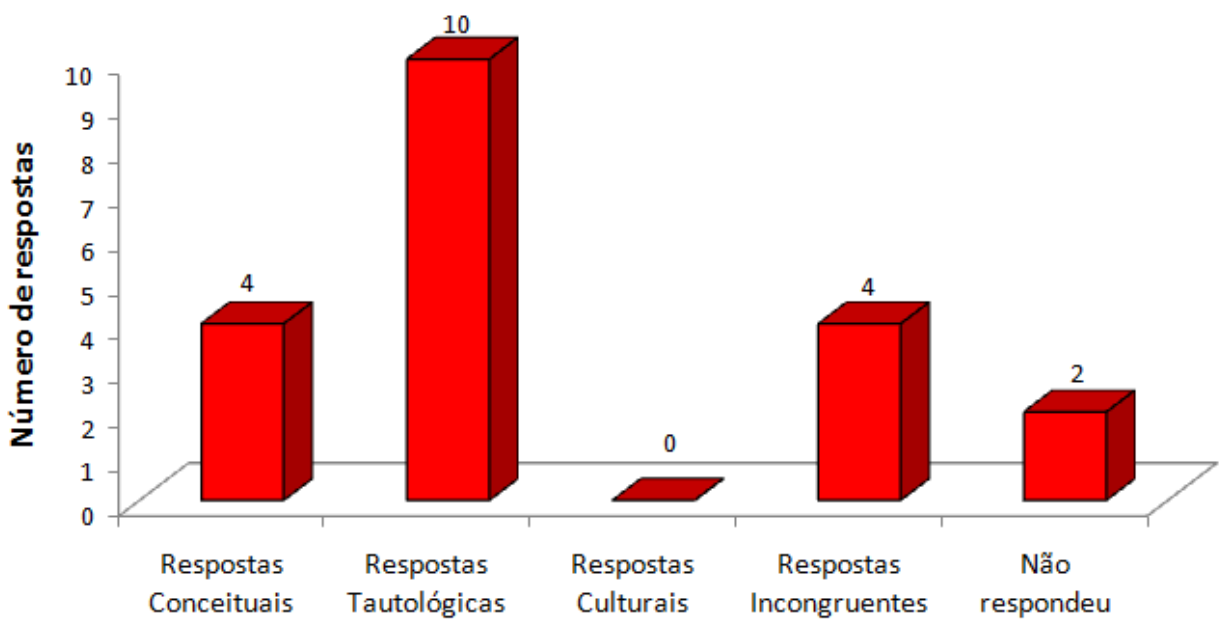

Fonte: Dados obtidos em pesquisa com alunos na Escola Escola Básica Filial - Dili, Timor-Leste, agosto de 2016

Pelo gráfico 1 é possível observar um predomínio de respostas categorizadas como "tautológicas", que pela análise das expressões dos alunos, infere-se uma interpretação a partir da literalidade da questão em que há a repetição das expressões ou conclusões do óbvio. Embora o gráfico demonstre a presença de "respostas conceituais", elas apenas refletem indícios de expressões como "movimento de rotação", "Lua", "marés", que representam apenas indícios sobre o conteúdo, demonstrando que já foram de alguma forma, expostos ao mesmo. Para a situação-problema 1, não houve nenhum indicativo de "respostas culturais", o que pode ser um indicativo de ausência ou pouco contato das crianças com atividades ligadas ao mar como pesca e navegação, embora o Timor seja uma ilha e a atividade pesqueira muito 
intensa. Todavia, a presença de respostas categorizadas como "incongruentes" tenderia a ser maior se só fossem admitidas na categoria "conceitual”, respostas que se aproximassem mais estreitamente do conceito científico buscado. Os dados da tabela 11 demonstram assim, que 80\% das respostas das crianças entrevistadas na Escola Básica Filial, para a situaçãoproblema 1 estão fora do entendimento conceitual esperado, ainda que as $20 \%$ das respostas na categoria conceitual não estejam enquadrada adequadamente como um conceito formado, podem ser identificadas como "indícios conceituais".

Para a situação-problema 2 (gráfico 2), no processo de entrevista aos alunos, a participação da professora da turma, em um constante diálogo em tétum com as crianças, possibilitou o enquadramento de uma quantidade maior de respostas na categoria conceitual,

\section{Gráfico 2. Frequência das respostas obtidas por categorias para a situação-problema 2 - Escola Básica Filial - Dili - Timor-Leste}

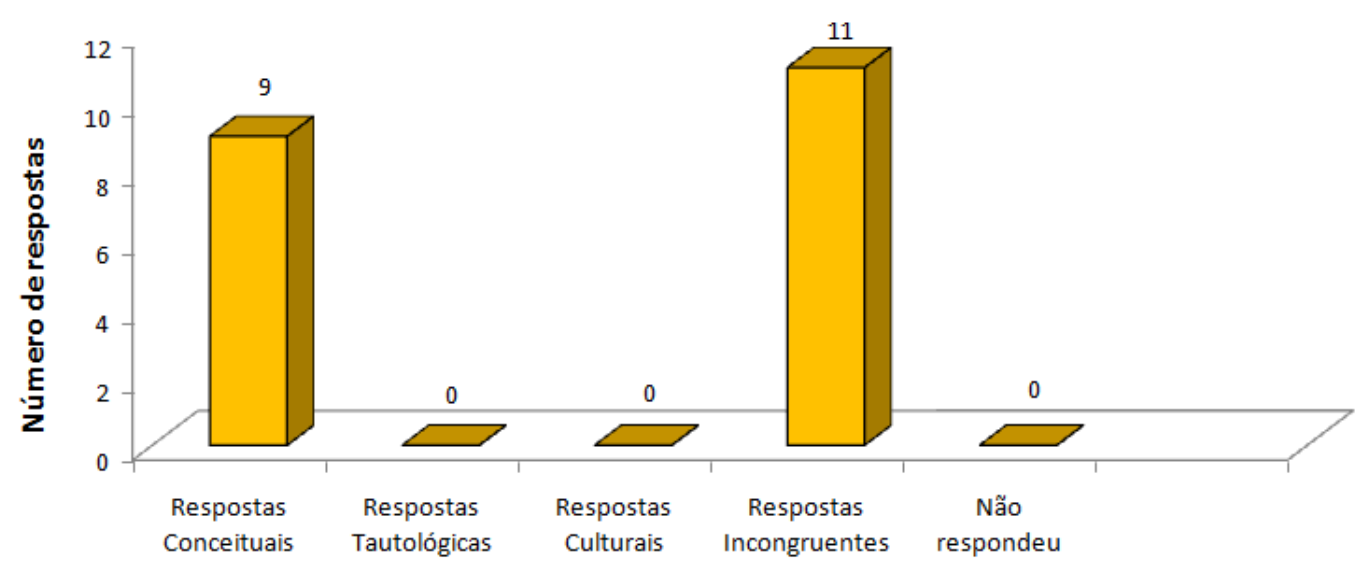

Fonte: Dados obtidos em pesquisa com alunos na Escola Básica Filial - Dili, Timor-Leste, agosto de 2016

embora estejam nesta categoria respostas nos mesmos parâmetros já mencionados anteriormente. Todavia, mesmo com essa categorização conceitual, as crianças não souberam responder diretamente ao perguntado na situação-problema 2 em que era esperado que dissessem que a impossibilidade do milho prosperar no algodão devia-se à ausências das condições no substrato que fossem semelhantes à do solo. Não se verificou nesta situação respostas que pudessem ser categorizadas como tautológicas, embora 55\% das respostas tenham sido categorizadas como incongruente. Nesta situação 2 em particular, dada as fortes tradições agrícolas do Timor, com grande parte da sua população ainda concentrada nas zonas rurais, a ausência de respostas culturais, reforçam a ideia de que as crianças que estão sendo escolarizadas, possivelmente, se afastam dos valores tradicionais das suas famílias nestes assuntos pertinentes ao campo. 


\section{Gráfico 3. Frequência das respostas obtidas por categorias para a situação-problema 3 - Escola Básica Filial - Dili - Timor-Leste}

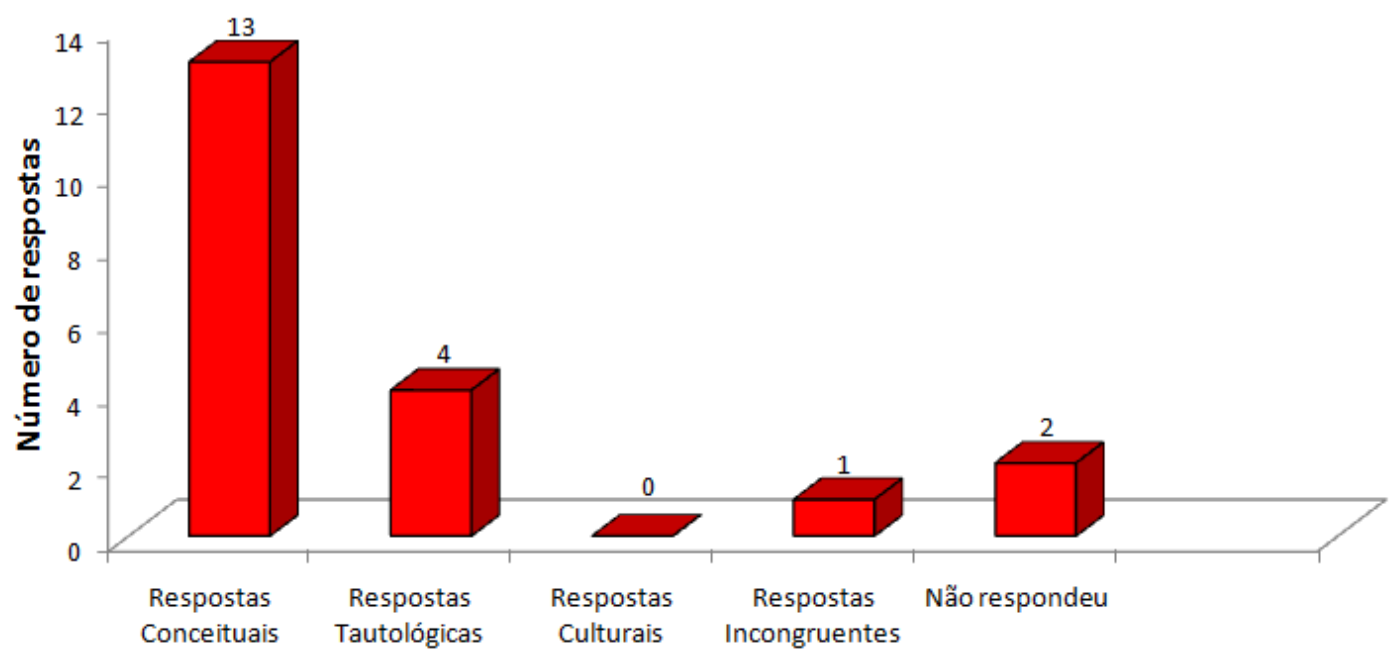

Fonte: Dados obtidos em pesquisa com alunos na Escola Básica Filial - Dili, Timor-Leste, agosto de 2016

Pelo gráfico 3, pode-se nitidamente perceber que a situação-problema 3, representa aquela em que mais respostas foram categorizadas como conceituais. O entendimento da impossibilidade de animais de espécies diferentes não poderem se reproduzir é evidente para $65 \%$ das crianças, ainda que não tenham manifestado o conceito de espécie. Apareceram ainda respostas tautológicas e incongruentes, porem em menor quantidade. Aqui também não apareceram respostas culturais. No processo de entrevistas, esta situação-problema especificamente, ocasionou as "recitações" coletivas do conceito de reprodução, mesmo em língua portuguesa, é perceptível um nível maior de compreensão. Segundo a professora, apesar de ser um conteúdo já tratado nos anos anteriores, como sempre tratam da fauna timorense ao longo dos anos do ensino básico, sempre revisa com seus alunos estes conceitos.

Já a situação-problema 4, como pode ser visualizado no gráfico 4, é aquela que menos apresenta respostas categorizadas como conceituais. Apenas $10 \%$ das respostas foram ajustadas nessa categoria, porém, como já reiterado algumas vezes, são apenas respostas que representam sinais de que as crianças foram expostas aos conteúdos. 


\section{Gráfico 4. Frequência das respostas obtidas por categorias para a situação-problema 4 - Escola Básica Filial - Dili - Timor-Leste}

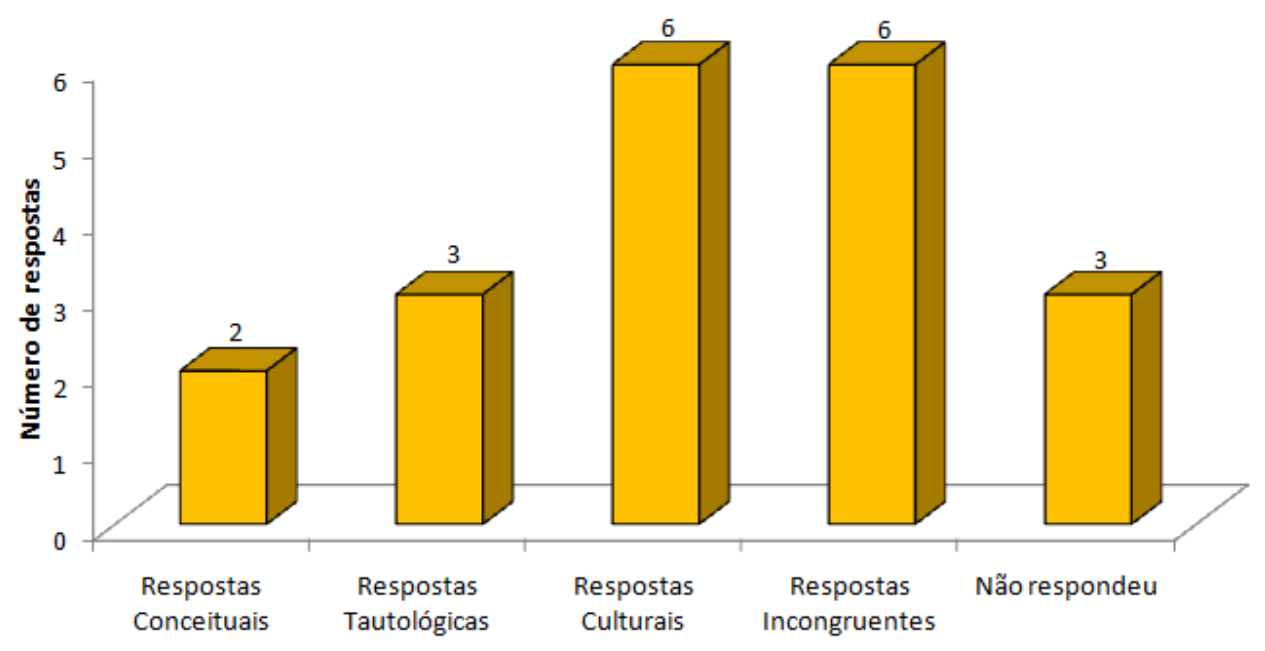

Fonte: Dados obtidos em pesquisa com alunos na Escola Básica Filial - Dili, Timor-Leste, agosto de 2016

Esta situação-problema, também foi a única em que se categorizou respostas como “culturais". 30\% das respostas puderam ser categorizadas desta forma. Embora as crianças não tenham demonstrado o entendimento sobre a relação de causa e efeito, entre o desaparecimento de ratos com o aumento de insetos atacando o milho, ao pensarem em resolver o problema, apresentaram alguns hábitos e costumes das comunidades agrícolas em proteger as colheitas em recipientes fechados. Apesar do processo de entrevista nesta situação-problema, tenha evidenciado a indução da professora a esses encaminhamentos, igual número de respostas foi categorizado como incongruentes.

Diante destas inferências sobre estes dados, é necessário entender que a educação de modo geral em Timor-Leste e em especial da educação básica passa por uma constante transformação em busca de um ajustamento curricular e metodológico com implicações para a língua portuguesa. A professora Cândida Belo, por exemplo, mencionou que utiliza o livro didático Estudo do Meio em português que é o material didático que dispõe, embora haja a necessidade de fazer traduções para o tétum para que as crianças possam entender. Como mencionado, as crianças conseguem ler o fonema em português e até articular algumas frases. É perceptível a dificuldade metodológica em lidar com duas línguas de instrução, onde a que dominam não possui material didático, e a que possui material didático não dominam.

Repetindo-se o mesmo tratamento para os estudantes da Escola João XXIII, a tabela 12 apresenta a categorização das respostas obtidas na coleta de dados. Todavia, como pode 
ser observado nas tabelas de 7 a 10, as respostas dos alunos em língua portuguesa apontam a maior parte nas categorias tautológicas e incongruentes. A falta de clareza nas expressões é um reflexo da dificuldade que as crianças possuem em língua portuguesa, porém, essa conclusão não permite afirmar que a falta de respostas em algumas situações na categoria conceitual se deva aos obstáculos da língua portuguesa, pois, por exemplo, tanto na situação 2 como na 3, muitas respostas que possuíam indícios de entendimento conceitual, foram categorizadas como tal.

TABELA 12. Quadro quantitativo de respostas obtidas por categorias - Escola João XXIII

\begin{tabular}{|l|c|c|c|c|c|}
\hline & $\begin{array}{c}\text { Respostas } \\
\text { Conceituais }\end{array}$ & $\begin{array}{c}\text { Respostas } \\
\text { Tautológicas }\end{array}$ & $\begin{array}{c}\text { Respostas } \\
\text { Culturais }\end{array}$ & $\begin{array}{c}\text { Respostas } \\
\text { Incongruentes }\end{array}$ & Não respondeu \\
\hline Situação-problema 1 & 0 & 19 & 0 & 4 & 1 \\
\hline Situação-problema 2 & 9 & 6 & 0 & 9 & 0 \\
\hline Situação-problema 3 & 13 & 6 & 0 & 5 & 0 \\
\hline Situação-problema 4 & 0 & 5 & 0 & 15 & 4 \\
\hline
\end{tabular}

O gráfico 5, aponta a concentração de respostas, dos alunos da Escola João XXIII que participaram da resolução das situações-problema, na categoria tautológica. Muitos escreveram como respostas, apenas fragmentos dos textos das situações. Outro elemento perceptível, diz respeito à semelhança de algumas respostas entre os alunos. Pela verificação da figura 15 pode-se observar as carteiras escolares geminadas e dado a proximidade das duplas, é perfeitamente explicável a semelhança entre algumas respostas. Embora tenha aparecido respostas incongruentes, 79\% representaram tautologias. As crianças não fizeram considerações sobre "maré", influência da lua, movimento de rotação, ou coisas semelhantes como realizado pela turma da Escola Básica Filial. Embora a comparação seja inevitável, alguns elementos devem ser considerados para evitá-la. Primeiramente, as crianças da Escola Básica Filial estavam respondendo com o auxílio da própria regente que interferiu com dicas e esclarecimentos. Segundo, as crianças não usaram a língua portuguesa escrita para a exposição das ideias, coisa que não ocorreu com os estudantes da Escola João XXIII. 


\section{Gráfico 5. Frequência das respostas obtidas por categorias para a situação-problema 1 - Escola João XXIII- Dili - Timor-Leste}

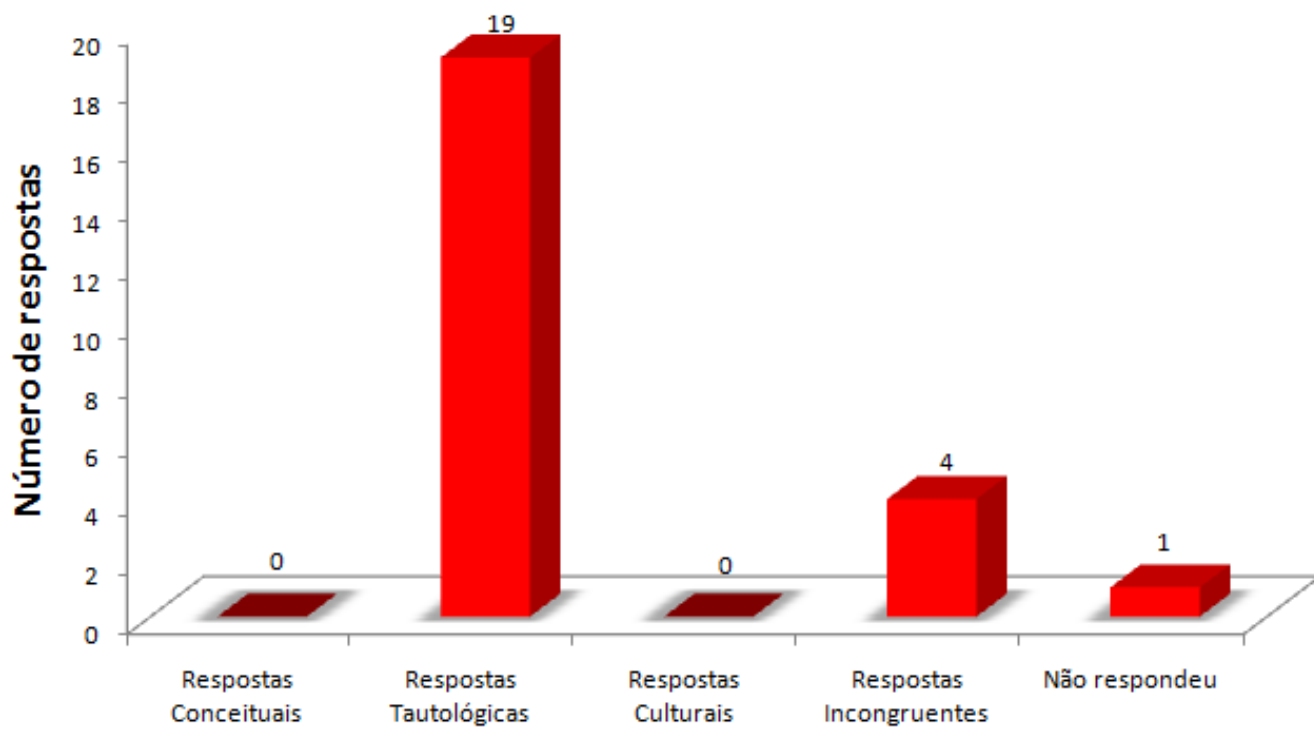

Fonte: Dados obtidos em pesquisa com alunos na Escola João XXIII - Dili, Timor-Leste, agosto de 2016

Embora tenham sido informados de que podiam perguntar diante de qualquer dúvida, mesmo em tétum, pois estava na sala acompanhado pela professora de língua portuguesa deles, os alunos se mantiveram silenciosos enquanto escreviam suas respostas para as situações-problema.

Outro fator interveniente diz respeito à minha própria interpretação das respostas dos estudantes da Escola João XXIII para a categorização das mesmas. Por ser fruto de uma subjetividade, possivelmente podem variar de categoria em função da interpretação de outro observador. O certo é que uma simples visualização das tabelas de respostas escritas destes estudantes permite entender a dificuldade no estabelecimento de categorias para as mesmas.

O gráfico 6 mostra a freqüência de respostas para a situação-problema 2, e para esta situação predominaram respostas categorizadas como conceituais e tautológicas. $37 \%$ das respostas foram classificadas como conceituais por indicarem a necessidade de solo no desenvolvimento do milho, coisa que não se encontrava no algodão. Apenas uma resposta (Porque o milho no copinho não tem minerais) aponta expressamente a necessidade de minerais para o seu desenvolvimento. Outras 37\% de respostas foram categorizadas como incongruentes por estarem totalmente obscuras quanto ao seu entendimento e outras $25 \%$ podem ser consideradas tautológicas por se limitarem a repetir fragmentos dos textos da situação-problema. 


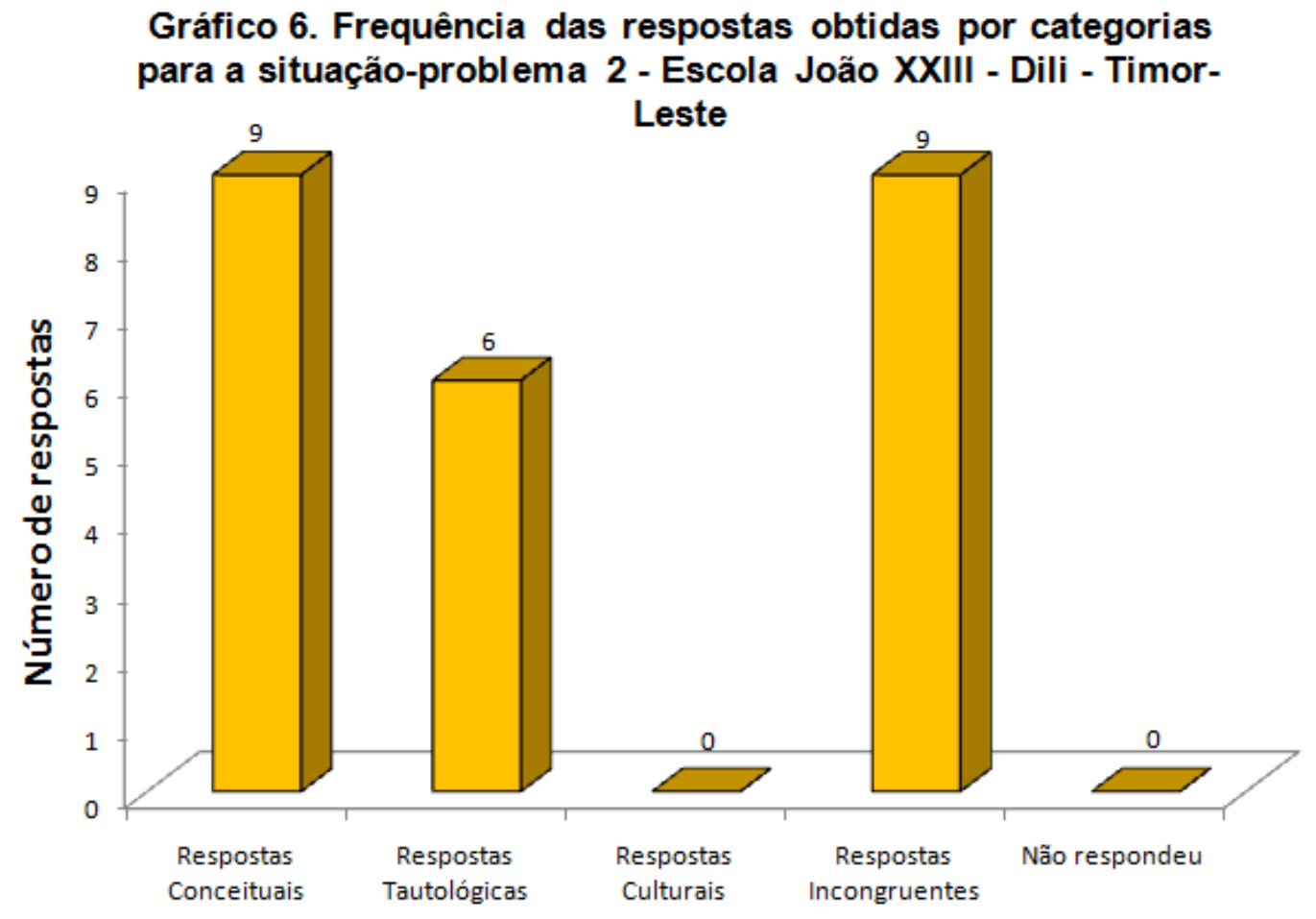

Fonte: Dados obtidos em pesquisa com alunos na Escola João XXIII - Dili, Timor-Leste, agosto de 2016

Embora não esteja fazendo comparações entre as duas escolas pesquisadas pelos motivos já apresentados, o gráfico 7 aponta um predomínio de respostas para a situaçãoproblema 3, categorizadas em conceituais, predomínio já verificado nas respostas da Escola Básica Filial. Entre os alunos respondentes da Escola João XXIII, 54\% atribuem à desigualdade das espécies como impeditivos para a reprodução, embora apenas uma resposta aponte isso na sua literalidade (Este animais não tiveram filhotes porque as espécies não são iguais). Todavia, a somatória de questões categorizadas entre tautológicas e incongruentes seja da ordem de 46\%, apontando a dificuldade de alguns no estabelecimento do entendimento conceitual.

Por fim, o gráfico 8 mostra a frequência das respostas nas categorias elencadas para situação-problema 4. Nota-se a ausência de respostas que poderiam ser apresentadas como conceituais. Aqui também, aparentemente não há o entendimento entre causa e efeito no desequilíbrio promovido com o desaparecimento dos ratos na população de insetos no milharal. 


\section{Gráfico 7. Frequência das respostas obtidas por categorias para}

a situação-problema 3 - Escola João XXIII- Dili - Timor-Leste

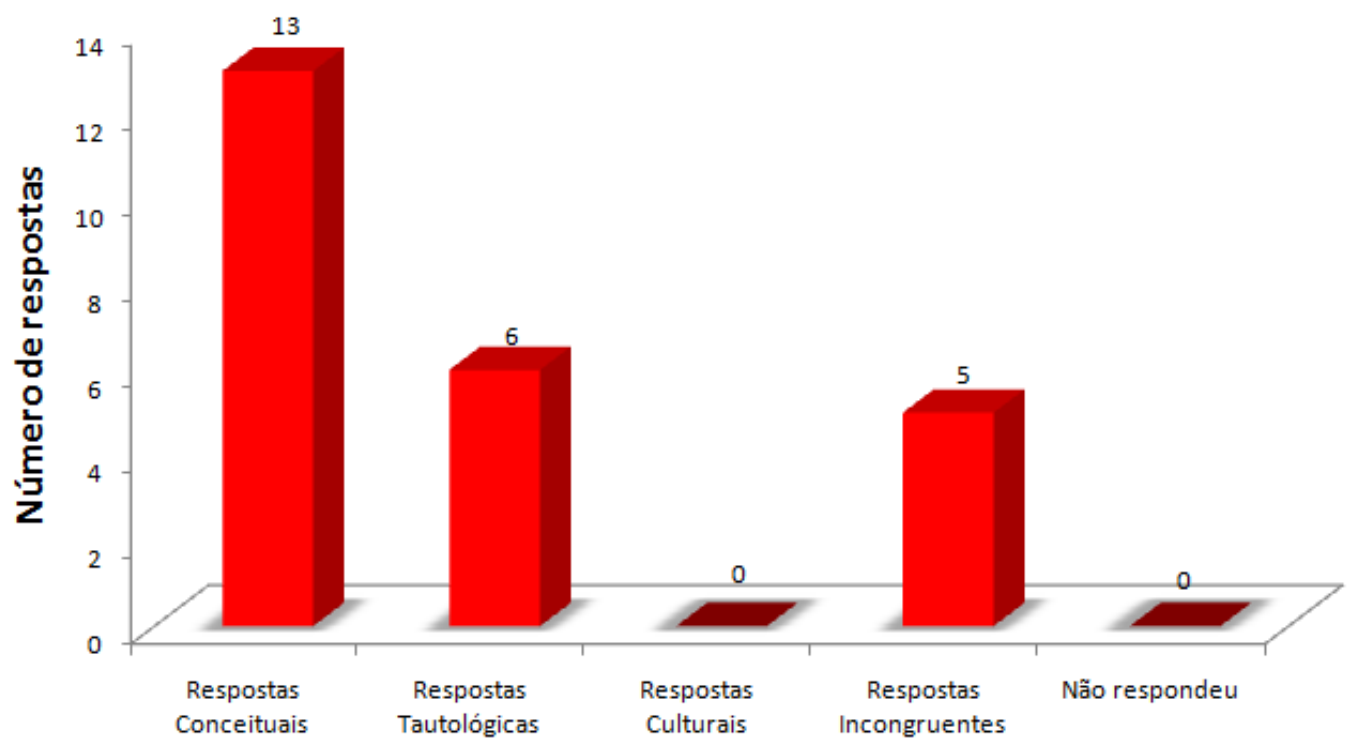

Fonte: Dados obtidos em pesquisa com alunos na Escola João XXIII - Dili, Timor-Leste, agosto de 2016

Gráfico 8. Frequência das respostas obtidas por categorias para a situação-problema 4 - Escola João XXIII - Dili - TimorLeste

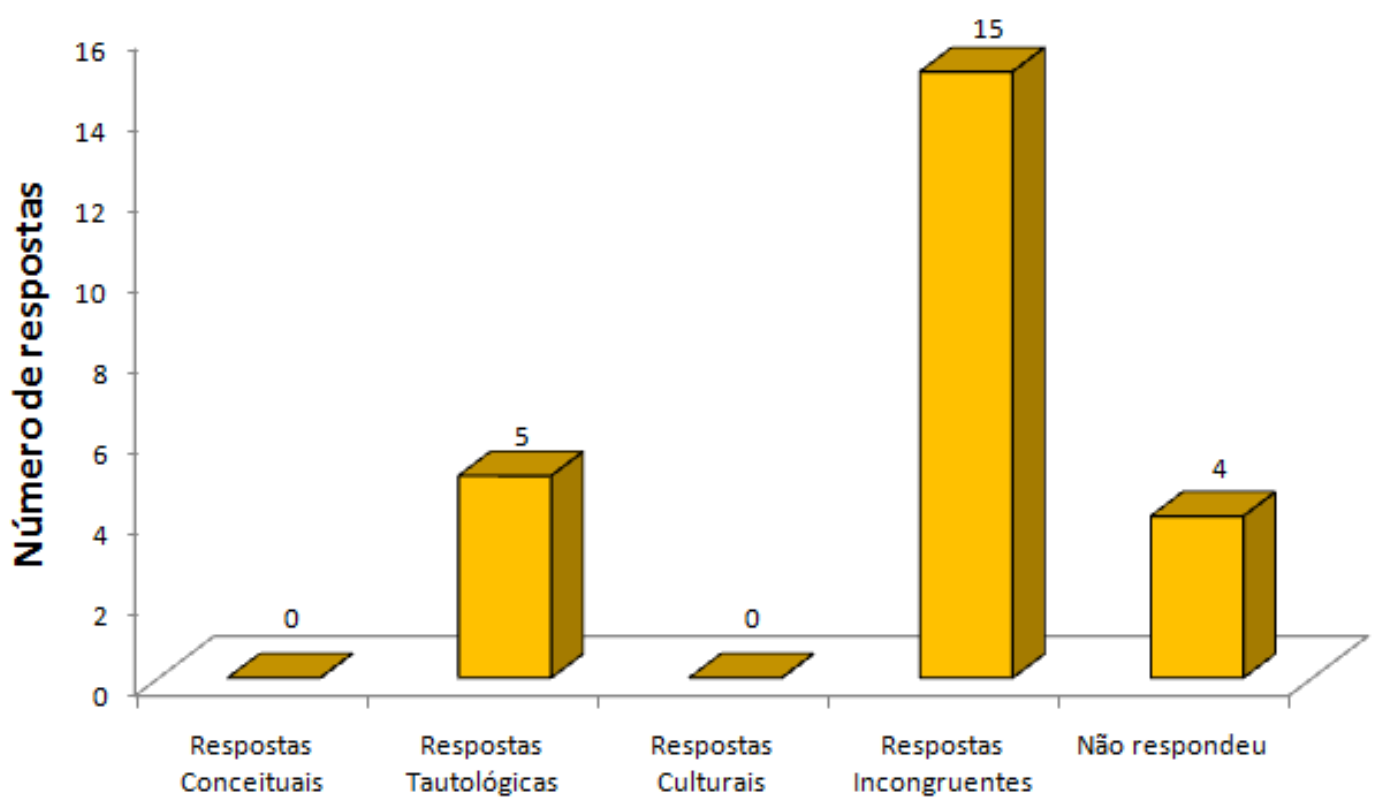

Fonte: Dados obtidos em pesquisa com alunos na Escola João XXIII - Dili, Timor-Leste, agosto de 2016 
$62 \%$ das respostas foram enquadradas como incongruentes, pois não houve nenhum indício nas mesmas que permitisse minimamente ser categorizadas de outra maneira.

Chama a atenção também nas respostas obtidas, a ausência de indícios que pudessem classificá-las no viés cultural. Os respondentes não manifestaram nenhuma consideração neste sentido. Se tomarmos como base que os alunos da João XXIII, por ser uma escola privada católica, são provenientes de família com um melhor poder aquisitivo de modo a poderem pagar mensalidades (em Timor, chamada de "propina"), possivelmente já é uma distinção econômica em relação aos estudantes da Escola Básica Filial. Isso permite inferir a procedência cultural distinta. Segundo a informação da professora da turma da Escola Básica Filial, boa parte das crianças da turma vem de distritos que predominam línguas diferentes do tétum, enquanto os alunos da João XXIII são predominantemente de Díli. Outra consideração a ser feita, pode ser entendida a partir da entrevista da Senhora Filomena Lay, Diretora do INFORDEPE no anexo 3 nos apêndices. Ao tratar das escolas católicas, Lay nos informa que nestas escolas ocorre ensino de religião e isso impõe certa disciplina. Diante disso, posso concluir que ensino religioso, possivelmente, oblitere valores culturais mais centrados nas tradições ancestrais animista. Embora, também não tenha notado a manifestação cultural nas respostas dos estudantes de Escola Básica Filial.

Outro aspecto que deve ser levado em conta, diz respeito à formação de professores tanto básica como continuada. Está última área constituiu o foco do meu trabalho realizado em Timor no ano de 2007. Passada a crise no país em 2006, testemunhei a assinatura dos novos acordos Brasil-Timor no campo da educação (ver memória "5. Assinatura de acordos na educação", apêndices, p. 286), atuando na formação continuada. Em auxílio ao entendimento sobre o que atualmente se tem em Timor nesta área, recorreu-se à contribuição da senhora Maria Filomena Lay, atual diretora do INFORDEPE, que em uma entrevista gentilmente concedida (ver anexo 3, p.265) nos apresenta alguns elementos indispensáveis.

Primeiramente, a senhora Filomena realizou seus estudos para mestrado no Instituto da Educação da Universidade de Lisboa, com dissertação intitulada "Choque de realidades dos professores principiantes em Díli (Timor-Leste), um estudo", defendida em 2011. No trabalho concentra sua atenção como objeto de pesquisa na realidade dos professores principiantes em Timor-Leste, sobretudo os de língua portuguesa e suas necessidades de formação continuada. Segundo LAY (2011, p.ix),

Os resultados obtidos permitiram-nos concluir que os professores que participaram no estudo revelam ter dificuldades consideráveis relacionados com os aspectos relativos ao ensino-aprendizagem. Permitiu-nos identificar as necessidades percebidas nos seus primeiros anos de carreira, nomeadamente necessidades relativas ao apoio pedagógico, às reformas no ensino do português e à obtenção de manuais escolares. (p.ix). 
$\mathrm{Na}$ sua entrevista, Filomena Lay deixa claro que a base de formação dos professores do ensino básico em Timor era precária, pois a maioria na época da independência do Timor não tinha a formação necessária para atuação na educação básica, mas, era esse o material humano que teriam que contar pois não havia outro. Só lembrando que os professores indonésios que atuavam na educação, se retiraram do país. As cooperações internacionais, a exemplo da brasileira, foram de grande auxílio nesta etapa de formação continuada, mas, dado o contingente de professores, não resolveram o problema. Assim, as formações prosseguem, centrando-se na língua portuguesa e nas áreas específicas, como matemática e ciências. Desta forma, não é de se esperar que as concepções dos professores da escola primária a respeito de conceitos importantes a serem trabalhados nesse nível de escolarização correspondessem ao esperado para um professor com licenciatura que o habilitasse neste nível. No entanto, por experiência própria no ano de 2007, tenha trabalhado na formação de professores timorenses com muitos anos de atuação na docência, mas sem a formação necessária, mesmo no tempo da Indonésia (ver memória “6. Relatório Bimestral 1 - PROFEP-Timor”. p. 288). 


\section{CAPÍTULO 5 Resultados e conclusões - considerações finais}

Ao estudar o Timor em um fragmento relacionado ao ensino de ciências na sua educação básica, sobretudo por meio das concepções de estudantes sobre alguns conceitos científicos básico, como postulante a pesquisador não poderia me afastar do objeto de estudo com um encaminhamento de distanciamento necessário, onde a imparcialidade desloca o sujeito do objeto em busca de conclusões mais neutras. Ou, dizendo de outra forma, dentro do "relativismo cultural” na acepção de Franz Boas, seria necessário pensar a cultura dentro de parâmetros culturais semelhantes, inserido nos valores desta cultura. As vivências com o povo do Timor-Leste que remontam o ano de 2007, revelou aos meus olhos sua história, seus complicadores linguísticos, sua pluralidade étnica e cultural que não encontravam em mim parâmetros de compreensão baseados nos repertórios ocidentais e na minha formação cultural e intelectual brasileira. Esta teve que ser posta de lado em um enfoque fenomenológico aqui pretendido e como afirma Rezende (1990, p.36-37),

\footnotetext{
Tudo quanto sabemos sobre o homem e sobre o mundo, graças à contribuição das ciências, deve ser posto entre parênteses, para que possamos redescobrir a experiência primitiva em toda sua riqueza. A volta às próprias coisas, a redescoberta do mundo vivido é condição radical para o nascimento da filosofia, e mesmo das ciências, que, quando aparecem, encontram o mundo já constituído. O momento do nascimento da filosofia é anterior à reflexão, sendo, ao contrário, sustentáculo de toda reflexão posterior, tanto da filosofia como da ciência. A não referência a esse momento originário é que deixa literalmente "no ar" toda filosofia meramente reflexiva, idealista ou conceitual.
}

Portanto, observar o fenômeno com o parâmetro dos preconceitos, é incorrer nas dicotomias, separando o homem do mundo e o sujeito do objeto. As narrativas nos apêndices podem oferecer um vislumbre das vivências no Timor-Leste que se completam com um novo contato para intencionalmente encerrar uma pesquisa. Por esta razão, o método fenomenológico se mostrou mais propício para as análises lindadas abaixo, pois acima de uma definição, está uma percepção e perceber é mais do que definir como aponta Merleau-Ponty (2004).

Embora não tenha explorado o fenômeno da escolarização em ciências no Timor nas mais variadas dimensões, pois a amplitude desta tese não permite, entendo que perceber esta escolarização apenas com meu "olhar frontal" para o objeto "concepções em conceitos científicos", é tirar conclusões apenas na minha perspectiva pautada em considerações diante do meu repertório e da minha experiência com educação e possivelmente, neste sentido, só perceba unilateralmente com os meus parâmetros. Em uma perspectiva fenomenológica, é 
necessário orbitar em torno do objeto, para vê-lo em todas as suas dimensões e vermos que uma análise "frontal", baseada em um único parâmetro do pesquisador que busca o reflexo do seu entendimento e conclui nesta base, não passa de platitude pálida. É como concluir sobre a profundidade de um lago observando apenas a linha d'água.

Em uma acepção fenomenológica, o que é que se mostra na tentativa de clarificar um conceito científico por meio de uma situação-problema apresentada para uma criança timorense na sua escola primária? Afinal, o processo pelo qual se procurou elucidar o que a criança sabia sobre o assunto, como se deu? É necessário "buscarmos o significado e o sentido daquilo que se mostra" (ALES BELLO, 2006, p. 18).

A análise fria das respostas obtidas sem a percepção de como o processo se deu, talvez represente apenas na superficialidade o entendimento do fenômeno. O sentar-se com o estudante timorense, crianças ainda, para colher dele o que sabe sobre um assunto que o pesquisador domina, possivelmente tenha o mesmo sentido de estar em uma guerra de dominação, tendo o agente invasor superioridade bélica e numérica, enfrentando o agente de resistência armado precariamente e em insuficiência numérica, como ocorrido entre Indonésia e Timor no processo de invasão nos anos setenta.

A analogia aqui pode parecer tragicamente exagerada, mas, após o conhecimento do Timor por experiência e sobre seu histórico em sua luta para integrar-se autonomamente no mundo, um estudo de levantamento de concepções de estudantes sobre conceitos científicos na sua embrionária escola básica se reveste do pioneirismo, dada a inexistência de trabalhos deste escopo para este nível de escolaridade no país. No entanto, os achados que apontam as dificuldades das crianças no estabelecimento de concepções sobre conceitos básicos das ciências, possivelmente não se revelam em sua essência, pois, pode parecer apenas um instantâneo sobre uma circunstância temporal a ser superada em breves tempos pelo Timor em sua busca por uma educação de qualidade. O desafio do Timor se dar atualmente, sobretudo no campo educacional e como já ofereceu exemplo de superação ao longo da sua conturbada história, se saindo vitorioso dos entreveros que já enfrentou, também aqui, vislumbro percalços transitórios. Compreender os sentidos do que se busca em uma pesquisa como essa, é perceber em nosso interior a capacidade para explicar um fenômeno, onde nada é o que parece ser. Os referenciais estão dentro de nós mesmos, a partir da construção do que sabemos, do que vivemos e como esse processo ocorreu, mas não em função dos nossos preconceitos. Assim, viver, sofrer, compartilhar com o Timor, organizou em mim parâmetros de compreensões que nunca serão os mesmo para um pesquisador afastado completamente do objeto. 
Todas as coisas que se mostram a nós, tratamos como fenômenos, que conseguimos compreender o sentido. Entretanto o fato de se mostrarem não nos interessa tanto, mas, sim, compreender o que são, isto é, o seu sentido. O grande problema da filosofia é buscar o sentido das coisas, tanto de ordem física quanto de caráter cultural, religioso etc., que se mostram a nós. Então, para compreender o sentido, nós devemos fazer uma série de operações, pois nem sempre compreendemos tudo imediatamente, que consiste em identificar o sentido, os fenômenos, de tudo aquilo que se manifesta a nós. (ALES BELLO, 2006, p. 19)

Nesta perspectiva, a pesquisa presente, não pretende ser algo que se encerará após a expressão dos seus achados e conclusões, ela perdurará como algo que poderá levar a outras conclusões que não foram expressas em função da ampliação do conhecimento e do amadurecimento do pesquisador. As conjecturas que são apresentadas aqui como conclusões, se baseiam nas descrições dos objetos da consciência e não em deduções meramente empíricas.

Está claro que as diferenças nas abordagens metodológicas entre a coleta de dados da Escola Básica Filial e a Escola João XXIII não contribuem para uma conclusão generalizada, pois se mostram em sua essência à consciência em formas diferentes. Essa consciência que é intencional, só é “consciência dirigida a um objeto” (DARTIGUES, 1992, p. 19).

Poderemos falar então, já inspirados em Brentano, de uma existência intencional do objeto na consciência. Por sua vez, isto não quer dizer que o objeto está inserido na consciência como que dentro de um recipiente, mas que só há sentido de objeto para uma consciência, que nunca esgotaremos as possibilidades de sentido do objeto, que sua essência é sempre o termo de uma visada de significação e que sem tal visada não se poderia falar de objeto nem de uma essência de objeto. Isto significa que as essências não têm existência própria, que as essências não têm existência alguma fora do ato de consciência que as visa e do modo pelo qual ela os apreende na intuição. Sendo assim, se o objeto é sempre objeto para uma consciência, ele não será jamais objeto em si, mas objeto-percebido, pensado, experienciado. (GONÇALVES; GARCIA; DANTAS; EWALD, 2008, p. 404).

Em uma concepção husserliana, é o noema, ou objeto constituído, pela atividade da consciência, ou noesis. Para Husserl, a consciência se define essencialmente em termos de intenção voltada para um objeto. "Perceber não é receber sensações na psique. Não nos é possível separar fenômeno e coisa em si. O fenômeno é conhecido diretamente, sem intermediários, ele é objeto de uma intuição originariamente doadora”. (CAPALBO, 1987, p.14).

Diante disso, a essência de alguns elementos pode ser evidenciada na pesquisa independente da escola. Primeiro, atribuo como crucial a dificuldade com a língua portuguesa e a obrigatoriedade do seu uso como língua de instrução. Isso representa o ponto fulcral essencial para o entendimento da dificuldade em outras áreas como especificamente o estudo das ciências. Uma educação bilíngue se constrói aos poucos, mas, é fundamental o domínio da língua com a qual os conceitos são construídos (BAKER, 2011). Apesar disso, abandonar a 
língua portuguesa ou diminuir sua importância como há indícios de que já ocorre, é renunciar a um passado que possibilitou a liberdade e autodeterminação do Timor-Leste e até de sua identidade. Como já referido anteriormente, volto a evidenciar que a presença portuguesa no passado colonial, garantiu uma nova identidade para o povo timorense, de modo que se tivesse sido colonizado pelos holandeses, como a porção ocidental da ilha de Timor o foi, hoje seria mais uma província da Indonésia.

De tudo que se apontou aqui, sobretudo em seu apanhado histórico, fica evidente que a língua portuguesa nunca foi unanimidade em Timor-Leste. Primeiro, pelo modelo colonial tocado pelos Dominicanos e pelo duradouro descaso de Portugal; segundo, por uma educação excludente destinada aos filhos dos liurais e seus agregados. Se por um lado isso possivelmente tenha contribuído para a preservação do plurilinguismo e da diversidade cultural, tão caros em uma perspectiva dentro da teoria pós-colonial, por outro, afastou a língua portuguesa de uma posição hegemônica. Este afastamento foi ainda mais intenso nos pesados anos da invasão Indonésia, em que aqueles falantes em português, foram proibidos terminantemente de usar a língua, aumentando ainda mais o desinteresse pelo português.

Com a independência do Timor-Leste e sua definitiva autonomia, a adoção da língua portuguesa como língua oficial, sobretudo para ser usada na educação, colocou o Timor com o desafio da educação bilíngue. Quando se observa na literatura (PACIFIC POLICY RESEARCH CENTER, 2010) nos encaminhamentos pós-coloniais em que povos que lidam com plurilinguismo são exortados a escolarizar-se em outra língua que não dominam, como em modelos bilíngües de educação em que uma das línguas é de povos indígenas, como no Canadá e nos Estados Unidos, a imersão total na língua, geralmente a segunda língua a ser aprendida, é o método mais eficiente para esse ensino. Todavia, mesmo que no Timor houvesse imersão total em língua portuguesa na escola, coisa que não ocorre por uma série de razões, entre elas, o baixo domínio da mesma entre os professores do ensino básico, as crianças em suas vidas sociais, na família e nas comunidades em que vivem, não praticam a língua portuguesa dada a profusão de línguas maternas disponíveis para o uso, sem falar no tétum (sobre isso, ver a entrevista a senhora Filomena Lay no anexo 3). Neste sentido, por falta de uso corrente, possivelmente a língua não se desenvolva tão facilmente. Observou-se esse fenômeno na Escola João XXIII, onde houve a afirmação de que as crianças conseguiam escrever e falar português e o que se viu foi uma grande dificuldade de expressão escrita. A não utilização corrente da língua, não a torna útil na comunicação diária e por conseqüência, não a desenvolve. 
Adeptos da língua portuguesa na educação em Timor chegam a radicalizar em métodos para o seu uso, como o corrido em julho de 2016 em uma escola pública em Díli (Figura 16):

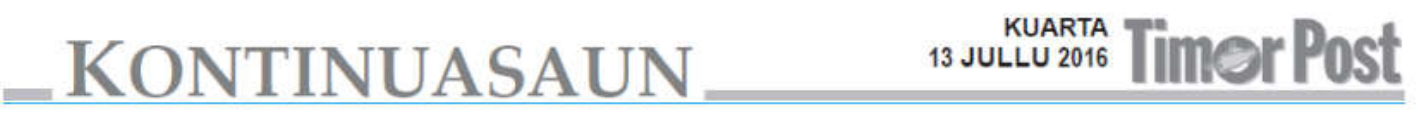

ba sira ba ne'e hetan apoiu hosi governu," Vise haktuir.

Embaixador mós hato'o nia difikuldade, nia mós orsamentu ladun barak, Brazil ne'e la'ós nasaun kiik, maibé nasaun boot hosi parte ida ba fali parte seluk ne'e, ho aviaun lori oras lima, maibé embaixador buka mekanismu lakontaktu dereitamente ho estudante sira, maibé liu hosi sira nia assosiasaun estudante iha universidade ida idak iha ne'eba.

"Ami mós estuda hamutuk halo nusa ba oin ita sei rekruta profesores Brazileiru mai fó kursu iha Timor, tanba ita nasaun ne'ebé maka ko'alia lian português tenke português ida los ka di'ak ninian, la'ós português ida sabraut ninian, se ita hakarak ko'alia inglês ko'alia inglês ida ne'ebé los, ne'e duni ita hakarak mellora ita nia inglês ita tenke buka ema nasaun ne'ebé ko'alia in-

\section{Estudante Ko'alia Tetun Multa Dollar 1 \\ DILI-Diretora Eskola ko'alia tetun sei multa dol- ne'ebé eskola iha, tanba Báziku Sentrál Fatumeta lar 1, karik maka lahtene bele eduka labarik sira atu Fernanda Belo Hateten, ko'alia di'ak lin nonok de'it bele hatene ko'alia lian por- estudante sira tama iha no labele temi buat ida mas tugés. \\ resintu eskola hotu-hotu bainhira nia hakarak ko'alia Ho programa ne'ebé iha tenke ko'alia portages, maka nia sei hatene por- tuir Diretora Eskola ne'e maibé bainhira ko'alia tugés" dehan Diretora Esko- katak, hakarak ka lakoi tetun maka tenke multa la Báziku Sentrál Fatumeta estudante sira tenke kum- dollar 1 Fernanda Belo, ba Timor pri, tanba programa refere Post iha edifisiu Fatumeta hetan apoiu masimu hosi “Ami ko'alia ona ho Posti, Tersa (12/7). inan-aman estudante sira sira tama iha resintu es- Enkuantu tuir Diretora no programa refere bazeia kola ne'e labele ko'alia eskola ne'e katak, inan- ba inisiativu hosi eskola tetun hotu-hotu ko'alia aman estudante sira mós ne'e rasik no kopera ho lian portugés, sé maka konkorda ho programa inan-aman sira. (MJ7)}

FIGURA 16. Notícia do Jornal Timor Post atestando o radicalismo de uma direção de escola para o uso da língua portuguesa.

A manchete do jornal da figura 16 estampa que: "Se o estudante falar Tétum recebe multa de 1 dólar". A notícia informa que a direção da Escola Básica de Fatumeta, em Díli, está impondo uma regra que proíbe seus estudantes de falar o tétum ou a língua materna no interior do estabelecimento de ensino. Todos estão obrigados ao uso do português como única língua autorizada, sob pena de quem descumprir a determinação ter que pagar US\$1,00 (um dólar americano) por dia de infração. De acordo com a notícia veiculada a diretora da Escola, Fernanda Belo, defende que só se pode falar Português e "quem não souber falar, é melhor ficar calado". Em seu argumento a diretora ainda atesta que sua decisão é apoiada pela maioria dos pais de alunos.

O radicalismo acima tem causado polêmica no Timor, e por ocasião da minha estadia para a pesquisa, era assunto corrente, pois, segundo atestam alguns, as línguas oficiais pela Constituição são tétum e o português, e impedir o uso do tétum é um atentado contra a Constituição. Outro argumento que suporta a decisão da escola reside no fato de que o TimorLeste, apesar de fazer parte da CPLP (Comunidade dos Países de Língua Portuguesa), é o país do grupo com menor penetração da língua portuguesa, com apenas cerca de $15 \%$ da sua 
população falando português. Esses posicionamentos divergentes na sociedade também estão refletidos nas disputas que são verificadas nas constantes reformas do currículo, conforme já demonstrado. A depender da corrente política que esteja no governo, a política educacional e seus encaminhamentos mudam ao sabor de ideologias, crenças e interesses locais e internacionais.

Outro objeto que se mostra à consciência refere-se ao respeito aos próprios valores culturais. Ainda que diversificados em Timor, estão sendo colocados em segundo plano, procedendo a uma gradual ocidentalização de costumes e compreensão do mundo no universo da infância timorense. Por exemplo, na busca de encaminhamentos multiculturais para as respostas às situações-problema apresentadas, nota-se uma ausência das mesmas. Uma explicação que se pode dar para este fato, foi oferecida, ainda que indiretamente, pela senhora professora Cândida Belo. Durante a entrevista com estudantes para situação-problema 4, uma aluna mencionou que não sabia responder ao perguntado. A professora Cândida Belo, que apontava, com as traduções, algumas explicações dos estudantes sobre o assunto, categorizadas aqui como "Respostas Incongruentes", ou seja, não demonstravam soluções conceituais, embora apresentassem respostas que aparentemente resolviam a situação, mencionou especificamente desta aluna que a mesma era de Liquiça e que teria vindo estudar na escola em Díli, muito nova. Este fato, segundo a professora, a afastou das tradições da família e, muitas situações no trato com insetos e outras pragas comumente praticadas no campo, já não faziam parte dos conhecimentos da criança, embora sejam antigos nas famílias da sua comunidade. Nota-se nessa explicação, o caminho de aculturação que a "escola" estava promovendo, portanto, sem a valorização multicultural tão propalada em Timor-Leste.

Esta compreensão se coaduna com a apresentada por Norberg-Hodge (2013) em seu livro "Ancient Futures: learning from Ladakh", segundo a qual, nas comunidades ancestrais, onde seus membros estão integrados na natureza na construção e manutenção de suas vidas, sem um processo educacional nos moldes formais e ocidentais, os contextos de sustentabilidade, produção de alimentos e utensílios, equilíbrio entre a conservação e o consumo de recursos naturais, garantem a sobrevivência cultural desses povos. A opção pela educação escolarizada nos modelos ocidentais, dentro de nações pós-coloniais, desloca os indivíduos dos seus pólos culturais afastando-os da sua ancestralidade de tal modo que perdem o contato com resoluções de problemas que em suas áreas originais são realizados por métodos ancestrais funcionantes, para supostamente adquirirem conhecimentos em métodos modernos conferidos pela escola, sem, no entanto, a garantia de que funcionem. $\mathrm{O}$ indivíduo fica despersonalizado. Não pertence à cultura ocidental dos modelos escolarizados e nem 
consegue mais voltar para sua ancestralidade. Ainda mais diante dos problemas linguísticos que Timor enfrenta em relação à sua língua de instrução.

Outro exemplo, que pode parecer até pueril, trago aqui das minhas reminiscências de 2007 e conclamo o leitor para observar a Figura 17. Ela é uma fotografia tirada em uma das salas de aula do atual INFORDEPE onde ocorriam formações. Notem que há um mapa mundi no fundo da sala cuja representação é pelo padrão asiático, sobretudo, usado amiúde na Indonésia. Nesta representação a Ásia está no centro do mapa. A utilização destes mapas era muito comum nas salas de aulas em Timor no ano de 2007. Todavia, como pode ser observado na fotografia da figura 13 (p.184), o mapa ao fundo da sala está na representação usada por nós no Ocidente, onde o que está ao centro é a Europa. Observando várias salas de aula, não encontrei mais a representação asiática do mapa mundi. Até nas livrarias do comércio de Díli, não os achei, somente encontrei o mapa da representação ocidental. Apenas fui encontrar um mapa semelhante em uma livraria de Bali na Indonésia.

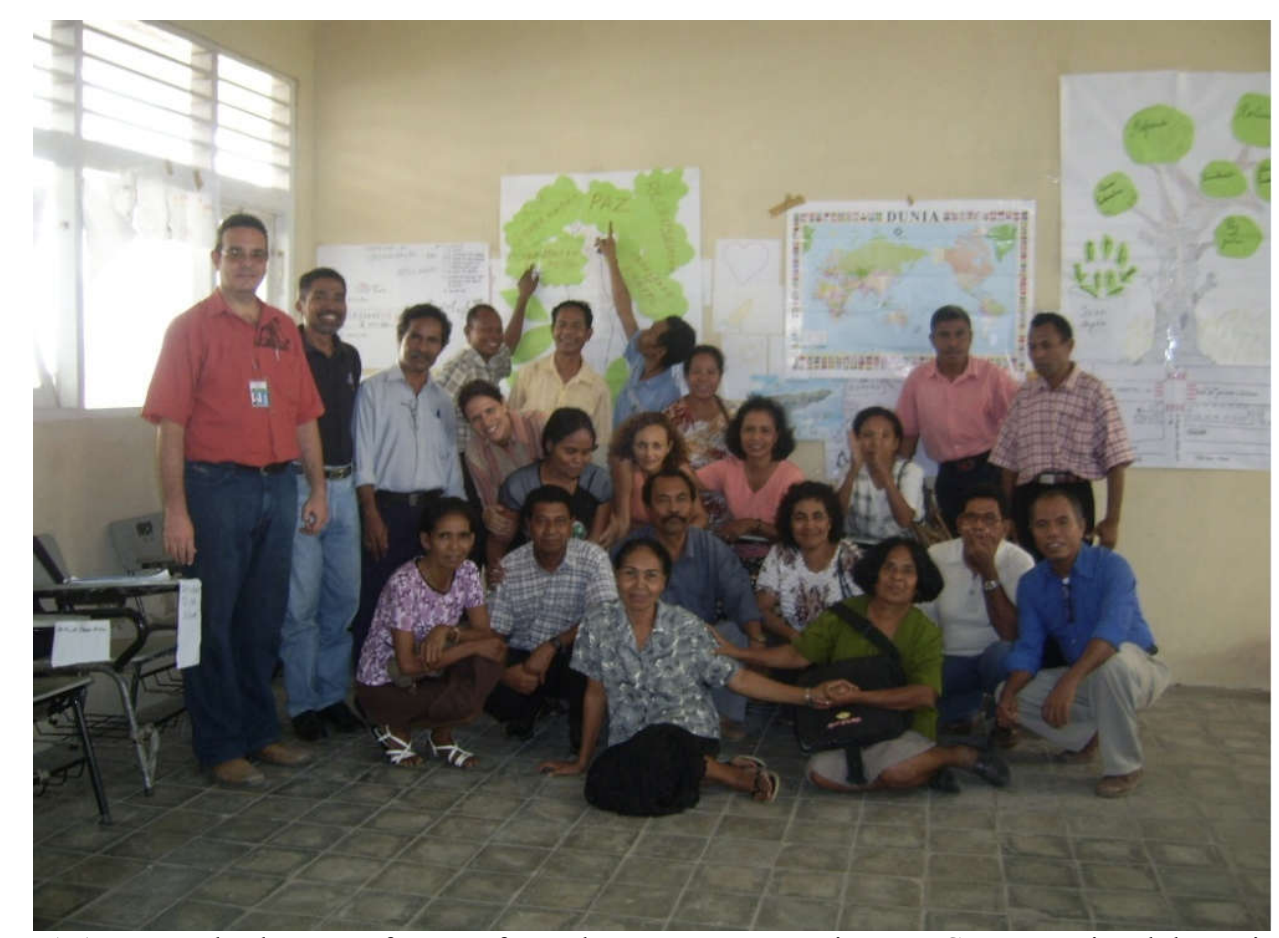

FIGURA 17 - Foto de alguns professores formadores, tutores e cursistas no Centro Nacional de Resistência Timorense (CNRT) em Díli

Mesmo que diante da busca por uma identidade nacional, uma análise dentro da teoria pós-colonial, em um país multicultural como o Timor-Leste, uma educação da infância, poderia ser recriada de forma socialmente mais justa e representativa desta diversidade, como apontam estudos neste sentido (CANNELLA, 1997; CANNELLA \& VIRURU, 2004; 
JIPSON \& HAUSER, 1998; WALKERDINE, 1997; STREINBERG \& KINCHELOE, 1997). Todavia é possível dizer que a educação da infância em Timor, passa por uma "colonização", desde a escolha da língua portuguesa até uma possível supressão dos valores das suas raízes ancestrais e até regionais, em relação aos países da vizinhança, nesta educação.

A suposta aquisição conceitual nos parâmetros científicos, provavelmente não consiga produzir soluções para problemas da vida real nestas comunidades ancestrais que tem seu próprio entendimento dos problemas e suas soluções sem um conhecimento escolarizado, pois suas línguas maternas, ainda que atualmente haja a tendência à sua utilização nos níveis iniciais de escolarização, estão alijadas deste processo. Possivelmente, a opção por uma escolarização já universalizada e em língua ocidental tenha também seus ganhos, sobretudo na inserção do país nos mercados globais e nas comunidades internacionais. Neste sentido, é um direito do Timor perseguir esses caminhos que também os tornem semelhantes ao resto do mundo, embora as dificuldades não sejam pequenas, como bem pode-se perceber diante de tudo que já se expressou aqui. Mas nessa busca do Timor, é de se constatar que a criança timorense está construindo seus saberes escolares como uma "nuvem sincrética", onde as línguas e suas possibilidades interpretativas se misturam. $\mathrm{O}$ discurso comum dos timorenses sobre impossibilidades das suas línguas para a educação está, sobretudo, na inexistência de literatura científica em suas línguas. E mesmo comparando as línguas internamente e suas funções dentro do próprio Timor, há limitações de uma língua para outra.

Neste entendimento, Dr. Benjamim de Araújo e Corte-Real, linguísta timorense, em sessão plenária realizada no dia 28 de 2016 na $2^{\text {a }}$ Conferência Internacional Produção do Conhecimento Científico em Timor-Leste, proferiu a conferência "Biologização $e$ biodiversidade linguística em Timor-Leste antes de sua evolução e depois de sua permanência", em que trouxe um exemplo que pode ser esclarecedor nesse sentido. Exemplificou ele, que "na área de Ainaro ${ }^{47}$, quando choramos os mortos, as pessoas preferem chorar em quemac, porque acham que essa é a lingua que devem chorar o morto, não o mambai. Mambai tem outras funções culturais. Quando se chora o morto, ou se faz o kakekuk $^{48}$, a língua mais apropriada é o quemac. O mambai é mais guerreiro, é mais macho, não tem sentimento para chorar". Esse exemplo deixa muito claro a situação do Timor e seu pluriliguismo pós-colonial. As línguas têm funções diferentes em Timor, e essa diversidade aponta para uma espécie de setorização segundo as incumbências das línguas e assim, vão usando línguas para aprender ciências, línguas para trabalhar, línguas para andar no mundo,

\footnotetext{
${ }^{47}$ Suco timorense a $78 \mathrm{~km}$ ao sul de Díli - Transcrição literal da sua fala que foi gravada.

${ }^{48}$ Prantear o morto, carpir em tétum.
} 
línguas para guerrear e até línguas para carpir os mortos.

O panorama de divergências a respeito da adoção de línguas maternas no início da escolarização em substituição ao português em Timor tem muitas faces e muitos argumentos, tanto da parte de quem assim o defende, quanto da parte dos que discordam. Segundo dona Filomena Lay (ver entrevista - anexo 3), a nova política visa a proteção das línguas maternas e sua preservação, pois, há muitas crianças que apenas falam língua materna na fase préescolar, sendo complicado a adoção do português e até mesmo do tétum. Uma criança que pela educação aprenda o português ou tétum nesta fase, não fará mais uso das línguas maternas se migrar para Díli, por exemplo, e uma língua com baixa adesão de falantes, tende a sumir e essa pluralidade é uma grande riqueza do Timor.

Segundo Gimeno (1984, p.30-31),

cada grupo humano tem a sua própria cultura; paralelamente, há uma cultura universal, que constitui um valioso patrimônio comum da humanidade. Estas duas dimensões da cultura devem inspirar a educação. Mas, a primeira delas, de raiz popular, rica em tradições e valores peculiares, elaborada ao longo da história, e que confere identidade cultural, foi desvalorizada em determinados países durante o período em que os mesmos foram submetidos ao jugo colonial, impondo-se-lhes o critério de que a cultura verdadeiramente valiosa era que vinha de fora. Face a esta tendência se vem reivindicando, cada vez com maior veemência, os valores próprios, autóctones, mas há ainda um caminho longo a percorrer. Basta pensar na situação de determinados grupos indígenas marginalizados, a quem se procura dar uma educação pouco consentânea com o seu meio e, não poucas vezes, num idioma diferente das suas próprias línguas. A fusão, a integração equilibrada da cultura universal com a própria cultura, constitui a melhor garantia para a eficácia do sistema educativo.

Por outro lado, os que defendem exclusivamente a língua portuguesa no Timor, apresentam argumentos que vão desde a sua importância como "língua científica", entendida como aquela língua que veicula de forma falada e escrita os saberes formais das ciências, a língua que distingue o timorense dos outros países da região. No entanto, os que assim argumentam, não estão atentos para a inferiorização cultural das suas línguas maternas em contextos pós-coloniais.

No processo de escolarização a que as sociedades ditas "primitivas" foram submetidas, não sobrou espaços para a consideração dos valores culturais antigos nestas sociedades, ainda mais quando se trata de conhecimentos veiculados no ensino de ciências em língua ocidental (McKINLEY, 2005). É possível que valores culturais antigos tenham permanecido na literatura dos povos como idiossincrasia, senso comum, que deve ser considerado apenas como curiosidades sobre os hábitos antigos e conhecidos no campo do folclore. Assim, o que se depreende dessa condição é que a escolarização com base nos modelos ocidentais tenda a 
homogeneizar o mundo nos mais variados caminhos, para além da educação, como tem ocorrido com a agricultura, com as narrativas das histórias e os modos de vida.

Esse modelo, nascido de uma ciência eurocêntrica e implementado pelos ocidentais e desenvolvido por uma elite ocidentalizada, está em processo de reduzir todas as diversas culturas do mundo a uma única monocultura. Baseia-se no pressuposto de que as necessidades são sempre as mesmas, que todos precisam comer a mesma comida, a viver no mesmo tipo de casa, usar as mesmas roupas. Os mesmos edifícios de cimento, os mesmos brinquedos, os mesmos filmes e programas de televisão encontram o caminho para os cantos mais remotos do mundo. A mesma linguagem se torna cada vez homogeneizada, uma vez que é necessário aprender inglês para fazer parte da comunidade moderna. (NORBERG-HODGE, 2013, p.94).

A uniformidade cultural coloca em riscos as comunidades culturalmente diversificadas espalhadas pelo mundo. Isso é especialmente visualizado no campo da agricultura. Muitas populações têm cultivado e se servido de variedades de alimentos locais que foram domesticados localmente há muito tempo por ancestrais e subitamente, têm visto seus bancos de sementes das variedades autóctones, seres substituídas por sementes modificadas geneticamente por companhias de agro-negócio, levando populações inteiras à dependência dessas empresas que sob a égide de praticarem uma agricultura mais científica, vendem essa ilusão às populações.

Para Norberg-Hodge (2013), o respaldo para o conhecimento local deveria estender-se a todas as áreas da educação, incluindo as ciências naturais. Para ir além da euro-centralidade da ciência moderna é preciso promover a investigação que é menos centralizada e mais acessível a um segmento mais amplo da população. Em vez de isolar variáveis em condições artificiais de laboratório, a ênfase será colocada em experimentação por pesquisadores locais em diversos ambientes culturais e ecológicos. Ao invés de manter elaborados bancos de sementes de alta tecnologia, por exemplo, os agricultores serão incentivados a cultivar variedades indígenas raras, perpetuando assim reservatórios da diversidade biológica.

Em acompanhamento de encontros pedagógicos presenciais no Timor-Leste em 2007, nas discussões com os professores timorenses, questionava-os em que o ensino de ciências poderia ajudar o país. Quase todos apresentavam visões salvacionistas da ciência (ver memórias 7, p. 297; 8, p.297, 9, p. 301; 10, p. 303; 11, p. 309; 12, p. 313; 14, p. 322 e 15, p. 323, nos apêndices). Sobre isso, Strieder (2012, p. 31) expressa que a "perspectiva salvacionista da Ciência e Tecnologia refere-se à compreensão de que os problemas da humanidade serão solucionados em algum momento pelos avanços científicos-tecnológicos”. 
Destarte, percebe-se que as crenças dos professores timorenses centram-se na possibilidade de mudanças serem promovidas pela educação em ciência na sociedade. Em 2007 quando questionados acerca do que achavam sobre a infraestrutura da cidade de Díli com seus esgotos expostos desaguando no Oceano Pacífico e o lixo espalhado por toda parte (ver figuras 18 e 19), muitos mencionaram isso como sinal de evolução econômica. Isso refletia um consumo, pois se havia produção de todo tipo de lixo, do orgânico ao inorgânico como papel, metais, restos de produtos industrializados, era um sinal de novos tempos, já que nos "tempos antigos", quando se vivia apenas na base da cultura de subsistência não se tinha esse tipo de rejeito, o que denotava uma sociedade primitiva. Esse argumento pareceu ter uma lógica no sentido de associar desenvolvimento econômico com impacto ambiental, o que de fato ocorreu nos países no período da revolução industrial e que tiveram na ciência e na tecnologia, os subsídios necessários a esse modelo de desenvolvimento econômico experimentado e que em suma, foi responsável pela acumulação primária de capitais e por todos os impactos causados no ambiente desses países.

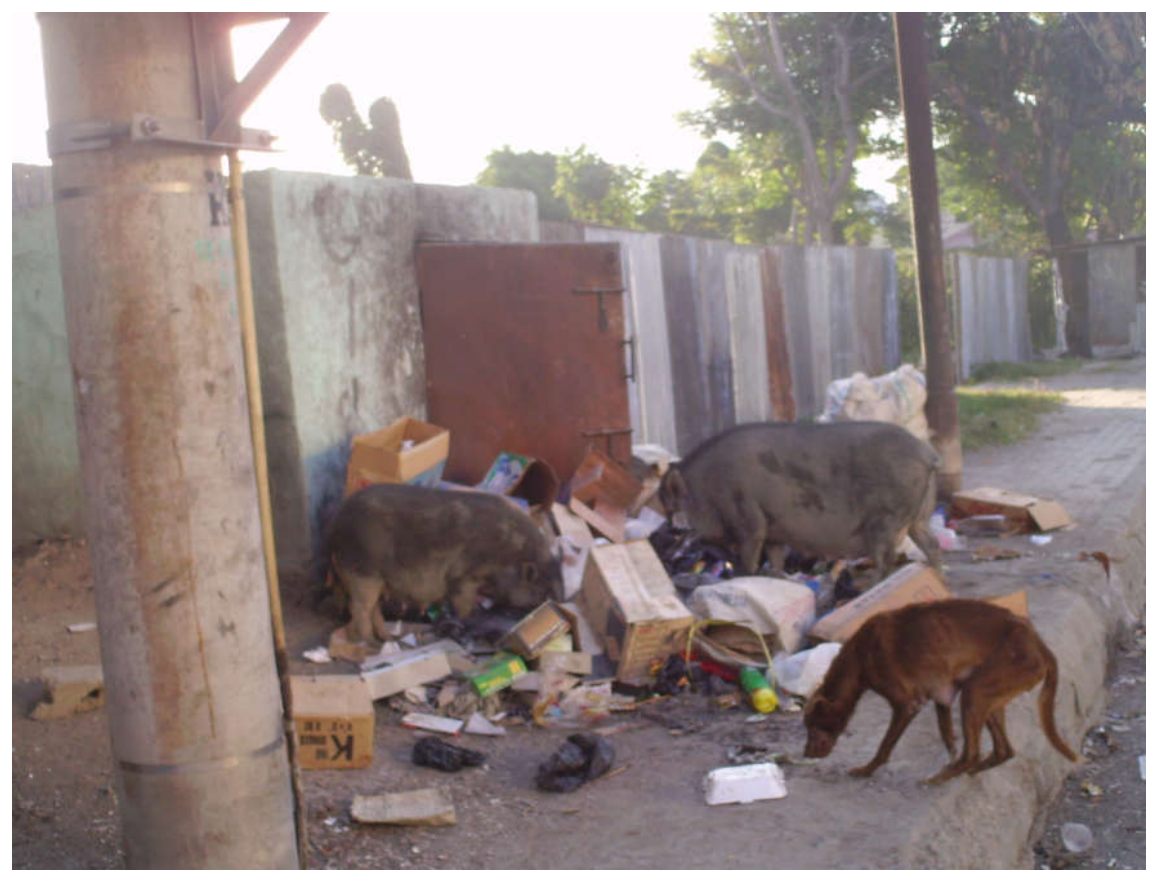

FIGURA 18 - Foto de cena comum na cidade de Díli: animais e lixo

Além do mais, essa percepção leva a crer que a sociedade timorense, sobretudo nos centros urbanos como sua capital Díli, encontra-se imersa nos valores do consumo ocidental, sem ter, porém, a aquisição dos elementos necessários para a compreensão dos impactos que esse consumo gera, o que seria papel da escolarização nos modelos ocidentais. Já que os valores de consumo e de comportamento importados do ocidente impõem certo 


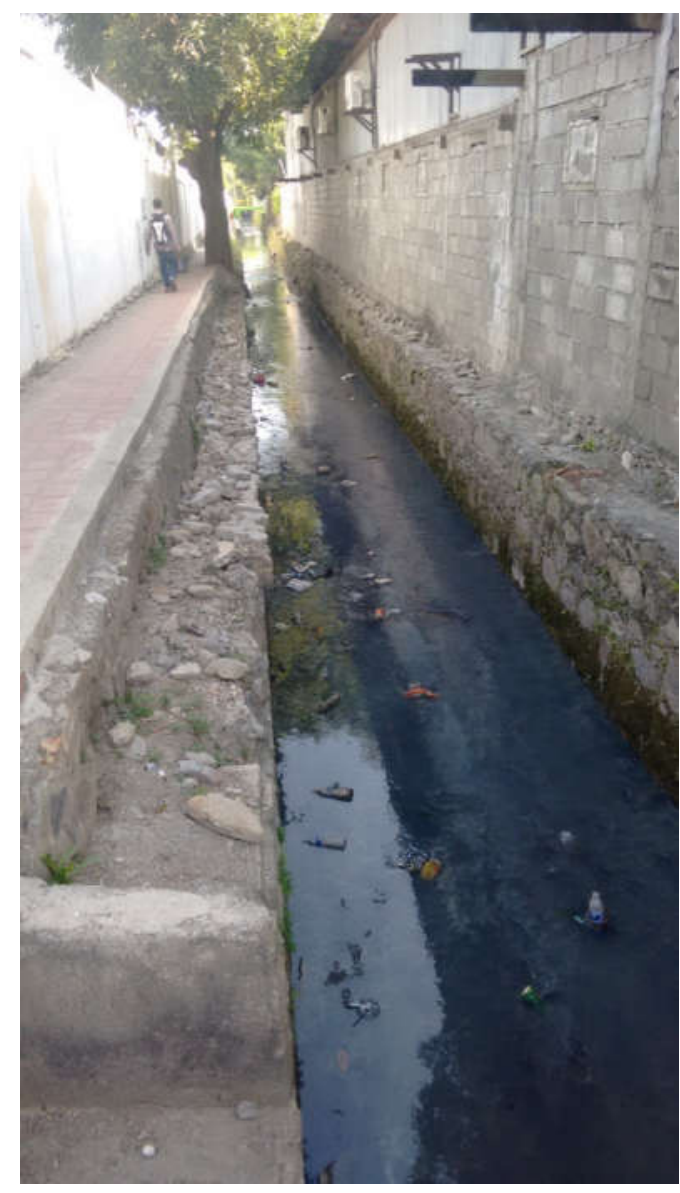

FIGURA 19. Foto de um valão de esgoto muito comum nas ruas de Dili.

comportamento que requer também medidas adotadas no ocidente e, os valores da escolarização ocidental se firmam.

Nos aspectos mencionados acima, é perceptível como a expansão da cultura de um povo sobre o outro, termina por minar e criar outras tantas necessidades que antes não faziam parte do repertório civilizacional de uma população. Embora o povo timorense deseje sua integração neste mundo globalizado, possivelmente pagará um alto preço por essa inserção e a educação já dá sinais do que pode vir: a substituição das línguas, dos valores culturais a partir do seu currículo escolar, em prol da adesão aos valores ditos universais, quase todos proveniente da cultura ocidental.

A busca pelas concepções de estudantes timorenses em relação a conceitos de ciências conduziu-me a um universo complexo de análise, onde o pós-colonial, com suas particularidades em Timor, insere o país no global. Quando se observa atualmente a abundância de estudos e materiais produzidos sobre o Timor na atualidade, nada faz lembrar o isolamento do seu período colonial, o esquecimento no seu período de ocupação indonésia e de resistência. A visibilidade que o país passou a ter a partir de elementos chaves do seu passado recente, como o Prêmio Nobel da Paz de 1996 compartilhado por dois timorenses, a visita do papa João Paulo II e a documentação da imprensa mundial neste episódio, conferiu ao Timor a inserção necessária para que a opinião pública mundial passasse a conhecer e fazer pressão para uma solução nas demandas do Timor, o que de certa forma, contribuiu para que a ONU pavimentasse o caminho à sua autonomia, conquistada posteriormente à custa de muito sacrifício e dor.

Mas, na fundação do Estado Timorense, as cooperações internacionais em solidariedade ou por interesse concederam aos timorenses a oportunidade de consolidar seu status no mundo ao participar da sua reconstrução. Muitos estudos passaram a ser realizados em todos os campos. Muito material sobre sua cultura, sobre a antropologia, sobre o jurídico, linguística, educação, etc., passou a pulular sobre o Timor. Esta tese não teve a pretensão de 
tecer considerações generalizantes que possam explicar todo o processo educacional de Timor. Seu recorte de estudo se limitou a uma abordagem sobre o ensino de ciências para o qual se utilizou do conhecimento do seu currículo, a experiência do autor no campo da formação de professores em exercício neste país no ano de 2007, opiniões de formadores de professores timorenses atuais, assim como, a quem se dirige todo o processo educacional, os estudantes.

Ao perseguir o objetivo de investigar o que a criança timorense sabe sobre ciências, o recorte metodológico por suas limitações pode não conduzir a respostas definitivas que possam ser generalizantes. Afinal, algumas limitações devem ser consideradas. Todavia o que se revela em mim, dão conta de que, primeiramente a língua é o grande fator limitante. Hoje, as disputas que existem no Timor neste campo ficaram explícitas diante de tudo que se relatou ao longo deste documento. Embora a língua portuguesa herdada pelo colonizador seja reconhecidamente imputada como um dos elementos determinantes da existência do Timor enquanto estado independente, ela não goza do prestígio como língua hegemônica no plurilinguismo timorense. Primeiro, por uma questão histórica que remete ao seu passado colonial nos moldes como se processou, com o desprezo de Portugal por aquelas terras por séculos e mesmo, em sua fase tardia, o processo de educação voltado para uma elite representada pela nobreza timorense, que participou do processo educacional tardio, praticamente inaugurado no final do século XIX e início do século XX por meio das missões religiosas em seminários e colégios excludentes.

Neste contexto, a massa de timorenses sem instrução e sem inserção na aquisição da língua portuguesa fez desta uma língua da elite para a interlocução governamental, que durante a invasão da Indonésia passou a ser a língua de resistência. Todos os que participaram dessas lutas, hoje se sucedem no poder em Timor e são os guardiões finais da língua portuguesa e por sua importância nestes longos anos de luta que conduziram à sua independência, passou a ser uma das línguas oficiais constitucionalmente. A complexidade da língua portuguesa é muito grande para ser de fácil aquisição por pessoas cujas línguas de origens austronésia ou papuas, com estruturas que remetem a uma simplicidade extrema quando comparada com a língua portuguesa. O português é a língua abundantemente usada pelos políticos e pelos funcionários públicos graduados. É a língua dos acadêmicos que também dominam o inglês e o bahasa em função da proximidade com a Indonésia.

Mas, o que resta às crianças? A pretensão do sistema educacional é que se aprenda o português na escola. Como bem pode ser notado nas memórias nos apêndices (ver memórias 6, p. $288 ; 7$, p. 297 ; 8, p.297, 9, p. 301; 10, p. 303; 11, p. 309; 12, p. 313; 14, p. 322 e 15, p. 
323), sobretudo as que versam sobre formação continuada. O grande propósito da formação de professores em língua portuguesa no Timor do qual participei em 2007, ainda que fosse um projeto piloto, era o de modificar a língua do professor timorense da escola básica e o fazendo, operasse mudança das línguas das crianças e em cadeia, mudasse a língua do país a longo prazo. Mas, para isso, as disputas curriculares não estão contribuindo. Se por um lado o timorense é por natureza um poliglota (ver considerações de Filomena Lay no anexo 3), pois no mínimo falam duas línguas, a materna e o tétum em função da imersão nestas e em outras línguas, por outro a aquisição da língua portuguesa só encontra espaço de aprendizagem na escola, pois, na maior parte das vezes, as crianças não estão em imersão nesta língua em suas casas com suas famílias, nem nos ambientes de lazer com seus colegas. Neste sentido, o próprio bahasa indonésio é mais fácil de aprender e as crianças aprendem, sem nem precisar de escola. Aprendem na televisão. O Timor tem apenas um canal de TV que é estatal, a RTTL (Rádio e Televisão do Timor-Leste), mas, em seu território são transmitidos muitos canais da Indonésia e essa exposição faz com que as crianças aprendam o bahasa assistindo programação infantil destes canais e com o passar do tempo, aprendem o bahasa espontaneamente sem ser no ambiente escolar.

Mas, o dilema da língua portuguesa também representa um entrave na escola para a aprendizagem em outras áreas como é o caso do ensino de ciências. O componente curricular "Estudo do Meio" nos ciclos básicos é trabalhado com a utilização de um livro didático em língua portuguesa o que permite ao estudante a memorização de conceitos nesta língua ainda que não o compreenda, como foi o caso exemplificado para o conceito de reprodução. Mas, a mobilização dessa aquisição memorística em uma língua que não se domina, possivelmente não permita a solução de situações-problema como as propostas, não por inadequação curricular, mas por impropriedade vernacular.

Um aspecto que deve ser tratado diz respeito ao que a Senhora Filomena Lay falou quando se referiu que a língua portuguesa, para quem continua os estudos em nível superior vai sendo adquirida, pois boa parte do material de estudo está em português e em inglês. Um exemplo disso é que na $2^{\mathrm{a}}$ Conferência do Conhecimento Científico e Tecnológico em TimorLeste que participei no final de julho de 2016, boa parte das comunicações orais e das conferências foi feita em português por timorenses, professores e alunos. Lembro-me de ter participado de uma sessão em que estudantes apresentavam trabalhos no campo do ensino de ciências e após a sessão, durante o intervalo, perguntei a um dos estudantes, que aparentava 20 anos e que havia apresentado seu trabalho em português, onde ele tinha aprendido a língua portuguesa. Só lembrando que este estudante devia ter em torno de dez anos no período que 
vivi em Timor no ano de 2007 e estava na escola básica com sua dificuldade nas línguas. O estudante me informou que havia aprendido português na escola ao longo dos anos, mas, a necessidade de ler e estudar na Universidade em língua portuguesa havia forçado a aprender mais, além da maior convivência em momentos de diálogos entre colegas e professores. Certamente uma questão associada a exposição à língua.

Então, talvez o objetivo de em um futuro o Timor ser uma nação que fale também o português com fluência se complete à medida em que a própria população seja submetida a um processo de escolarização mais ampla em todos os níveis e se integralize definitivamente no nível superior. Portanto, a aquisição da língua portuguesa por estes indícios possivelmente não represente nenhuma barreira impossível de ser transposta, mas, a aquisição de conceitos científicos, usando uma língua precarizada no nível básico, pode representar uma lacuna na construção desse conhecimento como constatado no nível de respostas obtidas nas investigações realizadas.

Embora os estudantes também estejam expostos a um mundo científico e tecnológico no próprio ambiente doméstico ao assistir televisão, a aquisição dos conhecimentos sistematizados que conduzem a uma forma de pensar em ciências, seja o mais problemático na escolarização da infância do Timor. Diante disso algumas considerações a título de conclusões podem ser apresentadas aqui.

A principal questão desta tese pode ser respondida a partir da reunião de todos os elementos que foram expostos. Assim, quando se pergunta como um país que se reconstrói de guerra civil para sua autonomia monta seu sistema educativo, pode-se concluir que por meio de elementos intervenientes das cooperações internacionais no setor, bem como pela interferência também de agentes internacionais no campo educacional tais como UNICEF, UNESCO entre outros, que buscam uma escolarização universal a partir da uniformização e ocidentalização dos currículos, ao tempo que se diminui a importância dos elementos culturais locais, haja vista, praticamente a ausência de respostas culturais no levantamento das concepções entre as crianças. O sistema educacional também se constrói em uma espécie de tentativa de erros e acertos, pois, a Diretoria de Currículo é uma entidade permanente no Ministério da Educação e o tempo todo está atenta ao currículo em constante mudança. $\mathrm{O}$ currículo, assim como a educação que ele tenta balizar, é instável e essa instabilidade é o que garante a estruturação de uma identidade timorense. Apesar da ingerência de outros agentes nesse currículo e no próprio sistema educacional, é perceptível a aquisição temporal de uma feição própria. 
Estas constatações se coadunam com o previsto na hipótese inicial, que aponta para a opção do Timor-Leste por um encaminhamento tradicional ao ensino de ciências. Tradicional no sentido do ensino sem um viés multicultural como já apontado em trabalhos mencionados anteriormente. Embora haja um esforço para a conservação do plurilinguismo, a partir da introdução das línguas maternas nas séries inicias da educação básica, isso não reflete uma mudança nos conteúdos, que segunda a Senhora Filomena Lay, são conteúdos comuns e usuais nos currículos dos países da região.

O sistema de educação, apesar de se reger por uma Lei de Diretrizes da Educação em suas linhas mestras, o que lhe confere uma unicidade temporal, é instável pelas diferentes orientações que passam a receber quando se muda de governo pela via eleitoral. Todos que chegam ao poder central querem contribuir para que as metas educacionais traçadas nas suas leis estruturantes se realizem e para isso, mudam orientações e encaminhamentos, como o observado nos planos de aulas construídos para os professores. Por mais que isso represente uma orientação atual, ela não tem a garantia que permanecerá após a mudança de governo. A grande conclusão que se revela ao analisar todos esses aspectos é que a educação do Timor passa por um fazer em efervescência e seus diversos atores estão em constante movimento para imprimir uma feição local identitária em um mundo plural e global. Dado os grandes desafios que o Timor enfrentou e superou ao longo da sua história, as problemáticas atuais possivelmente serão também superadas.

Muitas outras conclusões nesse campo podem ser expressas. $\mathrm{O}$ ensino de ciências é visto como salvacionista para a sociedade timorense, mas o apego a tradições antigas, como bem mencionou o professor João Freitas, representa entraves para a aquisição de conceitos científicos sólidos. Os hábitos de vida e a feição do que se pratica nas cidades pode ser outro entrave para a aquisição de conceitos. A criança na escola aprende os hábitos de higiene, por exemplo, para se ter saúde, mas, as ruas das cidades estão com seus esgotos abertos singrando para o Pacífico (Figura 19), demonstrando que o teórico aprendido na escola está muito distante do prático visto no mundo real.

A convivência na sociedade timorense no ano de 2007 e o registro em memórias utilizadas no trabalho, aqui apresentados com o recorte do ensino de ciência na escolarização da infância, assim como os levantamentos de concepções sobre conceitos realizados em 2016, evidenciam aspectos dos contextos pós-coloniais que permitem o estabelecimento de alguns resultados. Porém, é pertinente frisar que estes resultados podem não passar de instantâneos em face a ebulição, em todos os campos e em particular na educação, que este país vive, com sua eterna sede de mudanças. 
- A conformação diferenciada que sociedades pós-colonias apresentam, denotam a existência de elementos multifatoriais que influenciaram a configuração dessas sociedades atuais em função das suas histórias coloniais. Nesse sentido, é contrastante a existência de sociedades pós-coloniais que sob essa categoria, igualem Austrália, Estados Unidos, China, Índia, Brasil, com sociedades como a do Timor-Leste ou outras do continente africano. Assim, faz-se necessário entender que o pós-colonial é multifário e possivelmente não abrangente para toda uma sociedade, haja vista que certamente, os autóctones norte-americanos, os aborígenes australianos, os indígenas brasileiros, ou os genuínos mauberes timorenses, sejam os representados nos estudos póscoloniais, pois, boa parte das populações das sociedades existentes nos países citados acima, são hoje educadas na escolarização universal no modelo ocidental, só consideradas pós-coloniais em decorrência das suas independências políticas dos colonizadores.

- As populações locais de cultura ancestralmente diferentes da dos colonizadores, são muito sensíveis ao processo de aculturação que as envolvem em um caminho sem volta, pois pelos processos educacionais eurocêntricos, se modela um indivíduo que não mais consegue o retorno às origens e nem é totalmente inserido nas sociedades ocidentalizadas e perfeitamente adaptadas. Muitas vezes restringindo a sua amoldagem ao consumismo ocidental.

- Pelo descrito no item anterior, as crianças das culturas nativas, que seriam responsáveis pela sobrevivência de suas culturas ancestrais, são ainda mais sensíveis nestes contextos, pois, a depender da exposição à uma escolarização planejada ou não para aculturá-las, terminam por perder totalmente seus valores e toda uma ecologia cultural complexa, que é suplantada por outra exótica, como possivelmente está ocorrendo em Timor-Leste, extingue-se e uma riqueza da diversidade cultural humana é definitivamente perdida.

- Ao se analisar a ação da escolarização universal em um modelo único, os argumentos que o suportam centram-se sempre na ênfase da superioridade da cultura ocidental. É muito comum se argumentar com bases em construtos ocidentais, tais como, sociedades autóctones são pobres e não têm acesso ao mercado de consumo, escolariza-se para que possam trabalhar, "melhorar" de 
vida por meio da aquisição de dinheiro e de "bens". Note-se aqui que pobreza, riqueza, consumo, dinheiro, etc., são valores culturais do Ocidente, mas, na globalização que o mundo experimentou historicamente, passam a ser aceitos culturalmente como universais e necessidades absolutas.

- O currículo da educação básica do Timor-Leste é o novo campo de batalha no país. De um lado os adeptos da língua portuguesa tentam a preservação da mesma como língua de instrução segundo o previsto na Constituição do país, por outro, novas abordagens querem priorizar as línguas maternas para o uso na educação, a princípio na educação básica. Se por um lado, isso reforça o argumento da preservação plurilinguística, possivelmente, o interesse também seja o lucrativo mercado que uma ação nesse rumo abrirá. Pois, educação em língua materna pressupõe a adaptação de todo um sistema de livros e materiais instrucionais feitos em línguas maternas o que abre espaço para dezenas de consultorias nesse setor, por instituições como universidades e ONGs que apresentarão suas propostas. O Timor-Leste, com suas dezesseis línguas maternas, é campo de estudo de linguistas do mundo inteiro que atuam intensamente nas línguas locais em gramaticalizações, traduções entre outras interveniências. Provavelmente, todo esse esforço para a inserção dessas línguas timorenses em um ambiente mais acadêmico, guardem um interesse voltado para a essa produção de novos materiais direcionados para uma educação nos modelos do plurilinguismo.

- A educação em ciência na escola básica, pelo fragmento observado na pesquisa, é de caráter memorístico, em que ensinantes e aprendentes não dominam os códigos linguísticos necessário para uma aprendizagem autenticamente significativa na concepção ausbeliana, ao menos nessa fase inicial da escolarização. Mas, possivelmente, dado ao que se observa no nível superior com os estudantes universitários, vão superando com o tempo, obtendo as línguas por eles ditas "científicas" e os conceitos das ciências nas mais variadas áreas em que cursam suas graduações.

Embora uma observação pontual em um momento da escola básica, apresente elementos que não demonstram aquisições conceituais no componente curricular das ciências, ao final da escolarização, na pós-graduação, aos que lá conseguem chegar, este estudante será capaz de ler e falar em inglês, português, além do bahasa e do tétum, mais, no mínimo uma outra 
língua materna, além disso estará formado em direito, medicina, engenharias, licenciaturas entre outras tantas profissões que servem ao presente e ao futuro do país. Essa pluralidade garante a este indivíduo formado nesse "caldeirão de contradições" que este formidável país encerra, aculturado ou não, uma completa inserção no mundo com as ferramentas necessárias para reafirmar sua autonomia e sua identidade enquanto integrante de uma nação.

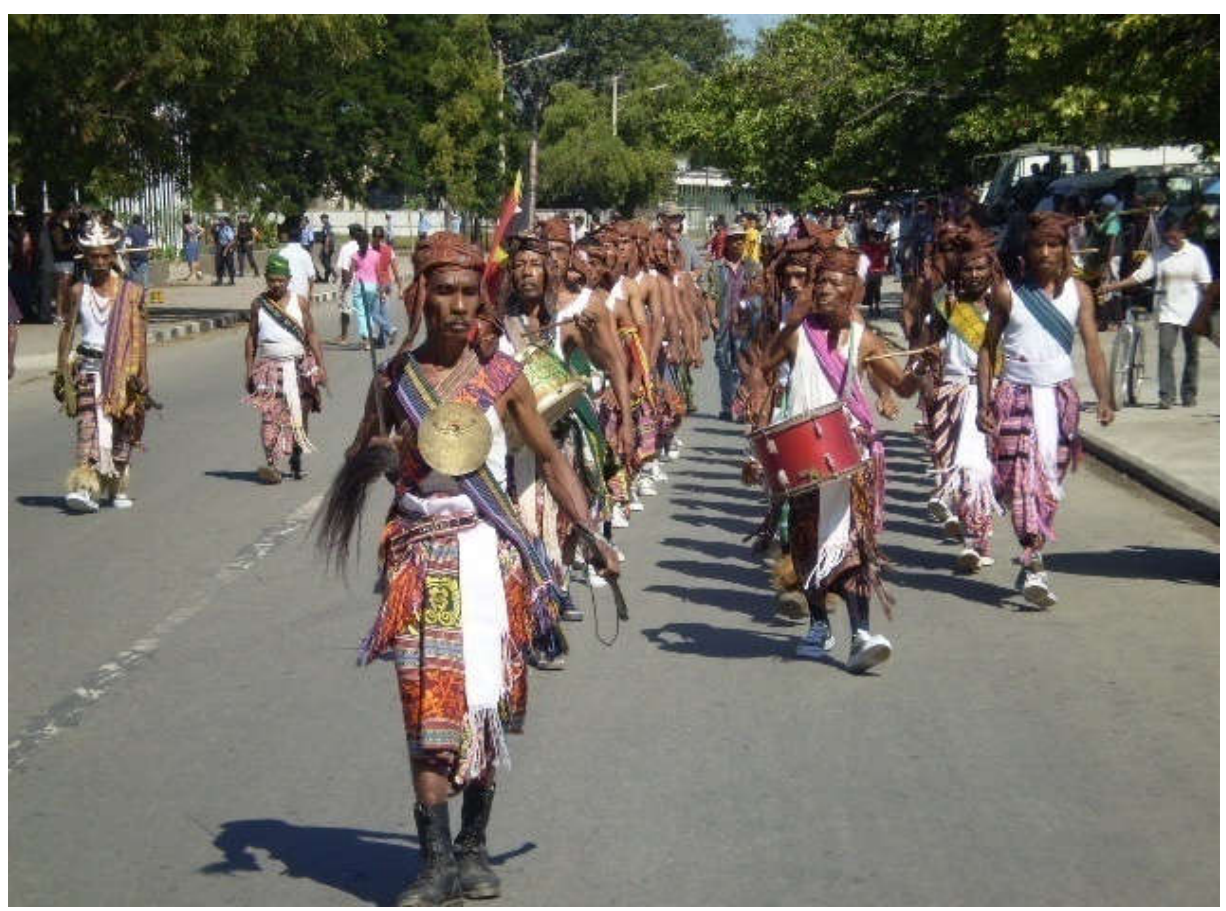

Figura 20. Guerreiros com vestimentas típicas por ocasião da pose do Presidente da República RamosHorta em 2007.

Ao povo de Timor-Leste, que na figura de seus Guerreiros, rumam ao futuro sem abandonar o seu passado de tradições! 


\section{Referências Bibliográficas}

ABBAGNANO, N. Dicionário de Filosofia. São Paulo: Martins Fontes, 2007.

ABDULLAHI, I. Diversity and intercultural issues in library and information science (LIS) education. New Library World, v. 108, n. 9/10, p. 453-459, 2007.

ACÁCIO, M. A última bala é a minha vitória: a história secreta da Resistência Timorense. Cruz Quebrada - Dafundo: Oficina do Livro, 2006.

AIKENHEAD, G. Integrating Western and Aboriginal Sciences: Cross-Cultural Science Teaching. Science Education, 2001, vol. 31, no. 3, pp. 337-355.

- Cross-cultural science teaching: Rekindling traditions for Aboriginal students. Canadian Journal of Math, Science \& Technology Education, v. 2, n. 3, p. 287-304, 2002.

AIKENHEAD, G.; JEGEDE, O. J. Cross-cultural science education: A cognitive explanation of a cultural phenomenon. Journal of research in science teaching, v. 36, n. 3, p. 269-287, 1999.

AIKENHEAD, G.S.; RYAN, A.G. The Development of a New Instrument: "Views on Science-Technology-Society" (VOSTS). Science Education 76(5): 477-491, 1992.

ALES BELLO, A. Introdução à fenomenologia. Bauru, SP: Edusc, 2006.

ALFRED, T. Colonialism and state dependency. Journal de la santé autochtone, v. 5, p. 4260, 2009.

AMERICAN SOCIETY OF INTERNATIONAL LAW. Award Rendered in Execution of the Compromis Signed at the Hague, April 3, 1913, Between the Netherlands and Portugal Concerning the Subject of the Boundary of a Part of their Possessions in the Island of Timor. The American Journal of International Law, Vol. 9, nº 1, p. 240-268, 1915.

ANDRADE, M.C.F.M. A Missão de Remexio: um caso de transição das religiões tradicionais para o cristianismo no contexto das missões católicas de Timor. Dissertação de mestrado. Universidade Católica Portuguesa, Faculdade de Teologia, Lisboa: 2012. Disponível em:

$<$ http://repositorio.ucp.pt/bitstream/10400.14/9739/1/VERS\%C3\%83O\%20FINAL.pdf>. Acesso em 03 de março de 2015.

ANGROSINO, M. Etnografia e observação participante. Porto Alegre: Artmed, 2009.

APPADURAI, A. Modernity At Large: Cultural Dimensions of Globalization. University of Minnesota Press, 1996.

APPELBAUM, P.; CLARK, S. Science! Fun? A critical analysis of design/content/evaluation. Journal of Curriculum Studies, v. 33, n. 5, p. 583-600, 2001.

ARIÈS, P. História social da criança e da família. Rio de Janeiro: Guanabara, 1986. 
ARNEBERG, M. Educational and human capital. In: PEDERSON, M \& ARNEBERG (Eds.). Report on social and economic conditions in East Timor (83-103). New York: International Conflict Resolution Program, Columbia University; Oslo: Fafo Institute of Aplied Social Science. 1999. Disponível em:

http://www.fafo.no/pub/rapp/929/easttimor.PDF. Acesso em 01de set. de 2013.

ASHCROFT, B.; GRIFFITHS, G.; TIFFIN, H. The post-colonial studies reader. London: Routledge and Taylor \& Francis e-Library, 2003. Disponível em $<$ http://www.mohamedrabeea.com/books/book1_3985.pdf> acesso em 10 de set. 2013.

AUSUBEL, D.P. The Acquisition and Retention of Knowledge: A Cognitive View. Dordrecht, Netherlands: Kluwer Academic Publisher, 2000.

BACHELARD, G. A filosofia do não. Coleção Os Pensadores. São Paulo: Abril Cultural, 1978.

A formação do espírito científico: contribuição para uma psicanálise do conhecimento. Rio de Janeiro: Contraponto, 2011. 316 ISBN 978-85-85910-11-2.

BAKER, C. Foundations of Bilingual Education and Bilingualism. Ontario: Multilingual Matters, 2011.

BANKS, J, A., \& BANKS, C .A .M. (org.). Multicultural education: Issues and perspectives. Hoboken, $\mathrm{NJ}$ :

Wiley. 2007.

BARAKOSKA, A. Multiculturalism as important characteristic of contemporary education. International Journal of Cognitive Research in Science, Engineering and Education (IJCRSEE), v. 1, n. 1, p. 51-56, 2013.

BARBEDO DE MAGALHÃES, A. Timor-Leste - Interesses Internacionais e actores locais. Vol. I: Da invasão australo-holandesa à decisão australo-indonésia de anexar, 19411974. Porto: Edições Afrontamento, 2007.

, A. Timor-Leste - Interesses Internacionais e actores locais. Vol. II: A luta pela independência, 1974-1999. Porto: Edições Afrontamento, 2007.

A. Timor-Leste - Interesses Internacionais e actores locais. Vol.

III: A difícil construção do Estado democrático, 1999-2007. Porto: Edições Afrontamento, 2007.

BARTON, A. C.; OSBORNE, M. D. Marginalized Discourse and Pedagogies: Constructively Confronting Science for All. Journal of Research In Science Teaching, v. 35, no 4, p. 339-340, 1998.

BATTISTE, M. Enabling the Autumn Seed: Toward a Decolonized Approach to Aboriginal Knowledge, Language, and Education. Canadian Journal of Native Education, v. 22, n. 1, p. 16,1998 . 
BECK, U. O que é Globalização? Equívocos do globalismo: respostas à globalização. São Paulo: Paz e Terra, 1999.

BEECH, J. Quem está passeando pelo jardim global? Agências educacionais e transferência educacional. In: COWEN, R.; KAZAMIAS, A.M. (org.). Educação Comparada: Panorama internacional e perspectiva. Vol. 1. Brasília: UNESCO, CAPES, 2012.

BENJAMIN, W. Magia e técnica, arte e política: Ensaios sobre literatura e história da cultura. Obras Escolhidas, Vol.1. São Paulo, Editora Brasiliense, 1985.

BERNSTEIN, B. La estrutura del discurso pedagógico. Madrid: Ediciones Morata, 2001. Pedagogía, control simbólico e identidade: teoria, investigación y crítica. Madrid: Ediciones Morata, 1998.

Petrópolis: Vozes, 1996.

A estruturação do discurso pedagógico: classe, código e controle.

BHABHA, H. K. O Local da Cultura. Belo Horizonte: Editora UFMG, 2001.

BISHOP, A. Western Mathematics: The Secret Weapon of Cultural Imperialism. In: ASHCROFT, B.; GRIFFITHS, G.; TIFFIN, H. The post-colonial studies reader. London: Routledgeand Taylor \& Francis e-Library, 2003.

BOGDAN, R.C.; BIKLEN, S.K. Investigação Qualitativa em educação: uma introdução à teoria e aos métodos. Porto, Portugal: Porto Editora, 1994.

BOVO, C.R.M. Anistia internacional: roteiros da cidadania em construção. São Paulo: Annablume, FAPESP, 2002.

BRASIL. Decreto $n^{\circ}$ 5.104, de 11 de junho de 2004. Promulga o Acordo de Cooperação Educacional entre o Governo da República federativa do Brasil e o Governo da República Democrática de Timor-Leste, celebrado em Díli em 20 de maio de 2002. Diário Oficial [da República Federativa do Brasil], Brasília, DF, n. 112, 14 jun. 2004. Seção I, p. 1.

BRASIL. Decreto ${ }^{0}$ 5.274, de 18 de novembro de 2004. Institui o Programa de Qualificação de Docente e Ensino de Língua Portuguesa no Timor-Leste, e dá outras providencias. Diário Oficial [da República Federativa do Brasil], Brasília, DF, n. 222, 19 dez. 2004. Seção I, p. 5.

BRITO, M.C.A. Desenvolvimento compartilhado de reservatórios comuns entre Estados. Rio de Janeiro: E-papers, 2006.

BRUNER, J. Process of education. Cambridge, MA: Harvard University Press, 1960.

BUSH, K.D.; SALTARELLI, D. The two faces of Education in Ethnic Conflict: Towards a Peace building Education for Children. Florence, Italy: UNICEF, 2000.

CAMBI, F. História da Pedagogia. São Paulo: Fundação Editora da UNESP, 1999. 
CAMÕES, L. Os Lusíadas: poema épico. Paris: Officina Typographica de Firmino Didot, 1819.

CANAVARRO, J.M. O que se pensa sobre a Ciência. Coimbra: Quarteto, 2000.

CANNELLA, G.S. Deconstructin early childhood education: social justice and revolution. New York: Peter Lang, 1997.

CANNELLA, G.S.; VIRURU, R. Childhood and (post-colonization): power, education and contemporary practice. London and New York: Routledge, 2004.

CAPALBO, C. Fenomenologia e Hermenêutica. Rio de Janeiro: Âmbito Cultural, 1983.

CARNEIRO, M. H. S. Construtivismo e ensino de ciências - módulo III - Consórcio Setentrional. In: Consórcio Setentrional - Alcântara, Marcelo Silveira (org.). (Org.). Processos de manutenção da vida. Brasília: Universidade de Brasília, 2007, p. 56-79.

CARRASCALÃO, M.V. Timor antes do futuro (Autobiografia). Díli: Mau Huran Printing, 2006.

CARTER, L. Thinking differently about cultural diversity: Using postcolonial theory to (re) read science education. Science Education, v. 88, n. 6, p. 819-836, 2004.

A Place for Alternative Readings: Can They Be of Use? Responding to Comments on "Thinking Differently About Cultural Diversity: Using Postcolonial Theory to (Re)read Science Education". Wiley Inter Science, 2005.

Sociocultural influences on science education: Innovation for contemporary times. Science Education, v. 92, n. 1, p. 165-181, 2008.

CARTER, N.P.; LARKE, P.J.; TAYLOR, G.S.; SANTOS, E. Multicultural Science Educacion: Moving Beyond Tradition. In: HINES, M. Multicultural Science Education: Theory, Practice and Promise. New York: Peter Lang Publishing, 2007.

CASSIANI S., LINSINGEN, I., LUNARDI, G. Enfocando a formação de professores de ciências no Timor-Leste. Alexandria revista de educação em ciência e tecnologia, v.5, n.2, p.189-208, $\quad$ set. $2012 . \quad$ Disponível em $<$ http://alexandria.ppgect.ufsc.br/files/2012/09/suzani.pdf > acesso em 10 de set. de 2013.

CASTRO, A. As Possessões Portuguezas na Oceania. Lisboa: Imprensa Nacional, 1867.

CIC, Citizenship and Immigration Canada (CIC) (2016) Canadian Multiculturalism: An Inclusive Citizenship. Disponível em:

$<$ http://www.cic.gc.ca/english/multiculturalism/citizenship.asp www.cic.gc.ca/multi/>. Acesso em 06 de agosto de 2016.

COBERN, W.W.; LOVING, C.C. Defining" science" in a multicultural world: Implications for science education. Science Education, v. 85, n. 1, p. 50-67, 2001. 
COFNAS, N. Science Is Not Always 'Self-Correcting': Fact-Value Conflation and the Study of Intelligence. Foundations of Science Journal, Springer Netherlands, Vol. 21, February 2015.

CONNELLY, Michael \& CLANDININ, Jean. Relatos de experiencia e investigacion narrativa. In: LARROSA, Jorge. Déjame que te cuente. Barcelona: Editorial Laertes, 1995.

CORREIA, A.A.M. Timor Português, contribuição para o seu estudo antropológico. Lisboa: Imprensa Nacional de Lisboa, 1954.

CORREAA, L.F.S.; MANCINI, L. Sérgio Vieira de Mello no Timor Leste: A Construção de um Estado Independente. In: MARCOVITCH, J. (org). Sérgio Vieira de Mello: Pensamento e Memória. São Paulo: Editora da Universidade de São Paulo/Editora Saraiva, 2004.

COSTA, L. Dicionário de Tétum-Português. Lisboa: Edições Colibri, 2001.

CRESWELL, J.W. Investigação Qualitativa \& Projeto de Pesquisa: escolhendo entre cinco abordagens. Porto Alegre: Penso, 2014.

CUNHA, J. S. C. A Questão de Timor-Leste: Origens e Evolução. Brasília: FUNAG/IRBr, 2001.

DARTIGUES, A. O que é a fenomenologia. São Paulo: Editora Moraes, 1992.

DE MEIS, L., Educação em Ciência. In: WERTHEIN, J. \& CUNHA, C. (org.). Ensino de Ciências e Desenvolvimento: o que pensam os cientistas. $2^{\mathrm{a} e d . ~ B r a s i ́ l i a: ~ U n e s c o, ~ I n s t i t u t o ~}$ Sangari, 2009. p. 173-179.

DENZIN, N.K.; LINCOLN, Y.S. Introduction: The discipline and practice of qualitative research. The Sage handbook of qualitative research. Thousand Oaks, CA: Sage, 2011.

DICK, H. (Ed.). Selected writings of Francis Bacon. New York: Random House.

DOREN, C. V. Uma breve história do conhecimento. Rio de Janeiro: Casa da Palavra, 2012.

DOWEL, J. A. M. Os jesuítas e a globalização uma alternativa. In: BINGEMER, M. C. L.; NEUTZLING, I., et al (Ed.). A Globalização e os Jesuítas: Origens, história e impactos. São Paulo: Edições Loyola, v.1, p.13, 2007.

DRAKELEY, S. The History of Indonesia. London: Greenwood Press, 2005.

DRIVER, R. Psicologia cognoscitiva y esquemas conceptuales de los alumnos. Rev. Enseñanza de las Ciencias. 4 (1), 1986, p.3-15.

DUARTE, T. Ocupação e Colonização Branca de Timor. Coleção Fórum - Estudos Coloniais, 13ª Secção, n.2. Porto: Editora Educação Nacional, LTDA, 1944.

DUNN, J. Timor a People Betrayed. Sydney: ABC Books, 2001.

FANON, F. Black skins, whitemasks. New York: Grove Press, 2008. 
FIGUEREDO, F.A. Timor, A Presença Portuguesa (1769-1945). Lisboa: Centro de Estudos Histórico, Universidade de Lisboa, 2011.

FILHO, M. B. L. Educação Comparada. Brasília, 2004.

FRANÇA, L. O método pedagógico dos jesuítas. Rio de Janeiro: Agir, 1952.

FIOLHAIS, C. A Ciência em Portugal. Lisboa: FFMS, 2016.

FREI, H. Japan's Reluctant Decision to Occupy Portuguese Timor, 1 January 1942 - 20 February, 1942. Australian Historical Studies, Number 107, October, 1996. Disponível em $<$ http://dx.doi.org/10.1080/10314619608596014>. Acesso em 10 de agosto de 2016.

FREYRE, G. China Tropical. São Paulo: Editora Universidade de Brasília, 2003.

GIL, A. C. Como Elaborar Projetos e Pesquisa. 4ª ed. Atlas, São Paulo, 2002.

GIMENO, J.B. El fracaso escolar en la enseñanza primaria: medios para combatirlo: Estudio comparativo internacional. Paris: UNESCO, 1984.

GODELIER, M. Infraestructuras, Sociedades, História. Madrid: En teoria. no 2, p. 3-21, julio-septiembre, 1979.

GONÇALVES, R.R.; GARCIA, F.A.F; DANTAS, J.B.; EWALD, A.P. Merleau-Ponty, Sartre e Heidegger: três concepções de fenomenologia, três grandes filósofos. Studies and Research in Psychology; V.8, $\mathrm{n}^{\mathrm{o}} 2$ 2, p. 402-435, 2008. Disponível em $<$ http://www.revispsi.uerj.br/v8n2/artigos/pdf/v8n2a19.pdf $>$. Acesso em 15 de setembro de 2016.

GRANT, C. A.; A. KHURSHID. Educação Multicultural em um contexto global: diversos temas e perspectivas. Educação Comparada: Panorama internacional e perspectivas. R. K. COWEN, A. M.; UNTERHALTER, E. Brasília, UNESCO, CAPES. 2012.

HALL, S. Da Diáspora: Identidades e Mediações Culturais. Belo Horizonte: Ed. UFMG; Brasília: Representação da UNESCO no Brasil, 2003.

HAMMERSMITH, J. A. Converging indigenous and western knowledge systems: Implications for tertiary education. 2009.

HARDEN, R.M.; STAMPER, N. What is a spiral curiculum? Medical Teacher, vol. $21, \mathrm{n}^{\mathrm{o}}$ 2. Scotland, 1999.

HARARI, Y.N. Sapiens: Uma breve história da humanidade. Porto Alegre, RS: L\&PM, 2015.

HARLEN, W. Inquiry in Science Education: Background resources for implementing inquiry in science and mathematics at school. Montrouge: Fibonacci Project, European Commission/Seventh Framework Programme, 2012. 
HILL, H. Stirrings of Nationalism in East Timor, Frentilin 1974-1978: The origins, ideologies and strategies of a nationalist movement. Miranda, Australia: Otford Press. Contemporary Series, 2002.

HILLIARD III, A.G.O rabequista e a festa: uma crítica africana à "Educação Multicultural" nos Estados Unidos. In: NASCIMENTO, E. L. AFROCENTRICIDADE: Uma abordagem epistemológica inovadora - Coleção Sankofa - Volume 4. São Paulo: Selo Negro, 2009.

HOWES, E. V. Connecting girls and science: Constructivism, feminism, and science education reform. Teachers College Press, 2002.

HULL, G.; ECCLES, L. Gramática da Língua Tétum. Lisboa - Porto - Coimbra: Lidel, 2005.

HUNTER, P. Is political correctness damaging science? Peer pressure and mainstream thinking may discourage novelty and innovation. EMBO reports, 6, 405-407, 2005. Disponível em $<$ http://embor.embopress.org/content/6/5/405>. Acesso em 10 de setembro de 2016.

HURD, P.D. Scientific Literacy: New Minds for a Changing World, Science Education, Stanford: John Wiley \& Sons, Inc. 1998, V. 82, n. 3, p.407-416.

JIPSON, J.; HAUSER, M. Intersections: feminisms and early childhoods. New York: Peter Lang, 1998.

JONES, G.W. East Timor: education and human resource development. In: FOX, J.J.; SOARES, D.B. (org.). Out of the Ashes destruction and Reconstruction of East Timor. Camberra: Publisher ANU E Press, 2003.

JOVCHELOVITCH, S.; BAUER, M.W. Entrevista Narrativa. In: BAUER, M.W.; GASKEL, G. Pesquisa qualitativa com texto, imagem e som: um manual prático. Petrópolis, RJ: Vozes, 2002.

LAY, M.F. Choque de realidades dos professores principiantes em Díli (Timor-Leste), um estudo. 2011. 121 f. Dissertação (Mestrado em Ciências da Educação) - Instituto de Educação da Universidade de Lisboa, Portugal, 2011. Disponível em

$<$ http://repositorio.ul.pt/bitstream/10451/6243/1/ulfpie039942_tm.pdf $>$. Acesso em 15 de agosto de 2016.

LAVILLE, C.; DIONNE, J. A construção do saber: manual da pesquisa em ciências humanas. Porto Alegre: Artmed; Belo Horizonte: Editora UFMG, 1999.

LEMKE, J. L. Articulating communities: Sociocultural perspectives on science education. Journal of research in science teaching, v. 38, n. 3, p. 296-316, 2001.

LOPES, A.C. Teorias de Currículo. São Paulo: Cortez Editora, 2013.

LÜDKE, Menga. Pesquisa em educação: abordagens qualitativas. São Paulo: EPU, 1986. 
MACHADO, M.M. Merleau-Ponty \& a Educação. Coleção Pensadores \& Educação, 19. Belo Horizonte: Autêntica Editora, 2010.

MARCHTONNI, A. Prefácio da Edição em português da obra Didascálicon da arte de ler. In: DE SÃO VÍTOR, H. Didascálicon da arte de ler. Petrópolis, Rj: Vozes, 2001.

MAGALHÃES, J.P.A. Brasil século XXI: uma alternativa ao modelo neoliberal, Paz e Terra, 2000. p.28.

MATTOSO, J. História de Portugal. Vol. 8, Portugal em Transe (1974-1985). Lisboa: Editorial Estampa, 1994.

McKINLEY, E. Locating the global: culture, language and science education for indigenous students. International Journal of Science Education, Volume 27 - Issue 2, New Zealand, 2005.

MENDES, N.C. A "Multidimensionalidade" da construção identitária em Timor-Leste: Nacionalismo, Estado e Identidade Nacional. Lisboa: Instituto Superior de Ciências Sociais e Políticas, Universidade Técnica de Lisboa, 2005.

MEYCS. Primary Curriculum Implementation Plan: Timor Leste 2004-2009. Díli: Ministry of Education, Culture, Youth and Sport, 2004.

MERLEAU-PONTY, M. Fenomenologia da percepção. 4.ed. São Paulo: Martins Fontes, 2011.

. Conversas, 1948. São Paulo: Martins Fontes, 2004.

MILLER, B. Antropología Cultural. Madrid: PEARSON EDUCACIÓN, 2011.

MORTON, T. Classroom talk, conceptual change and teacher reflection in bilingual science teaching. Teaching and Teacher Education, v. 28, n. 1, p. 101-110, 2012.

MORTIMER, E.F. Linguagem, e formação de conceitos no ensino de ciências. Belo Horizonte: Editora UFMG, 2000.

NICOLAI, S. (2004). Learning independence education in emergency and transition in Timor-Leste since. UNESCO: International Institute for education planning. Disponível em:

$<$ http://www.unesco.org/iiep/PDF/pubs/East_timor.pdf $>$. (Acesso em 01de setembro de 2009).

NORBERG-HODGE, H. Ancient Futures: learning from Ladakh. London, Sydney, Auckland, Johannesburg: Rider, 2013.

PACIFIC POLICY RESEARCH CENTER, Successful Bilingual and Immersion Education Models/Programs. Honolulu: Kamehameha Schools, Research \& Evaluation Division, 2010. Disponível em:

$<$ http://www.ksbe.edu/_assets/spi/pdfs/Bilingual_Immersion_full.pdf $>$. Acesso em 02 de setembro de 2016. 
PARREIRA, P.N.C. A economia de Timor-Leste: transição e integração regional e mundial. Gabinete de Estudos e Prospectivas Econômicas, Portugal, Ministério da Economia, 2003.

PESCE, L.; ABREU, C.B.M. Pesquisa Qualitativa: considerações sobre as bases filosóficas e os princípios norteadores. Rev. da FAEEBA, Educação e Contemporaneidade, Salvador, v.22, n.40, p. 19-29, jul./dez. 2013.

PERENOUD, P. As competências para ensinar no século XXI: a formação dos professores e o desafio da avaliação. Porto Alegre: Artmed, 2007.

PIRES, M.L. Relatório da Descolonização de Timor. Relatório do Governo de Timor. Presidência do Conselho de Ministros, 1981.

OBERG, K. Cultural Shock: Adjustment to New Cultural Environments. Pratical Antropology 7: 177-182. 1960.

ORTIZ, F. Contrapunteo cubano del tabaco y el azucar. Caracas, Biblioteca Ayacucho, 1978.

RACE, R. Multiculturalism and Education (Contemporary issues in education studies). London: Continuum, 2011.

RAMOS, A.M.; TELES, F. Memória das Políticas Educativas em Timor-Leste: A consolidação de um Sistema (2007-2012). Aveiro: Ed. Universidade de Aveiro, 2012.

REIS, L.G. Produção de Monografia: da teoria à prática - O método educar pela pesquisa (MEP). Brasília: Senac, 2008.

REZENDE, A.M. Concepção fenomenológica da educação. São Paulo: Cortez, Autores Associados, 1990.

RICHARDSON, R.J. Pesquisa social: métodos e técnicas. São Paulo: Atlas, 1999.

ROWLAND, P. McD.; ADKINS, C.R. American Science Education and Its Implications for Multicultural Science Education. In: HINES, M. Multicultural Science Education: Theory, Practice and Promise. New York: Peter Lang Publishing, 2007.

RUSSEL, T., BELL, D., LONGDEN, K., McGUIGAN, L. Rocks, soil and weather (Primary Space Project Research Report). Liverpool: Liverpool University Press, 1993.

SAID, E. W. Orientalismo. Barcelona: Debate Editorial, 2008.

SALOMÃO, S.N. A Língua Portuguesa nos seus percursos multiculturais. Roma, Itália: Edizioni Nuova Cultura, 2012.

SAlZANO, F.M. Ciência Para Que(m)?, WERTHEIN, J. \& CUNHA, C. (org) Ensino de Ciências e Desenvolvimento: o que pensam os cientistas. $2^{\mathrm{a} e d . ~ B r a s i ́ l i a: ~ U n e s c o, ~ I n s t i t u t o ~}$ Sangari, 2009. p. 117-120. 
SANTOS, B. D. S. A Non-Occidentalist West?: Learned Ignorance and Ecology of Knowledge. Theory, Culture \& Society, v. 26, n. 7-8, p. 103-125, 2010.

SANTOS, M.F. dos. Filosofia e História da Cultura. Vol I. São Paulo: Livraria e Editora Logos LTDA, 1962. p. 15.

SASSERON, L.H.\& CARVALHO, A.M.P. Alfabetização científica: uma revisão bibliográfica. Rev. Investigação em Ensino de Ciências, v.16 (1), pp. 59-77, 2011. Disponível em

$<$ http://www.if.ufrgs.br/ienci/artigos/Artigo_ID254/v16_n1_a2011.pdf>, acesso em 10 de set. de 2013.

SANTOS, M.F. Dicionário de Filosofia e Ciências Culturais. São Paulo: Editora Matese, 1965.

SHAH, R. Timor-Leste ten years on: Reconstructing curriculum for the future? $10^{\mathrm{a}}$ UKFIET Conference on Education and Development, Oxford, September, 2009.

SHOHAT, E. Notas sobre lo "postcolonial". In: Estuidio postcoloniales: ensayos fundamentales. Madrid: Traficantes de Sueños, 2008.

$<$ http://issuu.com/gonzalodxrex/docs/mezzadra_s._edit._._estudios_post?e=2087885/12924 $295>$.

SILVA, F.C.T. Sociedade Feudal: guerreiros, sacerdotes e trabalhadores. Editora Brasiliense, 1982.

SILVA, J.C. Relatório de Operações de Guerra no districto de Timor no anno de 1896. Lisboa, 1897.

SILVA, K.C.; SIMIÃO, D.S. (org.). Timor-Leste por trás do palco: Cooperação internacional e a dialética da formação do Estado. Belo Horizonte: Editora UFMG, 2007.

SILVA, N. A História da Educação no Timor-Leste e os seus distintos Processos de Alfabetização. Rev. História da Educação, Vol. 9, n 18, 2005, p. 145-158. Disponível em $<$ http://dialnet.unirioja.es/descarga/articulo/4063058.pdf $>$. Acesso em 12 de maio de 2015.

SILVA, T.T. Documentos de Identidade: uma introdução às teorias do currículo. Belo Horizonte: Autêntica, 2005.

SIQUEIRA, A.B. Currículo de ciências: Aspectos Históricos e Perspectivas atuais. Revista Húmus, Jan/Fev/Mar/Abr. 2011. $\quad \mathrm{N}^{\circ} \quad 1 . \quad$ Disponível em $<$ http://www.periodicoseletronicos.ufma.br/index.php/revistahumus/article/viewFile/1640/130 1> Acesso em 10 de set. de 2013.

SOARES, T. As actividades laboratoriais no ensino de ciências em Timor-Leste: uma investigação centrada nas percepções de autoridades educativas e de professores de Ciências Físico-Naturais. 2009. 134 f. Dissertação (Mestrado em Ciências da Educação) - Universidade do Minho, Portugal, 2009.

SPENCER, H. Education: Intellectual, moral and physical. 1859. 
SPIVAK, G. C. Crítica de La razón postcolonial: hacia una historia del presente evanescente. Madrid: Ediciones Akal, 2010. Disponível em:

$<$ http://issuu.com/normano/docs/la_interculturalidad?e=0>.Acessadoem 15 de julho de 2015.

STANlEY, C. D. The Colonized Apostle: Paul Through Postcolonial Eyes. Minneapolis: Fortress Press, 2011.

STEINBERG, S.; KINCHELOE, J.L. Kinderculture: the corporate construction of childhood. Boulder, CO: Westview Press, 1997.

SCHWARTZMAN, S.; CHRISTOPHE, M. A Educação em ciências no Brasil. Academia Brasileira de Ciências. Instituto do Estudo do Trabalho e Sociedade - IETS. Disponível no endereço <http://www.abc.org.br/IMG/pdf/doc-210.pdf>. Acesso em 26 de outubro de 2016.

TRAUBE, E. Cosmology and Social Life: Ritual Exchange among the Mambai of Timor. Chicago: The University of Chicago Press, 1986.

TRIVIÑOS, A.N.S. Introdução à pesquisa em ciências sociais: a pesquisa qualitativa em educação. 22. Reimpr. São Paulo: Atlas, 2013.

UNESCO. Education for All 2015 National Review Report: Timor-Leste. Disponível em $<$ http://unesdoc.unesco.org/images/0022/002298/229880E.pdf $>$. Acessado em 02 de junho de 2015 .

VALLADARES, L. La educación científica intercultural y el enfoque de las capacidades. Revista iberoamericana de ciencia tecnología y sociedad, v. 6, n. 16, p. 39-69, 2011.

XIMENES BELO, D.C.F. Os Reinos Antigos de Timor-Leste: Reys de Lorosay e Reys de Lorothoba, Coronéis e Datos. Porto, Portugal: Editora Porto Lda., 2013.

WALKERDINE, V. Daddy's girl: young girl and popular culture, Cambridge, MA: Harvard University Press, 1997.

WANG, Y. The Multicultural Science Literacy of Science Teachers in Taiwan. International Journal of Asian Social Science, 3(9): p.2052-2059, 2013. Disponível em:

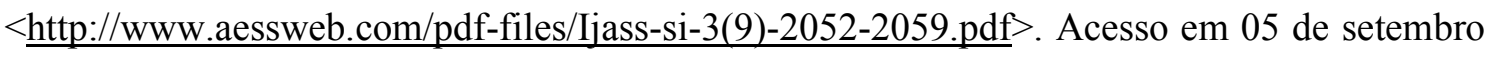
de 2016 .

WATERFALL, B. Native people and the social work profession: A critical exploration of colonizing problematic and the development of decolonized thought. The Journal of Educational Thought (JET)/Revue de la Pensée Educative, p. 149-166, 2002.

WHEATERBEE, D.E. The Indonesianization of East Timor. In: Contemporary Southeast Asia, Vol. 3, nº 1, June, 1981.

WOLPERT, Lewis. Is science dangerous?. Nature, v. 398, n. 6725, 1999.

WORTMANN, M.L.C. O uso do termo representação na Educação em Ciências e nos Estudos Culturais. Rev. Pro-Posições - vol. 12, nº 1 (34), março/2001. 


\section{APÊNDICES}


Anexo 1. Cópia da "Carta de Apresentação" do Programa de Pós-Graduação em Educação da Faculdade de Educação da Universidade de Brasília
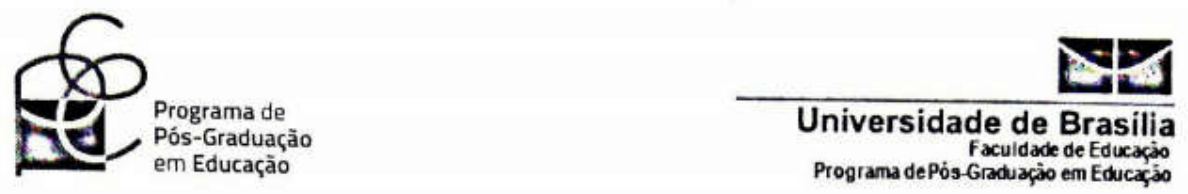

\section{CARTA DE APRESENTAÇÃO}

Prezados Senhores,

O Programa de Pós-Graduação da Faculdade de Educação da Universidade de Brasília, Brasil (PPGE/FE/UnB), vem por meio desta, proceder a apresentação do estudante de doutorado deste Programa, HELIO JOSÉ SANTOS MAIA, matrícula 14/0072195, passaporte n FP010436, cujo projeto busca o entendimento sobre o currículo de ciências na escola primária em Timor-Leste e procura analisar representações de conceitos das ciências em uma amostra de estudantes deste nível. Salienta-se que o doutorando já viveu em Timor de 2007 a 2008, trabalhando na Cooperação Internacional Brasil-TimorLeste no âmbito do Programa de Qualificação Docente em Língua Portuguesa (PQLP), no projeto de Formação de Professores em Exercício na Escola Primária do Timor-Leste (PROFEP-Timor) na área de ensino de ciências. Desta forma, aproveita-se o ensejo para também solicitar autorização oficial para a realização da sua pesquisa.

Brasilia/DF, Brasil, 11 de julho de 2016.

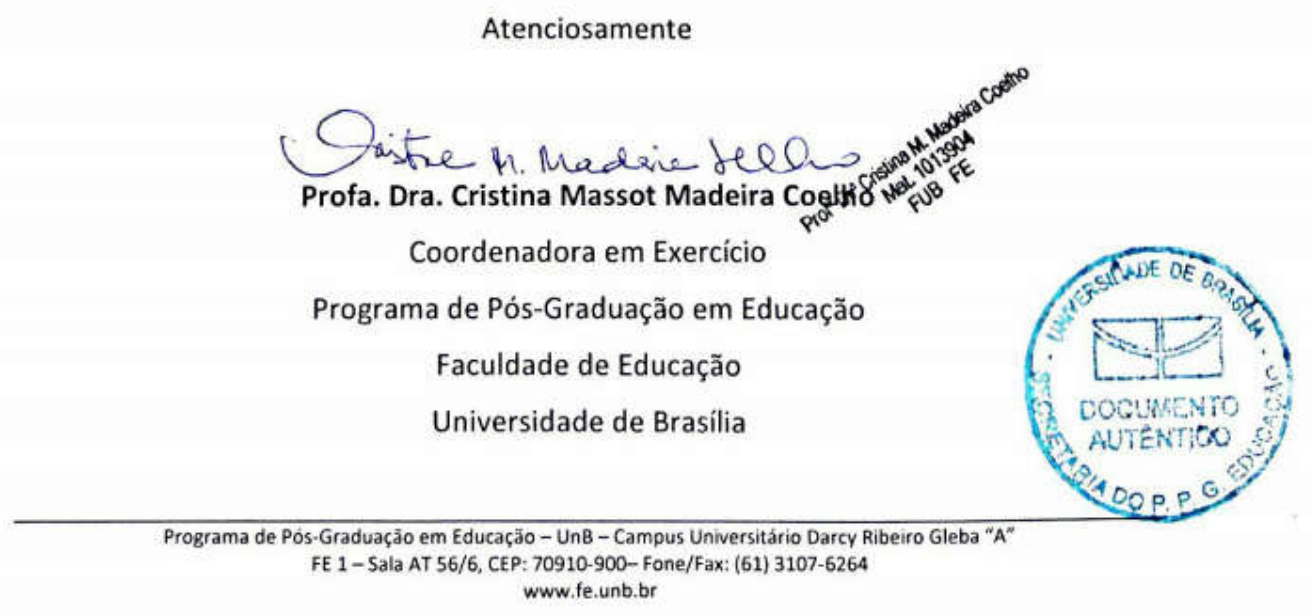


Anexo 2. Atestado de residência em Díli no Timor-Leste no ano de 2007

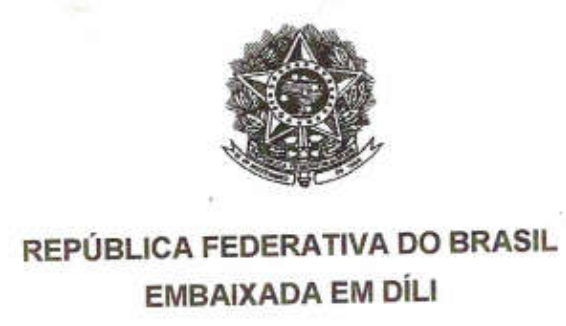

\section{ATESTADO DE RESIDÊNCIA}

Atesto, para os devidos fins, que, conforme documentação apresentada, o Senhor HELIO JOSÉ SANTOS MAIA, de nacionalidade brasileira, portador do passaporte $N^{\circ}$ SA 200003, expedido em 15 de fevereiro de 2007 pelo Ministério das Relações Exteriores/Divisão de Passaportes, reside em Timor-Leste desde vinte e seis de fevereiro de dois mil e sete. Durante este periodo, até a presente data, o Senhor MAIA tem residido no seguinte endereço: Rua Jacinto Cândido, Dili, Timor-Leste.

Em fé do que, a pedido do interessado, mandei lavrar o presente atestado, que vai por mim assinado e selado com o Selo de Armas desta Embaixada, aos nove dias do mês de janeiro do ano de dois mil e oito.

Pagou R\$15.00 ouro ou US\$15.00 Tabela 520

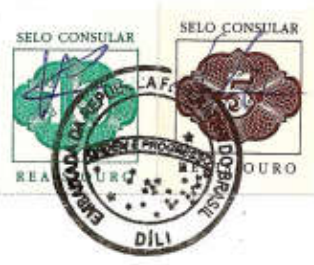

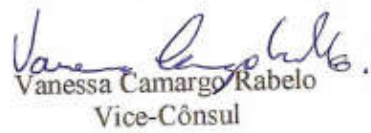

Dispensada a legalizaçåo da assinatura da autoridade consular, de acordo como artigo 2 do
Decreto $n^{\circ} 84.451$, de 31 de janeiro de 1980 
Anexo 3 - Entrevista com a Senhora Filomena Lay, Diretora do INFORDEPE, concedida no dia 25 de agosto de 2016.

A senhora Filomena Lay é a Diretora atual do Instituto Nacional de Formação de Docentes e Profissionais da Educação e gentilmente concedeu a entrevista abaixo:

Hélio Maia - Bom dia Senhora Filomena! Estive a semana passada com o Sr. Cidálio que me disponibilizou o currículo do ensino básico, fiz uma cópia para mim. $\mathrm{O}$ currículo está todo em tétum, não tinha uma versão em português.

Filomena Lay - Por enquanto ainda não tem e eu não sei qual é a política que estamos trabalhando. Atuamos de acordo com a política que orienta os trabalhos. Nós questionamos ainda, relativamente a presença da língua portuguesa no ensino básico. Os estudos que fizeram, só do quarto ano para cima [ensino de língua portuguesa].

Hélio Maia - Não estão implementando a língua portuguesa no primeiro ciclo, não é?

Filomena Lay - Não!

Hélio Maia - São aspectos interessantes! Bom... Eu vejo que há necessidade de um ajustamento do ponto de vista da identidade timorense, pois, afinal de contas, o que se pretende...

Filomena Lay - Mas na verdade... Até porquê o novo currículo tem seus pontos positivos... Sabe por quê? Os estudantes não têm como língua materna a língua portuguesa. Então, no início, a questão agora é aprender a ler e a escrever! Não é aprender língua! Uma língua se aprende no fim de uma rota! O que interessa agora é que o estudante saiba ler e contar, escrever. Isso é o que as pessoas aprendem em um nível mais básico... No entanto está sendo feito isso como uma meta que entrou já no currículo. Os estudantes vão aprendendo a ler também na língua portuguesa.

Hélio Maia - Eles lêem mesmo em português. Eu estive com alunos da escola básica do sexto e eles lêem...

Filomena Lay - Só não falam português... Mas agora deve-se aumentar o número de horas no ensina da língua... Mas, está bom! Nenhum currículo é adaptado em todos os anos, na medida em que evolui, procura se ajustar. 
Hélio Maia - Obviamente essas coisas vão se ajustando! Eu percebo que o que tem acontecido no Timor é um ajustamento educacional ao longo desse tempo, porque...

Filomena Lay - Porque sabe-se que na altura.. .No tempo do senhor João Câncio ${ }^{49}$, ainda tínhamos os vestígios da língua indonésia. Então na medida em que o "ponteiro vai subindo" tempo vai passando, vai desaparecendo a língua indonésia. Só que veio a nova política, tendo em conta a realidade, os estudantes em casa também não falam português!

Hélio Maia - Tá... Tem isso...

Filomena Lay - É um pouco complicado entrar diretamente com português no primeiro ano, na verdade, os estudantes não têm apoio em suas casas!

Hélio Maia - Veja... A Conferência que participei, tinha muitos estudantes de graduação e pós-graduação participando com apresentação de trabalhos e todos falavam português a nível da Universidade. Então, eu acho que há um gradual até chegar a essa aprendizagem de habilidade na língua portuguesa.

Filomena Lay - É... O Timor é um país novo. Só temos, portanto 14 anos, sem contarmos os dois anos de transição em que a autonomia estava na mão dos líderes da UNTAET... Então, olha... Não se pode comparar a nenhum país que tem sua história de autonomia muito mais antiga. Então, cada um por si e Deus por todos. É assim que continuamos a andar.

Hélio Maia - Eu poderia fazer algumas perguntas para a senhora? Se não for possível responder, não tem problema!

Filomena Lay - Sobre o quê?...

Hélio Maia - São dessas áreas do ensino básico, formação de professores...

Filomena Lay - Pode ser...

Hélio Maia - Bom... Eu escrevi aqui para não perdermos tempo! No Brasil, ao menos no ensino básico, a escola particular é considerada mais eficiente do que a escola pública em uma série de elementos, ou seja, no Brasil nós temos esse entendimento de que a escola pública é sempre malvista, quando comparada com a escola privada, em conteúdo, rigor, na avaliação, vigilância. Será que isso acontece aqui em Timor-Leste? A escola privada tem essa feição? A sociedade respeita mais neste sentido, como é o caso no Brasil?

\footnotetext{
${ }^{49}$ Ministro da Educação no primeiro governo constitucional do Timor-Leste independente.
} 
Filomena Lay - Talvez eu possa responder que em Timor temos diferentes escolas privadas. Temos escolas privadas católicas, privadas da comunidade, privadas de outros estilos, como as internacionais. Então, o que vejo é que ao longo da Indonésia até este momento, é que a escola privada católica é vista como uma escola com melhor qualidade. Até porque entre suas razões, os estudantes que entram são bem selecionados e....

Hélio Maia - Hum... Então passam por um processo de seleção para entrarem lá...

Filomena Lay - Sim. Passam por um processo! É diferentemente da escola pública que pela orientação dos nossos líderes, temos que receber sem distinção. Então isso afeta também o olhar público sobre as escolas públicas, já que há um maior número, porque entram todos, desde os que moram nos arredores da escola... Houve há um tempo atrás, uns critérios para admitir alunos que morassem a uns quantos quilômetros da escola, são aceitos nessa escola... Então. Mas, limitou-se em outros municípios, tendo em conta um número maior de estudantes em Dili em especial. Isso afeta o número de turmas. Então obviamente afeta a qualidade de ensino-aprendizagem, porque não se pode avaliar com métodos mais atrativos, melhores, em que os estudantes pudessem apresentar suas ideias ou discuti-las... Não dá porque são turmas muito grandes. Então esse olhar para as escolas católicas, dizendo que estas têm melhor qualidade, isso tem a ver com o número de alunos, isso tem a ver com a seleção de entrada... Obviamente que nas escolas católicas têm essas disciplinas católicas que disciplinam os alunos... Agora diferentemente das escolas públicas... Eu não vou dizer que estas não têm qualidade... Os professores são os mesmos, até... São formados na área! Entraram por uma seleção rigorosa, mas, têm que tomar conta de uma turma maior. Ensinar para 60 a 70 estudantes, obviamente que afeta já a qualidade de ensino... Mas, para fora, os que completam todos os níveis da escola são da escola pública, pela quantidade, mas, os que completam em mais línguas e entram mais para a Universidade são os das escolas católicas, tanto de Baucau, como de Dili. Só que, há uma escola pública em Timor-Leste em Lospalos, é uma escola pública, mas que na entrada para as Universidades, têm um maior número de estudantes. Eu não sei porquê... Mas acho que tem a ver com esse rigor de entrada. Eu não diria que as escolas católicas são de melhor qualidade, porque as condições são diferentes. Agora, falando das escolas particulares, não católicas, a escola portuguesa é outro caso, pois usam outro regulamento, currículo de Portugal, é um caso a parte! Mas, percebemos que estamos a melhorar na escola pública pela capacitação dos nossos professores, as cooperações na área de formação continuada atuaram intensamente, os brasileiros, os portugueses, assim como outras cooperações que vieram apoiar em língua inglesa... Então eu julgo que ao longo dos anos os 
professores foram melhorando suas capacidades acadêmicas e competências intelectuais para dar uma boa aula. Porque sabes que no início houve professores que não tiveram nenhuma licenciatura... Houve um momento que o Governo... O Ministério da Educação, tiveram que fazer uma formação complementar aos professores que ainda não tinha o bacharelado... Então eu julgo que isso veio a contribuir com a melhoria da competência de cada professor no seu trabalho.

Hélio Maia - Pensando nessa questão professora Filomena de salas super-lotadas, a oferta de vagas na escola pública aqui em Timor é suficiente para atender a demanda? Ou tem muitas crianças e jovens que ficam de fora porque não acham vagas?

Filomena Lay - Eu juro que há estudantes que se não entram na escola pública, vão para escolas privadas... Mas, como a escola privada é paga... Mas, pelo que vejo, no meu conhecimento, no Timor, há muitas crianças que estão nas escolas! Agora, superlotadas... Isso tem a ver com a gerência... A gestão da escola! Sabe... há certas escolas públicas que têm três turnos: pré-escolar até o primeiro ciclo, de sete horas da manhã, até as 10 horas, depois o segunda ciclo de 10 até as 13 horas e o terceiro ciclo em diante, o resto da tarde! Então, eu acho que as crianças, especialmente em Díli, entram todos nas escolas, embora estas escolas em três turnos, para os primeiros ciclos, encurte o tempo. Agora, felizmente nas escolas tem muitos estudantes. Há escolas que têm três mil estudantes no secundário. Principalmente as escolas mais centrais, há aquelas que têm 1.500 a 2.000 estudantes.

Hélio Maia - Em Timor a escola básica é obrigatória e Gratuita?

Filomena Lay - Sim. Em Timor é!

Hélio Maia - Há algum tipo de controle do Governo para verificar se os pais estão enviando suas crianças para a escola?

Filomena Lay - Olha a ideia é boa! Mas, não sei lhe responder se há! Eu sei que há controles estatísticos que o Governo faz sobre o número de matrículas, os que saem... Esse tipo de dado! Mas, seria interessante para verificarmos, até que ponto a consciência dos pais em preocupar-se com o futuro dos filhos!

Hélio Maia - Sobre o currículo... Veja, a gente pressupõe que um currículo é construído em cima de posições políticas e que se procura identificar a identidade do povo e imprimir de certa forma a identidade do povo nesse currículo. A senhora sabe informar como foi 
construído esse currículo em Timor-Leste na escola básica? E se havia, ou se há organismos internacionais, ou grupos, que estão interferindo ou interferiram na construção deste currículo?

Filomena Lay - Sei que houve um currículo até 2010 e depois eu não sei se houve uma avaliação! Mas depois eu sei que um currículo foi elaborado por agentes internacionais, em parceria com pessoas ligadas a nosso país. Houve um encontro sobre a escola básica em Laga, onde profissionais da Austrália, América, Portugal, Indonésia, outros países vizinhos, também estiveram presentes na elaboração deste currículo. Agora, intervenção ou imposição, acho que não houve. Houve sim, essa consulta entre vários currículos. Obviamente que o currículo do ensino básico, na verdade, é quase idêntico a todos aqui da região. Pois, estamos inseridos entre os países da Região! Um estudante timorense que queira adaptar-se a outro país da nossa vizinhança... Então eu acho que essa preocupação houve dos peritos que elaboraram o currículo!

Hélio Maia - O INFORDEPE é um instituto de formação de professores em exercício. Como é que ocorre o processo de seleção (se há) dos professores da rede pública para participarem das formações aqui?

Filomena Lay - Neste momento, na verdade, há um departamento do Ministério que identifica a necessidade e encaminha! Mas, penso que essa necessidade deveria ser identificada e propostas pelas direções de ensino. Mas, tendo em conta que nosso histórico dos professores... Os professores não partiram de uma base selecionada, consoante a uma habilitação literária, nem de experiências... Eles entraram no sistema, já no início da independência, então, não houve uma seleção que diga que este professor precisa disto ou daquilo. Então, neste momento o que o INFORDEPE está fazendo... Está identificando professores... Por exemplo, nós fizemos um senso de professores a nível nacional e identificamos que há um "x" número que estão no nível 1 , "x" número que estão no nível $2 \ldots$ b2, b3... então, nós temos a lista dos nomes... Então a direção da "contínua", pede a lista destes professores e então, pela quantidade, estabelecemos uma turma, por exemplo, de formação "nível 1". Isso para formação em língua portuguesa no geral. Mas, se for para as disciplinas específicas, de ciências, matemática... Nós identificamos se eles são, por exemplo, professores de matemática do "nível x". Obviamente, há certos professores que não têm a base em uma licenciatura em matemática... Então as escolas podem identificar e isso, na medida em que as escolas vão se queixando, vai seguindo formações. Tem sido pensado que 
estão efetivos, mas, também não podemos tirar professores do sistema... E se tirarmos, também não temos ninguém a ensinar... Especializados nessa área! Então... O que está fazendo o INFORDEPE neste momento é identificar se ele dá aula no primeiro ano... Mas, a formação é para o décimo ano. O décimo ano é do ensino secundário... É matemática, física, química e biologia. Agora para o ensino básico o que tem sido feito é uma formação geral. Todos os professores passam por formação. E agora nós entramos neste momento para as disciplinas do terceiro ciclo, tendo como base a disciplina que o professor ensina. Os nossos professores não são provenientes de uma base licenciada, pela qual ele tenha sido inserido no sistema. Então para salvaguardar o andamento das aulas, as formações são feitas nas férias letivas. Eu julgo que não seja a melhor forma, mas, para depois não deixarmos os estudantes sem aulas. Mas, estamos a pensar formas de fazermos as duas coisas andarem ao mesmo tempo, o ensino, a formação. Agora esta formação em Língua Portuguesa, será feitas nas sextas e no sábado. Porque é uma necessidade importantíssima, porque temos um grande número de professores nos níveis A1 e A2.

Hélio Maia - A Língua Portuguesa e o tétum estão previstas na Constituição como línguas oficiais e, sobretudo línguas de instrução. Mas, na sua percepção, qual o espaço da língua portuguesa, na perspectiva da criança, do jovem, que está na escola? Ele tem o espaço para aprender a língua portuguesa na escola, ou isso é um desejo ainda para o futuro?

Filomena Lay - Pronto! O que está na lei é lei. Agora, realizar, eu diria... 100\%... Onde é que estamos? Em Timor... Timor não é qualquer um dos países da CPLP.. Sabemos que nossos professores também não falam português... Então... O espaço dos estudantes para o português na escola é só aquela hora da língua portuguesa... Houve uma preocupação de como os diretores colocarem situações... Uma forma de divulgar mais a língua portuguesa, como um dia na escola que todos tenham que falar português por exemplo, outro dia tétum e assim, cultivar nos estudantes o hábito de falar bem o português, pois, na medida que vão falando, vão desenvolvendo a prática da fala! Mas, tem vezes que também não há uma atenção assim... Muito... Profunda por parte do Ministério... Em colocar o português para os estudantes falarem. Atualmente, o que sei é que é só na aula de língua portuguesa! Mas, no terceiro ciclo, no ensino secundário, o que é que ocorre? Obviamente no ensino básico a aula já é uma mistura de tétum e língua portuguesa, porque eles não têm nenhuma base... Agora é irônico que os alunos do terceiro ciclo, os alunos tenham aulas de português misturadas com tétum e os testes sejam feitos todos em língua portuguesa. 
Hélio Maia - Isso... A senhora não acha que isso prejudica no resultado final?

Filomena Lay - Eu acho que isso prejudica imenso. Mas, como não conheço o tipo de avaliação... Eu penso que os estudantes de alguma forma, entendem o português. Eu acho que o português está se desenvolvendo em Timor "pacificamente", ou seja, escrito e pensado... Agora, a minha pergunta é se o que eles entendem é correto ou não! Eu tenho uma filha que entrou na escola já no currículo da independência, ela tem agora 16 anos e está no secundário... E eu nunca falei com ela em português, nós sempre conversamos em tétum... Mas a miúda fala português, entende português e faz todos os trabalhos em língua portuguesa. Eu acho que é um dom que talvez o timorense tenha para línguas. É engraçado que eles falam muitas línguas... Minha filha fala indonésio, tétum, inglês... Mas também português e assim é com muitas crianças e jovens, falam quatro línguas! E minha neta que nasceu em 2007, fala fluentemente língua indonésia, através da televisão. O professor dela é a televisão!

Hélio Maia - Pois é... Eu tenho um amigo aqui no Timor que em 2007 trabalhamos juntos no PROFEP, hoje ele está no Ministério das Energias, ele é engenheiro elétrico e fez mestrado no Brasil recentemente, o professor José Mesquita. Eu estive sábado passado na casa dele, com a família, e ele me disse exatamente isso: que as crianças dele aprenderam o bahasa, a língua indonésia, pela televisão! Algo que parece muito comum aqui!

Filomena Lay - Isso é o Timor. Uma criança timorense fala três língua, pelo menos, desde criança! Vou lhe contar uma história: Tem uns sobrinhos meus que a mãe fala Galoli, o pai fala Uimá, os avós falam Galoli e o pai e a mãe também falam tétum. Os miúdos, de três e quatro anos, falam com os avós em Galoli e com os pais tétum. Falam fluentemente... Engraçado... E as crianças sabem definir isso!

Hélio Maia - Para encerrar, senhora Filomena, para não tomar mais o seu tempo... Em leitura de modo geral e em conversas que já tive, há uma tendência em usar na educação pré-escolar e nas classes do primeiro ciclo línguas maternas. Isso procede? As crianças estão, nestes ciclos iniciais, tendo instrução em língua materna?

Filomena Lay - É uma política da senhora vice-ministra que o pré-escolar e o básico seja ensinado em língua materna. E também, há um projeto piloto, não é em todas as escolas... Há um projeto piloto em Baikeno, Manatuto e Lospalos... Agora está a expandir para mais quatro municípios que estão a utilizar a língua materna, para o ensino do primeiro ciclo. A mim, não sei como será o futuro destas crianças... Mas, julgo ser também uma coisa que deveria ser 
bem pensada na sua implementação, porque... Olha a política diz que no primeiro ano, é só língua materna, no segundo também, mas no terceiro ano, já começa entrar o português. E somente português e tétum no quarto ano de modo oral e no $5^{\circ}$ ano, português mais elaborado! Julgo que esse projeto piloto é útil para as crianças que não falam a língua tétum. Há certas crianças que em seus municípios, eles não falam a língua tétum. Então, logo no início da escolaridade, eles já usam a língua materna, para depois o tétum e o português. Numa tentativa de incluí-los na educação! Porque, olha, agora somos um país independente e se essa toda riqueza, nós não preservarmos, julgo que vamos perder no futuro. Olha, porque... Eu pelo menos aprendi a língua... Eu tenho a língua materna tétum. Mas, meu marido tem a língua materna Uimá e Macassai. Eu casada com ele e convivendo com as crianças quando era menina... Agora nesse momento sei Macassai... Mas imagine que as crianças ao nascer, nunca ouçam língua materna, quando for crescido e quanto mais na idade adulta, eles não vão precisar usar língua materna. E sabe que em Timor também tem esse caráter? Quando encontramos pessoas da nossa origem, nós conversamos em língua materna dentro do país... Mas, fora do país, quando nos encontramos nós falamos a nossa língua tétum. Então, eu penso que esse projeto deveria ter sido mais bem pensado e ser implementado com rigor... Se for para usar a língua materna que se use na pré-escola e nos primeiros anos do primeiro ciclo, mas, a partir mesmo do $3^{\circ}$ ano, $4^{\circ}$ ano, se entre com a língua tétum e português para no futuro essas crianças não se sentirem excluídas. Há estudos que indicam que a aprendizagem com línguas maternas melhoram o desempenho das crianças na aprendizagem. Porém, o problema que eu acho que vai haver... É... Será que todos os livros vão ser traduzidos para língua materna? E a língua materna terá a mesma competência para dar aulas de uma língua científica? Isso é outra questão! Essa é a política da senhora vice- ministra, vamos ver o resultado no final agora deste ano neste projeto e olha... Se tiver bons resultados... Que se continue! Acho que é uma política de preservação até porque eu acho que tem a ver com alguma resolução da UNESCO sobre a preservação de línguas maternas. O fundamento deles é esse! Mas, também tem que avaliar o impacto disso nas crianças... Também há certas insatisfações... Mas senhor, para fazermos mudanças, implementá-las, é normal que haja insatisfações de alguns.

Hélio Maia - Desculpe senhora Filomena, mas para encerar mesmo... Essa questão do plurilinguísmo e do multicultural que aqui representa, cada povo tem sua cultura, suas imagens... É uma coisa muito impressionante isso... Agora, há alguma preocupação em 
colocar no currículo a cultura, os elementos culturais, sem ser a língua, aparece nesse processo, como uma preocupação também para sua preservação?

Filomena Lay - Eu acho que tem no currículo disciplinas de literatura, educação artística... Em que se trabalham estas questões... As músicas, as danças, eu acho também... Jogos... Só que uma coisa que eu noto é que as coisas... Como as danças vão se adaptando a algo de fora... As influências... Assim, há certas coisas que são originais, mas há outras adaptadas... Sabes que sofremos influências do sudeste da Ásia, especialmente da Indonésia... Isso pode vir a afetar a originalidade de nossas danças... E de nossa cultura como um todo. Mas acho que há coisas que não vão mudar como as tradições das "casas sagradas"... Nós temos nas nossas memórias todos os ancestrais guardados de memória por estes homens das "casas sagradas". Eu acho isso um prodígio... Embora o sacerdote das casas sagradas conheça as gerações... Há uma rede de outras pessoas também ligadas às casas sagradas que apóiam a memória do sacerdote, e cada um lembra um ramo das gerações. Pois pronto... É isso o Timor!

Hélio - Professor obrigado! Desculpe por ter tomado seu tempo! Já estou voltando ao Brasil amanhã...

Filomena Lay - Obrigado o senhor por ter me incluído no seu trabalho! Espero que tenha uma boa viagem e uma boa sorte! Adeus! 


\section{Prelúdio de incertezas}

Díli, 26 de fevereiro de 2007.

Após quase 27 horas viajando, por fim, a partir de Sydney chegamos ao norte da Austrália em Darwin às 23 horas. Uma longa noite no aeroporto ainda nos aguardava. Como havíamos comido no avião, não estava com fome. Fomos para a esteira de bagagem, pegamos as mesmas e tentamos despachá-las para a empresa que nos levaria a Díli. Fomos informados que para despachar bagagem e fazer o chekin, só a partir das 5 da manhã do outro dia. Então, nos arrebanhamos em um canto do aeroporto e nos preparamos para uma noite longa, já que não daria para dormirmos em outro lugar. Entre o uso da internet do aeroporto com laptop e cochilos rápidos, fomos chamados para o vôo. Carimbamos os passaportes, de saída da Austrália e nos instalamos no embarque 5. Assim que chamaram o vôo, fomos conduzidos pela comissária da AirNorth, para o aviãozinho turboélice Brasília da Embraer, que nos aguardava (Figura 21). Aí, pude entender o porquê do limite de bagagem. O avião, realmente é muito pequeno. E lá fomos nós naquilo que parecia mais um ônibus voando. Sacode daqui,

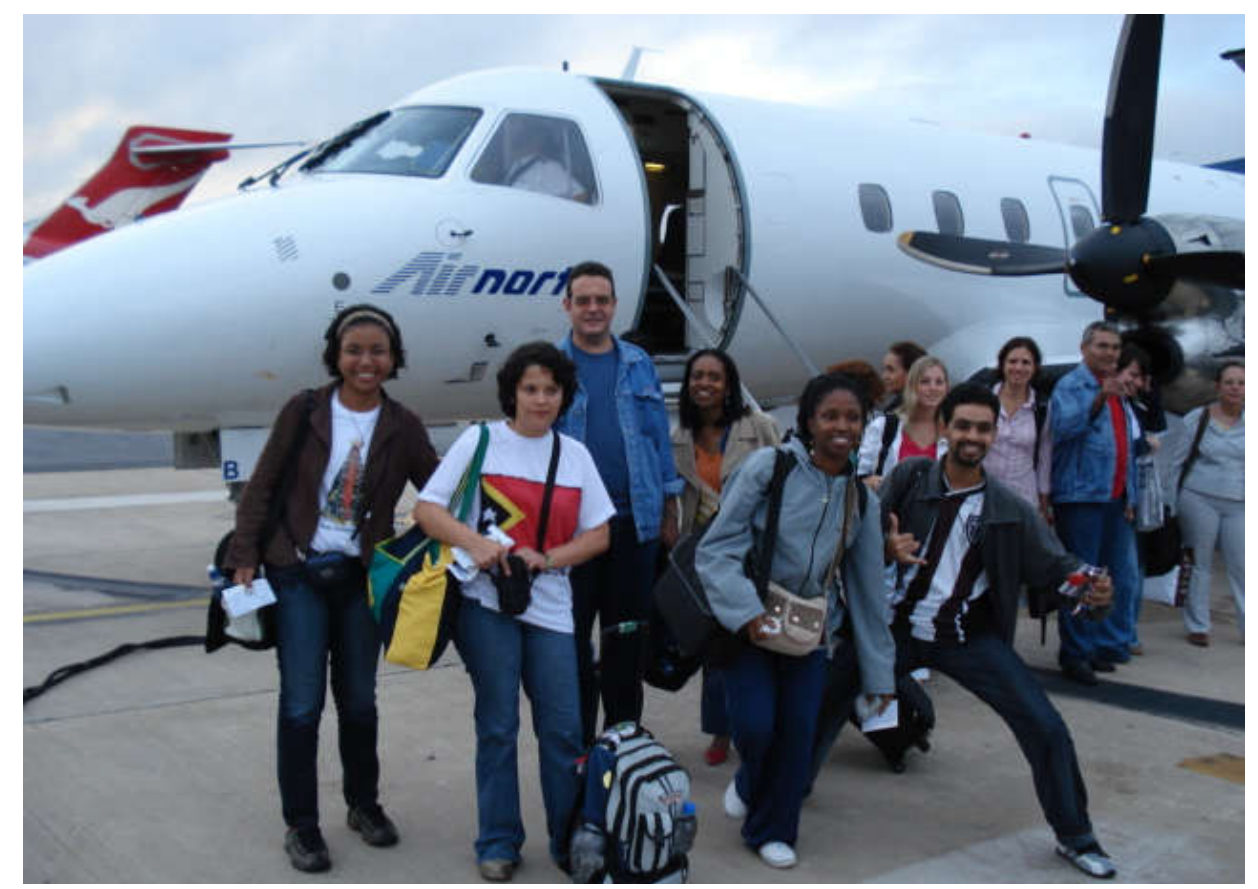

FIGURA 21 - Foto do embarque para o Timor, em Darwin, Austrália.

turbulência dali, fomos ao Timor-Leste em estilo aventureiro. Houve até um serviço de bordo, onde a comissária australiana nos serviu umas comidinhas com suco de laranja. Chegamos ao Timor, num dia nublado, dia 26 de fevereiro às $8 \mathrm{~h} 30 \mathrm{~min}$ da manhã. De Darwin para o Timor existe uma hora e meia de fuso horário para menos. São $500 \mathrm{~km}$ de distância voando por cima 
do mar do Timor sobre o banco de corais da Austrália, em baixa altitude para piorar a turbulência.

Ao descermos no Aeroporto Internacional Nicolau Lobato, tive a impressão que estava aterrizando em uma fazenda de bananeiras e mamoeiros, mas, havia muitas aeronaves da ONU pousadas, de modo que aceitei que aquilo era mesmo um aeroporto. A uma observação atenta, dá para notar o padrão fenotípico das pessoas aqui. São todas pequenas, pele morena e suaves traços orientais do chinês.

Após os procedimentos na imigração, fomos recebidos pela Embaixada do Brasil que nos escoltou até o hotel. Pelo caminho que fizemos nos carros da Embaixada, pude perceber o estado de tensão que Díli no dia de hoje se encontra. Estou sentindo Díli, como um barril de pólvora com o pavio aceso. Muitos soldados fortemente armados no caminho até o hotel, muita coisas destruída, aspecto de sujeira e desconfiança. O motorista da Embaixada nos contou que no dia 23 de fevereiro, soldados do exército australiano, que integram as forças de paz da ONU, haviam atirado e matado dois timorenses, diante disso os grupos de resistências prometeram para ontem o assassinato de australianos. Assim, tendo em vista a possibilidade de ataques, fomos recebidos no aeroporto pela Embaixada do Brasil com seus carros oficiais, que nos escoltou até o hotel onde estamos, pois aqui é muito comum jogarem pedras nos carros que não tenham identificação de organismos internacionais ou no caso, que não tenham a bandeirinha do Brasil. O hotel onde estamos fica no centro da cidade, é simples, mas tem arcondicionado nos quartos, televisão e frigobar, além de água quente no chuveiro. Ao chegar encontramos com Luciana e Suzi que são as dirigentes do PROFORMAÇÃO do Brasil e vieram para nossa capacitação nestes primeiros dias. Tivemos o restante do dia de ontem e hoje até as 15 horas, de folga.

Se a primeira impressão é a que fica, confesso que estou temeroso sobre o que me aguarda a partir desse "prelúdio". Um prelúdio da incerteza e da escuridão no horizonte, mas o cansaço era tão grande, que após um almoço aligeirado, o sono retirou qualquer espaço de consciência para maiores reflexões.

Hélio Maia

Para situar a morte dos timorenses por soldados australianos, abaixo notícias da época sobre o assunto. Disponível em:

$<$ http://www.portalangop.co.ao/angola/pt_pt/noticias/internacional/2007/1/8/Timor-leste-Soldados-australianosmatam-dois-civis,d6e51627-ea85-4b31-960b-92de4721d387.html> 


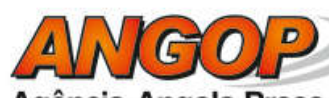

Agência Angola Press

Páaina Inicial Noticias x Internacional

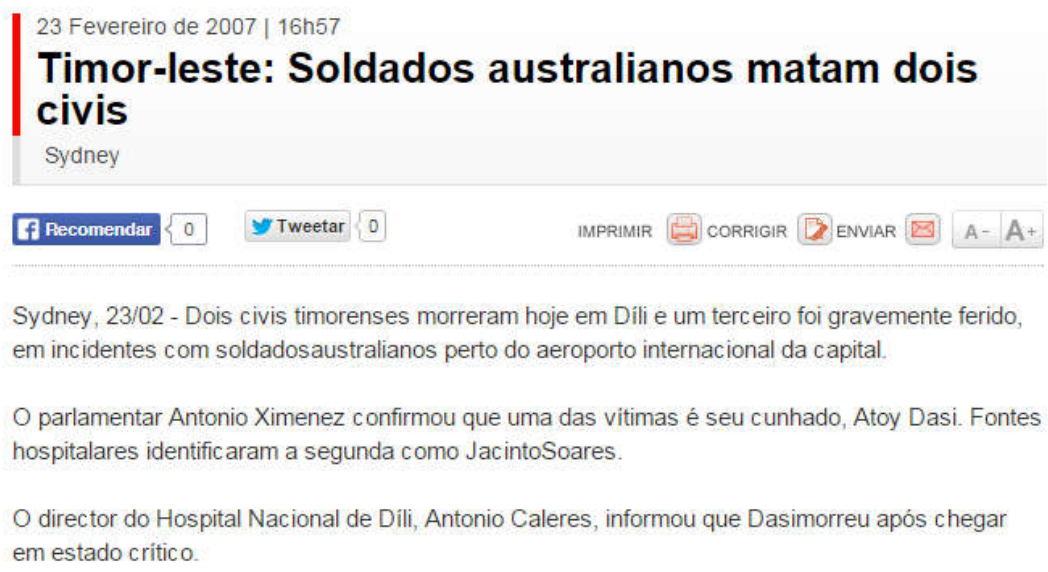

Há dias as forças internacionais de segurança presentes no Timor Leste tentam controlaruma nova onda de violência em Dili, envolvendo grupos rivais de jovens filiados a academiasde artes marciais.

A ONU mantém cerca de 1.300 policias no Timor para ajudar a restabelecer a ordem e conta com o apoio de uma Força Internacional de Estabilização, liderada pela Austrália, comcerca de mil soldados.

\section{Um encontro internacional no lixo}

Das histórias que vivemos ou testemunhamos na vida, algumas se esvaem como fumaça e liberamos a mente para outras memórias, outras se fixam da tal modo que passam a fazer parte do nosso ser como se fossem novos órgãos que alimentaremos para o resto das nossas existências. O tempo pode afastar-nos das lembranças de algumas dessas histórias por uma série de circunstâncias, entre elas, por serem muito trágicas ou desastrosas, o remédio é reprimi-las até que percam o poder de vir à tona, mas, algumas, por serem doces e prazerosas 
revisitamos sempre. Porém, há aquelas que reúnem características dos dois aspectos mencionados. Estas estão sempre perambulando no nosso espírito e a cada vez que as visitamos, somos surpreendidos por novas reflexões e lições. Nessa última categoria é que inscrevo a história que se segue.

Vivemos em um mundo pequeno pela característica de estar global e interligado pelas comunicações e pelos transportes modernos. Os povos interagem uns com os outros. As cooperações internacionais procuram muitas vezes suscitar o mais humano em nós que é ajudar o próximo. Assim, em missão internacional para a formação de professores em TimorLeste no ano de 2007, muitas situações pitorescas vivi naquele país. Entre tantas, algumas cômicas, outras nem tanto, outras ainda procuro classificação. Mas, uma sempre me assalta a lembrança e passo abaixo a narrar.

Timor-Leste, Díli, 2 de março de 2007

O Timor-Leste é um pequeno país do sudoeste asiático, de colonização portuguesa até 1975 e após esse ano, sob o domínio da Indonésia até 1999. Nos dias que se seguiram após o resultado do plebiscito em que a população timorense, por maioria, havia optado pela independência da Indonésia, milícias pró-Indonésia em confronto com forças timorenses destruíram quase toda infra-estrutura do país, surgindo cooperações internacionais para ajudar na sua reconstrução. Participo em uma dessas missões no campo da educação. Somos treze docentes brasileiros para um projeto de formação de professores para a escola primária de Timor-Leste. Logo que chegamos em Díli, a capital, ficamos instalados por uma semana em um hotel. Como o custo era muito alto para uma permanência maior, tínhamos que arranjar uma residência para alugar. Afinal, nossa estada naquelas terras era de um ano. Depois de idas e vindas com o auxílio de pessoas locais, conseguimos arranjar uma casa para habitarmos. 


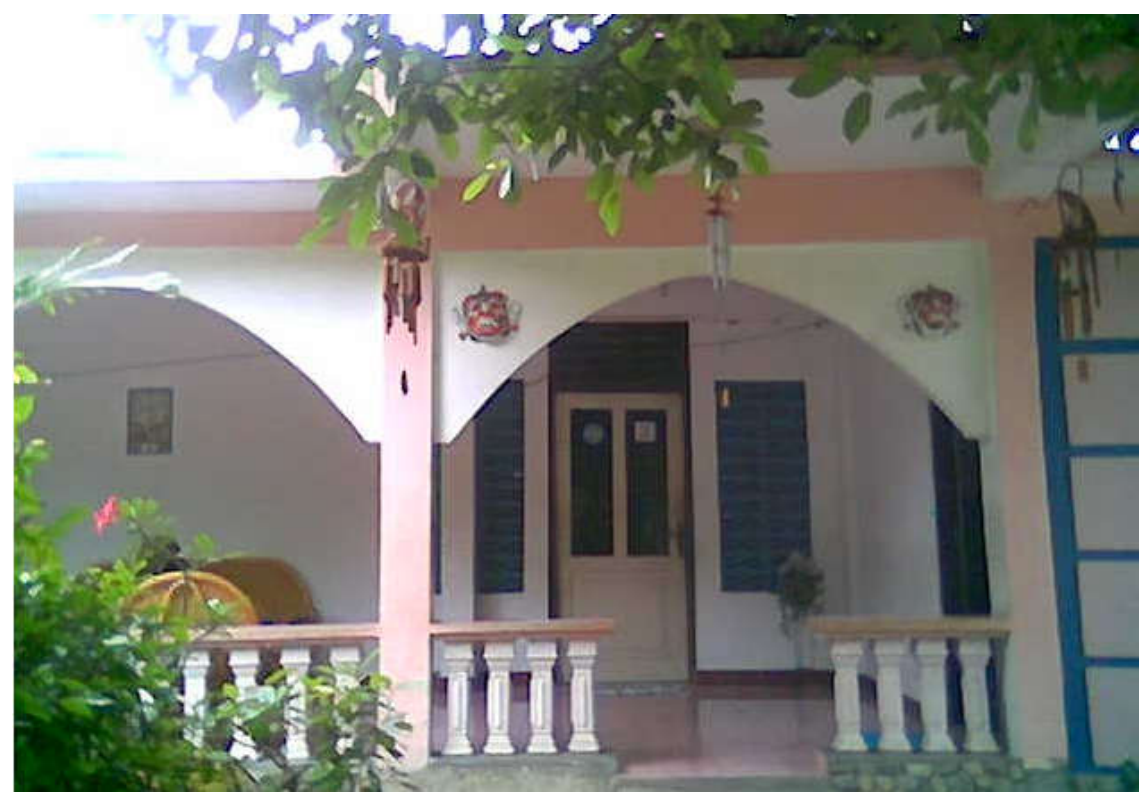

FIGURA 22 - Foto da casa da primeira morada em Bidau Lecidere

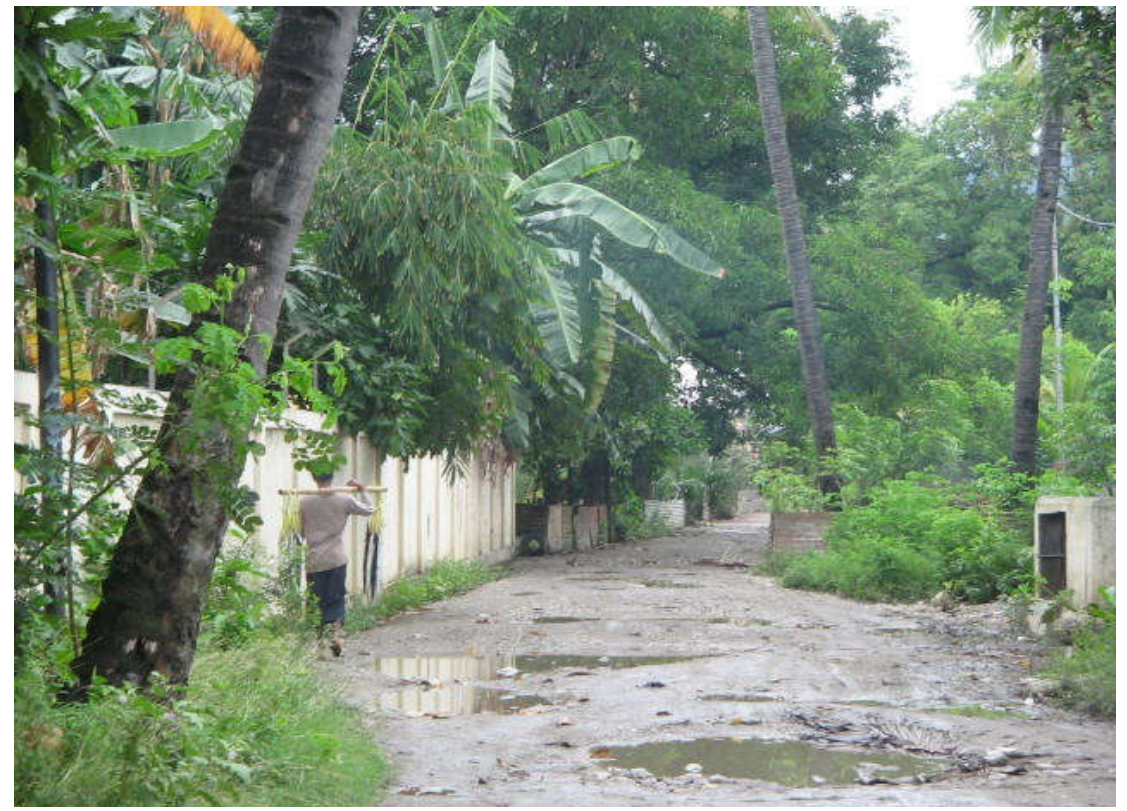

FIGURA 23. Foto da rua no bairro Bidau Lecidere em Díli, onde se localizava a casa alugada inicialmente.

A nova habitação nos foi entregue com móveis e utensílios, mas, um tanto quando suja e em desalinho (Figura 22). Tivemos que fazer uma limpeza intensa. Fui designado para limpar a cozinha. Fiquei assustado com sujeira que tive que limpar. O fogão tinha crostas de séculos de ação, por baixo dos armários e da pia que lá havia, tinham sujeiras do tempo em que Moisés atravessou o Mar Vermelho, mas fazer o que? Arregacei as mangas e fui limpar a sujeira timorense. Constatei que havia sujeiras lá que já tinham se integrado ao piso, às panelas, ao tampo da pia, às paredes, e que não daria jeito, nem escarificando com facas. 
Entreguei os pontos e limpei o possível. Recolhi o quase entulho, coloquei em sacos plásticos e fui levar até o depósito de lixo no início da rua.

A rua também merece descrição especial, tamanha a diferença com que normalmente estamos acostumados (Figura 23) embora tenhamos semelhantes no Brasil. Era totalmente sem pavimento, com crateras que formavam poças d'água da última chuva, de modo que não era possível medir-lhes a profundidade. À tardinha já se fazia quase noite ao chegar ao depósito de lixo. Lá, deparei-me com uma cena tragicômica: tinham cinco garotos timorenses dentro do reservatório de lixo feito de alvenaria, brincado, pulando em performances diversas. Eram garotinhos aparentemente de 6 anos de idade, todos muito sujos, vestindo bermudas mais sujas ainda, cabelos em desalinhos e narizes cheios de fluidos amarelados, rodeados por mosquitos e moscas de todas as espécies. Era um encontro intercultural e ainda para complicar, de gerações diferentes. Precisava jogar o lixo fora, não dava simplesmente para encostar o lixo no lado externo do reservatório, sobre pena de me sentir um boçal. Após certa relutância, paralisei por um tempo analisando o que poderia fazer. A garotada olhava demonstrando certa expectativa, como se esperassem um desfecho de uma atuação em que o ator esquece o papel e tenso diante do silêncio mais profundo, procurava nos cantos mais recônditos da mente, o improviso final. (Na figura 24 pode-se ver o padrão fenotípico da criança timorense).

Não soube o que fazer a não ser dizer um sonoro "boa tarde!" Todos responderam em quase uníssono. Quebrado o gelo pela lacônica interlocução, ainda constrangido, acrescentei mais lixo para a "diversão" deles. Depois que despejei nosso lixo, ainda ouvi de um garotinho o "obrigadu barak!" que em tétum, a língua nacional, quer dizer "muito obrigado". Sei que a circunstância é trágica, mas tive uma imensa vontade de dar gargalhadas daquela situação. Fiz uma alegoria na minha cabeça daquele cenário: vi-me como o "civilizado" branco ocidental, trazendo lixo para os "nativos primitivos" de uma ilhota no fim do Pacífico e ainda recebendo os agradecimentos deles, por isso. Por um breve tempo me senti numa pintura surrealista.

Certamente aquelas crianças já estavam imunizadas pela "civilização" ocidental e de certa forma, já toleravam nossa interveniência. Diante daquilo, comecei a entender o papel que desempenhava ali, um "aculturador", naquela cultura diversificada e plurilinguística. A inocência de crianças brincando ao lixo retratava a dominação que historicamente foi feita nos povos mais diversos. O meu lixo representava um estilo de vida que trazia para o outro, as crianças eram os inocentes colonizados que aceitam as piores coisas e ainda agradecem por elas. Aquele agradecimento ao final representava a subserviência diante da incapacidade de reação, a existência de um reservatório de lixo era o indício de que aquela sociedade já estava 
tomada pela contaminação de um estilo de vida que certamente havia sido importado. Caminhei de volta para a casa, desviando-me das "crateras" alagadas, já no lusco-fusco do crepúsculo refletindo aquele encontro internacional no lixo que haveria de deixar marcas profundas no meu coração.

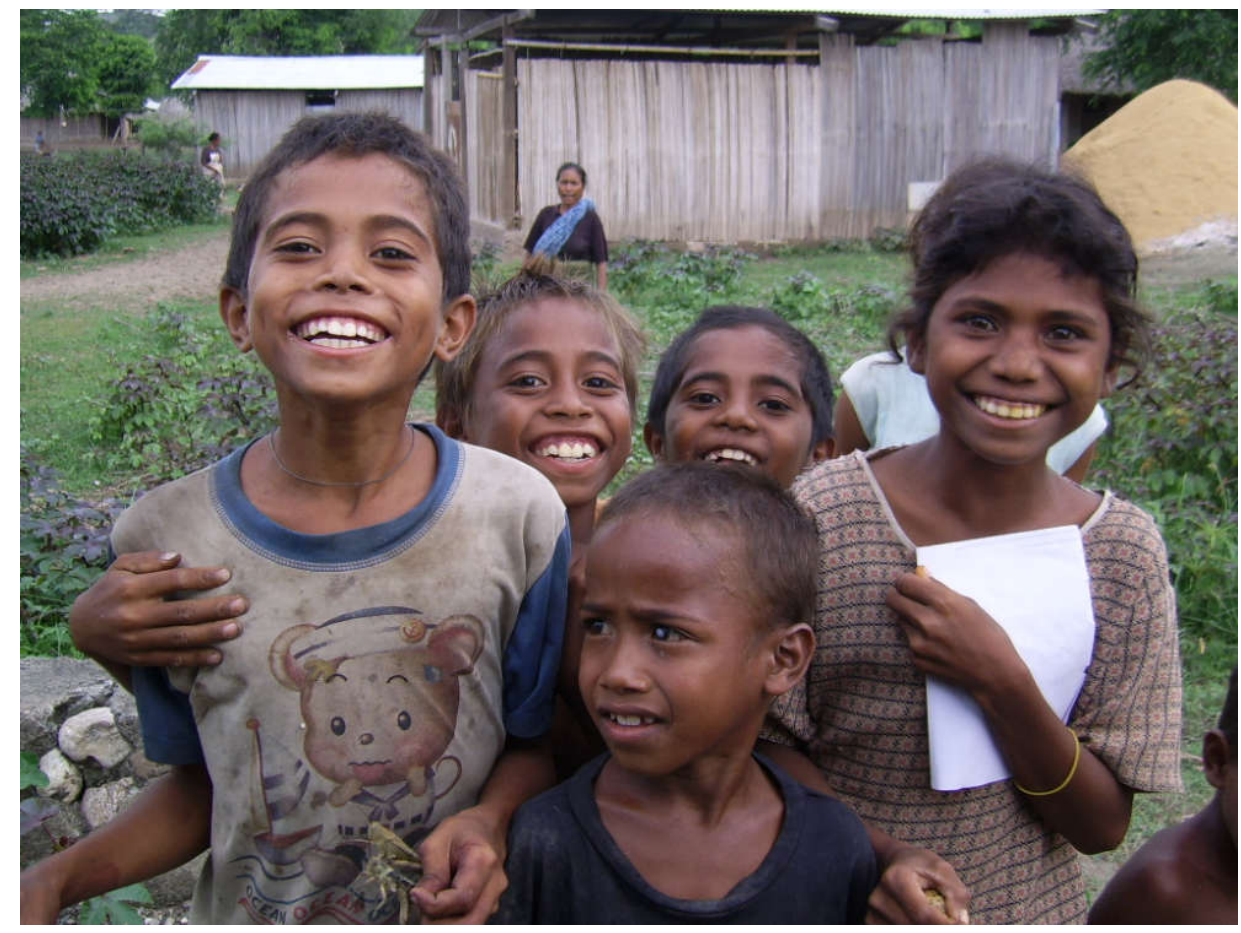

FIGURA 24 - Foto de crianças da periferia de Díli, Timor-Leste

\section{Momentos de tensão}

Díli, 4 de março de 2007

Os primeiros dias em Díli têm sido tensos. Diante do retrospecto da instabilidade que o país viveu, não é de se esperar que já tenham superado as celeumas e vivam em paz. Hoje, domingo 4 de março, fomos acordados às 4 horas da manhã com barulhos de tiros, parecia um foguetório de boas vindas a políticos. Mas eram muitos tiros mesmo. O celular tocou. Era Luciane do PROFORMAÇÃO, para nos avisar do que estava acontecendo. 


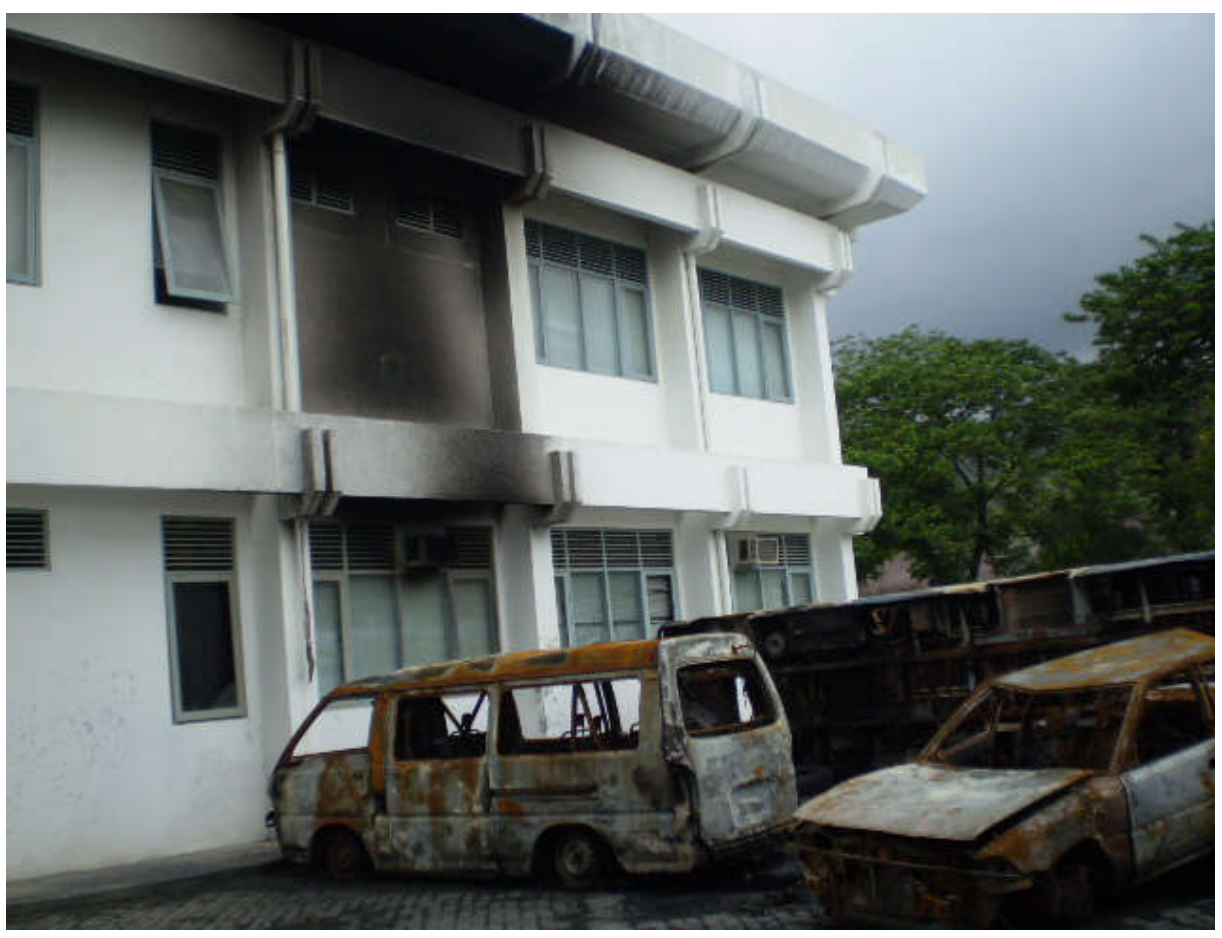

FIGURA 25 - Foto da sala do Ministério da Educação e do estacionamento com alguns carros incendiados

Ficamos todos em alertas, e arrumamos a bagagem de mão, sob a orientação da embaixada. Na manhã, por volta das oito horas, recebemos a visita da coordenadora, que veio trazer as notícias. O que está acontecendo no país, é o seguinte: nesse período eleitoral, estão candidatos a presidente da república, 10 políticos ao todo. Houve um militar das forças do Timor-Leste que tentou se candidatar, mas a sua candidatura foi negada porque esse militar, chamado de Capitão Alfredo, responde a processos no país e lidera amotinados nas montanhas. Diante dessa negativa, o tal capitão, se rebelou e passou a promover atos de instabilidade no país, isso desde novembro de 2006. A última dele foi assaltar as armas dos soldados da fronteira com o Timor-Oeste. Diante desse ato, as tropas australianas, saíram à caça do rebelado, e o sitiou numa montanha, com tanques de guerra e armamento pesado. Diante desse cerco, o Capitão Alfredo, enviou uma mensagem para seus aliados em Díli, promoverem ataques aos órgãos do governo, na tentativa de afastar as tropas do cerco. Então, nessa madrugada, acordamos com o tiroteio dos milicianos que atacaram e incendiaram um depósito (Figura 25), justamente no Ministério da Educação, onde ficavam guardados os livros didáticos e outros materiais escolares. O que ouvimos, não foram tiros de combates, foram tiros para cima dos milicianos de Alfredo, para avisar que estavam armados. A casa que alugamos, fica em área de segurança e é longe do local onde esse incidente ocorreu. Aqui fica 
perto da casa do Bispo e não há notícias de conflitos nessa área, mesmo no período mais cruento da guerra civil. O bairro aqui se chama Bidau Lecidere.

Há um casal de Brasileiros que mora perto do Ministério da Educação, que passou apuros nessa madrugada. Ninguém pôde ir resgatá-los. Ficaram lá na casa deles e testemunharam toda a arruaça. A Embaixada já está com todos os nossos telefones, qualquer coisa vem nos resgatar e enviar a Darwin. Informaram-nos que temos prioridades porque estamos em missão oficial e somos portadores dos passaportes de serviço e nesse deslocamento temos tudo custeado por eles, com diárias para cobrir nossa estadia na Austrália. Salientaram que precisamos estar com uma bagagem mínima numa mochila, para em caso de fuga, sermos rápidos. Fomos orientados a permanecermos em casa hoje.

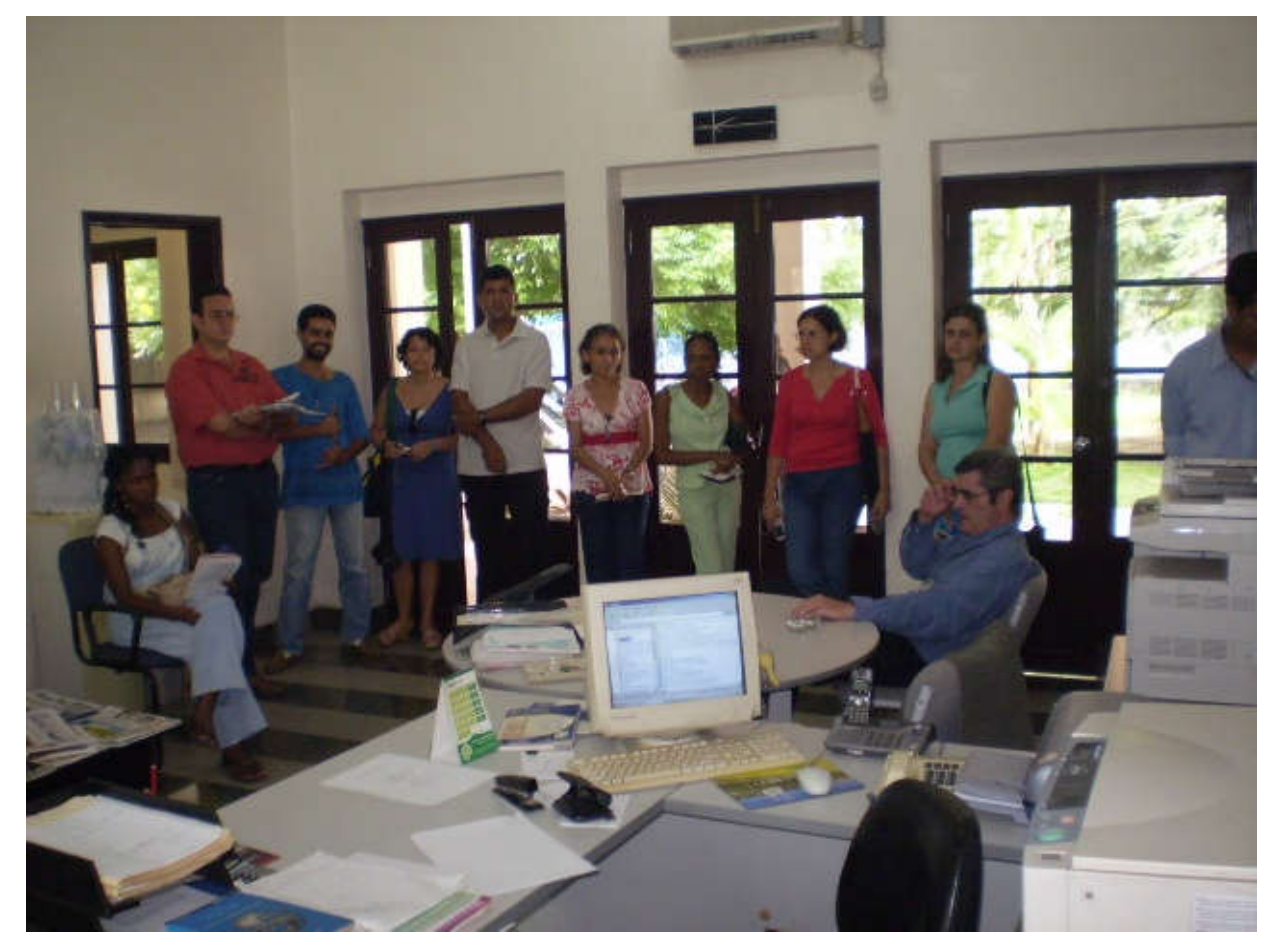

FIGURA 26 - Foto da reunião na Embaixada de Brasil em Díli com o Conselheiro Jairo.

Próximo às 14 horas do dia 5, recebemos uma ligação da Embaixada do Brasil, para que fossemos todos para lá às $15 \mathrm{~h} 30 \mathrm{~min}$. Foi um fuzuê, todo mundo apressado para tomar banho e colocar a roupa "domingueira". Mas no final, todos estavam prontos. Pegamos táxis que nos levou por engano à casa do embaixador, que, diga-se de passagem, é imensa e parece ser bastante confortável e muito maior do que a embaixada propriamente dita. Ao portão, o caseiro informou ao taxista que a embaixada do Brasil ficava ao lado da Embaixada da China. Rumamos para lá, fomos recebido pelo Conselheiro Jairo, que está interinamente como Embaixador, já que o mesmo está de férias no Brasil. O Sr. Jairo parece meio tenso, é um 
senhor carioca que fala muito rápido e fuma como uma caipora acuada, sem trégua para os cigarros. Lá estávamos todos os professores, mais a coordenadora, Suzi e Luciane.

A Embaixada Brasileira é tão pequena (figura 26), que não há lugar para todos sentarem, ficamos em pé, recebendo as instruções do Sr. Jairo. Ele nos deu um leque de telefones importantes, dele e da Embaixada, o telefone do próprio Embaixador, e nos disse que podíamos ligar para ele ou para qualquer daqueles telefones, a qualquer hora do dia ou da noite. Se precisássemos de atendimento médico, ele teria como vir nos pegar para levar-nos até a representação portuguesa que têm médicos que prestam atendimento gratuito aos brasileiros, como um acordo informal, diante dos serviços médicos que o Exército Brasileiro prestou aos portugueses na época que esteve por aqui. Hoje, o Exército Brasileiro já se retirou, mas aqui deve ter ainda uns quatro militares do Brasil a serviço da ONU.

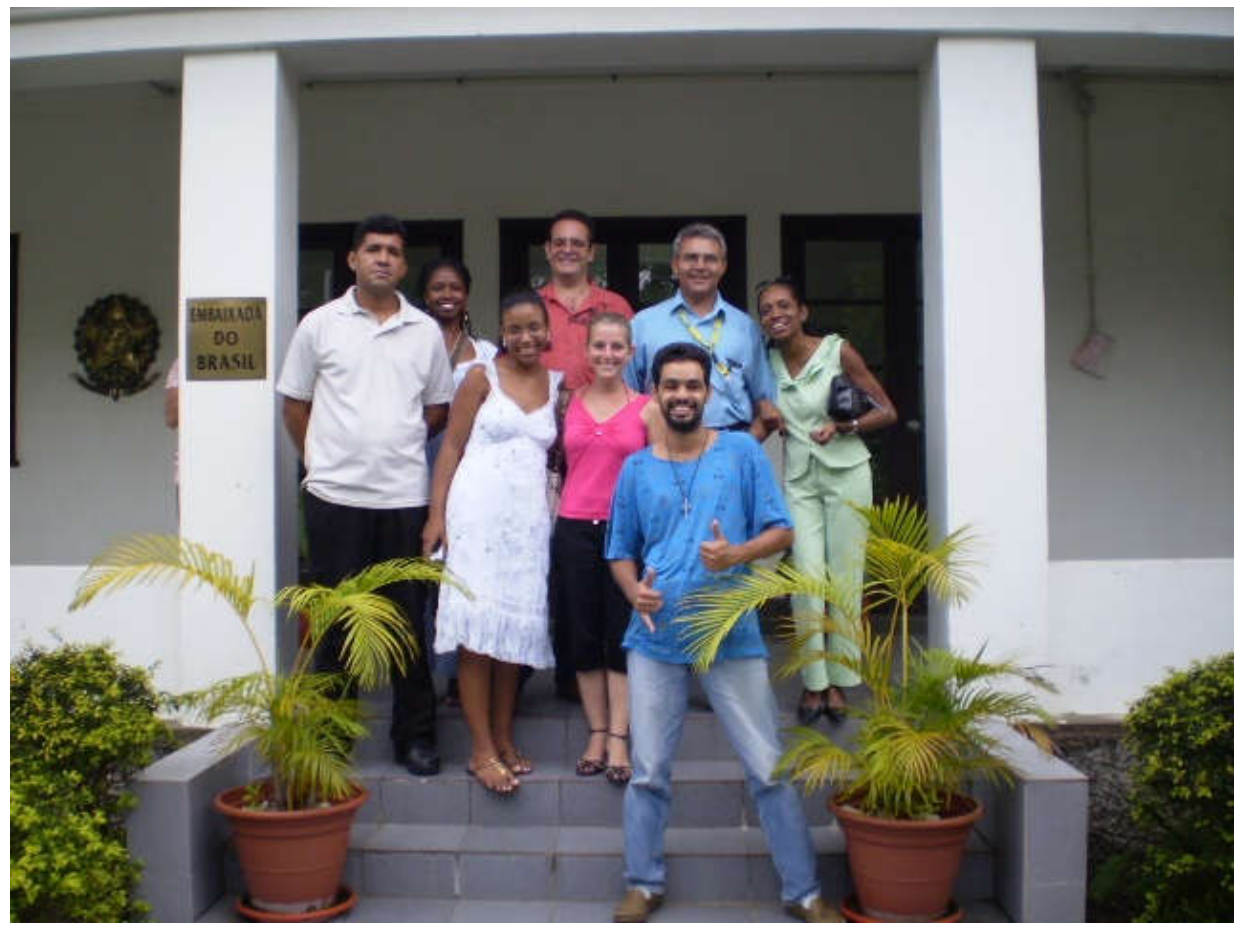

FIGURA 27 - Foto dos professores brasileiros em frente a Embaixada de Brasil em Díli.

Ainda na Embaixada fomos orientados das áreas de riscos e, sobretudo para não sairmos à noite (figura 27). Qualquer incidente grave estaríamos recebendo mensagens nos celulares, que todos temos e que deixamos os números na Embaixada. Relatou-nos sobre os motivos do que está ocorrendo e nos contou que a ONU ordenou a todos os seus funcionários, toque de recolher às 18 horas. $\mathrm{O}$ conselheiro nos disse que o que motivou o incêndio no depósito de materiais didáticos do Ministério da Educação, foi o fato do envolvimento político da Ministra da Educação com a fase política eleitoral que o Timor está vivendo. As 
eleições presidenciais são para dia 8 de abril, o dia depois da páscoa, e como aqui o povo é extremamente católico, há uma simbologia na escolha da data para essas eleições. Segundo o Sr. Jairo, a ministra andou falando à TV do Timor, sobre política ao invés de se ater aos problemas do ministério o que não agradou aos grupos, e passou a receber ameaça de ataques, o que terminou acontecendo. Estamos confinados em casa, devido a ameaças também ao Instituto de Formação de Professores, onde temos a nossa sala de trabalho. Em função dessas ameaças, não acham conveniente que trabalhemos lá. O Instituto está fechado. Lá também funciona um curso de graduação de nível superior, para formação de funcionários públicos, projeto que está na responsabilidade do governo português.

\section{A Lógica do Paradoxo}

Reflexão feita após alguns dias de ambientação em Díli, com seu povo, custo de vida e economia dolarizada. As impressões foram feitas diante do que testemunhei, portanto, sem auxílio de anuários ou dados oficiais.

Aqui no Timor-Leste deparei-me com uma das maiores contradições já vistas por mim na minha curta existência. O povo aqui vive numa pobreza absoluta, pelo menos para o meu

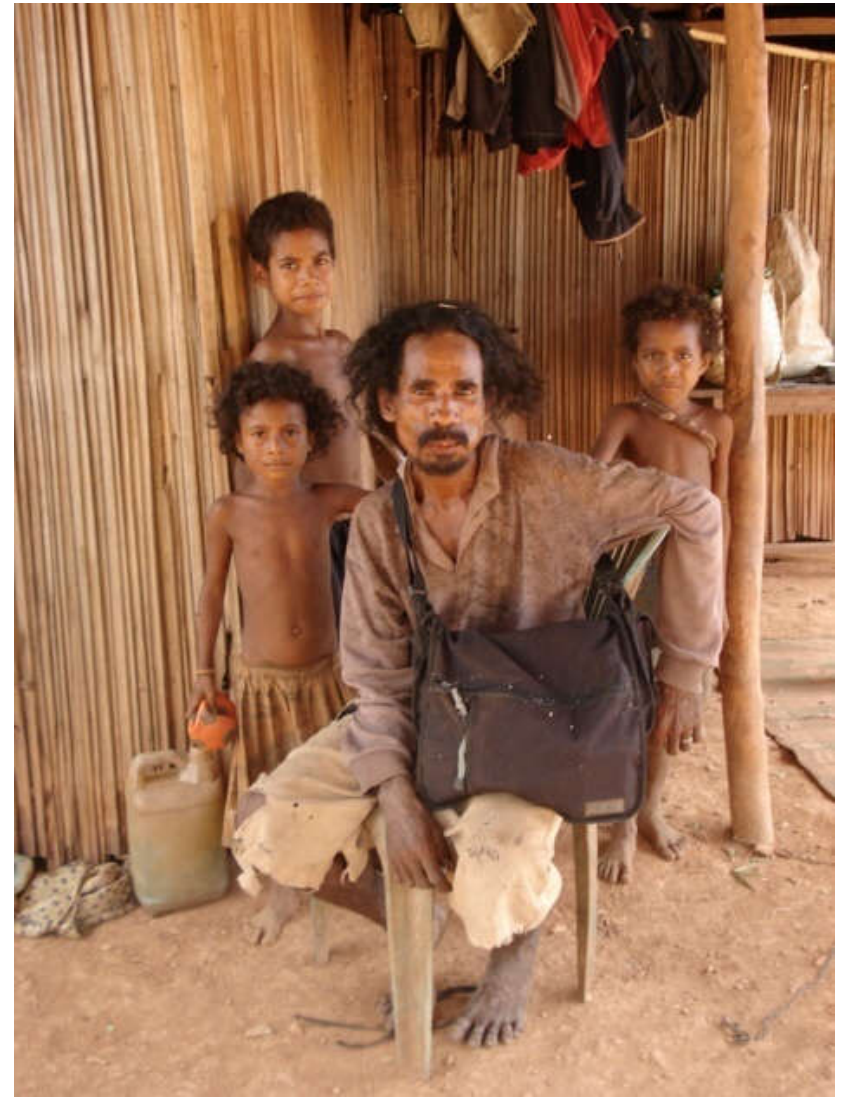

FIGURA 28. Foto de morador típico das montanhas com seus filhos. parâmetro (Figura 28). Ainda não identifiquei de fato a fonte de renda. Nas ruas há legiões de homens jovens e adultos vivendo de vender cartões de recarga telefônicas da Timor Telecom, para ganhar entre 10 a 20 centavos de dólar por cartão, e de outras coisas como frutas e verduras e tudo cotado ao dólar americano. A inflação também é em dólar americano. É um absurdo de se imaginar um país inteiro que adota a moeda de outro e está submetido ao estrangeiro em sua mais simples e aceitável manifestação econômica que é a sua própria moeda.

O grande paradoxo dessa ilha no fim do mundo, um pouco menor que 
o Estado de Sergipe no Brasil, que conquistou o status de país, é a pobreza convivendo com a moeda mais bem aceita do mundo, o dólar. O absurdo de se observar é a "vulgarização" dos custos em dólar. O dólar americano foi adotado pouco depois do plebiscito em que optaram por independência, em torno do ano 2000. Não consigo entender essa lógica de se tornarem independentes e adotarem a moeda de outro povo, e, diga-se de passagem, povo esse, "imperialista" na concepção do próprio timorense. Ao meu modo de ver, acho que essa experiência está fadada ao fracasso total. Não sou analista econômico, nem tenho estudo para tecer esse tipo de consideração, mais o meu entendimento é simples, acho que o Timor-Leste, chegando a uma estabilidade política a custa do trabalho das Nações Unidas e da enormidade de voluntários que aqui chega, vai deixar de ser atraente para esse tipo de trabalho. Como aqui não se produz nada, não tem indústria, não tem nada, a não ser a extração de petróleo a cargo dos australianos e o turismo de mergulho nos bancos de corais, quando deixar de receber o aporte financeiro das legiões de estrangeiros que correram para cá nas suas ONGs com as mais diversas intenções, deixará de receber novos dólares, e a população sucumbirá frente ao pequeno aporte desse dinheiro.

$\mathrm{Na}$ minha cabeça não entra, essa convivência pacífica do dólar com a miséria. É deprimente ver legiões de pessoas, os timorenses, entregues a própria sorte, vendendo bugigangas sem valor, pelas ruas de Díli, pedindo US\$ 10,00, US\$ 20,00 por uma porção de nada. É duro ver meninos vendendo mangas quase estragadas, por US\$ 5,00 uma ou duas, os taxistas com suas roupas sujas e em desalinho total, com seus carros velhos, sujos e sem conforto, cobrando em dólar para levar passageiros a lugar algum.

Como brasileiro convivo em um país cuja moeda, o real, vale em torno de $\mathrm{R} \$ 2,15$ por 1 dólar. Todo preço que vejo aqui, imediatamente estou dobrando na minha cabeça para perceber quanto seria em real. Assusta-me ver as diferenças de preços, sobretudo nos alimentos. Os produtos eletro-eletrônicos são mais baratos, mas nem tanto, quando se converte em reais. Os aluguéis aqui são totalmente desproporcionais. Não se acha casa alguma abaixo de US\$500,00. As melhores podem superar os US\$2.000,00. A casa que alugamos em Díli, no Brasil, acharíamos em qualquer favela por $\mathrm{R} \$ 100,00$. O valor que estamos pagando é de US\$700,00. Por esse valor alugaríamos um bom imóvel em qualquer grande centro brasileiro em lugares dignos. Pode-se até imaginar, como acontece nos países do primeiro mundo, que a valorização de uma moeda, eleva os custos que são compensados pela elevação da renda per capta, então os custos estariam compatíveis com os valores que compões as rendas das pessoas. Mas aqui no Timor-Leste, a renda per capta, é em média de US\$ 300,00, o que dá um ganho mensal de US\$25,00. Esse valor era o que estava pagando 
de diária do hotel, cujo padrão não teria classificação de nenhuma estrela no Brasil. O valor do salário-mínimo aqui é de US\$ 80,00, mesmo assim, as pessoas que ganham isso, são funcionários públicos e funcionários de algumas lojas. O grande contentamento dos professores cursistas daqui, é que com o aperfeiçoamento que estão fazendo com os projetos brasileiros, o governo elevou seus salários para US\$200,00.

\section{Assinatura de acordos na educação}

Díli, 26 de março de 2007

O dia de hoje seguiu-se com sua rotina, porém havia na pauta uma ida às 16 horas ao MEC-Timor para a assinatura do acordo Brasil-Timor, no campo da educação. Fomos convidados pela Embaixada Brasileira e pela Ministra da Educação para essa cerimônia. Já no prédio do Ministério da Educação, fomos conduzidos até o salão de cerimônias que fica no primeiro andar do prédio. A sala encontrava-se carcomida pelo tempo, havia uma grande mesa de reuniões, resultante da união de diversas mesas menores. Em cima da mesa, no lugar destinado à cadeira da ministra, haviam duas bandeirinhas, uma do Brasil e outra do Timor. Ao redor dessa mesa, cadeiras azuis acolchoadas encardidas por anos de uso. Tudo cheirava a cigarro e mofo. No teto apareciam placas de madeira pintadas de branco, como forro e com infiltrações da água das chuvas eternas, manchando de marrom, criando padrões esdrúxulos naquele espaço que certamente era o mais sofisticado ali. Haviam umas vinte cadeiras dispostas em fila além das que estavam em volta da mesa grande. Atrás do pequeno auditório duas mesas com comes e bebes. Em pouco tempo o Conselheiro Jairo, que está substituindo o embaixador ainda de férias no Brasil, chegou distribuindo simpatia. 
Logo a Ministra da Educação, a Senhora Rosália Corte-Real, chegou. Todos levantamos em respeito à presença da ministra. Ela é uma senhora de pele morena, com aparência de seus 60 anos, vestia um vestido bege muito elegante, foi saudada efusivamente pelo conselheiro Jairo e cumprimentou a todos nós com apertos de mãos. Sentou-se no lugar central e chamounos, os professores brasileiros, para sentarmos à mesa. Nos posicionamos ao redor da mesa, com o conselheiro Jairo ao lado direito da ministra e ao esquerdo o vice-ministro. $\mathrm{O}$ chefe de cerimônia iniciou os trabalhos atestando a importância daqueles acordos, um de Pós-

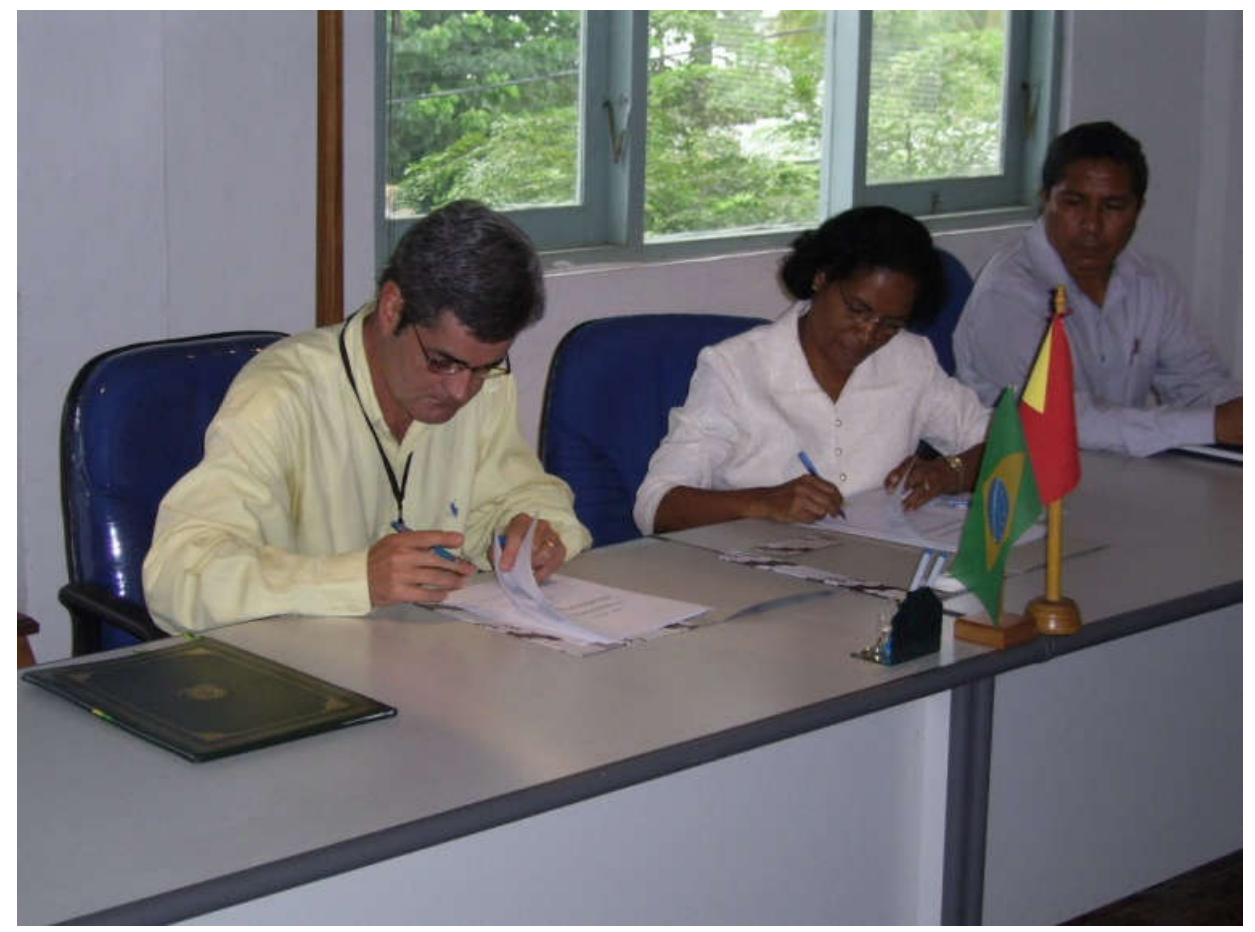

FIGURA 29 - Foto da assinatura de acordos no campo da educação, Brasil-Timor Conselheiro Jário e Ministra da Educação D. Rosália.

Graduação a nível de mestrado, outro de Educação Profissionalizante, um outro de Português Instrumental e o nosso, na Formação de Professores. Logo após a apresentação dos projetos, o chefe de cerimônia, passou a palavra para o Conselheiro Jairo que representava o Embaixador Brasileiro. Este falou da emoção que sentia naquele momento e que em 21 anos de serviço diplomático aquela era a primeira vez que assinava um acordo tão importante como representante do governo brasileiro (Fig. 29). Falou da importância do Timor como nação lusófona e aproveitou para reiterar que a presença brasileira no Timor só terminaria no dia que o Timor-Leste, assim se manifestasse. Falou sobre o fato de Brasil não disponibilizar auxílio financeiro ao Timor, mas disponibilizar material humano de alto-gabarito. Após esse breve discurso, o chefe de cerimônia retomou a condução da assinatura do acordo, e passou a palavra à ministra. 
A Senhora Rosália elogiou o Brasil por sua cooperação e sua disposição no auxílio ao Timor. Falou sobre a importância da língua portuguesa na formação científica do Timor, se manifestou sobre a indisponibilidade do Tétum como língua para a formação educacional, devido a "primitividade" dos seus vocábulos e a inexistência de muitas palavras que são importantes na formação técnica. Nos desejou uma boa estadia no Timor-Leste e reiterou sua simpatia e sua afeição por todos nós, os brasileiros. Após esse curto discurso, procederam as assinaturas na papelada dos acordos. Após, todos aplaudimos a cerimônia e a ministra convidou-nos para um pequeno lanche com o autêntico café timorense.

Hélio José Santos Maia

\section{Relatório Bimestral 1 - PROFEP-Timor}

Relatório de Atividades de Professor Formador da Área de Vida e Natureza no projeto piloto de Formação de Professores em Exercício da Escola Primária de Timor-Leste, referente ao primeiro bimestre de atividades do Módulo III. Díli - Timor-Leste - Agosto de 2007.

PROFESSOR FORMADOR: Hélio José Santos Maia

ÁREA TEMÁTICA: Vida e Natureza

PERÍODO: Primeiro Bimestre - Módulo III

\section{INTRODUÇÃO}

O presente relatório está dividido em duas partes, a primeira, trata dos dados técnicos segundo as orientações da Coordenação do PROFORMAÇÃO-Brasil para a construção do mesmo. A segunda parte compreende um anexo em que são acrescentados memoriais das minhas vivências nas atividades de acompanhamento Fase Presencial e de Encontros Quinzenais do PROFEP- Timor.

\section{EXECUÇÃO DO CALENDÁRIO LETIVO}

a. Comente o desempenho dos professores cursistas em sua área temática. Alguma dificuldade em algum conteúdo específico? Que estratégias de superação dessas dificuldades foram adotadas? Como foi o desempenho dos cursistas nas provas de sua área temática? 
O contato inicial com o professor cursista timorense, lembrou-me em tudo o professor cursista do PROFORMAÇÃO do Brasil. São senhores e senhoras, muitos com certa idade, a maior parte com muitos anos em educação mais sem a formação necessária para o exercício do magistério. Todavia, a grande dificuldade é mesmo a língua portuguesa. Dessa forma, a compreensão total dos conteúdos na área temática de VIDA e NATUREZA, passa pelo entendimento da língua portuguesa. Entretanto, nota-se que entre os conteúdos do primeiro bimestre do Módulo III, ou seja, as Unidades de 1 a 4, tiveram mais dificuldades na parte de genética da Unidade 3. Atribuo á dificuldade de compreender a terminologia própria dos diversos conceitos em genética. Na Fase Presencial, esses conteúdos foram trabalhados, usando-se como recurso uma espécie de "quebra-cabeça" que criamos, onde era possível montar diversas combinações de faces humanas. A partir das combinações montadas pelos cursistas, após discussão sobre as famílias timorenses, seus traços característicos etc., partiuse para as explicações acerca da hereditariedade, dos conceitos de genes, dominância e recessividade, etc. Acompanhando o desempenho dos cursistas na área de Vida de Natureza, no que se refere às notas dos Cadernos de Verificação de Atividades (CVA), observa-se que Vida e Natureza é a segunda área em recuperações dos mesmos, todavia, na Prova Bimestral 1, Vida e Natureza apresentou 17,5\% em recuperações, ou seja, dos 80 cursistas, 14 ficaram para recuperação, sendo 9 em Díli e 5 em Baucau, ocupando a $3^{\text {a }}$ área temática em número de recuperações, ficando abaixo de Matemática e Lógica e Linguagens e Códigos.

b. Como está a atuação do tutor sob sua responsabilidade. (Exemplos: a realização dos Encontros Quinzenais, a incorporação das sugestões dadas pela Agência Formadora, a frequência de visitas à Agência Formadora)? A entrega dos instrumentos de avaliação à Agência Formadora está sendo pontual? Comente sobre a qualidade do preenchimento dos formulários sobre os instrumentos de avaliação? Relate as principais orientações que tens dado ao tutor.

O PROFEP-Timor adotou o sistema de apadrinhamento de tutores, ou seja, cada Professor Formador ficou com a responsabilidade de assistir um tutor e seu grupo de cursistas. Assim, ficou sobre minha responsabilidade o Tutor Eleutério Mendonça da ilha de Ataúro. No grupo de tutores, é o único que não tinha experiência no PROFEP-Timor, entrou no projeto em substituição da Tutora Josefina Guterres da Costa. Nos primeiros dias, leu os manuais de funcionamento do Projeto e sempre estava na AGF tirando dúvidas. No primeiro Encontro Quinzenal, tive a oportunidade e acompanhá-lo à Ataúro, embora, devido às dificuldades de transporte não pudemos realizar as oito horas do encontro (ver anexos). $\mathrm{O}$ tutor Eleutério, apesar de ser novo no projeto, tem boas qualidades para o trabalho, fala bem o 
português, aceita as sugestões e procura aplicá-las. Sobre os seus cursistas, são cinco ao todo: Os senhores Fernando Conceição Soares, Agostinho da Costa, Luis da Cruz Silva, Natalino Cabral e Gil Belmonte Rosales. Percebo que todos eles têm imensas dificuldades em falar português, preciso me esforçar para entendê-los quando me perguntam alguma coisa. De todos eles, o professor Fernando, tem desempenho superior em todas as áreas, os outros têm grandes dificuldades. Porém, percebo pelo esforço e desempenho nos instrumentos de avaliação que têm se dedicado ao trabalho de estudo.

Com relação ao preenchimento dos formulários e entrega dos materiais à AGF, o tutor Eleutério tem se empenhado para fazê-lo, ainda que falhe em alguns momentos, a um simples pedido, cumpre suas tarefas. Teve algumas dificuldades a princípio em entender a dinâmica das recuperações dos CVA em que o cursista só precisa recuperar as questões que perdeu. Em todo caso, o tutor tem correspondido ao compromisso assumido com o projeto. Apesar de não morar na ilha de Ataúro, vai aos encontros quinzenais já na sexta-feira, haja vista que é impossível sair no sábado e chegar a tempo do horário de início do encontro.

\section{Atividades da agência formadora - atuação e monitoramento}

\section{a. Comente sobre a execução das Reuniões Mensais.}

As reuniões que temos feito, enquanto Agência Formadora têm aqui uma freqüência maior do que uma por mês. Após os encontros quinzenais é comum que tenhamos reuniões conduzidas pela Coordenadora, onde nossas observações dos mesmos são compartilhadas e avaliadas, bem como, sugere- se e aponta-se diretrizes a seguir com o intuito de melhorar o desempenho de tutores e cursistas. Nessas reuniões são passados os informes para o período, são discutidas a escala de capacitações que amiúde adotamos fazer com tutores e com cursistas. Vejo como muito importantes essas reuniões, pois possibilitam uma maior integração do grupo, tornando possível sabermos dos trabalhos de cada um.

\section{b. Comente sobre as visitas aos Encontros Quinzenais.}

A equipe do Professores Formadores do PROFEP-Timor permite-nos comparecer a todas as salas em que há encontros quinzenais e ainda uma parte dos professores que estão folgando no encontro, sendo escalados para o próximo. Assim, cada professor observa os encontros alternados.

Em reunião da AGF, decidiu-se que nos encontros quinzenais, o Professor Formador seria apenas observador do trabalho do tutor e dos cursistas, salvo nas revisões para a prova bimestral (PB) em que atua diretamente. Nas observações que tenho feito dos encontros que 
participei nesse primeiro bimestre, pude perceber a postura tradicional do Tutor. Boa parte deles senta-se atrás do birô e dão ordem aos cursista que executam as tarefas, a maior parte das vezes, são tarefas de resolver questões de Matemática e Lógica no quadro-negro. Nos encontros quinzenais, a maior parte do tempo é usada para resolução das questões de CVA, sobretudo o de matemática e lógica da quinzena, as outras áreas quase não são discutidas e quando o fazem, é de modo superficial e limitam-se a ler o que escreveram nas respostas. Em poucos momentos discutem plano de aula, memorial, prática pedagogia ou projeto de trabalho. A partir dessas observações iniciais, sentiu-se a necessidade de intensificar as capacitações dos tutores no que se refere a planejamento, memorial, projeto de trabalho, prática pedagógica, bem como capacitações nas áreas temáticas de Matemática e Lógica, Linguagens e Códigos e Vida e Natureza. Não obstante o esforço da AGF nas capacitações rotineiras dos tutores, não notei nos encontros subseqüentes, nenhum resultado substancial de mudanças nos encontros quinzenais dos tutores que visitei. Alguns passaram a trazer o plano do encontro quinzenal, como agenda das tarefas a serem cumpridas, porém, não há execução da mesma, continuam trabalhando apenas com resolução de CVA.

\section{c. Comente sobre as visitas a Prática Pedagógica.}

Diante da emergência nas adaptações dos Guias do PROFORMAÇÃO do Brasil para a realidade do Timor, não realizamos nenhuma visita à Prática Pedagógica dos Professores Cursistas.

\section{d. Avalie sua atuação como professor formador na Agência Formadora no que se refere a sua participação nas atividades de acompanhamento do trabalho do tutor e do desempenho dos cursistas.}

As atividades rotineiras na AGF consistem em adaptações e formatações dos guias do módulo III, discussões a cerca dos trabalhos nos encontros quinzenais, oficinas rotineiras de capacitações de Tutores e de cursistas, observação direta da correção dos instrumentos de avaliação feitas pelo Tutor, controle do preenchimento das fichas do tutor e lançamento dos dados dos cursistas na Ficha de Acompanhamento de Desempenho do Professor Cursista. Procuro desempenhar minhas atividades atento a todos os prazos agendados pela coordenação, seguindo as determinações acertadas tendo em vista o melhor andamento dos trabalhos coletivos e aqueles sobre minha responsabilidade, sendo cooperativo com todos. Procuro observar as dificuldades dos cursistas na área de Vida e Natureza através dos resultados dos CVAs, para melhor elaborar os exercícios de reforço tendo em vista a Prova Bimestral. 


\section{Atividades de adaptação do material}

a. Comente como foi o processo de adaptação do material em sua área temática. Relate sobre os conteúdos, o processo de pesquisa, as dificuldades encontradas, seu grau de satisfação com a qualidade do resultado do trabalho, a participação do professor timorense nesse processo de adaptação do material.

O processo de adaptação dos guias do PROFORMAÇÃO à realidade do Timor toma boa parte do tempo, além de estarmos atentos à correção das informações dos guias de estudo, ainda temos que adaptar as informações para o Timor-Leste. A equipe anterior do PROFEPTimor, trabalhou na formatação e adaptação dos guias do Módulo I, Módulo II e até a Unidade 4 do Módulo III, com exceção de Vida e Natureza que teve sua adaptação e formatação feita até a Unidade 3 do Módulo III. Assim, meu trabalho de formação começou pela Unidade 4 do referido módulo e se estendeu pelo restante, compartilhando o trabalho com Professora Fernanda também da área de Vida e Natureza. Os trabalhos nessa atividade de formatação e adaptação têm sido muito prazerosos, sobretudo pela participação do Professor Formador timorense. A área de Vida e Natureza, no início do Módulo III, contou com a colaboração do professor Antônio Saldanha. Todavia, em função da falta de professores timorenses para outras áreas, posteriormente, passou a fazer parte do grupo, a professora timorense Maria da Costa, licenciada em Biologia, que passou a ser a colaboradora de Vida e Natureza, passando o professor Antônio Saldanha para a cooperação em outra área. Os aspectos nacionais do Timor-Leste abordados nos guias, contou com a imensa colaboração dos professores timorenses, seja nas informações sobre cultura e tradições, quer na facilidade de pesquisas em órgãos públicos em Díli.

\section{TRABALHO EM CONJUNTO ENTRE BRASILEIROS E TIMORENSES}

a. Comente sobre o seu processo de aperfeiçoamento em sua área temática a partir da experiência de trabalho com o professor timorense. De que forma esse trabalho tem contribuído para sua formação? Comente sobre fatos e/ou conteúdos específicos que provocaram uma reflexão sobre sua área temática.

A interação com os professores timorenses enriquece minha experiência na área de Vida e Natureza grandemente. Tendo em vista que minha participação como Professor Formador e Multiplicador no PROFORMAÇÃO pelo Estado da Bahia no Brasil colocou-me em contado com uma realidade ainda desconhecida por mim, a do professor leigo no Brasil, 
suas dificuldades e suas lacunas em termos de conhecimento, pude perceber essas mesmas dificuldades e suas implicações aqui com o professor timorense, e cheguei à conclusão de que as deficiências na formação profissional, passam pelos mesmos caminhos e soluções, seja no Brasil, seja no Timor-Leste, demonstrando os valores universais da educação e da formação profissional. O contato direto com o professor timorense, o formador e, sobretudo os professores cursistas, dão como retorno à minha formação profissional, elementos culturais de um outro povo e seus diversos "modos" de fazer e desenvolver o conhecimento.

\section{b. Comente sobre o processo de desenvolvimento do professor timorense de sua área temática.}

Apesar das estruturas tradicionais que ainda noto na forma de exercer o magistério do professor timorense, percebo a mudança gradual do mesmo, para métodos mais modernos de educar, demonstrando com isso, a utilidade factível do PROFEP, pois aos poucos noto a operacionalização dos conceitos e conteúdos do PROFEP no dia-a-dia profissional dos professores timorenses, denotando a mudança de comportamento como sendo o primeiro indicativo da aprendizagem. Apesar da precariedade dos recursos didáticos, no que foi possível, elaboramos materiais utilizando-se sucata e materiais alternativos e é prazeroso perceber o interesse do cursista em aprender a confeccionar os materiais para utilizar com seus alunos. Um pequeno exemplo na área de Vida e Natureza foi a confecção de uma bússola utilizando-se fundo de garrafa e tampa de água mineral e uma simples agulha de costura. A simplicidade da montagem e a eficiência dos resultados obtidos foram importantes para salientar ao cursista, que às vezes não são necessárias coisas caras ou inacessíveis como recursos didáticos, que poderíamos observar os materiais que temos no nosso entorno e que certamente de lá poderíamos dispor de muitos deles como recursos didáticos.

c. Quais as estratégias que o grupo de sua área temática tem utilizado para o aperfeiçoamento de todos. Realizaram grupos de estudo, troca de bibliografia, discussões sobre estratégias metodológicas?

Temos realizado oficinas de reforço na área para aprofundar e aprimorar os conteúdos das unidades trabalhadas na Fase Presencial.

\section{SUGESTÕES}

a. Comente de que forma a sua atuação como professor formador poderia ser melhorada. 
Penso que o grande trabalho de formatação e adaptação dos guias de estudo consome quase todo nosso tempo e com isso, diante da emergência e da pressa que isso representa, embora seja crucial e fundamental para o projeto, não nos deixa com muito tempo para pensar em outras coisas, por exemplo, elaborar atividades e textos suplementares para reforço de conteúdo, sugestões de prática pedagógica, etc. Assim, acho que com a finalização das atividades de formatação e adaptação dos guias, pode-se partir para essas atividades suplementares.

\section{b. Comente como as atividades da Agência Formadora poderiam ser aperfeiçoadas.}

Ver letra "c".

\section{c. De que forma a implementação do projeto poderia ser aperfeiçoada?}

$\mathrm{O}$ aperfeiçoamento de qualquer atividade ou projeto se faz ao caminhar e penso que todas as contribuições de todos e da coordenação da AGF, já têm aperfeiçoado o Projeto. Como por exemplo, a capacitação continuada em pequenas oficinas semanais das diversas áreas que realizamos para os professores cursistas. Embora o projeto PROFORMAÇÃO, não

previsse esse tipo de atividade, restringindo-a a Fase Presencial e aos Encontros Quinzenais, o PROFEP, por iniciativa da coordenação, adotou as oficinas das áreas que apresentam mais dificuldades com a periodicidade semanal. Assim, o Professor Formador, além do tempo usado na fase presencial, intensifica um maior contato com o cursista também nesses encontros rotineiros, permitindo uma observação mais próxima das dificuldades dos professores cursistas, adotando estratégias de ensino que possibilitem a superação dessas dificuldades.

\section{COMENTÁRIOS FINAIS}

Este relatório apresentado nestes itens indicados pela Coordenação do PROFORMAÇÃO do Brasil, não abriu muito espaço para uma maior literalidade das minhas impressões. Dessa forma como anexo, acrescento memoriais das minhas observações e vivências no PROFEP-Timor, embora sua leitura não tenha nenhuma pretensão de ordem técnica, sendo dispensável até, penso ser válida como manifestação individual do que tenho vivido na minha rotina no Projeto.

Hélio Maia 


\section{Anexos - Relatório Bimestral - PROFEP-Timor}

\section{Introdução}

Neste anexo são apresentadas impressões e memoriais sobre as atividades desenvolvidas em um bimestre de trabalho como Professor Formador da Área Temática de Vida e Natureza. Embora esses dados estejam sendo encaminhados agora, a presente memória foi construída gradualmente no período correspondente ao relato. Em função de problemas de ordem pessoal, que não vêm ao caso nomeá-los aqui, mas que podem ser relatados à parte assim se deseje, houve o atraso no envio do mesmo. Aqui, nesta parte do relatório, procurei construir um texto no mesmo modelo dos memoriais do PROFORMAÇÃO. Relatos dos encontros quinzenais que participei, encontram- se no final desse anexo.

\section{PRIMEIRAS IMPRESSÕES}

Embora a chegada da Missão Brasileira para o PROFEP - Timor (Programa de Formação de Professores para o Ensino Primário de Timor- Leste), tenha ocorrido no dia 26 de fevereiro de 2007, os trabalhos iniciaram apenas no dia 28 de fevereiro. A Agência Formadora do PROFEP, localiza-se numa das salas do prédio do Centro Nacional de Formação de Professores, ex- CNRT.

Nosso primeiro encontro no Instituto se deu com as dirigentes do PROFOMAÇÃO do Brasil, Suzi e Luciane, Wanda, nossa coordenadora, o grupo dos 12 professores, e mais 4 professores formadores timorenses. Nesse primeiro encontro, o projeto do PROFORMAÇÃO, projeto brasileiro do qual participei no Brasil no Estado da Bahia, que pauta o PROFEP, começou a ser apresentado aos professores. Tivemos o dia de apresentações das dinâmicas do PROFORMAÇÃO adotados e adaptados pelo PROFEP.

Em decorrência das reservas que foram feitas no hotel onde inicialmente ficamos hospedados, terem prazo até o dia 2 de março, fomos autorizados a procuramos casa para alugar e fazer nossa mudança. Assim foi feito e mudamos para uma casa em Bidau Lecidere, no dia 2 de março.

$\mathrm{Na}$ madrugada do domingo, dia 4 de março, houve um incidente no MEC-Timor. Fomos acordados por muitos tiros e soubemos na manhã que uma sala que servia de depósito de material didático, havia sido deliberadamente destruída por um incêndio provocado por manifestantes. Diante do clima de insegurança que se instalou nos dias que se seguiram, fomos orientados pela coordenadora Wanda, que deveríamos permanecer em casa, porque as 
ruas onde funciona o Instituto, estavam tomadas de barricadas, de pneus queimados e pedras. Como estávamos na fase de estudarmos os módulos do PROFORMAÇÃO já modificados para a realidade do Timor, para podermos reescrever os outros módulos que ainda faltam, nos dedicamos a essa tarefa.

Na segunda-feira dia 5 de março de 2007, fomos chamados à Embaixada do Brasil. Lá estávamos todos os professores, mais a coordenadora, Suzi e Luciane. A Embaixada Brasileira é tão pequena, que não há lugar para todos sentarem, ficamos em pé, recebendo as instruções do Sr. Jairo. Ele nos deu um leque de telefones importantes, dele e da Embaixada, o telefone do próprio Embaixador, e nos disse que podíamos ligar para ele ou para qualquer daqueles telefones, a qualquer hora do dia ou da noite.

Ainda lá na Embaixada fomos orientados das áreas de riscos e, sobretudo para não sairmos à noite. E que qualquer incidente grave estaríamos recebendo mensagens nos celulares. Relatou-nos sobre os motivos do que está ocorrendo e nos contou que a ONU inclusive instruiu a todos os seus funcionários, toque de recolher às 18 horas.

Já na terça-feira, dia 6 de março, perto das 10 horas, Luciane e Suzi chegaram à casa que estávamos morando, no carro da Embaixada do Brasil, trazendo um computador do PROFEP-Timor, para que todos trabalhássemos no "confinamento" da casa, trouxeram também o material para esse trabalho.

Na manhã do dia 8 de março, a coordenadora Wanda nos ligou e disse que poderíamos ir trabalhar lá no Centro de Formação de Professores e assim o fizemos. De fato, do lado onde fica o Instituto, podia-se ver a marca dos incêndios de pneus nas ruas. Mas, as coisas voltaram ao normal. Trabalhamos até o meio-dia, ainda na fase de conhecimento da dinâmica de todo o projeto.

No dia 9 de março, fomos orientados a apresentarmos os tickets das passagens aéreas da nossa vinda ao Timor-Leste, pois, Suzi e Luciane, voltariam para o Brasil e teriam que levar esses tickets para a prestação de contas junto a CAPES.

A coordenadora Wanda, falou-nos ainda na ocasião, que a Fase Presencial do projeto, se dividiria em dois lugares, Díli e Baucau e em função do que já tinha se verificado nas primeiras fases presenciais, seria realizada em duas etapas, cada uma de 5 dias. Na primeira etapa se trabalharia as Unidades de 1 a 4, realizar-se-ia a Prova Bimestral 1 e posteriormente, após a PB1, se faria a segunda etapa da fase presencial com o restante das unidades. Diante da minha familiaridade com o projeto, a coordenadora me encarregou de abri essa primeira fase presencial do Módulo III em Díli e ela iria a Baucau. 
Os dias que se seguiram, a rotina consistiu na leitura do material didático e no estudo dos manuais do PROFORMAÇÃO. Parte do material do Módulo III, que se iniciaria com a Fase Presencial, já havia sido adaptada e formatada pela equipe anterior do PROFEP. Todo material tinha sido trabalhado até a Unidade 4, com exceção de Vida e Natureza que ainda faltava ser adaptada e formatada a Unidade 4. Dessa forma, minhas atividades nos dias que se seguiram, consistiram nesse trabalho no planejamento da Fase Presencial.

No dia 15 de março tivemos nosso primeiro contato com os Tutores de Díli e Baucau. Em uma das salas todos reunidos, Wanda fez uma introdução sobre a continuidade do projeto, muitos já nem achavam que o PROFEP-Timor teria continuidade, devido todos os problemas enfrentados pela turma anterior diante da crise de 2006. Na agenda da reunião com os Tutores, realizou-se à tarde com os mesmos, uma oficina de Matemática de Lógica, conduzida pelos professores formadores da área. Os demais continuamos no planejamento da Fase Presencial. Tivemos dificuldades nesse planejamento em função dos recursos didáticos escassos no Timor. Na área de Vida e Natureza, tivemos que usar a criatividade para criar materiais alternativos.

\section{Memorial da Fase Presencial - 1 - Módulo III}

No dia 19 de março, iniciou-se a Fase Presencial do Módulo III. Com a maioria dos cursistas já presente, iniciamos com um café da manhã. Quando terminamos, fomos para a sala onde se daria a abertura. De início, a abertura se deu com as palavras de Dona Manuela Gusmão, diretora do ex-CNRT, que se dirigiu a todos com carinho, apresentou a importância do PROFEP para todos e deu as boas vindas. Após o encerramento das palavras da diretora, assumi a condução dos trabalhos e, utilizando projetor multimídia, comecei a reapresentar o projeto a eles, seguindo a orientação de Wanda. Situei cada área temática, incluindo os eixos temáticos, os instrumentos de avaliação, a prática pedagógica, o memorial e o encontro quinzenal. Enfatizei a importância da formação deles como profissionais de educação. Após um intervalo para o lanche, continuei os trabalhos e compartilhei o restante do tempo com a professora Jacirema que fez uma apresentação sobre o Projeto de Trabalho. Retomei a apresentação e encerrei ao meio-dia segundo o horário previsto.

Em Díli, há 42 professores cursistas que foram divididos em duas turmas de 21 (Figura 30). À tarde, a professora formadora de Linguagens e Códigos entrou na turma A, e o professor formador de Matemática e Lógica entrou na turma B. Conduzi a oficina de Vida e Natureza a partir da tarde da terça-feira, dia 20 de março. Às 13:20 h, fui para sala de aula, 
para trabalhar 4 horas seguidas, os guias 1 e o 2, para a turma “A”. Os cursistas lembram-me, os professores leigos que encontramos no Brasil no PROFORMAÇÃO, são senhoras e senhores de meia idade, a maioria mulheres, já trabalham há muito tempo como professores. Fiz um apanhado geral do Módulo I, comecei falando bem calmamente, chamando à lembrança os conteúdos do módulo I, localizando o que haviam trabalhado em Vida e Natureza. Fui aos poucos falando de ambiente Terra, os componentes do espaço físico, a identificação da Atmosfera, hidrosfera e Litosfera, e fizemos terrários e finalizamos o dia fazendo uma bússola caseira com fundo de garrafas plásticas, agulhas e tampinhas de garrafas. Eles ficaram admirados com aquilo, fomos no guia 2, identificar os diversos ambientes da Terra, e muito me emocionou, poder está falando para aqueles senhores, sobre a Ásia deles, coisas que ainda não sabiam, como o cinturão de fogo, como havia se formado o Himalaia, a origem das ilhas indonésias, o vulcanismo no Pacífico, e me espantava vê-los totalmente desconhecedores dessas questões geográficas. Foi com muita honra que passei esses conhecimentos a todos, ainda mais porque são asiáticos que me deram o prazer de ensiná-los sobre os assuntos deles. Finalizamos nosso encontro já próximo das 17:30 h.

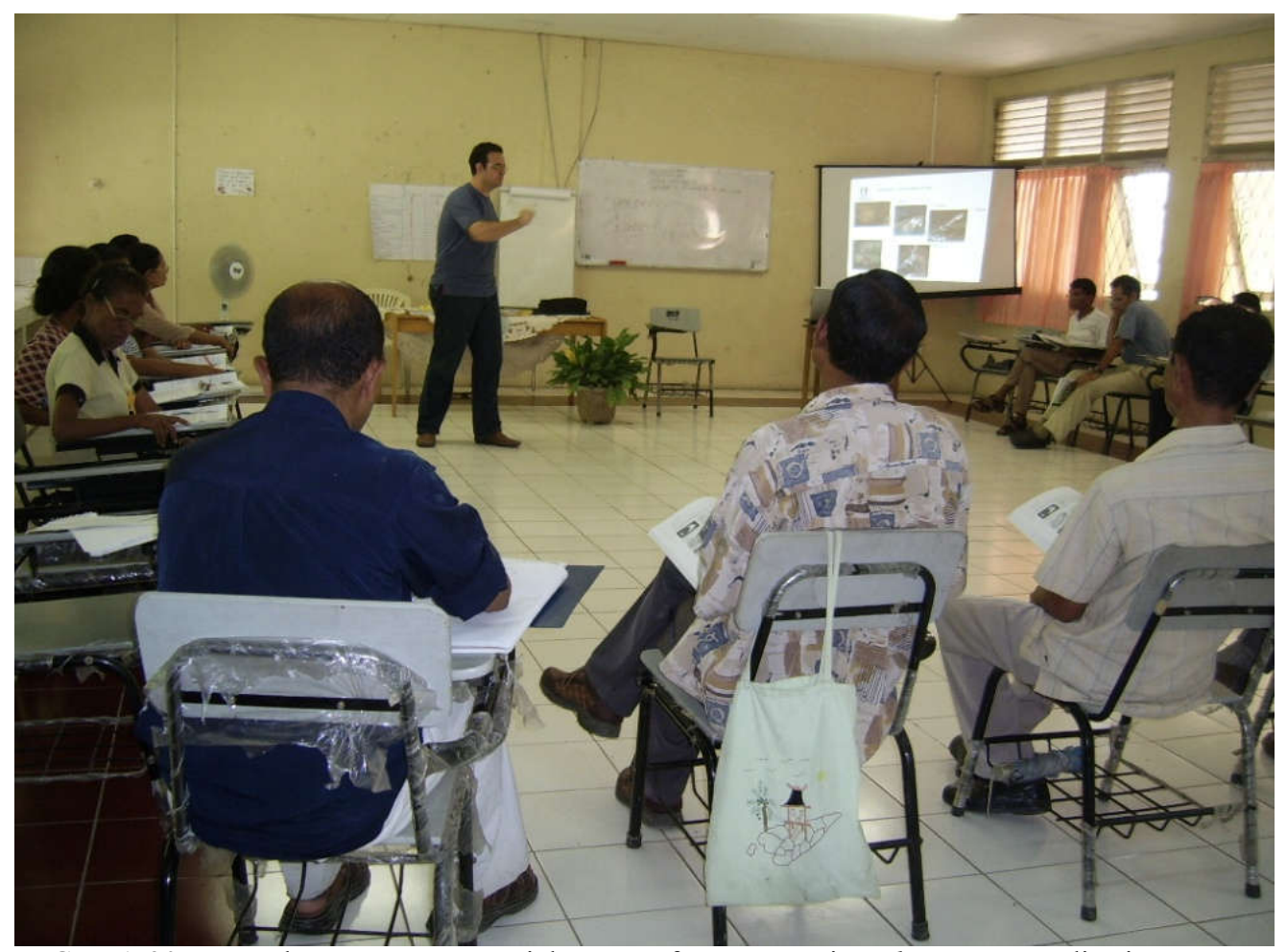

FIGURA 30 - Foto de encontro presencial com professores cursistas lorosae em Díli, Timor-Leste

Na manhã da quarta-feira, dia 21, fui para sala de aula que já havia trabalhado no dia anterior, e continuei com os guias 3 e 4. Tudo transcorreu em paz, me demorei mais em 
genética, tiveram dificuldade de entender os conceitos dos elementos que têm nos guias sobre mendelismo básico. Fiz o melhor que pude para esclarecer tudo. Todavia, acho que não conseguiram compreender todos os conceitos, não obstante termos discutido sobre os traços marcantes nas famílias timorenses. Encerrei com essa turma. Na tarde do mesmo dia, dei início aos trabalhos com a Turma B e realizei as mesmas dinâmicas da turma anterior, encerrando os trabalhos no horário previsto. Na turma B continuei a trabalhar por toda a manhã da quinta-feira, encerrando a oficina com a gratificante sensação de tarefa cumprida. As atividades da Fase Presencial se prolongaram até o sábado dia 24 de março, quando os Professores Cursistas fizeram a avaliação.

Na segunda-feira seguinte, dia 26 de março, um mês de nossa chegada, nos reunimos na AGF para nossa avaliação da Fase Presencial. Cada um falou das suas impressões, pontos positivos, pontos a melhorar e sugestões. Na minha avaliação, a grande dificuldade é mesmo a língua portuguesa. Embora se diga que todos conhecem o português, a mim não pareceu assim. Durante minhas oficinas, tive sempre o cuidado de certificar-me se estavam compreendendo o que estava dizendo e tive que colocar muitos dos termos em glossário no quadro. Outra dificuldade deveu-se a escassez de recursos para que as apresentações se tornassem menos expositivas. Como ponto positivo a mencionar, salientei o pouco desgaste em função das turmas serem apenas duas, aproveitando para mencionar a realidade que encarava no Brasil com o PROFORMAÇÃO de trabalhar em fase presencial com mais de seis turmas e cada uma com cerca de 40 cursistas.

Nos dias que se seguiram posterior à Fase Presencial, continuou-se trabalhado na formatação e adaptação dos últimos guias do módulo III. Pelo calendário do módulo III o primeiro encontro quinzenal seria dia 14 de abril. A coordenadora Wanda fez a distribuição dos Professores Formadores para a visita ao Encontro Quinzenal e diante de uma mudança de Tutor dos cursistas da Ilha de Ataúro, designou-me para participar desse encontro. (Ver final deste Anexo).

Nos dias que se sucederam após o nosso primeiro Encontro Quinzenal, os trabalhos de formatação continuaram nos guias. Foi feita a avaliação desse encontro pelos professores formadores em reunião na AGF e pude perceber que as dificuldades que observamos eram as mesmas para todos os tutores. A maioria ainda adota um estilo tradicional.

Ainda nesse período, adotamos o sistema de "apadrinhamento" aos tutores e fiquei com a responsabilidade de orientar e acompanhar o Sr. Eleutério, o tutor que acompanhei ao primeiro encontro quinzenal em Ataúro. Como ele é novo no projeto, haja vista que está substituindo a tutora anterior, tive que sentar-me com ele e explicar-lhe toda a dinâmica de 
funcionamento do PROFEP, juntamente com todas as atividades que estariam sobre sua responsabilidade.

Entre as decisões que se tomou nesse período, depois das primeiras impressões do encontro quinzenal inicial, salientou-se a necessidade de capacitações para os Tutores no que se refere a planejamento, práticas pedagógicas e memoriais, além de capacitações nas áreas temáticas com maior dificuldade.

Nossa dinâmica adotada de acompanhamento aos encontros quinzenais nos coloca em visitas a encontros alternados, de modo que o próximo encontro, dia 5 de maio, fui escalado para o sub-distrito Vemasse do distrito de Baucau (Ver no final deste anexo as memórias desse encontro), para acompanhar o encontro do tutor Francisco Cabral.

Na segunda-feira imediata, dia 7 de maio, atendendo a um convite do MEC-Timor, fui trabalhar no MEC na revisão dos Exames Nacionais nas áreas de Biologia e Química e pude perceber o nível elevado dos conteúdos dessas áreas adotadas como currículo do que eles chamam ensino secundário.

No dia 10 de maio, quinta-feira, durante a manhã na AGF, fizemos uma reunião para apresentar os relatos do encontro quinzenal acontecido no sábado passado. Levamos toda a manhã. Novamente, percebo a concordância que todos temos com relação às opiniões a respeito dos tutores. Todos são tradicionais nas suas posturas e nas suas conduções dos encontros quinzenais. Discutimos sobre a necessidade de capacitações na área de Organização do Trabalho Pedagógicos para os Tutores.

$\mathrm{Na}$ segunda quinzena de maio, além das formatações e adaptações dos guias que procedemos, começamos a planejar a segunda Fase Presencial. Desta vez, minha escala seria Baucau. Ainda nesse período, elaborou-se a PB1 e o exercício para essa prova. O acertado em reunião é que se faria as revisões pautadas no exercício que havia sido entregue aos cursistas no encontro quinzenal anterior, no sábado de encontro do dia 19 de maio. Em reunião, a coordenadora conversou comigo sobre minha possibilidade de fazer a revisão de todas as áreas no sub-distrito de Vemasse no encontro do dia 19, aceitei sem problemas. Durante toda a semana, participei das oficinas de Matemática e Lógica do Professore Sidnei para dar-me segurança na revisão (Ver anexo - Memória do Encontro Quinzenal do dia 19 de maio de 2007).

Todas as informações e impressões que se seguiram após esse encontro de revisão está no final deste anexo, como Memorial da Segunda Fase Presencial do Módulo III. 


\section{Memorial da Visita ao $1^{\circ}$ Encontro Quinzenal - PROFEP-Timor, à ilha de Ataúro - Timor-Leste - 14 de abril de 2007}

Desde o dia anterior (13 de abril, sexta-feira) que projetamos a nossa ida à Ataúro. Combinei com o Professor Francisco, formador timorense, e com o Professor Eleutério Mendonça, o novo tutor, que sairíamos na sexta-feira pela manhã, todavia, após uma longa espera no cais por um barco que nos levasse a Ataúro, desistimos ao meio-dia. Teríamos que embarcar no Nakroma no próprio sábado.

O sábado amanheceu ensolarado e depois de muito esperar o carregamento de dois caminhões de arroz no Nakroma, embarcamos às 10:30 h. Desembarcamos em Ataúro por volta de meio-dia, o encontro com os cursistas estava comprometido. O trabalho que era para ser feito em 8 horas, agora só restava menos de 3 horas. A ilha é muito bonita. Há praias muito limpas. Existem várias vilas em Ataúro, nosso trabalho seria em Beloi, local do atracadouro do Nakroma. Deve-se andar cerca de 100 metros para se chegar à escola. Já na rampa do atracadouro nos encontramos com os cursistas, os senhores Luis, Natalino, Fernando, Agostinho e Gil. Fomos até a escola, deixamos nossas coisas lá e voltamos até a praia para o almoço.

O lugar do almoço era uma palhoça tosca. Havia umas mesas de madeira, o chão na areia e mais recuado, o que seria a "cozinha", um cercadinho onde se via panelas encarvoadas em cima da lenha em brasa, algumas mulheres em desalinho a cozinhar, misturadas com crianças a se emborralharem no chão.

$\mathrm{O}$ almoço consistiu num pratinho de arroz sem tempero algum e um peixinho assado nas cinzas, de tão empoeirado que estava, cheio de espinhas. Para arrematar, foi servido uma jarra de água quente com gosto de fumaça e plástico. Como disse o professor Francisco, "comemos como guerreiros" e fomos à sala de aula, não havia muito tempo.

O trabalho do seu Eleutério não deu para ser observado direito. Quase não havia tempo para nada. Todavia, demonstrou que tinha preparado um planejamento. Realizou as tarefas de praxe, coletou os CVAs, o memorial, distribuiu os outros CVAs da Unidade II, e começou a falar de projeto de pesquisa. Surgiram algumas dúvidas do seu Fernando com relação aos termos "Amenizar, silício e diurnas". Seu Fernando dirigiu essas perguntas a mim. Todavia, seu Eliutério ouviu e prontamente escreveu no quadro os três termos. Começou a dar os significados, escreveu os termos e o conceito de "ameniza"r e "diurnas". Deixou anotado no quadro, enquanto se dirigiu a mim e pediu discretamente o significado de silício. Eu prontamente expliquei o que era, ele foi ao quadro-negro e anotou o termo. Continuou o 
trabalho sobre o projeto de pesquisa e anunciou que todos deveriam aprontar este trabalho para o dia 21 de maio. Escreveu a temática do projeto, “A História do Timor-Leste”, sugeriu outros temas: "A Escola", "A História de Ataúro", etc.

O tutor sugeriu passos a seguir no projeto: História, Tradições, Costumes e Fatos (fez um pequeno diagrama no quadro-negro, constando a definição do tema do projeto de trabalho, pediu um exemplo de um tema ao Sr. Gil, que disse que falaria de LosPalos e começou a narrar um costume do dote, chamado aqui de "barlaque" para casamento que ainda perdura.

Depois de alguns outros exemplos dos outros cursistas, seu Eliutério distribuiu um material impresso dos slides usados na apresentação do PROFEP e fez novos esclarecimentos sobre o termo "Cooperar" e chamou os professores cursistas à cooperação para o bom andamento dos trabalhos. Pediu ao professor Luis para ler sobre o ponto "Cooperar e competências da prática pedagógica”. Logo após, o tutor esclareceu sobre os tópicos das competências da prática pedagógica.

Seguiu-se o trabalho com um chamado ao memorial, e estimulou os cursistas a falarem sobre o memorial de cada um naquela quinzena, dessa forma cada um dos cursistas relatou fatos que estavam nos memoriais. Após essas explanações, seu Eliutério entrou nos planos de aulas. Anotou no quadro um plano de aula hipotético, e pude perceber a falta de entendimento deste, do que afinal deve ser um plano de aula. Entre outras falhas, o exemplo usado, não parecia fazer sentido objetivos com o conteúdo, os procedimentos com o material a ser usado. Acho que o trabalho nas capacitações sobre planejamento deve continuar e cobrar deles, os tutores, atividades práticas e individuais na construção de planos coerentes e passíveis de serem executados. Ainda aqui nessa parte, os cursistas fizeram uma queixa da falta de livros guias e do currículo para seguir com os alunos. Seu Fernando disse que no Módulo I, chegou a trabalhar com os conteúdos de matemática que estavam no guia do PROFEP, e que a mesma coisa está fazendo com o material de Vida e Natureza do Módulo III, mas os outros conteúdos das outras áreas não são possíveis de serem tratados. Aproveitou para mencionar, que a tutora anterior, coletava os planos que faziam, mas nunca os acompanhou numa prática pedagógica. Embora fizessem planos de aulas, eles não eram observados pela tutora na Prática Pedagógica.

Seu Eleutério mencionou que a partir da próxima semana, estaria visitando os cursistas nessa prática. Com relação ao conteúdo dos guias, não foi possível discuti-los, embora as dúvidas tenham sido colocadas por Seu Fernando no início do encontro e se restringiu aos significados das palavras mencionadas. Todavia, não foi possível tratar mais nada, o NAKROMA já apitava insistentemente e as pessoas com suas bagagens, "malas e cuias" 
desciam para a embarcação. Encerramos, seu Natalino fez uma oração e saímos todos ao NAKROMA. As 16:10 partimos de Ataúro.

Nas minhas reflexões sobre o trabalho do tutor, penso que ainda precisa melhorar muito. Sei que o tempo não permitiu o seu Eliutério executar o seu plano de trabalho. Mas, do que observei sobre sua explanação do projeto de pesquisa, há ainda falta de entendimento sobre o assunto. A capacitação sobre o projeto tem que ser mais prática. $\mathrm{Na}$ exemplificação sobre como deverá ser a capa do projeto, o tutor colocou a referência bibliográfica como sendo um elemento da capa e ainda explicou de maneira equivocada.

O professor tutor demonstra muita insegurança, embora seja humilde o suficiente para falar a todos que as dúvidas que não souber resolver, encaminhará à Agência Formadora, aos professores formadores e depois as esclarecerá a todos.

Seu Eleutério está consciente de que deve estar em Ataúro bem antes do sábado do encontro quinzenal, demonstrou preocupação com sua impossibilidade deste sábado do primeiro encontro, o infortúnio da falta de barco, não ter permitido executar o trabalho como teria que ser. Penso que é necessário a presença do formador observando a prática do tutor no encontro quinzenal, acho que deve ser observada todo o período de trabalho do dia, mas para isso, faz-se necessário o deslocamento a ilha, ainda na sexta-feira. Assim, deve-se chegar ao cais, próximo ao Palácio do Governo, no máximo às 6h30min da manhã, há pequenas embarcações que saem neste horário, todavia, pelo que observei da travessia no NAKROMA, em mar alto a situação das marolas repetidas e das ondulações maiores, não deve ser nada agradável para o viajante nesses barquinhos. Recomendo também, levar água e comida para passar o dia. Aos que não conseguem comer em situações precárias e de sofrível higiene, é bom está precavido para deparar-se com o fato.

Hélio Maia

\section{Memória do Encontro Quinzenal do dia 5 de maio de 2007 - PROFEP- Timor-Leste}

O dia começou madrugada literalmente. Fui escalado para a visita ao Encontro Quinzenal do Tutor Francisco Cabral em Vemasse, sub-distrito de Baucau. O acerto foi estar na porta Hotel Turismo às 5 horas da manhã. Coloquei o celular para despertar às 4:30h, mas nem precisou despertar, apesar de ter ido dormir cedo, quase não o fiz. Fiquei na expectativa, 
até sonhei que me atrasava para a saída e acordei assustado às 2:30h da madrugada, voltei a dormir e as 4:25h, já estava acordado. Tomei o banho e como o "mata-bicho" (termo usado para café da manhã em Timor) do hotel só inicia às 7 horas, tive que fazer um café solúvel no quarto, sobre a pena de ter dor de cabeça no fim do dia. Assim, como foi apenas café que tomei, ainda continuei com o "bicho-vivo" na barriga. Todavia, na escuridão das 4:55h estava na porta do Hotel Turismo e não demorou 5 minutos, o motorista contratado para essa viagem, seu Rui, já chegava com Helen a bordo. Rumamos para a casa de Ana e Sidnei em Bidau Lecideri, os encontramos na porta, seguimos então para o "Obrigadu Barak" onde pegamos dona Maria da Costa. Assim, continuamos a viagem ainda na escuridão da madrugada.

A estrada para Baucau é estreita e a beira de um precipício. Segundo o cônsul Jairo, é a melhor estrada do país e foi construída pelos japoneses ainda na Segunda Guerra Mundial quando os japoneses dominaram o Timor-Leste por quatro anos. Como estava tudo escuro, não deu para ver bem, mas a estrada vai bordejando e subindo o entorno das montanhas. De um lado o paredão da imensa montanha, do outro, a escarpa do precipício que dá para o Pacífico. Vez por outra a estrada desce ao nível do mar, outras vezes sobe a montanha, dobra a esquerda e dobra a direita, curvas fechadas e precipícios. Ainda na escuridão e em uma localidade chamada Erreira, encontramos um bloqueio na estrada do exército australiano, muitos soldados armados, mas que liberou nosso carro prontamente. Prosseguimos ainda na escuridão, pela estrada sinuosa. Por fim, já as 6:30h o sol, embora ainda não tivesse dado o ar da graça, já clareava o mundo de cá. Bem próximo às 7 horas pude vê-lo surgir no extremo do oceano como uma hóstia vermelha ainda pálida se anunciando para um dia limpo.

Já dia claro, pude observar melhor a estrada escarpada, assustadoramente estreita e perigosa. Passamos por algumas localidades como Manatuto, que logo ficou para trás, e se segue com a estrada agora por entre plantações de arroz em tabuleiros alagados separados uns dos outros por muretas de pedras e areia. Vê-se ao longo da estrada algumas manadas de búfalos. Depois de umas 2 horas de viagem chegamos ao meu ponto. Sou o primeiro professor a ficar e serei o último no retorno. Desci numa localidade chamada Vemasse em frente à Escola Primária Pública 01 Tabi Vemasse (Figura 31). Muito cedo ainda, fui recebido pela professora cursista Dona Angelina da Costa, os outros formadores seguiram viagem com seu Rui, o motorista. Eu fiquei com o material a ser entregue ao tutor, para os cursistas. 


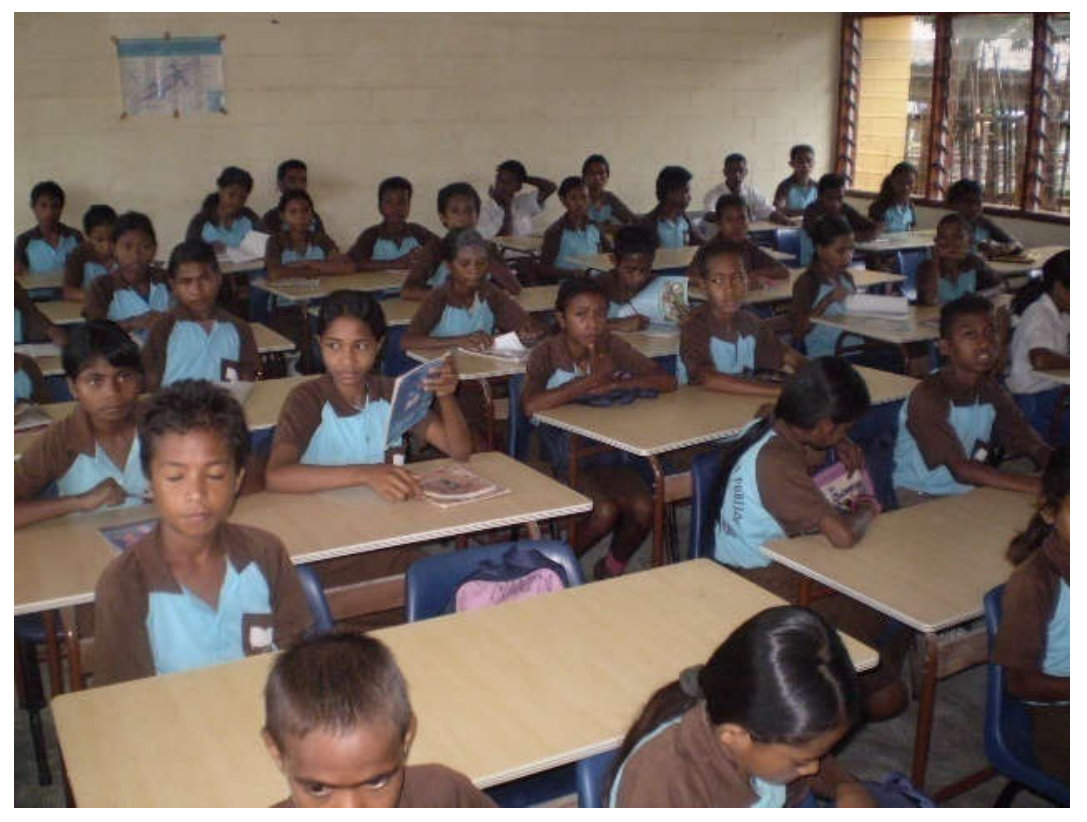

FIGURA 31 - Foto de alunos em escola primária do distrito de Vemasse - Timor-Leste

A cursista Dona Angelina, levou-me até a Direção da escola e me apresentou ao Sr. Diretor. Fiquei sentado num cantinho esperando e comecei a escrever. Ao todo são 5 cursistas, as senhoras Angelina da Costa, Ermelinda Correia e Felizarda Nolasco Correia e os senhores Antônio Soares Freitas e Domingos de Sá Freitas. Às 8:15h o professor tutor, o senhor Francisco Cabral chegou. O entreguei os materiais como o CVA da unidade IV, a lista de frequência dos professores cursistas, o envelope com o dinheiro para pagar o lanche e o almoço e os exercícios da revisão para a Prova Bimestral 1. Falei a ele das mudanças no calendário sobre a data da PB1. Por fim fomos para sala de aula, nos instalamos e o tutor, Seu Francisco Cabral, começou o encontro às 8:20h. Pediu desculpas a todos por causa do atraso em decorrência do transporte. Sentou-se por trás do birô, apresentou a agenda do dia. Leu em voz baixa dizendo cada coisa e em que hora ocorreria. Permaneceu sentado durante todo o tempo. Dessa forma recolheu os CVAs, os memoriais e anunciou que entraria nas oficinas de projeto de trabalho, todavia continuou falando (em voz baixa e sem clareza, pouco eu entendia) sobre o aproveitamento dos cursistas nos CVAs e frisou as dificuldades de todos em Matemática e Lógica. Diante disso, o tutor determinou que a sala se organizasse em dois grupos e designou seções do guia de Matemática e Lógica para que cada grupo trabalhasse os exercícios. A postura do tutor se mantém tradicional. Continuou sentado atrás do birô e mantém a voz muito baixa, dando ordem aos cursistas. Para falar mais rápido, eles falam em tétum. Não há dinamismo na sala de aula. Embora não estivesse entendendo muito bem o que o tutor falava, pareceu que em determinado ponto estava tratando de plano de aula e 
"orientava" o professor cursista para a utilização do tempo no plano. Depois de longo tempo, o tutor chamou o cursista Sr. Domingos no quadro para responder uma questão do CVA de Matemática e Lógica sobre raio e perímetro. Determinou que o senhor Domingos desenhasse a circunferência no quadro. O senhor domingos expôs os cálculos de área e de circunferência de maneira clara. D. Felizarda foi chamada ao quadro a seguir, para responder uma questão sobre o perímetro de um retângulo. A cursista calculou a área do retângulo ao invés do perímetro. O Sr. Domingos esclareceu que o perímetro era a soma de todos os lados do retângulo, a cursista refez os cálculos e o tutor nada mencionou. Pelo que pude observar, o uso das fórmulas não é acompanhada do entendimento dos conceitos. Eles não conseguem visualizar concretamente coisas tão simples como essas e o tutor em nenhum momento ajuda nisso. Os cursistas aprendem o uso das fórmulas, mas não raciocinam no entendimento dos porquês das fórmulas. Não há visualização concreta, por exemplo, do entendimento de um retângulo.

O tutor foi ajudar e confundiu ainda mais, pois mandou a cursista fazer algo louco que não entendi o que era. Depois dessa mistura, finalizou dizendo que "agora é que estava certo", embora o seu Domingos tenha dito que o perímetro era a soma de todos os lados. Fiquei sem saber o que fazer, querendo interferir, mas, tive receio de tirar a autoridade do tutor, haja vista a sua postura de "todo poderoso". Apesar da discordância do Sr. Domingos, o tutor o fez ir ao quadro e anotar valores totalmente errados. Permaneceu no birô dando informações erradas e sem sentido.

Chegou à merenda e fomos a ela. Uns rolinhos de farinha de uma palmeira com coco queimado dentro e uns bolinhos semelhantes a "sonhos". Para mim foi o "mata-bicho", definitivamente "matei o bicho". Depois do lanche, prosseguimos o encontro quinzenal. O tutor chamou agora dona Ermelinda Correia, esta foi ao quadro resolver outra questão de área de quadrado, triângulo e retângulo. O tutor não facilita as coisas. Faz o cursista ir ao quadro e fica dando ordem a partir do seu birô, sem facilitar ou auxiliar o cursista através de uma demonstração ele mesmo. Depois de muita ordem, o tutor disse assim: "Agora se viu o projeto de trabalho na área de Matemática e Lógica" e completou dizendo, "Se viu que a matemática não está bem!”. Falou que dia 17 vai ser entregue o projeto de pesquisa. Continuou o tempo todo sentado e falando baixinho. Não entendi o que quis dizer.

O tutor apenas tratou do projeto falando da data de entrega. Prosseguiu dizendo que iria corrigir Linguagens e Códigos. Pediu ao Senhor Antônio Soares para ler a primeira questão do CVA da Unidade 2 e pediu para os outros cursistas fossem dizendo se as alternativas eram verdadeiras ou falsas. Terminada a correção de Linguagens e Códigos, 
passou para Vida e Natureza. Dona Angelina fez a leitura e todos responderam. Assim se procedeu às correções das outras áreas temáticas restantes, Fundamentos da Educação, Organização do Trabalho Pedagógico. Após a leitura das questões e a apresentação das respostas, sem reflexões ou discussões, chegamos às 12 horas e fomos para o almoço, ali mesmo na sala.

Garotinhas miudinhas trouxeram pratos e as bandejas com as comidas. Arroz, carne de galinha, salada de agrião ou de algo que o valha, e pepino, temperada com alho, cebola e óleo, flor de mamão amarga para danar. Tão amarga que a professora dona Felomena, ao perceber minha cara de poucos amigos na degustação da flor de mamão se aproximou e me questionou sobre se estava gostando ou não da flor de mamoeiro daquela forma. Disse-lhe gentilmente que não estava acostumado com o amargor do sabor. A senhora professora se apressou em explicar que apesar do sabor desagradável, era aquilo que garantia a pequena mortalidade por malária do povo maubere há oito mil anos na ilha do Timor. Tinha também um refogado de berinjela e bananas. No geral a comida estava boa, ainda bem que a pimenta veio à parte. Comi ali, sentado entre os timorenses, isolado do mundo num calor monstruoso.

Às $12 \mathrm{~h} 40 \mathrm{~min}$, retornamos os trabalhos. O tutor entrou na sala de aula e se postou atrás do birô novamente e começou a ler em silêncio alguma coisa e assim ficou por longo tempo, enquanto os cursistas em silêncio ficaram esperando. Depois de um tempo o tutor expressou que daria continuidade as oficinas das áreas temáticas, estou tentando entender onde ocorreu a primeira parte da oficina, pois até então a única coisa que houve foi a correção do CVA, lembrando que os CVAs de Vida e Natureza, Linguagens e Códigos, Organização do Trabalho Pedagógico e Fundamentos da Educação, foram lidos as pressas apenas, somente o de matemática levou quase a manhã inteira.

O tutor perguntou se havia alguma dúvida em algum guia e o Sr. Antônio Soares aproveitou para colocar como tendo dúvida sobre Vida e Natureza, sobre plâncton, nécton e bêncton. O tutor pediu minha ajuda, dizendo ele que não entendia o guia. Fui ao quadro, salientando que embora a AGF não recomendasse nossa interferência, havia a necessidade dos esclarecimentos sobre os equívocos do guia a esse respeito. Depois que prestei os esclarecimentos e voltei ao meu posto de observação, o tutor colocou-se na impossibilidade de "dominar" todas as áreas. Continuou lá sentado, falando muito baixo. Chamou a atenção novamente para o plano de aula, citou os componentes de um plano e se deteve no tópico "tempo", como já tinha feito antes. Salientou ainda que tudo deveria estar escrito no plano. Depois começou a falar do ponto "avaliação" de um plano e disse que ela era importante para o professor saber até que ponto os alunos haviam compreendido a matéria dada. Depois de 
citar pela segunda vez os componentes do plano da aula, disse que quem tivesse dúvidas sobre plano que se expressasse. Todos fizeram silêncio profundo.

O Sr. Antônio Soares falou sabiamente sobre a dificuldade da língua, e disse que as crianças do Timor-Leste não nascem para a língua portuguesa, desde pequenas os pais só falam suas línguas maternas e elas, aprendem a pensar e a ver tudo com a língua dos pais. Então os professores, que também têm dificuldades com a língua portuguesa, têm que trabalhar dobrado para fazer a tradução de tudo para as línguas das crianças e ainda arranjar um jeito de fazê-las pensar em português, pois fazer a tradução apenas da língua, não adiantava muito, pois as crianças quando voltam para suas casas vão continuar ouvindo a família falar suas línguas e não treinam o português.

Depois dessa colocação de Seu Antônio, o tutor, sem aproveitar o assunto para alimentar uma discussão mais ampla, simplesmente foi chamando os cursistas para o recebimento do material de CVA e os exercícios para a PB1. Os cursistas constataram a desordem nos CVAs. Dos 5 CVAs, apenas dois estavam corretos. Os outros três estavam com as páginas impressas erradas, como uma parte de Vida e Natureza impressa na folha atrás da capa, e coisas mais loucas possíveis, além de ter faltado a primeira parte de Fundamentos da Educação. Ficaram sem saber o que fazer. Eu os orientei para que pegassem os que estavam certos e orientassem suas páginas e copiassem depois à parte de Fundamentos de Educação que havia faltado e que iria dizer isso na AGF para que orientasse a gráfica na impressão dos CVAs.

Depois dessas orientações, a merenda da tarde chegou e ficamos comendo e jogando conversa fora por um certo tempo. Voltamos ao encontro. O tutor chamou a avaliação do encontro e cada um dos cursistas se colocou a respeito de como tinha sido o encontro naquele dia. O Sr. Antônio Soares se queixou de que nos CVAs, as questões pessoais aparecem com muitas linhas e eles não têm fonte alguma de pesquisa que possam estudar e construir as ideias e que isso era um problema para ele. Essa opinião foi corroborada por todos. Por fim, após a fala do Tutor, fiz minha avaliação gentil do encontro. Encerramos, todos de pé rezando como de costume.

Já passava das 15h30min, quando saímos caminhado rumo a casa de seu Domingos que fica na beira da estrada. Lá chegando, uma garotinha trouxe duas cadeiras e eu e seu Francisco Cabral, nos assentamos na sombra de uma árvore na beira da estrada esperando nossos transportes, ele para Baucau e eu para Díli. Em pouco tempo apareceu um caminhão ele se foi. Seu Domingos me fez companhia, falando do tempo da resistência em que foi preso e ainda viveu no mato. 
Estava atento aos carros que apontavam na estrada e vi na hora que o nosso carro apontou ao longe, todavia só pararam porque eu acenei e fiz estardalhaço, iam passando direto por mim. Subi no carro e me assentei atrás. Sidnei me ofereceu água que estavam numa caixa térmica e foi muito bom beber água pela primeira vez naquele dia, embora tenha tomado chá nas merendas e o almoço um copo de água com gosto de fumaça e plástico. Voltamos pelas estradas sinuosas. O perigo a cada curva e o susto a cada subida e decida, e lá voltamos. A paisagem muito bonita beirando o precipício nas falésias do Pacífico, horas pela serra íngreme, horas fitando o mar, assim fomos. Passamos por algumas vilas e em Manatuto as meninas, Helen e Ana Maria quiseram comprar mel e seu Rui parou num "mercado" onde se via de tudo um pouquinho a venda, as coisas meio em desalinho, compraram duas garrafinhas de mel por um dólar as duas e seguimos viagem. No geral a viagem foi tranqüila, chagamos cedo em Díli, perto das $18 \mathrm{~h} 30 \mathrm{~min}$, estava no Hotel Turismo. Despedi-me de todos e disse que eu não era o pé frio, pois até agora, de todas as viagens que foram feitas a Baucau, a primeira sem incidentes foi essa.

\section{Balanço Geral do Encontro}

\section{Pontos positivos do encontro}

- O acompanhamento de todo o encontro.

- A integração dos cursistas.

\section{Pontos a melhorar}

- Maior dinamismo do cursista.

- Atenção ao planejamento.

- Postura tradicional do Tutor.

Hélio Maia

\section{Memória do Encontro Quinzenal do dia 19 de maio de 2007 - PROFEP- Timor-Leste}

Baucau, 19 de maio de 2007, sábado

Conforme o combinado desde a fase presencial anterior, essa semana em que ocorreria a segunda fase presencial do módulo III, fui escalado para ir a Baucau. Passaria a semana. Wanda preparou o seguinte esquema para irmos a Baucau: eu fico em Vemasse, embora não volte para Díli, Nelson fica em Baucau e vai voltar ainda hoje para Díli para retornar a Baucau na quinta-feira, dia em que retornarei para Díli. Às 5 da manhã estávamos na porta do Hotel Turismo esperando o carro para irmos a Baucau, como foi combinado. Todavia o nosso 
carro chegou, com um atraso imenso, já eram 05h45min. Abordo já estavam Milene, Jacirema, Sidinei, dona Maria da Costa, o motorista e mais dois outros tripulantes timorenses. Ainda teríamos que entrar, eu e Nelson. Além de tudo, ainda tínhamos as caixas dos guias dos cursista da fase presencial. Depois de muitas arrumações, concluíram que era melhor para mim e para todos, que eu fosse à frente. Assim fui meio espremido entre caixas de guias e minha pequena bagagem para a semana.

Seguimos pela estrada sinuosa na beira da falésia no Pacífico para Baucau. O mundo ainda estava escuro. Aos poucos a barra do dia foi dando o ar da graça e o Sol imenso e vermelho surgia no horizonte do Pacífico, torrando meus olhos. Todos pareciam dormir, tamanho era o silêncio que reinava na viagem. Depois de muitos tombos, curvas e solavancos, frenadas bruscas, cheguei, ligeiramente descangotado, ao meu destino, onde já estive da vez anterior. Fiquei no meio do caminho com minha bagagem exígua, para mais um duro dia de trabalho, ainda mais hoje que vou fazer revisão de todas as áreas para a prova bimestral que os cursista farão na segunda-feira.

Ao chegar achei os senhores Domingos e Antônio Soares. Chegando em seguida as senhoras Felizarda, Angelina e Ermelinda. Fiquei na direção da escola vendo a garotada chegar. Ouvi o gongo chamando todos para se perfilarem no largo pátio de brita. O professor Domingos hoje é o "chefe de instrução". Aos gritos arregimentou a "tropa" e os perfilou no pátio com uma disciplina militar, como é do seu modo de ser, seu Domingos também foi guerrilheiro no tempo da resistência e lutou pela libertação do país. Todos perfilados, fez a oração da Ave Maria em português, fez a "tropa" ficar toda em sentido e os chamou para entoarem o canto do Hino do Timor-Leste, todas as instruções eram em tétum e com a eficiência de um maestro deu o tom aos alunos e começaram a cantar o Hino em português. Um Hino que fala da luta e da liberdade, da vitória diante do colonizador e dos imperialistas. Todos cantam felizes e em sentido, estou diante da futura geração de timorenses tateando ainda nisso que chamam de liberdade e que ainda não sabem muito bem o que fazer com ela. Depois do canto do Hino Nacional, entoaram outro Hino que falava da batalha e das lutas. Para o encerramento deu umas instruções em tétum, todos os meninos responderam levantando "katanas" (facão timorense), que estavam postos ao chão, e as meninas levantaram vassoura de palha, depois todos saíram da escola. Não entendi do que se tratava perguntei ao seu Domingos se eles não teriam aulas hoje e ele me falou que hoje era dia de limpeza. Continuei sem entender. A impressão que tive é que todos "limpariam" algum matagal do jeito que estavam, com "katanas" e vassouras. Em todo caso, fomos para a sala de aula. O 
senhor Francisco Cabral chegara. Como mencionei, se o tutor não faz nada, hoje é dia dele ficar olhando, pois serei eu a fazer tudo.

Eis que diante daqueles timorenses, comecei fazendo revisão com base num exercício de Linguagem e Códigos. Trabalhei na área temática até o horário da merenda. De volta aos trabalhos, fui para Matemática e Lógica. Embora os conteúdos sejam simples, me preparei na sexta-feira com o Sidnei e pude trabalhar o "passo a passo" para o entendimento das questões da prova, utilizando um exercício preparado pelo Sidnei e por Camila. Não consegui trabalhar as 10 questões antes do almoço como tinha planejado, interrompi após estudarmos a sétima questão e fomos almoçar.

Aquelas mesmas menininhas, trouxeram as bandejas com as comidas timorenses. Um arroz com sabor de fumaça, uma bandeja de flor de mamão cozida, amarga como fel, um prato com magras sardinhas fritas num óleo preto não sei de que, outro prato com algo que parecia pedaços de galinhas pardacentas, e bananas meio verdosas. Enquanto não me sirvo, os cursistas não se servem, a gentileza beira a insanidade, assim tenho que aprontar meu prato primeiro para que eles façam os deles. Já com meu prato pronto e comendo, eles foram chegando e comemos todos juntos, ali mesmo na sala de aula. Apesar da aparência e das estranhezas, a comida estava boa.

Nem bem acabamos o almoço, seu Francisco já "determinou” que deveríamos voltar para a revisão. Fui para o quadro continuar a matemática. Todavia, não estava me sentindo bem, a cabeça começava a doer, estava com as pernas cansadas de ficar em pé. Mesmo assim, cumprir o que havia me proposto, terminei a revisão de matemática e procedi com a de Vida e Natureza. Entrei em OTP, mas o tempo não nos permitia mais avançar. Esse encontro de Vemasse, só vai até as 15 horas, pois o seu Francisco tem que pegar transporte para Baucau ainda hoje. De Vemasse para lá, são mais $30 \mathrm{~km}$, concordo com ele plenamente, pois o combinado é ir para Baucau com ele. Eu ainda não estive na cidade de Baucau, essa será a minha primeira vez desde que cheguei que irei à cidade. Encerramos o encontro e saímos andando pela estrada deserta, vez ou outra passa um carro. Andamos entremeando plantações de arroz por bem 1 quilômetro e fomos esperar carro na frente da casa de seu Domingos que gentilmente coloca umas cadeiras para gente sentar do outro lado da estrada em frente a sua casa, numa sombra fresca de uma árvore, estava tão cansado e com dor de cabeça que adormeci na cadeira, acordei com ele me chamando e com um pequeno ônibus esperando. Esses ônibus eles chamam aqui de Bis. Olhei para o ônibus e vinha tão lotado que duvidei que fosse capaz de entrar. Mas me esforcei, ouvi quando muito diziam coisas que pareciam agressivas e sei que era comigo, pois falavam em tétum e diziam "malaio" aqui e "malaio" 
acolá, estão falando de mim, pois sou o único "malaio" presente. Eu sei que depois de muito esforço e sem ajuda de nenhum timorense, consegui me espremer num canto e fui ajoelhado num monte de sacos de arroz. Para completar a tortura e o sofrimento, a estrada de Baucau é terrivelmente sinuosa, com subidas e descidas e curvas bruscas, a cada freada, batia o meu joelho esquerdo num ferro da porta e tinha que fazer um esforço maior ainda nos braços e na coluna para me manter naquela desconfortável posição. Foram 30 quilômetros do maior desconforto que já experimentei até agora por aqui, e ainda por cima, a cabeça doendo como um sino soando, e tendo que suportar o ônibus todo fumando "gudang garan". Para completar, além desse eterno aroma de cigarro, o cheiro acre de suor em todos.

Depois dessa torturante e sofrida viagem começamos a chegar nos arredores de Baucau e o povo começou a descer do ônibus minúsculo, vagando um lugar para mim. Foi nesse momento que sentei mais confortável. Pedi a ajuda ao seu Francisco que me dissesse o melhor lugar para saltar para chegar até a pousada onde ficaria. Baucau se divide em duas "cidades" a parte baixa e a parte alta. O ônibus entra pela parte baixa e vai subindo por ruas tortuosas e maltratadas até a parte alta, onde parece existir ruas e habitações melhores. Aos gritos seu Francisco fez o ônibus parar e gritou ao motorista algo com "malaio" pelo meio e disse para mim que devia saltar ali e que a pousada ficava acima, apontando para um lugar no meu lado esquerdo que ficava em cima de um morro, teria ainda que subir a ladeira, tateando sem saber bem para onde ir.

Desci do "bis" e perguntei a um vendedor de cartão onde ficava a "Albergaria Planalto" por ali. Ele olhou para mim e disse que não falava português, só inglês. Falei em inglês com ele, e vi que ele não falava era nada. Fui seguindo. Pedi informação a uma senhora e continuei na mesma. Estava me sentindo o pior dos seres, perdido num lugar estranho, morrendo de dor decabeça e sem ter como me comunicar. Os outros colegas estavam ainda em sala de aula. Apesar de ter ligado para o Sidnei, ele não sabia como é que eu chegaria à tal "Albergaria Planalto". Fui descendo ao longo de uma feira imunda, cheia de gente e escarros vermelhos pelo chão. Aqui só um adendo: Há um hábito no Timor-Leste, e principalmente das pessoas de Baucau, em Díli vemos pouco isso, mas muitas pessoas de Baucau, mascam uma mistura de cal hidratada com umas folhas, que faz uma reação vermelha na boca, penso que as folhas são indicadoras de "base" e reagem com o hidróxido de cálcio. Com o tempo essa reação e por se tratar de uma "base", vai corroendo os dentes e deixando-os todos vermelhos e carcomidos, dizem que fazem isso como uma forma de mitigar a fome e como hábito cultural. A sensação no estômago não é muito boa, ver aquelas mulheres e homens com os dentes carcomidos, todos vermelhos como se estivessem sangrando, mascando aquela 
coisa e cuspindo no chão aquela mistura de saliva e cal. A primeira coisa que vi, andando nessa rua de Baucau foram os escarros púrpuras pelo chão em toda parte. Segui a ermo naquela montoeira de gente sem saber para quem pedi ajuda, até que ouvi um rapazinho me oferecendo cartão telefônico e falando em inglês. Aproximei-me e pedi ajuda em inglês. Ele prontamente se colocou a disposição. Perguntou-me de onde eu era, disse que era brasileiro e que precisava chegar num lugar ali chamado "Albergaria Planalto". Disse-me que sabia onde ficava e pediu permissão para me acompanhar até lá. Assim fomos conversando em "nosso" inglês cada um mais sofrido do que o outro, mais ao menos, estávamos entendendo um ao outro. Muito curioso, perguntou meu nome e disse o dele, queria saber se eu o poderia ajudálo a trabalhar também no meu projeto, pois precisava de um emprego, disse-lhe que eu era apenas um professor do projeto, e esse projeto tinha uma coordenação, eu não poderia ajudálo. Assim, nesse diálogo chegamos a "Albergaria Planalto". Fiquei muito agradecido a ele e dei US\$1,00. Ele saiu muito feliz e me agradeceu.

Ao chegar à pousada, não encontrei ninguém para me atender, depois de ficar "zanzando" sem saber por quem chamar, me apareceu um senhor falando português, me perguntou se era do grupo dos professores brasileiros, confirmei. As reservas já haviam sido feitas na semana pela professora timorense Dona Maria da Costa. Assim me apontou um quarto de número 5. Falou-me da dificuldade que tem com água e disse-me que se quisesse tomar banho que o avisasse para que ele abrisse minha água e depois o avisasse para ele desligar. Disse-lhe que abrisse que tomaria banho de imediato. Eu fui o primeiro do grupo a chegar. A pousada parece ser uma das melhores em Baucau, todavia é apenas uma estalagem rude. Entra-se numa saleta que se abre para a imitação de um pátio central onde se vê o projeto de "jardim de inverno" com plantas mirradas a beira da falência e ao redor dessa área central, que deve dá um metro e meio por seis, ficam os quartos. São pequenos. Há uma cama com um colchão de molas, no meu, algumas estão frouxas e o colchão está deformado, para

alguém pesado como eu, vai ser "ótimo" dormir aqui, além do mais, todo descangotado com a viagem no "bis". Depois do duro dia e com a coluna doendo, fui pensar na Fase Presencial.

\section{Memória da Segunda Fase Presencial do Módulo III - Baucau}

Na segunda-feira, dia 21 de maio de 2007, estava na agenda fazer a Prova Bimestral 1 na parte da manhã e começarmos as oficinas na parte da tarde (Figura 32). Assim, para iniciarmos a segunda Fase Presencial do Módulo III, descemos uma ladeira imensa da 
Albergaria Planalto e chagamos à escola. Um lugar empoeirado que parecia não ter visto vassoura há um século. Olhei em todas as salas e todas pareciam estar abandonadas. Tudo sujo de areia e outras matérias. Havia um dedo de poeira em cima de tudo. Pegamos trapos e vassouras e fomos nós mesmos limpar o espaço das duas salas destinadas ao encontro. Em uma das salas, encontrei um armário com uma enciclopédia americana, completamente tomada de areia, como se há milênios não houvesse sido consultada. Foi de cortar o meu coração ao vê-la naquele estado. Limpamos as carteiras e cadeiras, o chão e os quadrosnegros. Logo os alunos regulares começaram a chegar e os cursistas também. A Prova Bimestral estava prevista para ser iniciada as $08 \mathrm{~h} 30 \mathrm{~min}$, com horário de término para as $12 \mathrm{~h} 50 \mathrm{~min}$, com um intervalo de 20 minutos para o lanche às $10 \mathrm{~h} 30 \mathrm{~min}$ para os que tivessem terminado as primeiras provas, de retorno fariam as duas outras provas.

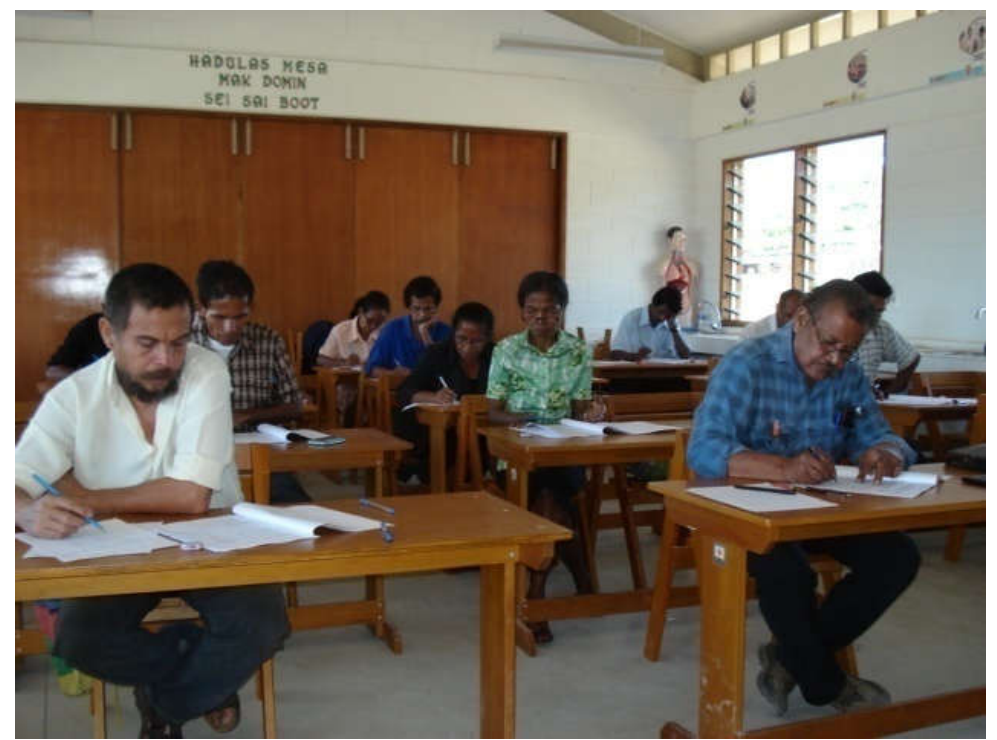

FIGURA 32 - Foto de professores Cursistas em fase presencial em Baucau - Timor-Leste

Organizamos as turmas meio aleatoriamente na medida em que os cursistas chegavam. Colocamos 19 em cada sala. As salas são geminadas e elas possuem uma porta que dá acesso de uma para a outra. Aos poucos as salas foram se completando. As 08h30min, todos presentes, Jacirema fez a orientação coletiva em umas das salas e Milene fez o mesmo na outra. Salientaram que nenhum cursista poderia entregar a prova antes das 10 horas. Todos a postos fizemos a distribuição das provas, começamos pelo caderno $\mathrm{A}$, onde estavam as áreas de Linguagens e Códigos, Matemática e Lógica e Vida e Natureza. Em funções de algumas ambigüidades e confusões nas questões da prova de LC, tivemos que esclarecer na sala, o que deveria ser feito nessas questões.

Notei que a prova de Matemática e Lógica, representou a maior dificuldades de todos. Ouvimos muitos comentários sobre esse fato dos cursistas. Observei que, não obstante, os 
exercícios elaborados pelos professores de matemática, algumas coisas na prova não foram esclarecidas nos exercícios, como as questões de operações com potências de fração. Apesar de terem oferecido uma tabela com a expressão das potências, não sei se ficou claro na cabeça dos cursista, a utilização das mesmas.

Apesar de algumas dúvidas individuais sobre uma ou outra questão da parte $\mathrm{A}$, os cursistas foram terminando e fomos gradualmente recolhendo as provas a partir das 10 horas e fomos encaminhando para o lanche. Ao término começamos a voltar aos poucos à sala. Na medida em que iam acabando as merendas, recebiam a prova B de OTP e FE.

Ao ler as provas das duas áreas, notei muitos termos que julguei complicados para o entendimento. Em todo caso, pensei se tratar de coisas que haviam sido colocadas no glossário dos guias. Mas, logo começaram os questionamentos. A todo instante, um chamava de um lado e de outro para as mesmas palavras. Assim, percebi que aquilo era coletivo e resolvemos, eu e Jacirema, montar um glossário no quadro-negro, na medida em que as dúvidas sobre o vocabulário fossem surgindo. Notei que o glossário foi longe, palavras como "sintonia", "posicionar-se", "persistência", “inibição" e por ai vai. Observei que isso aconteceu nas duas salas, as dúvidas eram nas mesmas palavras. Não sei o que aconteceu. Penso que temos que tomar mais cuidado da próxima vez, ou usar palavras que sabidamente sejam conhecidas de todos ou colocarmos um glossário na prova.

Apesar das inúmeras consultas nas palavras desconhecidas, eles foram rápidos na resolução das questões. Antes das 12 horas muitos já haviam entregado. Readaptamos os horários e combinamos que almoçaríamos a partir das 12 horas e começaríamos nossa fase presencial antes do horário previsto, para que pudéssemos sair antes das 17h40min. Assim fizemos. Como as comidas haviam chegado, começamos a almoçar. Arroz, bifes, saladas de flor de mamão, verduras, pimentas, saladas e bananas, e um copinho de água mineral. Estava muito bom o almoço.

Demos um pequeno tempo de descanso do almoço e às 13 horas, começava a fase presencial da segunda metade do módulo III. Distribuir os guias 5 a todos, mediante a assinatura de uma lista que funcionará como comprovante de recebimento. Salientei que os guias 5 eram deles e estariam com a responsabilidade de trazê-los todos os dias da fase presencial, terem o cuidado na preservação e manutenção dos mesmo, haja visto não ser possível a reposição de outro. Pouco tempo depois, introduzir Vida e Natureza na turma A. Jacirema estabeleceu onde os cursistas ficariam colocando os nomes dos tutores em cada sala. Milene começou OTP na turma B. Iniciei o trabalho fazendo um apanhado geral dos 4 primeiros guias para mostrar as conexões entre eles até chegar ao guia 5 de Vida e Natureza. 
Como não disponho de muitos recursos, fui conclamando a participação de todos, chamando a atenção para duas palavras-chaves para o guia 5, a saber: "propriedades" e "características", descrevendo objetos e fazendo perguntas sobre o que eram. Chamei a atenção para o fato de estarmos caracterizando coisa e apresentado as propriedades. Fomos construindo o entendimento passo a passo. Trabalhando lentamente os objetivos nas seções. Fiz um pequeno experimento sobre condutibilidade térmica em metais e pedi para que apresentassem conclusões sobre o que viram. Fomos adiante. Às 15 horas, alertados para o intervalo da merenda, fiz a pausa estratégica, todavia, ainda não tinha fechado o guia 5 . Percebi que tinha que acelerar o "passo" para dar conta até o final da tarde, do guia 6.

Merendas a mão, comemos os bolinhos e as frituras. Nesse intervalo, o professor José Manuel, chegava de Díli, com o restante do material que deveríamos trabalhar, os guias 6, 7 e 8. Fiquei feliz ao ver que haviam conseguido imprimi-los. Todavia, para minha frustração, se tratava dos guias 6, 7 e 8 do Brasil. Em todo caso, retornando a sala de aula as $15 \mathrm{~h} 20 \mathrm{~min}$. Continuei o restante da unidade 5 e distribuir a unidade 6 do Brasil. Notei uma pequena dificuldade sobre as questões associadas a "concentrações de soluções", me demorei mais do que o programado no esclarecimento dos pontos sobre concentrações. A tarde avançava e às 17h15min, faltando, portanto 5 minutos do horário do término previsto, ainda restava trabalhar a seção 4 do guia 6. Como a julgo muito importante, haja vista tratar de assunto a cerca dos cuidados com a água e os procedimentos para sua potabilidade, fiz as considerações finais e acertei com eles que continuaria na manhã da terça- feira com aquela seção do guia 6 e prosseguiria com o guia 7 e 8 . Às $17 \mathrm{~h} 20 \mathrm{~min}$, como o combinado, encerrei os trabalhos de na turma A.

Na manhã do dia 22, nos carregamos com o material que levaríamos para a sala de aula para mais um dia de Fase Presencial e descemos para a escola. A Albergaria Planalto, fica numa ladeira tão grande que a tarde quando subimos, dá vontade de subir de costa de tão difícil que é.

Na sala de aula, começamos os trabalhos na última seção do guia 6. Assunto essencial, mas, no entanto, um tanto quanto delicado. Falar de tratamento de água num país em que temos o tempo todo que consumir água mineral indonésia em função da ausência quase que total de um sistema confiável de tratamento de água. Apesar disso, falei sobre o problema de escassez de água potável no mundo, sobre os grandes problemas que um país recente como o Timor-Leste enfrenta em vários aspectos incluindo aí a água, elancei questões aos cursista sobre a relação dos mesmos com a água queconsumiam, de onde era essa água, quais os procedimentos que faziam para tratá-la, e etc., muitas contribuições interessantes foram 
apresentadas e apresentamos o conteúdo da seção. Após sua conclusão, iniciei o trabalho do guia 7 e o dei por concluído as 10 horas onde iniciamos o intervalo da merenda. Scsdcsd

Às 10h20min retornamos para a sala de aula. Meu trabalho nessa turma A se encerra nesta manhã. Noto que estão com dificuldades de entender conceitos importantes da química, como concentração de soluções, densidade de metais e etc. Volto várias vezes no conteúdo para explicar várias vezes. Em todo caso, concluo, sabendo que muitas dúvidas ainda restaram. Sei que em grande parte, essas questões relativas à dificuldade que experimentam, deve-se à língua portuguesa, muitos não conseguem entender adequadamente, apesar de falarmos devagar e claro. Fico o tempo todo me policiando sobre o vocabulário a ser usado, tomando o cuidado de perguntar sobre o entendimento das palavras. Isso toma mais tempo ainda. Em todo caso, ao meio-dia concluir os trabalhos com a turma A. Despedi-me de todos e fomos para a fila do almoço.

Às 13 horas, iniciamos os trabalhos dos dois guias, o 5 e o 6, e comecei a notar a diferença nas turmas. A turma A é mais atenta e interessada, já a "B”, notei uma certa apatia. Acho que estavam todos com sono depois do almoço. Vi a tarde se arrastar pesada sobre todos. Senti que não consegui render muitas discussões como as que haviam feito a turma A. Acho mesmo que à tarde o rendimento deles diminui em função de fatores como o aumento da temperatura, o sono vespertino, aliado a isso a dificuldade de entender conteúdos mais complexos. Às 15 horas fizemos uma pausa para a merenda.

De retorno, percebi meu cansaço na turma, notei que estava desmotivado em função da apatia dos mesmos, tentei animá-los, pedi que levantassem, estirassem os braços, girassem os pescoços para ver se acordavam, porém, meus esforços foram em vão. Cheguei até a Unidade 6 e procedi às mesmas questões que havia feito na turma $A$, não obtive os mesmos resultados, em todo caso fui trabalhando no guia até as $17 \mathrm{~h} 20 \mathrm{~min}$ quando por fim encerrei. Retomo amanhã pela manhã com esta mesma turma para encerrar a parte de Vida e Natureza.

Voltamos vagarosamente para a Albergaria Planalto, estou me sentindo muito cansado. No pé da ladeira, Jacirema me chama para vermos umas coisas que eles aqui em Baucau chamam de "shop". Na realidade, trata-se de vendas improvisadas em barracos toscos, onde comercializam de tudo. Enquanto entrávamos nas biroscas sem jeito, o Sidnei descobriu uns timorenses jogando xadrez, e pediu para jogar também, lá deixamos o Sidnei jogando e fomos entrando naquela barafunda de casebres vendendo de tudo. De coisas plásticas a roupas. Tudo com aspecto de abandono e sujeira. Chão de terra batida e esgotos escorrendo por entre as barracas. Crianças imundas para lá e para cá, mulheres velhas com as bocas "sanguinolentas" 
de mascarem a mistura que fazem com cal e folhas ${ }^{50}$, escarros púrpuras por toda a parte. Retornamos pelo emaranhado de barracos toscos e achamos o Sidnei jogando numa imensa roda de timorense. Todos contra ele. Jogava contra uma verdadeira "conferência". Fiquei a observar o que aconteceria, Jacirema seguiu andando. Conforme o Sidnei ia jogando, vi que o "bolo" de timorense ia aumentando ao redor do tabuleiro. Aquele emaranhado de opinião e de sugestão em tétum sobre lances. Como eles estavam se amontoando, com aqueles cigarros Gudang Garan e com as caras hostis, disse a Sidnei que ele tratasse de perder porque senão tomaríamos pedradas de revoltas. E vi que o Sidnei, de propósito começou a vacilar no jogo e em pouco tempo, para felicidade de todos, e para se evitar um conflito internacional, Sidnei toma "xeque mate", diante daquela platéia opinando ao jogador timorense. Fizeram gozação do Sidnei por haver perdido e saímos de volta à Albergaria Planalto, sãos e salvos.

A noite caiu e comecei a corrigir as provas de Vida e Natureza. Wanda ligou hoje para Jacirema, e informou que devíamos fazer as correções das provas até a quinta-feira, pois os resultados seriam dados no sábado. Já que não vou ficar até o sábado, tenho que dar conta das provas corrigidas antes. Todavia, devo ter corrigido apenas 10, o cansaço já me fazia cochilar. Encerrei tudo por hoje e perto das 22 horas dormi.

No dia 23 de maio, mesmo começando as atividades às 8 horas, temos que chegar mais cedo ao colégio, pois os cursistas estão tomando café da manhã lá, e eles ficam esperando por nós professores para que "permitamos" que eles tomem café. Logo quando cheguei, já estavam quase todos lá e os pães e o café na mesa, todos esperavam. Mesmo já tendo tomado meu café, peguei um pãozinho e coloquei café e disse a todos o habitual "faz favor", apontando para a mesa, ai todos se aproximam e começaram o café. Todos são muito "cerimoniosos" e a hierarquia é algo que prezam muito. Mesmo todos sendo tratados como professores e colegas, eles não admitem se servirem primeiro, antes dos professores formadores. Não adianta querermos fazer as gentilezas e insistirmos para que tomem a nossa frente ou peguem primeiro o que quiserem antes da gente, vamos ficar perdendo tempo nessa insistência, pois ficam "amuados" no lugar sem ceder, então, temos que fazer tudo primeiro do que eles.

Logo que todos terminaram o café, comecei o trabalho do o guia 7 de Vida e Natureza na sala da turma B. Todos se queixam dos conteúdos difíceis que estão nos guias de Vida e Natureza desse restante do Módulo III. São conteúdos de química e física. Modelos atômicos,

\footnotetext{
50 Também chamado de quid, embora a preparação exata varie entre os países e culturas asiáticas, é geralmente uma mistura de cal hidratada, uma folha de betel e temperos como cardamomo, canela e tabaco. A noz de betel, ou noz de areca é encontrada em toda a Ásia.Esta noz vem da palmeira de areca e é mascada por suas propriedades estimulantes.
} 
propriedades químicas dos metais, propriedades térmicas. Em todo caso, fui desenvolvendo as teorias e as explicações pausadamente até o intervalo das 10 horas quando dei por finalizado a unidade 7 e fomos às comidas timorenses. Hoje experimentei uma coisa nova aqui para mim, trata-se de mamão verde cozido com casca, todo fatiado. Fica parecendo chuchu, eles comem acompanhado de pimenta, o problema é que a casca amarga muito. Todavia, dizem eles que comem essas coisas amargas do mamão, como as flores cozidas em saladas e a casca do mamão cozido, pois esse amargor "protege contra a malária". Eu acho que faz sentido, pois a quinino, medicamento usado para combater a malária de quem já adoeceu, amarga como flor de mamão. E quem sou eu para duvidar da sabedoria milenar desse povo mais antigo do que os chineses, como eles gostam de dizer?

Às $10 \mathrm{~h} 20 \mathrm{~min}$ aproximadamente, retomei os trabalhos com o guia 8. Para mim é muito complicado olhar para as caras deles todos e ver que não estão compreendendo muita coisa. Falar da ultra-estrutura do átomo, seus componentes constituintes para pessoas que mal falam o português é muito difícil mesmo. Porém, fiz o melhor que pude, fui paciente e disse que compreendia a todos e suas dificuldades, mas teriam que estudar para entender aquilo. Não seria apenas com uma aula sobre o assunto que aprenderiam todos os termos e saberiam tudo,

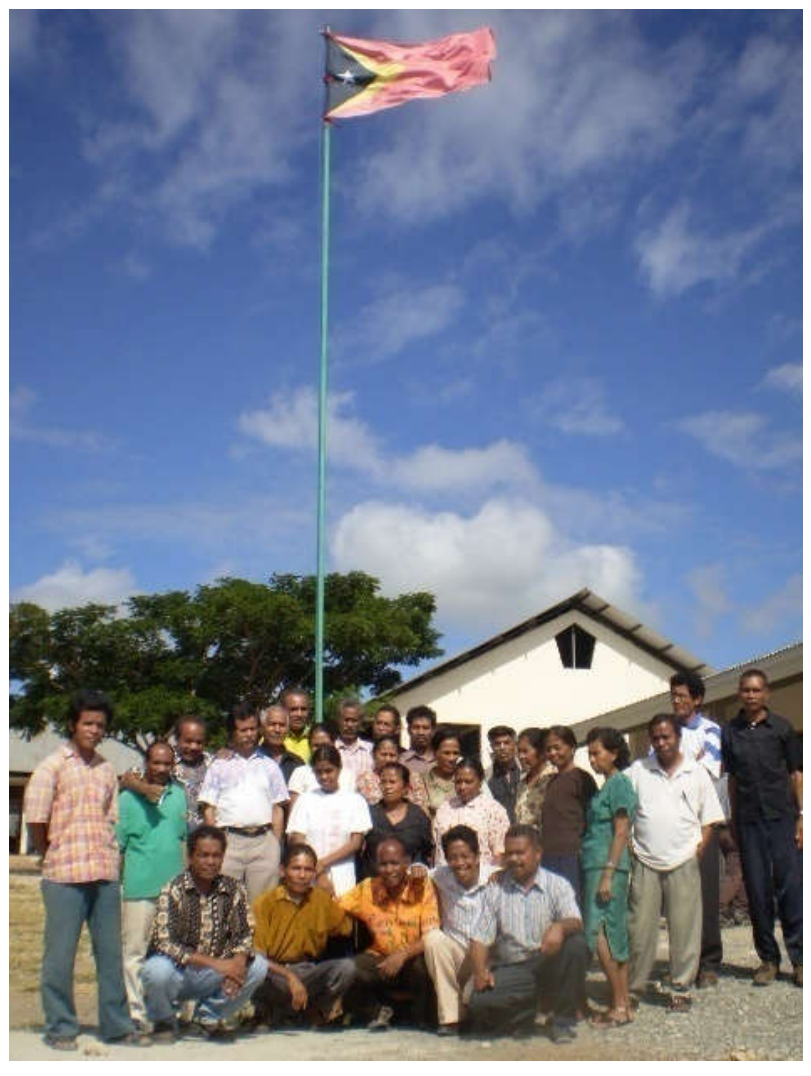

FIGURA 33 - Foto de professores cursistas loromonu, ex-guerrilheiros de Baucau - TimorLeste mas assim que começassem a estudar na quinzena correspondente os conteúdos do guia, veriam que ficaria mais fácil. Já estávamos quase no horário previsto para encerrar os trabalhos, sentei-me em uma cadeira na frente de todos, fui falar sobre o fato de todos serem vencedores, serem pessoas especiais, primeiro por serem timorenses, um povo persistente, batalhador e livre, que conseguiu superar barreiras imensas para estarem ali, todos vivos e com saúde, dessa forma, conseguir concluir o curso do PROFEP-Timor, seria a batalha mais suave das que eles já teriam enfrentado e para mim estava sendo de grande honra poder estar contribuindo para que isso se concretizasse. Disse ainda que 
em janeiro de 2008 eu estaria muito feliz vendo-os com os diplomas de professores nas mãos. Agradeci a atenção, o carinho e a boa vontade de estarem ali a me ouvi nestes dois dias e dei por encerrada a parte de Vida e Natureza. Fomos para o almoço que já estava a espera.

À tarde, antes de voltar ao trabalho, resolvi fazer uma fotografia do grupo de cursistas "loromonus" alguns ex-guerrilheiros (Figuras 33 e 34) para guardar na lembrança aqueles companheiros prestimosos do Timor. No resto da tarde o meu trabalho foi corrigir as provas restantes de Vida e Natureza e o fiz. Após a correção, procedi ao levantamento de quantos professores cursistas haviam ficado em recuperação da PB1 em Vida e Natureza, apenas cinco cursistas, mesmo assim, com pontuações muito próximas da média, em levantamento posterior, observei que em Díli ficaram nove cursistas em recuperação, no total então ficaram 14 , o que dá $17,5 \%$ no universo de 80 professores. Penso que mesmo assim, o resultado do trabalho desse bimestre foi satisfatório.

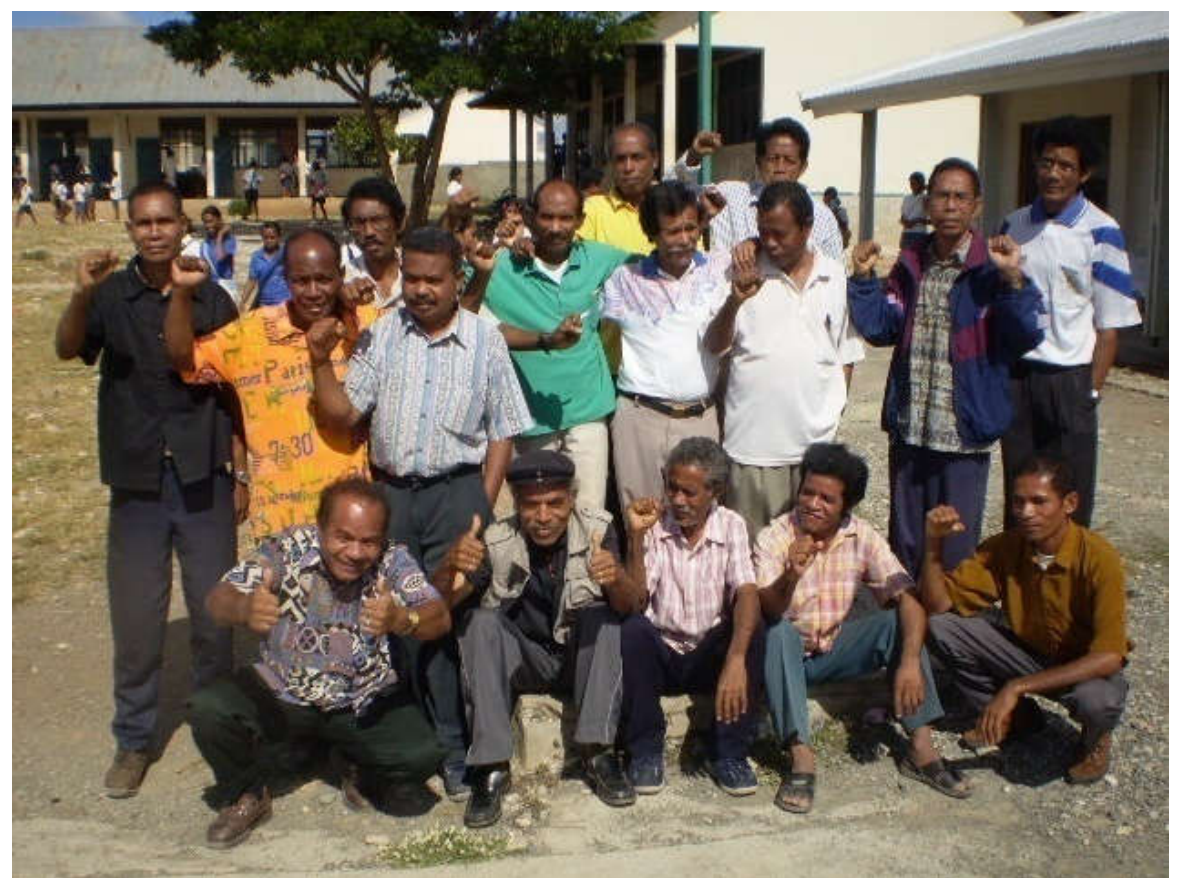

FIGURA 34 - Foto de professores cursistas Ioromonu de Baucau - Timor-Leste

Na manhã do 24 de maio, fomos para o encontro e passei a manhã assistindo as aulas do professor Sidnei de Matemática e Lógica. Ao meio-dia, nosso carro que nos levaria de volta a Díli, chegava com os outros professores que continuariam o trabalho até o sábado. Após o almoço, pegamos a estrada de volta a Díli.

Hélio Maia 


\section{Memória do acompanhamento do Encontro Quinzenal do dia 7 de julho de 2007}

Todos os encontros quinzenais que observei até o memento foram fora de Díli. Este é o primeiro que participo em Díli. $\mathrm{O}$ bom é que não precisamos acordar madrugada. Ao chegar à AGF, a sala ainda estava fechada. Logo chegaram os outros professores, Helen, Milene, Odílio e o professor timorense José Manoel. Ficamos "jogando" conversa fora esperando os tutores e os cursistas além de Alarico, o moço que tem a chave da Agência. Assim que as tutores e os cursistas chegaram, fui para sala da tutora dona Filomena.

A tutora demonstra muito autoridade, como é praxe do professor timorense. Ainda praticam a pedagogia tradicional. Embora os pedagogos do PROFEP tentem mudar esse quadro, parece que não adianta muito as capacitações. $\mathrm{O}$ típico professor timorense, ainda é muito severo e autoritário com os seus alunos. Usam a palmatória para alunos que erram ou que não procedem dentro dos padrões, como pude observar na Fase Presencial em Baucau. Estava em um dos intervalos e olhando a prática pedagógica de um professor que estava trabalhando na escola, pude vê-lo sabatinando um aluno batendo em sua mão de palmatória.

Voltando a tutora Dona Felomena, ela é uma senhora que tem sobre sua responsabilidade 8 professores cursistas, sendo apenas um homem e o restante mulheres. Começou o dia, recolhendo os instrumentos de avaliação da quinzena. E depois de distribuir os materiais da próxima unidade, procedeu a entrega dos Cadernos de Verificação de Aprendizagem (CVA) corrigidos na quinzena anterior, e procedeu à correção no quadro das áreas correspondentes. Começou por Linguagem e Códigos, escreveu as alternativas no quadro e foi chamando cursistas para apresentarem as respostas certas, assim fez com as 5 questões do CVA. Depois dessa correção, foi para a área de Matemática e Lógica e consumiu o resto da manhã com as questões da área. Como a Tutora não sabe matemática, como, aliás, é comum a todos os tutores, não obstante as capacitações na área, ela chama uma cursista que entende, e a coloca para responder e explicar no quadro as questões. Dona Felomena se limita a ordenar aos professores cursistas o que devem fazer, e a ler os enunciados das questões. $\mathrm{O}$ encontro tem sido muito entediante. Às 10 horas, o professor José Manuel, nos convidou para a merenda.

Retornamos para a sala e dona Felomena continuou a correção feita pela cursista do CVA de Matemática e Lógica. Deu a hora do almoço e ainda estavam no mesmo CVA. Durante esse tempo, limitei-me, no fundo da sala, a observá-los. Embora tenha vontade de interromper a prática pedagógica dos tutores nesses encontros, fico constrangido em fazê-lo 
diante dos professores cursistas e deixo a reclamação dessas posturas para o encontro com os tutores, mas, por mais que tenhamos conversas sobre essas práticas no coletivo de tutores, tenho a impressão que ou não entendem o que estamos falando ou fazem ouvidos de mercador.

No almoço as comidas timorenses traziam as flores amargas de mamão, o Kancun (a hortaliça cultivadas nos esgotos - ver figura 4), o arroz sem sal, mas ovos cozidos, além de uns pedacinhos de carne boiando numa "sopa" de verduras, uma banana e uma tangerina azeda. Pelo menos é uma mudança na rotina gastronômica, e mudança não é sinônimo de que seja para melhor.

Demos um intervalo de uma hora de descanso para recomeçarmos a tarde. O reinício das atividades do encontro quinzenal seguiu o mesmo ritmo lento timorense. A tutora e os cursistas continuaram com matemática até o intervalo para a mesma merenda da manhã. Já perto do final do encontro, dona Felomena, comentou rapidamente o CVA de Vida e Natureza. Perguntou aos cursistas se alguém tinha alguma dúvida, para aproveitar a minha presença.Como ninguém se manifestou, foi para as outras áreas temáticas e já bem próximo das 17 horas, o encontro foi encerrado

Ainda não percebo o Tutor timorense como o fomentador das discussões sobre temas educacionais, o mediador do conhecimento das Unidades nas áreas temáticas, enfim, como o profissional que de fato "tutora". Ele está apenas, como um agente que "determina" tarefas no quadro-negro, como as de responder os CVA, corrigi-los com base em chave de correção e preencher fichas. Todavia, estamos em processo contínuo de capacitações eacho que os tutores estarão bem melhores ao fim do projeto. Até porque é função do projeto transferência de "know-how" para que os profissionais timorenses possam andar com as próprias pernas na condução desse projeto em um futuro próximo.

\section{Memória da preparação para Prova Bimestral 2}

Aprontei na quinzena anterior, os exercícios de preparação da Prova Bimestral 2, bem como a própria prova, baseado nas Unidades 5 a 8, observando nos CVA, o aproveitamento das questões, para poder pautar-me na elaboração dos instrumentos de avaliação.

No dia 24 e 26 de agosto, procedi a atividade de preparação para a PB2 com os Professores Cursistas de Díli. A professora Fernanda, companheira de área, fará a preparação dos cursistas de Baucau no dia 27. Para essa preparação, os cursistas haviam recebido o 
exercício no último encontro quinzenal, todo ele com questões subjetivas, baseado nas questões presente na PB2. Embora os cursistas tenham recebido esse material com antecedência, poucos são aqueles que responderam os exercícios no período, a maior parte está sem responder.

Todos trouxeram os guias referentes e fomos pontuando os conteúdos das unidades baseadas no exercício, e percebi que as lacunas no conhecimento são imensas. Por mais oficinas que fizemos, todo cuidado na elaboração dos exercícios, com raras exceções, não conseguem absorver como se deseja. Noto muita dificuldade para concluir conceitos, fazerem abstrações e generalizações. Conseguem ler o que tem escrito em português em todo o texto, até porque os fonemas do tétum são os mesmo do português, assim, podemos entender o que lêem, mas se perguntado sobre o que estão entendendo do texto, alguns ficam "tateando no escuro". Isso me preocupa, pois existem muitas questões de interpretações de pequenos textos na PB2.

As maiores dificuldades dos professores cursistas têm sido nos pequenos cálculos de concentrações de soluções. Tenho feito muitos exercícios sobre isso, mas, ainda encontram complicações. Diante das grandes dificuldades que a unidade 8 apresentou, fiz questões muito simples sobre conceitos do modelo atômico e seus constituintes. Em sala de aula, pode-se perceber que o estudo do guia não foi suficiente, apesar de terem respondido CVA e obtido as notas de aprovação.Como não deu tempo de realizar a revisão toda no dia 24, marquei com eles a continuação da mesma para o dia 26 e ainda fiz uma revisão geral do que tinha sido visto no dia 24.

Hélio Maia

\section{Memória da realização da PB2, 28 de julho de 2007}

Na realização da PB1 do Módulo III, os cursistas fizeram as provas das cinco áreas temáticas, todas na parte da manhã, pensando-se no tempo da tarde para início da Fase Presencial 2 do Módulo III. Todavia, muitas foram as reclamações dos mesmos em função do tempo corrido para fazer as provas. Penso nisso, e atendo às reclamações, procedemos diferente nessa PB2. Eles iniciaram na parte da manhã com Linguagens e Códigos e Matemática e Lógica, ficando para parte da tarde as demais áreas. 
Assim, após o café da manhã e todos a postos em suas salas, distribuímos as provas da manhã e estabelecemos que o tempo mínimo que ele poderia entregar a prova seria às 10 horas. Não obstante o maior tempo disponível para a realização das provas, antes mesmo das 10 horas boa parte já havia terminado e ficaram esperando na sala pelo horário mínimo

estabelecido. Às 10 horas, boa parte entregava as PB2. Assim, ficamos esperando o almoço por longo tempo.

$\mathrm{Na}$ parte da tarde, o mesmo ocorreu com as outras provas, foram mais rápidos do que no período da manhã. Ao comentar com alguns esse fato de terem dispensado pouco tempo para a realização da prova, disseram que elas estavam simples. Assim, antes das 16 horas encerramos os serviços e após a merenda, todos se foram.

Os resultados dessa $\mathrm{PB} 2$ na área temática apresentaram um número maior de Professores Cursistas em recuperação do que os que tinham ficado na PB1. Penso que isso se deve ao fato dos conteúdos serem complexos, além do curto tempo que dispensaram na resolução das questões.

Hélio Maia

\section{Breves observações em uma viagem a Kupang, Nusa Tengara}

Bali, Indonésia, 23 de outubro de 2007

Muito tempo ainda levarei para narrar todos os pormenores dessa viagem por uma parte da Ásia, em todo caso, tomarei coragem e aos poucos darei forma escrita a tudo que vi e experimentei. A viagem serviria para testar meu inglês após meses de dedicação noturna aos estudos da língua e o presente texto narre apenas a passagem pela porção Ocidental da ilha de Timor, a província Indonésia Nusa Tengara, até sua capital Kupang.

Para viajar, fiz todo um estudo do roteiro e queria testar a viagem por terra do TimorLeste para Kupang no Timor-Oeste ou Nusa Tengara, que pertence à Indonésia. A semana foi escolhida mediante um recesso que a CAPES deu ao nosso projeto, embora já tivéssemos uma semana de folga dada pelo PROFEP, resolvi juntar as duas semanas e sair na aventura, sem reservas em hotéis ou vôos. O destino seria a Tailândia.

Comprei as passagens, com uns 15 dias de antecedência da data da viagem e reservei o hotel para o pernoite em Kupang. A agência de viagem (Tour \& Travel Timor) funciona ao lado de uma oficina mecânica e se resume a um cubículo sujo de óleo, com paredes 
encardidas, um par de cadeiras para os clientes e um indonésio falando bahasa e "inglês indonésio", atrás de uma mesa. Fiz todas as transações e a reserva do hotel usando meu inglês ainda tímido. Mas consegui entender e me fazer entender. $\mathrm{O}$ transporte não é bem um ônibus como pensava, é uma van com 11 lugares e a depender da demanda, eles podem colocar várias por dia. Além disso, eles prometem pegar as pessoas em casa. Assim, acertei com eles que estaria na manhã da viagem a postos.

Na manhã do dia 21 de outubro, véspera de meu aniversário, um domingo, como combinado, às 8 horas da manhã eu já estava na agência encardida de óleo e sujeira, esperando pelo transporte. Já havia muitas pessoas esperando o mesmo. Apareceu o primeiro, subiram uns africanos da ONU e outros indonésio, lotaram e foram despachados. $\mathrm{O}$ meu ainda viria. Demorou mais uns 40 minutos até que o próximo carro aparecesse, verifiquei a lista de passageiros e ainda não era a minha. A manhã foi se avantajando. Perto das 10:00h, finalmente apareceu o meu. Um timorense que não falava língua nenhuma, apenas tétum e bahasa indonésio era o motorista. Lá fomos naquela van de 11 lugares, pegando passageiros em todo canto. No trajeto de saída de Díli, o carro parou em um outro lugar e pegou dois indonésios, rumou para uma outra casa e pegou uma mulher com uma criança e por último ainda foi numa mesquita e pegou uma muçulmana de véu e tudo. Dessa forma estavam apinhados no carro 13 pessoas, com a criança, onde só cabiam 11. Todavia, os outros passageiros se apertaram nos acentos que restavam no fundo da van. Quando pensei que o carro já estava de saída para pegar a estrada, o motorista parou e foi conversar com um rapaz à beira do caminho. Ficou um tempão conversando não sei o que. Daqui a pouco ligou no celular para algum lugar e me trouxe o celular para falar com alguém, era o senhor indonésio da agência, me pedindo desculpas pelos transtornos e pelo atraso, mas que estavam com um problema para abastecer de combustível a van embora já estivesse resolvido. O motorista entrou no carro e foi para um posto de gasolina, abasteceu e seguimos viagem, eram 11:40h quando saímos de Díli finalmente.

Fomos viajando pelo Timor-Leste. Pude ver que está tudo muito seco. As montanhas desnudas mostram a marca da devastação ambiental por estas terras. Muitos casebres e muita pobreza na paisagem. Fomos viajando por uma estrada muito parecida com a de Baucau, precipícios à beira do Pacífico, curvas fechadas, buracos e estrada estreita. Passamos por muitos distritos da parte oeste, todos com a mesma aparência de pobreza de desordem. Senti fortemente a sensação de realmente estar no fim do mundo, a estranha sensação de "confins" gera uma insegurança no espírito e me percebo isolado do resto do planeta. Mais uma vez me 
questiono sobre o tão propalado potencial turístico dessa terra. As coisas são muito "sem jeito" e pobres, além de tudo ser muito caro, sobretudo para turistas.

Depois dos sacolejos e sustos na beira das falésias, chegamos ao posto de fronteira num lugar chamado Balibó. A van parou e descemos no posto de fronteira, para os guardas timorenses carimbarem o passaportes e receberem a ficha de imigração que todos devemos preencher. Peguei a bagagem e fui andando para a parte indonésia. $\mathrm{O}$ aspecto dos prédios e da estrutura começaram a mudar do lado indonésio. Atravessa-se uma ponte e se chega ao posto de fronteira da Indonésia. Pegamos as fichas de imigração, preenchemos e apresentamos os passaportes com o visto já obtido na embaixada de Indonésia no Timor-Leste, como tenho passaporte oficial, a embaixada oferece o visto de graça, para portadores de passaporte comum, a taxa do visto custa USD 40,00. Fomos cercados por um bando de indonésios querendo vender rupias. Depois de muitos carimbos e visualizações dos passaportes, fomos liberados e nos encaminhamos para outro carro que estava do lado indonésio a nos esperar. Este, embora fosse da mesma empresa, já tinha outra qualidade, estava com ar-condicionado e o motorista era indonésio. Embarcamos e seguimos viagem. Os indonésios que estavam espremidos atrás da van, ficaram na fronteira, assim o carro seguiu viagem mais confortavelmente.

O aspecto do Timor-Oeste é o mesmo do Timor-Leste, os casebres são do mesmo tipo e as pessoas parecem pertencer a mesma etnia do povo do Timor-Leste. Ouvi alguém dizer que muitas populações deste lado a ilha também falam o tétum. Com o avançar da viagem, a paisagem começou a mudar e de repente tudo estava verde, muitas plantações de arroz, muitos homens de saia trabalhando nos campos, semelhante com o que se observa também com os plantadores de arroz do Timor. Pequenas vilas de casas de palhas ladeavam a estrada que tinha outra qualidade, apesar de serem tão estreitas quantas as do Timor-Leste. A aparência da paisagem continua montanhosa, áreas imensas de eucalipto, diga-se de passagem, que aqui é nativo. Fomos tarde adentro parar numa cidade chamada Atambua. Cidade grande, com semáforos e tudo mais. O motorista da van nos levou para uma espécie de ponto de apoio onde podia-se trocar dólar por rupia. Depois das trocas, fomos para um restaurante, já passavam das três horas da tarde. No restaurante, os atendentes não falavam nada a não ser o bahasa indonésio. Para pedir as coisas era necessário apontar com o dedo. As comidas ficavam expostas numa espécie de vitrine e o cliente aponta o que quer, a depender do que seja, o preço do prato sobe, muito semelhante com o mesmo tipo de restaurante que se tem me Díli. Pedi arroz com uma carne que julguei ser um lombo de boi e ainda acenei para o atendente colocar o molho da carne sobre o arroz. Quando sentei para comer, percebi que a 
carne era doce e apimentada, por um lapso de tempo havia esquecido que estava na Ásia. Mas, como não sou de rejeitar a comida, encarei assim mesmo. Durante o almoço, escutei o almuadem (muezim) de uma mesquita próxima anunciar a oração a Alá. Muito interessante esse mundo islâmico.

Seguimos depois do almoço, por uma estrada sinuosa e cheia de precipícios, a peça do carro que mais o motorista usava era mesmo a buzina, bem semelhante ao modo de dirigir timorense. Na Indonésia a mão de direção é, como no Timor, mão inglesa. Acho mesmo que Alá é poderoso, pois só ele deve amparar esses pobres mortais que atravessam esse tipo de estrada. As curvas são tão fechadas que em algumas "dá para ler a placa traseira do próprio carro". A noite caiu em plena estrada que não acabava mais e mergulhamos na escuridão. Já perto das nove da noite, o movimento na estrada aumentou, percebi que estávamos próximo e de fato, chegamos em Kupang, capital da província Indonésia de Timor-Oeste. Estranhei o fato de não ter visto nenhuma espécie de iluminação, parecia em blackout como vivemos em Díli. O motorista entrou por umas ruas escuras que julguei ser periferia, para deixar a senhora indonésia que vinha com a criança e me apercebi que no carro vinha essa criança, que para minha surpresa, era tão comportada que nem parecia existir. $\mathrm{O}$ carro prosseguiu por ruas que estavam com iluminação tênue, de um poste ou outro perdido na paisagem urbana. Um ou outro prédio apresentava luz. Chegamos ao hotel Flobamor II, onde eu tinha feito reserva. Resolvi comer algo e fui para o restaurante do hotel, pedi um "migoren" (nome que chamam macarrão na língua indonésia) com frango. Apesar de apimentada, a comida estava boa. Depois da refeição finalmente fui tomar banho para dormir. Estava muito cansado da viagem longa e tortuosa. É de espantar que um território que cabe com folga no Estado de Sergipe no Brasil, seja tão longo para se atravessar. A precariedade das estradas, os precipícios e perigos, alongam o tempo que se gasta na viagem.

No quarto do hotel, vi que as coisas desse lado de cá da ilha do Timor, são tão precárias quanto o outro lado e entendi que os hábitos dos timorenses foram adquiridos dos indonésios. $\mathrm{O}$ banheiro parecia que não era limpo dignamente há anos. Havia um cheiro muito forte de banheiro sujo e as peças do mesmo pareciam não funcionar muito bem. Em todo caso havia água fria e sabonete. Tomei o banho e fui para cama. Coloquei o celular para despertarme, nessas terras o celular da Timor Telecom só serve como relógio despertador mesmo.

Acordei no dia 22 de outubro de 2007, meu aniversário de 38 anos, com o alarme do celular soando estridente as 6:30h, num hotel de uma cidade de fim do mundo na Indonésia, quem imaginava uma coisa dessa? Fiz os rituais assépticos matutinos e me dirigi para o restaurante do hotel para o café da manhã. 
Ao chegarmos na escuridão da noite em Kupang com sua iluminação tênue, não deu para mensurar a dimensão da cidade. À luz do dia, vi que a cidade era grande e muito movimentada, com prédios e comércio avantajado. Só um pequeno adendo aqui, o táxi que peguei para o aeroporto rumo a Bali, era tão sujo e o motorista tão maltrapilho quanto os de Díli. Parece que é mal da ilha do Timor. O trajeto do hotel para o aeroporto é longo, leva-se mais de meia hora para fazê-lo. O aeroporto é melhor do que o Nicolau Lobato em Díli, limpo e mais amigável, todavia, só tem um portão de embarque. Como a data era emblemática para mim, resolvi gastar alguns milhares de rupias, com um jornal de Kupang em bahasa, mas não me interessavam as notícias. O que ele trazia e que era importante, a data do dia 22 de outubro de 2007, para guardar de recordação do aniversário inusitado de 2007 em um lugar no fim do mundo, nos confins do Sudeste da Ásia.

Hélio Maia 
FRAGMENTO DO CURRÍCULO DO ESTUDO DO MEIO - CIÊNCIAS NATURAIS - TIMOR-LESTE - $1^{\circ}$ e $2^{\circ}$ CICLO

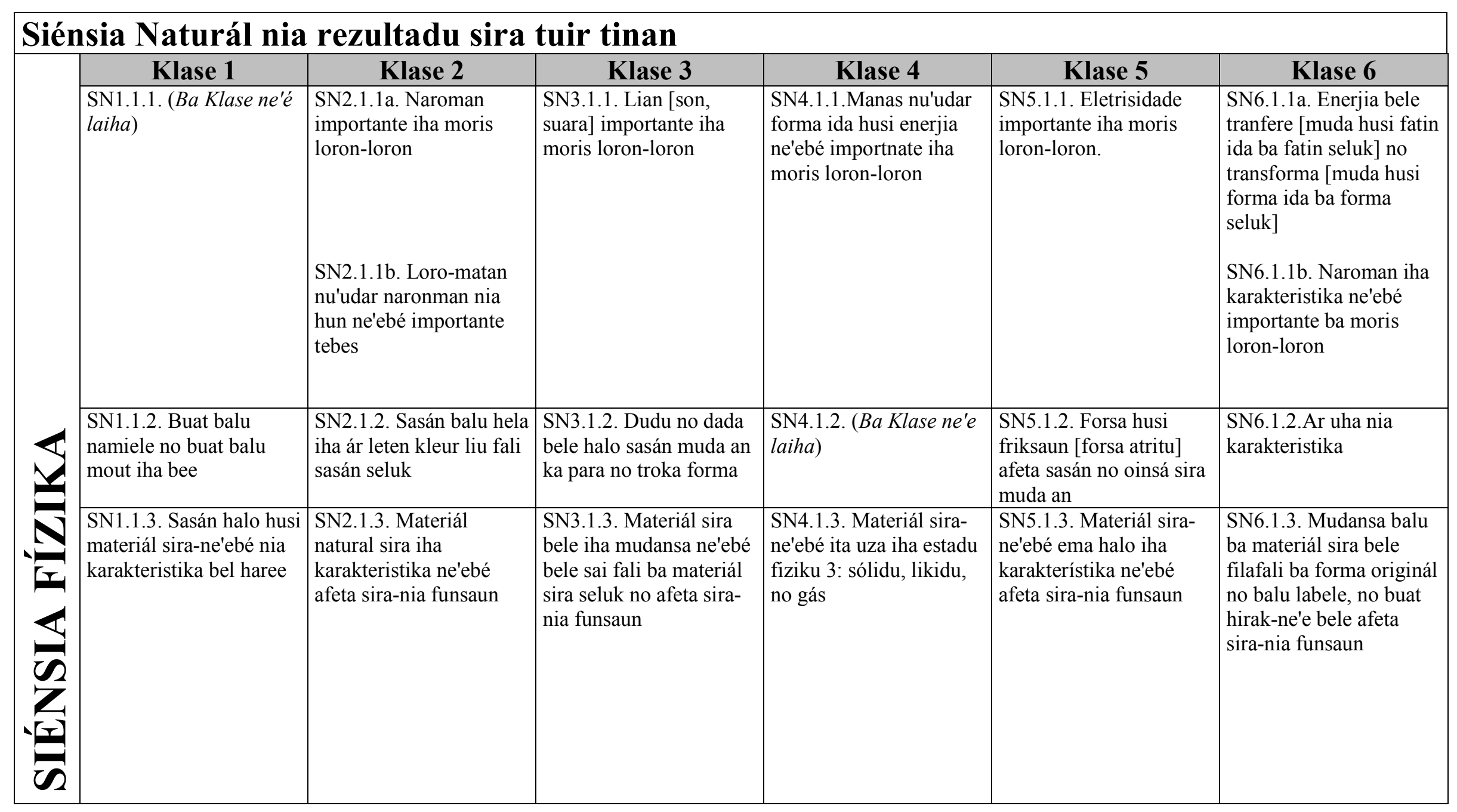




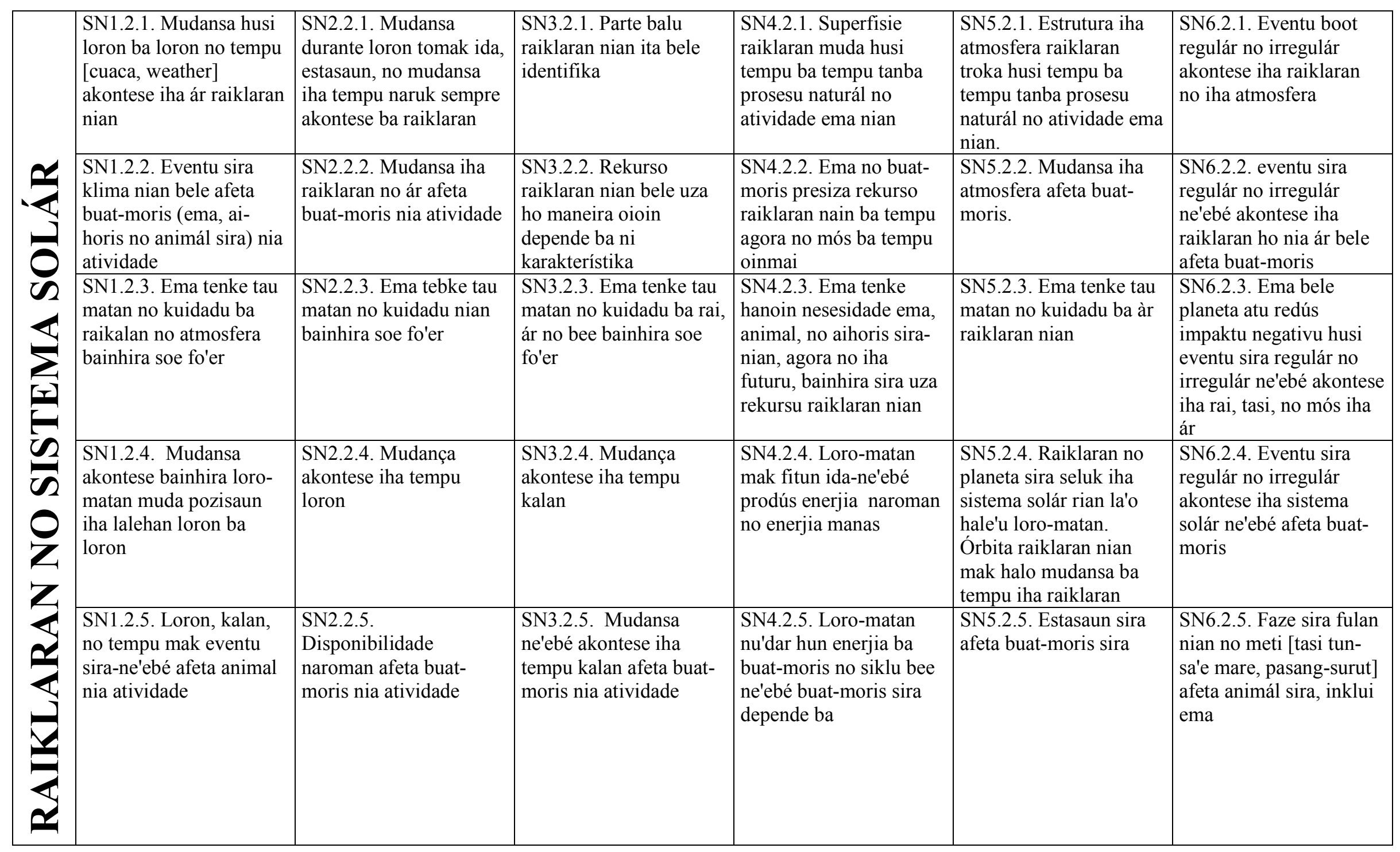




\begin{tabular}{|c|c|c|c|c|c|c|}
\hline & $\begin{array}{l}\text { SN1.3.1. Animál no mós } \\
\text { ema iha karakterístika } \\
\text { sira-ne'ebé bele ajuda } \\
\text { sira hodi responde ba } \\
\text { sira-nia nesesidade hodi } \\
\text { bele moris }\end{array}$ & $\begin{array}{l}\text { SN2.3.1. Ai-horis iha } \\
\text { karakterístika no } \\
\text { hahalok ne'ebé bele } \\
\text { ajuda sira hodi responde } \\
\text { ba sira-nia nesesidade }\end{array}$ & $\begin{array}{l}\text { SN3.3.1. Buat-moris } \\
\text { bele sai boot, muda, no } \\
\text { iha pan ne'ebé hanesan } \\
\text { ho sira-nia an }\end{array}$ & $\begin{array}{l}\text { SN4.3.1. Karakterístika } \\
\text { huzi buat-moris depende } \\
\text { ba fatin sira moris bá }\end{array}$ & $\begin{array}{l}\text { SN5.3.1. Buat-moris } \\
\text { balu, bainhira atu } \\
\text { responde sira-nia } \\
\text { nesesidade, fó impaktu } \\
\text { oioin ba ema, animal, no } \\
\text { ai-horis ne'ebé ema uza }\end{array}$ & $\begin{array}{l}\text { SN6.3.1. Buat-moris ida } \\
\text { nia karakterístika sira } \\
\text { mak determina oinsá nia } \\
\text { funsiona }\end{array}$ \\
\hline & $\begin{array}{l}\text { SN1.3.2. Iha animál } \\
\text { barak ne'ebé hanesan no } \\
\text { lahanesan }\end{array}$ & $\begin{array}{l}\text { SN2.3.2. Iha ai-horis } \\
\text { barak ne'ebé hanesan no } \\
\text { lahanesan }\end{array}$ & $\begin{array}{l}\text { SN3.3.2. Jerasaun foun } \\
\text { husi espésie ida hatudu } \\
\text { karakterístika ne'ebé } \\
\text { hanesan ho sira-nia } \\
\text { espésie no sira-nia inan- } \\
\text { aman, nune'e mós } \\
\text { hatudu karakterístika } \\
\text { foun balu }\end{array}$ & $\begin{array}{l}\text { SN4.3.2. Iha animál } \\
\text { barak mak bele moris } \\
\text { iha bee laran durante } \\
\text { sira-nia moris tomak no } \\
\text { bele mós moris iha fatin } \\
\text { seluk }\end{array}$ & $\begin{array}{l}\text { SN5.3.2. Tuir ema nia } \\
\text { haree, iha buat-moris } \\
\text { barak ne'ebé bele fó } \\
\text { benefisiu, no barak } \\
\text { ne'ebé la fó benefisiu }\end{array}$ & $\begin{array}{l}\text { SN6. 3.2. Iha } \\
\text { diversidade buat-moris } \\
\text { sira-ne'ebe eziste uiha } \\
\text { ambiente lokál no iha } \\
\text { Timor-Leste }\end{array}$ \\
\hline & $\begin{array}{l}\text { SN1.3.3. Animál sira iha } \\
\text { komunidade lokál bele } \\
\text { fare ba grupo oioin }\end{array}$ & $\begin{array}{l}\text { SN2.3.3. Ai-horis sira } \\
\text { iha komunidade lokál } \\
\text { bele fahe ba grupo oioin }\end{array}$ & $\begin{array}{l}\text { SN3.3.3. Buat-moris sira } \\
\text { bele fahe ba grupo tuir } \\
\text { oinsá sira reprodús no } \\
\text { dispersaun [fahe malu, } \\
\text { muda ba fatin seluk] }\end{array}$ & $\begin{array}{l}\text { SN4.3.3. Buat-moris } \\
\text { bele fahe ba grupu oioin } \\
\text { inklui iha-ne'ebé sira } \\
\text { moris }\end{array}$ & $\begin{array}{l}\text { SN5.3.3. Buat-moris } \\
\text { bele fahe ba grupo iha } \\
\text { maneira oioin, inklui } \\
\text { sira-nia benefísiu ka } \\
\text { perigu ba ema, animál, } \\
\text { no ai-horis sira-ne'ebé } \\
\text { sira uza }\end{array}$ & $\begin{array}{l}\text { SN6.3.3. Buat-moris } \\
\text { bele fahe ba grupo ho } \\
\text { maneira oioin, inklui tuir } \\
\text { sira-nia estrutura }\end{array}$ \\
\hline & $\begin{array}{l}\text { SN1.3.4. Mudansa } \\
\text { akontese iha área eskola } \\
\text { nian no ambiente lokál } \\
\text { durante loron tomak ida } \\
\text { no husi tempu ba tempu }\end{array}$ & $\begin{array}{l}\text { SN2.3.4. Mudansa } \\
\text { akontese iha área eskola } \\
\text { nian no ambiente lokál } \\
\text { durante loron tomak ida } \\
\text { no husi tempu ba tempo }\end{array}$ & $\begin{array}{l}\text { SN3.3.4. Dalaruma, } \\
\text { produsaun oan husi } \\
\text { buat-moris bele halo } \\
\text { mudansa ba ambiente }\end{array}$ & $\begin{array}{l}\text { SN4.3.4. Animál balu } \\
\text { moris iha fatin ne'ebé } \\
\text { hanesan durante sira-nia } \\
\text { moris tomak, amibé balu } \\
\text { moris iha fatin rua } \\
\text { ne'ebé lahanesan }\end{array}$ & $\begin{array}{l}\text { SN5.3.4. Mudansa } \\
\text { ne'ebé mak akontese ba } \\
\text { buat-moris no buat- } \\
\text { lamoris iha ambiente } \\
\text { lokál bele afeta } \\
\text { kuatidade buat-moris } \\
\text { ne'ebé fó benefisiu no } \\
\text { buat-moris ne'ebé fó } \\
\text { perigu }\end{array}$ & $\begin{array}{l}\text { SN6.3.4. SN6.3.4. } \\
\text { Mudansa ne'ebe } \\
\text { akontese ba ambiente } \\
\text { nia parte ne'ebé lamoris } \\
\text { afeta buat-moris sira- } \\
\text { ne'ebé hela iha fatin } \\
\text { ne'ebé }\end{array}$ \\
\hline
\end{tabular}




\begin{tabular}{|c|c|c|c|c|c|}
\hline $\begin{array}{l}\text { SN1.3.5. Ema tenke tau } \\
\text { matan no kuidadu ba } \\
\text { família, animál sira, no } \\
\text { sira-nia ambiente lokál }\end{array}$ & $\begin{array}{l}\text { SN2.3.5. Ema tenke tau } \\
\text { matan no kuidadu ba } \\
\text { sira-nia jardin ho natar } \\
\text { no to'os }\end{array}$ & $\begin{array}{l}\text { SN3.3.5. Ema nia } \\
\text { atividade bele tulun ai- } \\
\text { horis no animál sira balu }\end{array}$ & $\begin{array}{l}\text { SN4.3.5. Atividade ema } \\
\text { nian iha fatin ida bele } \\
\text { afeta populasaun buat- } \\
\text { moris no buat-lamoris } \\
\text { iha fatin ne'ébá ka iha } \\
\text { fatin seluk }\end{array}$ & $\begin{array}{l}\text { SN5.3.5. Atividade ema } \\
\text { nian iha eskola no área } \\
\text { lokál bele afeta } \\
\text { populasaun husi buat- } \\
\text { moris ria- ne'ebé la fó } \\
\text { benefisiu }\end{array}$ & $\begin{array}{l}\text { SN6.3.5. Ema tenke tau } \\
\text { matan no kuidadu ba } \\
\text { ambiente nia parte hotu, } \\
\text { inklui buat-moris no } \\
\text { buat ne'ebé lamoris }\end{array}$ \\
\hline $\begin{array}{l}\text { SN1.4.1. Estudante sira } \\
\text { hatán no husu pergunta } \\
\text { hirak kona-ba objetu no } \\
\text { eventu hirak-ne'ebé } \\
\text { estudante sira hatene } \\
\text { ona }\end{array}$ & $\begin{array}{l}\text { SN2.4.1. Estudante sira } \\
\text { hatán no husu pergunta } \\
\text { hirak kona-ba objetu no } \\
\text { eventu hirak-ne'ebé } \\
\text { estudante sira hatena } \\
\text { ona no hahú halo } \\
\text { predisaun kona-ba buat } \\
\text { hirak-ne'e }\end{array}$ & $\begin{array}{l}\text { SN3.4.1. Estudante hahú } \\
\text { identifika pergunta hirak } \\
\text { iha kontestu ne'ebé } \\
\text { hatene ona atubele } \\
\text { investiga tuir dalan } \\
\text { siénsia nian nune'e mós } \\
\text { hahú uza koñesimentu } \\
\text { ne'ebé sira iha ona } \\
\text { atubele halo predisaun } \\
\text { kona-ba saida mak atu } \\
\text { mosu }\end{array}$ & $\begin{array}{l}\text { SN4.4.1. Estudante sira } \\
\text { identifica pergunta hirak } \\
\text { iha kontestu ne'ebé } \\
\text { hatene ona hodi halo } \\
\text { investigasaun tuir dalan } \\
\text { siésia nian no uza } \\
\text { koñesimentu ne'ebe sira } \\
\text { iha ona hodi halo } \\
\text { predisaun ba buat ne'ebé } \\
\text { atu mosu }\end{array}$ & $\begin{array}{l}\text { SN5.4.1. Estudante sira } \\
\text { identifica pergunta hirak } \\
\text { iha kontestu ne'ebé la } \\
\text { hatene hodi halo } \\
\text { investigasaun tuir dalan } \\
\text { siénsia nian no uza } \\
\text { koñesimentu ne'ebé sira } \\
\text { iha ona hodi halo } \\
\text { predisaun ba buat ne'ebé } \\
\text { atu mosu }\end{array}$ & $\begin{array}{l}\text { SN6.4.1. Estudante sira } \\
\text { identifica pergunta hirak } \\
\text { iha kontestu ne'ebé la } \\
\text { hatene hodi halo } \\
\text { investigasaun tuir dalan } \\
\text { siénsia nian no uza } \\
\text { koñesimentu ne'ebé sira } \\
\text { iha ona hodi halo } \\
\text { predisaun ba buat ne'ebé } \\
\text { atu mosu }\end{array}$ \\
\hline $\begin{array}{l}\text { SN1.4.2. Estudante sira } \\
\text { esplora no halo } \\
\text { observasaun hodi uza } \\
\text { sira-nia sentidu sira. Sira } \\
\text { partisipa iha } \\
\text { investigasaun ne'ebé } \\
\text { lidera husi manorin hodi } \\
\text { uza materiál, teste ideia, } \\
\text { no hakerek observasaun. } \\
\text { Sira uza unidade-medida } \\
\text { lapadronizadu bainhira } \\
\text { halo ka hakerek } \\
\text { observasaun }\end{array}$ & $\begin{array}{l}\text { SN2.4.2. Estudante sira } \\
\text { partisipa iha tipu } \\
\text { investigasaun oioin } \\
\text { ne'ebé lidera husi } \\
\text { manorin, hanesan uza } \\
\text { materiál sira, teste ideia } \\
\text { sira, hakerek } \\
\text { observasaun, no aesu ba } \\
\text { informasaun. Sira sura } \\
\text { uza unidade-medida } \\
\text { lapadonizadu hakerek } \\
\text { observasaun }\end{array}$ & $\begin{array}{l}\text { SN3.4.2. Estudante sira } \\
\text { hahú hato'o sujestaun } \\
\text { kona-ba dalan atu halo } \\
\text { planu no hala'o } \\
\text { investigasaun atu nune'e } \\
\text { bele hetan resposta ba } \\
\text { pergunta sira. Sira halo } \\
\text { observasasaun no sura } \\
\text { uza unidade-medida } \\
\text { padronizadu no } \\
\text { lapadronizadu }\end{array}$ & $\begin{array}{l}\text { SN4.4.2. Estudante sira } \\
\text { hahú hato'o } \\
\text { investigasaun hodi bele } \\
\text { retan resposta ba } \\
\text { pergunta sira-ne'e. } \\
\text { Hainhira bel, sira sura } \\
\text { uza unidade-medida } \\
\text { padronizadu }\end{array}$ & $\begin{array}{l}\text { SN5.4.2. Estudante sira } \\
\text { hahú halo planu no } \\
\text { investigasaun atu hetan } \\
\text { resposta ba pergunta sira } \\
\text { no rezolve problema. } \\
\text { Bainhira bele, sira halo } \\
\text { observasaun no sura uza } \\
\text { unidade-medida } \\
\text { padronizadu }\end{array}$ & $\begin{array}{l}\text { SN6.4.2. Estudante sira } \\
\text { halo planu no halo } \\
\text { investigasaun simples } \\
\text { atubele hatan resposta } \\
\text { ba pergunta sura ka } \\
\text { rezolve problema. } \\
\text { Bainhira bele, sira bele } \\
\text { halo observasaun no } \\
\text { sura uza unidade-medida } \\
\text { padronizadu }\end{array}$ \\
\hline
\end{tabular}




\begin{tabular}{|c|c|c|c|c|c|}
\hline $\begin{array}{l}\text { SN1.4.3. Estudante sira } \\
\text { envolve iha diskusaun } \\
\text { kona-ba observasaun, no } \\
\text { hatudu no organiza sira- } \\
\text { nia observasaun no ideia } \\
\text { sira luihosi deseñu, } \\
\text { tabela, ka liafuan }\end{array}$ & $\begin{array}{l}\text { SN2.4.3a. Estudante sira } \\
\text { envolve iha diskusaun, } \\
\text { no hatudu no organiza } \\
\text { observasaun no ideia } \\
\text { sira liuhosi dezeñu, } \\
\text { liafuan, ka tabela } \\
\text { simples } \\
\text { SN2.4.3.b. Sira halo } \\
\text { komparasaun entre } \\
\text { observasau ho predisaun }\end{array}$ & $\begin{array}{l}\text { SN3.4.3a. Estudante sira } \\
\text { envolve iha diskusaun } \\
\text { no hatudu dadus ho } \\
\text { maneira oioin, inklui } \\
\text { tabela, hodi identifika } \\
\text { padraun no tendésia } \\
\text { SN3.4.3b. Sira kompara } \\
\text { resultadu sira ho } \\
\text { predisaun no sujere } \\
\text { razaun ba rezultadu sira- } \\
\text { ne'ebé sira hetan }\end{array}$ & $\begin{array}{l}\text { SN4.4.3a. Estudante sira } \\
\text { envolve iha diskusaun } \\
\text { no hatudu dadus ho } \\
\text { maneira oioin, inklui } \\
\text { tabela no gráfiku } \\
\text { simples koluna nian, } \\
\text { atubele identifica } \\
\text { padraun no tendénsia } \\
\\
\text { SN4.4.3b. Sira kompara } \\
\text { rezultado sira ho } \\
\text { predisaun no sujere } \\
\text { razaun ba resultadu sira- } \\
\text { ne'ebe sira hetan }\end{array}$ & $\begin{array}{l}\text { SN5.4.3a. Estudante sira } \\
\text { envolve iha diskusauun } \\
\text { no hatudu dadus ho } \\
\text { dalan ne'ebé apropriadu } \\
\text { atubele identifika } \\
\text { padraun no tendéncia }\end{array}$ & $\begin{array}{l}\text { SN6.4.3a. Estudante sira } \\
\text { envolve iha diskusaun } \\
\text { no aprezenta dadus ho } \\
\text { dalan ne'ebé apropriadu } \\
\text { atubele identifika } \\
\text { padraun no tebdénsia } \\
\\
\text { SN6.4.3b. Sira uza sira- } \\
\text { nia komprensaun no } \\
\text { rezultadu sira-ne'ebé } \\
\text { hetan ona kona-ba } \\
\text { tópiku atubele hanoin } \\
\text { kona-ba opsaun ba } \\
\text { futuro }\end{array}$ \\
\hline $\begin{array}{l}\text { SN1.4.4. Estudante sira } \\
\text { hahú kompara sira-nia } \\
\text { observasaun ho } \\
\text { observasaun estudante } \\
\text { sira seluk nian }\end{array}$ & $\begin{array}{l}\text { SN2.4.4. Estudante sira } \\
\text { kompara sira-nia } \\
\text { observasaun estudante } \\
\text { sira seluk nian, no hahú } \\
\text { hanoin filafali kona-ba } \\
\text { sira-nia investigasaun }\end{array}$ & $\begin{array}{l}\text { SN3.4.4. Estudante sira } \\
\text { hahú hanoin filafali } \\
\text { kona-ba sira-nia } \\
\text { investigasaun, inklui } \\
\text { hodi haree teste ne'e } \\
\text { loos ka lae }\end{array}$ & $\begin{array}{l}\text { SN4.4.4. Estudante sira } \\
\text { hahú hanoin filafali } \\
\text { kona-ba sira-nia } \\
\text { investigasaun, inklui } \\
\text { hodi haree teste ne'e } \\
\text { loos ka lae }\end{array}$ & $\begin{array}{l}\text { SN5.4.4. Estudante sira- } \\
\text { nia investigasaun no } \\
\text { komprensaun hodi hahú } \\
\text { foti pozisaun no justifika } \\
\text { sira-nia pozisaun }\end{array}$ & $\begin{array}{l}\text { SN6.4.4. Estudante sira } \\
\text { uza investigasaun ho } \\
\text { komprensaun hodi halo } \\
\text { predisaun kona-ba } \\
\text { opsaun ba futuru no halo } \\
\text { justificasaun ba sira-nia } \\
\text { vizaun }\end{array}$ \\
\hline $\begin{array}{l}\text { SN1.4.5. Estudante sira } \\
\text { fahe ba malu sira-nia } \\
\text { observasau sira no sira- } \\
\text { nia opiniaun ho dalan } \\
\text { oioin, hanesan: ko'alia, } \\
\text { pinta, hakerek, uza } \\
\text { liafuan no tabela, no } \\
\text { hala'o drama }\end{array}$ & $\begin{array}{l}\text { SN2.4.5. Estudante sira } \\
\text { fahe ba malu sira-nia } \\
\text { observasaun sira no sira- } \\
\text { nia opiniaun ho dalan } \\
\text { oioin, hanesan: ko'alia, } \\
\text { pinta, uza tabela, } \\
\text { hakerek liafuan no fraze } \\
\text { ne'ebé simples no hala'o } \\
\text { drama }\end{array}$ & $\begin{array}{l}\text { SN3.4.5. Estudante sira } \\
\text { apresenta no komunika } \\
\text { ideia no resultado sira } \\
\text { liuhosi dalan oioin, } \\
\text { inklui ko'alia, diagrama, } \\
\text { tabela, representasaun } \\
\text { fiziku, hala'o drama, no } \\
\text { relatóriu simples }\end{array}$ & $\begin{array}{l}\text { SN4.4.5. Estudante sira } \\
\text { apresenta no komunika } \\
\text { ideia no rezultadu sira } \\
\text { ho dalan oioin, inklui } \\
\text { ko'alia, diagrama, tabela, } \\
\text { gráfiku barra ne'ebé } \\
\text { simples, reprezentasaun } \\
\text { fiziku, hala'o drama, no } \\
\text { relaróriu simples }\end{array}$ & $\begin{array}{l}\text { SN5.4.5a. Estudante sira } \\
\text { aprezenta no komunika } \\
\text { ideia sira no rezultadu } \\
\text { sira ho dalan oion, inklui } \\
\text { diagrama, tabela, gráfiku } \\
\text { representasaun fiziku, } \\
\text { hala'o drama, no } \\
\text { relatório simples } \\
\text { SN5.4.5b. Sira hahú } \\
\text { halo argumentu atu } \\
\text { defende pozisaun ida }\end{array}$ & $\begin{array}{l}\text { SN6.4.5a. Estudante sira } \\
\text { aprezenta no komunika } \\
\text { ideia no rezultadu sira } \\
\text { ho dalan oioin, inklui } \\
\text { diagrama, tabela, } \\
\text { gráfiku, representasaun } \\
\text { fiziku, hala'o drama, no } \\
\text { relatóriu simples } \\
\text { SN6.4.5b. Sira hahú } \\
\text { hanoin kona-ba opsaun } \\
\text { ba futuro no esplika sira- } \\
\text { nia ideia kona-ba buat } \\
\text { hirak-ne'e, no justifika } \\
\text { sira-nia pozisaun }\end{array}$ \\
\hline
\end{tabular}


